\title{
Diversity of Garcinia species in the Western Ghats: Phytochemical Perspective
}

K. B. Rameshkumar
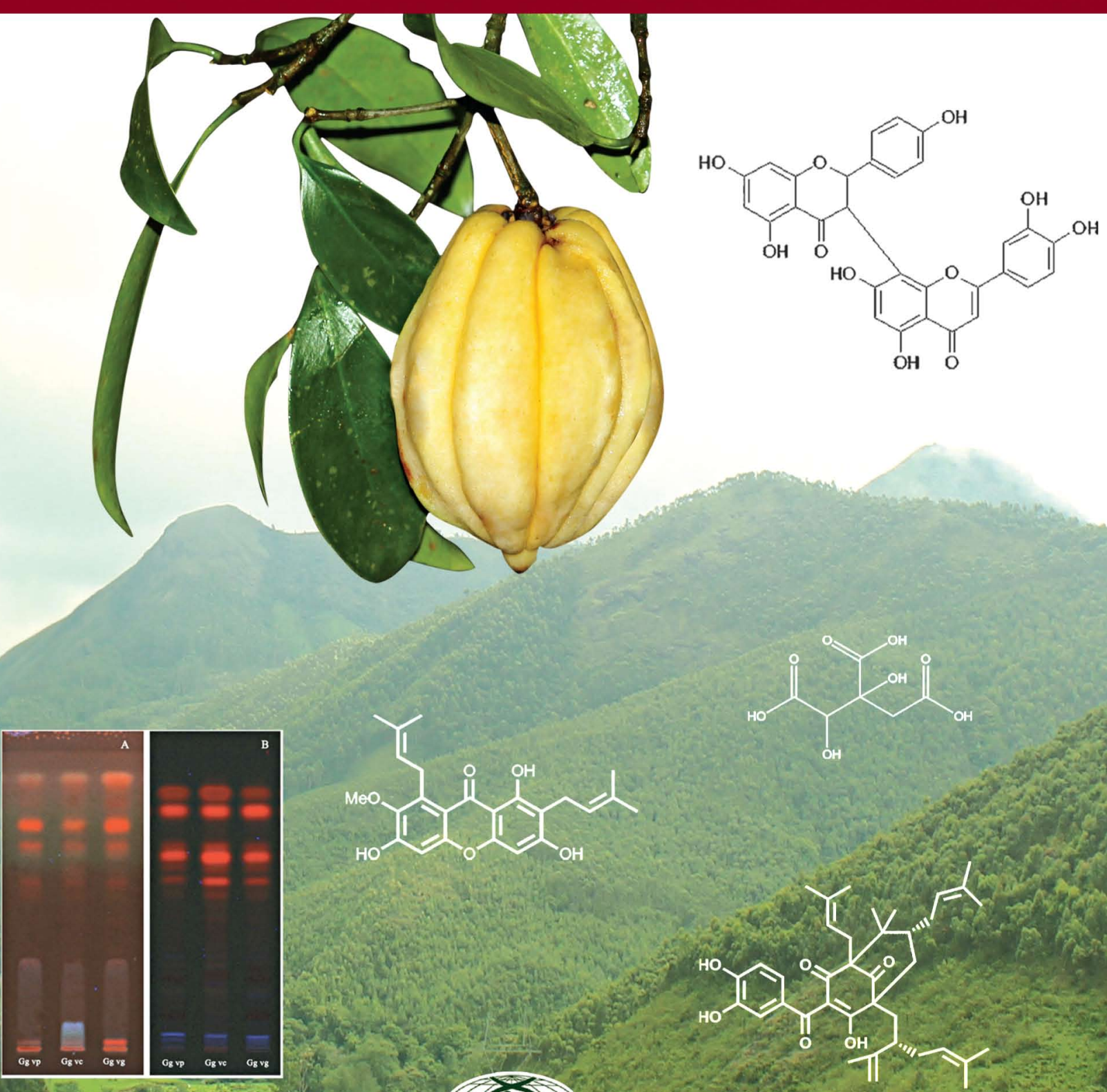

Whe

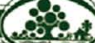

Jawaharlal Wehru Tropical Botanic Garden and Research Institute 



\section{Diversity of Garcinia species in the Western Ghats: Phytochemical Perspective}

Editor

K. B. Rameshkumar

Jawaharlal Nehru Tropical Botanic Garden and Research Institute Thiruvananthapuram 
Title: Diversity of Garcinia species in the Western Ghats: Phytochemical Perspective

Editor: K. B. Rameshkumar

Published by: Jawaharlal Nehru Tropical Botanic Garden and Research Institute, Palode, Thiruvananthapuram 695 562, Kerala, India

ISBN No.: 978-81-924674-5-0

Printed at: Akshara Offset, Thiruvananthapuram- 695035

Copyright (C) 2016: Editor and Publisher

All rights reserved. This book may not be reproduced in whole or in part without the prior written permission of the copyright owner. 


\section{Foreword}

I am delighted to write a Foreword to the Book 'Diversity of Garcinia species in the Western Ghats: Phytochemical Perspective' edited by my student Dr. K. B. Rameshkumar who took Garcinia imberti as a subject for his doctoral studies. It gives me all the more pleasure and gratification to see that he continued with his studies on Garcinia species of the Western Ghats along with his students and colleagues. Unlike many other doctoral students, he kept alive his passion for the studies on Garcinia and the present book is the outcome of his dedicated efforts during the last one and a half decades. Pursuit of science is a passion and unravelling the subtleties of nature is an ecstasy which fulfils the inner urge for quest and discovery.

The genus Garcinia is important by virtue of their reputation in traditional medicines, established pharmacological activities, diversity in chemical structures and potential nutritional properties. Despite recent progress in phytochemical and pharmacological studies on Garcinia species world over, significant gaps still exist concerning the exploration of the vast data on phytochemical diversity of Garcinia species. The present book provides a comprehensive and updated report on different aspects including distribution, conservation, morphology, chemotaxonomy, molecular taxonomy and pharmacology of Garcinia plants, with emphasis on Western Ghats species. Its specific focus on the Phytochemistry of Garcinia species is a great contribution to the lesser known subject Phytochemistry, especially in India. The authors are experts in their relevant field of research, as revealed by the contents and the in-depth presentation of individual chapters. The compiled data may provide useful clues to promote further investigations for the development of new lead molecules and value added products from Garcinia species. Furthermore, the book will give basic information on possible conservation strategies for the Western Ghats Garcinia plants. I personally am privileged to present this elegant work on 'Phytochemistry of Garcinia species' before the scientific community.

Prof. Dr. V. George Ph.D., FRSC

Director

Amity Institute of Phytochemistry and Phytomedicine Thiruvananthapuram 


\section{Preface}

The plant kingdom represents an extraordinary reservoir of molecules, that can be beneficial to mankind in several ways and currently there is a worldwide interest in the use of natural products, particularly plant derived products. The Western Ghats, one among 36 global biodiversity hotspots, harbors one of the finest tropical forests in the world. A recent enumeration has identified nearly 7500 flowering plants in the Western Ghats, of which more than 1250 are endemic to the region. Literature review revealed that nearly $80 \%$ of the endemic flowering plants of the region are hitherto uninvestigated for their chemical constituents, bioactivities or potential utilities. Garcinia species are one among such least explored group of plants, represented by 9 species and 2 varieties in the Western Ghats, of which 7 species and 2 varieties are endemic to the region. The genus Garcinia is important as a source of edible fruits, edible fats like kokum butter, oleoresin and coloring agents, the much valued anti-obesity phytochemical hydroxycitric acid (HCA) and other bioactive compounds like biflavonoids and xanthones. Due to the diversity of natural products and the presence of high value compounds, several industrial sectors like pharmaceutical, nutraceutical, paint and food additives are centred around this potential group of trees. In south India, G. gummi-gutta and G. indica are cultivated for commercial extraction of a variety of products such as bioactive acids, nutraceuticals, fats and condiments.

Literature review reveals that out of the nearly 250 Garcinia species, 120 species have so far been investigated for their chemical constituents. Garcinia species are found to be rich sources of structurally diverse secondary metabolites such as xanthones, benzophenones and biflavonoids, in addition to flavonoids, biphenyls, phloroglucinols, depsidones and triterpenoids as minor constituents. Though the Western Ghats has a rich diversity of Garcinia species, only a few species are exploited sustainably for their potential utilities. The rich floristic wealth can be harvested profitably by taking advantage of the developments in phytochemical analytical techniques. Phytochemistry, being an interdisciplinary subject linked to different disciplines, the present book also includes recent research activities in the fields such as botany, pharmacology and plant biotechnology of the genus. It is expected that the effort will open new vistas of knowledge and prove to be an excellent exposition of current research efforts in India in the field of Phytochemistry.

K. B. Rameshkumar 


\section{Acknowledgements}

First of all I would like to extend my profound thanks and sincere gratitude to my research guide, Dr. V. George, who introduced me to the fascinating world of plant chemistry. I am also indebted to the taxonomists of JNTBGRI for introducing me to the unexplored and fascinating world of tropical forest flora.

This book is indeed the result of the scholarly inputs from different experts and I would like to extend profound gratitude to all of the authors for their sincere efforts.

I also wish to acknowledge the assistance by the research students Mr. A. P. Anu Aravind and Mr. P. S. Shameer for their enduring effort during the preparation of the book.

This book is produced through the financial support of Kerala State Council for Science Technology and Environment (KSCSTE), SRS project entitled 'Biflavonoids from Garcinia species- Chemical, Molecular and Pharmacological Evaluation' (No. 008/SRSPS/2011/CSTE). The support of STP Division, KSCSTE and the advice and suggestions of the experts of SRS-GMW in successful completion of the project is also thankfully acknowledged here.

A special thanks to my family for their understanding and support during the time of producing this book.

K. B. Rameshkumar 
No.

Foreword

Preface

Acknowledgements

\section{Chapters}

1 Diversity of Garcinia species in the Western Ghats

2 Structural diversity of secondary metabolites in Garcinia species A. P. Anu Aravind, Lekshmi N. Menon and K. B. Rameshkumar

3 Phytochemical investigation of the Western Ghats endemic species Garcinia imberti Bourd.

K. B. Rameshkumar, Renu Pandey, Lekshmi N Menon, Brijesh Kumar and V. George

4 Phytochemical investigation of the Western Ghats endemic species Garcinia travancorica Bedd.

A. P. Anu Aravind, Renu Pandey, Brijesh Kumar and K. B. Rameshkumar

$5 \quad$ Leaf volatile chemical profiles of Garcinia species in the Western Ghats

K. B. Rameshkumar, A. P. Anu Aravind and Lekshmi N. Menon

6 Rapid estimation of bioactive constituents of Garcinia species in the Western Ghats using UHPLC-MS/MS method

Renu Pandey, Brijesh Kumar and K. B. Rameshkumar

7 Morphological, chemical and molecular taxonomy of a new Garcinia species- Garcinia pushpangadaniana Sabu et al.

P. S. Shameer, K. B. Rameshkumar, A. R. Sivu, T. Sabu, N. S. Pradeep and N. Mohanan

8 Diversity of Malabar Tamarind (Garcinia gummi-gutta (L.) N. Robson) in the Western Ghats- Morphological and phytochemical evaluation

P. S. Shameer, K. B. Rameshkumar, T. Sabu and N. Mohanan

9 Phytochemicals and bioactivities of Garcinia indica (Thouars) Choisy- A review

R. Ananthakrishnan and K.B. Rameshkumar

10 Phytochemicals and bioactivities of Garcinia gummi- gutta (L.) N. Robson- A review V. Anju and K.B. Rameshkumar

11 Gamboge- The bark exudate from Garcinia species Siji Aral and K.B. Rameshkumar

12 Nutrient properties of important Garcinia fruits of India Utpala Parthasarathy and O. P. Nandakishore A. P. AnuAravind, T. G. Nandu, S. Shiburaj and K. B. Rameshkumar

14 Antioxidant and cytotoxic activities of Fukugiside- The major biflavonoid from Garcinia travancorica Bedd.

A. P. Anu Aravind and K. B. Rameshkumar

15 Molecular characterisation of Garcinia species in the Western Ghats

A. R. Sivu, N. S. Pradeep and K. B. Rameshkumar

List of authors 



\title{
Chapter 1
}

\section{Diversity of Garcinia species in the Western Ghats}

\author{
P. S. Shameer ${ }^{1}$, K. B. Rameshkumar ${ }^{2}$ and N. Mohanan ${ }^{1, *}$ \\ ${ }^{1}$ Garden Management, Education, Information and Training Division \\ ${ }^{2}$ Phytochemistry and Phytopharmacology Division \\ Jawaharlal Nehru Tropical Botanic Garden and Research Institute \\ Palode, Thiruvananthapuram-695562, Kerala, India \\ * Corresponding author
}

\begin{abstract}
The Western Ghats, being one of the hotspots of biodiversity, support an enormous plant wealth. The genus Garcinia is an important component of the flora of the Western Ghats and is well known for their edible fruits and nutraceutical properties. The present chapter elaborates the diversity and distribution of Garcinia species in the Western Ghats. Conservation status of Garcinia species of the Western Ghats has also been revised. Field surveys, herbarium examinations and literature references revealed that there are 9 species and 2 varieties of the genus indigenous to the Western Ghats of which 7 species and 2 varieties are endemic to the region. The diversity of floral morphology, leaf morphology and fruit morphology were elaborated along with a dichotomous key to the Western Ghats species.
\end{abstract}

Key words: Garcinia, Clusiaceae, Western Ghats, Diversity, Conservation

\section{Introduction}

The dioecious genus Garcinia is the largest genus within the family Clusiaceae (formerly Guttiferae) and comprises nearly 250 species world over. Garcinia species are generally small or medium sized evergreen trees, (occasionally shrubs: G. buchneri Engl.), and are distributed in pantropical regions, with high species richness in South-East Asia (Figure 1). The centre of diversity of Garcinia species is the Malaysian region, with some species reaching India and the Micronesian islands and also extending to tropical Africa and the Neotropics (Rogers and Sweeney 2007, Stevens, 2007, Jones, 1980, Sharma et al., 2013, Nimanthika and Kaththriarchi 2010).

The genus name Garcinia honours the Dutch army doctor and naturalist Laurentius Garcin (1683-1752), who described the fruiting specimen of mangosteen collected from Moluccas, the Maluku islands, Indonesia (Garcin, 1733). This species was later named Garcinia mangostana by Linnaeus in 1753, which became the type species for the genus. The family Guttiferae was created by Jussieu (1789) based on the presence of the exudates secreted from cut stems and leaves. Thereafter, several monumental works such as that of Hooker (1875), Engler (1925), Robson (1961), Whitmore (1973) and Bamps (1978) reviewed the taxonomic status of Garcinia in different parts of the world. The first review of Indian Garcinia was in the 'Flora of British India', where Anderson describes 30 species in British India and including the pentamerous group also in section Xanthochymus (Anderson, 1874). 
Maheshwari in 1964, describes 31 species as naturally distributed in India (Maheshwari, 1964). In Flora of India, Singh (1993) included 34 indigenous Garcinia species.

India is one among the 12 megadiversity nations of the world. The wide range of climatic and topographical features have resulted in a high level of ecosystem diversity encompassing forests, wetlands, grasslands, deserts, coastal and marine ecosystems, each with unique assemblage of species. The Western Ghats, a mountain range that runs nearly $1,600 \mathrm{~km}$, extends from the west coast of peninsular India from the river Tapti in north to Kanyakumari in south. It is perhaps the most important centers of biodiversity and floristic wealth in India. The region is a UNESCO World Heritage Site and also one among the 36 global biodiversity hot spots in the world. Among the 36 global biodiversity hotspots, Western Ghats occupies $5^{\text {th }}$ position in the economic potential of its biological resources. Over 7,500 species of flowering plants, comprising about $27 \%$ of the Indian flora, were reported from the region, of which nearly 1250 are endemic to the region (Anonymous, 2014). Moreover, the Western Ghats is the centre of origin and diversity of a number of economically important plants and there exists a variety of wild relatives of important food and spice crops. The rich biodiversity of tropical forest is attributed to a constant amount of energy from the sun, abundant rain fall and year round warmth, which makes life more favourable than any other place on earth.

In India, the genus Garcinia is represented by 43 species and 5 varieties, of which 37 species and 4 varieties occur in wild, whereas the rest were introduced into cultivation (Anderson, 1874, Maheshwari, 1964, Singh, 1993, Srivastava, 1994, Mohanan et al., 1997, Sabu et al., 2013, Sarma et al., 2016). Among the 37 indigenous Garcinia taxa, 16 species and 4 varieties are endemic to the country. In India, Garcinia species are distributed mainly in three phyto-geographical zones; North East India, the Western Ghats and Andaman and Nicobar Islands. North East India hosts 17 species, of which 2 species and 1 variety are endemic to the region. The Western Ghats hosts 9 species and 2 varieties, of which 7 species and 2 varieties are endemic and the Andaman and Nicobar Islands hosts 15 taxa, of which 6 species and 1 variety are endemic.

A
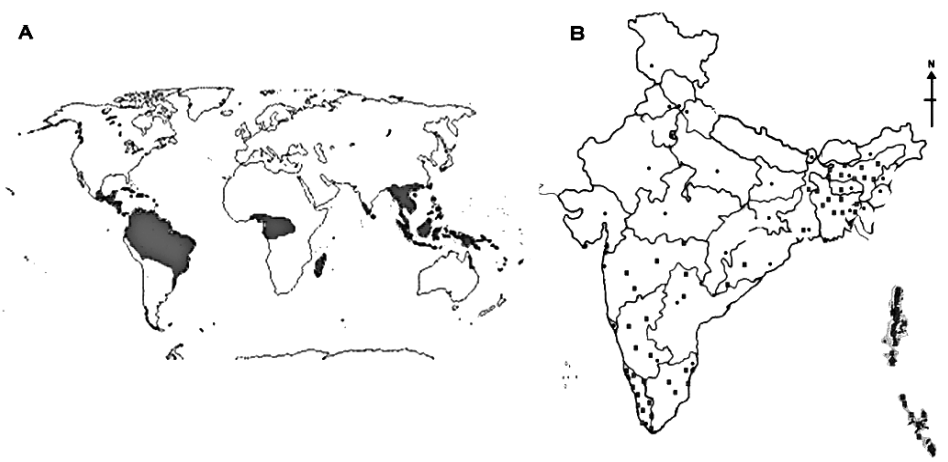

c

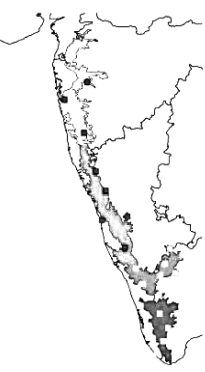

Figure 1. Distribution map of Garcinia species in the world (A), in India (B) and in the Western Ghats $(\mathbf{C})$ 


\section{Distribution of Garcinia species in the Western Ghats}

In the Western Ghats, most of the Garcinia species are distributed in semi evergreen to evergreen habitat, except $G$. wightii which is also found in riparian habitats. Altitude wise they are found from sea shore (G. gummi-gutta var. gummi-gutta) to high land up to $1500 \mathrm{~m}$ (G. travancorica). Recent checklist (Nayar et al., 2014) reported the natural occurrence of 10 species and 2 varieties of Garcinia in the Western Ghats region. However, field survey and detailed study of various flora revealed the presence of 9 species and 2 varieties as indigenous to the Western Ghats, of which 7 species and 2 varieties are endemic to the region (Table 1). G. morella, G. talbotii and G. gummi-gutta var. gummi-gutta are the most widely distributed species in the Western Ghats. Our study revealed that Agasthyamala Biosphere Reserve in the Western Ghats is the centre of maximum diversity of the genus, with 6 species of which three species viz., G. travancorica, G. imberti and G. rubro-echinata are endemic to the region (Table 1).

Among the nine species indigenous in the Western Ghats, G. gummi-gutta is an economically important and widely cultivated fruit crop in Southern Western Ghats, while $G$. indica is cultivated widely in Central Western Ghats region for their fruits. Besides, 6 introduced species (G. cowa Roxb. ex. DC., G. hombroniana Pierre, G. xanthochymus Hook. f. ex T. Anderson, G. cymosa (K. Schum.) I. M. Turner and P. F. Stevens, G. intermedia (Pittier) Hammel, G. mangostana L.) are also reported as cultivated in the Western Ghats region either as fruit plants or as ornamental plants. Garcinia mangostana L., source of the edible fruit mangosteen, is native to South East Asia and now cultivated throughout the Western Ghats for their delicious fruits. G. hombroniana, known as sea shore mangosteen, an allied species is getting popular in the Western Ghats region as source of edible fruits. The introduced tree G. xanthochymus is also getting popular as a fruit crop and avenue tree.

Garcinia echinocarpa Thw. (1854) was considered as a species distributed in South India and Sri Lanka, until Kostermans (1977) separated the South Indian taxon as a distinct species viz. G. rubro-echinata. Though later Singh (1993) reduced G. echinocarpa var. monticola as a synonym of G. rubro-echinata, detailed literature survey and examination of type specimens in the present study revealed that G. rubro-echinata is distinct from $G$. echinocarpa var. monticola.

Garcinia talbotii Raizada ex Santapau was considered as a species distributed in Western Ghats of India and was first reported from Gairsoppah Ghats, North Kanara, Karanataka (Raizada, 1960). This species is closely allied to Garcinia spicata Wight and Arn. which is native to Sri Lanka (1875). In most of the Indian Floras, G. talbotii has been misidentified as G. spicata, which is not naturally occurring in India. Thorough examination of literature, type specimens and live specimens from the Western Ghats, live specimen from AJCB Indian Botanic Garden Kolkata (G. spicata, Herb. Wallich 4838, Wight 138) and herbarium specimens housed at various Herbarium like MH, ASSAM, PBL, CAL, FRC, CALI, KFRI and KEW, it was found that G. talbotii is distinct from G. spicata by the milky exudation turning brownish after exposure, elliptic, ovate-oblong leaf, more number of lateral veins, fascicles or pseudo spikate male inflorescence, number of stamens and stigmatic lobes and globose fruit. 
Table 1. Garcinia species in the Western Ghats: IUCN status and distribution

\begin{tabular}{|c|c|c|c|c|}
\hline $\begin{array}{l}\text { Sl. } \\
\text { No. }\end{array}$ & Garcinia species & $\begin{array}{l}\text { IUCN } \\
\text { status }\end{array}$ & $\begin{array}{l}\text { Distribution (altitude, } \\
\text { meter) }\end{array}$ & Locality \\
\hline \multirow[t]{3}{*}{1} & $\begin{array}{l}\text { G. gummi-gutta (L.) } \\
\text { N. Robson var. } \\
\text { gummi-gutta N. P. } \\
\text { Singh }\end{array}$ & -- & $\begin{array}{l}\text { India, Sri Lanka } \\
(50-900 \mathrm{~m})\end{array}$ & $\begin{array}{l}\text { Throughout the evergreen-semi evergreen } \\
\text { forests of the Western Ghats }\end{array}$ \\
\hline & $\begin{array}{l}\text { G. gummi-gutta var. } \\
\text { conicarpa (Wight) } \\
\text { N. P. Singh }\end{array}$ & -- & $\begin{array}{l}\text { Endemic to the Western } \\
\text { Ghats } \\
(1350-1950 \mathrm{~m})\end{array}$ & $\begin{array}{l}\text { Kerala: Kadllar, Munnar, Rajamala, Chinnar } \\
\text { (Idukki); Vellarimala (Kozhikode) }\end{array}$ \\
\hline & $\begin{array}{l}\text { G. gummi-gutta var. } \\
\text { papilla (Wight) N. P. } \\
\text { Singh }\end{array}$ & -- & $\begin{array}{l}\text { Endemic to the Western } \\
\text { Ghats } \\
(800-1850 \mathrm{~m})\end{array}$ & $\begin{array}{l}\text { Kerala: Wallakkad, Silent Valley (Palakkad) } \\
\text { TamilNadu: Nilagiri Biosphere Reserve }\end{array}$ \\
\hline 2 & G. imberti Bourd. & EN & $\begin{array}{l}\text { Endemic to South } \\
\text { Western Ghats } \\
(900-1200 \mathrm{~m})\end{array}$ & $\begin{array}{l}\text { Kerala: Agasthyamala Biosphere Reserve } \\
\text { (Thiruvananthapuram), Shankily, Shendaruni } \\
\text { (Kollam). }\end{array}$ \\
\hline 3 & $\begin{array}{l}\text { G. indica (Thouars) } \\
\text { Choisy }\end{array}$ & VU & $\begin{array}{l}\text { Endemic to India. } \\
\text { the Western Ghats, } \\
\text { North East India } \\
(50-550 \mathrm{~m})\end{array}$ & $\begin{array}{l}\text { Kerala: Badi Baduka, Thaliparamba; } \\
\text { Maharashtra: Thungar Hill, North Kanara; } \\
\text { Karnataka: Tinai Ghat. } \\
\text { Assam: Karbi Anglong Dist. }\end{array}$ \\
\hline 4 & $\begin{array}{l}\text { G. morella (Gaertn.) } \\
\text { Desr. }\end{array}$ & -- & $\begin{array}{l}\text { Indo-Malay, Sri Lanka } \\
(500-1100 \mathrm{~m})\end{array}$ & $\begin{array}{l}\text { Kerala: Chenathnair, Kuruva Island, } \\
\text { Kambamala (Wayanad); Thamarassery, } \\
\text { Vellarimala (Kozhikode); Silent Valley } \\
\text { (Palakkad); Kodakkalthodu, Payampara } \\
\text { (Thrissur); Pampa (Pathanamthitta); } \\
\text { Pandimotta, Chemmunjii, Attayar } \\
\text { (Thiruvananthapuram) Karnataka: Horanad } \\
\text { Forests; } \\
\text { Tamil Nadu: Anamalai Hills, Iyyerpadi, } \\
\text { Kannikketyy. } \\
\text { Assam: Pasighat, Rani Dawa bang }\end{array}$ \\
\hline 5 & $\begin{array}{l}\text { G. } \\
\text { pushpangadaniana } \\
\text { T. Sabu, N. } \\
\text { Mohanan, Krishnaraj } \\
\text { and Shareef }\end{array}$ & -- & $\begin{array}{l}\text { Endemic to the Western } \\
\text { Ghats }(850-1400 \mathrm{~m})\end{array}$ & $\begin{array}{l}\text { Kerala: Kadalar, Pampadumchola, Munnar } \\
\text { (Idukki); Wallakad of Silent Valley } \\
\text { (Palakkad); } \\
\text { Tamil Nadu: Anamalai Hills }\end{array}$ \\
\hline 6 & $\begin{array}{l}\text { G. rubro-echinata } \\
\text { Kosterm. }\end{array}$ & VU & $\begin{array}{l}\text { Endemic to South } \\
\text { Western Ghats } \\
(800-1200 \mathrm{~m})\end{array}$ & $\begin{array}{l}\text { Kerala: Ponmudi, Chemmunji Hills } \\
\text { (Thiruvananthapuram). Tamil Nadu: Kalakkad } \\
\text { Mundanthurai Tiger Reserve (Thirunelveli) }\end{array}$ \\
\hline 7 & $\begin{array}{l}\text { G. talbotii Raizada } \\
\text { ex Santapau }\end{array}$ & -- & $\begin{array}{l}\text { Endemic to the Western } \\
\text { Ghats } \\
(100-500 \mathrm{~m})\end{array}$ & $\begin{array}{l}\text { Kerala: Uduma, Cheemani (Kasaragode); } \\
\text { Vellarimala (Kozhikode); Vazhachal } \\
\text { (Thrissur); Pampa, Pandarakayam } \\
\text { (Pathanamthitta); Pandimotta, Rosemala } \\
\text { (Thiruvananthapuram) }\end{array}$ \\
\hline 8 & $\begin{array}{l}\text { G. travancorica } \\
\text { Bedd. }\end{array}$ & VU & $\begin{array}{l}\text { Endemic to South } \\
\text { Western Ghats } \\
(950-1500 \mathrm{~m})\end{array}$ & $\begin{array}{l}\text { Kerala: Athirumala, Chemmunjii } \\
\text { (Thiruvananthapuram). Tamil Nadu: Kalakkad } \\
\text { Mundanthuarai Tiger Reservae (Thirunelveli) }\end{array}$ \\
\hline 9 & $\begin{array}{l}\text { G. wightii } \mathrm{T} \text {. } \\
\text { Anderson }\end{array}$ & VU & $\begin{array}{l}\text { Endemic to South } \\
\text { Western Ghats } \\
(250-700 \mathrm{~m})\end{array}$ & $\begin{array}{l}\text { Kerala: Vazhachal, Athirappally (Thrissur); } \\
\text { Paniyeli-poru (Eranakulam) }\end{array}$ \\
\hline
\end{tabular}

VU- Vulnerable, EN- Endangered 
According to Anderson (1874), Maheshwari (1964) and Singh (1993) Garcinia xanthochymus is distributed in the Western Ghats. However, detailed literature survey, herbarium references and field collections revealed that G. xanthochymus is naturally found only in the North East India and Andaman Nicobar Islands. G. xanthochymus is cultivated elsewhere in the Western Ghats for its delicious fruits. Most of the specimens identified in Indian Herbaria as G. xanthochymus, on close examination revealed to be distinct, which resembles to the new species G. pushpangadaniana, reported from Kadalar forest Division of Munnar, Southern Western Ghats of India (Sabu et al., 2013).

Garcinia gummi-gutta (L.) Robs. is an economically important fruit crop and a vital component of the forest flora of the Western Ghats. Three varieties of the species viz; G. gummi-gutta (L.) Robs. var. gummi-gutta, G. gummi-gutta var. papilla (Wight) N. P. Singh and G. gummi-gutta var. conicarpa (Wight) N. P. Singh are reported from India. Among the three varieties, var. gummi-gutta is the most common and economically important one, widely cultivated throughout the Western Ghats region, especially in Kerala, ranging from sea shore to high land and also found in the wild. The variety conicarpa and var. papilla are rare and distributed restrictedly in highlands of evergreen forest. The large fruit size, pulpy aril and more number of seeds (4-8) per fruit were the favorable features of var. gummi-gutta for its wide distribution and preference for cultivation over the other two varieties. The variety conicarpa was found morphologically distinct by the absence of leaf ligules and by the arrangement of stamens in convex torus head, in addition to the conical nature of fruits. We suggest reinstating the species status of G. gummi-gutta var. conicarpa to G. conicarpa based on the unique morphological characters.

\section{Conservation status}

Literature review revealed that Garcinia species in the Western Ghats have not been assessed critically for their distribution and conservation and a comprehensive revision on the conservation status of the Garcinia species appears to be vital.

G. travancorica, G. imberti and G. rubro-echinata are distributed strictly endemic to the forest regions of Agasthyamala Biosphere Reserve, at an altitude ranging from 800-1400 $\mathrm{m}$. According to the guidelines of IUCN Red List and World Conservation Monitoring Centre (Moat, 2007), G. imberti Bourd. is an endangered tree species, while G. travancorica and G. rubro-echinata belongs to 'vulnerable' category. Our field surveys revealed that population size of G. imberti is rather larger than that of G. travancorica and G. rubro-echinata. The two varieties of G. gummi-gutta; var. conicarpa and var. papilla are also very rare in the evergreen forest of Southern Western Ghats, suggesting vulnerable status for these two varieties.

\section{Taxonomy}

The genus Garcinia is considered as a taxonomically difficult one due to the complexity in floral characteristics. While majority of Garcinia species are dioecious, a few species or races are reported as hermaphrodite (Dunthorn, 2004). Garcinia species generally display an unusual evolutionary plasticity and there are many unresolved phylogenic issues surrounding the genus. Among the different phylogenic analytical strategies, morphology in all its aspects, from micromorphology to embryology, palynology, seed, fruit, floral, stem and leaf 
morphology, still remains to be the most indispensible tool. Several identification keys have been reported for Garcinia species across the globe based on morphological features of flower, fruit and leaf (Jones, 1980, Nimanthika and Kaththriarachchi, 2010).

\subsection{Diversity in floral morphology}

Male and female flowers are seen on different trees (dioecious) or rarely male or female and hermaphrodites flowers on the same tree (polygamodioecious) in Garcinia species. The basic inflorescence type of Garcinia is a simple cyme or few flowered (2 to 16) clusters in fascicles. Exceptions are in the case of $G$. travancorica with trichotomous cyme and $G$. wightii with solitary or rarely 2-3 flowers. Flowers of Garcinia are generally sessile except $G$. talbotii and G. pushpangadaniana with pedicellate (Figure 2). Flowers are solitary or in fascicles, terminal or axillary and variously coloured. Sepals and petals 4-5, stamens usually numerous, very variable in arrangement and structure, sometime with pistillode; ovary 1-12 loculed with a single apical ovule per locule, ovule 1 in each locule; stigma conspicuous and variously lobed, usually peltate. Characteristic differences in the floral architecture were observed even among closely related taxa of Garcinia (Pierre, 1883, Jones, 1980, Gustafsson et al., 2002, Sweeney, 2008).

Male flowers: Inflorescence of male flowers are observed both in terminal and axillary positions; axillary inflorescence being common. Species like G. morella, $G$. pushpangadaniana, G. wightii and G. gummi-gutta have flowers in axills, whereas in the case of G. imberti, G. indica, G. rubro-echinata and G. talbotii, flowers are found both in axillary and terminal position. G. travancorica flowers are found only terminal or sub-terminal.

The sepals are usually orbicular and green or yellowish in colour. Species like $G$. pushpangadaniana and G. talbotii have ciliate margins. The petals, however, have brighter colour, from yellow (G. imberti, G. gummi-gutta, G. indica) to white (G. talbotii, G. wightii), cream (G. morella), pink or red (G. pushpangadaniana), pale greenish (G. travancorica) and green (G. rubro-echinata). Petal of the male and female flowers of the same species are usually similar, but varies considerably among different species from ovate to oblong, or oblanceolate to obovate. The stamens are always united in a bundle at the centre of the flower. In the case of G. gunmmi-gutta, stamens were arranged usually on tetragonous receptacle and also as androphore. In Garcinia, pistillodes have a fungiform-shape, consisting of a cap and the shaft (or stipe), which is homologous to the stigma and ovary respectively. The pistillodes are small in diameter, varied from $1 \mathrm{~mm}$ for G. gummi-gutta to $5 \mathrm{~mm}$ for G. rubro-echinata. The stipe can be slender or ovoid and the margin of the cap may be crenate or lobed. However, pistillode is lacking in G. talbotii and G. pushpangadaniana. 


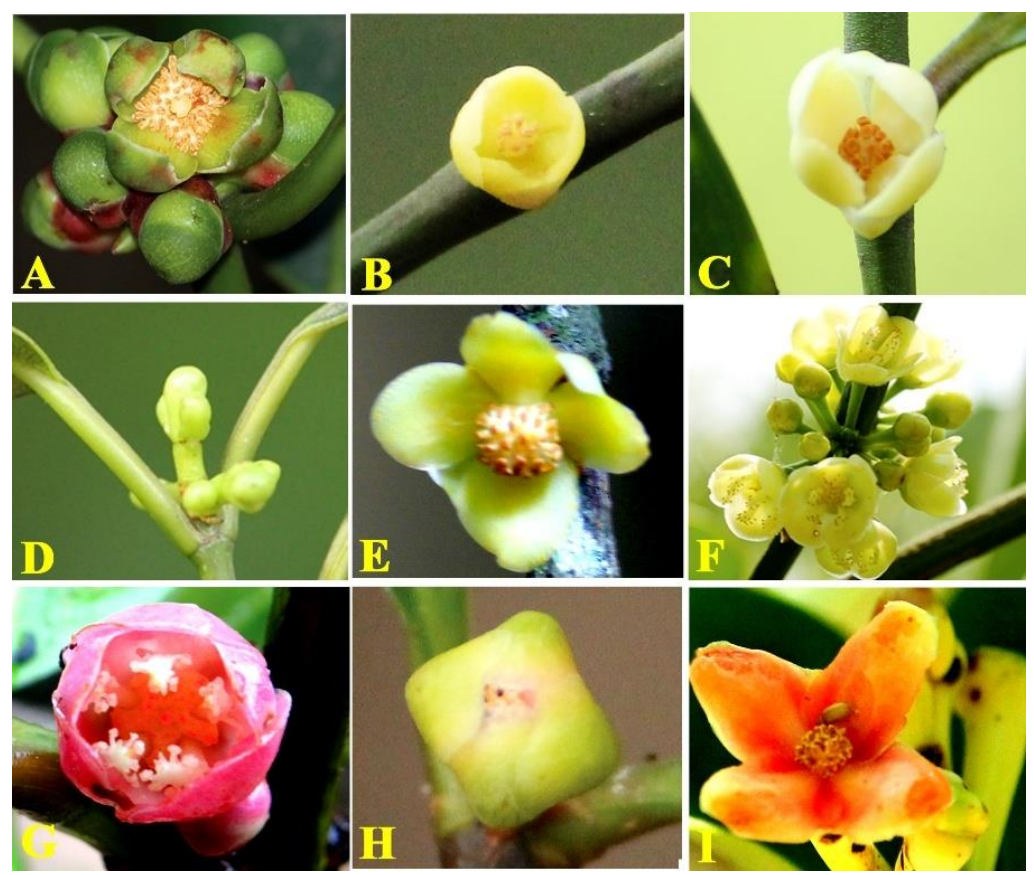

Figure 2. Male flowers of Garcinia species in the Western Ghats (A. G. rubro-echinata, B. G. imberti, C. G. wightii, D. G. travancorica, E. G. morella, F. G. talbotii, G. G. pushpangadaniana, H. G. indica and I. G. gummi-gutta)

Female flowers: Inflorescence of female flowers are usually terminal in position. G. morella, G. pushpangadaniana, G. talbotii and G. wightii have axillary flowers while G. gummigutta exhibit both axillary and terminal flowers (Figure 3). The female flowers are fewer compared to male flowers and in the case of G. rubro-echinata, G. imberti and G. wightii, the female flowers are strictly solitary. The female flowers have shorter, stouter pedicels and peduncles comparatively smaller than the male flowers. In general, the ovary in Garcinia is superior and very few species have constant locule numbers. Most of the Garcinia species have 4 or 5 locules (G. morella, G. wightii, G. rubro-echinata and G. talbotii) but rarely 1 or 2 loculed ( $G$. imberti, G. travancorica) and more than 5 loculed (G. indica, G. gummi-gutta, $G$. pushpangadaniana). Generally, ovary is globose to ovoid. Variation is also found in the shape of ovary, however, it has less taxonomic value and is not really an important character for species delimitation in Garcinia.

The stigma is usually sessile and wide variation exists. In most species the stigma is large and conspicuous, and in some species like G. travancorica and G. imberti the stigma is larger than the ovary. Lobes are slightly divided (G. pushpangadaniana, G. talbotii, $G$. rubro-echinata and $G$. wightii) to completely divided in to rays (G. gummi-gutta, G. indica and $G$. morella), whereas in some species stigma exists as broad convex disc $(G$. travancorica and $G$. imberti). 


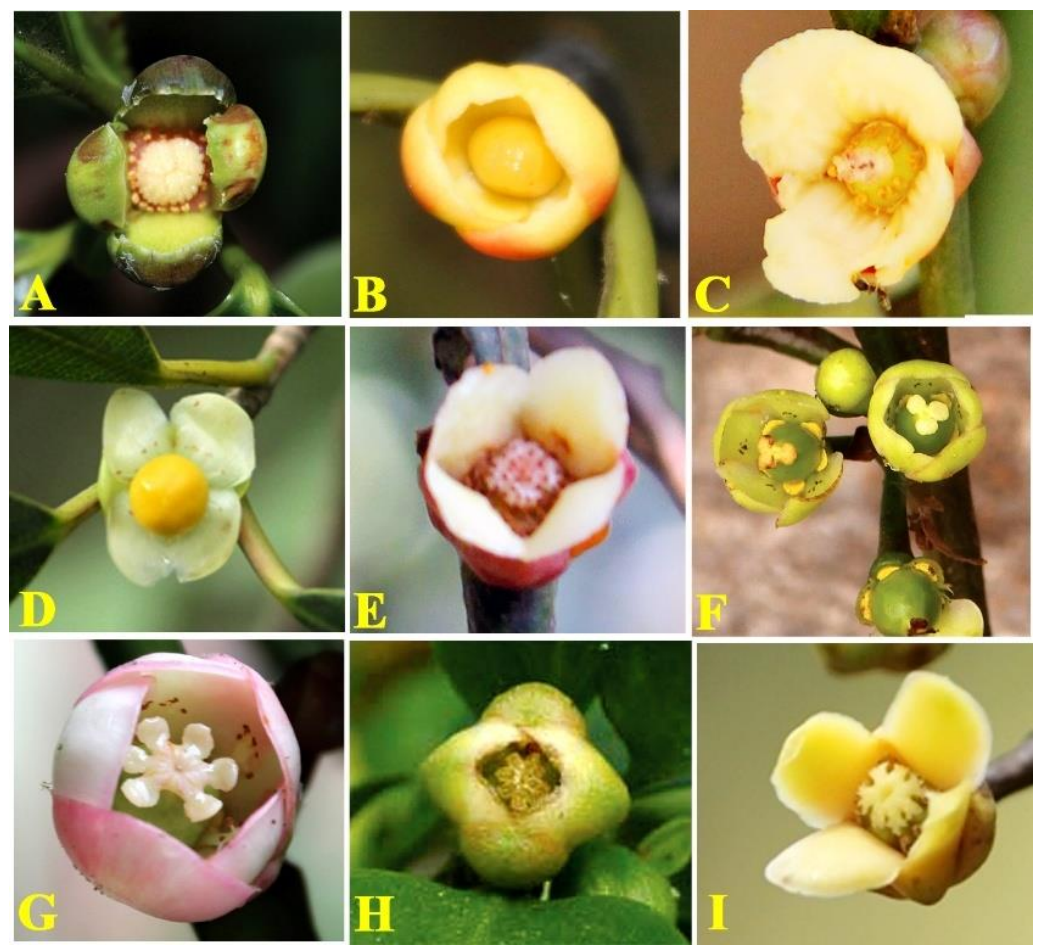

Figure 3. Female flowers of Garcinia species in the Western Ghats (A. G. rubro-echinata, B. G. imberti, C. G. wightii, D. G. travancorica, E. G. morella, F. G. talbotii, G. G. pushpangadaniana, H. G. indica and I. G. gummi-gutta)

\subsection{Diversity in branching and bark exudates}

Garcinia species were characterized by their monopodial branching form, where secondary shoots or branches arise behind the growing point but remain subsidiary to the main stem, which continues to grow indefinitely (Tootil, 1984). Hence Garcinia species usually exhibited horizontal spreading branching pattern. However, G. gummi-gutta var. gummi-gutta and G. morella showed pendulous drooping branchlets whereas $G$. indica showed crown shaped canopy ending with horizontal branchlets. G. pushpangadaniana has pyramidal crown with pendulous drooping branchlets.

Bark is usually grey to brown, inner bark is yellow or occasionally white. The stem and twigs produce yellow, white or cream exudates, known as 'Gamboge' (Figure 4). Gamboge is solidified resin and is sticky in nature and is also found in immature fruit rind and leaves in addition to stem bark. Gamboge is used as a pigment in paint and varnishes. The colour of the exudates varies from yellow to white and is a characteristic identification feature for Garcinia species. Species like G. travancorica, G. morella, G. wightii and $G$. gummi-gutta have yellow exudation. G. pushpangadaniana, G. imberti, G. talbotii, G. indica and G. rubro-echinata have white exudation. Gamboge of $G$. morella is widely used in the preparation of golden coloured water colours and spirit varnishes for metals and also for dyeing silk fabrics. A golden yellow coloured ink was prepared from the gamboge of $G$. morella for writing on black paper (Anonymous, 1950). 

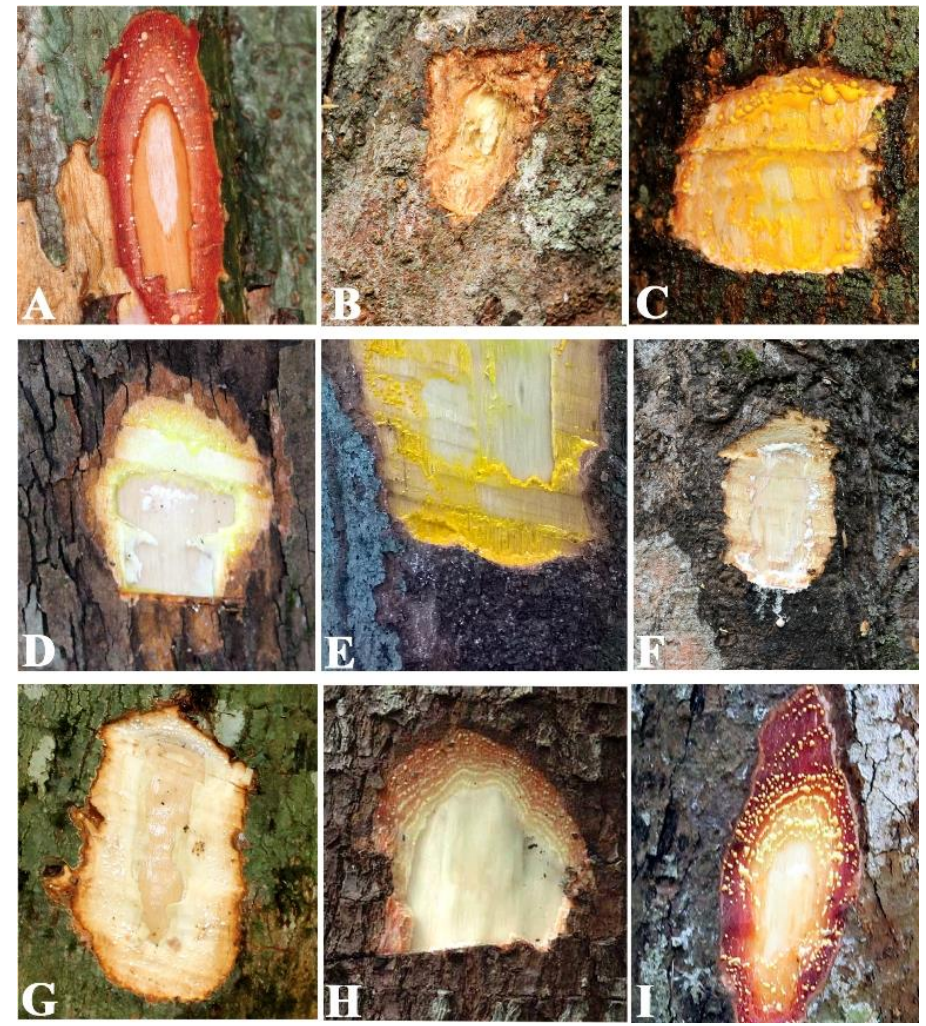

Figure 4. Stem bark exudates in Garcinia species in the Western Ghats (A. G. rubro-echinata, B. G. imberti, C. G. wightii, D. G. travancorica, E. G. morella, F. G. talbotii, G. G. pushpangadaniana, H. G. indica and I. G. gummi-gutta)

\subsection{Diversity in leaf morphology}

Leaves of Garcinia species are opposite, usually thick and characterized by the presence of a foveola (an excavation with an extension resembling a ligule) at the base of the petiole. Based on the arrangement of leaf lamina, the Western Ghats species can be classified into two groups, those possess lamina with conspicuous secondary veins and the group with inconspicuous secondary veins. Also, the arrangement of secondary veins falls into two patterns; loose and dense. G. travancorica and G. rubro-echinata exhibit loosely arranged secondary veins, while all other species showed densely arranged veins. Lamina size and nature of petiole were also distinguishing features. G. pushpangadaniana and G. talbotii have large leaves $(>15 \times 8 \mathrm{~cm})$ with stout petiole. Coriaceous leaf texture was prominent in most of the Garcinia species except G. imberti, G. wightii and G. indica which possess subcoriaceous leaves. G. talbotii and G. gummi-gutta were the two species that showed maximum diversity in leaf shape (Figure 5). 

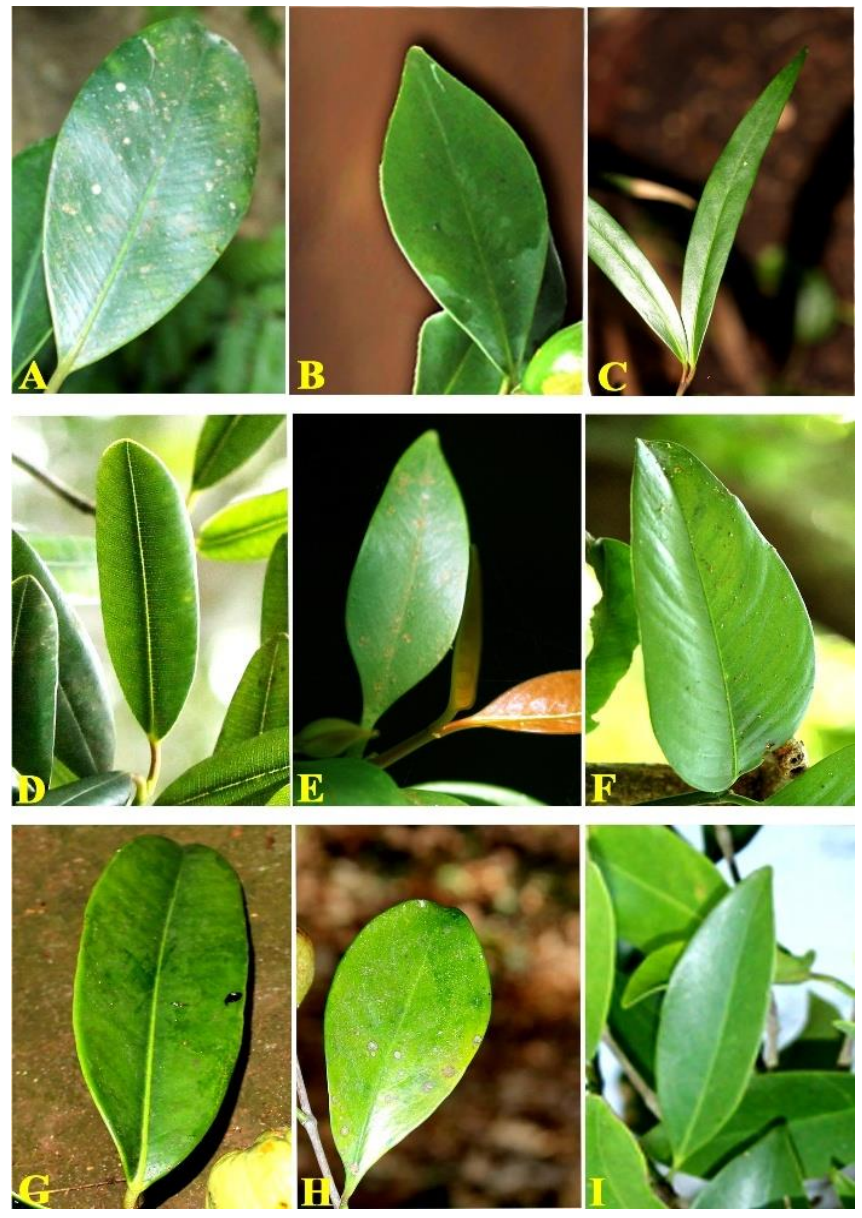

Figure 5. Leaf morphology of Garcinia species in the Western Ghats (A. G. rubro-echinata, B. G. imberti, C. G. wightii, D. G. travancorica, E. G. morella, F. G. talbotii, G. G. pushpangadaniana, H. G. indica and I. G. gummi-gutta)

\subsection{Diversity in fruit morphology}

Relatively few investigations have been carried out on fruit and seed morphology of Garcinia. Fruits are fleshy to woody berry; seated on the usually persistent calyx. Seed 1-12, often flattened and enclosed in pulp. Regarding fruit size, G. wightii has the smallest (10-15 gm), while the largest is that of G. pushpangadaniana, weighing upto $750 \mathrm{gm}$. Most of the fruits are globose in shape except sub-globose to ellipsoid in G. rubro-echinata, oblong to sub-globose in $G$. imberti and $G$. travancorica. Texture of fruit surface is another distinguishing feature, where G. imberti, G. travancorica, G. morella, G. wightii and $G$. indica possess smooth fruit surface, grooved in $G$. gummi-gutta, warty nature in $G$. pushpangadaniana while the fruit surface of G. rubro-echinata is covered with broad sharp tubercles (Figure 6). Species like G. imberti, G. wightii, G. travancorica, G. morella and G. indica have pulpy aril while the aril of $G$. pushpangadaniana is crispy and that of 

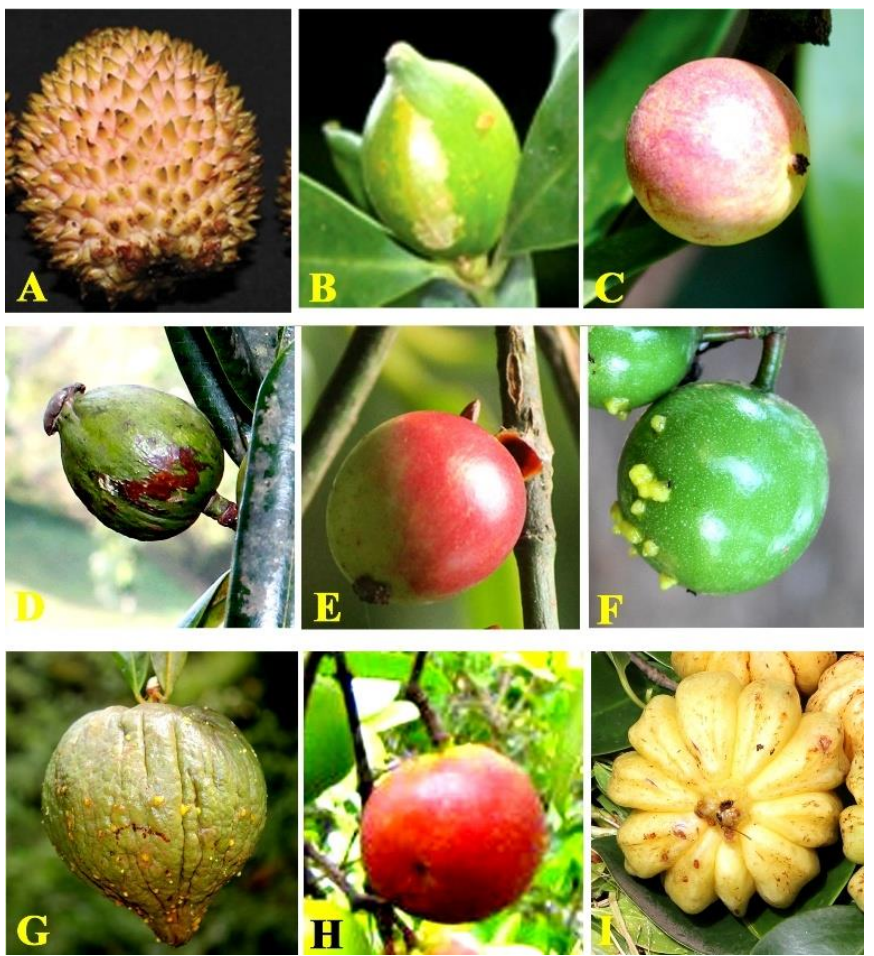

Figure 6. Fruit morphology of Garcinia species in the Western Ghats (A. G. rubro-echinata, B. G. imberti, C. G. wightii, D. G. travancorica, E. G. morella, F. G. talbotii, G. G. pushpangadaniana, H. G. indica and I. G. gummi-gutta)

G. rubro-echinata is fibrous. The seed shape was oblong in most of the Garcinia species, except plano-convex for G. pushpangadania, ovoid-reniform for G. morella and G. gummigutta. The fruit colour is a characteristic distinguishing feature which varies from yellowish green in $G$. travancorica, $G$. imberti and $G$. talbotii, brownish yellow in $G$. pushpangadaniana, yellow in G. gummi-gutta, red in G. wightii and G. morella and purple in G. indica.

\section{Key to the Garcinia species of the Western Ghats}

Vegetative morphological characters among the Garcinia species of the Western Ghats were evaluated systematically to construct an identification key, which will be a valuable tool for identification of the Western Ghats species in the field.

Fruit surface smooth................................

2a. Fruit less than $3 \mathrm{~cm}$ in diam. .........................

3a Fruit with 2 loculed ovary, rarely one..................4

4a Leaf linear-oblong with distinct closely arranged parallel veins.

\section{G. travancorica}

4b Leaf oblanceolate indistinct veins.

G. imberti

3b Fruit with more than 2 loculed ovary... .5

5a Leaves linear-lanceolate, fruit size of a small cherry, with pinkish 


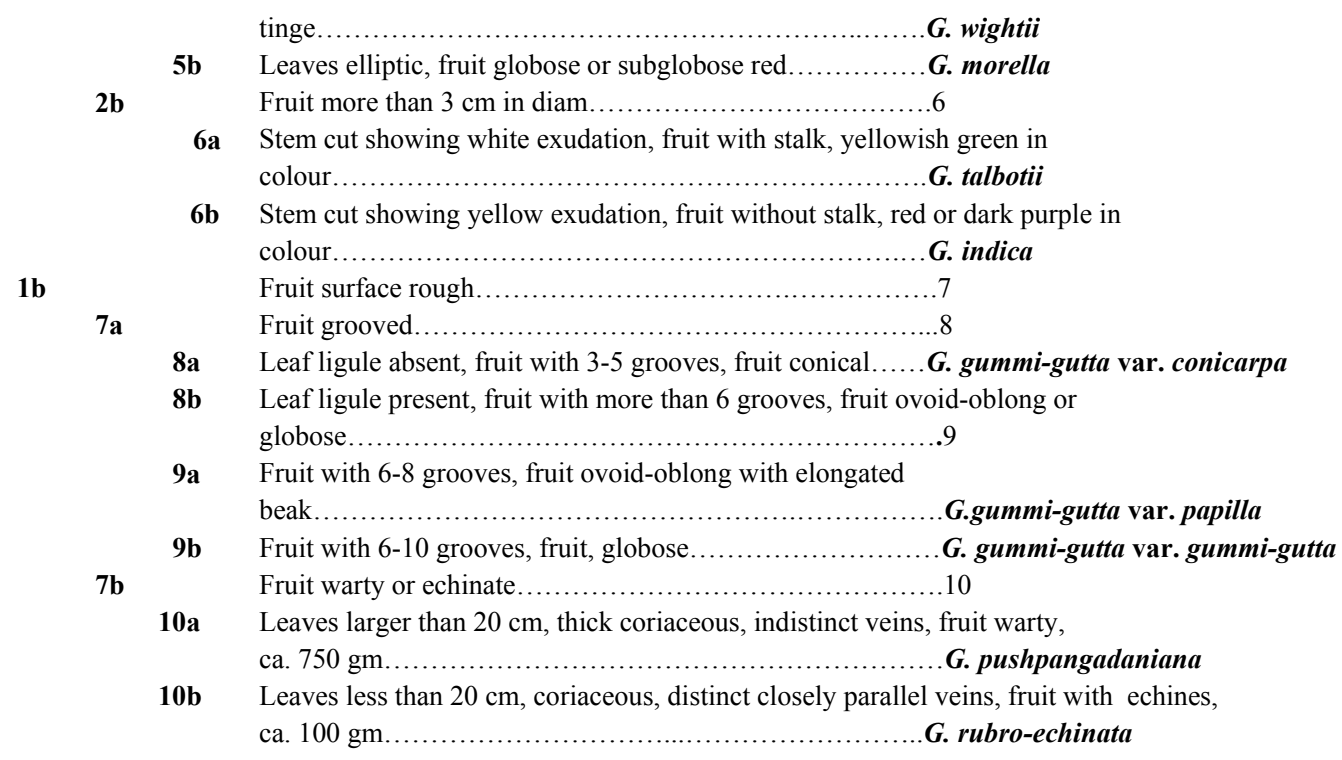

\section{Western Ghats Garcinia species}

\subsection{Garcinia gummi-gutta (L.) N. Robson}

Evergreen tree up to $20 \mathrm{~m}$ high; exudation pale yellow, sticky.

Leaves: Elliptic, obelliptic-ovate, $6-13 \times 2.5-6 \mathrm{~cm}$.

Male flowers: Tetramerous, 3-8 flowers on axillary fascicles, 1-1.7 x 1-1.2 cm, pedicel 7-12 mm long; sepals orbicular, margin membraneous with fimbril like projections; petals oblong, pale yellow or orange yellow, membraneous on margin; stamens in a globose head; rudimentary pistil absent or if present stigma discoid with 4 lobed cleft.

Female flowers: Tetramerous, solitary or 1-3 fascicle on terminal or axillary, $1.5-2 \times 1.5 \mathrm{~cm}$; staminodes 10-20; ovary 4-12 locular, ca. $1 \mathrm{~mm}$ long, ovule one in each locule, subglobose or ovoid, grooved, stigmatic rays spreading, free nearly to the base, margin crenate, tuberculate. Fruits: Globose, 6-8 cm in diam., 6-10 grooved, yellow or orange yellow on ripening, pericarp very thick, fleshy.

Seeds: 6-8, ovoid, 2-3.3 x 0.7-0.9 mm, compressed, surrounded by white or red pulpy aril.

Field identification characters

i. Leaves elliptic, 6-13 cm long.

ii. Stigmatic lobes 6-10.

iii. Fruit deeply grooved, grooves 6-10.

Garcinia gummi-gutta var. papilla (Wight) N. P. Singh

Evergreen tree up to $15 \mathrm{~m}$ high; exudation yellow.

Leaves: Elliptic, 6-9 x 1.5-3cm.

Male flowers: Tetramerous, 3-5 flowers in axillary fascicles, ,1-1.5 x 1-1.2 cm; pedicels stout, 5-7 mm long; sepals ovate to oblong, margin membraneous ; petals oblong, brick red, margin membraneous; stamens in a globose androphore; rudimentary pistil rarely present. 
Female flowers: Tetramerous, 1-3 flowers on solitary or fascicles, terminal or axillary, 1-1.2 x 7-10 mm; staminodes in a ring; ovary 6-8 locular, 1-ovule in each locule, subglobose, grooved, stigmatic rays 4-8.

Fruits: Subglobose, yellowish green, ca. $6 \mathrm{~cm}$ in diam., 4-8 grooved with a terminal mamilla, pericarp very thick, fleshy.

Seeds: 3-5, sub-triangular, 2-3 x 0.8-10 mm, enclosed in a thick mass of fibrous aril.

Field identification characters

i. Young shoot and margin of leaf shows reddish tinge.

ii. Fruit ovoid-oblong with 4-8 grooves and with terminal mamilla

Garcinia gummi-gutta var. conicarpa (Wight) N. P. Singh

Evergreen tree up to $15 \mathrm{~m}$ high; exudation yellow.

Leaves: Obovate-ovate, rarely oblong or broader beyond the middle, 6-10 x 4-8 cm.

Male flowers: Tetramerous, solitary or 2-5 flowered fascicles, axillary or terminal, 1-1.5 x 1$1.2 \mathrm{~cm}$, pedicels stout, ca. $5 \mathrm{~mm}$ long; sepals ovate, margin membraneous with fimbril like projection; petals yellow, oblong-orbicular, slightly membraneous margin; stamens in a convex torus head; rudimentary pistil absent or present.

Female flowers: Tetramerous, solitary or 2-3 flowered fascicles, terminal or sub terminal, 11.5 x 1-3 cm, sessile; staminodes in a ring; ovary 3-5 locular, ovule one in each locule, ovoid, grooved, stigmatic rays 3-5.

Fruits: Usually conical, rarely ovoid, yellowish green, ca. $5 \mathrm{~cm}$ in diam., 3-5 grooves with a terminal mamilla, grooves, pericarp very thick, fleshy.

Seeds: 2-4, ovate-oblong, 2-3 x 0.8-10 mm, enclosed in a thin fibrous aril.

Due to the distinct morphological and chemical characteristics, it is suggested that species status may be reinstated for the variety conicarpa (Chapter 8).

Field identification characters

i. Absence of leaf ligule on petiole.

ii. Shape of leaf broader beyond the middle.

iii. Conical shape of fruit with 3-5 grooves.

\subsection{Garcinia imberti Bourd.}

Evergreen medium sized tree up to $20 \mathrm{~m}$ high; exudation white; branches horizontal spreading.

Leaves oblanceolate, $6-12$ × 2-6 cm.

Male flowers: Tetramerous, 3-6 or 9 flowerered fascicles, or rarely cyme or paired, terminal 5-6 x 4-5 mm, sessile; sepals sub orbicular, membraneous; petals orbicular, pale yellow, membraneous; stamens in a central globose mass, pistil rudimentary.

Female flowers: Tetramerous, solitary, or rarely in pairs, terminal, 6-8 x $6 \mathrm{~mm}$; ovary 2loculed, globose, ovule one in each locule, stigma sessile, convex, capitate; staminodes many, united in a ring around the ovary.

Fruits: Sub-globose, greenish, 2.2-2.5 cm in diam., smooth

Seeds: 1-2, enclosed in a fibrous aril.

Field identification characters

i. Bark brown mottled with white. 
ii. Leaves less than $12 \mathrm{~cm}$ long, oblanceolate with shortly caudate acuminate at apex.

iii. Berry sub-globose, usually 1-2 seeded fruit, crowned by capitated stigma.

\subsection{Garcinia indica (Thouars) Choisy}

Evergreen to semi-evergreen tree up to $15 \mathrm{~m}$ high; exudation milky; branches with conical crown or pendulous drooping.

Leaves: Lanceolate or obovate-oblong, 6-12 x 1.5-5 cm, Male flowers: Tetramerous, 4-8 flowered fascicles, axillary or terminal, 5-9 x 5-8 mm, pedicel stout, ca. $4 \mathrm{~mm}$ long; sepals ovate-rotundate, membraneous; petals orbicular, creamy white, membraneous; stamens inserted on hemispheric, sub-quadrate torus; rudimentary pistil absent or if present as long as stamens.

Female flowers: Tetramerous, solitary, terminal, sub-sessile; ovary, subglobose, stigmas convex, 4-8 rayed, coronate, sessile.

Fruits: Spherical, orange-pink, deep purple when ripe, up to $4 \mathrm{~cm}$ in diam., pulp red, fleshy.

Seeds: 5-8, compressed.

Field identification characters

i. Branches with conical crown or pendulous drooping.

ii. Berries smooth, not grooved, deep purple when ripe.

5.4. Garcinia morella (Gaertn.) Desr.

Evergreen medium sized tree up to $18 \mathrm{~m}$ high; exudation deep yellow, sticky.

Leaves: Elliptic, ovate or obovate, $10-15 \times 4-8 \mathrm{~cm}$.

Male flowers: Tetramerous, ca. 3 flowered fascicles, axills of fallen leaves, 1-1.2 x 5-10 mm, sessile or short pedicel, 4-6 mm long; sepals orbicular or elliptic, membraneous; petals rotundate or orbicular, white to pink, membraneous; stamens in a central subglobose mass; rudimentary pistil absent.

Female flowers: Tetramerous, solitary, axillary, ca. 1 x ca. $0.5 \mathrm{~cm}$, sessile; staminodes, connate at base into a ring around ovary; ovary 4-locular, sub-globose; stigma coronate, tubercled.

Fruits: Sub-globose or globose, yellow with reddish tinge, $2.5-3$ x 2-3 cm, smooth

Seeds: Ovoid-reniform, 4, laterally compressed and dark brown.

Field identification characters

i. Petiole folding longitudinally above.

ii. Leaves with 8-12 pairs of lateral veins, midrib prominent below and margin revolute and wavy.

iii. Tubercled stigma.

5.5. Garcinia pushpangadaniana T. Sabu, N. Mohanan, Krishnaraj and Shareef

Evergreen to semi-evergreen medium sized tree up to $20 \mathrm{~m}$ high; bark exudation milky.

Leaves: Elliptic-oblong, $14-20$ x 6-8 cm.

Male flowers: Pentamerous, ca. 2-10 flowered fascicles, axillary, 1-1.5 x.1cm, pedicel 7-10 $\mathrm{mm}$ long; sepals orbicular-sub-orbicular, margin ciliate; petals orbicular, pinkish pale greenish white, membraneous margin; stamen 5-phalangiate; rudimentary pistil present. 
Female flowers: Pentamerous, ca. 2-8 flowered fascicles, axillary, 1-1.5 x 1-1.3 cm; staminodes arranged in 5-phalanges; ovary 6-8 loculed, $6 \mathrm{~mm}$ in diam., globose, stigma 6-8 lobed, oblong, stellate.

Fruits: Globose, pale yellowish brown, 13 x $11 \mathrm{~cm}$, fleshy, without pulpy aril, irregularly ridged surface.

Seeds: 1-4, plano-convex, whitish yellow, up to ca. $2 \mathrm{~cm}$ long.

Field identification characters

i. Tree with pyramidal crown.

ii. Leaves 14-20 × 6-8 cm long, elliptic-oblong, thick coriaceous, lateral nerves 28 34 pairs.

iii. Large fruits $(600-750 \mathrm{~g})$, globose and irregularly ridged on the surface.

\subsection{Garcinia rubro-echinata Kosterm.}

Evergreen tree up to $20 \mathrm{~m}$ tall; exudate brownish-white.

Leaves: Sub-obovate to broadly elliptic, $8-15$ x 3-8 cm.

Male flowers Tetramerous, fascicled, axillary or terminal, pale green, $1.6-2 \times 1.5 \mathrm{~cm}$, sessile; sepal orbicular-obtuse, margin membraneous; petals sub-orbicular to oblong, pale green, membraneous; stamens in a tetragonous torus; pistil rudimentary.

Female flowers: Tetramerous, solitary, terminal, pale green, 1.8-2.5 x 1.5-1.8 cm, sessile; staminodes ca.22, connate in to a ring at base, disc present at intercalary position; ovary 3-4 locular, covered with numerous fleshy scales; stigmas peltate, irregularly lobed.

Fruits: Sub-globose or ellipsoid, dark red, 4-6 x 2.5-4 cm, covered with spines or broad tubercles.

Seeds: $1-3$, oblong, up to $4 \mathrm{~cm}$ long with scanty aril.

Field identification characters

i. Bark greenish white with yellow red or white mottles.

ii. Lamina usually obovate with numerous parallel lateral veins.

iii. Fruit covered with spines.

\subsection{Garcinia talbotii Raizada ex Santapau}

Evergreen tree up to $20 \mathrm{~m}$ tall; exudate white, turning brownish after exposure.

Leaves: Elliptic-ovate, oblong or ovate-oblong, 7.5-18 x 3-10 cm.

Male flowers: Pentamerous, fascicled, axillary or terminal, creamy-white, $1.8-2.3 \mathrm{~cm}$ long, pedicel, ca. $1 \mathrm{~cm}$ long; sepal orbicular, margin membraneous, rarely ciliate; petals orbicularobovate, rarely sub-orbicular, creamy-white or greenish-yellow, margin membraneous; stamens in to 5 phalanges; rudimentary pistil absent.

Female flowers: Pentamerous, fascicled, axillary, creamy-white, 1.8-2.7 cm long, pedicel, ca. $1 \mathrm{~cm}$ long; staminodes in 5 delicate phalanges; ovary 3-locular, very rarely 4 , globose, stigma peltate, 3 lobed.

Fruits: Globose, greeninsh-yellow on ripening, 4-6 x 3.8-5 cm, fleshy, rind surface shows an yellow resins.

Seeds: 1-3, oblong, ca. $3 \mathrm{~cm}$ long with yellow pulpy aril.

Field identification characters

i. Exudation milky, turning brownish after exposure. 
ii. Leaves usually ovate.

iii. Fruit greenish yellow, ripe fruit pulp sweet-scented, stigmatic lobe 3.

\subsection{Garcinia travancorica Bedd.}

Evergreen tree up to $15 \mathrm{~m}$ high; exudate yellow.

Leaves: Linear-oblong, 5.5-10 x 1-2 cm.

Male flowers: Tetramerous, trichotomous short cymes, terminal or sub terminal, 1.2-1.5 x 0.8-1 cm, pedicel short, ca. 2-3 mm long; sepals orbicular, margin membraneous; petals orbicular, creamy white, membraneous; stamens numerous in 4-tetragone masse; rudimentary pistil columnar, with a circular peltate stigma.

Female flowers: Tetramerous, solitary or paired, terminal or sub terminal, 1.3-1.5 x 8-1.2 cm; staminodes in 5-phalanges; ovary 1-2 locular, subglobose or pyriform; stigma 3-lobed and spreading.

Fruits: Ovoid-oblong, 2-3 x 1-2.5 cm, stigma persistent to fruit.

Seeds: Usually 1, rarely 2, ovoid, up to $2-2.5$ x $0.7-1 \mathrm{~cm}$.

\section{Field identification characters}

i. Leaves narrow oblong, less than $3 \mathrm{~cm}$ broad with secondary nerves closely parallel and horizontal.

ii. Male flowers trichotomous cyme.

iii. Female flowers with broad yellow stigma.

\subsection{Garcinia wightii $\mathrm{T}$. Anderson}

Evergreen tree up to $15 \mathrm{~m}$ high; exudation deep yellow to orange yellow.

Leaves: Linear-lanceoalte, 6-14 x 1.5-3 cm.

Male flowers: Tetramerous, solitary or 2-3 together, sometimes numerous, axillary, 1-1.2 $\mathrm{x}$ 0.8-1 cm, sessile; sepals orbicular, margin membraneous; petals obovate, creamy white, membraneous; stamens in tetragons head.

Female flowers: Tetramerous, solitary, axillary, 1-1.5 x 5-7 mm, sessile; staminodes 4phalanges; ovary 4-locular, globose; stigma 4-lobed.

Fruits: Sub-globose, rose with pinkish tinged, 1.2-1.5 x 0.9-1 cm, smooth, with persistent stigma and sepals.

Seeds: 4 , up to ca. $9.5 \times 4.5 \mathrm{~mm}$ long.

Field identification characters

1. Leaves less than $3 \mathrm{~cm}$ wide, linear-lanceolate tapering at both ends, secondary veins very oblique.

2. Fruit colour rose with pinkish tinge.

\section{Conclusions}

Garcinia species are important components of the flora of the Western Ghats and also an economically important group. Field surveys revealed that 9 species and 2 varieties are indigenous to the Western Ghats of which 7 species and 2 varieties are endemic to the region. Distribution, distinguished morphological features and conservation aspects of Garcinia species of the Western Ghats were discussed in detail. Agasthyamala forests in the Western Ghats region, with natural distribution of 6 Garcinia species, can be considered as the centre of diversity of Garcinia species in the Western Ghats. 


\section{References}

1. Anderson T. 1874. Guttiferae. In: Hooker JD. (ed.) Flora of British India. 1. L. Reeve and Co., London. 259-278.

2. Anonymous. 1950. Wealth of India Raw Materials, 4. CSIR, New Delhi. 99-108.

3. Anonymous. 2014. Plant Discoveries, New genera, species and new records. Botanical Survey of India, Ministry of Environment and Forests.

4. Bamps P, Robson N and Verdcourt B. 1978. Flora of Tropical East Africa: Guttiferae. Crown Agents for Overseas Government and Administration, London.

5. Dunthorn M. 2004. Cryptic dioecy in Mammea (Clusiaceae). Plant Syst. Evol., 249, 191-196.

6. Engler A. 1925. Guttiferae. In: Engler A and Prantl K (eds.), Die natürlichen Pflanzenfamilien. 21, Engelmann W, Leipzig, 154-237.

7. Garcin L. 1733. The settling of a new genus of plants, called after the Malayans, Mangostans. Translated by Mr. Zollman. Philosophical Transactions (1683-1775) 38, 232-242.

8. Gustafsson MHG, Bittrich V and Stevens PF. 2002. Phylogeny of Clusiaceae based on rbcL sequences. Int. J. Plant Sci., 163, 1045- 1054.

9. Hooker JD. 1875. Observation on some Indian species of Garcinia. Journal of the Linnean Society Botany, 14, 484-486.

10. Jones S. 1980. Morphology and major taxonomy of Garcinia (Guttiferae). Ph.D. dissertation. London, University of Leicester and British Museum, 474.

11. Jussieu AL. 1789. Genera plantarum. Viduam Herissant, Paris.

12. Kostermans AJGH. 1977. Miscellaneous Botanical notes. Ceylon Journal of Science (Biological Sciences, 12, 128.

13. Linnaeus C. 1753. Species Plantarum 1. Salvius L, Stockholm.

14. Maheshwari JK. 1964. Taxonomic studies on Indian Guttiferae III. The genus Garcinia L. Bulletin of the Botanical Survey of India, (2-4), 107-135.

15. Moat J. 2007. Conservation assessment tools extension for ArcView 3.x, version 1.2. GIS Unit, Royal Botanic Gardens, Kew. Available at: http:/www.rbgkew.org.uk/gis/cats

16. Mohanan N, Shaju T, Rajkumar G and Pandurangan AG. 1997. Rediscovery of Garcinia imberti Bourd. (Clusiaceae), a little known endemic species of Western Ghats. Indian J. Forestry, 20 (4), 383-385.

17. Nayar TS, Beegam AR and Sibi M. 2014. Flowering plants of the Western Ghats, India. JNTBGRI, Thiruvananthapuram.

18. Nimanthika WJ, Kaththriarachchi HS. 2010. Systematics of genus Garcinia L. (Clusiaceae) in Sri Lanka. New insights from vegetative morphology. Journal of National Science Foundation, 38, 29-44.

19. Pierre L. 1882-1885. Flore forestiere de la Cochinchine, Paris. (1-2), pl. 54-98.

20. Raizada.1960. In: Santapau H. Flora of Khandala. Records of the Botanical Survey of India. 14 (1), 14.

21. Robson NKB. 1961. Guttiferae. In: Exell AW and Wild H (eds.), Flora Zambesiaca.1, Mozambique, Federation of Rhodesia and Nyasaland, Bechuanaland Protectorate Crown Agents for Overseas Government, London, 378-404.

22. Rogers SZ, Sweeney PW. 2007. Two distinctive new species of Malagasy Garcinia (Clusiaceae). Systematic Botany, 32,772-779. 
23. Sabu T, Mohanan N, Krishnaraj MV, Shareef SM, Shameer PS and Roy PE 2013. Garcinia pushpangadaniana, (Clusiaceae) a new species from southern Western Ghats, India. Phytotaxa, 116 (2), 51-56.

24. Sarma J, Shameer PS, Mohanan NN. 2016. A new species of Garcinia (Clusiaceae) from Assam, North East India. Phytotaxa, 252 (1), 73-76.

25. Sharma BPH, Handique PJ, Sunitibala Devi H. 2013. A Historical and Taxonomic Overview of Garcinia L. and its reproductive ecology. Folia Malaysiana, 14 (1), 63-76.

26. Singh NP. 1993. Clusiaceae (Guttiferae nom. alt.) In: Sharma, BD and Balakrishnan NP (eds.), Flora of India 3. Botanical Survey of India, Kolkatta, 86-151.

27. Srivastava SK. 1994 Garcinia dhanikhariensis (Clusiaceae), a new species from Andaman Islands, India. Nordic Journal of Botany, 14, 51-53.

28. Stevens PF. 2007. Clusiaceae. The families and genera of vascular plants. 9, Kubitzki K (ed.), Berlin, Springer, 48-66.

29. Sweeney PW. 2008. Phylogeny floral diversity in the genus Garcinia (Clusiaceae) and relatives. Int. J. Pl. Sci., 169 (9), 1288-1303.

30. Tootil E. 1984. The Penguin Dictionary of Botany. Penguin Books, London

31. Whitmore TC. 1973. Guttiferae. In: Whitmore TC (ed.), Tree Flora of Malaya, a Manual for Foresters. 2, Longman, London, 196-225. 


\title{
Chapter 2
}

\section{Structural diversity of secondary metabolites in Garcinia species}

\author{
A. P. Anu Aravind, Lekshmi N. Menon and K. B. Rameshkumar* \\ Phytochemistry and Phytopharmacology Division \\ Jawaharlal Nehru Tropical Botanic Garden and Research Institute \\ Palode, Thiruvananthapuram-695562, Kerala, India \\ ${ }^{*}$ Corresponding author
}

\begin{abstract}
Plants of the genus Garcinia produce structurally diverse secondary metabolites such as biflavonoids, xanthones, benzophenones, flavonoids, biphenyls, acyl phloroglucinols, depsidones and terpenoids. The rich diversity in chemical structures made the genus Garcinia attractive for the phytochemists. In addition, several industrial sectors such as cosmetic, food, pharmaceutics, neutraceutics and paints are centered around the genus. The genus is represented by more than 250 species, among which nearly 120 species were subjected to phytochemical investigation. A review of the structural diversity of secondary metabolites of Garcinia species revealed that xanthones are the important class of secondary metabolites, distributed in 74 Garcinia species, followed by benzophenones in 50 species and biflavonoids in 45 species. Biphenyls, acyl phloroglucinols, depsidones and flavonoids are some other interesting group of phenolic compounds in Garcinia species. The present chapter enlists the major phenolic compounds reported from Garcinia species.
\end{abstract}

Keywords: Garcinia, Secondary metabolites, Xanthones, Biflavonoids, Benzophenones

\section{Introduction}

Plants continue to be an important source of diverse chemical structures with broad utilities in several fields like medicines, cosmetics, food, neutraceutics and pesticides. Despite the availability of alternative synthetic substituents, there has been an increasing awareness worldwide towards the use of phytochemicals and other plant derived products. The ever increasing demand for phytochemicals can be attributed to their diverse and complex chemical structures that are difficult to replicate in the laboratory, greater number of chiral centres and increased steric complexity compared to synthetic compounds (Croteau et al., 2000, Hostettman and Marston, 2002).

The genus Garcinia is well known for the value added products such as essential oils, fats, resins and colouring materials. Gamboge, the yellow colouring pigment, is a well known product from Garcinia species. Fruits of some Garcinia species are rich source of red pigments in the plant kingdom. Garcinia fruits are the source for a natural diet ingredient (-) hydroxycitric acid (HCA), which is an anti-obesity compound (Hemshekhar, et al., 2011, Parthasarathy, et al.,2013).

Recently, Garcinia species have received considerable attention worldwide from scientific as well as industrial sectors and several novel structures, bioactivities and potential utilities have been reported. Several industrial sectors like pharmaceutical, nutraceutical, 
paint and food additives were centred around this potential group of trees (Hemshekhar, et al., 2011, Magadula and Mbwambo 2014). In south India, G. gummi-gutta and G. indica were cultivated for commercial extraction of a variety of products such as bioactive acids, nutraceuticals, fats and condiments. In USA alone, mangosteen based beverages had a turnover of more than $\$ 200$ million in 2008 .

The genus Garcinia is represented by 250 species in the pantropical region, with high species richness in South East Asia. In India, 43 species and 5 varieties of the genus are reported, of which 37 species and 4 varieties occur in wild naturally, while the rest were introduced into cultivation. Nine Garcinia species were reported to occure naturally in the Western ghtas, of which 7 are endemic to the region (Sabu et al., 2013, Sarma et al. 2016). Of the nearly 250 species reported from world over, nearly 120 species were subjected to phytochemical investigation. Though several monographs and reviews on Garcinia species have appeared, a compilation of the phytochemistry of the Garcinia species has seldom been attempted (Obolskiy et al., 2009). Venkataraman (1973) has reviewed the chemistry of pigments from Garcinia species. A recent review on phytochemistry of Garcinia species in Africa revealed that out of the 80 Garcinia species reported in Africa, only 21 species have been investigated phytochemicaly (Magadula and Mbwambo 2014). Literature review revealed that out of the 9 Garcinia species reported from the Western Ghats, only 4 species have been studied in detail for their phytochemicals (Pandey et al., 2015, Anu Aravind et al., 2015).

Garcinia species are reported as rich depository of structurally diverse secondary metabolites such as xanthones, benzophenones and biflavonoids, in addition to flavonoids, biphenyls, acyl phloroglucinols, depsidones and triterpenoids as minor constituents. Volatile mono and sesqui terpenoids, and phenyl proapnoids were also reported from Garcinia species. Present chapter review the diversity of phytochemicals, especially the phenolic compounds, reported from Garcinia species worldover.

\section{Xanthones}

Xanthones, with two aromatic rings linked via carbonyl and ether linkages, are a group of secondary metabolites originated biosynthetically by condensation of acetate and shikimate derived moieties. Xanthones can be considered as regioselectively cyclized benzophenone derivatives. The mixed biogenetic origin of xanthone necessitates that the carbons be numbered according to biosynthetic convention (Figure 1). Carbons 1-4 were assigned to the acetate derived ring A, while the carbons 5-8 to the shikimate derived ring B (Gottlieb, 1968, Bennett and Lee, 1989).

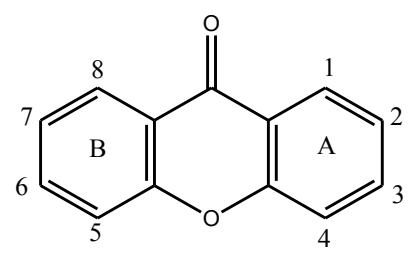

Figure 1. Numbering in typical xanthone structure 
Xanthones are limited in distribution to a few plant families such as Clusiaceae, Gentianaceae, Moraceae and Polygalaceae and several reviews on xanthones have been published (Afsal and Al Hassan, 1980, Sultanbawa, 1980; Bennet and Lee, 1989, Peres et al., 2000, Chantarasriwong et al., 2010, Anantachoke et al., 2012). Garcinia species are important sources of xanthones and literature review revealed that 74 Garcinia species, comprising more than half of all the Garcinia species studied so far, were reported to contain xanthones (Table 1). Among different Garcinia species, G. mangostana has been studied extensively, and reported to conatin the highest number of xanthones followed by G. cowa.

The xanthones isolated can be classified into five major groups: simple oxygenated xanthones, prenylated xanthones, xanthone glycosides, xanthonolignoids, and miscellaneous xanthones (Mandal et al.,1992). Simple oxygenated xanthones are subdivided according to the degree of oxygenation into mono-, di-, tri-, tetra-, penta- and hexa-oxygenated xanthones. Isopentenyl and geranyl substituted xanthones are the common types in the genus Garcinia. The isopentenyl group may be modified by terminal cyclisation with ortho hydroxyl group to give a chromene system as in the case of jacareubin (Bennet and Lee, 1989). In some cases, the geranyl group may undergo cyclisation leading to structurally intriguing class of secondary metabolites known as caged xanthones, where $\mathrm{C}$ ring has been converted into an unusual 4-oxa-tricyclo[4.3.1.03,7]dec-8-en-2-one ring (caged) scaffold (Yang, et al., 2012). Caged xanthones like gambogic acid and morellin were mainly reported from the genus Garcinia (Figure 2). Some of the bixanthones reported from Garcinia species are bigarcinenone ( $G$. xanthochymus), garcilivins ( $G$. livingstonei), garciobioxanthone ( $G$. oblongifolia) and griffipavixanthone (G. griffithi). Bennet and Lee (1989) have pointed that 1,3,5,6 tetraoxygenated xanthones were reported only from African Garcinia species and not from any of the Asian Garcinia species.<smiles>COc1c(O)cc2oc3cc(O)c(CC=C(C)C)c(O)c3c(=O)c2c1CC=C(C)C</smiles>

$\alpha-$ Mangostin

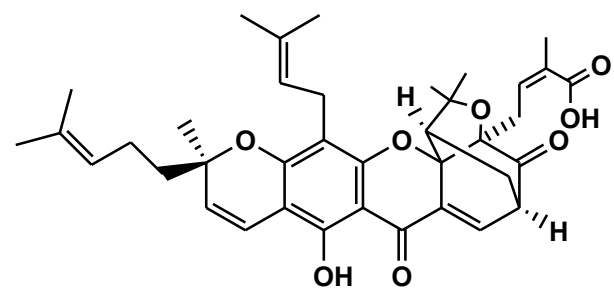

Gambogic acid<smiles></smiles>

Rheediaxanthone A<smiles>CC(C)=CCC/C(C)=C/Cc1c(O)c(O)c2oc3cc(O)cc(O)c3c(=O)c2c1CC=C(C)C</smiles>

Garciniaxanthone E

Figure 2. Prenylated xanthone ( $\alpha$-mangostin), xanthone with terminal cyclisation and ortho-hydroxyl group (rheediaxanthone), geranyl substituted xanthone (garciniaxanthone E) and caged xanthone (gambogic acid) 
Though complex in structure, Yang, et al. (2012) reported the rapid characterization of caged xanthones in the resin of $G$. hanburyi using multiple mass spectrometric scanning modes. The hyphenated approach combining centrifugal partition chromatography (CPC), highperformance liquid chromatography (HPLC) with diode-array detection (DAD) and mass spectrometry (MS) was applied to the fractionation and purification of xanthones from $G$. mangostana fruits, where CPC efficiently separated the metabolites while the structural information was obtained from mass spectral data (Michel et al., 2012). A simple UV-Vis spectrophotometry method has been reported for the estimation of xanthones in $G$. mangostana, using $\alpha$-mangostin, that has absorption maxima at 243.4 and $316.4 \mathrm{~nm}$, as the reference compound (Aisha et al., 2013).

Xanthones are attributed with remarkable bioactivities such as antibacterial, antifungal, antiviral, antioxidant, anti-inflammatory and cytotoxic to cancer cells (Chin et al., 2008; Peres et al.,2000). The xanthone $\alpha$-mangostin, attributed with antioxidant and anticarcinogenic properties, is one of the active ingredients of nutritional supplements derived from mangosteen (G. mangostana) fruits (Gutierrez-Orozco and Failla, 2013). Most of the caged xanthones are reported with potential antitumor activity, with gambogic acid being the best representative and most studied member of this group of compounds (Han and $\mathrm{Xu}, 2009$, Chantarasriwong et al., 2010, Xu et al., 2015). Desoxymorellin, morellic acid, gambogic acid, forbesione, hanburin, and dihydroisomorellin were reported to exhibit anti-HIV1 activity (Reutrakul et al., 2007). 7-O-methylgarcinone E, cowanin, cowanol, cowaxanthone, and $\beta$-mangostin were found to possess in vitro antimalarial activity against Plasmodium falciparum (Likhitwitayawuid et al.,1998). $\alpha$ - and $\beta$-Mangostins, and garcinone B exhibited strong inhibitory effect against Mycobacterium tuberculosis. Structure activity relationship (SAR) studies showed that tri- and tetra-oxygenated xanthones with di-C5 units or with a C5 and a modified C5 groups are essential for higher activities (Suksamrarn et al., 2003).

Table 1. Xanthones reported from Garcinia species

\begin{tabular}{|c|c|c|c|c|}
\hline $\begin{array}{l}\text { Sl. } \\
\text { No. }\end{array}$ & $\begin{array}{l}\text { Garcinia } \\
\text { species }\end{array}$ & Plant part & Xanthones & Reference \\
\hline 1 & G. afzelii & Stem bark & Afzeliixanthones A and B & $\begin{array}{l}\text { Waffo et al., } \\
2006\end{array}$ \\
\hline 2 & $\begin{array}{l}\text { G. } \\
\text { amplexicaulis }\end{array}$ & Stem bark & $\begin{array}{l}\text { Cudraxanthone G, 1,3,5-trihydroxy-4- } \\
\text { prenylxanthone, nigrolineaxanthone F, and 1,3,7- } \\
\text { trihydroxy-2-prenylxanthone }\end{array}$ & $\begin{array}{l}\text { Lavaud et al, } \\
2015\end{array}$ \\
\hline 3 & G. assigu & Stem bark & $\begin{array}{l}\text { Assiguxanthone A and B, dulxanthone A-D, and } \\
\text { latisxanthone A-D }\end{array}$ & Ito et al., 1997 \\
\hline 4 & G. atroviridis & Stem bark & Garcinexanthone $\mathrm{G}$ & Tan et al.,2016 \\
\hline \multirow[t]{2}{*}{5} & \multirow[t]{2}{*}{ G. benthamiana } & Leaf & 1,3,6,7-Tetrahydroxy xanthone & $\begin{array}{l}\text { Amelia et al., } \\
2015\end{array}$ \\
\hline & & Stem bark & Benthamianone & See et al., 2016 \\
\hline \multirow[t]{2}{*}{6} & \multirow[t]{2}{*}{ G. bracteata } & Leaf & $\begin{array}{l}\text { Garcibracteatone, xerophenone } \mathrm{C}, 5-\mathrm{O}- \\
\text { methylxanthone } \mathrm{V}_{1} \text {, nemorosonol, and 10-O- } \\
\text { methyl macluraxanthone }\end{array}$ & $\begin{array}{l}\text { Thoison et al, } \\
2005\end{array}$ \\
\hline & & Bark & $\begin{array}{l}\text { Neoisobractatins A and B, and bracteaxanthone I } \\
\text { and II }\end{array}$ & $\begin{array}{l}\text { Thoison et al, } \\
2005\end{array}$ \\
\hline
\end{tabular}




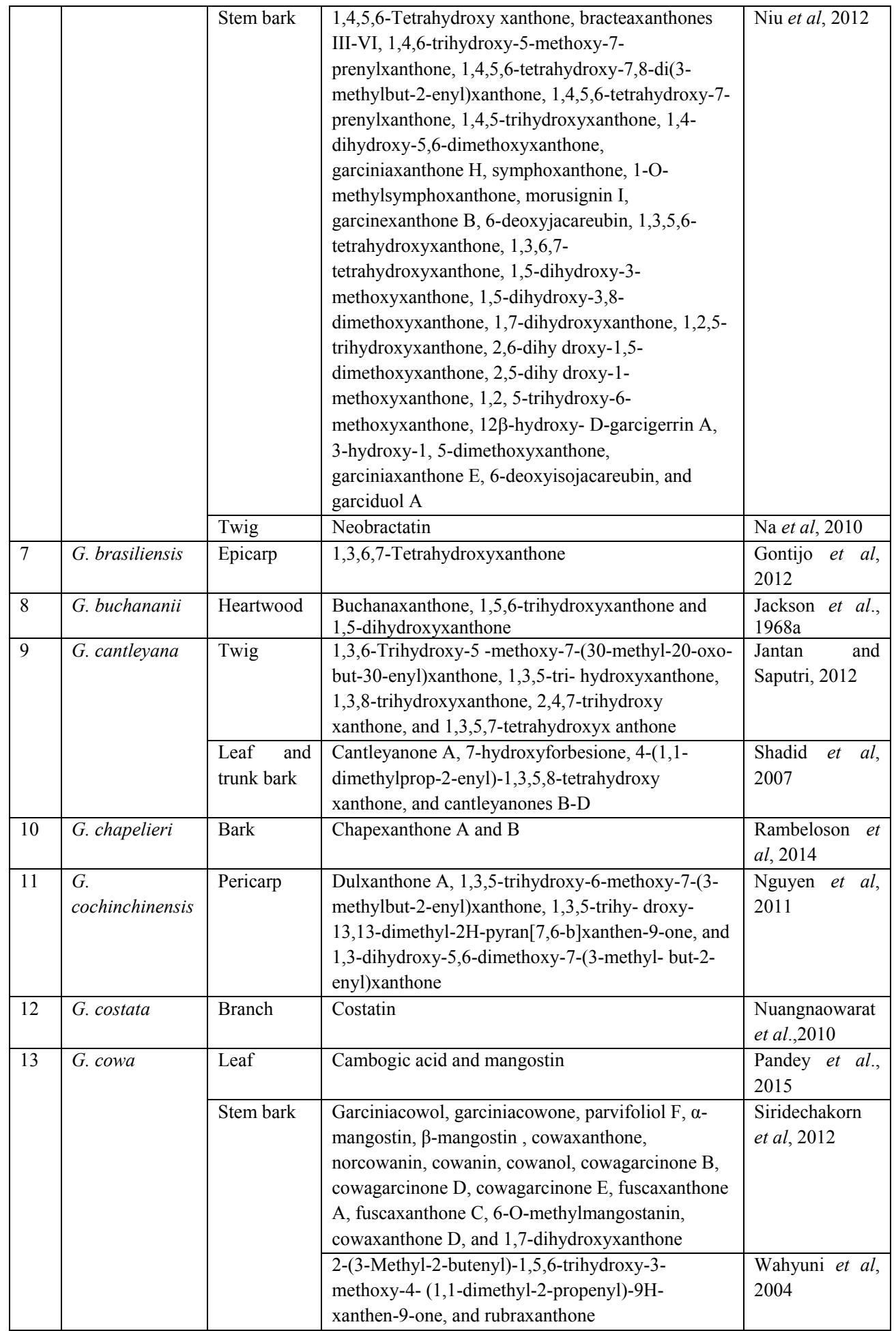




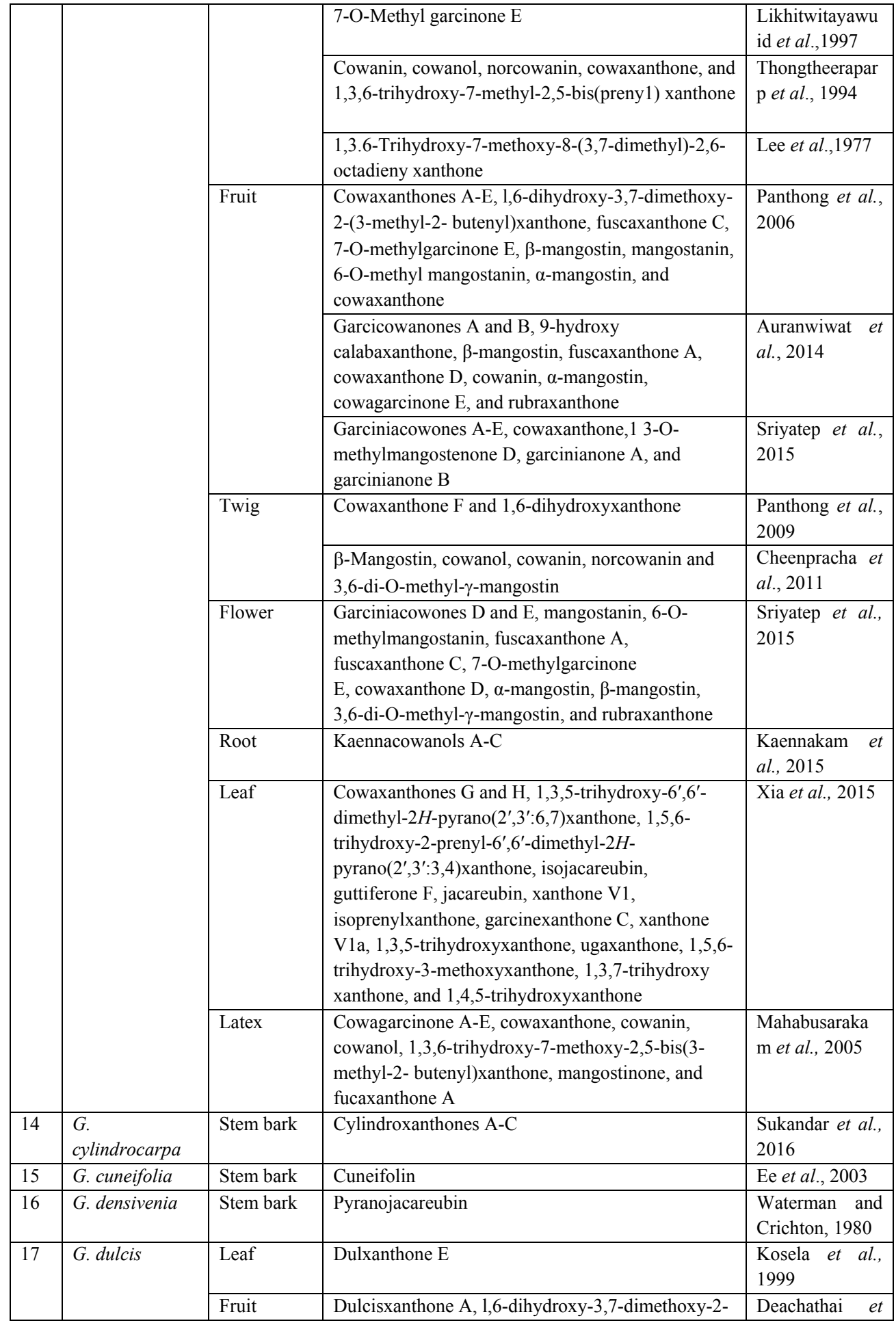




\begin{tabular}{|c|c|c|c|c|}
\hline & & & $\begin{array}{l}\text { (3-methyl-2-butenyl)xanthone, cowaxanthone, } \\
\text { cowanin, 1,7-dihydroxy-3-methoxy-2-(3- methyl-2- } \\
\text { butenyl)xanthone, 1,5,8-trihydroxy-3-methoxy-2- } \\
\text { (3-methyl-2- butenyl) xanthone, BR-xanthone A, } \\
\text { mangostin, 6,8,12-trihydroxy-7-(3-methyl-2- } \\
\text { butenyl)- 2-methyl-2-(4-methyl-3- } \\
\text { pentenyl)pyrano(20,30:7, 8)xan thone, garcinone D, } \\
\text { mangostenol, tovophyllin A, and cratoxylone }\end{array}$ & al., 2005 \\
\hline \multirow[t]{2}{*}{18} & \multirow[t]{2}{*}{ G. echinocarpa } & $\begin{array}{l}\text { Bark and } \\
\text { wood }\end{array}$ & $\begin{array}{l}\text { 1,5-Dihydroxyxanthone and 1,3,6,7-tetrahydroxy } \\
\text { xanthone }\end{array}$ & $\begin{array}{l}\text { Bandaranayake } \\
\text { et al., } 1975\end{array}$ \\
\hline & & Leaf & Cambogic acid and mangostin acid & $\begin{array}{l}\text { Pandey et al., } \\
2015\end{array}$ \\
\hline 19 & G. edulis & Root bark & $\begin{array}{l}\text { 1,4,6-Trihydroxy-3-methoxy-2-(3-methyl-2- } \\
\text { butenyl)-5-(1,1- dimethyl-prop-2-enyl) xanthone } \\
\text { and forbexanthone }\end{array}$ & Magadula, 2010 \\
\hline 20 & G. esculenta & Twig & 1,3,5,7-Tetrahydroxy-8-isoprenylxanthone & $\begin{array}{l}\text { Zhang et al., } \\
2015\end{array}$ \\
\hline \multirow[t]{2}{*}{21} & \multirow[t]{2}{*}{ G. eugenifolia } & Twig & $\begin{array}{l}\text { 5,9-Dihydroxy-8-methoxy-2,2-dimethyl -7-(3- } \\
\text { methylbut-2-enyl)pyrano[3,2-b]xanthen-6(2H)-one }\end{array}$ & $\begin{array}{l}\text { Mian et al., } \\
2010\end{array}$ \\
\hline & & Heart wood & $\begin{array}{l}\text { Euxanthone, gentisin, 1,4,7-trihydroxy-3- } \\
\text { methoxyxanthone, 1,5,6-trihydroxyxanthone, and } \\
\text { 1,6,7-trihydroxyxanthone }\end{array}$ & $\begin{array}{l}\text { Jackson et al., } \\
1969\end{array}$ \\
\hline 22 & G. forbesii & $\begin{array}{l}\text { Branch and } \\
\text { twig }\end{array}$ & $\begin{array}{l}\text { Forbexanthone, pyranojacareubin, and 1,3,7- } \\
\text { trihydroxy-2-(3-methylbut-2-enyl)-xanthone }\end{array}$ & $\begin{array}{l}\text { Harrison et } \\
\text { al., } 1993\end{array}$ \\
\hline \multirow[t]{2}{*}{23} & \multirow[t]{2}{*}{ G. fusca } & Root & $\begin{array}{l}\text { Fuscaxanthone I, } \beta \text {-mangostin, fuscaxanthone } \mathrm{A} \text {, } \\
\text { cowanin, cowaxanthone, } \alpha \text {-mangostin, cowanol, } \\
\text { isojacareubin, fuscaxanthone } \mathrm{G} \text {, and } 1,3,5,6- \\
\text { tetrahydroxyxanthone }\end{array}$ & $\begin{array}{l}\text { Nontakham et } \\
\text { al., } 2014\end{array}$ \\
\hline & & Stem bark & $\begin{array}{l}\text { Fuscaxanthone } \mathrm{A}-\mathrm{H} \text {, cowaxanthone, } \beta \text {-mangostin, } \\
\text { cowanin, rubraxanthone, } \alpha \text {-mangostin, cowanol, } \\
\text { norcowanin, } 7-\mathrm{O} \text {-methylgarcinone, and garbogiol }\end{array}$ & Ito et al., 2003a \\
\hline \multirow[t]{3}{*}{24} & \multirow[t]{3}{*}{ G. gaudichaudii } & \multirow[t]{2}{*}{ Bark } & Gaudispirolactone & Wu et al., 2001 \\
\hline & & & Gaudichaudiic acids F, G, H and I & Xu et al., 2000 \\
\hline & & Leaf & $\begin{array}{l}\text { Gaudichaudiones A- H, gaudichaudiic acids A-E, } \\
\text { morellic acid, and forbesione }\end{array}$ & Cao et al., 1998 \\
\hline \multirow[t]{4}{*}{25} & \multirow[t]{4}{*}{ G. griffithii } & \multirow[t]{3}{*}{ Stem bark } & $\begin{array}{l}\text { 1,5-Dihydroxy-3,6-dimethoxy-2,7- } \\
\text { diprenylxanthone and 1,6- dihydroxyxanthone }\end{array}$ & $\begin{array}{l}\text { Elfita et al., } \\
2009\end{array}$ \\
\hline & & & $\begin{array}{l}\text { 1,7-dihydroxyxanthone, } 1,3,6,7- \\
\text { tetrahydroxyxanthone and 1,3,5,6-tetrahydroxy } \\
\text { xanthone }\end{array}$ & $\begin{array}{l}\text { Nguyen et al., } \\
2005\end{array}$ \\
\hline & & & Griffipavixanthone & $\mathrm{Xu}$ et al., 1998 \\
\hline & & Leaf & $\begin{array}{l}\text { 1,3,5,6-Tetrahydroxy-7-(3-methylbut-2- } \\
\text { enyl)xanthone and rubraxanthone }\end{array}$ & $\begin{array}{l}\text { Alkadi et al., } \\
2013\end{array}$ \\
\hline \multirow[t]{3}{*}{26} & \multirow[t]{3}{*}{$\begin{array}{l}\text { G. gummi-gutta } \\
\text { (G. cambogia) }\end{array}$} & Leaf & Cambogic acid and mangostin & $\begin{array}{l}\text { Pandey et al., } \\
2015\end{array}$ \\
\hline & & Root & Garbogiol & $\begin{array}{l}\text { Iinuma et al., } \\
1998 \\
\text { Semwal et al., } \\
2015\end{array}$ \\
\hline & & Bark & Rheediaxanthone & $\begin{array}{l}\text { Semwal et al., } \\
2015\end{array}$ \\
\hline
\end{tabular}




\begin{tabular}{|c|c|c|c|c|}
\hline & & Fruit & $\begin{array}{l}\text { Oxy-guttiferone } \mathrm{K} \text {, oxy-guttiferone } \mathrm{K} 2 \\
\text { and oxy-guttiferone } \\
\text { Oxy-guttiferones } \mathrm{M}, \mathrm{K}, \mathrm{K} 2 \text { and I }\end{array}$ & $\begin{array}{l}\text { Masullo et al, } \\
2010 \text { and } \\
\text { Semwal et al., } \\
2015\end{array}$ \\
\hline \multirow[t]{6}{*}{27} & \multirow[t]{6}{*}{ G. hanburyi } & \multirow[t]{4}{*}{ Resin } & $\begin{array}{l}\text { Garcinolic acid, } 10 \alpha \text {-ethoxy-9,10-dihydromorellic } \\
\text { acid, and } 10 \alpha \text {-ethoxy-9,10-dihydrogambogenic } \\
\text { acid }\end{array}$ & $\begin{array}{l}\text { Deng et al., } \\
2012\end{array}$ \\
\hline & & & Gambogic aldehyde & $\begin{array}{l}\text { Wang et al., } \\
2008\end{array}$ \\
\hline & & & $\begin{array}{l}\text { Forbesione, isomorellic acid, morellic acid, R-30- } \\
\text { hydroxygambogic acid, S-30-hydroxygambogic } \\
\text { acid, isogambogenic acid, gambogenic acid, R- } \\
\text { isogambogic acid, S-isogambogic acid, R-gambogic } \\
\text { acid, S-gambogic acid, desoxymorellin, } \\
\text { isogambogenin and isomorellinol }\end{array}$ & $\begin{array}{l}\text { Zhou et al., } \\
2008 \mathrm{a}\end{array}$ \\
\hline & & & $\begin{array}{l}\text { Forbesione, forbesionic acid, isoforbesionic acid, } \\
\text { desoxygaudichaudione A, gaudichaudionol, } \\
\text { isogaudichaudionol, epoxylgaudichaudione A, } \\
\text { gaudichaudione A, isogaudichaudione A, } \\
\text { gaudichaudionic acid, isogaudichaudionic acid, } \\
\text { desoxymorellin, morellinol, isomorellinol, morellin } \\
\text { isomorellin, morellic acid, isomorellic acid, } \\
\text { desoxygambogenin, gambogeninol, } \\
\text { isogambogeninol, gambogenin, isogambogenin, } \\
\text { gambogenic acid, isogambogenic acid, } \\
\text { dihydrodesoxygambogenin S-gambogic acid,R- } \\
\text { gambogic acid, S-30-hydroxygambogic acid, R-30- } \\
\text { hydroxygambogic acid, R tetrahydrogambogic acid, } \\
\text { and hanburin R }\end{array}$ & $\begin{array}{lll}\text { Yang } & \text { et } a l ., \\
2012 & & \end{array}$ \\
\hline & & \multirow[t]{2}{*}{ Latex } & $\begin{array}{l}\text { Gambogin, morellin dimethyl acetal, isomoreollin } \\
\mathrm{B} \text {, moreollic acid, gambogenic acid, gambogenin, } \\
\text { isogambogenin, desoxygambogenin, gambogenin } \\
\text { dimethyl acetal, gambogellic acid, hanburin, } \\
\text { gambogic acid, isomorellin, morellic acid, and } \\
\text { desoxymorellin }\end{array}$ & $\begin{array}{l}\text { Asano et al., } \\
1996\end{array}$ \\
\hline & & & $\begin{array}{l}\text { Isogambogenic acid, desoxymorellinin, 10- } \\
\text { methoxygambogenic acid, 10-methoxygambogic } \\
\text { Acid, and 10-ethoxy gambogic acid }\end{array}$ & $\begin{array}{l}\text { Feng et al., } \\
2007\end{array}$ \\
\hline \multirow[t]{4}{*}{28} & \multirow[t]{4}{*}{$\begin{array}{l}\text { G. } \\
\text { hombroniana }\end{array}$} & Leaf & Cambogic acid and mangostin & $\begin{array}{l}\text { Pandey et al., } \\
2015\end{array}$ \\
\hline & & Twig & Garcihombronones A-D & $\begin{array}{l}\text { Klaiklay et al., } \\
2013\end{array}$ \\
\hline & & \multirow[t]{2}{*}{ Bark } & $\begin{array}{l}\text { 1,3,6-Trihydroxy-7-methoxy-2,8-(3-methyl- 2- } \\
\text { butenyl) xanthone }\end{array}$ & $\begin{array}{l}\text { Jamila et al., } \\
2014\end{array}$ \\
\hline & & & 1,3,6,7-Tetrahydroxy xanthone & $\begin{array}{l}\text { Jamila et al., } \\
2014 \mathrm{a}\end{array}$ \\
\hline 29 & G. indica & Leaf & Cambogic acid and mangostin & $\begin{array}{l}\text { Pandey et al., } \\
2015\end{array}$ \\
\hline 30 & G. linii & Root & $\begin{array}{l}\text { 1,5-Dihydroxy-6-methoxy xanthone and 1,7- } \\
\text { dihydroxy-3-methoxy xanthone }\end{array}$ & $\begin{array}{l}\text { Chen et al., } \\
2006\end{array}$ \\
\hline 31 & G. lancilimba & Stem bark & $\begin{array}{l}\text { 1,5,6-Trihydroxy-6',6'-dimethyl-2H- } \\
\text { pyrano(2',3':3,4)-2-(3-methylbut-2-enyl) xanthone }\end{array}$ & $\begin{array}{l}\text { Yang } \quad \text { et } \\
\text { al.,2007 }\end{array}$ \\
\hline
\end{tabular}




\begin{tabular}{|c|c|c|c|c|}
\hline & & & $\begin{array}{l}\text { and 1,6,7-trihydroxy-6',6'-dimethyl-2H- } \\
\text { pyrano(2',3':3,2)-4-(3-methylbut-2-enyl) xanthone }\end{array}$ & \\
\hline 32 & G. lateriflora & Stem bark & $\begin{array}{l}\text { Isomoreollic acid, isogaudichaudiic acid, } \\
\text { isogaudichaudiic acid E, 11,12-dihydro -12- } \\
\text { hydroxy morellic acid, and isogaudichaudiic acid B }\end{array}$ & Ren et al., 2010 \\
\hline \multirow[t]{2}{*}{33} & \multirow[t]{2}{*}{ G. livingstonei } & \multirow[t]{2}{*}{ Root bark } & $\begin{array}{l}\text { 1,4,5-Trihydroxy-3-(3-methylbut-2-enyl)-9H- } \\
\text { xanthen-9-one, 1,4,5-Trimetkoxy-3-(3-methylbut-2- } \\
\text { enyl)-9H-xanthen-9-one, 3,4-dihydro-6,11- } \\
\text { dihydroxy-2,2-dimethyl-pyrano[3,2-c]-xan-then- } \\
\text { 7(2H)-one, 6,11-dihydroxy-2,2-dimethyl-pyrano } \\
\text { [3,2-c] xanthen-7(2H)-one, and 6,1 1-dihydroxy-3- } \\
\text { methyl-3-(4-methylpent-3-enyL)-3H,7H- } \\
\text { pyrano[2,3-c] xanthen-7-one }\end{array}$ & $\begin{array}{l}\text { Sordat-Diserens } \\
\text { et al., } 1992 \mathrm{a}\end{array}$ \\
\hline & & & Garcilivin A-C & $\begin{array}{l}\text { Sordat-Diserens } \\
\text { et al., } 1992\end{array}$ \\
\hline 34 & G. lucida & Stem bark & $\begin{array}{l}\text { 1,2-Dihydroxy xanthone and 1-hydroxy-2-methoxy } \\
\text { xanthone }\end{array}$ & $\begin{array}{l}\text { Momo et al., } \\
2011\end{array}$ \\
\hline 35 & G. malaccensis & Stem bark & $\alpha$ and $\beta$-Mangostins & $\begin{array}{l}\text { Taher et al., } \\
2012\end{array}$ \\
\hline \multirow[t]{8}{*}{36} & \multirow[t]{8}{*}{ G. mangostana } & \multirow[t]{3}{*}{ Leaf } & Cambogic acid and mangostin & $\begin{array}{l}\text { Pandey et al., } \\
2015\end{array}$ \\
\hline & & & Gartanin & Sen et al., 1980 \\
\hline & & & $\begin{array}{l}\text { 1,5,8-Trihydroxy-3-methoxy-2[3-methyl-2- } \\
\text { butenyl] xanthone, and 1,6-dlhydroxy-3- methoxy- } \\
2 \text { [3-methyl-2-butenyl]xanthone }\end{array}$ & $\begin{array}{l}\text { Parveen and } \\
\text { Khan,1988 }\end{array}$ \\
\hline & & \multirow[t]{5}{*}{ Pericarp } & $\begin{array}{l}\text { Mangostinone, } \alpha, \beta \text { and } \gamma \text {-mangostins, gartanin, } \\
\text { garcinone E, 1,5-dihydroxy-2-(3-methylbut- 2- } \\
\text { enyl)-3-methoxy xanthone, and 1,7-dihydroxy-2-(3- } \\
\text { methylbut-2-enyl)-3-methoxyxanthone }\end{array}$ & Asai et al., 1995 \\
\hline & & & $\begin{array}{l}\text { 1,3,7-Trihydroxy-2-(3-methyl-2-butenyl)-8-(3- } \\
\text { hydroxy-3-methylbutyl)-xanthone, } \\
\text { 1,3,8-trihydroxy-2-(3-methyl-2-butenyl)-4-(3- } \\
\text { hydroxy-3-methylbutanoyl)-xanthone, garcinones C } \\
\text { and D, gartanin, xanthone I, and } \gamma \text {-mangostin }\end{array}$ & Xu et al., 2014 \\
\hline & & & $\begin{array}{l}\text { 3-Hydroxy-6-methoxy-5'-isopropyl-4',5'- } \\
\text { dihydrofuro [2',3': 7, 8]-6",6"'-dimethyl-4",5"- } \\
\text { dihydropyrano[2',3'": 1,2]xanthone, and 1,6- } \\
\text { dihydroxy-7-methoxy-8-(3-methylbut-3-enyl)-6',6'- } \\
\text { dimethyl-4',5'-dihyd ropyrano[2'3', : 3,2] xanthone }\end{array}$ & $\begin{array}{lll}\text { Zhao et al., } \\
2012\end{array}$ \\
\hline & & & $\begin{array}{l}\text { Garcimangosxanthone A-C, } \alpha \text {-mangostin, } \gamma \text { - } \\
\text { mangostin, garcinone C and D, trapezifolixanthone, } \\
\text { 8-deoxygartanin, gartanin, } 2 \text { - }(\gamma, \gamma \text {-dimethylallyl)- } \\
\text { 1,7-dihydroxy-3-methoxyxanthone } \\
\text { 1,5-dihydroxy-3-methoxy-2-prenylxanthone } \\
\text { garcinone B, 9-hydroxycalabaxanthone, } \\
\text { dulxanthone D and 1,3,7-trihydroxy-2-(3- } \\
\text { methylbut-2-enyl)-xanthone and tevophyllin A }\end{array}$ & $\begin{array}{lll}\text { Zhang et al., } \\
\text { 2010a }\end{array}$ \\
\hline & & & $\begin{array}{l}\text { 8-Hydroxycudraxanthone G, mangostingone [7- } \\
\text { methoxy- 2-(3-methyl-2-butenyl)-8-(3-methyl-2- } \\
\text { oxo-3-butenyl)-1,3,6-trihydroxyxanthone, } \\
\text { cudraxanthone G, 8-deoxygartanin, garcimangosone } \\
\text { B, garcinone D, garcinone E, gartanin, 1- }\end{array}$ & $\begin{array}{l}\text { Jung et al., } \\
2006\end{array}$ \\
\hline
\end{tabular}




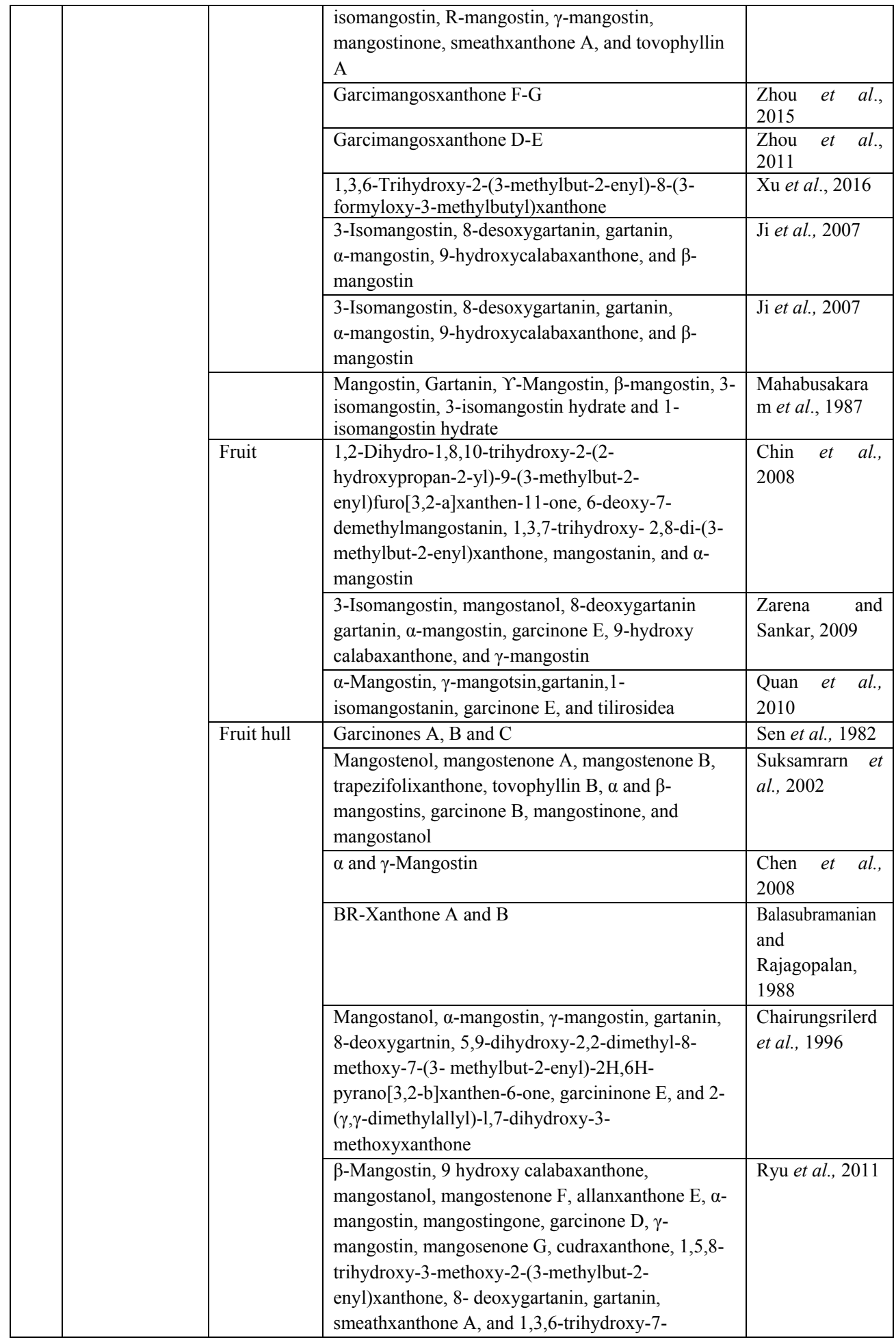




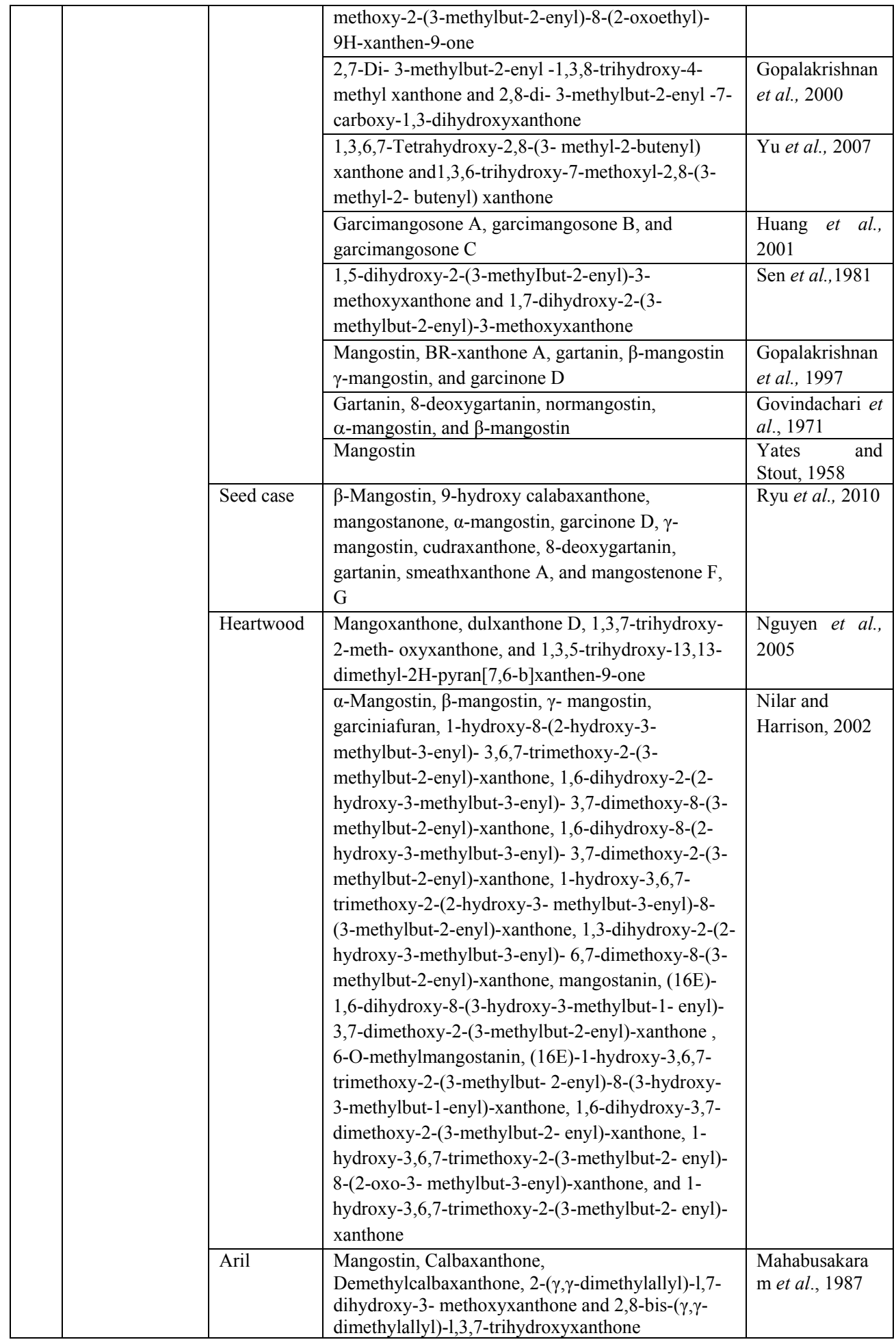




\begin{tabular}{|c|c|c|c|c|}
\hline & & $\begin{array}{l}\text { Aril and } \\
\text { pericarp }\end{array}$ & $\begin{array}{l}\text { 1,7-Dihydroxy-3-methoxy- 2-(3-methylbut-2- } \\
\text { enyl)xanthone, } \gamma \text {-mangostin, } 8 \text {-deoxygartanin } \\
\text { 1,3,7-trihydroxy-2,8-di- (3-methylbut-2- } \\
\text { enyl)xanthone, 1,3,7-trihydroxy-2,8-di- (3- } \\
\text { methylbut-2- enyl)xanthon gartanin, } \alpha \text {-mangostin, } \\
\text { and garcinon E }\end{array}$ & $\begin{array}{l}\text { Wittenauer et } \\
\text { al., } 2012\end{array}$ \\
\hline & & $\begin{array}{l}\text { Stem and } \\
\text { root }\end{array}$ & $\begin{array}{l}\text { 2,6-Dihydroxy-8-methoxy-5-(3- methylbut-2-enyl)- } \\
\text { xanthone }\end{array}$ & Ee et al., 2006 \\
\hline & & Stem & $\begin{array}{l}\text { Mangosharin ,(2,6-dihydroxy-8-methoxy-5-(3- } \\
\text { methylbut-2-enyl)-xanthone), } \alpha \text {-mangostin, } \beta \text { - } \\
\text { mangostin, garcinone D, 1,6-dihydroxy-3,7- } \\
\text { dimethoxy-2-(3-methylbut-2-enyl)-xanthone, } \\
\text { mangostanol and 5,9-dihydroxy-8- } \\
\text { methoxy-2,2-dimethyl-7-(3-methylbut-2-enyl)- } \\
\text { 2H,6H-pyrano-[3,2-b]-xanthene-6-one }\end{array}$ & Ee et al., 2006 \\
\hline & & \multirow[t]{2}{*}{ Stem bark } & Mangaxanthone $\mathrm{B}$, mangostanin, and mangostenol & See et al., 2014 \\
\hline & & & $\begin{array}{l}\text { 11-Hydroxy-3-O-methyl-1-isomangostin, } 11 \text { - } \\
\text { hydroxy-1-isomangostin, } 11 \alpha \text {-mangostanin, } 3 \text { - } \\
\text { isomangostin, } \alpha \text {-mangostin, } \beta \text {-mangostin, garcinone } \\
\mathrm{D}, 9 \text { hydroxy calabaxanthone, } 8 \text {-deoxygartanin, } \\
\text { gartanin, and cratoxyxanthone }\end{array}$ & Han et al., 2009 \\
\hline & & \multirow[t]{2}{*}{ Root bark } & $\begin{array}{l}\beta \text {-Mangostin, } \alpha \text {-mangostin, garcinone-D, } \\
\text { mangostanol, and gartanin }\end{array}$ & Ee et al.,2006 \\
\hline & & & Mangostin and $\beta$-mangostin & $\begin{array}{l}\text { Govindhachari } \\
\text { et al., } 1971\end{array}$ \\
\hline & & Latex & Mangostin and $\beta$-mangostin & $\begin{array}{l}\text { Govindachari et } \\
\text { al., } 1971\end{array}$ \\
\hline \multirow[t]{3}{*}{37} & \multirow[t]{3}{*}{ G. merguensis } & Bark & $\begin{array}{l}\text { Merguenone, 1,5-dihydroxy-60-methyl-60-(4- } \\
\text { methyl-3-pentenyl)- pyrano(20,30:3,2)-xanthone, } \\
\text { subelliptenone H, 8-deoxygartanin, rheediaxanthone } \\
\text { A, morusignin G, 6-deoxyjacareubin, 1,3,5-trihy- } \\
\text { droxy-4,8-di(3-methylbut-2-enyl)-xanthone, } \\
\text { rheediachromenoxanthone, and 6- } \\
\text { deoxyisojacareubin }\end{array}$ & $\begin{array}{l}\text { Nguyen et al., } \\
2003\end{array}$ \\
\hline & & Twig & $\begin{array}{l}\text { Merguensinone and 1,5,6- trihydroxy-2-prenyl- } \\
\text { 60,60-dimethyl-2H-pyrano(20,30:3,4)xanthone }\end{array}$ & $\begin{array}{l}\text { Trisuwan et al., } \\
2013\end{array}$ \\
\hline & & Wood & $\begin{array}{l}\text { 5-Farnesyltoxyloxanthone } \mathrm{B}, \alpha \text {-mangostin, } \\
\text { rubraxanthone, and isocowanol }\end{array}$ & $\begin{array}{l}\text { Kijjoa et al., } \\
2008\end{array}$ \\
\hline \multirow[t]{3}{*}{38} & \multirow[t]{3}{*}{ G. morella } & Seed & Morellin & $\begin{array}{l}\text { Rao } 1937, \text { Rao } \\
\text { and Natarajan } \\
1950 \text { and } \\
\text { Kartha et al., } \\
1963\end{array}$ \\
\hline & & Pericarp & Morellin & $\begin{array}{l}\text { Karanjgaokar et } \\
\text { al., } 1967\end{array}$ \\
\hline & & Leaf & Cambogic acid and mangostin & $\begin{array}{l}\text { Pandey et al., } \\
2015\end{array}$ \\
\hline 39 & G. nervosa & Stem bark & Nervosaxanthone & $\begin{array}{l}\text { Ampofo and } \\
\text { Waterman, } \\
1986\end{array}$ \\
\hline 40 & G. nobilis & Stem bark & $\begin{array}{l}\text { Caroxanthone, 4-prenyl-2-(3,7-dimethyl-2,6- } \\
\text { octadienyl)-1,3,5,8-tetrahydroxyxanthone, } \\
\text { smeathxanthone A, gartanin, euxanthone, 8- } \\
\text { hydroxycudraxanthone G, and morusignin I }\end{array}$ & $\begin{array}{l}\text { Fouotsa et } \\
\text { al.,2012 }\end{array}$ \\
\hline
\end{tabular}




\begin{tabular}{|c|c|c|c|c|}
\hline \multirow[t]{2}{*}{41} & \multirow[t]{2}{*}{ G. nigrolineata } & Leaf & Nigrolineaxanthones J-S & $\begin{array}{l}\text { Rukachaisirikul } \\
\text { et al., } 2003\end{array}$ \\
\hline & & Stem bark & $\begin{array}{l}\text { Nigrolineaxanthones A-I, 1,3,5-trihydroxy-4-(3- } \\
\text { hydroxy-3-methylbutyl)xanthone, 1,3,7-trihydroxy- } \\
\text { 2-(3-hydroxy- 3-methylbutyl)xanthone, 6- } \\
\text { deoxyjacreubin, morusignin C, 1,5-dihydroxy-6',6'- } \\
\text { dimethylpyrano[2',3':3,2] xanthone, and } \\
\text { tovoxanthone }\end{array}$ & $\begin{array}{l}\text { Rukachaisirikul } \\
\text { et al., 2003c }\end{array}$ \\
\hline 42 & G. nitida & Stem bark & $\begin{array}{l}\text { 1,6-Dihydroxy-5-methoxy-6,6- } \\
\text { dimethylpyrano[2',3':2,3]-xanthone, inophyllin B, } \\
\text { osajaxanthone, 3-isomangostin, and rubraxanthone }\end{array}$ & Ee et al., 2012 \\
\hline \multirow[t]{2}{*}{43} & \multirow[t]{2}{*}{ G. nujiangensis } & Twig & $\begin{array}{l}\text { Nujiangexanthones C-F, jacareubin, guttiferone F, } \\
\text { cudratricusxanthone E, and garcihombronone B }\end{array}$ & $\begin{array}{l}\text { Tang et al., } \\
2015\end{array}$ \\
\hline & & Leaf & Nujiangexanthones A and B & Xia et al., 2012 \\
\hline \multirow[t]{3}{*}{44} & \multirow[t]{2}{*}{ G. oligantha } & Stem & Oliganthins A-D and gaudichaudione $\mathrm{H}$ & Gao et al., 2012 \\
\hline & & Leaf & $\begin{array}{l}\text { Oliganthin } \mathrm{H}, \mathrm{I}, \mathrm{K} \text { and } \mathrm{L} \text {, oliganthic } \\
\text { acids A-C, oliganthaxanthone } \mathrm{A} \text {, oliganthaxanthone } \\
\mathrm{B} \text {, gaudichaudione } \mathrm{H} \text {, and cantleyanone }\end{array}$ & $\begin{array}{l}\text { Tang et al., } \\
2016\end{array}$ \\
\hline & & Stem bark & Macluraxanthone & $\begin{array}{l}\text { Waterman and } \\
\text { Crichton } 1980 \mathrm{~b}\end{array}$ \\
\hline 45 & G. opaca & Leaf & $\begin{array}{l}\text { Macluraxanthone, 1,3,5-trihydroxy-6',6'- } \\
\text { dimethylpyrano-(2,3':6,7)-4-( 1,1-dimethylprop-2- } \\
\text { enyl)xanthone, 1,3,5-trihydroxy-6',6'- } \\
\text { dimethylpyrano(2',3':6,7)-2-(3-methylbut-2- enyl)- } \\
\text { 4-(1,1- dimethylprop-2-enyl)xanthone, and 4",5"- } \\
\text { dihydro-1,5-dihydro-1,5-dihydroxy-6',6'- } \\
\text { dimethylpyrano(2',3':6,7)-2-(3- methylbut-2-enyl)- } \\
\left.4^{\prime \prime}, 4^{\prime \prime}, 5^{\prime \prime} \text {-trimethylfurano( } 2^{\prime \prime}, 3^{\prime \prime}: 3,4\right) \text { xanthone }\end{array}$ & Goh et al., 1992 \\
\hline 46 & G. paucinervis & Leaf & Paucinervins H-J & Li et al., 2016a \\
\hline \multirow[t]{3}{*}{47} & \multirow[t]{3}{*}{ G. parvifolia } & Twig & Parvifolixanthones A-C & $\begin{array}{l}\text { Rukachaisirikul } \\
\text { et al., } 2006\end{array}$ \\
\hline & & \multirow[t]{2}{*}{ Bark } & Parvixanthones A-I & Xu et al., 2001 \\
\hline & & & Parvixanthone $\mathrm{A}$ and rubraxanthone & $\begin{array}{l}\text { Kardono et al., } \\
2006\end{array}$ \\
\hline \multirow[t]{3}{*}{48} & \multirow[t]{3}{*}{ G. pedunculata } & Bark & $\begin{array}{l}\text { Pedunxanthones A-C, 1,5-dihydroxy-3- methoxy- } \\
\text { 6',6'-dimethyl-2H-pyrano(2',3':6,7)-4-(3- } \\
\text { methylbut-2-enyl)xanthone, 1,5-dihydroxy-3-meth- } \\
\text { oxy-4-(3-methylbut-2-enyl)xanthone, dulxanthone } \\
\text { A, and garbogiol }\end{array}$ & Vo et al., 2012 \\
\hline & & Heartwood & $\begin{array}{l}\text { 1,3,5,7-tetrahydroxyxanthone and 1,3,6,7- } \\
\text { tetrahydroxyxanthone }\end{array}$ & Rao et al., 1974 \\
\hline & & Pericarp & Pedunxanthones D-F & Vo et al., 2015 \\
\hline 49 & G. penangiana & Leaf & $\begin{array}{l}\text { 4-(1,1-Dimethylprop-2-enyl)-1,3,5,8- } \\
\text { tetrahydroxyxanthone penangianaxanthone, } \\
\text { cudratricusxanthone H, macluraxanthone C, and } \\
\text { gerontoxanthone C }\end{array}$ & $\begin{array}{l}\text { Jabit et al., } \\
2007\end{array}$ \\
\hline \multirow[t]{3}{*}{50} & \multirow[t]{3}{*}{ G. polyantha } & \multirow[t]{3}{*}{ Stem bark } & $\begin{array}{l}\text { Bangangxanthone A and B, 1,5-dihydroxyxanthone, } \\
\text { and 2-hydroxy-1,7-dimethoxyxanth- one }\end{array}$ & $\begin{array}{l}\text { Lannang et al., } \\
2005\end{array}$ \\
\hline & & & Isorheediaxanthone B & $\begin{array}{l}\text { Ampofo and } \\
\text { Waterman, } \\
1986\end{array}$ \\
\hline & & & Polyanxanthone & $\begin{array}{l}\text { Komguem et } \\
\text { al., } 2006\end{array}$ \\
\hline
\end{tabular}




\begin{tabular}{|c|c|c|c|c|}
\hline & & Root bark & $\begin{array}{l}\text { Garciniaxanthone I, smeathxanthone } \\
\text { A, smeathxanthone B, and chefouxanthone }\end{array}$ & $\begin{array}{l}\text { Lannang et al., } \\
2008\end{array}$ \\
\hline & & Wood trunk & $\begin{array}{l}\text { Polyanxanthone A, B, C, 1,3,5-trihydroxyxanthone, } \\
\text { 1,5-dihydroxyxanthone, 1,3,6,7-tetrahydroxy } \\
\text { xanthone, 1,6-dihydroxy-5-methoxy xanthone, and } \\
\text { 1,3,5,6-tetrahydroxy xanthone }\end{array}$ & $\begin{array}{l}\text { Louh et al., } \\
2008\end{array}$ \\
\hline 51 & G. porrecta & --- & Porxanthone A and dulxanthone E-G & $\begin{array}{l}\text { Kardono et al., } \\
2006\end{array}$ \\
\hline \multirow[t]{2}{*}{52} & \multirow[t]{2}{*}{ G. propinqua } & Twig & $\begin{array}{l}\text { Doitunggarcinone } \mathrm{C} \text {, dulxanthone } \mathrm{B}, 5-\mathrm{O}- \\
\text { methylxanthone } \mathrm{V} 1,10-\mathrm{O} \text {-methylmacluraxanthone, } \\
\text { macluraxanthone, gartanin, and morusignin J }\end{array}$ & $\begin{array}{l}\text { Tantapakul et } \\
\text { al., } 2012\end{array}$ \\
\hline & & Root & Doitunggarcinone D & $\begin{array}{l}\text { Meesakul et al., } \\
2016\end{array}$ \\
\hline 53 & $\begin{array}{l}\text { G. } \\
\text { pushpangadani } \\
\text { ana }\end{array}$ & Leaf & Cambogic acid and mangostin & $\begin{array}{l}\text { Pandey et al., } \\
2015\end{array}$ \\
\hline 54 & G. pyrifera & Stem bark & Rubraxanthone, isocowanin, and isocowanol & $\begin{array}{l}\text { Ampofo and } \\
\text { Waterman, } \\
1986\end{array}$ \\
\hline 55 & G. quadrifaria & Stem bark & $\begin{array}{l}\text { 1, 3, S-Trihydroxy-4, } 8 \operatorname{di}(3,3- \\
\text { dimethylallyl)xanthone }\end{array}$ & $\begin{array}{l}\text { Waterman and } \\
\text { Hussain, } 1982\end{array}$ \\
\hline \multirow[t]{2}{*}{56} & \multirow[t]{2}{*}{ G. rigida } & \multirow[t]{2}{*}{ Leaf } & Yahyaxanthone & Elya et al.,2008 \\
\hline & & & Musaxanthone and asmaxanthone & $\begin{array}{l}\text { Elya et al., } \\
2006 \mathrm{a}\end{array}$ \\
\hline \multirow[t]{3}{*}{57} & \multirow[t]{3}{*}{$\begin{array}{l}\text { G. } \\
\text { schomburgkian } \\
\text { a }\end{array}$} & Bark & $\begin{array}{l}\text { 6-O-Demethyloliverixanthone, schomburgxanthone, } \\
\text { cowanin, cowanol, fuscaxanthones A and B, 3- } \\
\text { isomangostin hydrate, and 1,7-dihydroxyxanthone }\end{array}$ & Vo et al., 2012a \\
\hline & & Root & Schomburgxanthone A & $\begin{array}{l}\text { Sukandar et al., } \\
2016 \mathrm{a}\end{array}$ \\
\hline & & Branch & Euxanthone and gentisein & $\begin{array}{l}\text { Meechai et al., } \\
2016\end{array}$ \\
\hline \multirow[t]{3}{*}{58} & \multirow[t]{3}{*}{ G. scortechinii } & Twig & Scortechinones A-C & $\begin{array}{l}\text { Rukachaisirikul } \\
\text { et al., 2000a }\end{array}$ \\
\hline & & Fruit & $\begin{array}{l}\text { Scortechinones Q-T, scortechinones U-X, } \\
\text { scortechinones A-F, H, I, M, L, and P }\end{array}$ & $\begin{array}{l}\text { Sukpondma et } \\
\text { al., } 2005\end{array}$ \\
\hline & & Latex & Scortechinones D-K & $\begin{array}{l}\text { Rukachaisirikul } \\
\text { et al., 2003b }\end{array}$ \\
\hline \multirow[t]{4}{*}{59} & \multirow[t]{4}{*}{$\begin{array}{l}\text { G. } \\
\text { smeathmannii }\end{array}$} & \multirow[t]{3}{*}{ Stem bark } & Smeathxanthone A and B & $\begin{array}{l}\text { Komguem et } \\
\text { al., } 2005\end{array}$ \\
\hline & & & $\begin{array}{l}\text { Cheffouxanthone, 1,5 dihy- droxyxanthone, 1,3,5- } \\
\text { trihydroxyxanthone, bangang xanthone A, } \\
\text { smeathxanthone B, and smeathxanthone A }\end{array}$ & $\begin{array}{l}\text { Kuete et al., } \\
2007\end{array}$ \\
\hline & & & $\begin{array}{l}\text { 1,3,5,8-Tetrahydroxy-2-(3-methybut-2-enyl)-4-(3,7- } \\
\text { dimethylocta-2,6-dienyl)xanthone, } \\
\text { cheffouxanthone, smeathxanthone A, } \\
\text { smeathxanthone B, and ananixanthone }\end{array}$ & $\begin{array}{l}\text { Fouotsa et al., } \\
2015\end{array}$ \\
\hline & & Root bark & $\begin{array}{l}\text { Cheffouxanthone, smeathxanthones A, and } \\
\text { smeathxanthones B }\end{array}$ & $\begin{array}{l}\text { Lannang et al., } \\
2006\end{array}$ \\
\hline 60 & G. speciosa & Bark & $\alpha$-Mangostin, cowanin and cowanol & $\begin{array}{l}\text { Okudaira et al., } \\
2000\end{array}$ \\
\hline 61 & G. spicata & Leaf & Cambogic acid and mangostin & Pandey et al., \\
\hline
\end{tabular}




\begin{tabular}{|c|c|c|c|c|}
\hline & & & & 2015 \\
\hline \multirow[t]{2}{*}{62} & \multirow[t]{2}{*}{ G. staudtii } & Stem bark & Rheediaxanthone-A & $\begin{array}{l}\text { Waterman and } \\
\text { Hussain, } 1982\end{array}$ \\
\hline & & Twig & $\begin{array}{l}\text { Staudtiixanthones A-D, } \alpha \text {-mangostin, } 9 \text { garcinone } \\
\mathrm{B}, 9 \text { demethylcalabaxanthone, gartanin, and } \\
\text { xanthone } \mathrm{V}_{1}\end{array}$ & $\begin{array}{l}\text { Ngoupayo et } \\
\text { al., } 2009\end{array}$ \\
\hline \multirow[t]{8}{*}{63} & \multirow[t]{8}{*}{ G. subelliptica } & Heartwood & Garciniaxanthones A and B & $\begin{array}{l}\text { Fukuyama et } \\
\text { al., } 1991\end{array}$ \\
\hline & & \multirow[t]{3}{*}{ Wood } & $\begin{array}{l}\text { Garciniaxanthone C, 1,2,5-trihydroxyxanthone, 2,6- } \\
\text { dihydroxy-1,5-dimethoxyxanthone, and 1,2- } \\
\text { dihydroxy-5,6-dimethoxyxanthone }\end{array}$ & $\begin{array}{l}\text { Minami et al., } \\
1994\end{array}$ \\
\hline & & & $\begin{array}{l}\text { 2,5-Dihydroxy-1-methoxylxanthone, 1-O- } \\
\text { methylsymphoxanthone, garciniaxanthone E } \\
\text { symphoxanthone, and subelliptenone A }\end{array}$ & $\begin{array}{l}\text { Minami et al., } \\
1996\end{array}$ \\
\hline & & & 1,6-O-Dimethylsymphoxanthone & $\begin{array}{l}\text { Minami et al., } \\
1998\end{array}$ \\
\hline & & \multirow[t]{4}{*}{ Root bark } & $\begin{array}{l}\text { 1,4,5,6-Tetrahydroxy-2-(1,1-dimethyl-2- propenyl)- } \\
\text { 7,8,-di-(3-methyl-2-butenyl)xanthone, and 1,2,5,6- } \\
\text { tetrahydroxy-4-(1,1-dimethyl-2-propenyl)-7- (3- } \\
\text { methyl-2-butenyl)xanthone, subelliptenones A and } \\
\text { B }\end{array}$ & $\begin{array}{l}\text { Iinuma et al., } \\
1994\end{array}$ \\
\hline & & & Subelliptenones C and subelliptenones D & $\begin{array}{l}\text { linuma } \\
\text { al., } 1995\end{array}$ \\
\hline & & & Subelliptenones $\mathrm{H}$ and subelliptenones I & $\begin{array}{l}\text { Iinuma et al., } \\
1995 \mathrm{a}\end{array}$ \\
\hline & & & Subelliptenones E and subelliptenones F & $\begin{array}{l}\text { Iinuma et al., } \\
1995 \mathrm{~b}\end{array}$ \\
\hline 64 & G. terpnophylla & $\begin{array}{l}\text { Timber and } \\
\text { bark }\end{array}$ & 1,5-Dihydroxyxanthone and mangostin & $\begin{array}{l}\text { Bandaranayake } \\
\text { et al., } 1975\end{array}$ \\
\hline 65 & G. tetralata & Stem bark & $\begin{array}{l}\text { Garcinexanthone B, morellic acid acetate, } \\
\text { toxyloxanthone A, 6,11-dihydroxy-2,2- } \\
\text { dimethylpyrano[3,2-c]xanthen-7(2H)-one, and 1,4- } \\
\text { dihydroxy-5,6-dimethoxy xanthone }\end{array}$ & Guo et al., 2011 \\
\hline 66 & G. tetrandra & Stem bark & $\begin{array}{l}\text { 1,3-Dihydroxy, } 2^{\prime}, 2^{\prime} \text {-dimethyl pyrano }\left(5^{\prime}, 6^{\prime}, 5,6\right) \\
\text { xanthone }\end{array}$ & $\begin{array}{l}\text { Hartati et al., } \\
2008\end{array}$ \\
\hline 67 & G. urophylla & Leaf & $\begin{array}{l}\text { 7-Hydroxydesoxymorellin, isocaledonixanthone D, } \\
\text { gaudichudione H, 1,7-dihydroxy-3-methoxy-2-(3- } \\
\text { methyl- 2-butenyl)xanthone, 1,5-dihydroxy-3- } \\
\text { methoxy-2-(3-methyl-2butenyl)xanthone, and 1,3,7- } \\
\text { trihydroxy-2-(3-methyl-2-butenyl)xanthone }\end{array}$ & $\begin{array}{l}\text { Khalid et al., } \\
2007\end{array}$ \\
\hline \multirow[t]{2}{*}{68} & \multirow[t]{2}{*}{ G. vieillardii } & \multirow[t]{2}{*}{ Stem bark } & $\begin{array}{l}\text { Vieillardiixanthones B and C, pancixanthones A, B, } \\
\text { 1,6-dihydroxyxanthone, pyranojacareubin and 5,6- } \\
\text { O-dimethyl-2-deprenylrheediaxanthone }\end{array}$ & Hay et al., 2008 \\
\hline & & & $\begin{array}{l}\text { 1,6-Dihydroxyxanthone, pancixanthone A, } \\
\text { isocudraniax- anthone B, isocudraniaxanthone A, 2- } \\
\text { deprenyl rheediaxanthone B and 1,4,5- } \\
\text { trihydroxyxanthone }\end{array}$ & Hay et al., 2004 \\
\hline 69 & G. vilersiana & Bark & $\begin{array}{l}\text { Globuxanthone, subelliptenone } \mathrm{H} \text {, subelliptenone } \mathrm{B} \text {, } \\
\text { 12b-hydroxy-des-D-garcigerrin A, 1-O- } \\
\text { methylglobuxanthone, and symphoxanthone }\end{array}$ & $\begin{array}{l}\text { Nguyen et al., } \\
2000\end{array}$ \\
\hline 70 & G. virgata & Stem bark & Virgataxanthone $\mathrm{A}$ and $\mathrm{B}$ & $\begin{array}{l}\text { Merza et al., } \\
2004\end{array}$ \\
\hline 71 & G. yunnanensis & Pericarp & Garciyunnanins A and B & Xu et al., 2008 \\
\hline
\end{tabular}




\begin{tabular}{|c|c|c|c|c|}
\hline 72 & G. wightii & Leaf & Cambogic acid and mangostin & $\begin{array}{l}\text { Pandey et al., } \\
2015\end{array}$ \\
\hline \multirow[t]{6}{*}{73} & \multirow[t]{6}{*}{$\begin{array}{l}\text { G. } \\
\text { xanthochymus }\end{array}$} & Leaf & Cambogic acid and mangostin & $\begin{array}{l}\text { Pandey et al., } \\
2015\end{array}$ \\
\hline & & wood & $\begin{array}{l}\text { 1,4,5,6-Tetrahydroxy-7,8-di(3-methylbut-2- } \\
\text { enyl)xanthone, 1,2,6-trihydroxy-5-methoxy-7-(3- } \\
\text { methylbut-2-enyl)xanthone, and 12 } 3 \text { - hydroxy- D- } \\
\text { garcigerrin }\end{array}$ & $\begin{array}{l}\text { Chanmahasathi } \\
\text { en et al., } 2003\end{array}$ \\
\hline & & \multirow[t]{3}{*}{ Bark } & $\begin{array}{l}\text { 1,6-Dihydroxy-4,5-dimethoxyxanthone and 1,5,6- } \\
\text { trihydroxy-7,8-di(3-methyl-2-butenyl)-60,60- } \\
\text { dimethylpyrano(20,30:3,4) xanthone }\end{array}$ & $\begin{array}{l}\text { Zhong et al., } \\
2007\end{array}$ \\
\hline & & & $\begin{array}{l}\text { 1,5,6- Trihydroxy-7-(3-methyl-2-butenyl)-8-(3- } \\
\text { hydroxy-3-methylbutyl)furano(2',3':3,4) xanthone, } \\
\text { 1,5,6-trihydroxy-7-(3-methyl-2-butenyl)- 8-(3- } \\
\text { hydroxy-3-methylbutyl)-6', 6'-dimethylpyrano } \\
\left(2^{\prime}, 3^{\prime}: 3,4\right) \text { xanthone, 1,5,6-trihydroxy-7-(3- methyl- } \\
\text { 2-butenyl)-8-(3-hydroxy-3-methylbutyl)-5'-(1- } \\
\text { hydroxy-1-methylethyl)-4', 5'-dihydrofurano } \\
\left(2^{\prime}, 3^{\prime}: 3,4\right) \text { xanthone, 1, 2, 5, 4'-tetrahydroxy-4-(1,1- } \\
\text { dimethylallyl)-5'-(2-hydroxypropan-2-yl)-4', 5'- } \\
\text { dihydrofurano-(2', 3': } 6,7) x a n t h o n e, 1,3,5,6- \\
\text { tetrahydroxy-7-geranylxanthone, and } 1,4- \\
\text { dihydroxy-6', 6'- dimethylpyrano }\left(2^{\prime}, 3^{\prime}: 5,6\right) \\
\text { xanthone }\end{array}$ & $\begin{array}{l}\text { Chen et al., } \\
2010\end{array}$ \\
\hline & & & 1,7-dihydroxyxanthone and 1,5-dihydroxyxanthone & $\begin{array}{l}\text { Baslas and } \\
\text { Kumar } 1979\end{array}$ \\
\hline & & Twig bark & $\begin{array}{l}\text { 1,4,6-Trihydroxy-5-methoxy-7-prenylxanthone, } \\
\text { 1,4,5,6-tetrahydroxy-7-prenylxanthone, 1,2,5,6- } \\
\text { tetrahydroxy-7-geranylxanthone, 1,4,5,6- } \\
\text { tetrahydroxy-7,8-diprenylxanthone , 1,3,5,6- } \\
\text { tetrahydroxy-4,7,8-triprenylxanthone, } \\
\text { garciniaxanthone E, and 6-prenylapigenin }\end{array}$ & Han et al., 2007 \\
\hline \multirow[t]{2}{*}{74} & \multirow[t]{2}{*}{$\begin{array}{l}\text { G. } \\
\text { xipshuanbannae } \\
\text { nsis }\end{array}$} & \multirow[t]{2}{*}{ Twig } & $\begin{array}{l}\text { Bannaxanthone } \mathrm{H}, 1,3,5,6 \text {-tetrahydroxy-2-(3- } \\
\text { methylbut-2-enyl)xanthone, bannaxanthone F, } \\
\text { garcinone } \mathrm{C}, 1,3,6,7 \text {-tetrahydroxy-8-(3-methylbut- } \\
\text { 2-enyl)xanthone, bannaxanthone G, bannaxanthone } \\
\mathrm{B}, \gamma \text {-mangostin, garcinone E, bananxanthone E, } \\
\text { allanxanthone C, bannaxanthone D, 1,3,5,6- } \\
\text { tetrahydroxy-7-(3-methylbut-2-enyl)xanthone, } \\
\text { xanthone V1a, and nigrolinexanthone V }\end{array}$ & $\begin{array}{l}\text { Zhou et al., } \\
2008\end{array}$ \\
\hline & & & $\begin{array}{l}\text { Bannaxanthones } \mathrm{A}-\mathrm{H} \text {, allanxanthone } \mathrm{C} \text {, } \\
\text { isojacareubin, garcinone } \mathrm{C} \text {, and } \gamma \text {-mangostin }\end{array}$ & Han et al., 2008 \\
\hline
\end{tabular}

\section{Benzophenones}

Benzophenones are a series of compounds with phenol-carbonyl-phenol skeleton, synthesised through the mixed shikimic acid and acetate pathway, in which the acetate derived benzene ring is modified by intervention of prenyl groups. Biogenetically isoprenylated benzophenones are derived from maclurin which was regarded as a precursor for many xanthones in higher plants. Garciduols A-E, reported from G. dulcis possesses the novel benzophenone xanthone dimer skeletal structure, supporting the biosynthetic route that benzophenones are precursors of xanthones (Iinuma et al.,1996). Naturally occurring 
benzophenones that consists of more than 300 members are reported with great structural diversity with oxidized and polyisoprenylated structures (Cuesta-Rubio et al., 2005, Acuna et al., 2009). The genus Garcinia and Clusia are the major source of natural benzophenones. Literature review revealed that out of 120 Garcinia species subjected to phytochemical investigation, 50 Garcinia species contain benzophenones (Table 2). Floral resins and latex of some of the Clusiaceae members are mainly constituted of benzophenones and can contain up to $70 \%$ of benzophenones (Cuesta-Rubio et al., 2001).

Generally the benzophenones can be classified into simple polyisoprenylated benzophenones and complex bicyclo-[3.3.1]-nonane derivatives (Figure 3, Figure 4). Most of the benzophenones reported from the genus Garcinia are polyisoprenylated bezophenones, derived from maclurin. Karanjgoakar et al. in 1973 isolated xanthochymol, the first bicyclo[3.3.1]-nonane benzophenone from the fruits of G. xanthochymus (Karanjgoakar et al., 1973). Camboginol (garcinol) and cambogin (isogarcinol; xanthochymol) were two important benzophenones isolated from the latex of G. gummi-gutta in large quantities $(37.0 \%$ and $5.5 \%$ respectively) (Rao et al., 1980). Porto et al (2000) attempted a chemotaxonomical approach based on the distribution of benzophenones in the floral resins of Clusia members, where simple benzophenone derivatives and the bicyclo-[3.3.1]-nonane benzophenone structures demarcated the species.
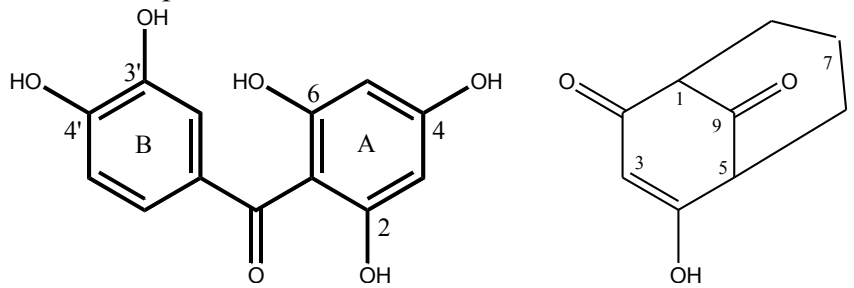

Figure 3. Typical benzophenone (maclurin) and bicyclo-[3.3.1]-nonane 2,4,9-trione structure

Recent developments in phytochemical analytical methods, especially the hyphenated LCMS techniques, made tremendous contributions to the detection of secondary metabolites that are present in minute quantities in plants. The limit of detection for xanthochymol in $G$. indica fruit rinds was reported as $20 \mu \mathrm{g} / \mathrm{mL}$ by HPLC and the method was inadequate to detect or estimate xanthochymol present in minute quantity in other parts of the plant. Consequently, LC-ESI/MS/MS method has been developed for the detection and quantification of xanthochymol at ppb level in Garcinia species. In addition, the isomeric compound isoxanthochymol can be differentiated from xanthochymol by the fragment ions obtained through MS/MS (Chattopadhyay and Kumar, 2006). Powder X-ray diffraction (PXRD) technique has been reported as a non-destructive analytical tool for the detection of the anti-HIV benzophenones, 7-epi-clusianone and guttiferone in G. brasiliensis extracts by Martins, et al., (2011). The compounds were detected in plant powder by comparing the powder diffraction profile of raw plant powder with the reported single crystal profiles of marker compounds (Martins, et al., 2011).

Benzophenones have shown different biological properties especially activity against HIV-1 (Cuesta-Rubio et al., 2005). Garcinol is an important polyisoprenylated benzophenone distributed in several Garcinia species and is one of the active ingredients of nutraceutical 
products from G. indica and G. cambogia. The structural similarity with curcumin, with $\beta$ diketone moiety that shows keto enol tautomerism, make garcinol interesting for pharmacological screening studies (Padhye et al., 2009). The significant antioxidant activity of Kokum syrup, a delicious drink popular in northern Kerala and Konkan region, made from $G$. indica fruits, is attributed mainly to the presence of garcinol and anthocyanins (Mishra, et al., 2006). Guttiferones, another class of benzophenones isolated from Garcinia species such as $G$. pyrifera and G. aristata are of great interest in pharmaceutical research particularly due to the anti-HIV, trypanocidal and cytotoxic activities (Acuna et al., 2009).<smiles>C=C1C=C(C)C(CC2(CC=C(C)CCC=C(C)C)C(=O)C(C(=O)c3cccc(O)c3)=C(O)C(CC=C(C)C)(CC=C(C)C)C2=O)CC1</smiles>

Figure 4. The simple benzophenone (semsinone B) and the bicyclo-[3.3.1]-nonane benzophenones (garcinol and guttiferone A)

Table 2. Benzophenones reported from Garcinia species

\begin{tabular}{|c|c|c|c|c|}
\hline $\begin{array}{l}\text { Sl. } \\
\text { No. }\end{array}$ & Garcinia species & $\begin{array}{l}\text { Plant } \\
\text { part }\end{array}$ & Benzophenones & Reference \\
\hline 1 & G. achachairu & Seed & Guttiferone A & $\begin{array}{l}\text { Dal Molin et al., } \\
2012\end{array}$ \\
\hline 2 & G. amplexicaulis & $\begin{array}{l}\text { Stem } \\
\text { bark }\end{array}$ & Garcinal & $\begin{array}{l}\text { Lavaud et al., } \\
2015\end{array}$ \\
\hline \multirow[t]{2}{*}{3} & \multirow[t]{2}{*}{ G. aristata } & Fruit & Aristophenones A-B & $\begin{array}{l}\text { Cuesta-Rubio et } \\
\text { al., } 2001\end{array}$ \\
\hline & & Fruit & $\begin{array}{l}\text { Guttiferone A, xanthochymol, and } \\
\text { Guttiferone E }\end{array}$ & $\begin{array}{l}\text { Acuna et al., } \\
2012 \text {, }\end{array}$ \\
\hline 4 & G. assigu & $\begin{array}{l}\text { Stem } \\
\text { bark }\end{array}$ & $\begin{array}{l}\text { Isogarcinol, garcinol ,18-0-methyl isogarcinol } \\
\text { 18-0-methyl garcinol, and clusianone }\end{array}$ & Ito et al., 2003 \\
\hline \multirow[t]{2}{*}{5} & \multirow[t]{2}{*}{ G. benthami } & \multirow[t]{2}{*}{$\begin{array}{l}\text { Stem } \\
\text { bark }\end{array}$} & Benthaphenone & $\begin{array}{l}\text { Nguyen et al., } \\
2011 \mathrm{a}\end{array}$ \\
\hline & & & Salimbenzophenone & Elya et al., 2006 \\
\hline \multirow[t]{5}{*}{6} & \multirow[t]{5}{*}{ G. brasiliensis } & Fruit & 7-epi-Clusianone and guttiferone $\mathrm{A}$ & $\begin{array}{l}\text { Martins et al., } \\
2011\end{array}$ \\
\hline & & Pericarp & $\begin{array}{l}\text { 7-epi-Clusianone, garciniaphenone, and } \\
\text { guttiferone-A }\end{array}$ & $\begin{array}{l}\text { Pereira et al., } \\
2010\end{array}$ \\
\hline & & Leaf & 7-epi-Clusianone & $\begin{array}{l}\text { Santa-Cecília et } \\
\text { al., } 2011\end{array}$ \\
\hline & & \multirow[t]{2}{*}{ Epicarp } & 7-epi-Clusianone and garciniaphenone & $\begin{array}{l}\text { Derogis et al., } \\
2008\end{array}$ \\
\hline & & & 7-epi-Clusianone & $\begin{array}{l}\text { Castro et al., } \\
2015\end{array}$ \\
\hline 7 & G. cantleyana & Twig & 2,6,3',5'-Tetrahydroxybenzophenone, & Jantan et al., \\
\hline
\end{tabular}




\begin{tabular}{|c|c|c|c|c|}
\hline & & & $\begin{array}{l}\text { 3,4,5,3',5'-pentahydroxybenzophenone, and } \\
\text { 3,5,3',5'-tetrahydroxy-4-methoxybenzophenone }\end{array}$ & 2012 \\
\hline 8 & G. cochinchinensis & Pericarp & Guttiferones Q-S and guttiferone I & $\begin{array}{l}\text { Nguyen et al., } \\
2011\end{array}$ \\
\hline \multirow[t]{2}{*}{9} & \multirow[t]{2}{*}{ G. cowa } & \multirow[t]{2}{*}{ Leaf } & Chamuangone & $\begin{array}{l}\text { Sakunpak and } \\
\text { Panichayupakara } \\
\text { nt, } 2012\end{array}$ \\
\hline & & & Garcinol & $\begin{array}{l}\text { Pandey et al., } \\
2015\end{array}$ \\
\hline 10 & G. echinocarpa & Leaf & Garcinol & $\begin{array}{l}\text { Pandey et al., } \\
2015\end{array}$ \\
\hline 11 & G. epunctata & $\begin{array}{l}\text { Stem } \\
\text { bark }\end{array}$ & Epunctanone, 7-epiisogarcinol & Fotso et al., 2014 \\
\hline \multirow[t]{2}{*}{12} & \multirow[t]{2}{*}{ G. eugenifolia } & Root & $\begin{array}{l}\text { (3,4-Dihydroxyphenyl),(3-hydroxy-5- } \\
\text { methoxyphenyl) methanone, and (3- hydroxy- } \\
\text { phenyl)3,4,5-trihydroxy phenyl) methanone }\end{array}$ & $\begin{array}{l}\text { Joong et al., } \\
2012\end{array}$ \\
\hline & & $\begin{array}{l}\text { Stem } \\
\text { bark }\end{array}$ & Eugeniaphenone & $\begin{array}{l}\text { Hartati et al., } \\
2008 \mathrm{a}\end{array}$ \\
\hline \multirow[t]{2}{*}{13} & \multirow[t]{2}{*}{ G. griffithii } & \multirow[t]{2}{*}{$\begin{array}{l}\text { Stem } \\
\text { bark }\end{array}$} & Guttiferone I & $\begin{array}{l}\text { Nguyen et al., } \\
2005\end{array}$ \\
\hline & & & Isoxanthochymol and guttiferone I & Elfita et al., 2009 \\
\hline \multirow[t]{4}{*}{14} & \multirow[t]{4}{*}{$\begin{array}{l}\text { G. gummi-gutta } \\
\text { (G. cambogia) }\end{array}$} & Fruit & $\begin{array}{l}\text { Garcinol, guttiferones } \mathrm{K}, \mathrm{I}, \mathrm{J}, \mathrm{M} \text { and } \mathrm{N} \\
\text { Garcinol, guttiferones- K, I, J, M and } \mathrm{N} \\
\text { Guttiferone I, guttiferone N, guttiferone J, } \\
\text { guttiferone K, and guttiferone M }\end{array}$ & $\begin{array}{l}\text { Masullo et al., } \\
2008 \\
\text { Masullo et al., } \\
2010 \\
\text { Semwal et al., } \\
2015\end{array}$ \\
\hline & & Latex & $\begin{array}{l}\text { Cambogin (isogarcinol) and camboginol } \\
\text { (garcinol) }\end{array}$ & Rao et al., 1980 \\
\hline & & Leaf & Garcinol & $\begin{array}{l}\text { Pandey et al., } \\
2015\end{array}$ \\
\hline & & Bark & Guttiferone $\mathrm{E}$ and isogarcinol & $\begin{array}{l}\text { Semwal et al., } \\
2015\end{array}$ \\
\hline \multirow[t]{4}{*}{15} & \multirow[t]{4}{*}{ G. hombroniana } & Leaf & Garcinol & $\begin{array}{l}\text { Pandey et al., } \\
2015\end{array}$ \\
\hline & & $\begin{array}{l}\text { Stem } \\
\text { wood }\end{array}$ & Bronianone & $\begin{array}{l}\text { Rao et al., } 1973 \\
\text { Ollis et al., } 1969\end{array}$ \\
\hline & & Fruits & $\begin{array}{l}\text { Guttiferone } \mathrm{A} \text {, xanthochymol, and } \\
\text { guttiferone } \mathrm{E}\end{array}$ & $\begin{array}{l}\text { Acuna et al., } \\
2012\end{array}$ \\
\hline & & Bark & $\begin{array}{l}\text { 2,3',4,5'-Tetrahydroxy-6-methoxybenzophenone, } \\
\text { 2,3',4,4'-tetrahydroxy-6-methoxybenzophenone, } \\
\text { and 2,3',4,6-tetrahydroxybenzophenone }\end{array}$ & $\begin{array}{l}\text { Jamila et al., } \\
\text { 2014b }\end{array}$ \\
\hline 16 & G. huillensis & $\begin{array}{l}\text { Stem } \\
\text { bark }\end{array}$ & Garcinol & $\begin{array}{l}\text { Phongi et al., } \\
1987\end{array}$ \\
\hline \multirow[t]{3}{*}{17} & \multirow[t]{3}{*}{ G. indica } & Leaf & Garcinol & $\begin{array}{l}\text { Pandey et al., } \\
2015\end{array}$ \\
\hline & & $\begin{array}{l}\text { All } \\
\text { parts }\end{array}$ & Xanthochymol and isoxanthochymol & $\begin{array}{l}\text { Chattopadhyay } \\
\text { et al., } 2006 \\
\text { Kumar et al., } \\
2009 .\end{array}$ \\
\hline & & Fruit & Isogarcinol, garcinol, and 14-deoxyisogarcinol & Kaur et al., 2012 \\
\hline 18 & G. intermedia & Fruit & Guttiferone A, xanthochymol, and & Acuna et al., \\
\hline
\end{tabular}




\begin{tabular}{|c|c|c|c|c|}
\hline & & & guttiferone $\mathrm{E}$ & 2012 \\
\hline \multirow[t]{2}{*}{19} & \multirow[t]{2}{*}{ G. kola } & \multirow[t]{2}{*}{ Fruit } & $\begin{array}{l}\text { Guttiferone A, xanthochymol, kolanone, and } \\
\text { guttiferone E }\end{array}$ & $\begin{array}{l}\text { Acuna et al., } \\
2012 \\
\text { Waterman et al., } \\
1983\end{array}$ \\
\hline & & & Kolanone & $\begin{array}{l}\text { Hussain et al., } \\
1982\end{array}$ \\
\hline \multirow[t]{2}{*}{20} & \multirow[t]{2}{*}{ G. livingstonei } & \multirow[t]{2}{*}{ Fruit } & $\begin{array}{l}\text { Guttiferone } \mathrm{A} \text {, xanthochymol, and } \\
\text { guttiferone } \mathrm{E}\end{array}$ & $\begin{array}{l}\text { Acuna et al., } \\
2012\end{array}$ \\
\hline & & & Guttiferone A & $\begin{array}{l}\text { Gustafson et al., } \\
1992\end{array}$ \\
\hline 21 & G. macrophylla & Twigs & Guttiferone $\mathrm{A}$ and guttiferone $\mathrm{G}$ & $\begin{array}{l}\text { Williams et al., } \\
2003\end{array}$ \\
\hline 22 & G. maingayii & $\begin{array}{l}\text { Stem } \\
\text { bark }\end{array}$ & Isoxanthochymol and camboginol & $\begin{array}{l}\text { Hartati et al., } \\
2007\end{array}$ \\
\hline \multirow[t]{6}{*}{23} & \multirow[t]{6}{*}{ G. mangostana } & Leaf & Garcinol & $\begin{array}{l}\text { Pandey et al., } \\
2015\end{array}$ \\
\hline & & $\begin{array}{l}\text { Heart } \\
\text { wood }\end{array}$ & $\begin{array}{l}\text { 3',6-Dihydroxy-2,4,4'- trimethoxy } \\
\text { benzophenone }\end{array}$ & $\begin{array}{l}\text { Nguyen et al., } \\
2005\end{array}$ \\
\hline & & Fruit & $\begin{array}{l}\text { Guttiferone A, xanthochymol, and } \\
\text { guttiferone } \mathrm{E}\end{array}$ & $\begin{array}{l}\text { Acuna et al., } \\
2012\end{array}$ \\
\hline & & \multirow[t]{2}{*}{$\begin{array}{l}\text { Fruit } \\
\text { hull }\end{array}$} & $\begin{array}{l}\text { 2,4,6,7- Tetrahydroxyxanthone, } 3,4,5,3 \text { '- } \\
\text { tetrahydroxybenzophenone, and 2,4,6,3',5'- } \\
\text { pentahydroxybenzophenone }\end{array}$ & Jiang et al., 2010 \\
\hline & & & Garcimangosone D & $\begin{array}{l}\text { Huang et al., } \\
2001\end{array}$ \\
\hline & & $\begin{array}{l}\text { Stem } \\
\text { bark }\end{array}$ & Mangaphenone & See et al., 2014 \\
\hline 24 & G. mannii & $\begin{array}{l}\text { Stem } \\
\text { bark }\end{array}$ & Xanthochymol & $\begin{array}{l}\text { Crichton et al., } \\
1979\end{array}$ \\
\hline 25 & G. morella & Leaf & Garcinol & $\begin{array}{l}\text { Pandey et al., } \\
2015\end{array}$ \\
\hline \multirow[t]{2}{*}{26} & \multirow[t]{2}{*}{ G. multiflora } & $\begin{array}{l}\text { Bark, } \\
\text { stem }\end{array}$ & $\begin{array}{l}\text { 4,6,4'-Trihydroxy-2,3'-dimethoxy-3- } \\
\text { prenylbenzophenone }\end{array}$ & $\begin{array}{l}\text { Chiang et al., } \\
2003\end{array}$ \\
\hline & & Fruit & $\begin{array}{l}\text { 13,14-Didehydoxyisogarcinol, garcimultiflorone } \\
\text { A, garcimultiflorone B, 13-hydroxy } \\
\text { garcimultiflorone B, and garcimultiflorone C }\end{array}$ & $\begin{array}{l}\text { Chen et al., } \\
2009 .\end{array}$ \\
\hline 27 & G. myrtifolia & Bark & Myrtiaphenone-A, B and vismiaphenone $\mathrm{C}$ & $\begin{array}{l}\text { Spino et al., } \\
1995\end{array}$ \\
\hline \multirow[t]{4}{*}{28} & \multirow[t]{4}{*}{ G. ovalifolia } & Leaf & Guttiferone E & $\begin{array}{l}\text { Gustafson et al., } \\
1992\end{array}$ \\
\hline & & $\begin{array}{l}\text { Stem } \\
\text { bark }\end{array}$ & Xanthochymol and isoxanthochymol & $\begin{array}{l}\text { Waterman and } \\
\text { Crichton, 1980b }\end{array}$ \\
\hline & & Fruit & Xanthochymol & $\begin{array}{l}\text { Waterman et al., } \\
1980 \mathrm{~b}\end{array}$ \\
\hline & & Root & Epigarcinol and isogarcinol & $\begin{array}{l}\text { Pieme et al., } \\
2015\end{array}$ \\
\hline \multirow[t]{2}{*}{29} & G. paucinervis & Leaf & Paucinones A-D & Gao et al., 2010 \\
\hline & & Seed & Paucinones E-I & Li et al., 2016 \\
\hline \multirow[t]{2}{*}{30} & \multirow[t]{2}{*}{ G. pedunculata } & Fruit & Pedunculol, garcinol, and cambogin & Sahu et al., 1989 \\
\hline & & Heart & 2,4,6,3',5'-Pentahydroxybenzophenone & Rao et al., 1974 \\
\hline
\end{tabular}




\begin{tabular}{|c|c|c|c|c|}
\hline & & wood & & \\
\hline 31 & G. picrorrhiza & Bark & Garcinopicobenzophenone and guttiferone $\mathrm{F}$ & $\begin{array}{l}\text { Soemiati et al., } \\
2006\end{array}$ \\
\hline 32 & G. polyantha & $\begin{array}{l}\text { Stem } \\
\text { bark }\end{array}$ & Xanthochymol and isoxanthochymol & $\begin{array}{l}\text { Ampofo and } \\
\text { Waterman, } 1986\end{array}$ \\
\hline 33 & G. propinqua & Twig & Doitunggarcinones A and B & $\begin{array}{l}\text { Tantapakul et al., } \\
2012\end{array}$ \\
\hline 34 & G. pseudoguttifera & $\begin{array}{l}\text { Heart } \\
\text { wood }\end{array}$ & $\begin{array}{l}\text { Myrtiaphenone-A, myrtiaphenone- } \mathrm{B}, \\
\text { myrtiaphenone- } \mathrm{C} \text {, and pseudoguttiaphenone-A }\end{array}$ & Ali et al., 2000 \\
\hline 35 & G. purpurea & Pericarp & $\begin{array}{l}\text { Xanthochymol, cambogin (isogarcinol), and } \\
\text { camboginol (garcinol) }\end{array}$ & $\begin{array}{l}\text { Matsumoto et } \\
\text { al., } 2003 \\
\text { Iinuma et al., } \\
1996 \\
\text { Steller, } 1995\end{array}$ \\
\hline 36 & $\begin{array}{l}\text { G. } \\
\text { pushpangadaniana }\end{array}$ & Leaf & Garcinol & $\begin{array}{l}\text { Pandey et al., } \\
2015\end{array}$ \\
\hline 37 & G. pyrifera & Fruit & Guttiferone E and Xanthochymol & Roux et al., 2000 \\
\hline 38 & G. schomburgkiana & Fruit & Schomburgkianones A-H & Le et $a l ., 2016$ \\
\hline 39 & G. semseii & $\begin{array}{l}\text { Stem } \\
\text { bark }\end{array}$ & Semsinones A-C & $\begin{array}{l}\text { Magadula et al., } \\
2008\end{array}$ \\
\hline \multirow[t]{2}{*}{40} & \multirow[t]{2}{*}{ G. smeathmannii } & $\begin{array}{l}\text { Stem } \\
\text { bark }\end{array}$ & Guttiferone I and isoxanthochymol & $\begin{array}{l}\text { Kuete et al., } \\
2007\end{array}$ \\
\hline & & $\begin{array}{l}\text { Root } \\
\text { bark }\end{array}$ & Guttiferone I and isoxanthochymol & $\begin{array}{l}\text { Lannang et al., } \\
2006\end{array}$ \\
\hline 41 & G. solomonensis & $\begin{array}{l}\text { Stem } \\
\text { bark }\end{array}$ & Guttiferones $\mathrm{O}$ and $\mathrm{P}$ & $\begin{array}{l}\text { Carrol et al., } \\
2009\end{array}$ \\
\hline 42 & G. speciosa & $\begin{array}{l}\text { Trunk } \\
\text { bark, } \\
\text { stem }\end{array}$ & Garciosaphenone & $\begin{array}{l}\text { Rukachaisirikul } \\
\text { et al., 2003a }\end{array}$ \\
\hline \multirow[t]{2}{*}{43} & \multirow[t]{2}{*}{ G. spicata } & Leaf & Garcinol & $\begin{array}{l}\text { Pandey et al., } \\
2015\end{array}$ \\
\hline & & Fruit & $\begin{array}{l}\text { Guttiferone A, xanthochymol, and } \\
\text { guttiferone E }\end{array}$ & $\begin{array}{l}\text { Acuna et al., } \\
2012\end{array}$ \\
\hline 44 & G. staudtii & $\begin{array}{l}\text { Stem } \\
\text { bark }\end{array}$ & Xanthochymol & $\begin{array}{l}\text { Waterman and } \\
\text { Hussain, } 1982\end{array}$ \\
\hline \multirow[t]{2}{*}{45} & \multirow[t]{2}{*}{ G. subelliptica } & Fruits & $\begin{array}{l}\text { Garcinialiptone } \mathrm{A} \text {, garcinialiptone } \mathrm{B},(-)- \\
\text { cycloxanthochymol, garcinialiptone } \mathrm{C}, \\
\text { garcinialiptone } \mathrm{D} \text {, xanthochymol, } \\
\text { isoxanthochymol, and cycloxanthochymol }\end{array}$ & $\begin{array}{l}\text { Zhang et al., } \\
2010\end{array}$ \\
\hline & & Wood & 4',6-dihydroxy-2,3'4-trimethoxybenzophenone & $\begin{array}{l}\text { Minami et al., } \\
1994\end{array}$ \\
\hline 46 & G. vieillardii & $\begin{array}{l}\text { Stem } \\
\text { bark }\end{array}$ & $\begin{array}{l}\text { Clusiachromene and 3-geranyl-2,4,6- } \\
\text { trihydroxybenzophenone }\end{array}$ & Hay et al., 2008 \\
\hline 47 & G. virgata & $\begin{array}{l}\text { Stem } \\
\text { bark }\end{array}$ & $\begin{array}{l}\text { Guttiferone E, xanthochymol, and guttiferones I } \\
\text { and J }\end{array}$ & $\begin{array}{l}\text { Merza et al., } \\
2006\end{array}$ \\
\hline 48 & G. wightii & Leaf & Garcinol & $\begin{array}{l}\text { Pandey et al., } \\
2015\end{array}$ \\
\hline \multirow[t]{2}{*}{49} & \multirow[t]{2}{*}{ G. xanthochymus } & Leaf & Garcinol & $\begin{array}{l}\text { Pandey et al., } \\
2015\end{array}$ \\
\hline & & Fruit & Guttiferone $\mathrm{H}$ and gambogenone & $\begin{array}{l}\text { Bagget et al., } \\
2005\end{array}$ \\
\hline
\end{tabular}




\begin{tabular}{|c|c|c|c|c|}
\hline & & & $\begin{array}{l}\text { Guttiferone } \mathrm{A} \text {, xanthochymol, and } \\
\text { guttiferone } \mathrm{E}\end{array}$ & $\begin{array}{l}\text { Acuna et al., } \\
2012\end{array}$ \\
\hline & & & Xanthochymol and garcinol & $\begin{array}{l}\text { Jackson et al., } \\
2015\end{array}$ \\
\hline & & & Xanthochymol, Isoxanthochymol, and maclurin & $\begin{array}{l}\text { Baslas and } \\
\text { Kumar } 1979\end{array}$ \\
\hline 50 & $\begin{array}{l}\text { G. } \\
\text { xipshuanbannaensi } \\
S\end{array}$ & Twig & Guttiferone E and xanthochymol & Han et al., 2008 \\
\hline
\end{tabular}

\section{Biflavonoids}

Biflavonoids are a distinct class of naturally occurring flavonoid dimers linked by a C-C or $\mathrm{C}-\mathrm{O}-\mathrm{C}$ bond. The biogenesis of biflavonoids involves the radical pairing of two embryonic flavonoid units. The ring $\mathrm{B}$ and $\mathrm{C}$ of flavonoid units were formed through shikimic acid pathway, while ring $\mathrm{A}$ is formed through acetate pathway (Figure 5). Depending on the monomeric unit like flavones, flavanones, isoflavones, flavanols, chalcones, aurones and dihydrochalcones, different combinations of flavonoid dimers such as flavanone-flavone, flavones-flavone, flavone-flavonol are possible. Naturally occurring biflavonoids contains hydroxy or methoxy groups substituted at different positions leading to diverse array of biflavonoids (Mercader and Pomilio, 2012). Amentoflavones with the 3-8 linkage is considered as the primitive or basic form of biflavonoids in vascular plants.

The rapid growth in literature on biflavanoids led to various systems of naming and though systematic IUPAC and Locksley names exists, most of the biflavonoids are known by their vernacular names (Locksley, 1973). In Locksley system, for example, amentoflavone is named as I-4', II-4', I-5, II-5, I-7, II-7-hexahydroxy I-3', II-8 biflavone, while in IUPAC system, amentoflavone is named as 8-5-(5,7-dihydroxy-4-oxo-4H-chromen-2-il)-2hydroxyphenyl-5,7-dihydroxy- 2-(4-hydroxy-phenyl)-chromen-4-on. Basic difference between the two systems is reference of structural skeleton, where Locksley use flavanoid structure, while IUPAC use chromen structure (Rahman et al.,2007).

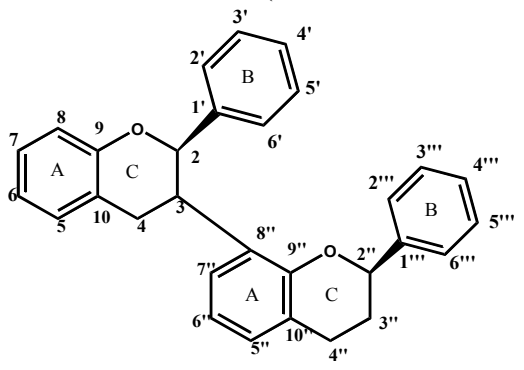

Figure 5. Numbering in typical biflavonoid structure

The distribution of biflavonoids is limited to some plant groups, especially in the primitive orders such as Bryales, Psilotales and Selaginellales, and sporadically in the angiosperms. According to Gieger and Quinn (1988), angiosperms lost the capacity to biosynthesis biflavonoids in the course of evolution, but was regained by a selected family. The genus Garcinia is a rich source of biflavonoids and out of the 120 Garcinia species studied for their secondary metabolites, biflavonoids were reported from 45 species (Table 3). 
Majority of the naturally occurring biflavonoids contain C-C linked monomers and I(3)-II (8) linkage is the most prevalent inter-linkage in Garcinia biflavonoids (Yamaguchi et al., 2008). Biflavonoids reported from the Garcinia species with 3-8'" interflavonoid linkage can generally be divided into two subgroups; biflavonones made up of two flavanone units (GB type of biflavonoids) and those made up of one flavanone and one flavone subunits (morelloflavone and volkensiflavone) (Figure 6). Of the two types, biflavonones is the major type in Garcinia species whereas the co-occurrence of the two types of biflavonoids is rare (Waterman and Hussain, 1983). Morelloflavone, isolated from G. morella in 1967 is the first biflavonoid reported with a flavone and a flavonone unit (Karanjgaokar et al., 1967). Amentoflavone $\left(5^{\prime}, 8^{\prime \prime}\right.$-biapigenin) is the common example for $\mathrm{I}\left(5^{\prime}\right)$ - $\mathrm{II}(8)$ biflavonoid distributed in Garcinia species. It is interesting to note that the biflavonoid linkage has potential significance in systematic (Waterman and Husain, 1983).

Biflavonoids generally exist as rotamers and can be monitored by variable temperature NMR studies, where at room temperature the biflavonoids exhibit duplicate NMR signals, while at elevated temperature a single set of signals was obtained (Jamila, et al., 2014). Mass spectrometry is perhaps the most informative tool for structure elucidation of biflavonoids (Zhang et al., 2011). The most useful fragmentations in terms of structural identification are those involving the C-ring cleavage of biflavonoids. Fragmentation peaks for phloroglucinol (m/z 126), p-methoxy benzyl (m/z 138), p-hydroxy benzyl (m/z 124) and retro Diels Alder cleavage products are usually observed for biflavonoids.

A variety of biological activities like anti inflammatory, anti HIV, antifungal, anti tumor, hypocholesterolemic, and anti-plasmodial were attributed to biflavonoids (Gil et al., 1997, Lin et al., 1997 Yamaguchi et al., 2008, Pang et al., 2009). Of the different activities, antioxidant activity is of highly significant, where biflavonoids inhibits transition metal ions in free radical generating reactions by complexing and quenching the metal ions (Yamaguchi, et al., 2008).

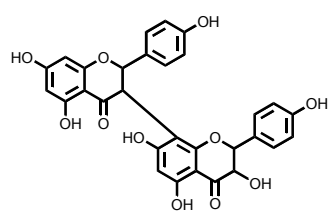

GB-1

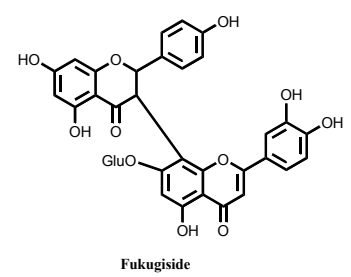

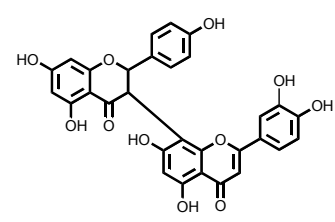

Morelloflavone

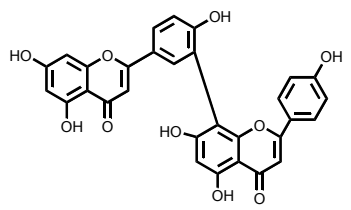

Amentoflavone

Figure 6. Structures of I(3)-II(8) linked biflavonones (GB1), flavanone-flavone (morelloflavone), flavanone-flavone glycoside (fukugiside) and I(5')-II(8) linked biflavone (amentoflavone) 
Table 3. Biflavonoids reported from Garcinia species

\begin{tabular}{|c|c|c|c|c|}
\hline $\begin{array}{l}\text { Sl. } \\
\text { No. }\end{array}$ & Garcinia species & Plant part & Biflavonoids & Reference \\
\hline 1 & G. atroviridis & Stem bark & Garcineflavonol & $\begin{array}{l}\text { Tan et al., } \\
2014\end{array}$ \\
\hline 2 & G. bakeriana & Leaf & $\begin{array}{l}\text { 4"'-O-Methyl-I3,II8-biapigenin, amentoflavone, } \\
\text { 4"'-O-methylamentoflavone, 4'-O- } \\
\text { methylcupressuflavone, GB-2a, volkensiflavone, } \\
\text { 6"-(2-hydroxy-3-methyl-3-butenyl)- } \\
\text { amentoflavone, I3,II8-biapigenin, and GB-1a }\end{array}$ & $\begin{array}{l}\text { Al-Shagdari et } \\
\text { al., } 2013\end{array}$ \\
\hline \multirow[t]{3}{*}{3} & \multirow[t]{3}{*}{ G. brasiliensis } & \multirow[t]{2}{*}{ Epicarp } & $\begin{array}{l}\text { Morelloflavone, morelloflavone-4"'-O- } \beta \text {-D- } \\
\text { glycoside, and morelloflavone-7"-O- } \beta \text {-D- } \\
\text { glycoside }\end{array}$ & $\begin{array}{l}\text { Gontijo et al., } \\
2012\end{array}$ \\
\hline & & & Fukugetin & $\begin{array}{l}\text { Castro et al., } \\
2015\end{array}$ \\
\hline & & $\begin{array}{l}\text { Branch, } \\
\text { leaf }\end{array}$ & $\begin{array}{l}\text { Procyanidin, fukugetin, amentoflavone, and } \\
\text { podocarpusflavone }\end{array}$ & $\begin{array}{l}\text { Arwa et al, } \\
2015\end{array}$ \\
\hline 4 & $\begin{array}{l}\text { G. } \\
\text { brevipedicellata }\end{array}$ & Heart wood & $\begin{array}{l}\text { Amentoflavone , 4"'-O-methyl amentoflavone, } \\
\text { Robustaflavone, 4'-O-methyl robustaflavone, } \\
\text { and tetrahinokiflavone }\end{array}$ & $\begin{array}{l}\text { Abderamane } e t \\
\text { al., } 2016\end{array}$ \\
\hline \multirow[t]{3}{*}{5} & \multirow[t]{3}{*}{ G. buchananii } & \multirow[t]{3}{*}{ Stem bark } & GB-1, GB1a, GB-2 and GB-2a & $\begin{array}{l}\text { Jackson et al., } \\
1968 \text { and } 1971\end{array}$ \\
\hline & & & $\begin{array}{l}\left(2 \mathrm{R}, 3 \mathrm{~S}, 2^{\prime \prime} \mathrm{R}, 3 \text { "R)-Manniflavanone, }\right. \\
\left(2 \mathrm{R}, 3 \mathrm{~S}, 2^{\prime \prime} \mathrm{R}, 3^{\prime \prime} \mathrm{R}\right) \text { - isomanniflavanone, } \\
\left(2^{\prime \prime} \mathrm{R}, 3 \text { "R)-preussianone, (2R,3S,2"R,3"R)-GB-2 }\right. \\
7 \text { "-O- } \beta \text {-D-glucopyranoside, and } \\
(2 \mathrm{R}, 3 \mathrm{~S}, 2 \text { "R,3"R)-manniflavanone-7"-O- } \beta \text {-D- } \\
\text { glucopyranoside }\end{array}$ & $\begin{array}{l}\text { Stark et al., } \\
2015\end{array}$ \\
\hline & & & $\begin{array}{l}\text { (2R,3S,2"R,3"R)-Manniflavanone, } \\
\left(2 \mathrm{R}, 3 \mathrm{~S}, 2^{\prime \prime} \mathrm{R}, 3 \text { "R)-GB-2 and (2R,3S,2"S)- }\right. \\
\text { buchananiflavanone }\end{array}$ & $\begin{array}{l}\text { Stark et al., } \\
2012\end{array}$ \\
\hline 6 & G. conrauana & $\begin{array}{l}\text { Stem bark } \\
\text { Heart wood }\end{array}$ & $\begin{array}{l}\text { GB-1, GB1a, GB-2, } \\
\text { morelloflavone, O-methyl fukugetin, and O- } \\
\text { methyl fukugetin glycoside }\end{array}$ & $\begin{array}{l}\text { Hussain and } \\
\text { Waterman, } \\
1982\end{array}$ \\
\hline 7 & G. cornea & Stem bark & Morelloflavone and fukugiside & $\begin{array}{l}\text { Elfita et al., } \\
2009\end{array}$ \\
\hline \multirow[t]{3}{*}{8} & \multirow[t]{3}{*}{ G. cowa } & Branch & $\begin{array}{l}\text { GB-2, morelloflavone, volkensiflavone, and } \\
\text { fukugiside }\end{array}$ & $\begin{array}{l}\text { Shen and } \\
\text { Yang, 2007; } \\
\text { Panthong et } \\
\text { al., } 2009\end{array}$ \\
\hline & & Fruit & Amentoflavone and morelloflavone & $\begin{array}{l}\text { Shen and } \\
\text { Yang, } 2006\end{array}$ \\
\hline & & Leaf & Fukugicide, amentoflavone, GB-1, and GB-2 & $\begin{array}{l}\text { Pandey et } \\
\text { al.,2015 }\end{array}$ \\
\hline 9 & G. cymosa & Stem bark & $\begin{array}{l}\text { Morelloflavone and morelloflavone-7"'-O- } \beta \text {-D- } \\
\text { glucoside }\end{array}$ & $\begin{array}{l}\text { Elfita et al., } \\
2009\end{array}$ \\
\hline 10 & G. densivenia & Stem bark & Morelloflavone and O-methyl fukugetin & $\begin{array}{l}\text { Waterman and } \\
\text { Crichton, } \\
1980 \mathrm{a}\end{array}$ \\
\hline 11 & G. dulcis & Leaf & $\begin{array}{l}\text { Amentoflavone, fukugetin, volkensiflavone, and } \\
\text { flavanone-(1-3:11-8)-chromone, 1-4' } \\
\text { (flavanone- chromone) }\end{array}$ & $\begin{array}{l}\text { Ansari et al., } \\
1976\end{array}$ \\
\hline
\end{tabular}




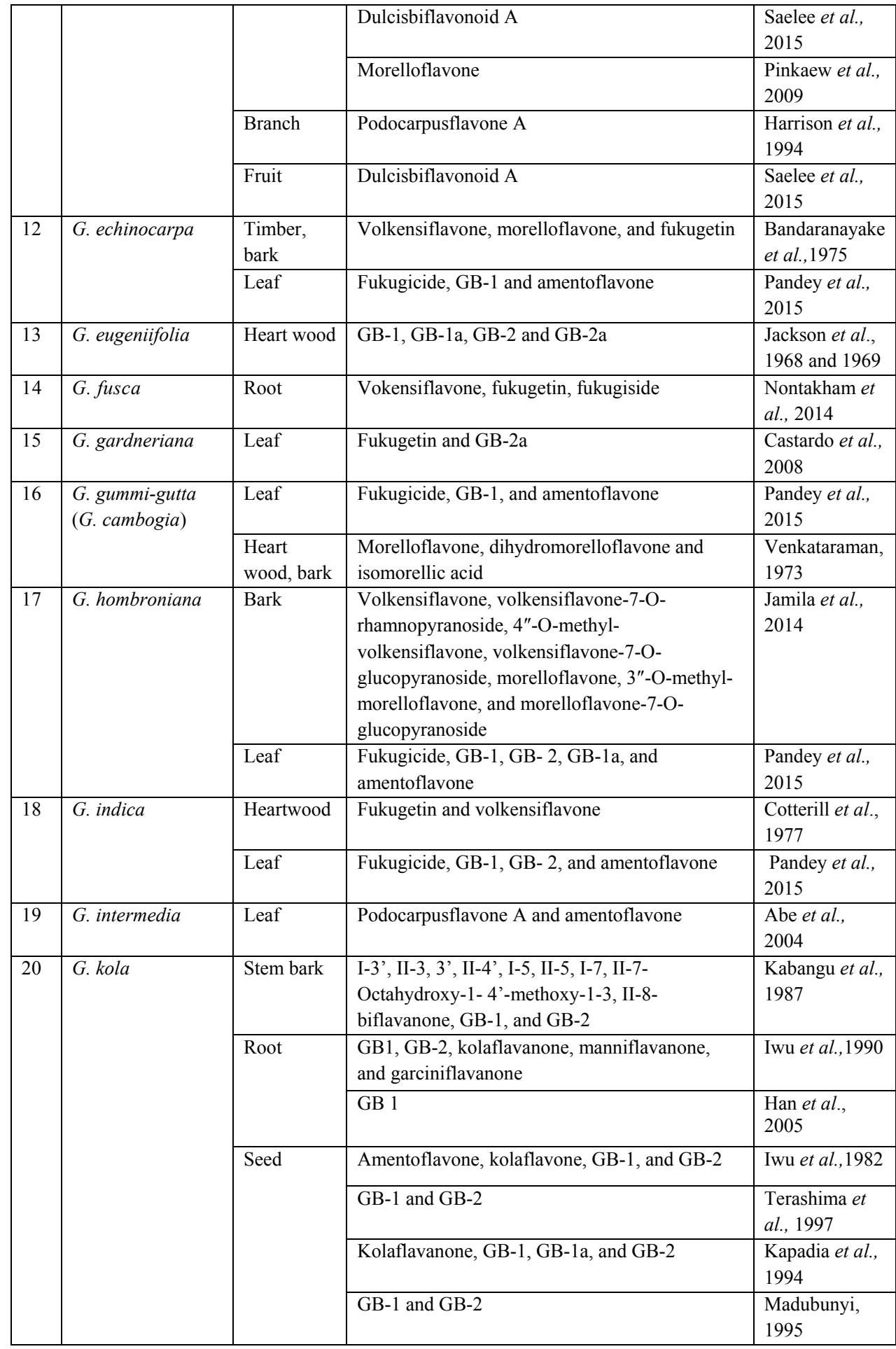




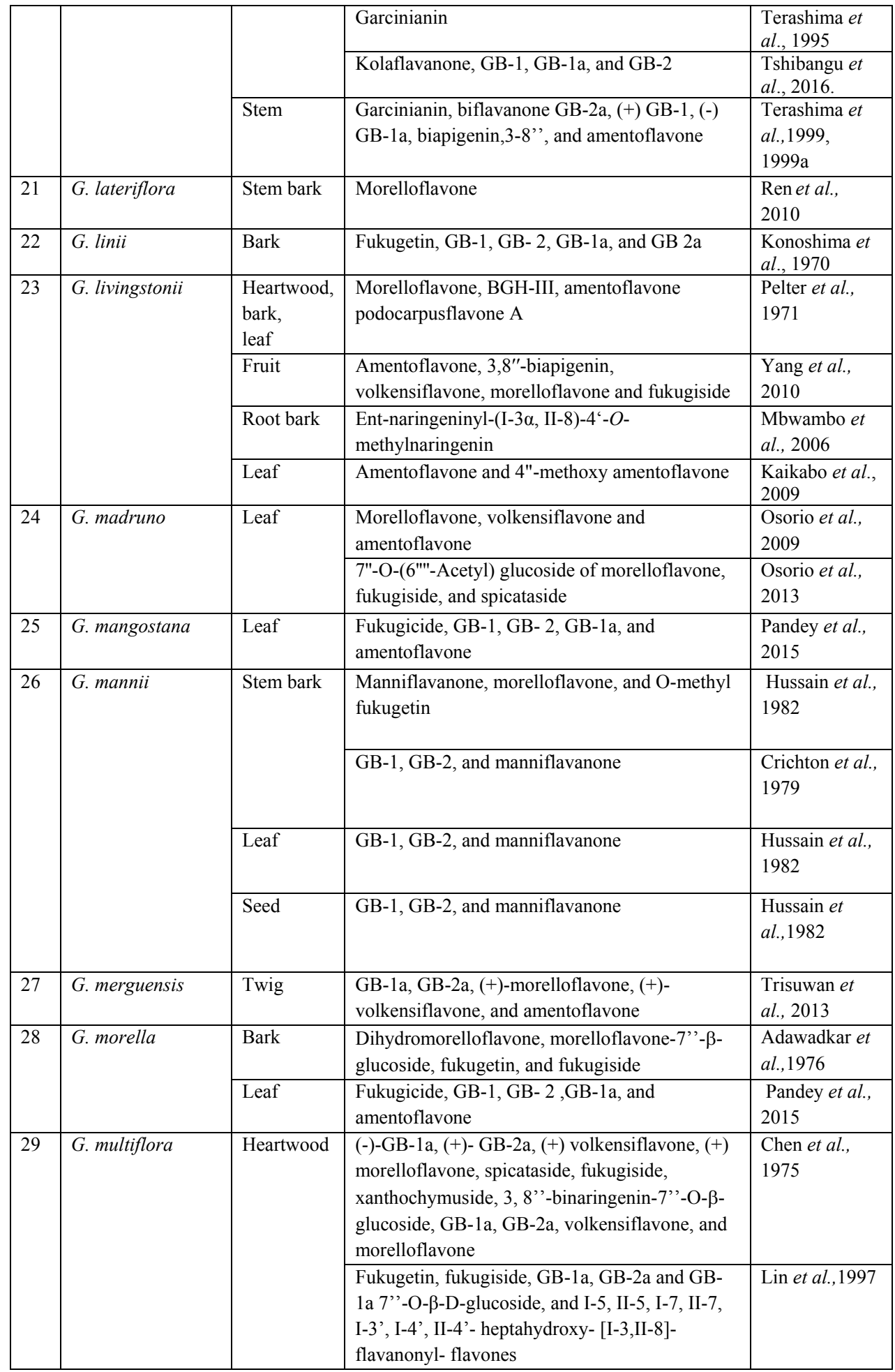




\begin{tabular}{|c|c|c|c|c|}
\hline & & Bark & $\begin{array}{l}\text { Fukugetin, GB-1, GB- } 2 \text {,GB-1a, GB-2a, and } \\
\text { volkensiflavone }\end{array}$ & $\begin{array}{l}\text { Konoshima et } \\
\text { al., } 1970\end{array}$ \\
\hline 30 & G. nervosa & Leaf & $\begin{array}{l}\text { I-5, II-5, I-7, II-7, I-3', I-4', II-4'- } \\
\text { Heptahydroxy- [I-3, II-8]- flavanonyl flavones } \\
\text { and I-3, II-3, I-5, II-5, I-7, II-7, I-4', II-4'- } \\
\text { octahydroxy [I-2', II-2'] biflavone }\end{array}$ & $\begin{array}{l}\text { Babu et al., } \\
1988 \\
\text { Parveen et al., } \\
2004\end{array}$ \\
\hline 31 & G. pedunculata & Heart wood & GB-1a and volkensiflavone & $\begin{array}{l}\text { Rao et al., } \\
1974\end{array}$ \\
\hline 32 & G. prainiana & Stem bark & $\begin{array}{l}\text { Morelloflavone, O-methyl fukugetin, } \\
\text { volkensiflavone, amentoflavone, and } 4{ }^{\prime \prime \prime} \text { - } \\
\text { methoxyamentoflavone }\end{array}$ & On et al., 2016 \\
\hline 33 & G. preussii & Leaf & Preussianone & $\begin{array}{l}\text { Messi et al., } \\
2012\end{array}$ \\
\hline 34 & $\begin{array}{l}\text { G. } \\
\text { pushpangadaniana }\end{array}$ & Leaf & $\begin{array}{l}\text { Fukugicide, GB-1, GB- } 2 \text {,GB-1a, and } \\
\text { amentoflavone }\end{array}$ & $\begin{array}{l}\text { Pandey et al., } \\
2015\end{array}$ \\
\hline 35 & G. quadrifaria & $\begin{array}{l}\text { Stembark } \\
\text { Seed }\end{array}$ & Fukugetin and O-methyl fukugetin & $\begin{array}{l}\text { Waterman and } \\
\text { Hussain, } 1982\end{array}$ \\
\hline 36 & $\begin{array}{l}\text { G. } \\
\text { schomburgkiana }\end{array}$ & Fruit & $\begin{array}{l}\text { GB-1a, GB-2a, morelloflavone, and } \\
\text { volkensiflavone }\end{array}$ & Le et al., 2016 \\
\hline 37 & G. scortechinii & Fruit & $(+)$ Volkensiflavone and $(+)$ morelloflavone & $\begin{array}{l}\text { Sukpodma et } \\
\text { al., } 2005\end{array}$ \\
\hline \multirow[t]{5}{*}{38} & \multirow[t]{5}{*}{ G. spicata } & \multirow[t]{2}{*}{ Leaf } & GB-1, GB-1a, GB-2a, and fukugetin & $\begin{array}{l}\text { Gunatilaka et } \\
\text { al., } 1984\end{array}$ \\
\hline & & & $\begin{array}{l}\text { Fukugicide, GB-1, GB- } 2 \text {,GB-1a, and } \\
\text { amentoflavone }\end{array}$ & $\begin{array}{l}\text { Pandey et al., } \\
2015\end{array}$ \\
\hline & & \multirow[t]{3}{*}{ Bark } & Fukugetin and 3-O-methyl fukugetin & $\begin{array}{l}\text { Konoshima } \\
\text { and Ikeshiro, } \\
1969\end{array}$ \\
\hline & & & Fukugiside & $\begin{array}{l}\text { Konoshima } \\
\text { and Ikeshiro, } \\
1970\end{array}$ \\
\hline & & & $\begin{array}{l}\text { Volkensiflavone, spicataside, biflavonoid } \\
\text { glycoside, GB-la, and GB-2a }\end{array}$ & $\begin{array}{l}\text { Konoshima et } \\
\text { al., 1970a }\end{array}$ \\
\hline \multirow[t]{2}{*}{39} & \multirow[t]{2}{*}{ G. subelliptica } & Pericarp & Podocarpusflavone A & $\begin{array}{l}\text { Iinuma et al., } \\
1996\end{array}$ \\
\hline & & NSf & $\begin{array}{l}\text { 2R,3S-5,7,4',5",7",3"',4"'-Heptahydroxy } \\
\text { flavanone[3-8"] flavone, and 5,7,4',5",7",3"',4"'- } \\
\text { heptahydroxy[3-8"] biflavanone }\end{array}$ & $\begin{array}{l}\text { Masuda et al., } \\
2005\end{array}$ \\
\hline 40 & G. talboti & Root & Talbotaflavone and morelloflavone & $\begin{array}{l}\text { Joshi et al., } \\
1970\end{array}$ \\
\hline \multirow[t]{2}{*}{41} & \multirow[t]{2}{*}{ G. terpnophylla } & $\begin{array}{l}\text { Timber, } \\
\text { bark }\end{array}$ & 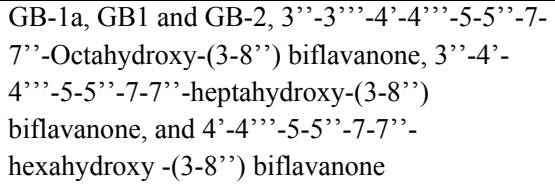 & $\begin{array}{l}\text { Bandaranayake } \\
\text { et al., } 1975\end{array}$ \\
\hline & & Wood & 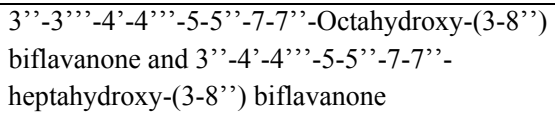 & $\begin{array}{l}\text { Bandaranayake } \\
\text { et al., } 1975\end{array}$ \\
\hline 42 & G. thwaitesii & $\begin{array}{l}\text { Timber, } \\
\text { bark }\end{array}$ & $\begin{array}{l}\text { II-3, I-4', II-4', I-5, II-5,I-7,II-7- Heptahydroxy } \\
\text { (I-3,II-8) biflavanone, I-4', Ii-4', I-5, II-5,I-7,II- } \\
\text { 7-hexahydroxy (I-3,II-8) biflavanone, II-3,II- } \\
\text { 3',I-4,II-4',I-5,II-5,I-7,II-7- octahydroxy (I-3,II- }\end{array}$ & $\begin{array}{l}\text { Gunatilaka et } \\
\text { al., } 1983\end{array}$ \\
\hline
\end{tabular}




\begin{tabular}{|c|c|c|c|c|}
\hline & & & $\begin{array}{l}\text { 8) biflavanone, I-4', II-3', II-4', I-5, II-5, I-7, II- } \\
\text { 7-heptahydroxy (I-3,II-8) biflavanone, I-4'-II-3'- } \\
\text { II-4'-I-5-II -5-I-7-II-7-Heptahydroxy-(I-3-II-8) } \\
\text { biflavanone, I-4'-II-4'-I-5-II-5-I-7 -II-7- } \\
\text { hexahydroxy-(I-3-II-8) biflavanone, } \\
\text { II-3-I-4'-II-4'-I-5-II-5-I-7-heptahydroxy-(I-3-II- } \\
\text { 8) biflavanone, II-3-II-3'-I-4'-II-4'-I -5-II-5-I-7- } \\
\text { II-7-octahydroxy-(I-3-II-8) biflavanone, } \\
\text { I-4'-II-3'-II-4'-I-5-II -5-I-7-II-7-Heptahydroxy- } \\
\text { (I-3-II-8) biflavanone, I-4'-II-4'-I-5-II-5-I-7 -II- } \\
\text { 7-hexahydroxy-(I-3-II-8) biflavanone, and } \\
\text { II-3-I-4'-II-4'-I-5-II- 5-I-7-II-7-heptahydroxy-(I- } \\
\text { 3-II-8) biflavanone }\end{array}$ & \\
\hline 43 & G. volkensii & Heartwood & $\begin{array}{l}\text { GB-1a, GB-2a, morelloflavone, and } \\
\text { volkensiflavone }\end{array}$ & $\begin{array}{l}\text { Herbin et al., } \\
1970\end{array}$ \\
\hline 44 & G. wightii & Leaf & $\begin{array}{l}\text { Fukugicide, GB-1, GB- 2, GB-1a, and } \\
\text { amentoflavone }\end{array}$ & $\begin{array}{l}\text { Pandey et al., } \\
2015\end{array}$ \\
\hline \multirow[t]{6}{*}{45} & \multirow[t]{6}{*}{ G. xanthochymus } & \multirow[t]{2}{*}{ Leaf } & Agathisflavone and 7-O-methyl amentoflavone & $\begin{array}{l}\text { Parveen et al., } \\
1994\end{array}$ \\
\hline & & & $\begin{array}{l}\text { Fukugicide, GB-1, GB- 2, GB-1a, and } \\
\text { amentoflavone }\end{array}$ & $\begin{array}{l}\text { Pandey et al., } \\
2015\end{array}$ \\
\hline & & \multirow[t]{2}{*}{ Fruit } & $\begin{array}{l}\text { Volkensiflavone, morelloflavone, GB-1, and } \\
\text { GB-1a }\end{array}$ & $\begin{array}{l}\text { Baslas and } \\
\text { Kumar } 1979\end{array}$ \\
\hline & & & $\begin{array}{l}\text { 3-8'’-3'’-4'-4','-5-5'’-7'’-Heptahydroxy } \\
\text { biflavanone, 3-8'’-4'-4'’-5-5',-7-7',- } \\
\text { hexahydroxy biflavanone, fukugetin, and } \\
\text { volkensiflavone }\end{array}$ & $\begin{array}{l}\text { Baslas and } \\
\text { Kumar } 1981\end{array}$ \\
\hline & & $\begin{array}{l}\text { Leaf, root } \\
\text { and fruit }\end{array}$ & GB-2a glucoside, GB-2a, and fukugetin & Li et al.,2014 \\
\hline & & Wood, leaf & $\begin{array}{l}\text { GB-1a, GB-2, volkensiflavone, fukugiside, } \\
\text { xanthochymoside, and morelloflavone }\end{array}$ & $\begin{array}{l}\text { Konoshima et } \\
\text { al., } 1970\end{array}$ \\
\hline
\end{tabular}

\section{Depsidones}

Depsidones comprise benzoic acid and phenol skeletons condensed at the ortho-positions through ester and ether linkages (Figure 7). This class of compounds is well known in Garcinia species (Ha et al., 2012).

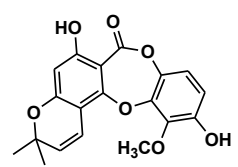

Brevipsidone C

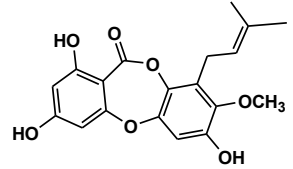

Cowadepsidone

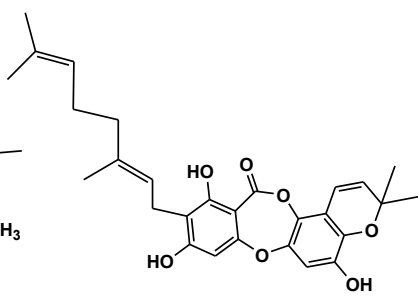

Parvifolidone B

Figure 7. Structures of brevipsidone $\mathrm{C}$ (simple despidone), cowadespidone (monoprenylated despidone) and parvifolidone $\mathrm{B}$ (geranyl substituted despidone) 
Table 4. Despidones reported from Garcinia species

\begin{tabular}{|l|l|l|l|l|}
\hline $\begin{array}{l}\text { Sl. } \\
\text { No. }\end{array}$ & Garcinia species & Plant part & Depsidones & Reference \\
\hline 1 & G. assigu & Stem bark & Garcinisidone A & Ito et al., 1997 \\
\hline 2 & G. atroviridis & Root & $\begin{array}{l}\text { Atrovirisidone, } \\
\text { Atrovirisidone B }\end{array}$ & $\begin{array}{l}\text { Permana } \text { et al., 2001, } \\
2005\end{array}$ \\
\hline 3 & G. brevipedicellata & Stem bark & Brevipsidones A-D & Ngoupayo et al., 2008 \\
\hline 4 & G. buchananii & Stem bark & Garcinisidone G & Stark et al., 2015a \\
\hline 5 & G. celebica & Bark & Garcinisidone H & Bui et al., 2016 \\
\hline 6 & G. cowa & Twig & Cowadepsidone & $\begin{array}{l}\text { Cheenpracha } \text { et al., } \\
\text { 2011 }\end{array}$ \\
\hline 7 & G. dulcis & Stem bark & Garcinisidone A & Ito et al., 1997 \\
\hline 8 & G. latissima & Stem bark & Garcinisidone A & Ito et al., 1997 \\
\hline 9 & G. neglecta & Leaf & Garcinisidone B-F & Ito et al., 2001 \\
\hline 10 & G. oliveri & Bark & Oliveridepsidones A-D & Ha et al., 2012 \\
\hline 11 & G. parvifolia & Leaf & Garcidepsidone A, B, C, and & Xu et al., 2000 \\
& & & D & $\begin{array}{l}\text { Rukachaisirikul } \text { et al., } \\
\text { 2008 }\end{array}$ \\
\cline { 3 - 5 } & & & Garcidepsidone B & $\begin{array}{l}\text { Rukachaisirikul } \text { et al., } \\
\text { 2006 }\end{array}$ \\
\cline { 3 - 5 } & & Twig & Parvifolidones A, B & Ito et al., 2001 \\
\hline 12 & G. puat & Leaf & Garcinisidone B-F & Sukandar et al., 2016a \\
\hline 13 & G. schomburgkiana & Root & Schomburgdepsidones A, B &
\end{tabular}

\section{Biphenyls}

Biphenyls, reported as potential phytoalexins, are restricted to certain families and Clusiaceae is one among the families reported to contain biphenyls. Biphenyls are biosynthetically closely related to benzophenones and in a phylogenetic tree, biphenyl synthase (BIS) and benzophenone synthase (BPS) group together closely, indicating that they arise from a common ancestral gene. Biphenyl synthase (BIS) and benzophenone synthase (BPS) catalyze the formation of identical linear tetraketide intermediates from benzoyl-CoA (Beerhues and Liu, 2009).<smiles>COc1cc(-c2ccc(O)cc2)cc(OC)c1O</smiles>

Garcibiphenyl C

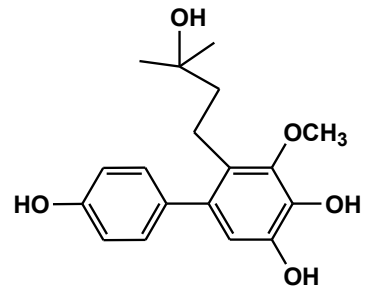

Schomburgbiphenyl

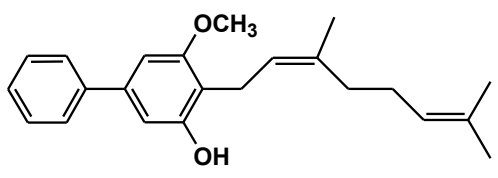

3-hydroxy-4-geranyl-5-methoxybiphenyl

Figure 8. Structures of simple biphenyl (garcibiphenyl C), monoprenylated biphenyl (schomburgbiphenyl) and geranyl substituted biphenyl (3-hydroxy,4-geranyl,5-methoxy biphenyl) 
Table 5. Biphenyls reported from Garcinia species

\begin{tabular}{|c|c|c|c|c|}
\hline $\begin{array}{l}\text { Sl. } \\
\text { No. }\end{array}$ & Garcinia species & Plant part & Biphenyls & Reference \\
\hline 1 & G. bancana & Twigs & $\begin{array}{l}\text { [1,1'-Biphenyl]-2-(3-methyl-2-butenyl)-3- } \\
\text { methoxy- 4,4',5,6-tetraol }\end{array}$ & $\begin{array}{l}\text { Rukachaisirikul et al., } \\
2005\end{array}$ \\
\hline 2 & G. bracteata & Twigs & $\begin{array}{l}\text { Bractebiphenyls A-C, doitungbiphenyl A, } \\
\text { doitungbiphenyl B, 2,2-dimethyl-3,5- } \\
\text { dihydroxy-7-(4-hydroxyphenyl) chromane, } \\
\text { oblongifoliagarcinine A, and } \\
\text { schomburgbiphenyl }\end{array}$ & Li et al., 2015 \\
\hline 3 & G. fucsa & Root & Nigrolineabiphenyl B & $\begin{array}{l}\text { Nontakham et al., } \\
2014\end{array}$ \\
\hline \multirow[t]{2}{*}{4} & \multirow[t]{2}{*}{ G. linii } & \multirow[t]{2}{*}{ Root } & Garcibiphenyl C, D and E & Chen et al., 2006 \\
\hline & & & Garcibiphenyl A and B & Chen et al., 2004 \\
\hline 5 & G. mangostana & Root bark & 3-Hydroxy-4-geranyl-5-methoxybiphenyl & $\begin{array}{l}\text { Dharmaratne et al., } \\
2005\end{array}$ \\
\hline \multirow[t]{4}{*}{6} & \multirow[t]{4}{*}{ G. multiflora } & Twig & Multiflorabiphenyls A and B & Xu et al., 2016a \\
\hline & & Leaf & Multiflorabiphenyls B-D & Fu et al., 2015 \\
\hline & & Stem & Multiflorabiphenyls A-C & Gao et al., 2016 \\
\hline & & Stem bark & Multiflorabiphenyls A & Jing et al., 2013 \\
\hline 7 & G. nigrolineata & Twig & Nigrolineabiphenyls A and B & $\begin{array}{l}\text { Rukachaisirikul et al., } \\
2005 \mathrm{a}\end{array}$ \\
\hline 8 & G. oblongifolia & Leaf & Oblongifoliagarcinines A-D & Wu et al., 2008 \\
\hline 9 & G. oligantha & Stem & $\begin{array}{l}\text { 3-Methoxy-5-methoxycarbonyl-4-hydroxy } \\
\text { biphenyl }\end{array}$ & Liu et al., 2015 \\
\hline \multirow[t]{3}{*}{10} & \multirow{3}{*}{$\begin{array}{l}\text { G. } \\
\text { schomburkiana }\end{array}$} & \multirow[t]{2}{*}{ Wood } & Schomburgbiphenyl & Mungmee et al.,2013 \\
\hline & & & $\begin{array}{l}\text { Aucuparin, nigrolineabiphenyl B and } \\
\text { Garcibiphenyl C }\end{array}$ & Mungmee et al., 2012 \\
\hline & & Stem & Schomburgbiphenyl A and B & Ito et al., 2013 \\
\hline 11 & G. spp & Twig & Doitungbiphenyls A and B & $\begin{array}{l}\text { Siridechakorn et al., } \\
2014\end{array}$ \\
\hline 12 & G tetralata & Twig & Tetralatabiphenyls A-C & Hu et al., 2016 \\
\hline
\end{tabular}

\section{Phloroglucinols}

Phloroglucinols are an interesting group of phenolic compounds, based on a phloroglucinol or 1,3,5-benzenetriol skeleton. Phloroglucinols can be divided into subclasses such as acyl phloroglucinols, phloroglucinol glycosides and prenylated/geranylated phloroglucinols (Dakanali and Theodorakis, 2011). About 700 naturally occurring phloroglucinol compounds were reported, of which acylphloroglucinols (APGs) comprise the largest group of natural phloroglucinol compounds (Singh et al., 2010). Several Garcinia species have been reported to contain phloroglucinol derivatives (Zhou, et al., 2009). Benzophenones such as nemerosone and clusianone with close resemblance to phloroglucinol derivatives were also considered under the phloroglucinol category (Dakanali and Theodorakis, 2011).

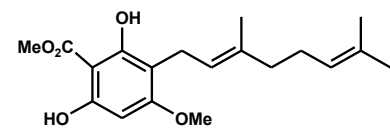

Parvifoliol A
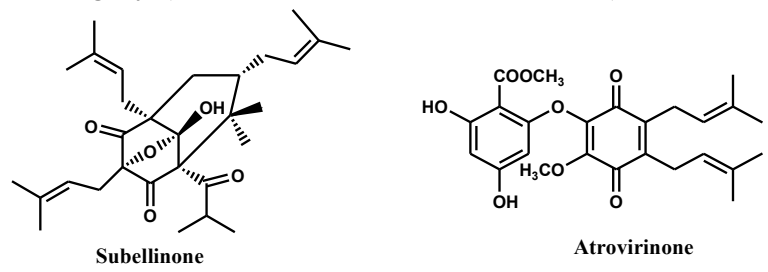

Figure 9. Structurs of monoprenylated phloroglucinol (parvifoliol A), polyprenylated phloroglucinol (subellinone) and phloroglucinic acid ester linked to a quinone moiety (atrovirinone) 
Ultra performance liquid chromatography (UPLC) coupled with precursor ion discovery (PID) and tandem mass (MS/MS) scans has been reported as an efficient analytical tool for rapid screening of polycyclic polyprenylated acyl phloroglucinols from Garcinia species (Zhou, et al., 2009).

Phloroglucinol and its derivatives were reputed with biological activities such as antibacterial, cytotoxic, antiproliferative and antiangiogenic effects and have been widely used in medicine, cosmetics, pesticides, paints and dyes (Singh et al., 2010). The phloroglucinol Garsubellin A induces biosynthesis of acetylcholine, a neurotransmitter that at low concentrations can lead to Alzheimer's disease (Fukuyama et al., 1997).

Table 6. Phloroglucinols reported from Garcinia species

\begin{tabular}{|c|c|c|c|c|}
\hline $\begin{array}{l}\text { Sl. } \\
\text { No. }\end{array}$ & Garcinia species & Plant part & Phloroglucinols & Reference \\
\hline 1 & G. atroviridis & Root & Atrovirinone & Permana et al., 2001 \\
\hline 2 & G. cowa & Twig & Garcicowins A-D & Lin et al., 2010 \\
\hline 3 & G. eugeniaefolia & Stem bark & Enervosanone & Taher et al., 2007 \\
\hline 4 & G. goudotiana & Leaf & Goudotianone 1 and 2 & $\begin{array}{l}\text { Mahamodo et al., } \\
2014\end{array}$ \\
\hline 5 & G. multiflora & Root & Garcinialone & Chien et al., 2008 \\
\hline 6 & G. nujiangensis & Leaf & Nujiangefolins A-C & Xia et al., 2012 \\
\hline \multirow[t]{2}{*}{7} & \multirow[t]{2}{*}{ G. parvifolia } & Twig & Parvifoliols A-G & $\begin{array}{l}\text { Rukachaisirikul et al., } \\
2006\end{array}$ \\
\hline & & Leaf & Parvifoliols B-E & $\begin{array}{l}\text { Rukachaisirikul et al., } \\
2008\end{array}$ \\
\hline 8 & G. schomburgkiana & Fruit & $\begin{array}{l}\text { Oblongifolin } \mathrm{C} \text {, garcicowin } \mathrm{B} \text {, and } \\
\text { garciyunnanin }\end{array}$ & Le et al., 2016 \\
\hline \multirow[t]{12}{*}{9} & \multirow[t]{12}{*}{ G. subelliptica } & \multirow[t]{2}{*}{ Heartwood } & Garcinielliptone HF & Wu et al., 2008 \\
\hline & & & $\begin{array}{l}\text { Garcinielliptone } \mathrm{HA}, \mathrm{HB}, \mathrm{HC}, \mathrm{HD} \text {, and } \\
\mathrm{HF}\end{array}$ & Lu et al., 2008 \\
\hline & & Pericarp & Garcinielliptone FB & Wu et al., 2005 \\
\hline & & Fruit & Garcinielliptone & Lin et al., 2005 \\
\hline & & \multirow[t]{4}{*}{ Wood } & Subellinone & $\begin{array}{l}\text { Fukuyama et al., } \\
1993\end{array}$ \\
\hline & & & Garsubellins A & $\begin{array}{l}\text { Fukuyama et al., } \\
1997\end{array}$ \\
\hline & & & Garsubellins B-E & $\begin{array}{l}\text { Fukuyama et al., } \\
1998\end{array}$ \\
\hline & & & Cohulupone & Lin et al., 2010a \\
\hline & & \multirow[t]{4}{*}{ Seed } & $\begin{array}{l}\text { Garcinielliptone A, B, C and D, and } \\
\text { Garsubellins A }\end{array}$ & Weng et al., 2003 \\
\hline & & & Garcinielliptone $\mathrm{K}, \mathrm{L}$ and $\mathrm{M}$ & Weng et al., 2004 \\
\hline & & & Garcinielliptone $\mathrm{R}$ & Lin et al., 2012 \\
\hline & & & Garcinielliptone P & Lin et al., 2010a \\
\hline 10 & $\begin{array}{l}\text { G. verrucosa } \\
\text { ssp orientalis }\end{array}$ & Stem bark & Garcicosin & $\begin{array}{l}\text { Rajaonarivelo et } \\
\text { al., } 2009\end{array}$ \\
\hline
\end{tabular}




\section{Flavonoids}

A variety of simple flavonoids such as quercetin, luteolin and apigenin were also reported from different Garcinia species.

Table 7. Flavonoids reported from Garcinia species

\begin{tabular}{|c|c|c|c|c|}
\hline $\begin{array}{l}\text { Sl. } \\
\text { No. }\end{array}$ & Garcinia species & Plant part & Flavonoids & References \\
\hline \multirow[t]{2}{*}{1} & \multirow[t]{2}{*}{ G. andamanica } & \multirow[t]{2}{*}{ Leaf } & $\begin{array}{l}\text { Scutellarein-7-diglucoside and } \\
\text { sorbifolin-6-galactoside }\end{array}$ & Alam et al., 1986 \\
\hline & & & 4'-Hydroxy wogonin 7-neohesperidoside & Alam et al., 1987 \\
\hline \multirow[t]{3}{*}{2} & \multirow[t]{3}{*}{ G. bracteata } & \multirow[t]{2}{*}{ Stem } & $\begin{array}{l}\text { Bracflavones } \mathrm{A} \text { and } \mathrm{B} \text {, quercetin, } \\
\text { luteolin, apigenin, rhamnazin, and pilloin }\end{array}$ & Hu et al., 2014 \\
\hline & & & $\begin{array}{l}\text { 7-Methoxy-4',6-dihydroxy-8-isobutyryl- } \\
\text { flavone }\end{array}$ & Li et al., 2015 \\
\hline & & Twig & $\begin{array}{l}\text { Bracteflavones A, bracteflavones, } \\
\text { artocarmin D, 6-prenyl apigenin, } \\
\text { cycloartocarpesin, and artochamin C }\end{array}$ & Yang et al., 2015 \\
\hline 3 & G. brevipedicellata & Stem bark & Pilloin & $\begin{array}{l}\text { Ngoupayo et al., } \\
2007\end{array}$ \\
\hline 4 & G. celebica & Stem bark & Epicatechin & Elfita et al., 2009 \\
\hline 5 & G. conrauana & Stem bark & Eriodictyol & $\begin{array}{l}\text { Waterman and } \\
\text { Chrichton, } 1980\end{array}$ \\
\hline 6 & G. cowa & Stem & Quercetin & Shen et al., 2007 \\
\hline \multirow[t]{2}{*}{7} & \multirow[t]{2}{*}{ G. dulcis } & Branch & 3'-(3-Methyl-but-2-enyl) naringenin, & Harrison et al., 1994 \\
\hline & & Ripe fruit & $\begin{array}{l}\text { Dulcinoside, dulcisisoflavone, and } \\
\text { dulcisflavan }\end{array}$ & $\begin{array}{l}\text { Deachathai et al., } \\
2005\end{array}$ \\
\hline 8 & G. epunctata & Stem bark & Taxifolin 6-C-glucoside & Mbafor et al., 1989 \\
\hline 9 & G. eugenifolia & Stem bark & Epicatechin & Taher et al., 2007 \\
\hline 10 & G. gracilis & Leaf & $\begin{array}{l}\text { Apigenin- } 8 \text {-C- } \alpha \text {-L-rhamnopyranosyl- } \\
(1 \rightarrow 2)-\beta \text {-D-glucopyranoside }\end{array}$ & $\begin{array}{l}\text { Supasuteekul et al., } \\
2016\end{array}$ \\
\hline 11 & G. hombroniana & Bark & $\begin{array}{l}\text { 3,3',4',5,5',7-Hexahydroxyflavone, } \\
\text { 3,3',5,5',7-pentahydroxyflavanone, and } \\
\text { 3,3',4',5,7-pentahydroxyflavone }\end{array}$ & Jamila et al., 2014 \\
\hline \multirow[t]{2}{*}{12} & \multirow[t]{2}{*}{ G. kola } & \multirow[t]{2}{*}{ Seed } & $\begin{array}{l}\text { Acacetin, apigenin-4'-5-7-trimethyl } \\
\text { ether, and fisetin }\end{array}$ & Iwu and Igboko, 1982 \\
\hline & & & Naringin-7-rharmnoglucoseside & $\begin{array}{l}\text { Okwu and Morah } \\
2007\end{array}$ \\
\hline 13 & G. livingstonei & Seed & Eriodictyol & $\begin{array}{l}\text { Srivastava and } \\
\text { Sharma } 1966\end{array}$ \\
\hline \multirow[t]{3}{*}{14} & \multirow[t]{3}{*}{ G. mangostana } & \multirow[t]{3}{*}{ Fruit hull } & Taxifolin-3-o- $\alpha$-L-rhamnoside & Huang et al., 2001 \\
\hline & & & Epicatechin & Yu et al., 2007 \\
\hline & & & $\begin{array}{l}\text { Aromadendrin-8-C-glucopyranoside, and } \\
\text { epicatechin }\end{array}$ & Abdallah et al., 2016 \\
\hline 15 & G. multiflora & Heart wood & Apigenin & Fa-Ching et al., 1975 \\
\hline 16 & G. neglecta & Leaf & Apigenin and narigenin & Ito et al., 2001 \\
\hline 17 & G. nervosa & Leaf & $\begin{array}{l}\text { Nervosin, irigenin, and 7-methyl } \\
\text { tectoirigenin }\end{array}$ & Ilyas et al., 1994 \\
\hline 18 & G. parvifolia & Leaf & Nigrolineaisoflavone A & $\begin{array}{l}\text { Rukachaisirikul et al., } \\
2008\end{array}$ \\
\hline 19 & G. paucinervis & Stem & Pauciisoflavone A & Hu et al., 2014 \\
\hline 20 & G. purpurea & Pericarp & $\begin{array}{l}\text { Vitexin and apigenin-7-o-(6"-methyl } \\
\text { ester)-glucuronide }\end{array}$ & Iinuma et al., 1996 \\
\hline 21 & G. schomburgkiana & Branch & $\begin{array}{l}\text { Kaempferol, dihydrokaempferol and } \\
(-)-5,7,3^{\prime}, 5^{\prime} \text {-tetrahydroxyflavanone }\end{array}$ & Meechai et al., 2016 \\
\hline 22 & G. vitiens & Leaf & Vitexin & Parveen et al., 1994 \\
\hline 23 & G.xipshuanbannaensis & Fruit & Luteolin and 3',5,7-4'-methoxy-flavone & Shen et al., 2006 \\
\hline
\end{tabular}




\section{Conclusions}

Garcinia species are rich depository of structurally diverse secondary metabolites such as biflavonoids, prenylated and caged xanthones and polyisoprenylated benzophenones. Most of the Garcinia species are not yet explored for their chemical constituents or bioactivities. Literature survey revealed that, of the nearly 250 Garcinia species, less than $50 \%$ have been studied for their chemical constituents. Xanthones are the major class of phenolic compounds in Garcinia species, followed by benzophenones and biflavonoids. The chapter enlists the major phenolic compounds xanthones, benzophenones and biflavonoids, along with minor constituents biphenyls, despidones, phloroglucinols and simple flavonoids reported in Garcinia species world over.

\section{References}

1. Abdallah HM, El-Bassossy H, Mohamed GA, El-Halawany AM, Alshali KZ and Banjar ZM. 2016. Phenolics from Garcinia mangostana inhibit advanced glycation endproducts formation: Effect on amadori Products, cross-linked structures and protein thiols. Molecules, 21(2), 251.

2. Abderamane B, Tih AE, Ghogomu RT, Blond A and Bodo B. 2016. New flavonoid CO-C dimers and other chemical constituents from Garcinia brevipedicellata stem heartwood. Z. Naturforsch.C. DOI: 10.1515/znc-2015-0125.

3. Abe F, Nagafuji S, Okabe H, Akahane H, Estrada-Muñiz E, Huerta-Reyes M and Reyes-Chilpa R. 2004. Trypanocidal constituents in plants 3 leaf of Garcinia intermedia and heartwood of Calophyllum brasiliense. Biol. Pharm. Bull., 27(1), 141143.

4. Acuna UM, Dastmalchi K, Basile MJ and Kennelly EJ. 2012. Quantitative highperformance liquid chromatography photo-diode array (HPLC-PDA) analysis of benzophenones and biflavonoids in eight Garcinia species. J. Food Compos. Anal., 25(2), 215-220.

5. Acuna UM, Jancovski $\mathrm{N}$ and Kennelly EJ. 2009. Polyisoprenylated benzophenones from Clusiaceae: Potential drugs and lead compounds. Curr. Top. Med. Chem., 9(16), 1560-1580.

6. Adawadkar PD, Srinivasan R and Yemul SS. 1976. Coloring matters of Garcinia morella: Part VIII Morellinol, dihydromorelloflavone and morelloflavone-7"- $\beta$ glucoside. Indian J. Chem. Sect. B, 17, 19-21.

7. Afzal M and Alhassan JM. 1980. Synthesis and biosynthesis of phytoxanthones. Heterocycles, 14(8), 1173-1205.

8. Aisha AFA, Abu-Salah KM, Ismail Z and Majid AMSA. 2013. Determination of total xanthones in Garcinia mangostana fruit rind extracts by ultraviolet (UV) spectrophotometry. J. Med. Plants Res., 7(1), 29-35.

9. Alam MS, Kamil M and Ilyas M. 1987. 4'-Hydroxywogonin 7-neohesperidoside from Garcinia andamanica. Phytochemistry, 26(6), 1843-1844.

10. Alam MS, Qasim MA, Kamil M and Ilyas M. 1986. Sorbifolin 6-galactoside from Garcinia andamanica. Phytochemistry, 25(12), 2900-2901.

11. Ali S, Goundar R, Sotheeswaran S, Beaulieu C and Spino C. 2000. Benzophenones of Garcinia pseudoguttifera (Clusiaceae). Phytochemistry, 53(2), 281-284. 
12. Alkadi KA, Adam A, Taha M, Hasan MH and Shah SAA. 2014. Prenylated xanthone and rubraxanthone with antiplatelet aggregation activity in human whole blood isolated from Garcinia griffithii. Orient. J. Chem., 29(4), 1291-1295.

13. Al-Shagdari A, Alarcón AB, Cuesta-Rubio O, Piccinelli AL and Rastrelli L. 2013. Biflavonoids, main constituents from Garcinia bakeriana leaf. Nat. Prod. Commun., 8(9), 1237-1240.

14. Amelia P, Elya B and Hanafi M. 2015. Antioxidative activity of xanthone from Garcinia benthami Pierre Leaf. Int. J. PharmTech. Res., 7, 254-257.

15. Ampofo SA and Waterman PG. 1986. Xanthones from three Garcinia species. Phytochemistry, 25(10), 2351-2355.

16. Anantachoke N, Tuchinda P, Kuhakarn C, Pohmakotr M and Reutrakul V. 2012. Prenylated caged xanthones: chemistry and biology. Pharm. Biol., 50(1), 78-91.

17. Ansari WH, Rahman W, Barraclough D, Maynard R and Scheinmann F. 1976. Biflavanoids and a flavanone-chromone from the leaf of Garcinia dulcis (Roxb) Kurz. J. Chem. Soc., Perkin Trans., 1(13), 1458-1463.

18. Anu Aravind AP, Asha KRT and Rameshkumar KB. 2015. Phytochemical analysis and antioxidant potential of the leaf of Garcinia travancorica Bedd. Nat. Prod. Res., 30 (2), 232-236.

19. Arwa PS, Zeraik ML, Ximenes VF, da Fonseca LM, da Bolzani SV and Silva DHS. 2015. Redox-active biflavonoids from Garcinia brasiliensis as inhibitors of neutrophil oxidative burst and human erythrocyte membrane damage. J. Ethnopharmacol., 174, 410-418.

20. Asai F, Tosa H, Tanaka T and Iinuma M. 1995. A xanthone from pericarps of Garcinia mangostana. Phytochemistry, 39(4), 943-944.

21. Asano J, Chiba K, Tada M and Yoshii T. 1996. Cytotoxic xanthones from Garcinia hanburyi. Phytochemistry, 41(3), 815-820.

22. Auranwiwat C, Trisuwan K, Saiai A, Pyne SG and Ritthiwigrom T. 2014. Antibacterial tetraoxygenated xanthones from the immature fruits of Garcinia cowa. Fitoterapia, 98, 179-183.

23. Babu V, Ali SM, Sultana S and Ilyas M. 1988. A biflavonoid from Garcinia nervosa. Phytochemistry, 27(10), 3332-3335.

24. Baggett S, Protiva P, Mazzola EP, Yang H, Ressler ET, Basile MJ, Weinstein B and Kennelly EJ. 2005. Bioactive benzophenones from Garcinia xanthochymus Fruits. $J$. Nat. Prod., 68(3), 354-360.

25. Balasubramanian K and Rajagopalan K. 1988. Novel xanthones from Garcinia mangostana, structures of BR-xanthone-A and BR-xanthone-B. Phytochemistry, 27(5), 1552-1554.

26. Bandaranayake WM, Selliah SS, Sultanbawa MUS and Ollis WD. 1975. Biflavonoids and xanthones of Garcinia terpnophylla and Garcinia echinocarpa. Phytochemistry, 14(8), 1878-1880.

27. Baslas RK and Kumar P. 1979. Chemical examination of the fruits of Garcinia xanthochymus. Curr. Sci., 48 (18). 
28. Baslas RK, and Kumar P. 1981. Isolation and characteristation of biflavnone and xanthones in the fruits of Garcinia xanthochymus. Acta Cienc. Indica, Chem., 71, 3134.

29. Beerhues L and Liu B. 2009. Biosynthesis of biphenyls and benzophenones-Evolution of benzoic acid-specific type III polyketide synthases in plants. Phytochemistry. 70 (1516), 1719-1727.

30. Bennet GJ and Lee HH. 1989. Xanthones from guttiferae. Phytochemistry, 28(4), 967998.

31. Bui TQ, Bui AT, Nguyen KT, Nguyen VT, Trinh BT and Nguyen LHD. 2016. A depsidone and six triterpenoids from the bark of Garcinia celebica. Tetrahedron Lett., 57(23), 2524-2529.

32. Cao SG, Sng, VH, Wu XH, Sim KY, Tan BHK, Pereira JT and Goh SH. 1998. Novel cytotoxic polyprenylated xanthonoids from Garcinia gaudichaudii (Guttiferae). Tetrahedron, 54(36), 10915-10924.

33. Carroll AR, Suraweera L, King G, Rali T and Quinn RJ. 2009. Guttiferones O and P, prenylated benzophenone MAPKAPK-2 inhibitors from Garcinia solomonensis. J. Nat. Prod., 72(9), 1699-1701.

34. Castardo JC, Prudente AS, Ferreira J, Guimarães CL, Delle Monache F, Cechinel Filho V, Otuki FO and Cabrini DA. 2008. Anti-inflammatory effects of hydroalcoholic extract and two biflavonoids from Garcinia gardneriana leaf in mouse paw oedema. $J$. Ethnopharmacol., 118(3), 405-411.

35. Castro AP, de Mattos AC, Pereira NA, Anchieta NF, Silva MS, Dias DF and Marques MJ. 2015. Potent schistosomicidal constituents from Garcinia brasiliensis. Planta Med., 81(9), 733-741.

36. Chairungsrilerd N, Takeuchi K, Ohizumi Y, Nozoe S and Ohta T. 1996. Mangostanol, a prenyl xanthone from Garcinia mangostana. Phytochemistry, 43(5), 1099-1102.

37. Chanmahasathien W, Li Y, Satake M, Oshima Y, Ruangrungsi N and Ohizumi Y. 2003. Prenylated xanthones with NGF-potentiating activity from Garcinia xanthochymus. Phytochemistry, 64(5), 981-986.

38. Chantarasriwong O, Batova A, Chavasiri $\mathrm{W}$ and Theodorakis EA. 2010. Chemistry and biology of the caged Garcinia xanthones. Chem. Eur. J., 16(33), 9944-9962.

39. Chattopadhyay SK and Kumar S. 2006. Identification and quantification of two biologically active polyisoprenylated benzophenones xanthochymol and isoxanthochymol in Garcinia species using liquid chromatography-tandem mass spectrometry. J. Chromatogr. B, 844(1), 67-83.

40. Cheenpracha S, Phakhodee W, Ritthiwigrom T, Prawat U and Laphookhieo S. 2011. A new depsidone from the twigs of Garcinia cowa. Heterocycles, 83, 1139-1144.

41. Chen FC, Lin YM and Hung JC. 1975. A new biflavanone glucoside from Garcinia multiflora. Phytochemistry, 14(3), 818-820.

42. Chen JJ, Chen IS and Duh CY. 2004. Cytotoxic xanthones and biphenyls from the root of Garcinia linii. Planta Med., 70(12), 1195-1200.

43. Chen JJ, Peng CF, Huang HY and Chen IS. 2006. Benzopyrans, biphenyls and xanthones from the root of Garcinia linii and their activity against Mycobacterium tuberculosis. Planta Med., 72(05), 473-477. 
44. Chen JJ, Ting CW, Hwang TL and Chen IS. 2009. Benzophenone derivatives from the fruits of Garcinia multiflora and their anti-inflammatory activity. J. Nat. Prod., 72(2), 253-258.

45. Chen LG, Yang LL and Wang CC. 2008. Anti-inflammatory activity of mangostins from Garcinia mangostana. Food Chem. Toxicol., 46(2), 688-693.

46. Chen Y, Fan H, Yang GZ, Jiang Y, Zhong FF and He HW. 2010. Prenylated xanthones from the bark of Garcinia xanthochymus and their 1,1-diphenyl-2-picrylhydrazyl (DPPH) radical scavenging activities. Molecules, 15(10), 7438-744.

47. Chiang YM, Kuo YH, Oota S and Fukuyama Y. 2003. Xanthones and benzophenones from the stems of Garcinia multiflora. J. Nat. Prod., 66(8), 1070-1073.

48. Chien SC, Chyu CF, Chang IS, Chiu HL and Kuo YH. 2008. A novel polyprenylated phloroglucinol, garcinialone, from the roots of Garcinia multiflora. Tetrahedron Lett., 49(36), 5276-5278.

49. Chin YW, Jung HA, Chai H, Keller WJ and Kinghorn AD. 2008. Xanthones with quinone reductase-inducing activity from the fruits of Garcinia mangostana (Mangosteen). Phytochemistry, 69(3), 754-758.

50. Cotterill PJ, Scheinmann F and Puranik GS. 1977. Phenolic compounds from the heartwood of Garcinia indica. Phytochemistry, 16(1), 148-149.

51. Crichton EG, and Waterman PG. 1979. Manniflavanone, a new 3, 8-linked flavanone dimer from the stem bark of Garcinia mannii. Phytochemistry, 18(9), 1553-1557.

52. Croteau R, Kutchan TM and Lewis NG. 2000. Natural products (secondary metabolites). Biochem. Mol. Biol. Plants, 1250-1318.

53. Cuesta-Rubio O, Padron A, Castro HV, Pizza C and Rastrelli L. 2001. Aristophenones A and B: A new tautomeric pair of polyisoprenylated benzophenones from Garcinia aristata. J. Nat. Prod., 64(7), 973-975.

54. Cuesta-Rubio O, Piccinelli AL and Rastrelli L. 2005. Chemistry and biological activity of polyisoprenylated benzophenone derivatives. Stud. Nat. Prod. Chem., 32, 671-720.

55. Dakanali $M$ and Theodorakis EA. 2011. Polyprenylated Phloroglucinols and Xanthones. In: Biomimetic Organic Synthesis. ed. Erwan Poupon, Bastien Nay. Wiley \& Sons, pp. 433-467.

56. Dal Molin MM, Silva S, Alves DR, Quintao NLM, Delle Monache F, Cechinel Filho V and Niero R. 2012. Phytochemical analysis and antinociceptive properties of the seeds of Garcinia achachairu. Arch. Pharm. Res., 35(4), 623-631.

57. Deachathai S, Mahabusarakam W, Phongpaichit S and Taylor WC. 2005. Phenolic compounds from the fruit of Garcinia dulcis. Phytochemistry, 66(19), 2368-2375.

58. Deng YX, Pan SL, Zhao SY, Wu MQ, Sun ZQ, Chen XH and Shao ZY. 2012. Cytotoxic alkoxylated xanthones from the resin of Garcinia hanburyi. Fitoterapia, 83(8), 1548-1552.

59. Derogis PB, Martins FT, de Souza TC, de CM, Maria E, Souza Filho JD, Doriguetto AC, De Souza KRD, Veloso MP and Dos Santo MH. 2008. Complete assignment of the $1 \mathrm{H}$ and 13C NMR spectra of garciniaphenone and keto-enol equilibrium statements for prenylated benzophenones. Magn. Reson. Chem. , 46(3), 278-282.

60. Dharmaratne HRW, Piyasena KGNP and Tennakoon SB. 2005. A geranylated biphenyl derivative from Garcinia mangostana. Nat. Prod. Res., 19(3), 239-243. 
61. Ee GCL, Daud S, Taufiq-Yap YH, Ismail NH and Rahmani M. 2006. Xanthones from Garcinia mangostana (Guttiferae). Nat. Prod. Res., 20(12), 1067-1073.

62. Ee GCL, Foo CH, Jong VYM, Ismail NH, Sukari MA, Yap YT and Awang K. 2012. A new xanthone from Garcinia nitida. Nat. Prod. Res., 26(9), 830-835.

63. Ee GCL, Mong XH and Sukari MA. 2003. Cuneifolin, a new xanthone from Garcinia cuneifolia (Guttiferae). Nat. Prod. Sci., 9(3), 174-176.

64. Elfita E, Muharni M, Latief M, Darwati D, Widiyantoro A, Supriyatna S, Bahtic HH, Dachriyanusf D, Cosg P, Maesg L, Fouberth K, Apers S and Pieters L. 2009. Antiplasmodial and other constituents from four Indonesian Garcinia spp. Phytochemistry, 70(7), 907-912.

65. Elya B, He HP, Kosela S, Hanafi M and Hao X J. 2008. A new cytotoxic xanthone from Garcinia rigida. Fitoterapia, 79(3), 182-184.

66. Elya B, He HP, Kosela S, Hanafi M and Hao XJ. 2006. A new benzophenone from the stem bark of Garcinia benthami. Nat. prod. Res., 20(12), 1059-1062.

67. Elya B, He HP, Kosela S, Hanafi M and Hao XJ. 2006a. Two new xanthons from Garcinia rigida leaf. Nat. prod. Res., 20(9), 788-791.

68. Fa-Ching C, Yuh-Meei L and Jeng-Ching H. 1975. Phenolic compounds from the heartwood of Garcinia multiflora. Phytochemistry, 14(1), 300-303.

69. Feng F, Liu WY, Chen YS, Guo QL and You QD. 2007. Five novel prenylated xanthones from Resina Garciniae. J. Asian Nat Prod Res., 9(8), 735-741.

70. Fotso GW, Ntumy AN, Ngachussi E, Dube M, Mapitse R, Kapche GD, AndraeMarobela K, Ngadjui BT and Abegaz B M. 2014. Epunctanone, a new benzophenone, and further secondary metabolites from Garcinia epunctata Stapf (Guttiferae). Helv. Chim. Acta, 97(7), 957-964.

71. Fouotsa H, Lannang AM, Mbazoa CD, Rasheed S, Marasini BP, Ali Z, Devkotae KP, Kengfacka AE, Shaheenb F, Choudhary MI and Sewald N. 2012. Xanthones inhibitors of $\alpha$-glucosidase and glycation from Garcinia nobilis. Phytochem. Lett., 5(2), 236-239.

72. Fouotsa H, Lannang AM, Dzoyem JP, Tatsimo SJ, Neumann B, Mbazoa CD, Razakarivony AA, Nkengfack AE, Eloff JN and Sewald N. 2015. Antibacterial and antioxidant xanthones and benzophenone from Garcinia smeathmannii. Planta Med., 81(7), 594-599.

73. $\mathrm{Fu} \mathrm{W,} \mathrm{Wu} \mathrm{M,} \mathrm{Zhu} \mathrm{L,} \mathrm{Lao} \mathrm{Y,} \mathrm{Wang} \mathrm{L,} \mathrm{Tan} \mathrm{H,} \mathrm{Yuan} \mathrm{Q} \mathrm{and} \mathrm{Xu} \mathrm{H.} \mathrm{2015.} \mathrm{Prenylated}$ benzoylphloroglucinols and biphenyl derivatives from the leaf of Garcinia multiflora Champ. RSC Adv., 5(95), 78259-78267.

74. Fukuyama Y, Kamiyama A, Mima YN and Kodama M. 1991. Prenylated xanthones from Garcinia subelliptica. Phytochemistry, 30(10), 3433-3436.

75. Fukuyama Y, Kuwayama A and Minami H. 1997. Garsubellin A, a novel polyprenylated phloroglucin derivative, increasing choline acetyltransferase (ChAT) activity in postnatal rat septal neuron cultures. Chem. Pharm. Bull., 45(5), 947-949.

76. Fukuyama Y, Minami H and Kuwayama A. 1998. Garsubellins, polyisoprenylated phloroglucinol derivatives from Garcinia subelliptica. Phytochemistry, 49(3), 853-857.

77. FukuyamaY, Kaneshi A, Tani N and Kodama M. 1993. Subellinone, a polyisoprenylated phloroglucinol derivative from Garcinia subelliptica. Phytochemistry, 33(2), 483-485. 
78. Gao XM, Ji BK, Li YK, Ye YQ, Jiang ZY, Yang HY, Du G, Zhou M, Pan XX, Liu WX and Hu QF. 2016. New biphenyls from Garcinia multiflora. J. Braz. Chem. Soc., 27(1), 10-14.

79. Gao XM, Yu T, Cui MZ, Pu JX, Du X, Han QB, Hua QF, Liua TC, Luob KQ, and Xu HX. 2012. Identification and evaluation of apoptotic compounds from Garcinia oligantha. Bioorg. Med. Chem. Lett., 22(6), 2350-2353.

80. Gao XM, Yu T, Lai FSF, Pu JX, Qiao CF, Zhou Y, Liua X, Songa JZ, Luob KQ and $\mathrm{Xu}$ HX. 2010. Novel polyisoprenylated benzophenone derivatives from Garcinia paucinervis. Tetrahedron Lett., 51(18), 2442-2446.

81. Geiger H and Quinn C. 1988. Biflavonoids: The Flavonoids Advances in Research since 1980. Harborne JB. ed. Academic Press, New York.

82. Gil B, Sanz MJ, Terencio MC, Gunasegaran R, Paya M and Alcaraz MJ. 1997. Morelloflavone, a novel biflavonoid inhibitor of human secretory phospholipase A2 with anti-inflammatory activity. Biochem. Pharmacol., 53(5), 733-740.

83. Goh SH, Jantan I, Gray AI and Waterman PG. 1992. Prenylated xanthones from Garcinia opaca. Phytochemistry, 31(4), 1383-1386.

84. Gontijo VS, de Souza TC, Rosa IA, Soares MG, da Silva MA, Vilegas W and dos Santos MH. 2012. Isolation and evaluation of the antioxidant activity of phenolic constituents of the Garcinia brasiliensis epicarp. Food Chem., 132(3), 1230-1235.

85. Gopalakrishnan G and Balaganesan B. 2000. Two novel xanthones from Garcinia mangostana. Fitoterapia, 71(5), 607-609.

86. Gopalakrishnan G, Banumathi B and Suresh G. 1997. Evaluation of the antifungal activity of natural xanthones from Garcinia mangostana and their synthetic derivatives. J Nat. Prod., 60, 519-524.

87. Gottlieb OR. 1968. Biogenetic proposals regarding aucuparins and xanthones. Phytochemistry, 7(3), 411-421.

88. Govindachari TR, Kalyanaraman PS, Muthukumaraswamy N and Pai BR. 1971. Xanthones of Garcinia mangostana Linn. Tetrahedron, 27(16), 3919-3926.

89. Gunatilaka AAL, De Silva AJ, Sotheeswaran S, Balasubramaniam S, and Wazeer MI. 1984. Terpenoid and biflavonoid constituents of Calophyllum calaba and Garcinia spicata from Sri Lanka. Phytochemistry, 23(2), 323-328.

90. Gunatilaka AAL, Sriyani HB, Sotheeswaran S and Waight ES. 1983. 2,5-dihydroxy-1, 6-dimethoxyxanthone and biflavonoids of Garcinia thwaitesii. Phytochemistry, 22(1), 233-235.

91. Guo YE, Wang LL, Li ZL, Niu SL, Liu XQ, Hua HM, Chenc H, Chu J and Zhang TC. 2011. Triterpenes and xanthones from the stem bark of Garcinia tetralata. J. Asian Nat. Prod. Res. , 13(05), 440-443.

92. Gustafson KR, Blunt JW, Munro MHG, Fuller RW, McKee TC, Cardellina JH, McMahon JB, Cragg GM and Boyd MR. 1992. HIV Inhibitory Natural-Products. 8. The Guttiferones, HIV-Inhibitory Benzophenones Symphonia globulifera, Garcinia livingstonei, Garcinia ovalifolia and Clusia rosea. Tetrahedron, 48(46), 10093-10102.

93. Gutierrez-Orozco F and Failla ML. 2013. Biological activities and bioavailability of mangosteen xanthones: A critical review of the current evidence. Nutrients, 5(8), 31633183. 
94. Ha LD, Hansen PE, Duus F, Pham HD and Nguyen LHD. 2012. Oliveridepsidones AD, antioxidant depsidones from Garcinia oliveri. Magn. Reson. Chem., 50(3), 242-245.

95. Han AR, Kim JA, Lantvit DD, Kardono LB, Riswan S, Chai H, de Blanco EJC, Farnsworth NR, Swanson SM and Kinghorn AD. 2009. Cytotoxic xanthone constituents of the stem bark of Garcinia mangostana (mangosteen). J. Nat. Prod., 72(11), 2028-2031.

96. Han QB and Xu HX. 2009. Caged Garcinia xanthones: Development since 1937. Curr. Med. Chem., 16(28), 3775-3796.

97. Han QB, Lee SF, Qiao CF, He ZD, Song JZ, Sun HD and Xu HX. 2005. Complete NMR assignments of the antibacterial biflavonoid GB1 from Garcinia kola. Chem. Pharm. Bull., 53(8), 1034-1036.

98. Han QB, Qiao CF, Song JZ, Yang NY, Cao XW, Peng Y, Yang DJ, Shen SL and Xu H $X$. 2007. Cytotoxic prenylated phenolic compounds from the twig bark of Garcinia xanthochymus. Chem. Biodivers., 4(5), 940-946.

99. Han QB, Yang NY, Tian HL, Qiao CF, Song JZ, Chang DC, Chend SL, Luob KQ and $\mathrm{Xu}$ HX. 2008. Xanthones with growth inhibition against HeLa cells from Garcinia xipshuanbannaensis. Phytochemistry, 69(11), 2187-2192.

100. Harrison LJ, Leong LS, Leong YW, Sia GL, Sim KY and Tan HTW. 1993. Xanthones from Garcinia forbesii. Phytochemistry, 33(3), 727-728

101. Harrison LJ, Leong LS, Leong YW, Sia GL, Sim KY and Tan HTW. 1994. Xanthone and flavonoid constituents of Garcinia dulcis (Guttiferae). Nat. Prod. Lett., 5(2), 111 116.

102. Hartati S, Kadono LBS, Kosela S and Harrison LJ. 2008. A new pyrano xanthone from the stem barks of Garcinia tetrandra Pierre. Pak. J. Bio.Sci., 8(1), 137-142.

103. Hartati S, Soemiati A, Wang HB, Kardono LB, Hanafi M, Kosela S and Qin GW. 2008a. A novel polyisoprenyl benzophenone derivative from Garcinia eugeniaefolia. $J$. Asian nat. Prod. Res., 10(6), 509-513.

104. Hartati S, Wang HB, Kardono LS, Kosela S and Qin GW. 2007. Chemical constituents of Garcinia maingayii. Zongguo tianran Yaowu, 5(4), 272-276.

105. Hay AE, Hélesbeux JJ, Duval O, Labaïed M, Grellier P and Richomme P. 2004. Antimalarial xanthones from Calophyllum caledonicum and Garcinia vieillardii. Life Sci., 75(25), 3077-3085.

106. Hay AE, Merza J, Landreau A, Litaudon M, Pagniez F, Le Pape P, and Richomme P. 2008. Antileishmanial polyphenols from Garcinia vieillardii. Fitoterapia, 79(1), 42-46.

107. Hemshekhar M, Sunitha K, Santhosh MS, Devaraja S, Kemparaju K, Vishwanath BS and Girish KS. 2011. An overview on genus Garcinia: Phytochemical and therapeutical aspects. Phytochem. Rev. , 10(3), 325-351.

108. Herbin GA, Jackson B, Locksley HD, Scheinmann F and Wolstenholme WA. 1970. The biflavonoids of Garcinia volkensii (Guttiferae). Phytochemistry, 9(1), 221-226.

109. Hostettman $\mathrm{K}$ and Marston A. 2002. Twenty years of research into medicinal plants: Results and perspectives. Phytochem. Rev., 1, 275-285.

110. Hu Q, Niu D, Wang S, Qin Y, Yang Z, Zhao G, Yang Z, Gao X and Chen Z. 2014. New flavones from Garcinia bracteata and their biological activities. Chem. Nat. Compd., 50(6), 985-988. 
111. Hu QF, Wang YD, Zhu DL, Yu ZH, Zhan JB, Xing HH, Ma HY, Yang Y, Li YK, Chen ZY and Gao XM. 2016. Three new biphenyls from the twigs of Garcinia tetralata and their anti-tobacco mosaic virus activity. J. Asian Nat. Prod. Res., 1-7.

112. Huang YL, Chen CC, Chen YJ, Huang RL and Shieh BJ. 2001. Three xanthones and a benzophenone from Garcinia mangostana. J. nat. prod., 64(7), 903-906.

113. Hussain RA and Waterman PG. 1982. Lactones, flavonoids and benzophenones from Garcinia conrauana and Garcinia mannii. Phytochemistry, 21(6), 1393-1396.

114. Hussain RA, Owegby AG, Parimoo P and Waterman PG. 1982. Kolanone, a novel polyisoprenylated benzophenone with antimicrobial properties from the fruit of Garcinia kola. Planta Med., 44(02), 78-81.

115. Iinuma M, Ito T, Miyake R, Tosa H, Tanaka T and Chelladurai V. 1998. A xanthone from Garcinia cambogia. Phytochemistry, 47(6), 1169-1170.

116. Iinuma M, Tosa H, Tanaka T, Asai F and Shimano R. 1995. Two new xanthones from the root bark of Garcinia subelliptica. Heterocycles, 1(40), 279-284.

117. Iinuma M, Tosa H, Tanaka T, Asai F and Shimano R. 1995a. Two xanthones with a 1 , 1-dimethylallyl group in root bark of Garcinia subelliptica. Phytochemistry, 39(4), 945947.

118. Iinuma M, Tosa H, Tanaka T, Asai F and Shimano R. 1995b. Three xanthones from root bark of Garcinia subelliptica. Phytochemistry, 38(1), 247-249.

119. Iinuma M, Tosa H, Tanaka T, Kanamaru S, Asai F, Kobayashi Y, Miyauchi K and Shimano R. 1996. Antibacterial activity of some Garcinia benzophenone derivatives against methicillin-resistant Staphylococcus aureus. Biol. Pharm. Bull., 19(2), 311-314.

120. Iinuma M, Tosa H, Tanaka T, Shimano R, Asai F and Yonemori S. 1994. Two xanthones from root bark of Garcinia subelliptica. Phytochemistry, 35(5), 1355-1360.

121. Ilyas M, Kamil M, Parveen M and Khan MS. 1994. Isoflavones from Garcinia nervosa. Phytochemistry, 36(3), 807-809.

122. Ito C, Itoigawa M, Mishina $\mathrm{Y}$, Tomiyasu $\mathrm{H}$, Litaudon M, Cosson JP, Mukainaka T, Tokuda H, Nishino H and Furukawa H. 2001. Cancer chemopreventive agents. New depsidones from Garcinia plants. J. Nat. Prod., 64(2), 147-150.

123. Ito C, Itoigawa M, Miyamoto $\mathrm{Y}$, Onoda S, Rao KS, Mukainaka T, Tokuda H, Nishino H Furukawa H. 2003. Polyprenylated benzophenones from Garcinia assigu and their potential cancer chemopreventive activities. J. Nat. Prod., 66(2), 206-209.

124. Ito C, Itoigawa M, Takakura T, Ruangrungsi N, Enjo F, Tokuda H, Nishino M and Furukawa H. 2003a. Chemical constituents of Garcinia fusca: Structure elucidation of eight new xanthones and their cancer chemopreventive activity 1. J. Nat. Prod., 66(2), 200-205.

125. Ito C, Matsui T, Noda E, Ruangrungsi N and Itoigawa M. 2013. Biphenyl derivatives from Garcinia schomburgkiana and the cytotoxicity of the isolated compounds. Nat. Prod. Commun., 8(9), 1265-1267.

126. Ito C, Miyamoto Y, Nakayama M, Kawai Y, Rao KS and Furukawa H. 1997. A novel depsidone and some new xanthones from Garcinia Species. Chem. Pharm. Bull., 45(9), 1403-1413.

127. Iwu M and Igboko O. 1982. Flavonoids of Garcinia kola seeds. J. Nat. Prod., 45(5), 650-651. 
128. Iwu MM, Igboko OA and Tempesta MS. 1990. Biflavonoid constituents of Garcinia kola roots. Fitoterapia, 61(2), 178-181.

129. Jabit L, Khalid R, Abas F, Shaari K, Hui LS, Stanslas J and Lajis NH. 2007. Cytotoxic xanthones from Garcinia penangiana Pierre. Z. Naturforsch. C, 62(11-12), 786-792.

130. Jackson B, Locksley HD and Scheinmann F. 1968. The structure of the "GB" biflavanones from Garcinia buchananii Baker and $G$. eugeniifolia Wall. Chem.Commun., (18), 1125-1127.

131. Jackson B, Locksley HD, Moore I and Scheinmann F. 1968a. Extractives from Guttiferae. Part IX. The isolation of buchanaxanthone and two related xanthones from Garcinia buchananii Baker. J. Chem. Soc. C, 2579-2583.

132. Jackson B, Locksley HD and Scheinmann F. 1969. Extractives from Guttiferae. Part XIII. Isolation and structure of five xanthones from Garcinia eugeniifolia wall. $J$. Chem. Soc. C, (16), 2201-2203.

133. Jackson B, Locksley HD, Scheinmann F and Wolstenholme WA. 1971. Extractives from Guttiferae Part XXII The isolation and structure of four novel biflavanones from the heartwoods of Garcinia buchananii Baker and G. eugeniifolia Wall. J. Chem. Soc. C: Organic, 3791-3804.

134. Jackson DN, Yang L, Wu S, Kennelly EJ and Lipke PN. 2015. Garcinia benzophenones promote hyphal apoptosis and potentiate activity of fluconazole in Candida albicans biofilms. Planta Med., 81(11), PU2.

135. Jamila N, Khairuddean M, Khan SN and Khan N. 2014. Complete NMR assignments of bioactive rotameric $(3 \rightarrow 8)$ biflavonoids from the bark of Garcinia hombroniana, Magn. Reson. Chem., 52(7), 345-352.

136. Jamila N, Khairuddean M, Khan SN, Khan N and Osman H. 2014a. Phytochemicals from the bark of Garcinia hombroniana and their biological activities. Rec. Nat. Prod., 8(3), 312-316.

137. Jamila N, Khairuddean M, Yaacob NS, Kamal NNSNM, Osman H, Khan SN and Khan N. 2014b. Cytotoxic benzophenone and triterpene from Garcinia hombroniana. Bioorg. Chem., 54, 60-67.

138. Jantan I and Saputri FC. 2012. Benzophenones and xanthones from Garcinia cantleyana var cantleyana and their inhibitory activities on human low-density lipoprotein oxidation and platelet aggregation. Phytochemistry, 80, 58-63.

139. Ji X, Avula B and Khan IA. 2007. Quantitative and qualitative determination of six xanthones in Garcinia mangostana L by LC-PDA and LC-ESI-MS. J. Pharm. Biomed. Anal., 43(4), 1270-1276.

140. Jiang HZ, Quan XF, Tian WX, Hu JM, Wang PC, Huang SZ, Chenga ZQ, Lianga WJ, ZhouaJ, Ma XF and Zhao YX. 2010. Fatty acid synthase inhibitors of phenolic constituents isolated from Garcinia mangostana. Bioorg. Med. Chem. Lett., 20(20), 6045-6047.

141. Jing WY, Jiang C, Ji F, Hua HM and Li ZL. 2013. Chemical constituents from the stem barks of Garcinia multiflora. J. Asian Nat. Prod. Res., 15(11), 1152-1157.

142. Joong VYM, Ee GCL, Hin Y, Yap T, Khong HY and Chan MKY. 2012. Benzophenone constituents from the roots of Garcinia eugenifolia. Res. J. Chem. Environ., 16(1), 36-39. 
143. Joshi BS and Viswanathan N. 1970. The isolation and structure of two biflavones from Garcinia talboti. Phytochemistry, 9(4), 881-888.

144. Jung HA, Su BN, Keller WJ, Mehta RG and Kinghorn AD. 2006. Antioxidant xanthones from the pericarp of Garcinia mangostana (Mangosteen). J. Agric. Food. Chem., 54(6), 2077-2082.

145. Kabangu K, Galeffi C, Aonzo E, Nicoletti M, and Messana I. 1987. A new biflavonoid from the bark of Garcinia kola. Planta Med., 53, 275-277.

146. Kaennakam S, Siripong P and Tip-pyang S. 2015. Kaennacowanols A-C, three new xanthones and their cytotoxicity from the roots of Garcinia cowa. Fitoterapia, 102, 171-176.

147. Kaikabo AA, Samuel BB and Eloff JN. 2009. Isolation and activity of two antibacterial biflavonoids from leaf extracts of Garcinia livingstonei (Clusiaceae). Nat. prod. Commun., 4(10), 1363-1366.

148. Kapadia GJ, Oguntimein B and Shukla YN. 1994. High-speed counter-current chromatographic separation of biflavanoids from Garcinia kola seeds. J. Chromatogr. $A, 673(1), 142-146$.

149. Karanjgaokar CG, Radhakrishnan PV and Venkataraman K. 1967. Morelloflavone, a 3(8-)flavonylflavanone, from the heartwood of Garcinia Morella. Tetrahedron Lett., 8 (33), 3195-3198.

150. Karanjgoakar CG, Rao AR, Venkataraman K, Yemul SS and Palmer KJ. 1973. The constitution of xanthochymol and isoxanthochymol. Tetrahedron Lett., 14(50), 49774980.

151. Kardono LB, Hanafi M, Sherley G, Kosela S and Harrison LJ. 2006. Bioactive constituents of Garcinia porrecta and G. parvifolia grown in Indonesia. Pak. J. Biol. Sci., 9(3), 483-486.

152. Kartha G, Ramachandran GN, Bhat HB, Nair PM, Raghavan VKV and Venkataraman K. 1963. The constitution of morellin. Tetrahedron Lett., 4(7), 459-472.

153. Kaur R, Chattopadhyay SK, Tandon S and Sharma S. 2012. Large scale extraction of the fruits of Garcinia indica for the isolation of new and known polyisoprenylated benzophenone derivatives. Ind. Crops Prod., 37(1), 420-426.

154. Khalid RM, Jabit ML, Abas F, Stanslas J, Shaari K and Lajis NH. 2007. Cytotoxic xanthones from the leaf of Garcinia urophylla. Nat. Prod. Commun., 2(3), 271-276.

155. Kijjoa A, Gonzalez MJ, Pinto MM, Nascimento MS, Campos N, Mondranondra IO, Silva AM, Eaton G and Herz W. 2008. Cytotoxicity of prenylated xanthones and other constituents from the wood of Garcinia merguensis. Planta Med., 74(8), 864-866.

156. Klaiklay S, Sukpondma Y, Rukachaisirikul V and Phongpaichit S. 2013. Friedolanostanes and xanthones from the twigs of Garcinia hombroniana. Phytochemistry, 85, 161-166.

157. Komguem J, Lannang AM, Tangmouo JG, Louh GN, Ngounou FN, Lontsi D, Choudhary MI and Sondengam BL. 2006. Polyanxanthone, a xanthone from the stem bark of Garcinia polyantha. Nat. Prod.Commun., 1(5), 363-365.

158. Komguem J, Meli AL, Manfouo RN, Lontsi D, Ngounou FN, Kuete V, Kamdemc HW, Tanec P, Ngadjuia BT, Sondengama BL and Connolly JD. 2005. Xanthones from 
Garcinia smeathmannii (Oliver) and their antimicrobial activity. Phytochemistry, 66(14), 1713-1717.

159. Konoshima M and Ikeshiro Y. 1970. Fukugiside, the first biflavonoid glycoside from Garcinia spicata hook f. Tetrahedron Lett., 11(20), 1717-1720.

160. Konoshima M, Ikeshiro Y, Nishinaga A, Matsuura T, Kubota T and Sakamoto H. 1969. The constitution of flavonoids from Garcinia spicata hook f. Tetrahedron Lett., 10(2), 121-124.

161. Konoshima M, Ikeshiro Y, Miyahara S and Yen KY. 1970a. The constitution of biflavonoids from Garcinia plants. Tetrahedron Lett., 11(48), 4203-4206.

162. Kosela S, Hu LH, Yip SC, Rachmatia T, Sukri T, Daulay TS, Tana GK, Vittala JJ and Sim KY. 1999. Dulxanthone E: A pyranoxanthone from the leaf of Garcinia dulcis. Phytochemistry, 52(7), 1375-1377.

163. Kuete V, Komguem J, Beng VP, Meli AL, Tangmouo JG, Etoa FX and Lontsi D. 2007. Antimicrobial components of the methanolic extract from the stem bark of Garcinia smeathmannii Oliver (Clusiaceae). S. Afr. J. Bot., 73(3), 347-354.

164. Kumar S, Sharma S and Chattopadhyay SK. 2009. High-performance liquid chromatography and LC-ESI-MS method for identification and quantification of two isomeric polyisoprenylated benzophenones isoxanthochymol and camboginol in different extracts of Garcinia species. Biomed Chromatogr, 23,888-907.

165. Lannang AM, Komguem J, Ngninzeko FN, Tangmouo JG, Lontsi D, Ajaz A, Choudhary MI, Sondengam BL and Rahman AU. 2006. Antioxidant benzophenones and xanthones from the root bark of Garcinia smeathmannii. Bull. Chem. Soc. Ethiop., 20(2), 247-252.

166. Lannang AM, Komguem J, Ngninzeko FN, Tangmouo JG, Lontsi D, Ajaz, A, Choudhary MI, Ranjit R, Devkota KP and Sondengam BL. 2005. Bangangxanthone A and B, two xanthones from the stem bark of Garcinia polyantha Oliv. Phytochemistry, 66(19), 2351-2355.

167. Lannang AM, Louh GN, Lontsi D, Specht S, Sarite SR, Flörke U, Hussain H, Hoerauf A and Krohn K. 2008. Antimalarial compounds from the root bark of Garcinia polyantha Olv. J. Antibiot, 61(8), 518-523.

168. Lavaud A, Richomme P, Gatto J, Aumond MC, Poullain C, Litaudon M, Andriantsitohaina $\mathrm{R}$ and Guilet D. 2015. A tocotrienol series with an oxidative terminal prenyl unit from Garcinia amplexicaulis. Phytochemistry, 109, 103-110.

169. Le DH, Nishimura K, Takenaka Y, Mizushina $Y$ and Tanahashi T. 2016. Polyprenylated benzoylphloroglucinols with DNA polymerase inhibitory activity from the fruits of Garcinia schomburgkiana. J. Nat. Prod. 79 (7),1798-1807.

170. Lee HH and Chan HK. 1977. 1,3,6-Trihydroxy-7-methoxy-8-(3,7-dimethyl-2,6octadienyl) xanthone from Garcinia cowa. Phytochemistry, 16(12), 2038-2040.

171. Li DH, Li CX, Jia CC, Sun YT, Xue CM, Bai J, Hua HM, Liu XQ and Li ZL. 2016a. Xanthones from Garcinia paucinervis with in vitro anti-proliferative activity against HL-60 cells. Arch. Pharmacal Res., 39(2), 172-177.

172. Li LM, Zhou J, Lou J, Wang YD, Zhou K, Dong W, Gao XM, Hu QF and Jiang ZY. 2015. A new flavone from stems of Garcinia bracteata and its anti-TMV activity. Zhongguo Zhong Yao Za Zhi, 40(21), 4205-4207. 
173. Li P, Anandhi Senthilkumar H, Figueroa M, Wu SB, Fata JE, Kennelly EJ and Long C. 2016. UPLC-QTOFMSE-Guided dereplication of the endangered Chinese species Garcinia paucinervis to identify additional benzophenone derivatives. J. Nat. Prod., 79 (6), 1619-1627.

174. Li Y, Chen Y, Xiao C, Chen D, Xiao Y and Mei Z. 2014. Rapid screening and identification of $\alpha$-amylase inhibitors from Garcinia xanthochymus using enzymeimmobilized magnetic nanoparticles coupled with HPLC and MS. J. Chromatogr. $B, 960,166-173$.

175. Li Y, Wang Z, Wu X, Yang Y, Qin Y, Xia C, Meng Y, Li M, Gao XM and Hu Q. 2015. Biphenyl derivatives from the twigs of Garcinia bracteata and their biological activities. Phytochem. Lett., 11, 24-27.

176. Likhitwitayawuid K, Phadungcharoen T and Krungkrai J. 1998. Antimalarial xanthones from Garcinia cowa. Planta Med., 64(1), 70-72.

177. Likhitwitayawuid K, Phadungcharoen T, Mahidol C and Ruchirawat S. 1997. 7-Omethylgarcinone E from Garcinia cowa. Phytochemistry, 45(6), 1299-1301.

178. Lin CN, Wang JP and Weng JR. 2005. Anti-inflammatory and cure for ageing, Alzheimer's disease on phloroglucinol derivatives. U.S. Patent Application 11/078,194.

179. Lin $\mathrm{G}$ and $\mathrm{Xu}$ HX. 2010. Cytotoxic acylphloroglucinol derivatives from the twigs of Garcinia cowa. J. Nat. Prod., 73, 104-108.

180. Lin KW, Huang AM, Tu HY, Lee LY, Wu CC, Hour TC, Yang SC, Pu YS and Lin C. N. 2010a. Xanthine oxidase inhibitory triterpenoid and phloroglucinol from guttiferaceous plants inhibit growth and induced apoptosis in human NTUB1 cells through a ROS-dependent mechanism. J. Agric. Food. Chem., 59(1), 407-414.

181. Lin KW, Huang AM, Yang SC, Weng JR, Hour TC, Pu YS and Lin CN. 2012. Cytotoxic and antioxidant constituents from Garcinia subelliptica. Food. Chem., 135(2), 851-859.

182. Lin YM, Anderson H, Flavin MT, Pai YHS, Mata-Greenwood E, Pengsuparp T, Pezzuto JM, Scinazi RF, Hughes SH and Chenn FC. 1997. In vitro anti-HIV activity of biflavonoids isolated from Rhus succedanea and Garcinia multiflora. J. Nat. Prod., 60(9), 884-888.

183. Liu G, Li L, Wang H, Yang J, Lou J, Hu Q, Ye Y and Gao X. 2015. A new biphenyl from Garcinia oligantha and its cytotoxicity. Asian J. Chem., 27(7), 2731.

184. Locksley HD. 1973.The Chemistry of Biflavanoid Compounds. In: Fortschritte der Chemie Organischer Naturstoffe Springer Vienna, pp. 207-312.

185. Louh GN, Lannang AM, Mbazoa CD, Tangmouo JG, Komguem J, Castilho P, Qamarc NN, Lontsia D, Choudhary MI and Sondengam BL. 2008. Polyanxanthone A, B and C, three xanthones from the wood trunk of Garcinia polyantha Oliv. Phytochemistry, 69(4), 1013-1017.

186. Lu YH, Wei BL, Ko HH and Lin CN. 2008. DNA strand-scission by phloroglucinols and lignans from heartwood of Garcinia subelliptica Merr. and Justicia plants. Phytochemistry, 69(1), 225-233.

187. Madubunyi II. 1995. Antimicrobial activities of the constituents of Garcinia kola seeds. Int. J. Pharmacogn., 33(3), 232-237. 
188. Magadula J, Kapingu MC, Bezabih M and Abegaz BM. 2008. Polyisoprenylated benzophenones from Garcinia semseii (Clusiaceae). Phytochem. Lett., 1(4), 215-218.

189. Magadula JJ and Mbwambo ZH. 2014. Garcinia Plant Species of African Origin: Ethnobotanical, Pharmacological and Phytochemical Studies. Open Science Publishers, New York.

190. Magadula JJ. 2010. A bioactive isoprenylated xanthone and other constituents of Garcinia edulis. Fitoterapia, 81(5), 420-423.

191. Mahabusarakam W, Chairerk P and Taylor WC. 2005. Xanthones from Garcinia cowa Roxb latex. Phytochemistry, 66(10), 1148-1153.

192. Mahabusarakam W, Wiriyachitra P and Taylor WC. 1987. Chemical constituents of Garcinia mangostana. J. Nat. Prod., 50(3), 474-478.

193. Mahamodo S, Rivière C, Neut C, Abedini A, Ranarivelo H, Duhal N, Roumy V, Hennebelle T, Sahpaz S, Lemoine A, Razafimahefa B, Bailleul F, Razafimahefa D and Andriamihaja B. 2014. Antimicrobial prenylated benzoylphloroglucinol derivatives and xanthones from the leaf of Garcinia goudotiana. Phytochemistry, 102, 162-168.

194. Mandal S, Das PC and Joshi PC. 1992. Naturally occuring xanthones from terrestrial flora. J. Indian Chem. Soc., 69(10), 611-636.

195. Martins FT, dos Santos MH, Coelho CP, Barbosa LC, Dias GC, Fracca MP, Neves $P P$, Stringheta PC and Doriguetto AC. 2011. A powder X-ray diffraction method for detection of polyprenylated benzophenones in plant extracts associated with HPLC for quantitative analysis. J. Pharm. Biomed. Anal., 54(3), 451-457.

196. Masuda T, Yamashita D, Takeda Y and Yonemori S. 2005. Screening for tyrosinase inhibitors among extracts of seashore plants and identification of potent inhibitors from Garcinia subelliptica. Biosci. Biotech. Biochem., 69(1), 197-201.

197. Masullo M, Bassarello C, Suzuki H, Pizza C and Piacente S. 2008. J. Agric. Food Chem., 56, 5205-5210.

198. Masullo M, Bassarello C, Bifulco G and Piacente S. 2010. Polyisoprenylated benzophenone derivatives from the fruits of Garcinia cambogia and their absolute configuration by quantum chemical circular dichroism calculations. Tetrahedron, 66(1), 139-145.

199. Matsumoto K, Akao Y, Kobayashi E, Ito T, Ohguchi K, Tanaka T and Nozawa Y. 2003. Cytotoxic benzophenone derivatives from Garcinia species display a strong apoptosis-inducing effect against human leukemia cell lines. Biol. Pharm. Bull., 26(4), 569-571.

200. Mbafor JT, Fomum ZT, Promsattha R, Sanson DR and Tempesta MS. 1989. Isolation and characterization of taxifolin 6-C-glucoside from Garcinia epunctata. J. Nat. Prod., 52(2), 417-419.

201. Mbwambo ZH, Kapingu MC, Moshi MJ, Machumi F, Apers S, Cos P, Ferreira D, Marais JPJ, Berghe DV, Maes L, Vlietinck A and Pieters L. 2006. Antiparasitic activity of some xanthones and biflavonoids from the root bark of Garcinia livingstoneii. $J$. Nat. Prod., 69(3), 369-372.

202. Meechai I, Phupong W, Chunglok W and Meepowpan P. 2016. Anti-radical activities of xanthones and flavonoids from Garcinia schomburgkiana. Int. J. Pharm. Pharm. Sci., 8(9). 
203. Meesakul P, Pansanit A, Maneerat W, Sripisut T, Ritthiwigrom T, Machana T, Cheenpracha S and Laphookhieo S. 2016. Xanthones from Garcinia propinqua Roots. Nat. Prod. Commun., 11(1), 87.

204. Mercader A and Pomilio AB. 2012. (Iso) Flav (an) ones, chalcones, catechins, and theaflavins as anticarcinogens: Mechanisms, anti-multidrug resistance and QSAR studies. Curr. Med. Chem., 19(25), 4324-4347.

205. Merza J, Aumond MC, Rondeau D, Dumontet V, Le Ray AM, Séraphin D and Richomme P. 2004. Prenylated xanthones and tocotrienols from Garcinia virgata. Phytochemistry, 65(21), 2915-2920.

206. Merza J, Mallet S, Litaudon M, Dumontet V, Séraphin D and Richomme P. 2006. New cytotoxic guttiferone analogues from Garcinia virgata from New Caledonia. Planta Med., 72(01), 87-89.

207. Messi BB, Ndjoko-Ioset K, Hertlein-Amslinger B, Lannang AM, Nkengfack AE, Wolfender JL, Hostettmann K and Bringmann G. 2012. Preussianone, a new flavanonechromone biflavonoid from Garcinia preussii Engl. Molecules, 17(5), 6114-6125.

208. Mian VJY, Lian GEC and Yen KH. 2010. Xanthone from Garcinia eugenifolia (Clusiaceae). In: Science and Social Research (CSSR), 2010 International Conference,pp 786-788 IEEE.

209. Michel T, Destandau E, Fougere L, Elfakir C. 2012. New hyphenated CPC-HPLCDAD-MS strategy for simultaneous isolation, analysis and identification of phytochemicals: Application to xanthones from Garcinia mangostana. Anal. Bioanal. Chem., 404, 2963- 2972.

210. Minami H, Hamaguchi K, Kubo M and Fukuyama Y. 1998. A benzophenone and a xanthone from Garcinia subelliptica. Phytochemistry, 49(6), 1783-1785.

211. Minami H, Kinoshita M, Fukuyama Y, Kodama M, Yoshizawa T, Sugiura M, Nakagawa K and Tago H. 1994. Antioxidant xanthones from Garcinia subelliptica. Phytochemistry, 36(2), 501-506.

212. Minami H, Takahashi E, Kodama M and Fukuyama Y. 1996. Three xanthones from Garcinia subelliptica. Phytochemistry, 41(2), 629-633.

213. Mishra A, Bapat MM, Tilak JC and Devasagayam T. 2006. Antioxidant activity of Garcinia indica (kokam) and its syrup. Curr. Sci. India, 91(1), 90-93.

214. Momo IJ, Kuete V, Dufat H, Michel S and Wandji J. 2011. Antimicrobial activity of the methanolic extract and compounds from the stembark of Garcinia lucida Vesque (Clusiaceae). Int. J. Pharm. Pharmaceut. Sc., 3(11), 215-217.

215. Mungmee C, Sitthigool S, Buakeaw A and Suttisri R. 2013. A new biphenyl and other constituents from the wood of Garcinia schomburgkiana. Nat. Prod. Res., 27(21), 1949-1955.

216. Mungmee C, Supotchana Sitthigool R and Buakeaw A. 2012. Xanthones and biphenyls from Garcinia schomburgkiana and their cytotoxicity. Thai J. Pharm. Sci., 36, 6-9.

217. Na Z, Hu HB and Fan QF. 2010. A novel caged-prenylxanthone from Garcinia bracteata. Chin. Chem. Lett., 21(4), 443-445.

218. Ngoupayo J, Noungoue DT, Lenta BN, Tabopda TK, Khan SN, Ngouela S, Shaiq MA and Tsamo E. 2007. Brevipsidone, a new depsidone and other alpha-glucosidase 
inhibitors from Garcinia brevipedicellata (Clusiaceae). Nat. Prod. Commun., 2(11), 1141-1144.

219. Ngoupayo J, Tabopda TK and Ali MS. 2009. Antimicrobial and immunomodulatory properties of prenylated xanthones from twigs of Garcinia staudtii. Bioorg. Med. Chem., 17(15), 5688-5695.

220. Ngoupayo J, Tabopda TK, Ali MS and Tsamo E. 2008. ALPHA-Glucosidase Inhibitors from Garcinia brevipedicellata (Clusiaceae). Chem. Pharm. Bull., 56(10), 1466-1469.

221. Nguyen HD, Trinh BT and Nguyen LHD. 2011. Guttiferones Q-S, cytotoxic polyisoprenylated benzophenones from the pericarp of Garcinia cochinchinensis. Phytochem. Lett., 4(2), 129-133.

222. Nguyen HD, Trinh BT, Tran QN, Nguyen HD, Pham HD, Hansen PE, Duus F, Connolly JD and Nguyen LHD. 2011a. Friedolanostane, friedocycloartane and benzophenone constituents of the bark and leaf of Garcinia benthami. Phytochemistry, 72(2), 290-295.

223. Nguyen LHD and Harrison LJ. 2000. Xanthones and triterpenoids from the bark of Garcinia vilersiana. Phytochemistry, 53(1), 111-114.

224. Nguyen LHD, Venkatraman G, Sim, KY and Harrison LJ. 2005. Xanthones and benzophenones from Garcinia griffithii and Garcinia mangostana. Phytochemistry, 66(14), 1718-1723.

225. Nguyen LHD, Vo HT, Pham HD, Connolly JD and Harrison LJ. 2003. Xanthones from the bark of Garcinia merguensis. Phytochemistry, 63(4), 467-470.

226. Nilar and Harrison LJ. 2002. Xanthones from the heartwood of Garcinia mangostana Phytochemistry, 60(5), 541-548.

227. Niu SL, Li ZL, Ji F, Liu GY, Zhao N, Liu XQ, Jing YK and Hua HM. 2012. Xanthones from the stem bark of Garcinia bracteata with growth inhibitory effects against HL-60 cells. Phytochemistry, 77, 280-286.

228. Nontakham J, Charoenram N, Upamai W, Taweechotipatr M and Suksamrarn S. 2014. Anti-Helicobacter pylori xanthones of Garcinia fusca. Arch. Pharmacal. Res., 37(8), 972-977.

229. Nuangnaowarat W, Phupong W, Intereya K and Isaka M. 2010. New prenylated xanthone from the branch of Garcinia costata. Heterocycles, 81(10), 2377-2384.

230. Obolskiy D, Pischel I, Siriwatanametanon N and Heinrich M. 2009. Garcinia mangostana L.: A phytochemical and pharmacological review. Phytother. Res., 23 (8) 1047-1065.

231. Okudaira C, Ikeda Y, Kondo S, Furuya S, Hirabayashi Y, Koyano T, Saito Y and Umezawa K. 2000. Inhibition of acidic sphingomyelinase by xanthone compounds isolated from Garcinia speciosa. J. Enzyme Inhib. Med. Chem., 15(2), 129-138.

232. Okwu DE and Morah FNI. 2007. Isolation and characterization of flavanone glycoside 4I, 5, 7-trihydroxy flavanone rhamnoglucose from Garcinia kola seed. J. Appl. Sci., 7, 306-309.

233. Ollis WD, Redman BT, Sutherland IO and Jewers K. 1969. The constitution of bronianone. J. Chem. Soc. D, (15), 879-880. 
234. On S, Aminudin N, Ahmad F, Sirat H M and Taher M. 2016. Chemical constituents from stem bark of Garcinia prainiana and their bioactivities. Internat.J. Pharmacog. Phytochem. Res., 8(5), 756-760.

235. Osorio E, Londoño J and Bastida J. 2013. Low-Density lipoprotein (LDL)-Antioxidant biflavonoids from Garcinia madruno. Molecules, 18(5), 6092-6100.

236. Osorio E, Montoya G, and Bastida J. 2009. Phytochemical characterization of a biflavonoid fraction from Garcinia madruno: Inhibition of human LDL oxidation and its free radical scavenging mechanism. Vitae, 16(3), 369-377.

237. Padhye S, Ahmad A, Oswal N and Sarkar FH. 2009. Emerging role of Garcinol, the antioxidant chalcone from Garcinia indica Choisy and its synthetic analogs. J. Hemat. Oncol. 2(38).

238. Pandey R, Chandra P, Kumar B, Srivastva M, Aravind AA, Shameer PS and Rameshkumar KB. 2015. Simultaneous determination of multi-class bioactive constituents for quality assessment of Garcinia species using UHPLC-QqQ LITMS/MS. Ind. Crops Prod., 77, 861-872.

239. Pang X, Yi T, Yi Z, Cho SG, Gu W, Pinkaew D, Fujise, K and Liu M. 2009. Morelloflavone, a biflavonoids inhibits tumor angiogenesis by targeting Rho GTPases and extracellular signal regulated kinase signaling pathway. Cancer Res., 69(2), 518525.

240. Panthong K, Hutadilok-Towatana $N$ and Panthong A. 2009. Cowaxanthone F, a new tetraoxygenated xanthone and other anti-inflammatory and antioxidant compounds from Garcinia cowa. Can. J. Chem., 87(11), 1636-1640.

241. Panthong K, Pongcharoen W, Phongpaichit S and Taylor W C. 2006. Tetraoxygenated xanthones from the fruits of Garcinia cowa. Phytochemistry, 67(10), 999-1004.

242. Parthasarathy U, Nirmal Babu K, Senthil Kumar R, Ashis GR, Mohan S and Parthasarathy VA. 2013. Diversity of Indian Garcinia-A Medicinally Important Spice Crop in India. In: II International Symposium on Underutilized Plant Species: Crops for the Future-Beyond Food Security. 979, pp. 467-476.

243. Parveen $M$ and Khan NUD. 1988. Two xanthones from Garcinia mangostana. Phytochemistry, 27(11), 3694-3696.

244. Parveen M, Ilyas M, Mushfiq M, Busudan OA and Muhaisen HM. 2004. A new biflavonoid from leaf of Garcinia nervosa. Nat. Prod. Res., 18(3), 269-275.

245. Parveen N, Singh MP, Khan NU and Logani MK. 1994. Flavonoidic constituents of Garcinia xanthochymus leaf. Fitoterapia, 65, 89.

246. Pelter A, Warren R, Chexal KK, Handa BK and Rahman W. 1971. Biflavonyls from Guttifereae-Garcinia livingstonii. Tetrahedron, 27(8), 1625-1634.

247. Pereira IO, Marques MJ, Pavan ALR, Codonho BS, Barbieri, CL, Beijo LA and Dos Santos MH. 2010. Leishmanicidal activity of benzophenones and extracts from Garcinia brasiliensis Mart fruits. Phytomed., 17(5), 339-345.

248. Peres V, Nagem TJ and de Oliveira FF. 2000. Tetraoxygenated naturally occurring xanthones. Phytochemistry, 55(7), 683-710.

249. Permana D, Abas F, Maulidiani F, Shaari K, Stanslas J, Ali AM and Lajis NH. 2005. Atrovirisidone B, a new prenylated depsidone with cytotoxic property from the roots of Garcinia atroviridis. Z. Naturforsch. C, 60(7-8), 523-526. 
250. Permana D, Lajis NH, Mackeen MM, Ali AM, Aimi N, Kitajima M and Takayama H. 2001. Isolation and bioactivities of constitutents of the roots of Garcinia atroviridis. $J$. Nat. Prod., 64(7), 976-979.

251. Phongi BMC, Totte J, Pieters LAC, Hoof LV, Van Den Berghe TVDA and Vlietinck AJ. 1987. Structure and chemotherapeutical activity of a polyisoprenylated benzophenone from the stem bark of Garcinia huillensis. J. Ethnopharmacol., 21, 7584.

252. Pieme CA, Ambassa P, Yankep E and Saxena AK. 2015. Epigarcinol and isogarcinol isolated from the root of Garcinia ovalifolia induce apoptosis of human promyelocytic leukemia (HL-60 cells). BMC research notes, 8(1), 700.

253. Pinkaew D, Cho SG, Hui DY, Wiktorowicz JE, Hutadilok-Towatana N, Mahabusarakam W and Fujise K. 2009. Morelloflavone blocks injury-induced neointimal formation by inhibiting vascular smooth muscle cell migration. Biochim. Biophys. Acta. (BBA)-General Subjects, 1790(1), 31-39.

254. Porto AL, Machado SM, de Oliveira CM, Bittrich V, Maria do Carmo EA and Marsaioli AJ. 2000. Polyisoprenylated benzophenones from Clusia floral resins. Phytochemistry, 55(7), 755-768.

255. Quan GH, Oh SR, Kim JH, Lee HK, Kinghorn AD and Chin YW. 2010. Xanthone constituents of the fruits of Garcinia mangostana with anticomplement activity. Phytother. Res., 24(10), 1575-1577.

256. Rahman M, Riaz $M$ and Desai UR. 2007. Synthesis of biologically relevant biflavanoids-A review. Chem. Biodivers., 4(11), 2495-2527.

257. Rajaonarivelo M, Rakotonandrasana O, Raharinjato F, Martin MT, Dumontet V, Rasoanaivo P, Gueritte F. 2009. New cytotoxic compounds from Madagascar plants. In: Proceedings of Biomedical symposium, Antanarivo, Madagascar, p. 65.

258. Rambeloson VHV, Rasoanaivo LH, Wadouachi A, Randrianasolo R, Krebs HC and Raharisololalao A. 2014. Two new xanthones from Garcinia chapelieri: Chapexanthone A; chapexanthone B. J. Pharmacog. Phytochem., 2(5), 164-171.

259. Rao AR, Sarma MR, Venkataraman K and Yemul SS. 1974. A benzophenone and xanthone with unusual hydroxylation patterns from the heartwood of Garcinia pedunculata. Phytochemistry, 13(7), 1241-1244.

260. Rao AR, Venkataraman K and Yemul SS. 1973. The structure of bronianone. Tetrahedron Lett., 14(50), 4981-4982.

261. Rao AR, Venkatswamy $G$ and Pendse D. 1980. Camboginol and cambogin. Tetrahedron Lett., 21(20), 1975-1978.

262. Rao BS. 1937. Morellin, a constituent of the seeds of Garcinia morella. J. Chem. Soc., 853-855.

263. Rao RR and Natarajan S. 1950. On 'morellin', the antibacterial principle of the seeds of Garcinia morella Desrous. Curr. Sci., 19(2), 59-60.

264. Ren Y, Lantvit DD, de Blanco EJC, Kardono LB, Riswan S, Chai H, Cottrellg CE, Farnsworth NR, Swanson SM, Ding Y, Li XC, Marais JPJ, Ferreira D and Kinghorn AD. 2010. Proteasome-inhibitory and cytotoxic constituents of Garcinia lateriflora: Absolute configuration of caged xanthones. Tetrahedron, 66(29), 5311-5320. 
265. Reutrakul V, Anantachoke N, Pohmakotr M, Jaipetch T, Sophasan S, Yoosook C, Kasisit J, Napaswat C, Santisuk T, Tuchinda P and Tuchinda P. 2007. Cytotoxic and anti-HIV-1 caged xanthones from the resin and fruits of Garcinia hanburyi. Planta Med., 73(1), 33-40.

266. Roux D, Hadi HA, Thoret S, Guénard D, Thoison O, Païs M and Sévenet T. 2000. Structure-activity relationship of polyisoprenyl benzophenones from Garcinia pyrifera on the tubulin/microtubule system. J. Nat. Prod., 63(8), 1070-1076.

267. Rukachaisirikul V, Kaewnok W, Koysomboon S, Phongpaichit S and Taylor WC. 2000a Caged-tetraprenylated xanthones from Garcinia scortechinii. Tetrahedron, 56(43), 8539-8543.

268. Rukachaisirikul V, Kamkaew M, Sukavisit D, Phongpaichit S, Sawangchote P and Taylor WC. 2003. Antibacterial xanthones from the leaf of Garcinia nigrolineata. J. Nat. Prod., 66(12), 1531-1535.

269. Rukachaisirikul V, Naklue W, Phongpaichit S, Towatana NH and Maneenoon K. 2006. Phloroglucinols, depsidones and xanthones from the twigs of Garcinia parvifolia. Tetrahedron, 62(36), 8578-8585.

270. Rukachaisirikul V, Naklue W, Sukpondma Y and Phongpaichit S. 2005. An antibacterial biphenyl derivative from Garcinia bancana MIQ. Chem. Pharm. Bull., 53(3), 342-343.

271. Rukachaisirikul V, Pailee P, Hiranrat A, Tuchinda P, Yoosook C, Kasisit J and Reutrakul V. 2003a. Anti-HIV-1 protostane triterpenes and digeranylbenzophenone from trunk bark and stems of Garcinia speciosa. Planta Med., 69(12), 1141-1146.

272. Rukachaisirikul V, Painuphong P, Sukpondma Y, Koysomboon S, Sawangchote P and Taylor WC. 2003b. Caged-triprenylated and-tetraprenylated xanthones from the latex of Garcinia scortechinii. J. Nat. Prod., 66(7), 933-938.

273. Rukachaisirikul V, Ritthiwigrom T, Pinsa A, Sawangchote P and Taylor WC. 2003c. Xanthones from the stem bark of Garcinia nigrolineata. Phytochemistry, 64(6), 11491156.

274. Rukachaisirikul V, Tadpetch K, Watthanaphanit A, Saengsanae N, and Phongpaichit S. 2005a. Benzopyran, biphenyl, and tetraoxygenated xanthone derivatives from the twigs of Garcinia nigrolineata. J. Nat. Prod., 68(8), 1218-1221.

275. Rukachaisirikul V, Trisuwan K, Sukpondma Y and Phongpaichit S. 2008. A new benzoquinone derivative from the leaf of Garcinia parvifolia. Arch. Pharmacal Res., 31(1), 17-20.

276. Ryu HW, Cho JK, Curtis-Long MJ, Yuk HJ, Kim YS, Jung S, Kima YS, Lee BW and Park KH. 2011. $\alpha$-Glucosidase inhibition and antihyperglycemic activity of prenylated xanthones from Garcinia mangostana. Phytochemistry, 72(17), 2148-2154.

277. Ryu HW, Curtis-Long MJ, Jung S, Jin YM, Cho JK, Ryu YB, Lee WS and Park KH. 2010. Xanthones with neuraminidase inhibitory activity from the seedcases of Garcinia mangostana. Bioorg. Med. Chem., 18(17), 6258-6264.

278. Sabu T, Mohanan N, Krishnaraj MV, Shareef SM, Shameer PS and Roy PE. 2013. Garcinia pushpangadaniana (Clusiaceae), a new species from southern Western Ghats, India. Phytotaxa, 116(2), 51-56. 
279. Saelee A, Phongpaichit S and Mahabusarakam W. 2015. A new prenylated biflavonoid from the leaf of Garcinia dulcis. Nat. Prod. Res., 29(20), 1884-1888.

280. Sahu A, Das B and Chatterjee A. 1989. Polyisoprenylated benzophenones from Garcinia pedunculata. Phytochemistry, 28(4), 1233-1235.

281. Sakunpak A and Panichayupakaranant P. 2012. Antibacterial activity of Thai edible plants against gastrointestinal pathogenic bacteria and isolation of a new broad spectrum antibacterial polyisoprenylated benzophenone, chamuangone. Food Chem., 130(4), 826-831.

282. Santa-Cecília FV, Freitas LA, Vilela FC, Veloso CDC, da Rocha CQ, Moreira ME, Diasa DF, Giusti-Paivab A and dos Santos MH. 2011. Antinociceptive and antiinflammatory properties of 7-epiclusianone, a prenylated benzophenone from Garcinia brasiliensis. Eur. J. Pharmacol., 670(1), 280-285.

283. Sarma J, Shameer PS, Mohanan NN. 2016. A new species of Garcinia (Clusiaceae) from Assam, north east India. Phytotaxa, 252(1), 73-76.

284. See I, Ee GCL, Teh SS, Kadir AA and Daud S. 2014. Two new chemical constituents from the stem bark of Garcinia mangostana. Molecules, 19(6), 7308-7316.

285. See I, Ee GCL, Teh SS, Mah SH, Karjiban RA, Daud S and Jong VYM. 2016. A New benzophenone from Garcinia benthamiana. Rec. Nat. Prod., 10(3), 355-361.

286. Semwal RB, Semwal, DK, Vermaak I and Viljoen A. 2015. A comprehensive scientific overview of Garcinia cambogia. Fitoterapia, 102, 134-148.

287. Sen AK, Sarkar KK, Majumder C and Banerji N. 1981. Minor xanthones of Garcinia mangostana. Phytochemistry, 20(1), 183-185.

288. Sen AK, Sarkar KK, Mazumder PC, Banerji N, Uusvuori R and Hase TA. 1982. The structures of garcinones A, B and C: Three new xanthones from Garcinia mangostana. Phytochemistry, 21(7), 1747-1750.

289. Sen AK, Sarkar KK, Mazumder PC, Banerji N, Uusvuori R and Haset TA. 1980. A xanthone from Garcinia mangostana. Phytochemistry, 19(10), 2223-2225.

290. Shadid KA, Shaari K, Abas F, Israf DA, Hamzah AS, Syakroni N, Saha K and Lajis NH. 2007. Cytotoxic caged-polyprenylated xanthonoids and a xanthone from Garcinia cantleyana. Phytochemistry, 68(20), 2537-2544.

291. Shen J and Yang J. 2007. Chemical constituents of branch of Garcinia cowa Roxb. Zhongcaoyao, 38, 993-994.

292. Shen J and Yang JS. 2006. Chemical constituents from fruit of Garcinia cowa. Chinese Pharmaceut. J., 41(9), 660-661.

293. Shen J, Tian $Z$ and Yang JS. 2007. The constituents from the stems of Garcinia cowa Roxb. and their cytotoxic activities. Die Pharmazie, 62(7), 549-551.

294. Shen J, Yang JS and Zhou SX. 2006. Chemical constituents from the fruit of Garcinia xipshuanbannaensis. Zhongguo Tianran Yaowu, 4(6), 440-443.

295. Singh IP, Sidana J, Bharate SB and Foley WJ. 2010. Phloroglucinol compounds of natural origin: Synthetic aspects. Nat. Prod. Rep. 27, 393-416.

296. Siridechakorn I, Maneerat W, Sripisut T, Ritthiwigrom T, Cheenpracha S and Laphookhieo S. 2014. Biphenyl and xanthone derivatives from the twigs of a Garcinia sp. (Clusiaceae). Phytochem. Lett., 8, 77-80. 
297. Siridechakorn I, Phakhodee W, Ritthiwigrom T, Promgool T, Deachathai S, Cheenpracha S, Prawat U and Laphookhieo S. 2012. Antibacterial dihydrobenzopyran and xanthone derivatives from Garcinia cowa stem barks. Fitoterapia, 83(8), 14301434.

298. Soemiati A, Kosela S, Hanafi M and Harrison LJ. 2006. Garcinopicrobenzophenone, a novel polyprenyl benzophenone from the bark of Indonesian Garcinia picrorrhiza Miq. ACGC Chem. Res. Commun. 20, 1-5.

299. Sordat-Diserens I, Hamburger M, Rogers C and Hostettmannt K. 1992. Dimeric xanthones from Garcinia livingstonei. Phytochemistry, 31(10), 3589-3593.

300. Sordat-Diserens I, Rogers C, Sordat B and Hostettmann K. 1992a. Prenylated xanthones from Garcinia livingstonei. Phytochemistry, 31(1), 313-316.

301. Spino C, Lal J, Sotheeswaran S and Aalbersberg W. 1995. Three prenylated phenolic benzophenones from Garcinia myrtifolia. Phytochemistry, 38(1), 233-236.

302. Srivastava SN and Sharma V. 1966. Chemical constituents of Garcinia livingstonei $\mathrm{T}$ Anders. Curr. Sci., 35(11), 290.

303. Sriyatep T, Siridechakorn I, Maneerat W, Pansanit A, Ritthiwigrom T, Andersen RJ and Laphookhieo S. 2015. Bioactive prenylated xanthones from the young fruits and flowers of Garcinia cowa. J. Nat. Prod., 78(2), 265-271.

304. Stark TD, Lösch S, Salger M, Balemba OB, Wakamatsu J, Frank O and Hofmann T. 2015. A new NMR approach for structure determination of thermally unstable biflavanones and application to phytochemicals from Garcinia buchananii. Magn. Reson. Chem., 53(10), 813-820.

305. Stark TD, Matsutomo T, Lösch S, Boakye PA, Balemba OB, Pasilis SP and Hofmann T. 2012. Isolation and structure elucidation of highly antioxidative 3,8 "-linked biflavanones and flavanone-C-glycosides from Garcinia buchananii bark. J. Agric. Food Chem., 60(8), 2053-2062.

306. Stark TD, Salger M, Frank O, Balemba OB, Wakamatsu J and Hofmann T. 2015a. Antioxidative compounds from Garcinia buchananii stem bark. J. Nat. Prod., 78(2), 234-240.

307. Steller H. 1995. Mechanisms and genes of cellular suicide. Science, 267(5203), 14451449.

308. Sukandar ER, Ersam T, Fatmawati S, Siripong P, Aree T and Tip-pyang S. 2016. Cylindroxanthones A-C, three new xanthones and their cytotoxicity from the stem bark of Garcinia cylindrocarpa. Fitoterapia, 108, 62-65.

309. Sukandar ER, Siripong P, Khumkratok S and Tip-pyang S. 2016a. New depsidones and xanthone from the roots of Garcinia schomburgkiana. Fitoterapia, 111, 73-77.

310. Sukpondma Y, Rukachaisirikul V and Phongpaichit S. 2005. Xanthone and Sesquiterpene derivatives from the fruits of Garcinia scortechinii. J. Nat. Prod., 68(7), 1010-1017.

311. Suksamrarn S, Suwannapoch N, Phakhodee W, Thanuhiranlert J, Ratananukul P, Chimnoi $\mathrm{N}$ and Suksamrarn A. 2003. Antimycobacterial activity of prenylated xanthones from the fruits of Garcinia mangostana. Chem. Pharm. Bull., 51(7), 857859 . 
312. Suksamrarn S, Suwannapoch N, Ratananukul P, Aroonlerk N and Suksamrarn A. 2002. Xanthones from the green fruit hulls of Garcinia mangostana. J. Nat. Prod., 65(5), 761-763.

313. Sultanbawa MUS.1980. Xanthonoids of tropical plants. Tetrahedron, 36(1), 1465-1506.

314. Supasuteekul C, Nonthitipong W, Tadtong S, Likhitwitayawuid K., Tengamnuay P and Sritularak B. 2016. Antioxidant, DNA damage protective, neuroprotective, and $\alpha$ glucosidase inhibitory activities of a flavonoid glycoside from leaf of Garcinia gracilis. Revista Brasileira de Farmacognosia, 26(3), 312-320.

315. Taher M, Idris MS and Arbain D. 2007. Antimicrobial, antioxidant, anti-inflammatory and cytotoxic activities of Garcinia eugenifolia and Calophyllum enervosum. Iranian J. Pharmacol. Therapeut., 6(1), 93-98.

316. Taher M, Susanti D, Rezali MF, Zohri FSA, Ichwan SJA, Alkhamaiseh SI and Ahmad F. 2012. Apoptosis, antimicrobial and antioxidant activities of phytochemicals from Garcinia malaccensis Hk. f. Asian Pacific journal of tropical medicine, 5(2), 136-141.

317. Tan WN, Khairuddean M, Wong KC, Khaw KY and Vikneswaran M. 2014. New cholinesterase inhibitors from Garcinia atroviridis. Fitoterapia, 97, 261-267.

318. Tan WN, Khairuddean M, Wong KC, Tong WY and Ibrahim D. 2016. Antioxidant compounds from the stem bark of Garcinia atroviridis. J. Asian Nat. Prod. Res., 18(8), 804-811.

319. Tang YX, Fu WW, Wu R, Tan HS, Shen ZW and Xu HX. 2016. Bioassay-Guided isolation of prenylated xanthone derivatives from the leaves of Garcinia oligantha. $J$. Nat. Prod., 79(7), 1752-1761.

320. Tang ZY, Xia ZX, Qiao SP, Jiang C, Shen GR, Cai MX and Tang XY. 2015. Four new cytotoxic xanthones from Garcinia nujiangensis. Fitoterapia, 102, 109-114.

321. Tantapakul C, Phakhodee W, Ritthiwigrom T, Cheenpracha S, Prawat U, Deachathai S and Laphookhieo S. 2012. Rearranged benzophenones and prenylated xanthones from Garcinia propinqua twigs. J. Nat. Prod., 75(9), 1660-1664.

322. Terashima K, Kondo Y, Aqil M and Niwa M. 1999. A new xanthone from the Stems of Garcinia Kola. Nat. Prod. Lett., 14(2), 91-97.

323. Terashima K, Kondo Y, Aqil M, Niwa M. 1995. Garcinianin, a novel biflavonoid from the roots of Garcinia kola. Heterocycles, 41, 2245-2250.

324. Terashima K, Kondo $Y$, Aqil M, Waziri M and Niwa M. 1999a. A study of biflavanones from the stems of Garcinia kola (Guttiferae). Heterocycles, 50(1), 283290.

325. Terashima K, Shimamura T, Tanabayashi M, Aqil M, Akinniyi JA and Niwa M. 1997. Constituents of the seeds of Garcinia kola: Two new antioxidants, garcinoic acid and garcinal. Heterocycles, 8(45), 1559-1566.

326. Thoison O, Cuong DD, Gramain A, Chiaroni A, Van Hung N and Sévenet T. 2005. Further rearranged prenylxanthones and benzophenones from Garcinia bracteata. Tetrahedron, 61(35), 8529-8535.

327. Thongtheeraparp W, Wiriyachitra P and Taylor WC. 1994. Xanthones of Garcinia cowa. Planta Med., 60(4), 365-368. 
328. Trisuwan K, Rukachaisirikul V, Phongpaichit S and Hutadilok-Towatana N. 2013. Tetraoxygenated xanthones and biflavanoids from the twigs of Garcinia merguensis. Phytochem. Lett., 6(4), 511-513.

329. Tshibangu PT, Kapepula PM, Kapinga MK, Lupona HK, Ngombe NK, Kalenda DT, Marini RD, Jansen O, Wauters JN, Angenot L, Ph Hubert and Rozet E. 2016. Fingerprinting and validation of a LC-DAD method for the analysis of biflavanones in Garcinia kola-based antimalarial improved traditional medicines. J. Pharm. Biomed. Anal., 125, 382-390.

330. Venkataraman K. 1973. Pigments of Garcinia species. Indian National Science Academy, New Delhi. 39(A)6, 365-381.

331. Vo HT, Ngo NT, Bui TQ, Pham HD and Nguyen LHD. 2015. Geranylated tetraoxygenated xanthones from the pericarp of Garcinia pedunculata. Phytochem. Lett., 13, 119-122.

332. Vo HT, Nguyen NTT, Maas G, Werz, UR, Pham HD and Nguyen LHD. 2012. Xanthones from the bark of Garcinia pedunculata. Phytochem. Lett., 5(4), 766-769.

333. Vo HT, Nguyen NTT, Nguyen HT, Do KQ, Connolly JD, Maas G, Heilmannc J, Werzb UR, Phama HD and Nguyen LHD. 2012a. Cytotoxic tetraoxygenated xanthones from the bark of Garcinia schomburgkiana. Phytochem. Lett., 5(3), 553-557.

334. Waffo AFK, Mulholland D, Wansi JD, Mbaze LM, Powo R, Mpondo TN, Fomum ZT, König W, Nkengfack AE. 2006. Afzeliixanthones A and B, Two new prenylated xanthones from Garcinia afzelii ENGL. (Guttiferae). Chem. Pharm. Bull., 54, 448-451.

335. Wahyuni FS, Byrne LT, Dianita R, Jubahar J, Lajis NH and Sargent MV. 2004. A new ring-reduced tetraprenyltoluquinone and a prenylated xanthone from Garcinia cowa. Aust. J. Chem., 57(3), 223-226.

336. Wang LL, Li Z L Xu YP, Liu XQ, Pei YH, Jing YK and Hua HM. 2008. A new cytotoxic caged polyprenylated xanthone from the resin of Garcinia hanburyi. Chin. Chem. Lett., 19(10), 1221-1223.

337. Waterman PG and Crichton EG. 1980. Pyrones from the bark of Garcinia conrauana: Conrauanalactone, a novel C 20 derived $\alpha$-pyrone. Phytochemistry, 19(6), 1187-1189.

338. Waterman PG and Crichton EG. 1980a. Xanthones and biflavonoids from Garcinia densivenia stem bark. Phytochemistry, 19(12), 2723-2726.

339. Waterman PG and Crichton EG. 1980b. Xanthones, benzophenones and triterpenes from the stem bark of Garcinia ovalifolia. Planta Med., 40(12), 351-355.

340. Waterman PG and Hussain RA. 1982. Major xanthones from Garcinia quadrifaria and Garcinia staudtii stem barks. Phytochemistry, 21(8), 2099-2101.

341. Waterman PG and Hussain RA. 1983. Systematic significance of xanthones, benzophenones and biflavonoids in Garcinia. Biochem. Syst. Ecol., 11(1), 21-28.

342. Weng JR, Lin CN, Tsao LT and Wang JP. 2003. Novel and anti-Inflammatory constituents of Garcinia subelliptica. Chem.Europ. J., 9(9), 1958-1963.

343. Weng JR, Tsao LT, Wang JP, Wu RR and Lin CN. 2004. Anti-inflammatory phloroglucinols and terpenoids from Garcinia subelliptica. J. Nat. Prod., 67(11), 17961799. 
344. Williams RB, Hoch J, Glass TE, Evans R, Miller JS, Wisse JH and Kingston DG. 2003. A novel cytotoxic guttiferone analogue from Garcinia macrophylla from the Suriname rainforest. Planta Med., 69(9), 864-866.

345. Wittenauer J, Falk S, Schweiggert-Weisz U and Carle R. 2012. Characterisation and quantification of xanthones from the aril and pericarp of mangosteens (Garcinia mangostana $\mathrm{L}$ ) and a mangosteen containing functional beverage by HPLC-DAD-MSn. Food Chem., 134(1), 445-452.

346. Wu CC, Lu YH, Wei BL, Yang SC, Won SJ and Lin CN. 2008. Phloroglucinols with prooxidant activity from Garcinia subelliptica. J. Nat. Prod., 71(2), 246-250.

347. Wu CC, Weng JR, Won SJ and Lin CN. 2005. Constituents of the pericarp of Garcinia subelliptica. J. Nat. Prod., 68(7), 1125-1127.

348. Wu J, Xu YJ, Cheng XF, Harrison LJ, Sim KY and Goh SH. 2001. A highly rearranged tetraprenylxanthonoid from Garcinia gaudichaudii (Guttiferae). Tetrahedron Lett., 42(4), 727-729.

349. Wu X, Ke CQ, Yang YP and Ye Y. 2008. New biphenyl constituents from Garcinia oblongifolia. Helv. Chim. Acta, 91(5), 938-943.

350. Xia Z, Zhang H, Xu D, Lao Y, Fu W, Tan H, Cao P,Yang L and Xu H. 2015. Xanthones from the leaf of Garcinia cowa induce cell cycle arrest, apoptosis, and autophagy in cancer cells. Molecules, 20(6), 11387-11399.

351. Xia ZX, Zhang DD, Liang S, Lao YZ, Zhang H, Tan HS, Chen SL, Wang XH and Xu HX. 2012. Bioassay-guided isolation of prenylated xanthones and polycyclic acylphloroglucinols from the leaf of Garcinia nujiangensis. J. Nat. Prod., 75(8), 14591464.

352. Xu G, Feng C, Zhou Y, Han QB, Qiao CF, Huang SX, Chang DC, Zhao QS, Luo KQ and $\mathrm{Xu}$ HX. 2008. Bioassay and ultraperformance liquid chromatography/mass spectrometry guided isolation of apoptosis-inducing benzophenones and xanthone from the pericarp of Garcinia yunnanensis Hu. J. Agric. Food. Chem., 56(23), 11144-11150.

353. Xu L, Lao Y, Zhao Y, Qin J, Fu W, Zhang Y and Xu H. 2015. Screening active compounds from Garcinia species native to China reveals novel compounds targeting the STAT/JAK signaling pathway. Biomed. Res. Int., 10, 1-10.

354. Xu T, Deng $\mathrm{Y}$, Zhao $\mathrm{S}$ and Shao Z. 2016. A new xanthone from the pericarp of Garcinia mangostana. J. Chem. Res., 40(1), 10-11.

355. Xu X, Shi J, Li L, Zhu D, Yu Z, Yu W, Zhou M, Hu Q, Guo Y, Lou J, Gao X and Deng L. 2016a. Biphenyls from the twigs of Garcinia multiflora and their anti-tobacco mosaic virus activities. Rec. Nat. Prod., 10(5), 566-571.

356. Xu YJ, Cao SG, Wu XH, Lai YH, Tan BHK, Pereira JT, Goh SH, Venkatramana G, Harrison LJ and Sim KY. 1998. Griffipavixanthone, a novel cytotoxic bixanthone from Garcinia griffithii and G. pavifolia. Tetrahedron Lett., 39(49), 9103-9106.

357. Xu YJ, Chiang PY, Lai YH, Vittal JJ, Wu XH, Tan BKH, Imiyabir Z and Goh SH. 2000. Cytotoxic prenylated depsidones from Garcinia parvifolia. J. Nat. Prod., 63(10), 1361-1363.

358. Xu YJ, Lai YH, Imiyabir Z and Goh SH. 2001. Xanthones from Garcinia parvifolia. J. Nat. Prod., 64(9), 1191-1195. 
359. Xu YJ, Yip SC, Kosela S, Fitri E, Hana M, Goh SH and Sim KY. 2000. Novel Cytotoxic, polyprenylated heptacyclic xanthonoids from Indonesian Garcinia gaudichaudii (Guttiferae). Org. Lett., 2(24), 3945-3948.

360. Xu Z, Huang L, Chen XH, Zhu XF, Qian XJ, Feng GK, Lan WJ and Li HJ. 2014. Cytotoxic prenylated xanthones from the pericarps of Garcinia mangostana. Molecules, 19(2), 1820-1827.

361. Yamaguchi LF, Katto MJ and Mascio PD. 2008. Perspectives in Biflavonoids-A Review. In: Recent Progress in Medicinal Plants. Ed. Govil JN, Singh VK and Mishra SK. Vol. 20, pp. 1-54.

362. Yang H, Figueroa M, To S, Baggett S, Jiang B, Basile MJ, Weinsteinand IB and Kennelly EJ. 2010. Benzophenones and biflavonoids from Garcinia livingstonei fruits. J. Agric. Food. Chem., 58(8), 4749-4755.

363. Yang J, Ding L, Hu L, Jin S, Liu W, You Q and Guo Q. 2012. Rapid characterization of caged xanthones in the resin of Garcinia hanburyi using multiple mass spectrometric scanning modes: The importance of biosynthetic knowledge based prediction. $J$. Pharm. Biomed. Anal., 60, 71-79.

364. Yang NY, Han QB, Cao XW, Qiao CF, Song JZ, Chen SL, Yang DJ, Yiu H and Xu HX. 2007. Two new xanthones isolated from the stem bark of Garcinia lancilimba. Chem. Pharm. Bull., 55(6), 950-952.

365. Yang Y, Li L and Lou J. 2015. Isoprenylated flavones from Garcinia bracteata and their anti-tobacco mosaic virus activity. Heterocycles, 91(2), 375-380.

366. Yates P and Stout GH. 1958. The structure of mangostin. J. Am. Chem. Soc., 80(7), 1691-1700.

367. Yu L, Zhao M, Yang B, Zhao Q and Jiang Y. 2007. Phenolics from hull of Garcinia mangostana fruit and their antioxidant activities. Food Chem., 104(1), 176-181.

368. Zarena AS and Sankar KU. 2009. Supercritical carbon dioxide extraction of xanthones with antioxidant activity from Garcinia mangostana: Characterization by HPLC/LCESI-MS. J. Supercrit. Fluids, 49(3), 330-337.

369. Zhang DD, Zhang H, Lao YZ, Wu R, Xu JW, Murad F, Bian K and Xu HX. 2015. Anti-Inflammatory effect of 1,3,5,7- tetrahydroxy-8-isoprenylxanthone isolated from twigs of Garcinia esculenta on stimulated macrophage. Mediators Inflammation, 2015, 1-11.

370. Zhang LJ, Chiou CT, Cheng JJ, Huang HC, Kuo LMY, Liao CC, Bastow KF, Lee KH and Kuo YH. 2010. Cytotoxic polyisoprenyl benzophenonoids from Garcinia subelliptica. J. Nat. Prod., 73(4), 557-562.

371. Zhang Y, Song Z, Hao J, Qiu S and Xu Z. 2010a. Two new prenylated xanthones and a new prenylated tetrahydroxanthone from the pericarp of Garcinia mangostana. Fitoterapia, 81(6), 595-599.

372. Zhao Y, Liu JP, Lu D, Li PY and Zhang LX. 2012. Two new xanthones from the pericarp of Garcinia mangostana. Nat. Prod. Res., 26(1), 61-65.

373. Zhong FF, Chen Y, Mei ZN and Yang GZ. 2007. Xanthones from the bark of Garcinia xanthochymus. Chin. Chem. Lett., 18(7), 849-851. 
374. Zhou X, He L, Wu X, Zhong Y, Zhang J, Wang Y, Wangb B, Xu Z and Qiu S. 2015. Two new xanthones from the pericarp of Garcinia mangostana. Nat. Prod. Res., 29(1), 19-23.

375. Zhou X, Huang R, Hao J, Huang H, Fu M, Xu Z, Zhou Y, Li XE, Qiu SX and Wang, B. 2011. Two new prenylated xanthones from the pericarp of Garcinia mangostana (mangosteen). Helv. Chim. Acta., 94(11), 2092-2098.

376. Zhou Y, Han QB, Song JZ, Qiao CF, and Xu HX. 2008. Characterization of polyprenylated xanthones in Garcinia xipshuanbannaensis using liquid chromatography coupled with electrospray ionization quadrupole time-of-flight tandem mass spectrometry. J. Chromatogr. A, 1206(2), 131-139.

377. Zhou Y, Huang SX, Song JZ, Qiao CF, Li SL, Han QB and Xu HX. 2009. Screening of polycyclic polyprenylated acylphloroglucinols from Garcinia species using precursor ion discovery (PID) scan and ultra performance liquid chromatography electrospray ionization Q-TOF tandem mass spectrometry. J. Am. Soc. Mass. Spectrom., 20(10), 1846-1850.

378. Zhou Y, Liu X, Yang J, Han QB, Song J Z, Li SL, Qiaoa CF, Ding LS and Xu HX. 2008a. Analysis of caged xanthones from the resin of Garcinia hanburyi using ultraperformance liquid chromatography/electrospray ionization quadrupole time-of-flight tandem mass spectrometry. Anal. Chim. Acta., 629(1), 104-118. 


\title{
Chapter 3
}

\section{Phytochemical investigation of the Western Ghats endemic species Garcinia imberti Bourd.}

\author{
K. B. Rameshkumar ${ }^{*}$, Renu Pandey ${ }^{2}$, Lekshmi N Menon ${ }^{1}$, Brijesh Kumar ${ }^{2}$ and V. George ${ }^{3}$ \\ ${ }^{1}$ Phytochemistry and Phytopharmacology Division, Jawaharlal Nehru Tropical Botanic Garden and \\ Research Institute, Palode, Thiruvananthapuram-695562, Kerala, India \\ ${ }^{2}$ Sophisticated Analytical Instrument Facility, CSIR-Central Drug Research Institute, Lucknow- \\ 226031, Uttar Pradesh, India \\ ${ }^{3}$ Amity Institute of Phytochemistry and Phytomedicine, Peroorkada, Thiruvananthapuram 695005 , \\ Kerala, India \\ * Corresponding author
}

\begin{abstract}
Phytochemical investigation of the stem bark of Garcinia imberti, a Western Ghats endemic species, resulted in the isolation and characterization of the biflavonoid morelloflavone, the triterpenoid $2 \alpha$-hydroxy-3 $\beta$-acetoxy-urs-12-en-28-oic acid and the steroid stigmasterol. The high content of morelloflavone $(0.76 \% \mathrm{w} / \mathrm{w})$ in the stem bark, estimated by HPTLC, projects the plant as a rich source of the bioactive biflavonoid. The major compound from the hexane extract of the leaves was isolated and characterized as the triterpenoid friedelin. HPTLC estimation showed high content of friedelin in the plant leaves $(2.2 \% \mathrm{w} / \mathrm{w})$. Quantitative screening of the phenolic compounds present in the leaf methanol extract of G. imberti was carried out using UHPLC-QqQLiT-MS/MS technique. Twenty two phenolic compounds comprising xanthones ( $\alpha$-mangostin and gambogic acid), biflavonoids (fukugiside, GB-2, GB-1, GB-1a, amentoflavone), benzophenone (garcinol), flavonoids (epicatechin, isoorientin, orientin, isovitexin, vitexin, kaempferol-3-O-rutinoside, luteolin, quercetin, apigenin, kaempferol) and phenolic acids (protocatechuic acid, caffeic acid, ferulic acid, vanillic acid) were identified and estimated in the leaves of the plant. The LC-MS study revealed the biflavonoid GB1 in abundance in the leaf methanol extract $(22.1000 \mathrm{mg} / \mathrm{g})$. The plant was also found as a rich source of essential oils and the volatile chemical studies revealed caryophyllene derivatives as the major constituents of the essential oils from leaf, bark and fruits.
\end{abstract}

Keywords: Garcinia imberti, Morelloflavone, GB1, Friedelin, Essential oil, Caryophyllene, UHPLC-QqQLiT-MS/MS

\section{Introduction}

Garcinia species have multiple applications in culinary, pharmaceutical and nutraceutical field. The genus has been the subject of elaborate phytochemical studies worldwide that revealed it as a rich source of diverse compounds such as xanthones, benzophenones, biflavanoids, flavonoids, acids, and lactones (Han et al., 2008). The phytochemicals reported from Garcinia species exhibited a wide range of pharmacological activities such as antimicrobial, anti-HIV, anti-diabetic, antioxidant and cytotoxic (Kim et al., 2008, Hemshekhar, 
2011). The Western Ghats, one among the 36 global biodiversity hot spots, hosts 9 Garcinia species, of which 7 are endemic to the region (Maheswari, 1964, Sabu et al., 2013). Of the 9 Garcinia species distributed in the Western Ghats, G. gummi gutta and G. indica are cultivated widely and studied for their constituents and bioactivities. However, most of the endemic species are yet to be studied for their phytochemicals or potential utilities.

Garcinia imberti Bourd. is an evergreen tree, endemic to the Agastyamala forests of the Western Ghats (Figure 1). The species was originally described by T. F. Bourdillon in 1899 and rediscovered after nearly a century by Mohanan et al from the Agasthyamala Hills (Bourdillon, 1899, Mohanan, 1997). G. imberti is least investigated for their phytochemicals or bioactivities (Rameshkumar et al., 2005). Present chapter elaborates the phytochemical investigation of $G$. imberti and reports the presence of sesquiterpenoids, triterpenoids, steroids, flavonoids, biflavonoids, xanthones, benzophenones, and phenolic acids in the plant. Conventional phytochemical investigation techniques such as extraction, separation and characterization as well as modern rapid analytical techniques such as LC-MS and GC-MS were utilized for the phytochemical profiling.

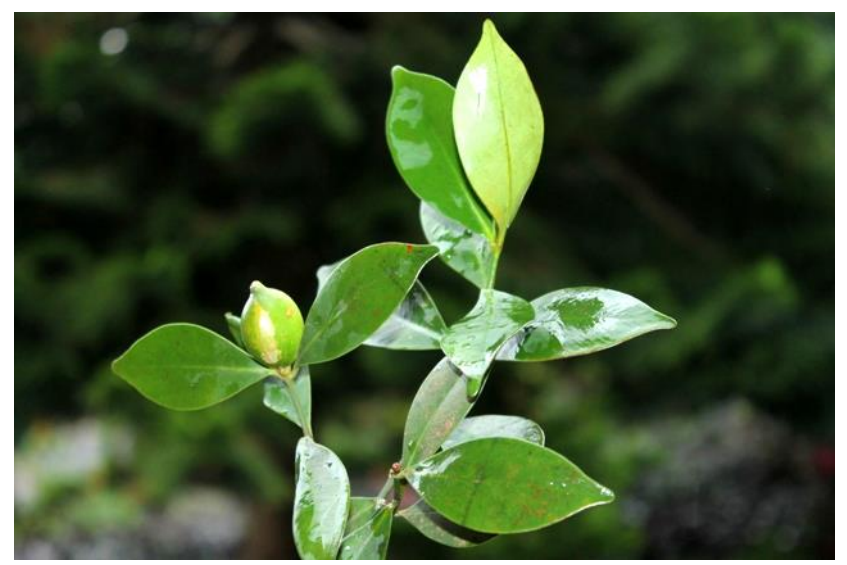

Figure 1. Garcinia imberti twig with fruit

\section{Phytochemical investigation of the stem bark of Garcinia imberti}

The plant parts were collected from Chemmungi forest area of south Western Ghats, Thiruvananthapuram district, Kerala state, India and authenticated by Mr. M.S. Kiran Raj, JNTBGRI. A voucher specimen (TBGT No.40076) has been deposited at the JNTBGRI Herbarium (TBGT). IR spectra of the isolated compounds were taken on an ABB FTLA2000 spectrometer, UV spectra using Shimadzu (1650 PC) UV-Visible spectrometer, NMR spectra using JEOL FT-NMR (300MHz) and Mass spectra using JEOL JMS-600 spectrometer.

Analyses of the hexane and methanol extracts of the stem bark of the plant resulted in the isolation and characterization of the steroid stigmasterol (1), the triterpenoid $2 \alpha$-hydroxy, $3 \beta$ acetoxy urs-12-en, 28-oic acid (2) and the biflavonoid morelloflavone (3) (Figure 2). The isolated compounds were identified by detailed spectroscopic studies and comparison with literature data. 
Compound 1 was isolated by column chromatography of the hexane extract of the stem bark. The compound was eluted in the solvent system hexane: chloroform $(9: 1)$ and identified as stigmasterol by comparison of the NMR and MS data (Conolly and Hill, 1994). The steroid is a common phytochemical distributed widely in the plant kingdom and has been isolated previously from several Garcinia species as well (Elfita et al., 2009).

Compound 2 was eluted from the hexane extract using the solvent system hexane: chloroform (1:1) and was identified as $2 \alpha$-hydroxy-3 $\beta$-acetoxy-urs-12-en-28-oic acid by analyzing the mass spectra, ${ }^{1} \mathrm{H}$ and ${ }^{13} \mathrm{C}$ NMR spectral data and comparison of the spectral data with those reported in the literature (Chaturvedula et al., 2004). Despite the large number of literature reports of different urs-12-en triterpenoids with different possible substitutions and stereochemical orientations, the occurrence of ursolic acid derivatives with acetoxy group at $3-\beta$ position and a free carboxylic acid group at $\mathrm{C}-17$ are rare. The compound has been reported to possess polymerase $\beta$-lyase activity (Chaturvedula et al 2004). The ursane triterpenoid has been isolated for the first time from Clusiaceae family.

Compound 3 was isolated by column chromatography of the stem bark methanol extract. The compound was eluted using hexane: EtOAc $(7.5: 2.5)$ and was identified as 3',',4',4', ,5,5', 7,7''-heptahydroxy-3(8')-flavonyl flavonone (morelloflavone) by comparison of the spectral data with those reported in the literature (Li et al., 2002). The biflavonoid morelloflavone, first reported from Garcinia morella by Karanjgaokar et al. is a common constituent among Garcinia species (Karanjgaokar et al., 1967). It is also the first biflavonoid reported with a flavone and a flavonone unit. Morelloflavone has been reported as anti inflammatory, anti HIV, anti fungal, anti tumor, hypocholesterolemic and anti plasmodial (Lin et al., 1997, Li et al., 2002, Pang et al., 2009, Ngouamegne et al., 2008). The biflavonoid also inhibits tyrosinase, the major enzyme responsible for skin melanization (Masuda et al., 2005) and prevents restenosis (Pinkaew et al., 2009).

Stigmasterol (1): Colourless crystals, mp: $160-162^{\circ} \mathrm{C}$. Rf: 0.48 (chloroform 100\%). IR (KBr $\left.\mathrm{cm}^{-1}\right): 3435,2961,2937,2889,2864,1461,1382,1368,1061,970 \mathrm{~cm}^{-1}$. EI-MS $(70 \mathrm{eV}) \mathrm{m} / \mathrm{z}$ (\%): 412 (M+, 70), 369 (8), 351 (13), 300 (28), 273 (17), 271 (28), 255 (30), 231 (10), 213 (20), 161 (19), 159 (22), 145 (42), 121 (26), 105 (36), 83 (60), 55 (100). ${ }^{1} \mathrm{H}$ NMR (300 MHz, $\left.\mathrm{CDCl}_{3}\right): \delta 0.84(3 \mathrm{H}, \mathrm{d}, \mathrm{J}=6.6 \mathrm{~Hz}, \mathrm{H}-27) ; \delta 0.81(3 \mathrm{H}, \mathrm{d}, \mathrm{J}=7.2 \mathrm{~Hz}, \mathrm{H}-26) ; \delta 5.03(1 \mathrm{H}, \mathrm{dd}$, $\mathrm{J}=15.1,8.4, \mathrm{H}-23) ; \delta 5.14(1 \mathrm{H}, \mathrm{dd}, \mathrm{J}=15.1,8.4, \mathrm{H}-22) ; \delta 1.02(\mathrm{~d}, \mathrm{~J}=6.6 \mathrm{~Hz}, \mathrm{H}-21) ; \delta 1.01$ (s, $\mathrm{H}-19) ; \delta 0.69(\mathrm{~s}, \mathrm{H}-18) ; \delta 5.35(1 \mathrm{H}, \mathrm{d}, \mathrm{J}=4.8 \mathrm{~Hz}, \mathrm{H}-6) ; \delta 3.52(\mathrm{~m}, \mathrm{H}-3) .{ }^{13} \mathrm{C}$ NMR $(75 \mathrm{MHz}$, $\left.\mathrm{CDCl}_{3}\right): 12.0\left(\mathrm{CH}_{3}\right), 12.2\left(\mathrm{CH}_{3}\right), 19.0\left(\mathrm{CH}_{3}\right), 19.4\left(\mathrm{CH}_{3}\right), 21.1\left(\mathrm{CH}_{3}\right), 21.1\left(\mathrm{CH}_{2}\right), 21.2\left(\mathrm{CH}_{3}\right)$, $24.3\left(\mathrm{CH}_{2}\right), 25.4\left(\mathrm{CH}_{2}\right), 28.9\left(\mathrm{CH}_{2}\right), 31.6\left(\mathrm{CH}_{2}\right), 31.9(\mathrm{CH} \mathrm{x}), 36.5(\mathrm{C}), 37.2\left(\mathrm{CH}_{2}\right), 39.7$ $\left(\mathrm{CH}_{2}\right), 40.5(\mathrm{CH}), 42.3(\mathrm{C}), 50.1(\mathrm{CH}), 51.2(\mathrm{CH}), 55.9(\mathrm{CH}), 56.9(\mathrm{CH}), 71.8(\mathrm{CH}), 121.7$ $(\mathrm{CH}), 129.3(\mathrm{CH}), 138.3(\mathrm{CH}), 140.7(\mathrm{C})$

2 $\boldsymbol{\alpha}$-Hydroxy-3 $\beta$-acetoxy-urs-12-en-28-oic acid (2): Colourless crystals, mp: $199-202^{\circ} \mathrm{C}$. $\mathrm{R}_{\mathrm{f}}$ : 0.54 (hexane: chloroform: methanol, 5:4.5:0.5), $[\alpha]_{\mathrm{D}}:-40.9$ (c 0.10, MeOH), IR (KBr): 3450, 2970, 2931, 2873, 1720, 1693, 1458, 1373, 1245, 1049, 1029, 960, $\mathrm{cm}^{-1}$. ${ }^{1} \mathrm{H}$ NMR (300 $\left.\mathrm{MHz}, \mathrm{CDCl}_{3}\right): 1.02(1 \mathrm{H}, \mathrm{m}, \mathrm{H}-1 \alpha, \mathrm{ax}), 2.1(1 \mathrm{H}, \mathrm{m}, \mathrm{H}-1 \beta, \mathrm{eq}), 3.76(1 \mathrm{H}, \mathrm{m}, \mathrm{H}-2), 4.51(1 \mathrm{H}$, $\mathrm{d}, \mathrm{J}=9 \mathrm{~Hz}, \mathrm{H}-3), 1.96(2 \mathrm{H}, \mathrm{m}, \mathrm{H}-11), 5.23(1 \mathrm{H}, \mathrm{m}, \mathrm{H}-12), 2.20(1 \mathrm{H}, \mathrm{d}, \mathrm{J}=12 \mathrm{~Hz}) .{ }^{13} \mathrm{C}$ NMR (75 MHz, $\left.\mathrm{CDCl}_{3}\right): 16.3\left(\mathrm{CH}_{3}\right), 16.7\left(\mathrm{CH}_{3} \times 2\right), 17.3\left(\mathrm{CH}_{3}\right), 17.9\left(\mathrm{CH}_{2}\right), 20.8\left(\mathrm{CH}_{3} \times 2\right), 22.9$ 
$\left(\mathrm{CH}_{2}\right), 23.1\left(\mathrm{CH}_{3}\right), 23.7\left(\mathrm{CH}_{2}\right), 27.6\left(\mathrm{CH}_{2}\right), 28.2\left(\mathrm{CH}_{3}\right), 30.3\left(\mathrm{CH}_{2}\right), 32.4\left(\mathrm{CH}_{2}\right), 36.3\left(\mathrm{CH}_{2}\right)$, $37.6(\mathrm{C}), 38.4(\mathrm{CH}), 38.6(\mathrm{CH}), 38.8(\mathrm{C}), 39.2(\mathrm{C}), 41.7(\mathrm{C}), 47.0(\mathrm{CH}), 47.1(\mathrm{C}), 47.3\left(\mathrm{CH}_{2}\right)$, $52.2(\mathrm{CH}), 54.6(\mathrm{CH}), 66.2(\mathrm{CH}), 84.3(\mathrm{CH}), 124.6(\mathrm{CH}), 138.0(\mathrm{C}), 171.4(\mathrm{C}), 179.5(\mathrm{C})$. FAB-MS (pos.) m/z (\%): 537 [M+Na] (3), 514 (5), 469 (10), 455 (19), 437 (100), 262 (31), 248 (50), 203 (62), 189 (58), 133 (81).

(-) Morelloflavone (3): Yellow solid from acetone/methanol, mp: $210^{\circ} \mathrm{C}$ (decomposing), $\mathrm{R}_{\mathrm{f}}$ $0.62\left(\mathrm{CHCl}_{3}: \mathrm{MeOH}, 17.0: 3.0\right),[\alpha]_{\mathrm{D}}:-59.9$ (c 0.10, MeOH), IR (KBr): 3224, 1643, 1610, $1515,1426,1448,1367,1261,1184,1164,839, \mathrm{~cm}^{-1}$ UV/Vis $\lambda_{\max }(\mathrm{MeOH}) \mathrm{nm}: 341,288$, 277 and 227, ${ }^{1} \mathrm{H}$ NMR (300 MHz, $\left.\mathrm{CDCl}_{3}\right): 5.76(1 \mathrm{H}, \mathrm{d}, \mathrm{J}=12 \mathrm{~Hz}, \mathrm{H}-2), 4.77(1 \mathrm{H}, \mathrm{d}, \mathrm{J}=12 \mathrm{~Hz}$, H-3), 12.94 (1H, s, 5-OH), 5.96 (1H, s, H-6), $6.35\left(1 \mathrm{H}, \mathrm{s}, \mathrm{H}-3\right.$ '”), $6.26\left(1 \mathrm{H}, \mathrm{s}, \mathrm{H}-6\right.$ ') ${ }^{13} \mathrm{C}$ NMR (75 MHz, $\left.\mathrm{CDCl}_{3}\right)$ : 48.9, 81.3, 95.7, 96.6, 99.1, 100.8, 101.9, 102.7, 103.7, 113.6, $114.8,116.5,119.3,121.6,128.6,128.7,128.9,146.3,150.0,155.7,157.4,161.1,161.9$, $163.3,163.9,164.3,166.9,182.1,196.5$

\section{Phytochemical investigation of the leaves of Garcinia imberti}

Compound 4 was isolated from the hexane extract of the leaves and identified as the triterpenoid friedelin by comparison of the spectral data with those reported in the literature (Antonisamy et al., 2011). Friedelin has been reported in different Garcinia species as well (Magadula, 2010, Jantan and Saputri, 2012). Friedelin and its derivates have anti-cancer, analgesic, anti-inflammatory, anti-bacterial, antioxidant, hepatoprotective, vascularizing activities and have potential to be used in pharmaceuticals or functional foods for the treatment or prevention of cardiovascular and cerebrovascular diseases and tumours (Moiteiro et al., 2006, Antonisamy et al., 2011, Sunil et al., 2013, ).

Friedelin (4): White solid, m.p. $242-246^{\circ} \mathrm{C}$. MS $m / z$ (rel. int.): $449[\mathrm{M}+\mathrm{Na}]^{+}$(8), $341[\mathrm{M}-$ $\mathrm{Me}^{+}$(4), 302(14), 289 (7), 273[M-Me-H20 ] + (24), 246 (16), 231 (16), 205 (24), 191 (20),

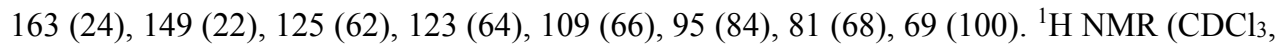
$500 \mathrm{MHz}) \delta: 1.96(1 \mathrm{H}, \mathrm{m}, \mathrm{H}-1 \mathrm{a}), 1.71(1 \mathrm{H}, \mathrm{m}, J=10.1, \mathrm{H}-1 \mathrm{~b}), 2.37$ (1 H, dd, $J=10,3.5$ and $4 \mathrm{~Hz}, \mathrm{H}-2 \mathrm{a}), 2.26(1 \mathrm{H}, \mathrm{M}, \mathrm{H}-2 \mathrm{~b}), 1.219-1.698(\mathrm{~m}, \mathrm{H} 3-\mathrm{H} 22), 0.86(3 \mathrm{H}, \mathrm{d}, \mathrm{J}=6.1 \mathrm{~Hz}, \mathrm{Me}-23)$, $0.70(3 \mathrm{H}, \mathrm{s}, \mathrm{Me}-24), 0.84(3 \mathrm{H}, \mathrm{s}, \mathrm{Me}-25), 0.93(3 \mathrm{H}, \mathrm{s}, \mathrm{Me}-26), 1.03(3 \mathrm{H}, \mathrm{s}, \mathrm{Me}-27), 1.16(3 \mathrm{H}, \mathrm{s}, \mathrm{Me}-$ 28), 0.98(3H, s ,H-29), 0.98(3H,s,H-30). $\left.{ }^{13} \mathrm{C} \mathrm{NMR} \mathrm{(500} \mathrm{MHz,} \mathrm{CDCl} 3\right): \delta 22.3(\mathrm{C}-1), 41.5(\mathrm{C}-$ 2), 213.3 (C-3), 58.2 (C-4), 42.2 (C-5), 41.3 (C- 6), 18.2 (C-7), 53.1 (C-8), 37.4 (C-9), 59.5 (C-10), 35.6 (C-11), 32.4 (C-12), 38.3 (C-13), 39.7 (C-14), 30.5 (C- 15), 36.0 (C-16), 30.0 (C-17), 42.8 (C-18), 35.3 (C-19), 28.2 (C-20), 32.8 (C-21), 29.6 (C-22), 6.8 (C-23), 14.7 (C24), 18.2 (C-25), 18.7 (C-26), 20.3 (C-27), 32.1 (C- 28), 31.8 (C-29), 35.0 (C-30)

\section{HPTLC estimation of the major compounds in Garcinia imberti}

Among the different analytical techniques, HPTLC has emerged as a widely applied technique for qualitative and quantitative purposes in natural product analysis and the method has successfully been explored for the estimation of bioactive compounds from plant sources (Reich and Schibli, 2006, Aravind et al., 2008). In the present study, the HPTLC estimations were carried out using Camag HPTLC system (Switzerland) equipped with LinomatV sample applicator and Camag TLC scanner 3. 


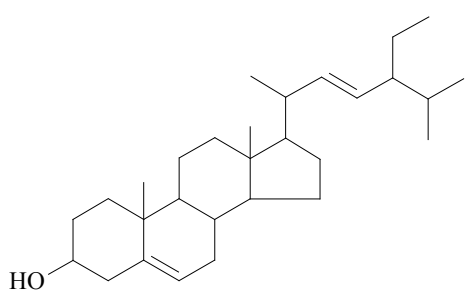

Stigmasterol

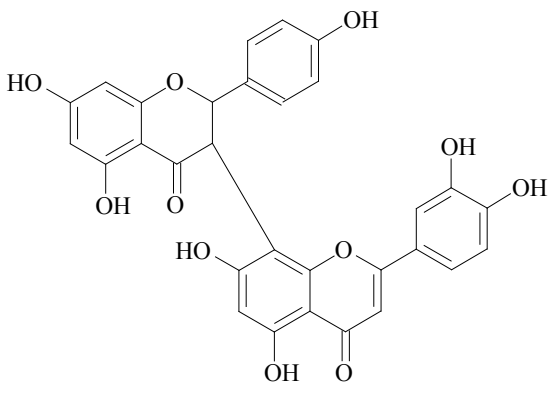

Morelloflavone

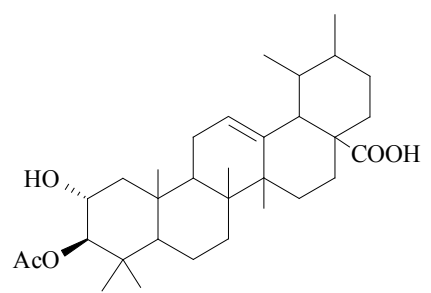

$2 \alpha$ - Hydroxy-3 $\beta$-acotoxy-urs-12-en-28-oic acid

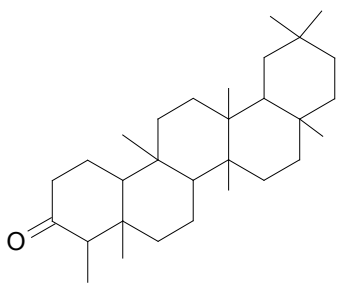

Friedelin

Figure 2. Structures of compounds 1 to 4

\subsection{HPTLC estimation of morelloflavone in $G$. imberti stem bark}

The dried, powdered stem bark ( $5 \mathrm{~g}$ ) was extracted with methanol using Soxhlet apparatus for $6 \mathrm{~h}$ and made up to $200 \mathrm{ml}$ using methanol. Morelloflavone isolated from the plant was used as the standard compound. $1.5 \mu \mathrm{L}$ of the extract was applied on the pre-coated silica gel plate $60 \mathrm{~F}_{254}$ (E. Merk, Germany) along with standard morelloflavone (1.0 to $2.5 \mu \mathrm{g}$ gave linear response). The separation was carried out in twin trough chamber using the solvent system chloroform: methanol (17:3) as mobile phase. Quantitation was carried out in absorbance mode at $254 \mathrm{~nm}$. The percentage content of morelloflavone was found $0.76 \pm 0.09 \%(\mathrm{w} / \mathrm{w})$ in the stem bark. The plant can be considered as a new natural source of the bioactive biflavonoid morelloflavone.

\subsection{HPTLC estimation of friedelin in $G$. imberti leaves}

The dried, powdered leaf sample ( $2 \mathrm{~g}$ ) was extracted with hexane using Soxhlet apparatus for $6 \mathrm{~h}$ and made up to $100 \mathrm{ml}$ using hexane. For estimation of friedelin in the leaf samples, the solvent system hexane-chlorofom-ethylacetate (9:0.5:0.5) gave the best resolution. $3.0 \mu \mathrm{L}$ of the hexane extract was applied on the pre-coated silica gel plate $60 \mathrm{~F}_{254}$ (E. Merk, Germany). Standard friedelin at concentrations $0.5-4.0 \mu \mathrm{g}$ gave linear response with regression equation $y=257 x+356.8$ and the regression $\left(r^{2}\right) 0.949$ indicated a good linear relationship between peak area and concentration of the analyte. The specificity of the developed method was confirmed by close $\mathrm{R}_{\mathrm{f}}$ values of standard friedelin $(0.31)$. The content of friedelin was $2.2 \pm 0.5 \%(\mathrm{w} / \mathrm{w})$. The high content of friedelin proposes the plant as a novel source of the compound. 


\section{UHPLC-QqQLiT-MS/MS analysis of $G$. imberti leaf methanol extract}

Liquid chromatography-mass spectrometry using different combination of separation, ionisation and mass analysing techniques have proven as an efficient tool for the qualitative as well as quantitative characterization of phytochemicals (Wu et al., 2013). The hyphenated analytical technique provided extremely powerful tools for natural product researchers that offered both the separation and characterization in single run. Several Garcinia species have been studied by various LC-MS techniques like LC-ESI-MS, UPLC-Q-TOF-MS and HPLCDAD-MS ${ }^{\mathrm{n}}$ and reported the distribution of acids, benzophenones, xanthones, biflavonoids and acylphloroglucinols (Acuna et al, 2012, Ji et al, 2007; Zhou et al, 2010).

In the present study, the dried leaf powder $(2 \mathrm{~g})$ was defatted with hexane and extracted with methanol using Soxhlet apparatus. The methanol extract $(1 \mathrm{mg} / \mathrm{ml})$ was diluted with acetonitrile and spiked with internal standard curcumin $(20 \mathrm{ng} / \mathrm{mL}$ final working concentration) and $4 \mu \mathrm{L}$ aliquot was injected into the UHPLC-MS/MS system for analysis. A mixed standard stock solution $(1 \mathrm{mg} / \mathrm{mL})$ of the selected analytes were also prepared and diluted with acetonitrile to get final concentrations of 0.1 to $300 \mathrm{ng} / \mathrm{mL}$, along with internal standard curcumin $(20 \mathrm{ng} / \mathrm{mL})$. The separation was achieved on Waters Acquity UPLC ${ }^{\mathrm{TM}}$ system (Waters, Milford, MA, USA) equipped with binary solvent manager, sample manager, column oven and photodiode array detector (PAD). The chromatographic separation of selected analytes was carried out on an Acquity UPLC BEH $\mathrm{C}_{18}$ column $(50 \mathrm{~mm} \times 2.1 \mathrm{~mm}$ $\mathrm{id}, 1.7 \mu \mathrm{m})$ at a column temperature of $25^{\circ} \mathrm{C}$. Analysis was done with gradient elution of $0.1 \%$ formic acid in water (A) and acetonitrile (B) as mobile phase at a flow rate of $0.3 \mathrm{~mL} / \mathrm{min}$. The $7.5 \mathrm{~min}$ UPLC gradient elution program was as follows: $0-0.70 \mathrm{~min}, 5-15 \% \mathrm{~B} ; 0.7-2.5$ $\min , 15-23 \%$ B; $2.5-2.8 \mathrm{~min}, 23-33 \%$ B, 2.8-4.0 min, 33-40\% B; 4.0-4.8 min, 40-95\% B; 4.8$6.8 \mathrm{~min}, 95-95 \% \mathrm{~B}$; 6.8-7.5 $\mathrm{min}, 95-5 \% \mathrm{~B}$; equilibration time $1.5 \mathrm{~min}$. The LC was interfaced with hybrid linear ion trap triple-quadrupole mass spectrometer (API 4000 QTRAPTM MS/MS system from AB Sciex, Concord, ON, Canada) equipped with an electrospray (Turbo V) ion source. AB Sciex Analyst software version 1.5.1 was used to control the LC-MS/MS system and for data acquisition and processing. Precursor ion scan was used for the screening and MRM acquisition mode for quantification of the analytes. All the analytes with internal standard (IS) were detected in negative electrospray ionization and mass spectra were recorded in the range of $m / z 100-1000$ at a cycle time of 9 s with a step size of $0.1 \mathrm{Da}$. Nitrogen was used as the nebulizer, heater, and curtain gas as well as the collision activated dissociation gas (CAD). The optimized mass spectrometric source parameters were; ion spray voltage set at $-4200 \mathrm{~V}$, curtain gas, nebulizer gas (GS1) and heater gas (GS2) were set at $20 \mathrm{psi}$ and source temperature was set at $550^{\circ} \mathrm{C}$. The compound dependent MRM parameters: DP, EP, CE and CXP were optimized for each investigated analyte by injecting the individual standard solution into the mass spectrometer to achieve the most abundant, specific and stable MRM transition.

The MS spectra generated for all the compounds by ESI-MS in the negative ion mode gave the deprotonated molecule $[\mathrm{M}-\mathrm{H}]$. The structures were further identified through characteristic fragment ions. The detected compounds and their quantities were shown in Table 1 and Figure 3. Among the 22 phenolic compounds, content of the biflavonoid GB-1 was the highest $(22.1000 \mathrm{mg} / \mathrm{g})$ in the leaf extract of $G$. imberti, followed by the xanthone gambogic acid $(2.8500 \mathrm{mg} / \mathrm{g})$ and the biflavonoid GB-1a $(2.4700 \mathrm{mg} / \mathrm{g})$. 
<smiles>O=C(O)c1ccc(O)c(O)c1</smiles>

Protocatechuic acid<smiles>O=C(O)/C=C/c1ccc(O)c(O)c1</smiles>

Caffeic acid<smiles>O=C(O)/C=C/c1ccc(O)c([18O])c1</smiles>

Ferulic acid<smiles>COc1cc(C(=O)O)ccc1O</smiles>

Vanillic acid<smiles>Oc1ccc2c(c1)OC(c1ccc(O)c(O)c1)C(O)C2</smiles>

Epicatechin<smiles>O=c1cc(-c2ccc(O)c(O)c2)oc2ccc(O)c(O)c12</smiles>

Isoorientin<smiles>O=c1cc(-c2ccc(O)c(O)c2)oc2c(Cl)ccc(O)c12</smiles>

Orientin<smiles>O=c1cc(-c2ccc(O)cc2)oc2ccc(Cl)c(O)c12</smiles>

Isovitexin<smiles>O=c1cc(-c2ccc(O)cc2)oc2c(Cl)cc(O)cc12</smiles>

Vitexin<smiles></smiles><smiles>O=c1cc(-c2ccc(O)c(O)c2)oc2cc(O)cc(O)c12</smiles>

Luteolin<smiles>O=c1c(O)c(-c2ccc(O)c(O)c2)oc2cc(O)cc(O)c12</smiles>

Quercetin<smiles>O=c1cc(-c2ccc(O)cc2)oc2cc(O)cc(O)c12</smiles>

Apigenin<smiles>O=C1c2c(O)cc(O)cc2Oc2c(O)cc(O)c3c2OC(c2ccc(O)cc2)C(O)C3C1c1ccc(O)cc1</smiles>

GB-1<smiles>O=C1c2c(O)ccc(O)c2OC(c2ccc(O)c(O)c2)C1O</smiles>

GB-2
Fukugiside<smiles></smiles><smiles></smiles>

GB-1a<smiles>O=c1cc(-c2ccc(O)cc2)oc2c(O)cc(O)c(Cc3ccc(O)cc3)c12</smiles>

Amentoflavone<smiles></smiles>

Mangostin

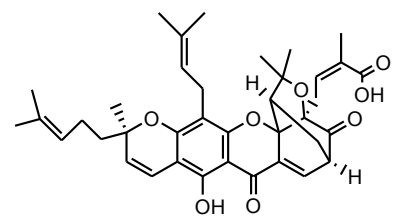

Gambogic acid

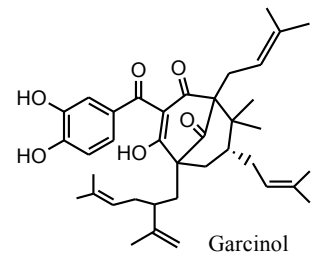

Figure 3. Structures of the 22 phenolic compounds detected in Garcinia imberti leaf methanol extract by UHPLC-QqQLIT-MS/MS method 
Table 1. The content $(\mathrm{mg} / \mathrm{g})$ of 22 phenolic compounds in the leaf extract of Garcinia imberti

\begin{tabular}{|c|c|c|}
\hline $\begin{array}{l}\text { Retention } \\
\text { Time (min) }\end{array}$ & Compound & $\begin{array}{l}\text { Content }(\mathrm{mg} / \mathrm{g}) \\
(\text { mean } \pm \mathrm{SD}, n=3)\end{array}$ \\
\hline & Phenolic acids & \\
\hline 1.43 & Protocatechuic acid & $0.9890 \pm 0.002$ \\
\hline 1.81 & Caffeic acid & $0.1420 \pm 0.005$ \\
\hline 2.47 & Ferulic acid & $0.5220 \pm 0.001$ \\
\hline \multirow[t]{2}{*}{3.31} & Vanillic acid & $0.0008 \pm 0.0002$ \\
\hline & Flavonoids & \\
\hline 1.79 & Epicatechin & $0.9240 \pm 0.001$ \\
\hline 1.91 & Isoorientin & $0.6070 \pm 0.005$ \\
\hline 2.04 & Orientin & $0.5340 \pm 0.004$ \\
\hline 2.26 & Isovitexin & $1.4100 \pm 0.029$ \\
\hline 2.28 & Vitexin & $1.1800 \pm 0.015$ \\
\hline 2.53 & Kaempferol-3-O-rutinoside & $0.0637 \pm 0.0005$ \\
\hline 3.62 & Luteolin & $0.1053 \pm 0.0004$ \\
\hline 3.63 & Quercetin & $0.1920 \pm 0.026$ \\
\hline 4.04 & Apigenin & $0.7010 \pm 0.027$ \\
\hline \multirow[t]{2}{*}{4.14} & Kaempferol & $0.2820 \pm 0.003$ \\
\hline & Biflavonoids & \\
\hline 3.56 & Fukugiside & $0.2910 \pm 0.002$ \\
\hline 3.57 & GB-2 & $0.3850 \pm 0.012$ \\
\hline 4.05 & GB-1 & $22.1000 \pm 1.054$ \\
\hline 4.46 & GB-1a & $2.4700 \pm 0.165$ \\
\hline \multirow[t]{2}{*}{4.52} & Amentoflavone & $0.0440 \pm 0.003$ \\
\hline & Xanthones & \\
\hline 5.71 & $\alpha$-Mangostin & $0.0056 \pm 0.001$ \\
\hline \multirow[t]{2}{*}{6.19} & Gambogic acid & $2.8500 \pm 0.032$ \\
\hline & Benzophenone & \\
\hline 6.50 & Garcinol & $0.3290 \pm 0.011$ \\
\hline
\end{tabular}

\section{Volatile chemical profile of Garcinia imberti}

Hydrodistillation of the stem bark, leaves and fruits revealed $G$. imberti as a rich source of essential oil. The oil yield was $0.62 \% \mathrm{v} / \mathrm{w}$ for stem bark, $0.32 \%$ for leaf and $1.50 \%$ for fruits. A total of 25 volatile compounds were detected by GC-MS analysis of the essential oils (Table 2). The major constituents were humulene and $\beta$-caryophyllene in stem bark and leaf oil, while caryophyllene oxide and humulene epoxide were the major constituents in fruit oil (Figure 4). The caryophyllene derivatives such as humulene, caryophyllene and their oxides are biosynthetically derived from the common humulyl intermediate (Cane, 1999). The plant can be considered as a rich source of the caryophyllene compounds. It will be interesting to study the chemical ecological aspects of the high content of caryophyllene compounds in the species.
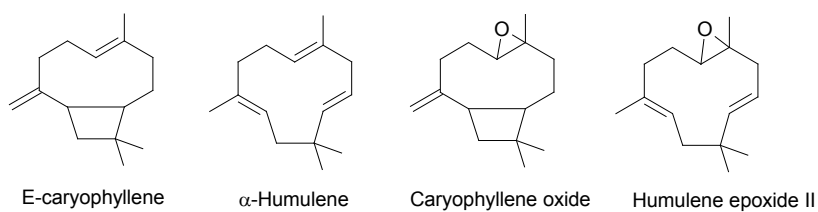

Figure 4. Structures of major volatile chemicals of Garcinia imberti 
Table 2. Volatile chemical profiles of Garcinia imberti leaf, stem bark and fruits

\begin{tabular}{|c|c|c|c|c|}
\hline Compound & RRI & LF & SB & FR \\
\hline$\delta$-Elemene & 1338 & 0.1 & -- & -- \\
\hline$\alpha$-Cubebene & 1348 & 0.3 & -- & -- \\
\hline$\alpha$-Ylangene & 1373 & 0.3 & -- & -- \\
\hline$\alpha$-Copaene & 1376 & 0.4 & -- & 0.1 \\
\hline$\beta$-Cubebene & 1387 & 0.3 & -- & -- \\
\hline 2 -epi- $\beta$-funebrene & 1415 & -- & -- & 6.7 \\
\hline$\beta$-Funebrene & 1414 & -- & -- & 2.9 \\
\hline$\beta$-Caryophyllene & 1419 & 38.1 & 41.4 & 1.8 \\
\hline$\beta$-Copaene & 1430 & 0.4 & & 3.7 \\
\hline$\alpha$-Humulene & 1452 & 30.5 & 50.8 & 5.4 \\
\hline Allo aromadendrene & 1458 & 5.5 & & \\
\hline$\alpha$-Acoradiene & 1464 & 0.3 & -- & -- \\
\hline 9 epi E- Caryophyllene & 1466 & -- & -- & 8.7 \\
\hline$\beta$-Acoradiene & 1469 & 4.5 & -- & -- \\
\hline cis $\beta$-Guaiene & 1492 & 0.1 & -- & -- \\
\hline$\beta$-Alaskene & 1498 & 2.5 & -- & -- \\
\hline E- $\gamma$-Bisabolene & 1507 & 0.1 & -- & -- \\
\hline$\delta$-Amorphene & 1511 & 0.4 & -- & -- \\
\hline Germacrene B & 1559 & 0.3 & -- & -- \\
\hline Caryophyllene oxide & 1582 & 0.3 & 2.3 & 33.2 \\
\hline Humulene epoxide II & 1608 & -- & 1.4 & 21.3 \\
\hline 1,10-di epi Cubenol & 1618 & 0.1 & -- & -- \\
\hline Caryophylla-4(12),8(13) diene & 1639 & -- & -- & 2.0 \\
\hline Cubenol & 1645 & 0.1 & -- & -- \\
\hline 14- Hydroxy 9-epi-E-caryophyllene & 1668 & -- & -- & 1.5 \\
\hline$\gamma$-Costol & 1688 & -- & -- & 3.3 \\
\hline Total $\%$ & & 84.6 & 95.9 & 90.6 \\
\hline Sesquiterpene- hydrocarbons & & 84.1 & 92.2 & 29.3 \\
\hline Sesquiterpene-oxygenated & & 0.5 & 3.7 & 61.3 \\
\hline Total sesquiterpenoids & & 84.6 & 97.9 & 92.6 \\
\hline
\end{tabular}

RRI: Relative retention index calculated on HP-5 column

\section{Conclusions}

Garcinia species were studied worldwide for the variety of interesting secondary metabolites and the present study revealed the Western Ghats endemic species G. imberti as a rich source of the bioactive biflavonoids morelloflavone and GB-1, along with the triterpenoid friedelin. The species is also a rich source of the volatile caryophyllene compounds. The chapter also elaborates a comprehensive quantitative analysis of multi class bioactive constituents including prenylated xanthones, polyisoprenylated benzophenones, biflavonoids, phenolic acids and flavonoids in leaf methanol extract of $G$. imberti using UHPLC-QqQLiT-MS/MS method. 


\section{References}

1. Acuna UM, Dastmalchi K, Basile MJ and Kennelly EJ. 2012. Quantitative high-performance liquid chromatography photo diode array (HPLC-PDA) analysis of benzophenones and biflavonoids in eight Garcinia species. J. Food Comp. Anal., 25, 215-220.

2. Antonisamy P, Duraipandiyan V and Ignacimuthu S. 2011. Anti-inflammatory, analgesic and antipyretic effects of friedelin isolated from Azima tetracantha Lam. in mouse and rat models. J. Pharm. Pharmacol., 63 (8), 1070-1077.

3. Aravind SG, Arimboor R, Rangan M, Madhavan SN and Arumughan C. 2008. Semipreparative HPLC preparation and HPTLC quantification of tetrahydroamentoflavone as marker in Semecarpus anacardium and its polyherbal formulations. J. Pharm. Biomed. Anal., 48, 808-813.

4. Bourdillon TF. 1899. Descriptiones of some new or rare trees from Travancore. J. Bombay Natural History Society, 12, 349-353.

5. Cane DE. 1999. Sesquiterpene biosynthesis: cyclization mechanisms. In: Cane DE. (Ed.), Comprehensive Natural Products Chemistry: Isoprenoids Including Carotenoids and Steroids, Vol. 2. Elsevier, Oxford, pp. 155-200.

6. Chaturvedula VSP, Gao Z, Jones SH, Feng X, Hecht SM and Kingston DGI. 2004. A new ursane triterpene from Monochaetum vulcanicum that inhibits DNA polymerase lyase. J. Nat. Prod., 67, 899-901.

7. Conolly JD and Hill RA. 1994. Dictionary of Natural Products, Chapman and Hall.

8. Elfita E, Muharni M, Latief M, Darwati D, Widiyantoro A, Supriyatna S, Bahti HH, Dachriyanus D, Cos P, Maes L, Foubert K, Apers S and Pieters L. 2009. Antiplasmodial and other constituents from four Indonesian Garcinia spp. Phytochemistry, 70(7), 907-912.

9. Han QB, Yang NY, Tian HL, Qiao CF, Song JZ, Chang DC, Chen SL, Luo KQ and Xu HX. 2008. Xanthones with growth inhibition against $\mathrm{HeLa}$ cells from Garcinia xipshuanbannaensis. Phytochemistry, 69, 2187-2192.

10. Hemshekhar M. 2011. An overview on genus Garcinia: Phytochemical and therapeutical aspects, Phytochem. Rev., 10, 325-351.

11. Jantan I and Saputri FC. 2012. Benzophenones and xanthones from Garcinia cantleyana var. cantleyana and their inhibitory activities on human low-density lipoprotein oxidation and platelet aggregation. Phytochemistry, 80, 58-63.

12. Ji X, Avula B and Khan IA. 2007. Quantitative and qualitative determination of six xanthones in Garcinia mangostana L. by LC-PDA and LC-ESI-MS. J. Pharm. Biomed. Anal., 43, 1270-1276.

13. Karanjgaokar CG, Radhakrishnan PV and Venkataraman K. 1967. Morelloflavone, a 3-(8-) flavonyl flavanone, from the heartwood of Garcinia morella. Tetrahedron Lett., 8, 31953198.

14. Kim HP, Park H, Son KH, Chang HW and Kang SS. 2008. Biochemical pharmacology of biflavonoids: Implications for anti-inflammatory action. Arch. Pharmacal Res., 31, 265-273.

15. Li XC, Joshi AS, Elsohly HN, Khan SI, Jacob MR, Zhang Z, Khan IA, Ferreira D, Walker LA, Broedel SE, Raulli RE and Cihlar RL. 2002. Fatty acid synthase inhibitors from plants: Isolation, structure elucidation and SAR studies. J. Nat. Prod., 65, 1909-1914.

16. Lin YM, Anderson H, Flavin MT and Pai YHS. 1997. In vitro anti-HIV of biflavonoids isolated from Rhus succedanea and Garcinia multiflora. J. Nat. Prod., 60, 884-888. 
17. Magadula JJ. 2010. A bioactive isoprenylated xanthone and other constituents of Garcinia edulis. Fitoterapia, 81(5), 420-423.

18. Maheswari JK. 1964. Taxonomic studies on Indian Guttiferae III. The genus Garcinia Linn. Bull. Bot. Surv. India, 6, 107-135.

19. Masuda T, Yamashita D, Takeda Y and Yonemori S. 2005. Screening for tyrosinase inhibitors among extracts of seashore plants and identification of potent inhibitors from Garcinia subelliptica. Biosc. Biotech. Biochem., 69, 197-201.

20. Mohanan N, Shaju T, Rajkumar G and Pandurangan AG. 1997. Rediscovery of Garcinia imberti Bourd. (Clusiaceae)- A little known endemic species of Western Ghats. Indian J. Forestry, 20, 383-385.

21. Moiteiro C, Curto M J M, Mohamed N, Bailen M, Martinez-Diaz R and Gonzalez-Coloma A. 2006. Biovalorization of friedelane triterpenes derived from cork processing industry byproducts. J. Agric. Food Chem., 54 (10), 3566-3571.

22. Ngouamegne ET, Fongang RS, Ngovela S, Boyom FF, Rohmer M, Tsamo E, Gut J and Rosenthal PJ. 2008. Endodesmiadiol, a friedelane triterpenoid, and other antiplasmodial compounds from Endodesmia calophylloides. Chem. Pharm. Bull., 56, 374-377.

23. Pang X, Yi T, Yi Z, Cho SG, Gu W, Pinkaew D, Fujise K and Liu M. 2009. Morelloflavone, a biflavonoids inhibits tumor angiogenesis by targeting Rho GTPases and extracellular signal regulated kinase signaling pathway. Cancer Res., 69, 518-525.

24. Pinkaew D, Cho SG, Hui DY, Wiktorowicz JE, Towatana NH, Mahabusarakam W, Tonganunt M, Stafford LJ, Phongdara A, Liu M and Fujise K. 2009. Morelloflavone block injury induced neointimal formation by inhibiting vascular smooth muscle cell migration. Biochemica et Biophysica Acta., 1790, 31-39.

25. Rameshkumar KB, Shiburaj S and George V. 2005. Constituents and antibacterial activity of the stem bark oil of Garcinia imberti. J. Trop. Med. Plants., 6, 271-273.

26. Reich E and Shibli A. 2006. High Performance Thin Layer Chromatography for the Analysis of Medicinal Plants. Thieme Publishers, Germany.

27. Sabu T, Mohanan N, Krishnaraj MV, Shareef SM, Roy PE and Shameer PS. 2013. Garcinia pushpangadanii, (Clusiaceae) a new species from southern Western Ghats, India. Phytotaxa, $116(2), 51-56$.

28. Sunil C, Duraipandiyan V, Ignacimuthu S and Al-Dhabi NA. 2013. Antioxidant, free radical scavenging and liver protective effects of friedelin isolated from Azima tetracantha Lam. leaves. Food Chem., 139 (1-4), 860-865.

29. Wu H, Guo J, Chen S, Liu X, Zhou Y, Zhang X and Xu X. 2013. Recent developments in qualitative and quantitative analysis of phytochemical constituents and their metabolites using liquid chromatography-mass spectrometry. J. Pharm. Biomed. Anal., 72, 267- 291.

30. Zhou Y, Lee S, Fung F, Choi K, Xu G, Liu X, Song JZ, Li SL, Qiao CF and Xu HX. 2010. Qualitative and quantitative analysis of polycyclic polyprenylated acylphloroglucinols from Garcinia species using ultra performance liquid chromatography coupled with electrospray ionization quadrupole time-of-flight tandem mass spectrometry. Anal. Chim. Acta., 678, 96107. 


\title{
Chapter 4
}

\section{Phytochemical Investigation of the Western Ghats endemic species}

\section{Garcinia travancorica Bedd.}

\author{
A. P. Anu Aravind ${ }^{1}$, Renu Pandey ${ }^{2}$, Brijeshkumar $^{2}$ and K. B. Rameshkumar ${ }^{1 *}$ \\ ${ }^{1}$ Phytochemistry and Phytopharmacology Division, Jawaharlal Nehru Tropical Botanic Garden and \\ Research Institute, Palode, Thiruvananthapuram- 695562, Kerala, India \\ ${ }^{2}$ Sophisticated Analytical Instrument Facility, CSIR-Central Drug Research Institute, Lucknow- \\ 226031, Uttar Pradesh, India \\ ${ }^{*}$ Corresponding author
}

\begin{abstract}
The leaves of Garcinia travancorica, an endemic species to the Western Ghats of south India, yielded the polyisoprenylated benzophenones, 7-epi-nemorosone and garcinol along with the biflavonoids GB-1a, GB-1, GB-2, morelloflavone and morelloflavone-7-O- $\beta$-D-glycoside (fukugiside). G. travancorica leaves were found as a rich source of the biflavonoid glycoside morelloflavone-7"-O- $\beta$-D-glycoside (7.12\% dry wt) through a validated HPTLC estimation method. Qualitative screening of multiclass secondary metabolites present in the fruits, leaves and stem bark methanol extracts of G. travancorica using HPLC-QTOF-MS analysis resulted in the identification of 23 compounds including two acids (hydroxycitric acid and hydroxycitric acid lactone), eight biflavonoids (morelloflavone, GB-1, GB-1a, GB-2, GB-2a, fukugiside, xanthochymusside and GB-1a glucoside), nine xanthones ( $\alpha$-mangostin, $\gamma$ mangostin, 1,5-dihydroxy-3-methoxyxanthone, garciniaxanthone E, 4-(1,1-dimethylprop-2enyl)-1,3,5,8-tetrahydroxy-xanthone, garcinone $\mathrm{A}$, garcinone $\mathrm{B}$, garcinone $\mathrm{C}$ and polyanxanthone $\mathrm{C}$ ) and four polyisoprenylated benzophenones (gambogenone, aristophenone A, garcinol and garciyunnanin A). G. travancorica was also found as a rich source of essential oils and the aliphatic hydrocarbon n-undecane was the major volatile compound in leaf, stem bark and fruit.
\end{abstract}

Keywords: Garcinia travancorica, fukugiside, n-Undecane, Essential oil, Biflavonoids, Xanthones, Benzophenones, HPLC-QTOF-MS

\section{Introduction}

Garcinia species, with its rich diversity of biologically active compounds such as biflavonoids, xanthones, benzophenones and acids, received considerable attention worldwide from scientific as well as industrial sectors (Hemshekhar et al., 2011). Xanthones, biflavonoids and benzophenones from different Garcinia species were reported to possess remarkable levels of bioactivities against various ailments (Carvalho-Silva et al. 2012; Osorio et al. 2013). Among the different phenolic compounds reported from Garcinia species, the biological activities of biflavonoids are diverse, including anticancer, antibacterial, antifungal, antiviral, anti-inflammatory, analgesic, antioxidant, vasorelaxant and anticlotting. The mechanisms of activity of biflavonoids have also been elaborated in most of the cases 
(Kim et al. 2008). Garcinia travancorica is a rare and endemic species, distributed in the evergreen forests of Agastyamala region of southern Western Ghats of India, where scattered populations were seen at altitude 1000-1300m (Mohanan and Sivadasan, 2002) (Figure 1). The species is least investigated for their phytochemicals (Anuaravind et al., 2016) and the present chapter reports the secondary metabolite profile of G. travancorica.

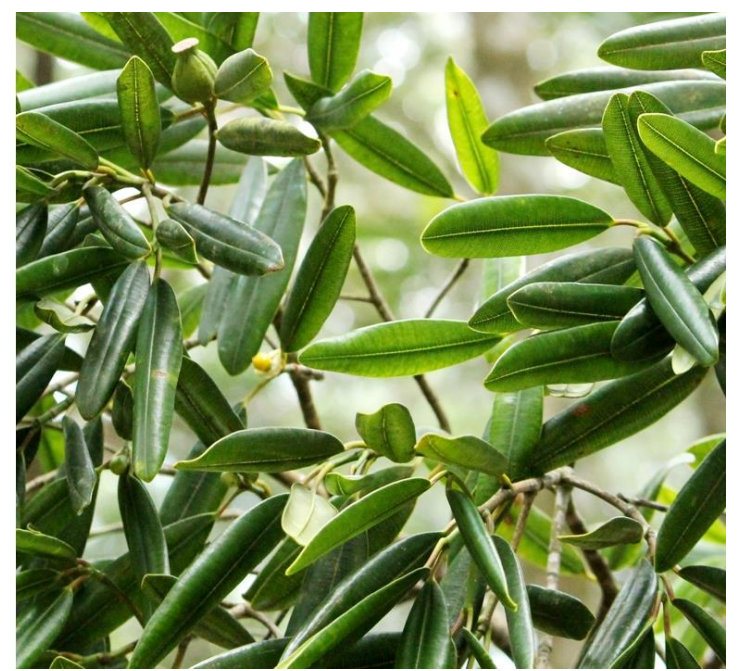

Figure 1. Garcinia travancorica twig with flower and fruit

\section{Phytochemical investigation of the leaves of $\boldsymbol{G}$. travancorica}

Fresh leaves were collected from Chemunji forest area, part of the Agasthyamala forest region of South Western Ghats, Thiruvananthapuram district, Kerala, India and a voucher specimen (No. 66417) was deposited at the JNTBGRI Herbarium (TBGT).

UV spectra were recorded on a Shimadzu spectrophotometer -UV 1800, Japan. IR spectra were taken with Alpha FT-IR, Bruker Optics. ${ }^{1} \mathrm{H}$ and ${ }^{13} \mathrm{C}$ NMR spectra were recorded on a Bruker-Avance $400 \mathrm{MHz}$ FT-NMR spectrometer operating at $400 \mathrm{MHz}$ for ${ }^{1} \mathrm{H} \mathrm{NMR}$ and $100 \mathrm{MHz}$ for ${ }^{13} \mathrm{C} \mathrm{NMR}$. The chemical shifts were expressed as $\delta$ (ppm, parts per million) referring to internal standard, tetramethyl- silane $\left(\mathrm{Me}_{4} \mathrm{Si}\right)$. Mass spectra were recorded using JEOL JMS $600 \mathrm{H}$ mass spectrometer.

The polyisoprenylated benzophenones, 7-epi-nemorosone (1) and garcinol (2) were isolated from the hexane extract by column chromatography. Structures of these compounds were confirmed by UV, IR and NMR spectroscopic data, together with comparison of literature data (Rao et al. 1980; Padhye et al. 2009; de Castro et al. 2011). The bioactive benzophenone garcinol, also known as camboginol, was reported from different Garcinia species and showed antiglycation, antioxidant and free radical scavenging activities (Sahu et al. 1989; Rastogi \& Mehrotra 1990; Yamaguchi et al. 2000; de Souza Marques et al. 2012).

The biflavonoids, namely GB-1a (3), GB-1 (4), GB-2 (5), morelloflavone (6) and morelloflavone-7"-O- $\beta$-D-glycoside or fukugiside (7) were isolated from the methanol extract by column chromatography (Figure 2). Structures of these compounds were elucidated by NMR, MS and comparison with the literature spectroscopic data (Kapadia et al. 
1994; Elfita et al. 2009). The (3->8") linked biflavonoids isolated from G. travancorica can be generally divided into two groups; those made up of flavone and flavanone subunits and those made up of two flavanone units. GB-1a, GB-1 and GB-2 were biflavanones, while morelloflavone and morelloflavone-7"-O- $\beta$-D-glycoside were flavanone-flavone type biflavonoids. Of the two types, biflavonones were the dominant type in different Garcinia species, while the co-occurrence of the two types of biflavonoids is rare (Waterman and Hussain 1983).

7-epi-Nemorosone (1): Yellow liquid; TLC: Hexane-ethylacetate (9:1), $\mathrm{R}_{\mathrm{f}}=0.76$; UV $\left(\mathrm{CH}_{3} \mathrm{Cl}, 0.1 \%\right) \lambda \max / \mathrm{nm}: 281,265$. HRMS m/z-501.3018 (M-H) ${ }^{-}$for $\mathrm{C}_{33} \mathrm{H}_{41} \mathrm{O}_{4}$ (calcd. 501.3005); $\mathrm{MS}^{\mathrm{n}}$ experiment $\mathrm{m} / \mathrm{z}-501.3,432.2,417.2,363.2,309.1,242.0,145.0 .{ }^{1} \mathrm{H}$ NMR $\left(\mathrm{CDCl}_{3}, 400 \mathrm{MHz}, \delta \mathrm{ppm}\right): \delta 2.09$ (H-6a, m); $2.11(\mathrm{H}-6 \mathrm{~b}, \mathrm{~m}) ; 1.52(\mathrm{H}-7, \mathrm{~m}) ; 7.55$ (H-12, dd, $\mathrm{J}=7.6$ and 1); $7.38(\mathrm{H}-13, \mathrm{t}, \mathrm{J}=7.6) ; 7.39(\mathrm{H}-14, \mathrm{t}, \mathrm{J}=7.6) ; 7.37(\mathrm{H}-15, \mathrm{t}, \mathrm{J}=7.6) ; 7.54(\mathrm{H}-$ 16, d, J = 7.6); 2.72 (H-17a, overlapped); 2.72 (H-17b, overlapped); 5.01 (H-18, m); 1.70 $\left(3 \mathrm{H}, \mathrm{s}, \mathrm{CH}_{3}=20\right) ; 1.70\left(3 \mathrm{H}, \mathrm{s}, \mathrm{CH}_{3}=21\right) ; 2.54(\mathrm{H}-22 \mathrm{a}, \mathrm{m}) ; 2.55(\mathrm{H}-22 \mathrm{~b}, \mathrm{~m}) ; 5.04(\mathrm{H}-23, \mathrm{~m})$; $1.54\left(3 \mathrm{H}, \mathrm{s}, \mathrm{CH}_{3}-25\right) ; 1.99(\mathrm{H}-27 \mathrm{a}, \mathrm{m}) ; 2.16(\mathrm{H}-27 \mathrm{~b}, \mathrm{~m}) ; 4.90(\mathrm{H}-28, \mathrm{~m}) ; 1.60(3 \mathrm{H}$, overlapped, $\left.\mathrm{CH}_{3}-30\right) ; 1.64$ (3H, overlapped, $\left.\mathrm{CH}_{3}-31\right) ; 1.51\left(3 \mathrm{H}, \mathrm{s}, \mathrm{CH}_{3}-32\right) ; 1.25(3 \mathrm{H}, \mathrm{s}$, $\left.\mathrm{CH}_{3}-33\right) .{ }^{13} \mathrm{C}$ NMR $(100 \mathrm{MHz}, \delta \mathrm{ppm}): \delta 73.0(\mathrm{C} 1) ; 192.6(\mathrm{C} 2) ; 120.4(\mathrm{C} 3) ; 193.9(\mathrm{C} 4)$; 64.6 (C5); 41.5 (C6); 47.6 (C7); 48.6 (C8); 207.5 (C9); 197.5 (C10); 137.3 (C-11); 128.9 (C12), 127.8 (C-13); 132.5 (C-14); 127.7 (C-15); 128.8 (C-16); 23.7 (C-17); 120.4 (C-18); 134.5 (C-19); 17.9 (C-20); 25.8 (C-21); 30.2 (C-22); 119.9 (C-23); 133.3 (C- 24); 18.1 (C25); 25.6 (C-26); 29.7 (C-27); 123.3 (C-28); 132.5 (C- 29); 18.1 (C-30); 26.1 (C-31); 26.7 (C32); 23.7 (C-33).

Garcinol (2): Pale yellow crystal; TLC solvent system: hexane-chloroform (7:3); $\mathrm{R}_{\mathrm{f}}=0.27$; $\mathrm{UV}\left(\mathrm{CH}_{3} \mathrm{Cl}, 0.1 \%\right) \lambda \max (\mathrm{nm}) 306,244$. IR 3200-3500, 1727, $1562 \mathrm{~cm}^{-1}$, HR-MS $\mathrm{m} / z$ : $603.3681(\mathrm{M}+\mathrm{H})^{+}$for $\mathrm{C}_{38} \mathrm{H}_{51} \mathrm{O}_{6}$ (calcd. 603.3686); $\mathrm{MS}^{\mathrm{n}}$ experiment $m / z$ : 603.3, 467.2, 411.1, 343.1, 287.0, 233.0, 177.0, 137.1, 95.0; ${ }^{1} \mathrm{H}$ NMR (400 MHz, CD $\left.{ }_{3} \mathrm{OD}\right): \delta$ 7.05, 6.71, 6.69 (d; $\mathrm{J}=8 \mathrm{~Hz}$, aromatic protons) 4.91 .581 .68 (isopropylidine groups) 4.51 (isopropenyl group), $1.68(\mathrm{Me}), 0.97$ and 1.17 (methyl groups) to 1.4 to 2.7 (methylene and methane). ${ }^{13} \mathrm{C}$ NMR spectrum of garcinol showed the presence of three methine carbons of trisubstituted olefinic groups at $\delta 124.4,124.6$ and 122.6 and at $\delta 112.0$ for a terminal methylene carbon. Other assignments were $\delta 206.2(\mathrm{C}-9, \mathrm{C}=\mathrm{O}), 194.0(\mathrm{C}-2, \mathrm{C}=\mathrm{O}), 195.1$ (C-4, C-OH), 199.0 (C-15, $\mathrm{C}=\mathrm{O}) ; 131.5$ (C-12, $\left.\mathrm{CMe}_{2}\right), 132.3\left(\mathrm{C}-34, \mathrm{CMe}_{2}\right), 134.0\left(\mathrm{C}-26, \mathrm{CMe}_{2}\right) ; 149.8(\mathrm{C}-28, \mathrm{C}(\mathrm{Me})$ $\left.=\mathrm{CH}_{2}\right), \delta 116.6(\mathrm{C}-17, \mathrm{Ar}-\mathrm{CH}), 149.8(\mathrm{C}-20, \mathrm{Ar}-\mathrm{CH}), 122.5(\mathrm{C}-21, \mathrm{Ar}-\mathrm{CH}) ; 145.2(\mathrm{C}-18, \mathrm{Ar}-$ C-OH), 132.5 (C-19, Ar-C-OH); 126.3 (C-16, Ar-C-C=O); 116.9 (C-3), 68.6 (C-1), 48.8 (C8), 47.9 (C-7), 59.9 (C-5), 43.0 (C-6, 23); 26.8, 27.4, 32.9, 37.4, 43.0 ( $\left.5 \mathrm{CH}_{2}\right)$; 18.1, 18.3, 18.7, 25.9, $26.3(6 \mathrm{Me}, \mathrm{C}=\mathrm{CMe}) ; 23.3\left(\mathrm{C}(\mathrm{Me})=\mathrm{CH}_{2}\right)$; 17.6 and 26.7 (ring $\left.\mathrm{CMe}_{2}\right)$.

GB-1a (3): Yellow crystalline solid; TLC solvent system: Hexane-ethyl acetate (3:7); $\mathrm{R}_{\mathrm{f}}=$ 0.37; UV ( $\left.\mathrm{CH}_{3} \mathrm{OH}, 0.1 \%\right) \lambda \max / \mathrm{nm}$ : 289, 207. IR: 3227, 1598, 1515, 1158, 1084, $830 \mathrm{~cm}^{-1}$. HR-MS m/z: $543.1264(\mathrm{M}+\mathrm{H})^{+}$for $\mathrm{C}_{30} \mathrm{H}_{23} \mathrm{O}_{10}$ (calcd. 543.1291); $\mathrm{MS}^{\mathrm{n}}$ experiment $\mathrm{m} / \mathrm{z}$ : 541.1 , 447.0, 415.0, 389.1, 179.3. ${ }^{1} \mathrm{H}$ NMR (CD $3 \mathrm{OD}, 400 \mathrm{MHz}, \delta$-ppm): $\delta 5.42(1 \mathrm{H}, \mathrm{d}, \mathrm{J}=11.2 \mathrm{~Hz}$, H-2), $5.2(1 \mathrm{H}, \mathrm{d}, \mathrm{J}=12 \mathrm{~Hz}, \mathrm{H}-3), 5.91(1 \mathrm{H}, \mathrm{d}, \mathrm{J}=2 \mathrm{~Hz}, \mathrm{H}-6), 5.72(1 \mathrm{H}, \mathrm{d}, \mathrm{J}=2 \mathrm{~Hz}, \mathrm{H}-8), 7.05$ 
(2H, d, J=8.4 Hz, H-2',6'), 6.61 (2H, d, J=8.4 Hz, H-3',5'), 5.32 (1H, d, J=12 Hz, H-2'’),

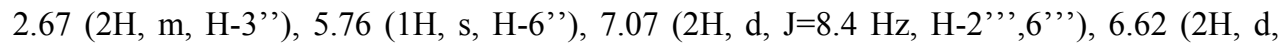
$\mathrm{J}=8.4 \mathrm{~Hz}, \mathrm{H}-3$ ', ',5 ', '). ${ }^{13} \mathrm{C}$ NMR: $\delta 80.5$ (C-2), 48.4 (C-3), 197.0 (C-4), 163.0 (C-5), 96.6 (C6), 164.8 (C-7), 96.2 (C-8), 165.6 (C-9), 103.2 (C-10), 129.0 (C-1'), 127.9 (C-2'/6'), 115.7 (C-3'/5'), 158.7 (C-4'), 83.7 (C-2''), 44.0 (C-3'’), 197.0 (C-4'), 164.8 (C-5'’), 97.3 (C-6'), 168 (C-7'’), 102.3 (C-8), 165.6 (C-9), 102.3 (C-10''), 83.7 (C-1'”'), 129.8 (C-2','/6','), 116.3 (C-3','/5','), 158.7 (C-4',').

GB-1 (4): Yellow crystalline solid; TLC solvent system: Hexane-ethyl acetate (3:7); $\mathrm{R}_{\mathrm{f}}=$ 0.48; UV ( $\left.\mathrm{CH}_{3} \mathrm{OH}, 0.1 \%\right) \lambda \max / \mathrm{nm}$ : 290, 211. IR: 3200, 1595, 1515, 1155, 1083, $828 \mathrm{~cm}^{-1}$. HR-MS m/z: $559.1221[\mathrm{M}+\mathrm{H}]^{+}$for $\mathrm{C}_{30} \mathrm{H}_{23} \mathrm{O}_{11}$ (Calcd. 559.1240) and $581.1043[\mathrm{M}+\mathrm{Na}]^{+}$; $\mathrm{MS}^{\mathrm{n}}$ experiment $(\mathrm{M}-\mathrm{H})^{-} \mathrm{m} / z$ : 557.1, 431.0, 285.0. ${ }^{1} \mathrm{H}$ NMR $\left(\mathrm{CD}_{3} \mathrm{OD}, 400 \mathrm{MHz}, \delta\right.$-ppm): $\delta$ $5.66(1 \mathrm{H}, \mathrm{d}, \mathrm{J}=12 \mathrm{~Hz}, \mathrm{H}-2), 3.31$ (1H, s, H-3), 5.90 (1H, d, J=2 Hz, H-6), 5.97 (1H, m, H-8), 7.15 (2H, d, J=8 Hz, H-2',6'), 6.61 (2H, d, J=8 Hz, H-3',5'), 4.50 (1H, m, H-2'’), 4.07 (2H, m, H-3'), 6.04 (1H, s, H-6'), 7.17 (2H, d, J=8 Hz, H-2',',6','), 6.67 (2H, m, H-3', ,5','). ${ }^{13} \mathrm{C}$ NMR (100 MHz, $\delta$-ppm): $\delta 79.5$ (C-2), 49.1 (C-3), 196.0 (C-4), 164.9 (C-5), 97.2 (C-6), 165.1 (C-7), 98.4 (C-8), 105.7 (C-9), 103.2 (C-10), 129.4 (C-1'), 124.0 (C-2'/6'), 115.7 (C3'/5'), 158.7 (C-4'), 82.8 (C-2'’), 71.0 (C-3'), 196.0 (C-4'), 165.7 (C-5'), 98.9 (C-6'), 165.8 (C-7'), 102.0 (C-8'”), 168.8 (C-9'’), 103.3 (C-10’'), 129.9 (C-1','), 129.9 (C2','/6", $), 116.1$ (C-3",'/5','), 158.7 (C-4',').

GB-2 (5): Yellow crystalline solid; TLC solvent system: Hexane-ethyl acetate (3:7); $\mathrm{R}_{\mathrm{f}}=$ 0.62; UV ( $\left.\mathrm{CH}_{3} \mathrm{OH}, 0.1 \%\right) \lambda \max / \mathrm{nm}: 291,207 . \mathrm{IR}: 3226,1736,1633,1516,1159,1083,830$ $\mathrm{cm}^{-1}$. HR-MS $m / z$ : $575.1175(\mathrm{M}+\mathrm{H})^{+}$for $\mathrm{C}_{30} \mathrm{H}_{23} \mathrm{O}_{12}$ (cald. 575.1189) and 597.0993 $(\mathrm{M}+$ $\mathrm{Na})^{+}{ }^{+} \mathrm{MS}^{\mathrm{n}}$ experiment $(\mathrm{M}-\mathrm{H})^{-} \mathrm{m} / z: 573.1,447.8,447.0,268.6 .{ }^{1} \mathrm{H}$ NMR (DMSO-d 6,400 MHz, $\delta$-ppm): $\delta 5.35$ (1H, d, J=12 Hz, H-2), 4.48 (1H, d, J=12 Hz, H-3), 5.89 (1H, d, J=2 Hz, H-6), 5.77 (1H, d, J=2, H-8), 7.11 (2H, d, J=2 Hz, H-2',6'), 6.65 (2H, d, J=8 Hz, H-3',5'), 12.14 (1H, s, Chelated OH), 4.67 (1H, d, J=12, H-2'’), 3.97 (2H, d, J=11, H-3'’), 5.93 (1H, s, H-6’'), 6.85 (1H, s, H-2', '), 6.81 (2H, d, J=8, H-5', '), 6.79 (1H, d, J=8, H-6' '), 11.7 (1H, s, Chelated OH). ${ }^{13} \mathrm{C}$ NMR (100 MHz, $\delta$-ppm): $\delta 79.1$ (C-2), 47.0 (C-3), $196.4(\mathrm{C}-4), 160.1$ (C5), 94.9 (C-6), 160.7 (C-7), 96.0 (C-8), 162.7 (C-9), 100.9 (C-10), 127.8 (C-1'), 128.0 (C2'/6'), 115.3 (C-3'/5'), 157.7 (C-4'), 82.7 (C-2'’), 71.9 (C-3'’), 197.5 (C-4'’), 162.0(C-5')), 96.0 (C-6'), 166.3 (C-7'’), 101.2 (C-8'’), 163.5 (C-9'’), 106.0 (C-10'’), 127.8 (C-1'’'), 118.4 (C-2','/5','), 144.9 (C-3'’'), 145.0 (C-4','), 128.2 (C-6',').

Morelloflavone (6): Yellow crystalline solid; TLC solvent system: Ethyl acetate (100\%); $\mathrm{R}_{\mathrm{f}}$ $=0.47$; UV $\left(\mathrm{CH}_{3} \mathrm{OH}, 0.1 \%\right) \lambda \max / \mathrm{nm}: 376,288$. IR: 3348, 1557, 1410, 1269, 1167, $619 \mathrm{~cm}^{-1}$. ${ }^{1} \mathrm{H}$ NMR (CD $3 \mathrm{OD}, 400 \mathrm{MHz}, \delta$-ppm): $\delta 5.35(1 \mathrm{H}, \mathrm{d}, \mathrm{J}=12 \mathrm{~Hz}, \mathrm{H}-2), 4.48(1 \mathrm{H}, \mathrm{d}, \mathrm{J}=12 \mathrm{~Hz}, \mathrm{H}-$ 3), 5.89 (1H, d, J=2 Hz, H-6), 5.77 (1H, d, J=2, H-8), 7.11 (2H, d, J=2 Hz, H-2',6'), 6.65 (2H, d, J=8 Hz, H-3',5'), 4.67 (1H, d, J=12, H-2'), 3.97 (2H, d, J=11, H-3'’), 5.93 (1H, s, H-6' '),

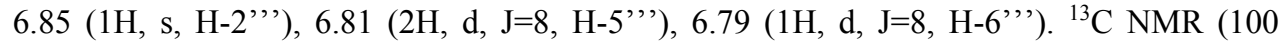
MHz, $\delta$-ppm): $\delta 80.9$ (C-2), 49.9 (C-3), 196.3 (C-4), 163.7 (C-5), 96.2 (C-6), 166.4 (C-7), 95.2 (C-8), 162.1 (C-9), 101.5 (C-10), 128.0 (C-1'), 128.4 (C-2'), 114.4 (C-3'), 157.2 (C-4'), 114.4 (C-5'), 128.4 (C-6'), 162.8 (C-2'’), 102.4 (C-3'’), 179.5 (C-4'’), 159.7 (C-5'), 97.9 
(C-6'), 161.3 (C-7'), 100.0 (C-8'), 154.0 (C-9'’), 103.0 (C-10'), 121.6 (C-1','), 114.6 (C2','), 145 (C-3','), 147.6 (C-4','), 116.2 (C-5','), 120.3 (C-6"',).

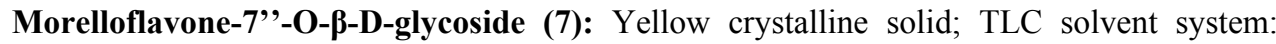
Ethyl acetate-methanol (8:2); $\mathrm{R}_{\mathrm{f}}=0.57 ; \alpha_{\mathrm{D}}^{29}+46.49$ (c. $\left.1 \% \mathrm{CH}_{3} \mathrm{OH}\right), \mathrm{UV}\left(\mathrm{CH}_{3} \mathrm{OH}, 0.1 \%\right)$ $\lambda \max / \mathrm{nm}: 377,288$. IR: 3252, 1738, 1593, 1364, 1069, 1083, $824 \mathrm{~cm}^{-1}$. HR-MS m/z: $717.1446(\mathrm{M}-\mathrm{H}){ }^{-}$for $\mathrm{C}_{36} \mathrm{H}_{31} \mathrm{O}_{16}$ (calcd. 717.1461); $\mathrm{MS}^{\mathrm{n}}$ experiment $(\mathrm{M}-\mathrm{H})^{-} \mathrm{m} / z$ : 717.1, 555.0, 403.55. ${ }^{1} \mathrm{H}$ NMR (DMSO-d6, $400 \mathrm{MHz}, \delta$-ppm): $\delta 5.80(1 \mathrm{H}, \mathrm{d}, \mathrm{J}=12 \mathrm{~Hz}, \mathrm{H}-2), 4.91$ $(1 \mathrm{H}, \mathrm{d}, \mathrm{J}=12 \mathrm{~Hz}, \mathrm{H}-3), 5.94(1 \mathrm{H}, \mathrm{d}, \mathrm{J}=4.6 \mathrm{~Hz}, \mathrm{H}-6), 5.96(1 \mathrm{H}, \mathrm{d}, \mathrm{J}=4, \mathrm{H}-8), 7.17$ (2H, d, J=8.4 Hz, H-2',6'), 6.53 (2H, d, J=8.4 Hz, H-3',5'), 12.65 (1OH, s, OH-5) 6.47 (1H, s, H-3' '), 6.73 (2H, s, H-3' '), 7.25 (1H, s, H-2','), 6.93(1H, d, J=8.4, H-5','), 7.59 (1H, d, J=8, H-6','), 5.15

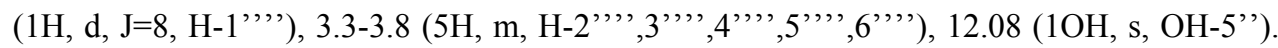
${ }^{13} \mathrm{C}$ NMR (100 MHz, $\delta$-ppm): $\delta 82.5$ (C-2), 50.7 (C-3), 195.0 (C-4), 164.5 (C-5), 96.5 (C-6), 165.7 (C-7), 97.7 (C-8), 167.0 (C-9), 103.5 (C-10), 130.3 (C-1'), 129.6 (C-2'/6'), 115.5 (C3'/5'), 158.0 (C-4'), 165.8 (C-2'’), 103.5 (C-3'’), 182.0 (C-4'’), 162.0 (C-5'’), 100.0 (C-6'”), 161.2 (C-7'’), 103.5 (C-8'), 155.0 (C-9''), 106.4 (C-10'’), 123.7(C-1','), 114.9 (C-2'”'), 146.0 (C-3','), 152.5 (C-4','), 114.9 (C-5','), 120.6 (C-6'”'), 101.6 (C-1',',), 76.1 (C-2',',), 77.5 (C-3',', $), 69.6$ (C-4',', $), 79.1$ (C-5',', $), 60.9$ (C-6',',).

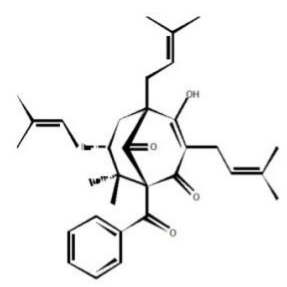

7-epi-Nemorosone

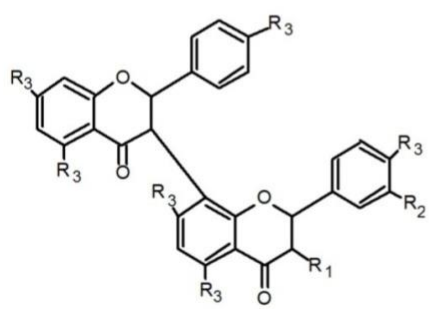

R1 $=$ R2 $=$ H, R3 = OH (GB-1a)

R2 $=$ H, R1 = R3 = OH (GB-1)

$\mathrm{R} 1=\mathbf{R 2}=\mathbf{R 3}=\mathrm{OH}(\mathrm{GB}-2)$

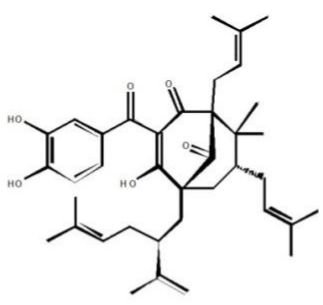

Garcinol<smiles>[R20]c1cc(O)c2c(=O)cc(-c3ccc(O)c(O)c3)oc2c1C1C(=O)c2c(O)cc(O)cc2OC1c1ccc(O)cc1</smiles>

R1 = H (Morelloflavone)

R1 = Glycoside

(Morelloflavone-7"-O- $\beta$-D-glycoside)

Figure 2. Structures of compounds 1 to 7

\subsection{GC-MS analysis of low polar fraction of hexane extract}

Column chromatographic separation of hexane extract of the leaves of G. travancorica using $100 \%$ hexane yielded a waxy white semi-solid. TLC of the fraction in reverse phase plates using $100 \%$ methanol as the solvent system revealed that the fraction was mixture of several 
compounds with very close $\mathrm{R}_{\mathrm{f}}$ values. GC-MS analysis revealed $\mathrm{n}$-heptacosane $\left(\mathrm{C}_{27} \mathrm{H}_{56}\right)$, a saturated hydrocarbon, as the major constituent of the waxy solid isolated from the leaves of G. travancorica.

The role of hydrocarbons is to prevent desiccation and to act as agents in chemical communications. n-Heptacosane is found in the epi-cuticular wax layer of different insects and is the major male courtship pheromeone of Colias eurytheme (Sappington and Taylor, 1990). It has been reported that the cuticular hydrocarbons in social insects signal the reproductive status of an individual and n-heptacosane has been identified as the major hydrocarbon on the wax coat of the mated queen of the ants Ectatomma tuberculatum (Hora et al., 2008).

\section{HPTLC estimation of GB-2 and morelloflavone-7'"-O- $\beta$-D-glycoside}

HPTLC estimation of the biflavonoids, GB-2 and morelloflavone-7' '-O- $\beta$-D-glycoside in the leaves of $G$. travancorica were carried out using CAMAG HPTLC system, using the mobile phase of $70 \%$ ethyl acetate in hexane $(\mathrm{v} / \mathrm{v})$. GB-2 gave $\mathrm{R}_{\mathrm{f}}$ value of 0.30 and chromatogram of the compound was recorded at $288 \mathrm{~nm}$. Standard GB-2 in the range 0.2 to $1.0 \mu \mathrm{g}$ per band showed good linear response with correlation coefficient 0.983 . The content of GB-2 was $0.91 \%$ (dry wt.).

Morelloflavone-7' '-O- $\beta$-D-glycoside in the leaves was estimated using ethylacetatemethanol-formic acid (80:17.5:2.5 v/v) solvent system $\left(R_{f}\right.$ value 0.35$)$. Development of the plates in this mobile phase resulted in sharp, symmetric and well resolved peaks (Figure 3). The HPTLC chromatogram of the compound was recorded in the visible range at $580 \mathrm{~nm}$. Peak area and concentration were subjected to linear regression analysis to calculate the calibration equation and correlation coefficients. Morelloflavone-7''-O- $\beta$-D-glycoside in the range 0.5 to $1.5 \mu \mathrm{g}$ per band gave linear response and the correlation coefficient 0.982 indicated a good linear relationship between peak area and concentration of standard. The content of morelloflavone-7' '-O- $\beta$-D-glycoside was $7.12 \%$ (dry wt.).
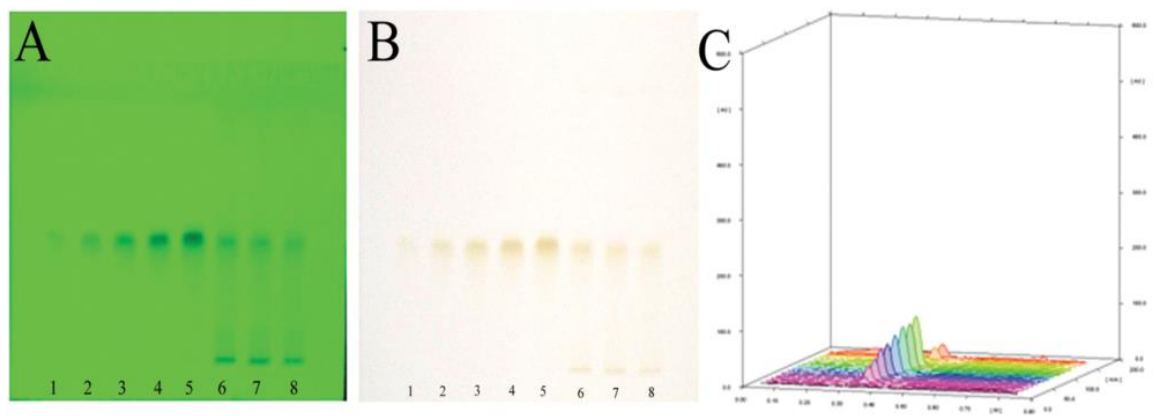

Figure 3. HPTLC densitogram of morelloflavone-7"'-O- $\beta$-D-glycoside: A- UV (254 nm), B: Visible (580 nm), C: 3D Graph

\section{HPLC-QTOF-MS Analysis of G. travancorica leaves, stem bark and fruits}

Isolation, purification and structural elucidation of compounds, using conventional methods, from complex mixtures of natural origin are quite expensive in terms of time consumption 
and labour (Shu, 1998; Konishi et al., 2007). The introduction of hyphenated analytical techniques provided natural product researchers extremely powerful tools that provided both the separation and characterisation in single run (Phonde and Magdum, 2015). Among the different hyphenated analytical techniques, liquid chromatography-mass spectrometric techniques became an important tool in phytochemical analysis for the rapid identification of secondary metabolites (Rosenberg, 2003). LC-MS is a powerful technique for identifying nontarget components where LC fractionate complex extracts with good resolution, sensitivity and reproducibility and MS techniques generate mass spectra with greater accuracy and precision (Shen et al., 2005; Konishi et al., 2007). G. travancorica fruits, leaves and stem bark were subjected to HPLC-QTOF-MS analysis for the identification of secondary metabolites present.

LC-MS analysis was carried out using Agilent 1200 HPLC (Agilent technologies, USA) coupled with an Agilent 6520 QTOF-MS/MS system via an electrospray ionisation interface (ESI). Agilent 1200 HPLC system consists of thermo stated column compartment (G1316C) and diode-array detector (G1315D). The HPLC separation was carried out on a Supelco Ascentis Express C18 column $(10 \mathrm{~cm} \times 2.1 \mathrm{~mm}, 2.7 \mu \mathrm{m})$ operated at $25^{\circ} \mathrm{C}$. The mobile phase, consisted of $0.1 \%$ formic acid aqueous solution (A) and acetonitrile (B), was delivered at a flow rate of $0.3 \mathrm{~mL} / \mathrm{min}$ under the gradient program: $0-30 \%$ (B) from $0 \mathrm{~min}$ to $5 \mathrm{~min}, 30-55 \%$ (B) from $5 \mathrm{~min}$ to $10 \mathrm{~min}, 55-60 \%$ (B) from $10 \mathrm{~min}$ to $15 \mathrm{~min}, 60-70 \%$ (B) from $15 \mathrm{~min}$ to $20 \mathrm{~min}, 70-80 \%$ (B) from $20 \mathrm{~min}$ to $25 \mathrm{~min}, 80-85 \%$ (B) from $25 \mathrm{~min}$ to 30 $\mathrm{min}, 85-95 \%$ (B) from $30 \mathrm{~min}$ to $40 \mathrm{~min}$, and return to initial condition over $5 \mathrm{~min}$. The sample injection volume was $5 \mu 1$.

In the ESI source, nitrogen was used as drying and collision gas. The heated capillary temperature was set at $320^{\circ} \mathrm{C}$ and nebulizer pressure at 40 psi. The drying gas flow rate was $10 \mathrm{lit} / \mathrm{min}$. VCap, fragmentor, skimmer and octapole RF peak voltages were set at $3500 \mathrm{~V}$, $150 \mathrm{~V}, 65 \mathrm{~V}$ and $750 \mathrm{~V}$ respectively in the ion source. Detection was carried out in negative ion mode within a mass range of m/z 100-1500 and resolving power above 15000 (FWHM). The data analyses were performed using Mass Hunter software version B.04.00 build 4.0.479.0 (Agilent Technology, USA).
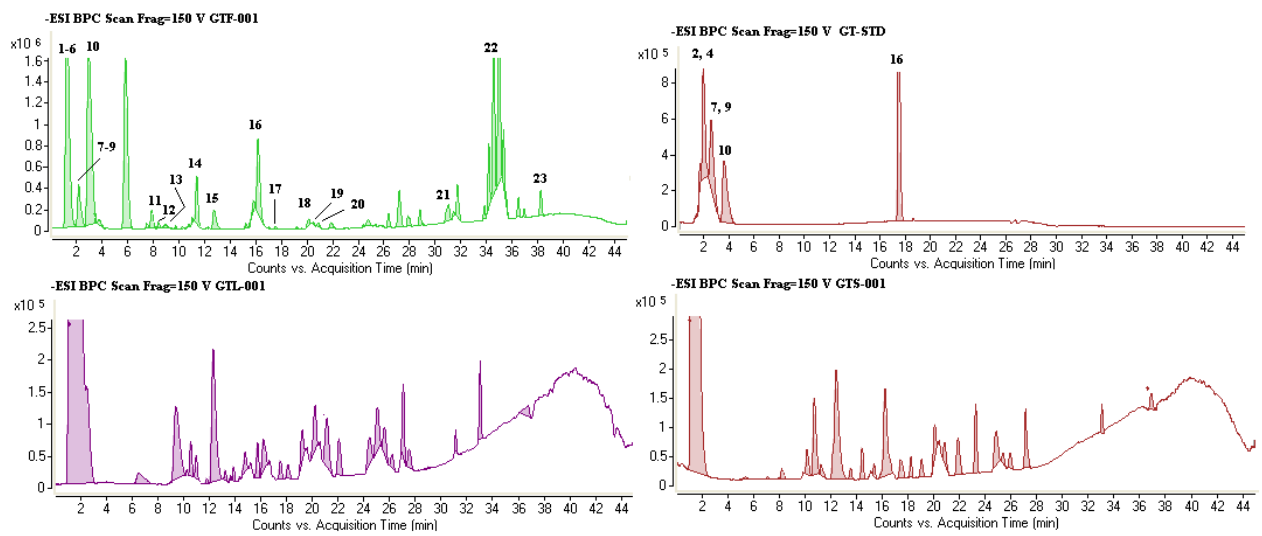

Figure 4. HPLC-QTOF-MS Base peak chromatograms of fruit, leaf, stem bark and mix reference standards of G. travancorica. (GTF; fruit, GT-STD; mix reference standards, GTL; leaf, GTS; stem bark) 
A total of 23 compounds were identified by comparing retention times, MS spectra with available standards (hydroxycitric acid, fukugiside, $\alpha$-mangostin, GB-1a, GB-1 and GB-2), HRMS of (M-H) ${ }^{-}$and fragmentation patterns (Table1, Figure 4, Figure 5). The proposed HPLC-QTOF-MS/MS method for the qualitative analysis is rapid, sensitive and efficient for simultaneous determination of acids, prenylated xanthones, benzophenoes and biflavonoids present in the plant species.

Hydroxycitric acid and its derivative hydroxycitric acid lactone (garcinia acid) were the two acids identified in fruits, leaves and stem bark of G. travancorica. Hydroxycitric acid is an antiobesity agent and the distribution of the compound is reported from many Garcinia species including G. indica, G. cambogia, G. atrovirdis and G. cowa. (Majeed et al., 1994; Kumar et al., 2013).

Morelloflavone, GB-1a, GB-1, GB-2 and GB-2a were the biflavonoids and fukugiside (morelloflavone-7',-O- $\beta$-D-glycoside), xanthochymusside, GB-1a glucoside were the biflavonoid glycosides identified from the plant. These compounds were distributed in all the plant parts studied.

Xanthones identified from the fruits were $\alpha$-mangostin, $\gamma$-mangostin, 1,5-dihydroxy-3methoxyxanthone, 4-(1, 1 - dimethylprop - 2 - enyl) -1, 3, 5, 8 - tetrahydroxy - xanthone, garciniaxanthone $\mathrm{E}$, garcinone $\mathrm{A}$, garcinone $\mathrm{B}$, garcinone $\mathrm{C}$ and polyanxanthone $\mathrm{C}$, while $\gamma$ mangostin and garcinone $\mathrm{A}$ were the xanthones identified from the leaves. $\gamma$-Mangostin, garcinone A, 1,5-dihydroxy-3-methoxy xanthone, garcinone $\mathrm{B}$ and garcinone $\mathrm{C}$ were present in the stem bark. Xanthones were especially noted for their potential antitumour and chemopreventive abilities along with other biological activities such as antibacterial, antifungal, antiviral, antioxidant and anti-inflammatory (Chin and Kinghorn 2008; Peres et al. 2000).

The benzophenones identified from the fruits were gambogenone, aristophenone A, garcinol and garciyunnanin A. Aristophenone A and garcinol were present in the leaves, while none of the benzophenones were detected in the stem bark of $G$. travancorica. Garciyunnanin A with 3-monohydroxy benzophenone skeleton is rarely distributed in Garcinia species (Xu et al., 2008). Most of the benzophenones reported from Garcinia species were polyisoprenylated structural group and exhibited wide spectrum of biological activities like antifungal, anti-HIV, antimicrobial, antioxidant, antiviral and cytotoxic (Kumar et al., 2007; Williams et al., 2003; Diaz-Carballo et al., 2012).

The study reports the chemical finger printing of G. travancorica leaves, stem bark and fruits using the hyphenated MS techniques. HPLC-QTOF-MS method was optimized and established for selective, reliable and simultaneous determination of 23 multiclass chemical constituents including acids, benzophenones, biflavonoids and xanthones present in the plant species. 
Table 1. Identification of compounds from Garcinia travancorica by HPLC-QTOF-MS analysis

\begin{tabular}{|c|c|c|c|c|c|c|c|c|c|}
\hline $\begin{array}{l}\text { Sl. } \\
\text { No. }\end{array}$ & $\begin{array}{l}\mathrm{RT} \\
(\mathrm{min})\end{array}$ & $\begin{array}{l}\text { Molecular } \\
\text { Formula }\end{array}$ & $\begin{array}{l}\text { HRMS, } \\
\mathrm{m} / \mathrm{z} \text {, calc. }\end{array}$ & $\begin{array}{l}\text { [M-H]- } \\
\text { Obs. }\end{array}$ & $\begin{array}{l}\text { Error } \\
(\Delta \mathrm{ppm})\end{array}$ & Compound & Fruit & Leaf & $\begin{array}{l}\text { Stem } \\
\text { bark }\end{array}$ \\
\hline 1 & 1.1 & $\mathrm{C}_{6} \mathrm{H}_{6} \mathrm{O}_{7}$ & 189.0041 & 189.0042 & -0.55 & $\begin{array}{l}\text { Hydroxycitric acid } \\
\text { lactone }\end{array}$ & $\mathrm{P}$ & $\mathrm{P}$ & $\mathrm{P}$ \\
\hline 2 & 1.2 & $\mathrm{C}_{36} \mathrm{H}_{30} \mathrm{O}_{16}$ & 717.1461 & 717.1468 & -0.92 & Fukugiside & $\mathrm{P}$ & $\mathrm{P}$ & $\mathrm{P}$ \\
\hline 3 & 1.3 & $\mathrm{C}_{36} \mathrm{H}_{32} \mathrm{O}_{17}$ & 735.1567 & 735.1564 & 0.32 & Xanthochymusside & $\mathrm{P}$ & $\mathrm{P}$ & $\mathrm{P}$ \\
\hline 4 & 1.5 & $\mathrm{C}_{6} \mathrm{H}_{8} \mathrm{O}_{8}$ & 207.0146 & 207.0147 & -0.32 & Hydroxycitric acid & $\mathrm{P}$ & $\mathrm{P}$ & $\mathrm{P}$ \\
\hline 5 & 1.5 & $\mathrm{C}_{30} \mathrm{H}_{22} \mathrm{O}_{11}$ & 557.1089 & 557.1090 & -0.12 & GB-2a & $\mathrm{P}$ & $\mathrm{P}$ & $\mathrm{P}$ \\
\hline 6 & 1.8 & $\mathrm{C}_{30} \mathrm{H}_{20} \mathrm{O}_{11}$ & 555.0933 & 555.0933 & 0.1 & Morelloflavone & $\mathrm{P}$ & $\mathrm{N}$ & $\mathrm{P}$ \\
\hline 7 & 2.1 & $\mathrm{C}_{30} \mathrm{H}_{22} \mathrm{O}_{12}$ & 573.1038 & 573.1039 & -0.15 & GB-2 & $\mathrm{P}$ & $\mathrm{P}$ & $\mathrm{P}$ \\
\hline 8 & 2.3 & $\mathrm{C}_{36} \mathrm{H}_{32} \mathrm{O}_{15}$ & 703.1668 & 703.1666 & 0.44 & GB-1a glucoside & $\mathrm{P}$ & $\mathrm{P}$ & $\mathrm{P}$ \\
\hline 9 & 2.5 & $\mathrm{C}_{30} \mathrm{H}_{22} \mathrm{O}_{11}$ & 557.1089 & 557.1090 & -0.15 & GB-1 & $\mathrm{P}$ & $\mathrm{P}$ & $\mathrm{P}$ \\
\hline 10 & 5.5 & $\mathrm{C}_{30} \mathrm{H}_{22} \mathrm{O}_{10}$ & 541.1140 & 541.1143 & 0.52 & GB-1a & $\mathrm{P}$ & $\mathrm{P}$ & $\mathrm{P}$ \\
\hline 11 & 7 & $\mathrm{C}_{24} \mathrm{H}_{26} \mathrm{O}_{6}$ & 409.1657 & 409.1663 & -1.16 & $\alpha$-Mangostin & $\mathrm{P}$ & $\mathrm{N}$ & $\mathrm{N}$ \\
\hline 12 & 8 & $\mathrm{C}_{14} \mathrm{H}_{10} \mathrm{O}_{5}$ & 257.0455 & 257.0451 & 1.62 & $\begin{array}{l}\text { 1,5-Dihydroxy-3- } \\
\text { methoxyxanthone }\end{array}$ & $\mathrm{P}$ & $\mathrm{N}$ & $P$ \\
\hline 13 & 8.3 & $\mathrm{C}_{18} \mathrm{H}_{16} \mathrm{O}_{6}$ & 327.0874 & 327.0876 & -0.59 & $\begin{array}{l}\text { 4-(1,1-Dimethylprop- } \\
\text { 2-enyl)-1,3,5,8- } \\
\text { tetrahydroxy- } \\
\text { xanthone }\end{array}$ & $\mathrm{P}$ & $\mathrm{N}$ & $\mathrm{N}$ \\
\hline 14 & 11.2 & $\mathrm{C}_{27} \mathrm{H}_{32} \mathrm{O} 6$ & 451.2126 & 451.2130 & -0.95 & Gambogenone & $\mathrm{P}$ & $\mathrm{N}$ & $\mathrm{N}$ \\
\hline 15 & 13.4 & $\mathrm{C}_{23} \mathrm{H}_{26} \mathrm{O}_{7}$ & 413.1606 & 413.1605 & 0.39 & Garcinone C & $\mathrm{P}$ & $\mathrm{N}$ & $\mathrm{P}$ \\
\hline 16 & 16 & $\mathrm{C}_{23} \mathrm{H}_{24} \mathrm{O}_{6}$ & 395.1500 & 395.1502 & -0.6 & $\gamma$-Mangostin & $\mathrm{P}$ & $\mathrm{P}$ & $\mathrm{P}$ \\
\hline 17 & 17.9 & $\mathrm{C}_{28} \mathrm{H}_{32} \mathrm{O}_{6}$ & 463.2126 & 463.2128 & -1.15 & Garciniaxanthone E & $\mathrm{P}$ & $\mathrm{N}$ & $\mathrm{N}$ \\
\hline 18 & 19.9 & $\mathrm{C}_{23} \mathrm{H}_{22} \mathrm{O}_{6}$ & 393.1344 & 393.1345 & -0.45 & Garcinone B & $\mathrm{P}$ & $\mathrm{N}$ & $\mathrm{P}$ \\
\hline 19 & 20.4 & $\mathrm{C}_{23} \mathrm{H}_{24} \mathrm{O}_{5}$ & 379.1551 & 379.1553 & -0.46 & Garcinone A & $\mathrm{P}$ & $\mathrm{P}$ & $\mathrm{P}$ \\
\hline 20 & 20.7 & $\mathrm{C}_{33} \mathrm{H}_{42} \mathrm{O}_{6}$ & 533.2909 & 533.2901 & 1.49 & Aristophenone A & $\mathrm{P}$ & $\mathrm{P}$ & $\mathrm{N}$ \\
\hline 21 & 30.5 & $\mathrm{C}_{28} \mathrm{H}_{32} \mathrm{O}_{4}$ & 431.2228 & 431.2235 & -1.72 & Polyanxanthone $\mathrm{C}$ & $\mathrm{P}$ & $\mathrm{N}$ & $\mathrm{N}$ \\
\hline 22 & 35.1 & $\mathrm{C}_{38} \mathrm{H}_{50} \mathrm{O}_{6}$ & 601.3535 & 601.3539 & -0.69 & Garcinol & $\mathrm{P}$ & $\mathrm{P}$ & $\mathrm{N}$ \\
\hline 23 & 38.4 & $\mathrm{C}_{38} \mathrm{H}_{50} \mathrm{O}_{5}$ & 585.3585 & 585.3582 & 0.6 & Garciyunnanin A & $\mathrm{P}$ & $\mathrm{N}$ & $\mathrm{N}$ \\
\hline
\end{tabular}

P: present, N: not present

\section{Volatile chemical profile of Garcinia travancorica}

Hydrodistillation revealed $G$. travancorica as rich source of essential oils with yield of $0.70 \%, 0.60 \%$ and $1.50 \% \mathrm{v} / \mathrm{w}$ respectively for leaf, stem bark and fruit. In total, 23 components were identified from the oils (Table 2). Fifteen components comprising $96.1 \%$ of the leaf oil were identified. The major components in the leaf oil were n-undecane $(44.0 \%)$ followed by $\alpha$-copaene $(15.8 \%)$ and $\delta$-amorphene (7.0\%). Fifteen components comprising $95.0 \%$ of the stem bark oil were identified and n-undecane $(39.0 \%)$ was the major constituent followed by $\beta$-alaskene (9.4\%) and $\alpha$-himachalene (6.4\%). Fourteen components comprising $92.9 \%$ of fruit essential oil were identified where n-undecane $(58.2 \%)$ was the major volatile constituent, followed by $\alpha$-copaene $(8.2 \%)$ and $\gamma$-cadinene $(6.7 \%)$. $\alpha$-Copaene and $\alpha$ himachalene were the common sesquiterpene constituents in the oils. 
<smiles>O=C(O)C[C@@](O)(C(=O)O)[C@@H](O)C(=O)O</smiles>

Hydroxycitric acid<smiles>O=C1C[C@@](O)(C(=O)O)[C@H](C(=O)O)O1</smiles>

Hydroxycitric acid lactone

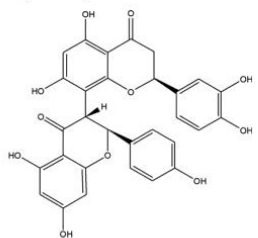

GB-2a

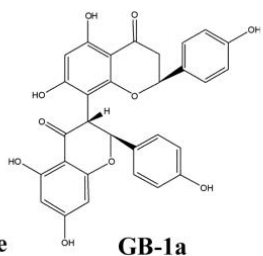<smiles>C=C1CC(c2ccc(C)c(C)c2)CC2C(=O)CC(C)C=C(C)C12</smiles>

Morelloflavone

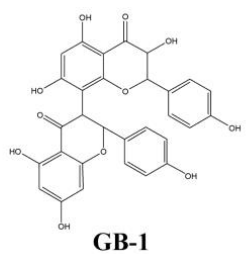

GB-1

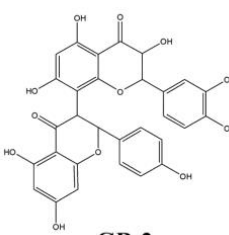

GB-2

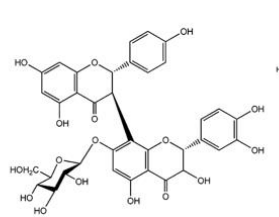

Xanthochymusside

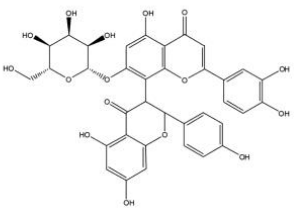

Fukugiside

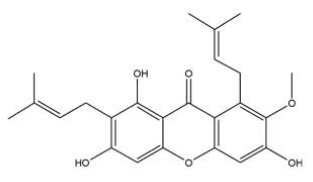

$\alpha$-Mangostin

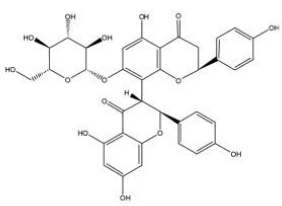

GB-1a glucoside<smiles>C=C1c2cccc(CCCC(C)C)c2Cc2ccc(CC=C(C)C)c(CCC=C(C)C)c21</smiles>

Polyanxanthone C<smiles>CC(C)=CCc1c(O)c(CCC(C)C)c2oc3cc(O)ccc3c(=O)c2c1O</smiles>

Garcinone A

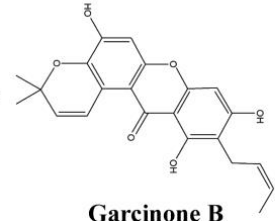

Garcinone B<smiles>COc1cc(O)c2c(=O)c3cccc(O)c3oc2c1</smiles>

1,5-Dihydroxy-3methoxyxanthone<smiles>CC(C)=CCC/C(C)=C/Cc1c(O)c(C)c2oc3cc(O)cc(C)c3c(=O)c2c1CC=C(C)C</smiles>

Garciniaxanthone E<smiles></smiles>

$\gamma$-Mangostin

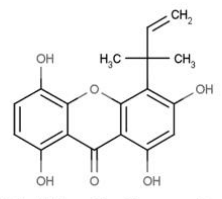

4-(1,1-Dimethylprop-2-enyl)1,3,5,8-tetrahydroxyxanthone

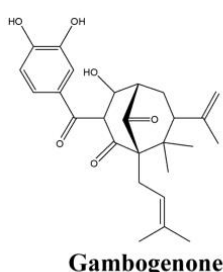

Gambogenone

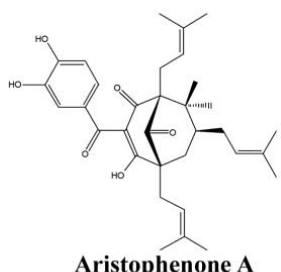

Aristophenone A

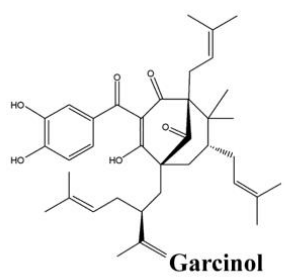

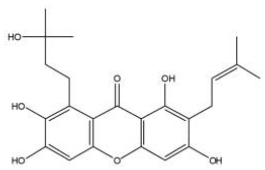

Garcinone C

Figure 5. Structures of compounds identified from Garcinia travancorica by HPLC-QTOF-MS/MS analysis 
Identification of the major compound n-undecane was further confirmed by the presence of their characteristic ${ }^{13} \mathrm{C}$ NMR signals in the ${ }^{13} \mathrm{C}$ NMR spectra of the oil (Formacek and Kubeczka, 2002) (Table 3, Figure 6, Figure 7). High content of the hydrocarbon nundecane, with gasoline type odour, may possibly contribute to the characteristic smell of the plant. n-Undecane predominantly present in all the three oil samples. High quantity of nundecane in the plant parts may play a key role in pollination as the compound was reported to possess pheromone type character which attracts the flies, moths and ants (Schiestl, 2000).

Table 2. Composition of the leaf, stem bark and fruit essential oils of Garcinia travancorica

\begin{tabular}{|c|c|c|c|c|}
\hline Compound & RRI & Leaf & $\begin{array}{l}\text { Stem } \\
\text { Bark }\end{array}$ & Fruit \\
\hline Z- $\beta$-Ocimene & 1037 & ng & 2.6 & ng \\
\hline n-Undecane & 1100 & 40.1 & 39.0 & 58.2 \\
\hline$\alpha$-Ylangene & 1373 & 1.0 & ng & 1.4 \\
\hline$\alpha$-Copaene & 1374 & 15.8 & 4.1 & 8.2 \\
\hline$\beta$-Funebrene & 1414 & 3.3 & - & 1.8 \\
\hline$\beta$-Caryophyllene & 1419 & 4.0 & - & 1.2 \\
\hline$\alpha$-Funebrene & 1402 & - & 3.9 & \\
\hline$\alpha$-Trans bergamotene & 1434 & 1.8 & 7.4 & 1.0 \\
\hline$\alpha$-Himachalene & 1449 & 3.1 & 6.4 & 1.9 \\
\hline Amorpha-4,11-diene & 1451 & 2.2 & 4.1 & 1.5 \\
\hline$\alpha$-Humulene & 1452 & 0.1 & & \\
\hline Cis cadina-1(6),4- diene & 1461 & 2.4 & 2.9 & - \\
\hline Trans cadina-1(6),4- diene & 1476 & 1.0 & - & - \\
\hline$\beta$-Acoradiene & 1469 & - & 3.4 & \\
\hline ar-Curcumene & 1481 & - & 2.3 & 1.6 \\
\hline$\gamma$-Himachalene & 1482 & 2.3 & - & - \\
\hline$\beta$-Alaskene & 1498 & 3.8 & 9.4 & 2.7 \\
\hline Epizonarene & 1501 & - & 4.0 & - \\
\hline$\gamma$-Cadinene & 1513 & - & - & 6.7 \\
\hline$\beta$-Bisabolene & 1505 & - & 1.2 & - \\
\hline$\delta$-Amorphene & 1512 & 7.0 & - & - \\
\hline$\beta$-Curcumene & 1514 & - & 4.3 & - \\
\hline$\delta$-Cadinene & 1522 & 4.5 & - & 4.2 \\
\hline 1-Epi-cubenol & 1627 & - & - & 2.5 \\
\hline Total identified & & 92.4 & 95.0 & 92.9 \\
\hline Monoterpene hydrocarbons (\%) & & ng & $2.6 \%$ & ng \\
\hline Oxygenated monoterpenes (\%) & & - & - & - \\
\hline Sesquiterpene hydrocarbons (\%) & & $52.1 \%$ & $53.4 \%$ & $34.7 \%$ \\
\hline Oxygenated sesquiterpenes $(\%)$ & & - & - & - \\
\hline Aliphatic hydrocarbons & & $40.1 \%$ & $39.0 \%$ & $58.2 \%$ \\
\hline
\end{tabular}<smiles>CCCCCCCCCCC</smiles>

Figure 6. Structure of n-undecane 
Table 3. NMR spectroscopic data of $\mathrm{n}$ - undecane $\left(\mathrm{CDCl}_{3}, \delta\right.$ in $\left.\mathrm{ppm}\right)$

\begin{tabular}{lll}
\hline Carbon Atom & $\delta \mathrm{C}$ & $\delta \mathrm{H}$ \\
\hline $\mathrm{a}$ & 14.13 & 0.90 \\
$\mathrm{~b}$ & 22.71 & 1.30 \\
$\mathrm{c}$ & 31.94 & 1.26 \\
$\mathrm{~d}$ & 29.63 & 0.90 \\
$\mathrm{e}$ & 29.67 & 0.90 \\
\hline
\end{tabular}

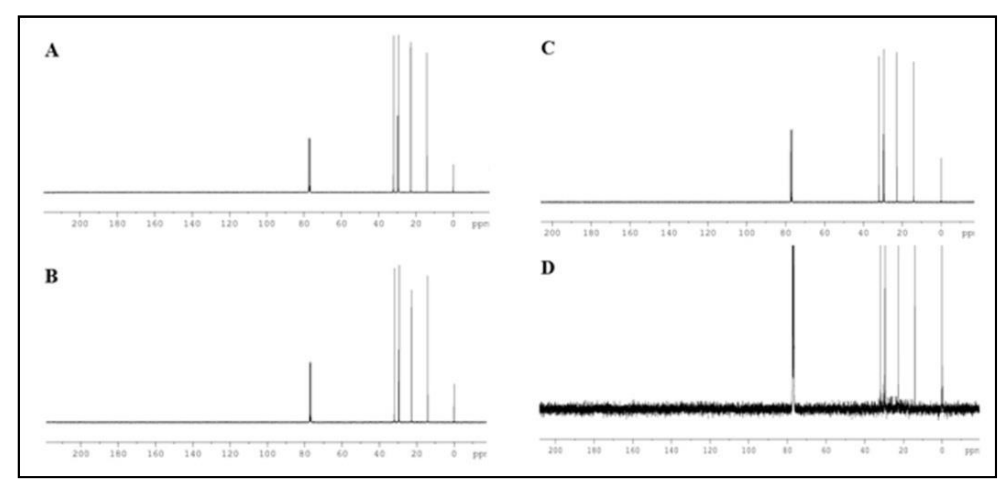

Figure 7. ${ }^{13} \mathrm{C}$ NMR of essential oils and n- undecane: A- Leaf oil, B- Stem bark oil, C-Fruit oil and D- n-undecane

\section{Conclusions}

Seven phenolic compounds including two polyisoprenylated benzophenones and five biflavonoids were isolated and characterised from $G$. travancorica leaves. The study highlights the plant as a rich source of the biflavonoid morelloflavone-7"-O- $\beta$-D-glycoside. HPLC-QTOF-MS method was optimized and established for selective, reliable and simultaneous determination of 23 multiclass chemical constituents including two acids, four benzophenones, seven biflavonoids and nine xanthones from $G$. travancorica fruits, leaves and stem bark. The essential oil composition of the leaves, stem bark and fruit of $G$. travancorica revealed the plant as a rich source of essential oils and the oils were predominated by the presence of aliphatic hydrocarbon $n$ - undecane.

\section{References}

1. A. P. Anu Aravind, K. R. T. Asha and K. B. Rameshkumar. 2016. Phytochemical analysis and antioxidant potential of the leaves of Garcinia travancorica Bedd. Nat. Prod. Res., 30 (2). 232-236.

2. Carvalho-Silva LB, do Vale Oliveira M, GontijoVS, Oliveira WF, Priscilla BMC, Derogis PBMC, Stringheta PC, Nagem TJ, Brigagao MRPL and dos Santos MH. 2012. Antioxidant, cytotoxic and antimutagenic activities of 7-epi-clusianone obtained from pericarp of Garcinia brasiliensis. Food Res. Int., 48: 180-186. 
3. Chin YW and Kinghorn AD. 2008. Structural characterization, biological effects, and synthetic studies on xanthones from mangosteen (Garcinia mangostana), a popular botanical dietary supplement. Mini. Rev. Org. Chem., 5(4), 355.

4. de Castro IVF, Negri G, Salatino A and Bandeira MFC. 2011. A new type of Brazilian propolis: Prenylated benzophenones in propolis from Amazon and effects against cariogenic bacteria. Food Chem., 125(3), 966-972.

5. de Souza Marques E, Silva S, Niero R, de Andrade SF, Rosa PCP, Perazzo FF and Maistro EL. 2012. Genotoxicity assessment of Garcinia achachairu Rusby (Clusiaceae) extract in mammalian cells in vivo. J. Ethnopharmacol., 142(2), 362-366.

6. Díaz-Carballo D, Gustmann S, Acikelli AH, Bardenheuer W, Buehler H., Jastrow H, Ergun S and Strumberg D. 2012. 7-epi-nemorosone from Clusia rosea induces apoptosis, androgen receptor down-regulation and dysregulation of PSA levels in LNCaP prostate carcinoma cells. Phytomedicine, 19(14), 1298-1306.

7. Elfita E, Muharni M, Latief M, Darwati D, Widiyantoro A, Supriyatna S, Bahti HH, Dachriyanus D, Cos P, Maes L, Foubert K, Apers S and Pieters L. 2009. Antiplasmodial and other constituents from four Indonesian Garcinia spp. Phytochemistry, 70(7), 907-912.

8. Formacek V and Kubeczka KH. 2002. Essential oil analysis by capillary gas chromatography and carbon-13 NMR spectroscopy. Second edition. John Wiley \& Sons, NewYork.

9. Hemshekhar M, Sunitha K, Santhosh M S, Devaraja S, Kemparaju K, Vishwanath BS, Niranjana SR and Girish KS. 2011. An overview on genus Garcinia: Phytochemical and therapeutical aspects. Phytochem. Rev., 10(3), 325-351.

10. Hora RR, Ionescu-Hirsh A, Simon T, Delabie J, Robert J, Fresneau D and Hefetz A. 2008. Postmating changes in cuticular chemistry and visual appearance in Ectatomma tuberculatum queens (Formicidae: Ectatomminae). Naturwissenschaften, 95(1), 55-60.

11. Kapadia GJ, Oguntimein B and Shukla YN. 1994. High-speed counter-current chromatographic separation of biflavanoids from Garcinia kola seeds. J. Chromatogr. A, 673(1), 142-146.

12. Kim HP, Park H, Son KH, Chang HW, Kang SS. 2008. Biochemical pharmacology of biflavonoids: Implications for anti-inflammatory action. Arch. Pharm. Res., 31, 265-273.

13. Konishi Y, Kiyota T, Draghici C, Gao JM, Yeboah F, Acoca S, Jarussophon S and Purisima E. 2007. Molecular formula analysis by an MS/MS/MS technique to expedite dereplication of natural products. Anal. Chem., 79(3), 1187-1197.

14. Kumar S, Chattopadhyay SK, Darokar MP, Garg A and Khanuja SP. 2007. Cytotoxic activities of xanthochymol and isoxanthochymol substantiated by LC-MS/MS. Planta Med., 73(14), 1452-1456.

15. Kumar S, Sharma S and Chattopadhyay SK. 2013. Rapid and sensitive HPLC-PDA method for simultaneous identification and quantification of dietary weight reducing compound hydroxy citric acid lactone and chemo preventive compounds isoxanthochymol and xanthochymol in Garcinia indica. Int. Food Res. J., 20(1), 397-402.

16. Majeed M, Rosen R, Mc Carty M, Conte A, Patil D and Butrym E. 1994. Citrin; A revolutionary, herbal approach to weight management. New Editions Publishing, California.

17. Mohanan N and Sivadasan M. 2002. Flora of Agasthyamala. Bishen Singh MahendraPal Singh, Dehradun, India. 
18. Osorio E, Londono J and Bastida J. 2013. Low-Density Lipoprotein (LDL)-Antioxidant Biflavonoids from Garcinia madruno. Molecules, 18, 6092-6100.

19. Padhye S, Ahmad A, Oswal N and Sarkar FH. 2009. Emerging role of Garcinol, the antioxidant chalcone from Garcinia indica Choisy and its synthetic analogs. J. Hematol. Oncol., 2(1), 1-13.

20. Peres V, Nagem TJ and de Oliveira FF. 2000. Tetraoxygenated naturally occurring xanthones. Phytochemistry, 55(7), 683-710.

21. Phonde RY and Magdum CS. 2015. Hyphenated techniques: An overview. Int. J. Univers. Pharm. Life Sci., 4(3), 1-37.

22. Rao AR, Venkatswamy G and Pendse D. 1980. Camboginol and cambogin. Tetrahedron Lett., 21(20), 1975-1978.

23. Rastogi RP and Mehrotra BN. 1990. Compendium of Indian Medicinal Plants. Central Drug Research Institute, Lucknow and National Institute of Science Communication, Council of Scientific and Industrial Research, New Delhi, 1, pp.434-436.

24. Rosenberg E. 2003. The potential of organic (electrospray-and atmospheric pressure chemical ionisation) mass spectrometric techniques coupled to liquid-phase separation for speciation analysis. J. Chromatogr. A, 1000(1), 841-889.

25. Sahu A, Das B and Chatterjee A. 1989. Polyisoprenylated benzophenones from Garcinia pedunculata. Phytochemistry, 28(4), 1233-1235.

26. Sappington TW and Taylor OR. 1990. Developmental and environmental sources of pheromone variation in Colias eurytheme butterflies. J. Chem. Ecol., 16 (9), 2771-2786.

27. Schiestl FP, Ayasse M, Paulus HF, Löfstedt C, Hansson BS, Ibarra F and Francke W. 2000. Sex pheromone mimicry in the early spider orchid (Ophrys sphegodes): Patterns of hydrocarbons as the key mechanism for pollination by sexual deception. J. Comp. Physiol. A, 186(6), 567-574.

28. Shen YF, Zhang R, Moor RJ, Kim J, Metz TO, Hixson KK, Zhao R, Livesay EA, Udseth HR and Smith RD. 2005. Automated $20 \mathrm{kpsi}$ RPLC-MS and MS/MS with chromatographic peak capacities of 1000-1500 and capabilities in proteomics and metabolomics. Anal. Chem., 77, 3090-3100.

29. Shu YZ. 1998. Recent natural products based drug development: A pharmaceutical industry perspective. J. Nat. Prod., 61(8), 1053-1071.

30. Waterman PG and Hussain RA. 1983. Systematic significance of xanthones, benzophenones and biflavonoids in Garcinia. Biochem. Sys. Ecol., 11(1), 21-28.

31. Williams RB, Hoch J, Glass TE, Evans R, Miller JS, Wisse JH and Kingston DG. 2003. A novel cytotoxic guttiferone analogue from Garcinia macrophylla from the Suriname rainforest. Planta Med., 69(9), 864-866.

32. Xu G, Feng C, Zhou Y, Han QB, Qiao CF, Huang SX, Chang DC, Zhao QS, Luo KQ and Xu HX. 2008. Bioassay and ultraperformance liquid chromatography/mass spectrometry guided isolation of apoptosis-inducing benzophenones and xanthone from the pericarp of Garcinia yunnanensis Hu. J. Agric. Food Chem., 56(23), 11144-11150.

33. Yamaguchi F, Ariga T, Yoshimura Y and Nakazawa H. 2000. Antioxidative and antiglycation activity of garcinol from Garcinia indica fruit rind. J. Agric. Food Chem., 48(2), 180-185. 


\title{
Chapter 5
}

\section{Leaf volatile chemical profiles of Garcinia species in the Western Ghats}

\author{
K. B. Rameshkumar ${ }^{*}$, A. P. Anu Aravind and Lekshmi N Menon \\ Phytochemistry and Phytopharmacology Division \\ Jawaharlal Nehru Tropical Botanic Garden and Research Institute \\ Palode, Thiruvananthapuram-695562, Kerala, India \\ * Corresponding author
}

\begin{abstract}
The volatile chemical profiles of nine Garcinia species occurring naturally in the Western Ghats (G. gummi-gutta, G. imberti, G. indica, G. morella, G. pushpangadaniana, G. rubroechinata, G. talbotii, G. travancorica and G. wightii) were studied for the first time. The leaf volatile chemicals were isolated by hydrodistillation and analyzed by GC-FID, GC-MS and ${ }^{13} \mathrm{C}$ NMR. The oil yield varied from $0.75 \% \mathrm{v} / \mathrm{w}(G$. travancorica) to $0.01 \% \mathrm{v} / \mathrm{w}$ ( $G$. pushpangadaniana). A total of 99 volatile compounds were identified, of which sesquiterpenoids derived from the mevalonic acid pathway were the predominant class of compounds distributed in all the Garcinia species. The sesquiterpene hydrocarbon $\alpha-$ copaene, which is present in all the Garcinia species studied, can be considered as the marker compound for the genus. In addition, specific marker compounds were also determined for the Garcinia species studied. The distribution of volatile compounds was analyzed by statistical methods and differentiation of the species was done by cluster analysis. Comparison with morphological classification revealed that the volatile chemical profiles were not related to the taxonomic classification of the genus, but rather to ecological interactions.
\end{abstract}

Keywords: Garcinia, Leaf essential oil, GC-MS, Chemotaxonomy, $\alpha$-Copaene

\section{Introduction}

Garcinia species are an important component of the forest flora of the Western Ghats and some of the species are economically important as well. Nine Garcinia species were distributed wildly in the Western Ghats region, of which 7 species are endemic to the region (Table 1) (Maheswari, 1964, Sabu et al., 2013). The genus Garcinia is well reputed as a source of valuable non wood forest products such as fats, oils, resins and colouring materials. Fruits of some Garcinia species are rich source of red pigments in the plant kingdom. Camboge, the yellow colouring pigment, is a well known product from Garcinia species. Recently, Garcinia species have received considerable attention worldwide from the scientific as well as industrial sectors due to the report of several bioactive structures such as biflavonoids, xanthones and benzophenones (Hemshekhar et al., 2011). In south India, G. gummi-gutta and G. indica were cultivated for commercial extraction of a variety of value added products such as bioactive acids, nutraceuticals, fats and condiments (Parthasarathy et al., 2013). 
Although most of the species of the family Clusiaceae are known for their oil glands and secretary canals, literature review revealed that the reports on essential oils from Garcinia species are rare (Macleod and Pieris, 1982, Onayade, et al., 1998, Rameshkumar et al., 2005, Martins et al., 2008). Essential oils are complex mixtures of steam volatile chemical compounds, isolated generally by hydrodistillation of crude plant material. Essential oils occur in specialized secretary structures such as resin canals, lysigenous cavities, epidemic cells, glandular hairs, schizogenous passages, modified parenchymal cells or in oil tubes called vittae, in different plant parts such as buds, flowers, leaves, stems, twigs, seeds, fruits, roots, wood and bark (Handa, 2008). Majority of the volatile chemical constituents belong to the structural types terpenoids and phenylpropanoids, synthesized through the mevalonic acid pathway and shikimic acid pathway respectively. Different secondary metabolites present in these complex mixtures play diverse role in plants as antimicrobial, insecticidal and also as attractors of pollinating agents.

The present chapter discusses the volatile chemical profiles of Garcinia species of the Western Ghats and explores the possibility of evaluating species relationships through chemotaxonomy and to identify marker compounds for Garcinia species. Possible chemical ecological interactions were also discussed in the chapter.

\section{Essential oil yield of Garcinia species}

Fresh leaves of 9 Garcinia species, collected from different parts of the Western Ghats, were hydrodistilled using Clevenger type apparatus for $3 \mathrm{~h}$ each. Comparison of essential oil yield (Table 1) revealed that $G$. travancorica possess maximum oil content $(0.75 \% \mathrm{v} / \mathrm{w})$, while $G$. pushpangadaniana possess the least oil content $(0.01 \% \mathrm{v} / \mathrm{w})$. G. imberti can also be considered as a rich source of essential oil $(0.70 \% \mathrm{v} / \mathrm{w})$. It is interesting to note that the three endemic Garcinia trees to Agasthyamala forests viz; G. travancorica G. imberti and $G$. rubro-echinata that occur at high altitudes possess high oil yield. However, the altitude is not a detrimental factor in essential oil yield, as evident from Table $\mathbf{1 .}$

Table 1. Essential oil yield of fresh leaves of Garcinia species from the Western Ghats

\begin{tabular}{|c|c|c|c|c|c|}
\hline $\begin{array}{l}\text { Sl. } \\
\text { No. }\end{array}$ & Garcinia species & $\begin{array}{l}\text { Herbariu } \\
\text { m No. }\end{array}$ & Location, District & Altitude & $\begin{array}{l}\text { Essential oil } \\
\text { yield }(\% \mathrm{v} / \mathrm{w})\end{array}$ \\
\hline 1 & G. gummi-gutta & 66446 & Vaikom, Kottayam & $50 \mathrm{~m}$ & 0.07 \\
\hline 2 & G. imberti & 66416 & $\begin{array}{l}\text { Agastyamala forests, } \\
\text { Thiruvananthapuram }\end{array}$ & $994 \mathrm{~m}$ & 0.70 \\
\hline 3 & G. indica & 66423 & Thaliparampa, Kannur & $75 \mathrm{~m}$ & 0.03 \\
\hline 4 & G. morella & 66418 & $\begin{array}{l}\text { Agastyamala forests, } \\
\text { Thiruvananthapuram }\end{array}$ & $650 \mathrm{~m}$ & 0.45 \\
\hline 5 & G. pushpangadaniana & 66421 & Kadalar, Munnar, Idukki & $1401 \mathrm{~m}$ & 0.01 \\
\hline 6 & G. rubro-echinata & 66419 & $\begin{array}{l}\text { Agastyamala forests, } \\
\text { Thiruvananthapuram }\end{array}$ & $1074 \mathrm{~m}$ & 0.33 \\
\hline 7 & G. talbotii & 72622 & Pampa, Pathanamthitta & $224 \mathrm{~m}$ & 0.50 \\
\hline 8 & G. travancorica & 66417 & $\begin{array}{l}\text { Agastyamala forests, } \\
\text { Thiruvananthapuram }\end{array}$ & $1168 \mathrm{~m}$ & 0.75 \\
\hline 9 & G. wightii & 50987 & $\begin{array}{l}\text { Athirapally Vazhachal, } \\
\text { Thrissur }\end{array}$ & $149 m$ & 0.03 \\
\hline
\end{tabular}


The present observation on oil yield warrants detailed study on the distribution and nature of the secretary structures of Garcinia species in the Western Ghats (Esau 1965 and Schofield 1968). In a previous study, among the 10 Sri Lankan Garcinia species, G. morella and G. spicata stand out from the rest of the Sri Lankan Garcinia taxa on the basis that secretary spaces were observed in the palisade tissue rather than in the spongy tissue of lamina (Pathirana, 2004).

\section{Analysis of essential oils}

The essential oils were analyzed by GC-FID, GC-MS and ${ }^{13} \mathrm{C}$ NMR. GC-FID analyses were carried on a Shimadzu GC-2010 Plus Gas Chromatograph (Shimadzu, Japan), fitted with an Rxi-5 Sil MS capillary column (5\% phenyl and 95\% dimethyl polysiloxane, $30 \mathrm{~m}$ x $0.25 \mathrm{~mm}$, $0.25 \mu \mathrm{m}$ film thickness, Restek USA). $1 \mu \mathrm{L}$ of the diluted oil in diethyl ether (1:50 dilution) were injected in both GC-FID and GC-MS under splitless condition. GC operation conditions: injector temperature, $270^{\circ} \mathrm{C}$; oven temperature programme, $60-250^{\circ} \mathrm{C}\left(3^{\circ} \mathrm{C} / \mathrm{min}\right)$; hold time $2 \mathrm{~min}$. at $250^{\circ} \mathrm{C}$; carrier gas, $\mathrm{N}_{2}$ at $3 \mathrm{~mL} / \mathrm{min}$; detector temperature $270^{\circ} \mathrm{C}$. Relative percentages of cinnamaldehyde were obtained from the peak area percent report of volatiles from GC-FID data.

GC-MS analysis was done on a Hewlett Packard 6890 Gas Chromatograph fitted with an HP-5 (5\% phenyl 95\% dimethyl polysiloxane, $30 \mathrm{~m} \times 0.32 \mathrm{~mm}, 0.25 \mu \mathrm{m}$ film thickness) capillary column, coupled with a Model 5973 mass detector. GC-MS operation conditions: injector temperature, $220^{\circ} \mathrm{C}$; transfer line, $240^{\circ} \mathrm{C}$; oven temperature programme, $60-250^{\circ} \mathrm{C}$ $\left(3^{\circ} \mathrm{C} / \mathrm{min}\right)$; carrier gas, He at $1.4 \mathrm{~mL} / \mathrm{min}$. Mass spectra: Electron Impact $(\mathrm{EI}+)$ mode, $70 \mathrm{eV}$ with a mass range of 40 to $450 \mathrm{~m} / \mathrm{z}$; ion source temperature, $240^{\circ} \mathrm{C}$. Relative retention indices (RRIs) of the constituents in HP-5 column were determined using standard C6-C30 hydrocarbons (Aldrich Chemical Company, USA) (Dool and Kratz, 1963). Individual components were identified by Wiley 275.L and NIST 05.L database matching, Co-GC with authentic standards, comparison of retention indices and comparison of mass spectra of constituents with published data (Adams, 2007). ${ }^{13} \mathrm{C}$ NMR was also used for confirmation of structures. A total of 99 compounds were identified from the essential oils of 9 Garcinia species (Table 2).

Table 2. Composition of the essential oils of the leaves of 9 Garcinia species in the Western Ghats

\begin{tabular}{|l|l|l|l|l|l|l|l|l|l|l|}
\hline Compound & $\mathrm{RI}_{\text {lit }}$ & G. gg & G. im & G. in & G. $m$ r & G. $p s$ & G. re & G. $t$ l & G. tr & G. wg \\
\hline Myrcene & 988 & & & & 0.1 & & & & & \\
\hline Z- $\beta$-Ocimene & 1032 & & & & & 0.2 & & & & \\
\hline E- $\beta$-Ocimene & 1044 & 1.1 & & & & & & & & \\
\hline Terpinolene & 1086 & 0.2 & & & & & & & & \\
\hline Linalool & 1095 & & & & & 1.8 & & & & \\
\hline n-Undecane & 1100 & & & & & & & & 40.1 & \\
\hline Terpineol & 1186 & & & & & 0.4 & & & & \\
\hline Ascaridiole & 1234 & & & & 0.1 & & & & & \\
\hline Geraniol & 1249 & & & & & 0.4 & & & & \\
\hline$\delta$-Elemene & 1338 & & 0.1 & & 1.1 & 0.3 & 0.4 & & & 2.4 \\
\hline$\alpha$-Cubebene & 1348 & 0.4 & 0.3 & 1.2 & & 0.7 & & 0.7 & & \\
\hline Cyclosativene & 1371 & 1.3 & & & & & & & & \\
\hline$\alpha$-Ylangene & 1373 & & 0.3 & & & 0.8 & & & 1.0 & \\
\hline
\end{tabular}




\begin{tabular}{|c|c|c|c|c|c|c|c|c|c|c|}
\hline$\alpha$-Bourbonene & 1374 & & & 4.1 & & & & & & \\
\hline$\alpha$-Copaene & 1376 & 30.2 & 0.4 & 1.2 & 1.3 & 3.1 & 0.2 & 27.0 & 15.8 & 1.7 \\
\hline$\beta$-Panasinsene & 1381 & 1.3 & & & & & & & & \\
\hline$\beta$-Bourbonene & 1387 & & & & & 6.8 & & 0.1 & & \\
\hline$\beta$-Cubebene & 1387 & & 0.3 & & & 0.4 & & & & \\
\hline$\beta$-Elemene & 1390 & & & & & & & & & 0.9 \\
\hline$\alpha$-Gurjunene & 1409 & 0.3 & & & & & & & & 3.1 \\
\hline$\beta$-Funebrene & 1414 & & & & & & & & 3.3 & \\
\hline$\beta$-Caryophyllene & 1419 & 5.7 & 38.1 & 18.6 & 0.1 & 11.4 & 37.9 & 30.4 & 4.0 & 19.0 \\
\hline$\beta$-Copaene & 1430 & 1.3 & 0.4 & 1.6 & 49.4 & & & 0.1 & & \\
\hline$\alpha$-trans Bergamotene & 1434 & & & & & & 0.8 & & 1.8 & \\
\hline$\beta$-Gurjunene & 1433 & & & & 0.1 & & & 2.2 & & 1.2 \\
\hline$\gamma$-Elemene & 1434 & 2.1 & & & & 0.4 & & & & \\
\hline$\alpha$-Guaiene & 1437 & 0.3 & & & 0.1 & & & & & \\
\hline Aromadendrene & 1439 & & & 0.5 & 2.8 & 1.1 & & 1.6 & & 6.8 \\
\hline $\begin{array}{l}\text { cis- Muurola- 3,5- } \\
\text { diene }\end{array}$ & 1448 & 0.8 & & & & & & & & \\
\hline$\alpha$-Himachalene & 1451 & & & & & & & & 3.1 & \\
\hline Amorpha 4, 11- diene & 1451 & 0.4 & & & & & & & 2.2 & \\
\hline$\alpha$-Humulene & 1452 & 1.8 & 30.5 & 17.6 & 18.5 & 3.2 & 40.6 & 10.7 & 0.1 & 4.6 \\
\hline Allo aromadendrene & 1458 & & 5.5 & & 0.1 & & & & & 2.9 \\
\hline $\begin{array}{l}\text { cis Cadina-1(6)-4- } \\
\text { diene }\end{array}$ & 1461 & 0.9 & & & & 1.4 & & 0.1 & 2.4 & \\
\hline$\alpha$-Acoradiene & 1464 & & 0.3 & & & & & 0.1 & & \\
\hline $\begin{array}{l}9 \text { epi E- } \\
\text { Caryophyllene }\end{array}$ & 1466 & & & & & & & & & 0.5 \\
\hline$\beta$-Acoradiene & 1469 & & 4.5 & & & & & & & \\
\hline $\begin{array}{l}\text { 4,5-di epi- } \\
\text { Aristalochene }\end{array}$ & 1471 & & & 0.6 & & & & & & \\
\hline$\gamma$-Gurjunene & 1475 & & & & & & & 3.1 & & \\
\hline $\begin{array}{l}\text { trans Cadina-1 (6), 4- } \\
\text { diene }\end{array}$ & 1476 & 0.9 & & & & & & & 1.0 & \\
\hline$\gamma$-Muurolene & 1478 & 4.3 & & 5.9 & & 11.7 & 7.2 & 3.8 & & \\
\hline $\begin{array}{l}\text { Amorpha- 4,7(11)- } \\
\text { diene }\end{array}$ & 1480 & 0.5 & & & & & & & & \\
\hline$\gamma$-Himachalene & 1482 & & & & & & & & 2.3 & 1.1 \\
\hline$\alpha$-Amorphene & 1483 & & & & & & & 1.3 & & \\
\hline$\beta$-Selinene & 1489 & 1.1 & & 12.3 & & 0.6 & & & & \\
\hline cis $\beta$-Guaiene & 1492 & & 0.1 & & & & & & & \\
\hline$\delta$-Selinene & 1492 & & & & & 0.9 & & & & \\
\hline$\gamma$-Amorphene & 1495 & & & & & 2.6 & & & & \\
\hline$\alpha$-Selinene & 1498 & 1.5 & & 18.2 & & & & & & \\
\hline$\beta$-Alaskene & 1498 & & 2.5 & & & & & & 3.8 & \\
\hline Bicyclogermacrene & 1500 & & & & & & 3.6 & & & 22.6 \\
\hline$\alpha$-Muurolene & 1500 & 1.5 & & & & 3.7 & & & & \\
\hline$\beta$-Bisabolene & 1505 & & & & & & 0.5 & & & \\
\hline E- $\gamma$-Bisabolene & 1507 & & 0.1 & & & & & & & \\
\hline Germacrene A & 1508 & 0.6 & & & & & & & & \\
\hline
\end{tabular}




\begin{tabular}{|c|c|c|c|c|c|c|c|c|c|c|}
\hline$\alpha$-Bulnesene & 1509 & & & & & & 0.2 & & & \\
\hline$\delta$-Amorphene & 1511 & & 0.4 & & 0.5 & 1.2 & 0.3 & & 7.0 & \\
\hline$\gamma$-Cadinene & 1513 & 3.4 & & 4.6 & & 12.4 & & & & 0.5 \\
\hline 7 epi $\alpha$-Selinene & 1520 & & & & & & & & & 1.9 \\
\hline$\delta$-Cadinene & 1522 & 32.4 & & 5.3 & & 13.1 & & & 4.5 & \\
\hline $\begin{array}{l}\text { trans Cadina 1,4- } \\
\text { diene }\end{array}$ & 1533 & 0.7 & & 0.8 & & 1.0 & & 0.1 & & \\
\hline Cadina-1(2),4-diene & 1535 & & & & & & & 0.9 & & \\
\hline$\alpha$-Cadinene & 1537 & 0.5 & & 0.7 & & 1.4 & & 0.1 & & \\
\hline $\begin{array}{l}\text { Cadala-1(10),3,8- } \\
\text { triene }\end{array}$ & 1540 & & & & & & & 0.3 & & \\
\hline$\alpha$-Calacorene & 1544 & 0.5 & & 0.5 & & 1.2 & & & & \\
\hline Selina-3,7(11) diene & 1545 & & & & 0.2 & & & & & \\
\hline Elemol & 1548 & & & 0.3 & & & & & & \\
\hline Germacrene B & 1559 & 0.3 & 0.3 & & 0.8 & 0.4 & & & & \\
\hline E-Nerolidol & 1561 & & & & & 0.4 & & & & \\
\hline Maaliol & 1566 & & & & & & 0.2 & & & 2.0 \\
\hline $\begin{array}{l}\text { Caryophyllenyl } \\
\text { alcohol }\end{array}$ & 1570 & & & 0.9 & & & & & & \\
\hline Epiglobulol & 1576 & & & & & & & 0.2 & & \\
\hline Spathulenol & 1577 & & & & 0.1 & & & & & 1.9 \\
\hline Caryophyllene oxide & 1582 & & 0.3 & & 6.7 & 0.8 & & 2.6 & & \\
\hline Globulol & 1590 & & & & 1.9 & & 0.7 & 0.1 & & 6.0 \\
\hline Viridiflorol & 1592 & & & & & & 0.1 & & & 5.5 \\
\hline $\begin{array}{l}\text { 3,7-Cyclo } \\
\text { undecadiene 1-ol, } \\
\text { 1,5,5,8-tetramethyl }\end{array}$ & 1584 & & & 1.4 & & & & & & \\
\hline Cubeban-11-ol & 1595 & & & & 0.1 & & & 0.1 & & \\
\hline Widdrol & 1599 & & & & 0.1 & & & & & \\
\hline Rosifoliol & 1600 & & & & 1.2 & & 0.5 & & & \\
\hline Humulene epoxide II & 1608 & & & & 0.7 & & & 0.5 & & \\
\hline Junenol & 1618 & & & & & & 0.2 & & & \\
\hline 1,10-di epi Cubenol & 1618 & & 0.1 & & & & & 1.2 & & \\
\hline$\alpha$-Corocalene & 1622 & & & & & 0.2 & & & & \\
\hline 1-epi-Cubenol & 1627 & & & & & 1.5 & 0.1 & 0.1 & & \\
\hline $\begin{array}{l}\text { Muurola-4,10 (14)- } \\
\text { diene-1- } \beta \text {-ol }\end{array}$ & 1630 & & & & & & & & & 1.0 \\
\hline$\gamma$-Eudesmol & 1630 & & & 0.3 & & & & & & \\
\hline cis-Cadina-4-en-7-ol & 1635 & & & & & 0.9 & & & & \\
\hline $\begin{array}{l}\text { Caryophylla- } \\
4(12), 8(13) \text { diene }\end{array}$ & 1639 & & & & & & & 0.1 & & \\
\hline epi- $\alpha$-Muurolol & 1640 & & & 0.3 & & & 0.4 & & & \\
\hline$\alpha$-Muurolol & 1644 & 0.4 & & & & 0.5 & & 0.2 & & \\
\hline Cubenol & 1645 & 0.2 & 0.1 & & & & & 0.8 & & \\
\hline$\alpha$-Cadinol & 1652 & & & & & 0.9 & 0.3 & 0.1 & & \\
\hline Selin-11-en-4 $\alpha$-ol & 1659 & & & & & & & & & 0.5 \\
\hline $\begin{array}{l}\text { 14- Hydroxy (Z)- } \\
\text { caryophyllene }\end{array}$ & 1666 & & & & & & & 0.5 & & \\
\hline $\begin{array}{l}\text { 14- Hydroxy 9-epi-E- } \\
\text { caryophyllene }\end{array}$ & 1668 & & & & & & & 0.1 & & \\
\hline
\end{tabular}




\begin{tabular}{|c|c|c|c|c|c|c|c|c|c|c|}
\hline $\begin{array}{l}\text { Germacra- } 4(15), 5,10 \\
\text { (14) trien- } 1-\alpha \text {-ol }\end{array}$ & 1685 & & & & & & & & & 0.7 \\
\hline$\delta$-Cedren-13-ol & 1688 & & & & & & & & & 0.7 \\
\hline $\begin{array}{l}\text { Amorpha 4,9-dien-2- } \\
\text { ol }\end{array}$ & 1700 & & & & & & & & & 0.2 \\
\hline Total \% & & 96.9 & 84.6 & 96.9 & 86.0 & 87.8 & 94.2 & 89.2 & 92.4 & 87.7 \\
\hline Total No (99) & & 30 & 19 & 21 & 21 & 34 & 18 & 30 & 15 & 23 \\
\hline Monoterpenoids & & 1.3 & Nil & Nil & 0.2 & 2.8 & Nil & Nil & Nil & Nil \\
\hline $\begin{array}{l}\text { Sesquiterpene- } \\
\text { hydrocarbons }\end{array}$ & & 95.0 & 84.1 & 93.7 & 75.0 & 79.8 & 91.7 & 82.6 & 52.3 & 69.2 \\
\hline $\begin{array}{l}\text { Sesquiterpene- } \\
\text { oxygenated }\end{array}$ & & 0.6 & 0.5 & 3.2 & 10.8 & 5.2 & 2.5 & 6.6 & Nil & 18.5 \\
\hline $\begin{array}{l}\text { Total } \\
\text { sesquiterpenoids }\end{array}$ & & 95.6 & 84.6 & 96.9 & 85.8 & 85.0 & 94.2 & 89.2 & 52.3 & 87.7 \\
\hline Aliphatic compounds & & & Nil & Nil & Nil & Nil & Nil & Nil & 40.1 & Nil \\
\hline
\end{tabular}

G.gg-G. gummi-gutta; G.im-G. imberti, G.in-G. indica; G.mr-G. morella; G.ps-G. pushpangadaniana; G.re-G. rubro-echinata; G.tl-G. talbotii; G.wg-G.wightii; G.tr-G.travancorica; RRI: Relative retention index calculated on HP-5 column.

The ubiquitous sesquiterpene hydrocarbons $\beta$-caryophyllene and the isomeric compound $\alpha$ humulene were present in all the Garcinia species. The maximum content of $\beta$-caryophyllene was in G. imberti (38.1\%), followed by G. rubro-echinata (37.9\%), G. talbotii $(30.4 \%), G$. wightii (19.0\%), G. indica (18.6\%) and G. pushpangadaniana (11.4\%). Except in G. rubroechinata and G. morella, $\beta$-caryophyllene was in higher amount compared to $\alpha$-humulene. $\alpha$ Humulene was present in significant quantity in G. rubro-echinata $(40.6 \%)$, G. imberti (30.5\%), G. indica (17.6\%), G. morella (18.5\%) and G. talbotii $(10.7 \%)$.

$\alpha$-Copaene was the major compound in G. gummi-gutta (30.2\%), G. talbotii $(27.0 \%)$ and G. travancorica (15.8\%). $\beta$-Copaene was the major compound in G. morella $(49.4 \%)$. $\alpha$ Selinene and $\beta$-selinene were present in significant quantity in G. indica (18.2 and $12.3 \%$ respectively). $\delta$-Cadinene (13.1\%), $\gamma$-cadinene (12.4\%) and $\gamma$-muurolene (11.7\%) were predominant in G. pushpangadaniana. Bicyclogermacrene $(22.6 \%)$ was characteristically present in significant quantity in G. wightii.

Though petrochemicals are the raw materials for synthetic perfumery chemicals, natural isolates from plant sources are preferred over synthetics in many aspects and discovery of novel sources of natural aroma chemicals has a detrimental role in flavor and fragrance industries. Garcinia species of the Western Ghats can be considered as a rich source of volatile chemicals such as caryophyllene, humulene and undecane.

\section{Biosynthetic pathways of volatile chemicals in Garcinia species}

Three distinct chemical groups viz; monoterpenoids, sesquiterpenoids and aliphatic hydrocarbons could be characterized in the volatile chemicals of Garcinia species. An evaluation of the biosynthetic pathways of the volatile chemicals revealed that sesquiterpenoids derived from mevalonic acid pathway were the predominant volatile chemicals (Figure 1) (David, 1999). 


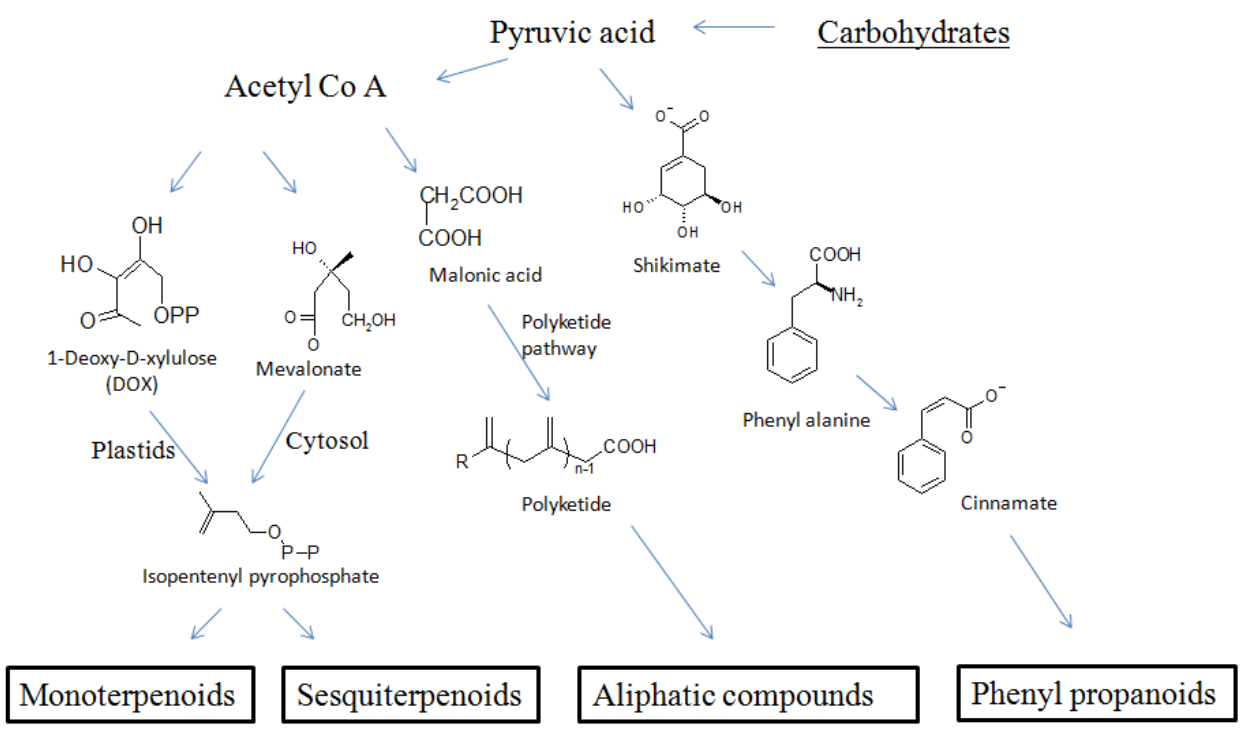

Figure 1. General biosynthetic pathways of different classes of volatile chemicals in Garcinia species

\section{4. $\alpha$-Copaene- The volatile chemical marker compound for the genus Garcinia}

Biosynthesis of essential oil and volatile chemicals is a genetically determined attribution and it is possible to trace common progenies for volatile chemicals in related taxa. The volatile chemical profile analysis suggested that the sesquiterpene hydrocarbon $\alpha$-copaene, can be considered as chemotaxonomic marker compound for the Garcinia species in the Western Ghats. Though $\beta$-caryophyllene and $\alpha$-humulene were present in all the Garcinia species studied, the compounds are ubiquitous in most of the aromatic plants. The characteristic compound $\alpha$-copaene with an unusual tricyclic decane ring system, that is present in all the Garcinia species studied, has been selected as the marker compound for the genus. The structure of $\alpha$-copaene was unambiguously identified through ${ }^{13} \mathrm{C}$ NMR spectroscopic studies. ${ }^{13} \mathrm{C}$ NMR has now been evolved as a reliable tool for identification of volatile constituents in crude essential oils, where the Identification by ${ }^{13} \mathrm{C}$ NMR was carried out by comparison of the ${ }^{13} \mathrm{C}$ NMR signals of the total oil to the ${ }^{13} \mathrm{C}$ NMR signals for pure compounds compiled in our laboratory and available in the literature (Kubeczka and Formacek, 2002). The major compounds can unambiguously be identified by ${ }^{13} \mathrm{C}$ NMR taking into account the number of identified carbons, the number of overlapped signals and the difference of chemical shift of each resonance in the mixture and in the reference spectra. Further, $\alpha$-copaene was isolated from the plants and the structure was confirmed through ${ }^{13} \mathrm{C}$ NMR studies of the isolated compound (Figure 2). $\alpha$-Copaene exists as 2 isomeric forms, $\alpha$-copaene and $\alpha$-ylangene with different properties (Figure 3). $\alpha$-Copaene, has been reported to be attractive to the Mediterranean fruit fly Ceratitis capitata, a highly destructive pest to several crops, while the attractive property of its isomeric form $\alpha$-ylangene has not been confirmed in the fields. Through GC-MS it is quite difficult to differentiate the isomeric forms due to their close similarity in mass fragmentation pattern as well as close RRI values and $\alpha$-copaene reported from various sources through GC-MS analysis might be a 
mixture of $\alpha$-copaene and $\alpha$-ylangene. The structure of $\alpha$-copaene was unambiguously differentiated from its stereoisomeric form $\alpha$-ylangene by ${ }^{13} \mathrm{C}$ NMR. The ${ }^{13} \mathrm{C}$ chemical shifts of C-2 and C-6 of $\alpha$-copaene showed striking differences of nearly $11 \mathrm{ppm}$ from that of $\alpha$ ylangene, enabling their differentiation through ${ }^{13} \mathrm{C}$ NMR (Buyck et al., 1989).

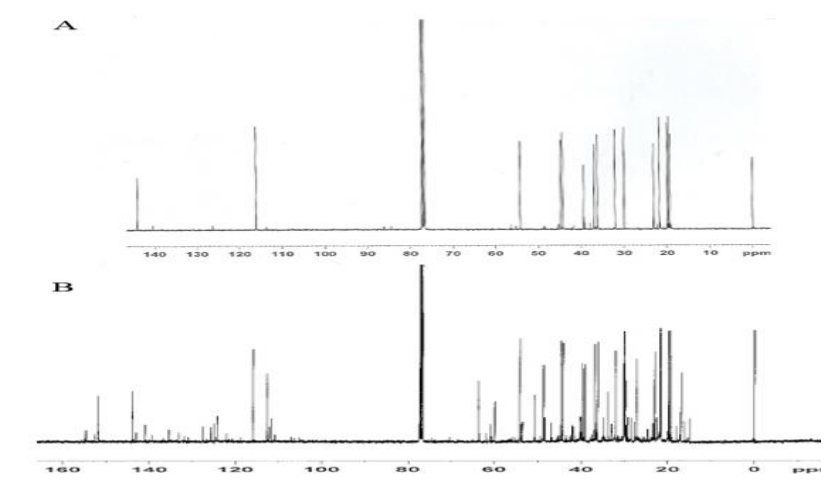

Figure 2. ${ }^{13} \mathrm{C}$ NMR of $\alpha$-copaene (A) and Garcinia talbotii leaf essential oil (B).
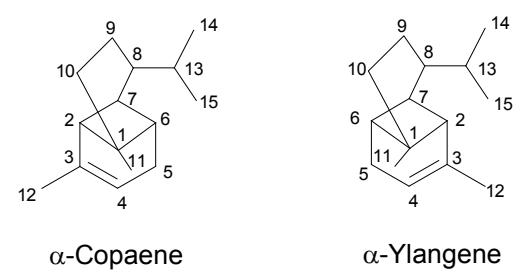

Figure 3. Structures of $\alpha$-copaene and $\alpha$-ylangene

\section{Chemotaxonomic marker compounds for Garcinia species}

Among the different volatile chemicals detected from Garcinia species, chemotaxonomic marker compounds were identified based on their uniqueness in the species. The marker compound may not be the major compound present in the species, but the uniqueness in chemical structure and biosynthetic pathway along with their presence in the species make the compound marker for the species. The consistency of the compound has been confirmed by analyzing at least 4 different accessions from different bio-geographical locations. The aliphatic compound n-undecane was exclusively present in G. travancorica and was also the major compound in the species. Other marker compounds identified were $\delta$-Cadinene $(G$. gummi-gutta), $\beta$-caryophyllene ( $G$. imberti), $\alpha$-selinene $(G$. indica), $\beta$-copaene $(G$. morella), $\beta$-bourbonene (G. pushpangadaniana), $\alpha$-copaene $(G$. talbotii) and bicyclogermcrene $(G$. wightii).

\section{Chemotaxonomy of Garcinia species based on volatile chemical profile}

The systematics of Garcinia species primarily depends on analysis of reproductive morphological features and the genus is often considered as a taxonomically difficult group due to the dioceous nature of plants and strict seasonality in flowering and fruiting 
(Nimanthika and Kaththriarachchi, 2010). Combined multidisciplinary analysis of various tools such as vegetative and reproductive morphology, anatomy, molecular as well as chemotaxonomy will yield more robust phylogeny of this group. A comprehensive study on the vegetative anatomy has been carried out to assess the phylogenetic relationships of the genus Garcinia (Pathirana, 2004). Molecular analysis has also been reported as effective in such phylogenetic studies (Sweeney, 2008). The use of distribution patterns of secondary metabolites is well established as a major tool for characterize, classify and describe taxa. The vast information of secondary metabolites can also be utilized for investigating population structures, species and phyletic relationships and evolutionary status. The genus Garcinia is characterized by the presence of a large number of secondary metabolites with diverse structural features such as xanthones, benzophenones, biflavonoids and terpenoids. Several attempts have been made to evaluate the phylogeny among Clusiaceae members through secondary metabolite profiling (Waterman and Hussain, 1983, Nogueira et al., 2001). Volatile chemicals can efficiently be utilized for chemotaxonomic purposes. Though environmental factors affect the chemical composition of the essential oils, these changes particularly influence the accumulation of essential oil, as terpenoids and phenyl propanoids are generally under strict genetic control (Hiltunen and Holm 1999).

The relative percentages of all the 99 components of the essential oils were taken as variables and submitted to cluster analysis to sub group Garcinia species using SPSS 16.0 software (SPSS Inc, USA). The derived dendrogram depicts the grouping based on their chemical compositions.

Similarity and cladistic analyses performed statistically based on the distribution of volatile chemicals delimited the Western Ghats Garcinia species in the dendrogram (Figure 4, Table 3). Among the 9 Garcinia species, G. travancorica was isolated from other species. The aliphatic hydrocarbon n-undecane derived from polyketide pathway was the major constituent of the leaf oil of $G$. travancorica, while in all other species, the major constituents were sesquiterpenoids derived from mevalonic acid pathway. G. morella was also distinct from other species by the high content of $\beta$-copaene. G. rubro-echinata and G. imberti were close to each other by the presence of $\beta$-caryophyllene and $\alpha$-humulene as the major compounds in both the species.

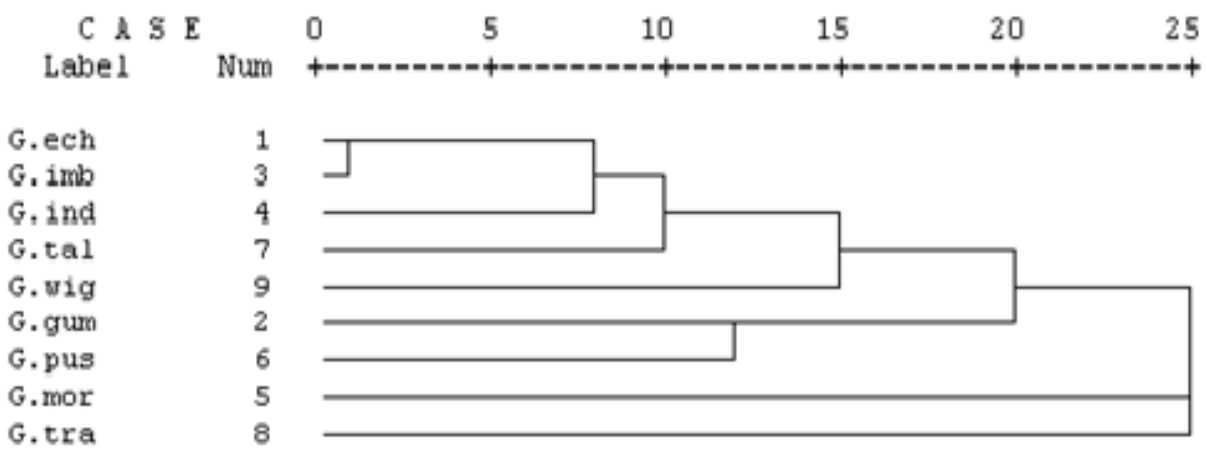

Figure 4. Dendrogram showing subgrouping of Garcinia species based on volatile chemical profile using between groups linkage (SPSS version 16.0) 
Table 3. Similarity matrix between nine Garcinia species of the Western Ghats

\begin{tabular}{|l|l|l|l|l|l|l|l|l|l|}
\hline \multirow{2}{*}{ Case } & \multicolumn{9}{|c|}{ Correlation between vectors of values } \\
\cline { 2 - 11 } & $1: 1$ & $2: 2$ & $3: 3$ & $4: 4$ & $5: 5$ & $6: 6$ & $7: 7$ & $8: 8$ & $9: 9$ \\
\hline $1: 1$ & 1.0000 & 0.0959 & 0.9664 & 0.7287 & 0.2322 & 0.4093 & 0.6665 & 0.0311 & 0.5284 \\
\hline $2: 2$ & 0.0959 & 1.0000 & 0.0943 & 0.2244 & 0.0233 & 0.5505 & 0.5101 & 0.2897 & 0.0620 \\
\hline $3: 3$ & 0.9664 & 0.0943 & 1.0000 & 0.7041 & 0.2024 & 0.3792 & 0.7017 & 0.0451 & 0.5316 \\
\hline $4: 4$ & 0.7287 & 0.2244 & 0.7041 & 1.0000 & 0.1822 & 0.4642 & 0.5117 & 0.0197 & 0.3368 \\
\hline $5: 5$ & 0.2322 & 0.0233 & 0.2024 & 0.1822 & 1.0000 & -0.0011 & 0.0853 & -0.0230 & 0.0289 \\
\hline $6: 6$ & 0.4093 & 0.5505 & 0.3792 & 0.4642 & -0.0011 & 1.0000 & 0.4203 & 0.0781 & 0.2236 \\
\hline $7: 7$ & 0.6665 & 0.5101 & 0.7017 & 0.5117 & 0.0853 & 0.4203 & 1.0000 & 0.2565 & 0.4688 \\
\hline $8: 8$ & 0.0311 & 0.2897 & 0.0451 & 0.0197 & -0.0230 & 0.0781 & 0.2565 & 1.0000 & 0.0181 \\
\hline $9: 9$ & 0.5284 & 0.0620 & 0.5316 & 0.3368 & 0.0289 & 0.2236 & 0.4688 & 0.0181 & 1.0000 \\
\hline
\end{tabular}

Comparison with morphological classification (Chapter 1) revealed that the composition of the leaf volatiles was not related to the taxonomic position of different Garcinia species. G. pushpangadaniana and G. talbotii are morphologically very similar with stamens in 5 phalanges and 5 set of sepals and petals and are placed as a separate clad in morphological classification. However, the volatile chemical composition was quite different in both the species, placing them in distant clads (Figure 4). Dendrograms based on end use related traits, such as oil composition, may be of practical interest related to ecological interactions, but do not necessarily correlate with taxonomy. Chemometric studies of the chemical composition of the floral volatiles of 16 species of the genus Clusia (family: Clusiaceae) revealed the composition was in part, but not always related to the taxonomic position of the genus, but to a minor extent to the type of pollinators visiting the flower (Nogueira et al., 2001). In the present study, it would be interesting to correlate the environmental and ecological factors to the leaf volatile profile, rather than the taxonomic positions based on morphological classifications.

\section{Chemical ecology of the volatile chemicals of Garcinia species}

Chemical ecology is an active, interdisciplinary field between chemistry and biology, dealing with the role of chemical compounds in interactions between organisms. Volatile organic compounds (VOCs) are important in chemical ecology and in plants, VOCs have important role in reproduction, by attracting and orienting pollinators and also as defense against feeding by ants, beetles and other insects (Huang et al., 2012). The present study of volatile organic compounds of Garcinia species revealed some interesting observations that can be related to chemical ecology.

High quantity of n-undecane with gasoline type odour may play a key role in pollination of G. travancorica, as the compound was reported to possess pheromone type character which attracts the flies, moths and ants (Schiestl, 2000). n-Undecane is the major pheromone found in Dufour's gland of the ant Camponotus obscuripes (Formicinae), while formic acid was the major component in the poison gland. When the ants sensed formic acid, they eluded the source of the odor; however, they aggressively approached odor of nundecane. The mutualism in any possible ant-plant interaction need to be studied on a chemical ecological basis.

The sesquiterpene E-caryophyllene, a major volatile compound in several Garcinia species has been reported as a defence compound against herbivores and pathogens (Huang et 
al., 2012). E-Caryophyllene is an important volatile sesquiterpene of plants that may serve as allelochemical to influence the neighboring plant growth or as an indirect defence to attract natural herbivore enemies (Wang et al., 2009). E-Caryophyllene is the major volatile organic compound in G. imberti and it is interesting to note that the diversity of other species in and around populations of $G$. imberti is much less, indicating possible allelopathic effect of the compound. E-caryophyllene has been reported as emitted from plants in response to herbivore attack. The compound has been reported as a semiochemical that attracts Asian lady beetle, Harmonia axyridis Pallas, a natural predator to aphids, the sap sucking plant lice.

\section{Conclusions}

The genus Garcinia is an important component of the forest flora of the Western Ghats and also an economically important group of plants. Even though 9 Garcinia species were distributed in the Western Ghats, none of them were previously investigated for their leaf volatile chemical constituents. Present study reports Garcinia species as a rich depository of essential oils. The chemotaxonomic relationships found in this study were not related to the taxonomic position of the genus based on morphological features. The volatile chemicals were rather evolved based on environmental and ecological interactions and the information may be useful in unraveling ecological interactions of Garcinia species.

\section{References}

1. Adams RP. 2007. Identification of Essential Oil Components by Gas Chromatography/Mass Spectrometry. Fourth edition. Allured Pub. Co., Carol Stream, IL.

2. De Buyck LF, De Pooter HL, Schamp NM, De Bruyn R, Zhang W, Budesinsky M and Motl O. 1989. Terpenes from Otacanthus coeruleus Lindl.: Identification of $\beta$-copaen$4 \alpha$-ol and a new criterion for discriminating between isomeric copaene and ylangene structures. Flavour Fragr. J., 4, 53-57.

3. David EC. 1999. Sesquiterpene Biosynthesis: Cyclisation Mechanisms. In: Comprehensive Natural Product Chemistry (Ed.). Derek Barton and Koji Nakanishi. Elsevier, Amsterdam, Vol.II, p.167.

4. Dool VH and Kratz PD. 1963. A generalization of the retention index system including linear temperature programmed gas liquid partition chromatography. J. Chromatogr., 11, 463-471.

5. Esau, K. 1965. Plant Anatomy. $2^{\text {nd }}$ ed. Wiley Eastern Limited, New Delhi.

6. Handa SS. 2008. An overview of extraction techniques for medicinal and aromatic plants. In: Extraction Technologies for Medicinal and Aromatic Plants. (Eds.) Handa SS, Singh SP, Longo KG and Rakesh DD. International Centre for Science and High Technology, ICS-UNIDO, Trieste. pp. 21-52.

7. Hemshekhar M, Sunitha K, Santhosh MS, Devaraja S, Kemparaju K, Vishwanath BS, Niranjana SR and Girish KS. 2011. An overview on genus Garcinia: Phytochemical and therapeutical aspects. Phytochem. Rev., 10(3), 325-351.

8. Hiltunen R and Holm Y. 1999. Basil: The Genus Ocimum. Harwood Academic Publishers, Amsterdam.

9. Huang M, Sanchez-Moreiras A M, Abel C, Sohrabi R, Lee S, Gershenzon J and Tholl D. 2012. The major volatile organic compound emitted from Arabidopsis thaliana flowers, 
the sesquiterpene (E)-b-caryophyllene, is a defense against a bacterial pathogen. New Phytologist 193: 997-1008.

10. Kubeczka KH and Formacek V. 2002. Essential Oils Analysis by Capillary Gas Chromatography and Carbon-13 NMR Spectroscopy. John Wiley and Sons, Chichester.

11. Macleod JA and Pieris NM. 1982. Volatile flavour components of Mangosteen, Garcinia mangostana. Phytochemistry, 21(1), 117-119.

12. Maheswari JK. 1964. Taxonomic studies on Indian Guttiferae III. The genus Garcinia Linn. Bull. Bot. Surv. India, 6, 107-135.

13. Martins FT, Doriguetto AC, de Souza TC, de Souza KR, dos Santos MH, Moreira ME and Barbosa LC. 2008. Composition and anti-inflammatory and antioxidant activities of the volatile oil from the fruit peel of G.brasiliensis. Chem. Biodivers., 5(2), 251-258.

14. Nimanthika WJ, Kaththriarachchi HS. 2010. Systematics of genus Garcinia L. (Clusiaceae) in Sri Lanka. New insights from vegetative morphology. Journal of National Science Foundation, 38, 29-44.

15. Nogueira PC, Bittrich V, Shepherd GJ, Lopes AV and Marsaioli AJ. 2001. The ecological and taxonomic importance of flower volatiles of Clusia species (Guttiferae). Phytochemistry, 56(5), 443-452.

16. Onayade OA, Looman AMG, Scheffer JJC and Gbile ZO. 1998. Lavender lactone and other volatile constituents of the oleoresin from seeds of Garcinia kola Heckel. Flavor and Fragrance Journal, 13(6), 409-412.

17. Parthasarathy U, Nirmal Babu K, Senthil Kumar R, Ashis GR, Mohan S and Parthasarathy VA. 2013. Diversity of Indian Garcinia - A medicinally important spice crop in India. Acta Hortic., 979, 467-476.

18. Pathirana PSK and Herat TR. 2004. Comparative vegetative anatomical study of the genus Garcinia L. (Clusiaceae/ Guttiferae) in Sri Lanka. Ceylon Journal of Science, 32, 39-66.

19. Rameshkumar KB, Shiburaj S and George V. 2005. Constituents and antibacterial activity of the stem bark oil of Garcinia imberti. J. Trop. Med. Plants, 6, 271-273.

20. Sabu T, Mohanan N, Krishnaraj MV, Shareef SM, Shameer PS and Roy PE 2013. Garcinia pushpangadaniana, (Clusiaceae) a new species from southern Western Ghats, India. Phytotaxa, 116 (2), 51-56.

21. Schiestl FP, Ayasse M, Paulus HF, Löfstedt C, Hansson BS, Ibarra F and Francke W. 2000. Sex pheromone mimicry in the early spider orchid (Ophrys sphegodes): Patterns of hydrocarbons as the key mechanism for pollination by sexual deception. J. Comp. Physiol. A, 186(6), 567-574.

22. Schofield EK 1968. Petiole anatomy of the Guttiferae and related families. Mem. New York Bot. Gard. 18,1-55.

23. Sweeney PW. 2008. Phylogeny and floral diversity in the genus Garcinia (Clusiaceae) and relatives. Int. J. Plant Sci., 169(9), 1288-1303.

24. Wang R, Peng S, Zeng R, Ding LW and Xu Z. 2009. Cloning, expression and wounding induction of $\beta$-caryophyllene synthase gene from Mikania micrantha H.B.K. and allelopathic potential of $\beta$-caryophyllene. Allelopathy Journal, 24 (1), 35-44.

25. Waterman PG and Hussain RA. 1983. Systematic significance of xanthones, benzophenones and biflavonoids in Garcinia. Biochem. Syst. Ecol., 11(1), 21-28. 


\title{
Chapter 6
}

\section{Rapid estimation of bioactive constituents of Garcinia species in the Western Ghats using UHPLC-MS/MS Method}

\author{
Renu Pandey ${ }^{1}$, Brijesh Kumar ${ }^{1 *}$ and K. B. Rameshkumar ${ }^{2}$ \\ ${ }^{I}$ Sophisticated Analytical Instrument Facility, CSIR-Central Drug Research Institute, \\ Lucknow-226031, Uttar Pradesh, India \\ 2 Phytochemistry and Phytopharmacology Division, Jawaharlal Nehru Tropical Botanic Garden and \\ Research Institute, Palode, Thiruvananthapuram-695562, Kerala, India \\ * Corresponding author
}

\begin{abstract}
Species of the genus Garcinia (Family: Clusiaceae) are traditionally used in the preparation of food and as herbal supplements. Organic acids, prenylated xanthones, polyisoprenylated benzophenones and biflavonoids are the major medicinally active constituents present in different parts of Garcinia plants. Though the Western Ghats has a rich diversity of Garcinia species, only a few species have been exploited for their potential utilities. The rich floristic wealth can be harnessed profitably by exploiting the advances in phytochemical analytical techniques. Also, the establishment of an efficient analytical methodology for detection and estimation of the medicinally active constituents is crucial for quality assessment of derived herbal products from the Garcinia species. The present chapter provides an overview of different LC-MS analytical techniques used for quality control of Garcinia species. Further, detection and estimation of multi-class bioactive constituents in the leaf extracts of nine Garcinia species in the Western Ghats were reported using a validated UHPLC-ESI- QTOFMS/MS method. Among the twenty six multi-class bioactive constituents analysed, biflavonoids and organic acids were the major class of compounds detected in Garcinia species. Acid content was high in the two economically important and widely distributed species, G. gummi-gutta and G. indica, while the biflavonoid content was highest in $G$. travancorica followed by G. talbotii.
\end{abstract}

Keywords: Garcinia species, Western Ghats, Quality control, UHPLC-ESI-QTOF-MS/MS

\section{Introduction}

The genus Garcinia belonging to the family Clusiaceae comprises more than 250 species of tropical trees and shrubs, indigenous to Asia, Southern Africa and Polynesia (Ritthiwigrom et al., 2013). About 37 species of Garcinia are distributed in the evergreen forest of the Western Ghats, Gujarat, Andaman and Nicobar Islands and the North Eastern region of India (Hemshekhar et al., 2011, Sarma et al., 2016). The fruits of several species of Garcinia are edible and used as spice in traditional Indian cuisines. Different plant parts of Garcinia species, mostly fruit, fruit rind, leaves and bark have been used worldwide as traditional medicine in the treatment of various ailments such as obesity, inflammation, microbial infection, abdominal pain, dysentery, diarrhea, infected wound, leucorrhea, chronic ulcer, gonorrhea, oxidative stress and cancer (Hemshekhar et al., 2011; Ritthiwigrom et al., 2013). 
Numerous pharmacological activities such as anticancer, antiobesity, diuretic, antiinflammatory, antibacterial, antiviral, antifungal, anti-HIV, antidepressant and antioxidant have been reported for the Garcinia species (Han et al., 2006; Padhye et al., 2009; Ritthiwigrom et al., 2013; Xu et al., 2010). The antiobesity effect of Garcinia has been exploited commercially and several herbal supplements are available in the market.

Previous chemical investigations on the leaves, bark and fruits of Garcinia species have shown that the major constituents included biologically active biflavonoids, xanthones, benzophenones and organic acids and the minor constituents were terpenoids, steroids, flavonoids and phenolic acids (Hemshekhar et al., 2011; Ritthiwigrom et al, 2013). As the genus Garcinia has received much attention from pharmaceutical industries due to its extensive use in herbal dietary supplements, the quality control of its extracts in terms of bioactive constituents is essential to guarantee clinical efficacy and safety. Therefore, it is important to simultaneously monitor the bioactive constituents for their quality control and also explore the best suited species in terms of active constituents.

In recent years, numerous research groups reported analytical methods, using various chromatographic conditions and spectophotometric technologies, to develop quick and accurate analytical approaches for the identification, structural characterization and determination of chemical constituents of Garcinia species (Acuna et al., 2012; Aisha et al., 2012; Bharate et al., 2014; Chattopadhyay and Kumar, 2006, 2007; Jayaprakasha and Sakariah, 2000; Jena et al., 2002; Ji et al., 2007; Kumar et al., 2013, 2009; Li et al., 2008; Wittenauer et al., 2012; Zhou et al., 2010; Zhou et al., 2009; Zhou et al., 2008a, 2008b; Zadernowski et al., 2009).

Quantitative analysis of the major bioactive constituents of Garcinia is essential for quality control. Untill now only a few constituents (camboginol, garcinol, xanthochymol and isoxanthochymol) have been quantitatively determined by LC-MS/MS methods in $G$. combogia and G. indica (Chattopadhyay and Kumar, 2006, 2007; Bharate et al., 2014; Kumar et al., 2009). However, many species of Garcinia native to the Western Ghats of India are still unexplored in terms of their active chemical constituents. The main emphasis of the present chapter is the application of a validated UHPLC-ESI-MS/MS method for the rapid detection of multi-class bioactive constituents in the leaf extracts of nine Garcinia species distributed naturally in the Western Ghats of south India.

\section{Bioactive chemical constituents from Garcinia species}

The genus Garcinia is a rich source of organic acids, prenylated xanthones, polyisoprenylated benzophenones, biflavonoids, triterpenoids, phenolic acids and flavonoids which are also biologically active constituents (Xu et al., 2010; Hemshekhar et al., 2011; Ritthiwigrom et al, 2013). Garcinol, a polyisoprenylated benzophenone isolated from Garcinia species is a potent bioactive compound possessing antioxidant, anti-bacterial, anti-inflammatory, anticancer, anti-HIV and antiulcer activities (Hemshekhar et al., 2011; Padhye et al., 2009). The prenylated xanthones, gambogic acid and $\alpha$-mangostin isolated from Garcinia species were found to have antioxidant, antibiotic, antitumor, anti-inflammatory and anticarcinogenic properties (Han et al., 2006; Ritthiwigrom et al, 2013; Xu et al., 2010). Hydroxycitric acid (HCA), a potential antiobesity and hypocholesterolaemic agent is present in fruits and leaves of Garcinia species and used as an ingredient in popular dietary supplements for weight loss 
(Jena et al., 2002; Padhye et al., 2009). Biflavonoids, triterpenoids, flavonoids and phenolic acids found in Garcinia are also responsible for various pharmacological activities (Baggett et al., 2005; Hemshekhar et al., 2011; Ritthiwigrom et al, 2013).

\section{Analytical methods used for quality control of Garcinia species}

Several analytical methods, including high-performance liquid chromatography coupled to photodiode array detection/diode array detection (HPLC-PDA/DAD) and gas chromatography coupled to mass spectrometry (GC-MS) were used to evaluate the quality of Garcinia species (Acuna et al., 2012; Aisha et al., 2012; Jayaprakasha and Sakariah, 2000; Jena et al., 2002; Ji et al., 2007; Kumar et al., 2013; Li et al., 2008; Zadernowski et al., 2009). Most of the previous researchers have developed HPLC-PDA/DAD methods focusing on the simultaneous determination of only few classes of compounds in one or two Garcinia species except the work by Acuna et al. (2012).

Jena et al., and Jayaprakasha and Sakariah have developed HPLC-UV methods for the determination of organic acids (HCA, HCA lactone, oxalic acid, citric acid, tartaric acid and malic acid) in leaves, fruits, and dried rinds of $G$. cowa and commercial samples of $G$. combogia respectively. Kumar et al. have simultaneously determined the organic acid (HCA lactone) and xanthones (isoxanthochymol and xanthochymol) in leaves, seeds, fruit rinds and stem bark of $G$. indica by HPLC-PDA method. The xanthones were also determined by Aisha et al, Ji et al and Li et al. using HPLC-PDA method in the fruit rinds of G. mangostana and in the commercial samples of G. hanburyi.

Acuna et al. has developed an HPLC-PDA method for simultaneous detection and quantification of three benzophenones (guttiferone A, guttiferone E, and xanthochymol) and four biflavonoids amentoflavone, fukugiside, fukugetin, and volkensiflavone) in eight Garcinia species including seven edible fruits, G. aristata, G. hombroniana, G. intermedia, G. livingstonei, G. mangostana, G. spicata, and G. xanthochymus and the wood of G. kola. These analyses have shown that $G$. spicata contained all the seven phytoconstituents and the highest amounts of guttiferone E and xanthochymol was found in fruits of G. spicata and $G$. xanthochymus.

A GC-MS method was also applied for the identification of ten phenolic acids in various parts (peel, aril and rind) of the mangosteen fruit (G. mangostana) by Zadernowski et al. Quantification of the identified phenolic acids was carried out by GC coupled to flame ionization detection (FID) which showed protocatechuic acid as the major phenolic acid in the peel and rind, whereas $p$-hydroxybenzoic acid was the predominant phenolic acid in the aril.

The main drawbacks of the reported methods are low sensitivity, low resolution, and long analysis time with large solvent consumption and the need of derivatization in some cases. These drawbacks could be surmounted by using a more sensitive, selective and validated liquid chromatography tandem mass spectrometry (LC-MS/MS) method. Literature review revealed that there are a few reports on the development of LC-QTOF-MS/MS methods for the identification and characterization of xanthones and polyprenylated acylphloroglucinols in Garcinia species (Wittenauer et al., 2012; Zhou et al., 2010, 2009, 2008a, 2008b). The analytical techniques used for detection and estimation of bioactive constituents in Garcinia species are summarized in Table 1. 


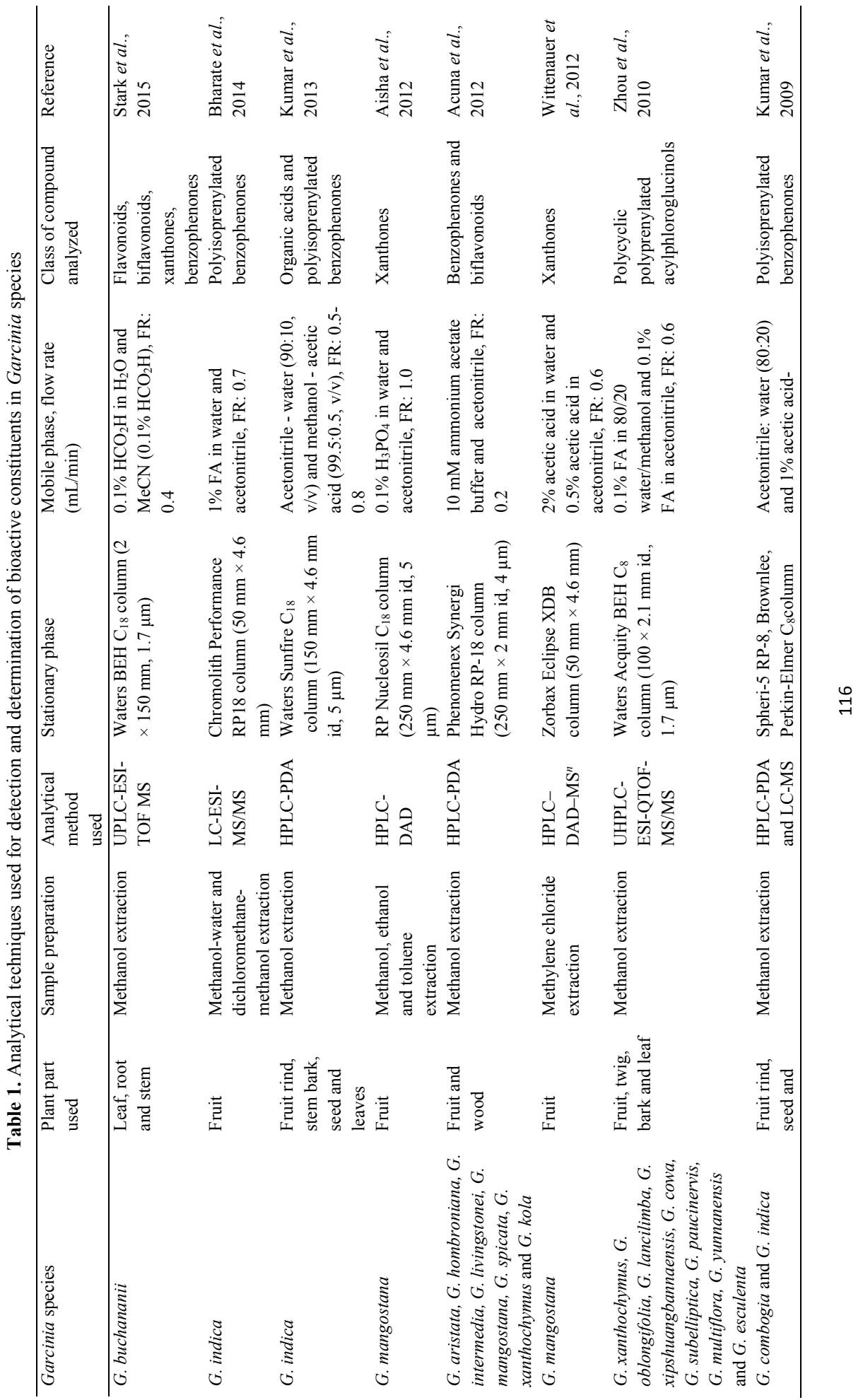




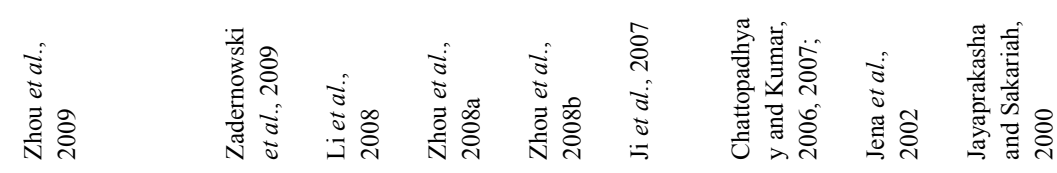

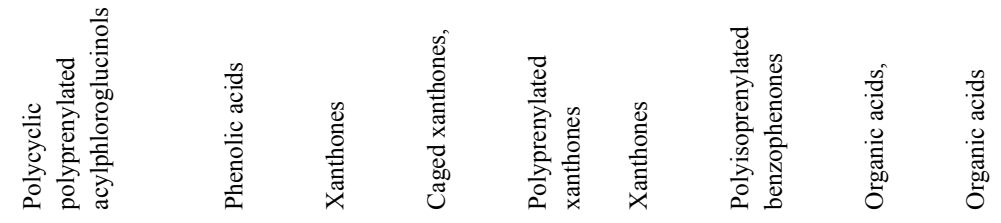

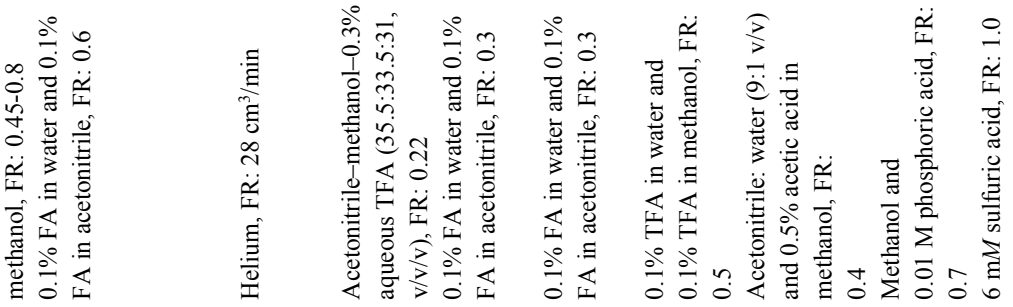
ఏ .ृ 竞言

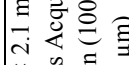

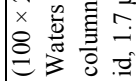

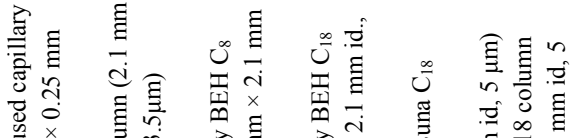

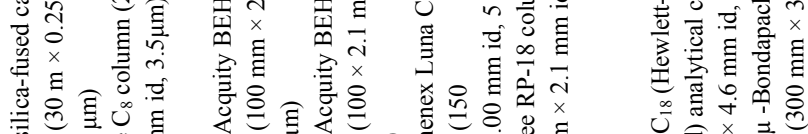

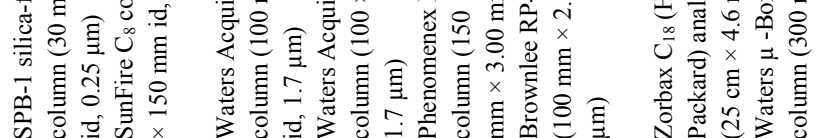

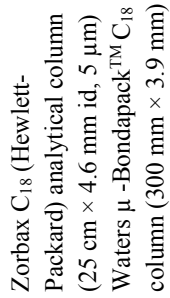

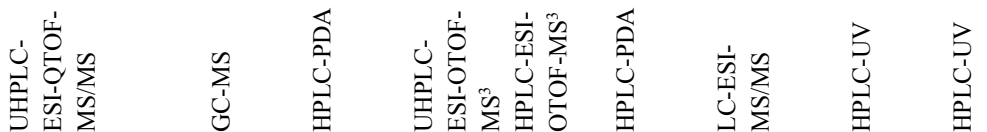
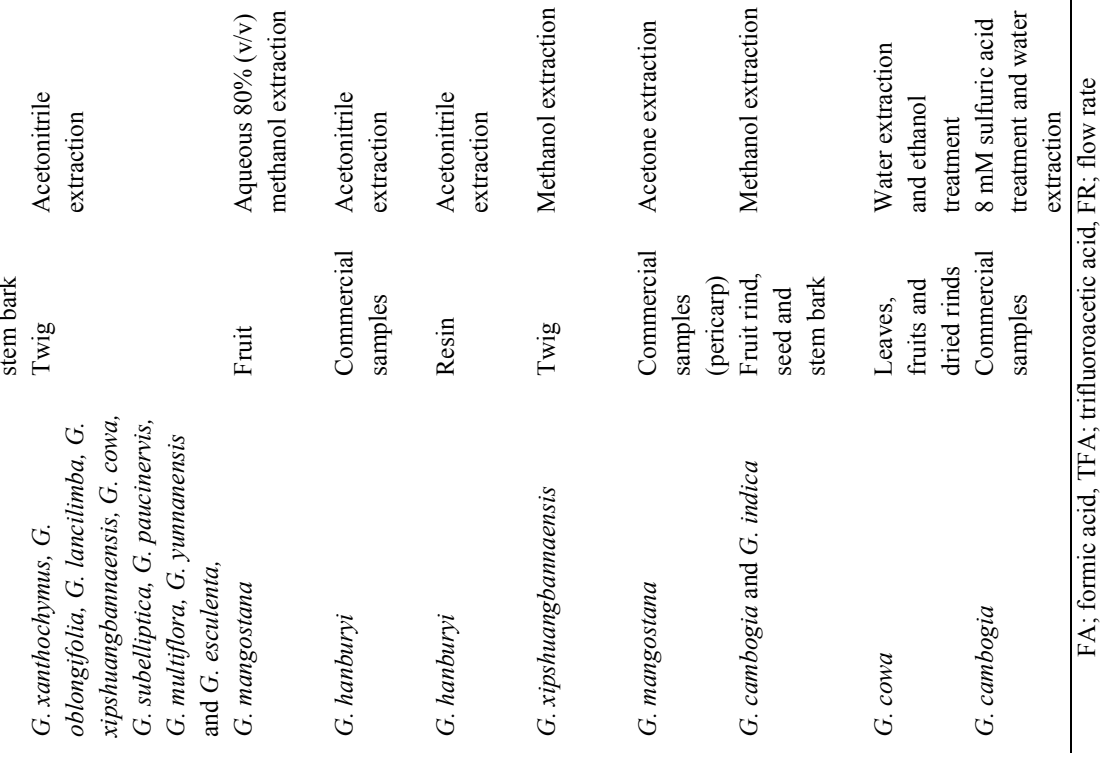


\section{UHPLC-MS/MS analysis of Garcinia species in the Western Ghats}

A sensitive and efficient UHPLC-ESI-MS/MS method has been developed and validated in the MRM mode for rapid detection and determination of twenty six multi-class bioactive constituents in the leaf extracts of nine Garcinia species, viz. G. rubro-echinata, G. gummigutta (L.) Robs. (Syn. G. cambogia Desr.), G. imberti, G. indica, G. morella, G. pushpangadaniana, G. talbotii, G. travancorica and G. wightii. The sample leaves were collected from various locations of Kerala, India and the sample code, specimen voucher number and collection location are shown in Table 2.

Table 2. Sample code, specimen voucher number and collection location of Garcinia species from Western Ghats, Kerala, India

\begin{tabular}{|c|c|c|c|c|}
\hline $\begin{array}{l}\text { Sl. } \\
\text { No. }\end{array}$ & Garcinia species & $\begin{array}{l}\text { Sample } \\
\text { code }\end{array}$ & $\begin{array}{l}\text { Voucher specimen } \\
\text { number }\end{array}$ & Collection location \\
\hline 1 & G. rubro-echinata & G.re & 66419 & Chemungi, Thiruvananthapuram \\
\hline 2 & G. gummi-gutta & G. $g g$ & 66446 & Palode, Thiruvananthapuram \\
\hline 3 & G. indica & G. in & 66423 & Talipparamba, Kannur \\
\hline 4 & G. morella & G. $m r$ & 66418 & Chemungi, Thiruvananthapuram \\
\hline 5 & G. pushpangadaniana & G. $p s$ & 66421 & Kadalar, Idukki \\
\hline 6 & G. talbotii & G. $t l$ & 50985 & Palode, Thiruvananthapuram \\
\hline 7 & G. wightii & G. $w g$ & 50987 & Athirappilly, Thrissur \\
\hline 8 & G. imberti & G. im & 66416 & Chemungi, Thiruvananthapuram \\
\hline 9 & G. travancorica & G. $t r$ & 66417 & Chemungi, Thiruvananthapuram \\
\hline
\end{tabular}

Methanolic extracts of the leaves were quantitatively analyzed by Waters Acquity UPLC ${ }^{\mathrm{TM}}$ system (Waters, Milford, MA, USA) hyphenated with hybrid linear ion trap triple-quadrupole mass spectrometer (API 4000 QTRAPTM MS/MS system from AB Sciex, Concord, ON, Canada) using electrospray (Turbo V) ion source. Chromatographic separation of analytes was carried out on an Aquity UPLC BEH $\mathrm{C}_{18}$ column $(50 \mathrm{~mm} \times 2.1 \mathrm{~mm}$ id, $1.7 \mu \mathrm{m})$ using gradient elution of $0.1 \%$ formic acid in water and acetonitrile within $7.5 \mathrm{~min}$. The targeted analytes in the samples were unambiguously identified using authentic standards based on their MS spectral data and diagnostic fragmentations (Pandey et al., 2015). Structures of targeted analytes are shown in Figure 1. The developed analytical method was validated as per International Conference on Harmonization ( $\mathrm{ICH}, \mathrm{Q} 2 \mathrm{R} 1)$ guidelines (Pandey et al., 2015).

The UHPLC-ESI-MS/MS analysis showed significant chemical variation among the nine Garcinia species (Table 3). Among the twenty six multi-class bioactive constituents, organic acids were the major class of compounds in G. rubro-echinata, G. gummi-gutta and $G$. indica. Hydoxycitric acid lactone or garcinia acid was the major constituent in the leaf extract of G. rubro-echinata, G. gummi-gutta, and G. indica. The acid content was highest in $G$. gummi-gutta $(308.0 \mathrm{mg} / \mathrm{g})$ while G. talbotii possess the least acid content $(7.0 \mathrm{mg} / \mathrm{g})$. Literature survey indicated that G. gummi-gutta and G. indica are incorporated into many pharmaceutical preparations and marketed as popular weight loss products due to the higher amount of hydoxycitric acid and garcinia acid in their fruit extracts (Jena et al., 2002; Padhye et al., 2009). Our findings suggested that the leaf extracts of G. gummi-gutta and G. indica might be a suitable source for swapping fruit extract due to the presence of higher level of organic acids (308 mg/g, $276 \mathrm{mg} / \mathrm{g}$ and $265 \mathrm{mg} / \mathrm{g}$, respectively) (Jena et al., 2002). 
Table 3. Contents $(\mathrm{mg} / \mathrm{g})$ of twenty six investigated bioactive constituents in the leaf extracts of nine Garcinia species distributed in the Western Ghats

\begin{tabular}{|c|c|c|c|c|c|c|c|c|c|}
\hline Analytes $(\mathrm{mg} / \mathrm{g})$ & G. $g g$ & G. in & G.re & G. $m r$ & G.ps & G. $t l$ & G. wg & G. im & G. $t r$ \\
\hline \multicolumn{10}{|l|}{ Organic acids } \\
\hline Hydroxycitric acid & 95.0 & 120.0 & 1.75 & 3.55 & 3.18 & 1.2 & 2.32 & 0.9930 & 1.6600 \\
\hline Garcinia acid & 213.0 & 156.0 & 26.4 & 6.46 & 9.01 & 5.83 & 6.61 & 7.3800 & 9.4500 \\
\hline \multicolumn{10}{|l|}{ Phenolic acids } \\
\hline Protocatechuic acid & 0.427 & 0.407 & 0.67 & 10.7 & 0.294 & 0.341 & 1.00 & 0.9890 & 2.1700 \\
\hline Caffeic acid & 0.379 & 0.578 & 0.622 & 0.595 & 0.263 & 0.34 & 0.413 & 0.1420 & 1.4200 \\
\hline Ferulic acid & 0.094 & 0.123 & 0.121 & 0.191 & 0.1 & 0.117 & 0.078 & 0.5220 & 0.0403 \\
\hline Vanillic acid & 0.0003 & 0.099 & 0.0285 & 0.001 & nd & 0.107 & 0.0005 & 0.0008 & 0.0222 \\
\hline \multicolumn{10}{|l|}{ Flavonoids } \\
\hline Epicatechin & 0.132 & 0.219 & 2.55 & 0.218 & 1.34 & 0.199 & 0.191 & 0.9240 & 0.1190 \\
\hline Isoorientin & 0.441 & 0.626 & 0.297 & 1.32 & 0.343 & 1.02 & 0.409 & 0.6070 & 0.4340 \\
\hline Orientin & 0.004 & 0.147 & 0.065 & 2.21 & 0.011 & 0.614 & 0.064 & 0.5340 & 0.1260 \\
\hline Isovitexin & 1.47 & 3.03 & 1.81 & 3.55 & 1.67 & 3.38 & 1.79 & 1.4100 & 2.1000 \\
\hline Vitexin & 1.19 & 2.86 & 1.37 & 2.16 & 1.24 & 1.59 & 1.57 & 1.1800 & 1.6400 \\
\hline $\begin{array}{l}\text { Kaempferol-3-O- } \\
\text { rutinoside }\end{array}$ & 0.022 & 0.033 & 0.011 & 0.006 & 0.006 & 0.007 & 0.011 & 0.0637 & 0.2657 \\
\hline Luteolin & 0.008 & 0.059 & 0.478 & 0.588 & 0.066 & 0.042 & 0.701 & 0.1053 & 0.0830 \\
\hline Quercetin & 0.148 & 0.126 & 0.188 & 0.238 & 0.147 & 0.077 & 0.276 & 0.1920 & 0.6030 \\
\hline Apigenin & 0.416 & 0.614 & 0.659 & 0.724 & 1.11 & 0.687 & 0.485 & 0.7010 & 1.4600 \\
\hline Kaempferol & 0.246 & 0.253 & 0.237 & 0.289 & 0.287 & 0.281 & 0.274 & 0.2820 & 0.2320 \\
\hline \multicolumn{10}{|l|}{ Biflavonoids } \\
\hline Fukugiside & 0.066 & 0.075 & 0.020 & nd & 1.21 & 52.10 & 0.141 & 0.2910 & 35.3000 \\
\hline GB-2 & bdl & 0.338 & bdl & 6.14 & 2.077 & 28.3 & 0.683 & 0.3850 & 17.1333 \\
\hline GB-1 & 0.215 & 0.231 & 0.219 & 399 & 279 & 25.8 & 46.4 & 22.1000 & 72.0000 \\
\hline GB-1 a & bdl & bdl & bdl & 22.1 & 13.4 & 6.24 & 2.143 & 2.4700 & 3.9000 \\
\hline Amentoflavone & 0.309 & 0.309 & 2.98 & 2.51 & 3.06 & 1.443 & 0.046 & 0.0440 & 0.0467 \\
\hline \multicolumn{10}{|l|}{ Xanthones } \\
\hline Mangostin & 0.002 & 0.017 & 0.002 & 0.085 & 0.024 & 0.002 & 0.008 & 0.0056 & 0.0015 \\
\hline Gambogic acid & 2.79 & 2.86 & 2.78 & 1.79 & 2.80 & 2.89 & 2.87 & 2.8500 & 2.7800 \\
\hline \multicolumn{10}{|l|}{ Benzophenones } \\
\hline Garcinol & 0.593 & 0.383 & 0.37 & 0.318 & 0.284 & 0.262 & 0.267 & 0.3290 & 0.2900 \\
\hline \multicolumn{10}{|l|}{ Triterpenoids } \\
\hline Ursolic acid & 0.742 & 0.73 & 0.915 & 1.25 & 1.35 & 0.92 & 0.757 & 1.4700 & 2.6200 \\
\hline Betulinic acid & 2.44 & 1.37 & 1.55 & 1.83 & 1.64 & 3.75 & 1.19 & 1.3200 & 2.6500 \\
\hline
\end{tabular}

G.re-G. rubro-echinata; G.gg-G. gummi-gutta; G.in-G. indica; G.mr-G. morella; G.ps-G. pushpangadaniana; G.tl-G. talbotii; G.wg-G.wightii; G.im-G.imberti, G.tr-G.travancorica; nd- not detected; bdl- below detection level (Pandey et al., 2015)

Biflavonoids were the major class of compounds in in G. imberti, G. morella, G. pushpangadaniana, G. talbotii, G. travancorica and G. wightii. The biflavonoid content was highest in G. morella, followed by $G$. pushpangadania. Among the five biflavonoids screened, GB-1 and GB-1a were the major ones distributed in the Garcinia species. Garcinia biflavonoid, GB-1 was the major constituent in the leaf extract of G. morella, $G$. pushpangadaniana and G. wightii. Fukugiside, GB-2 and GB-1were the major components in the leaf extracts of G.talbotii. 


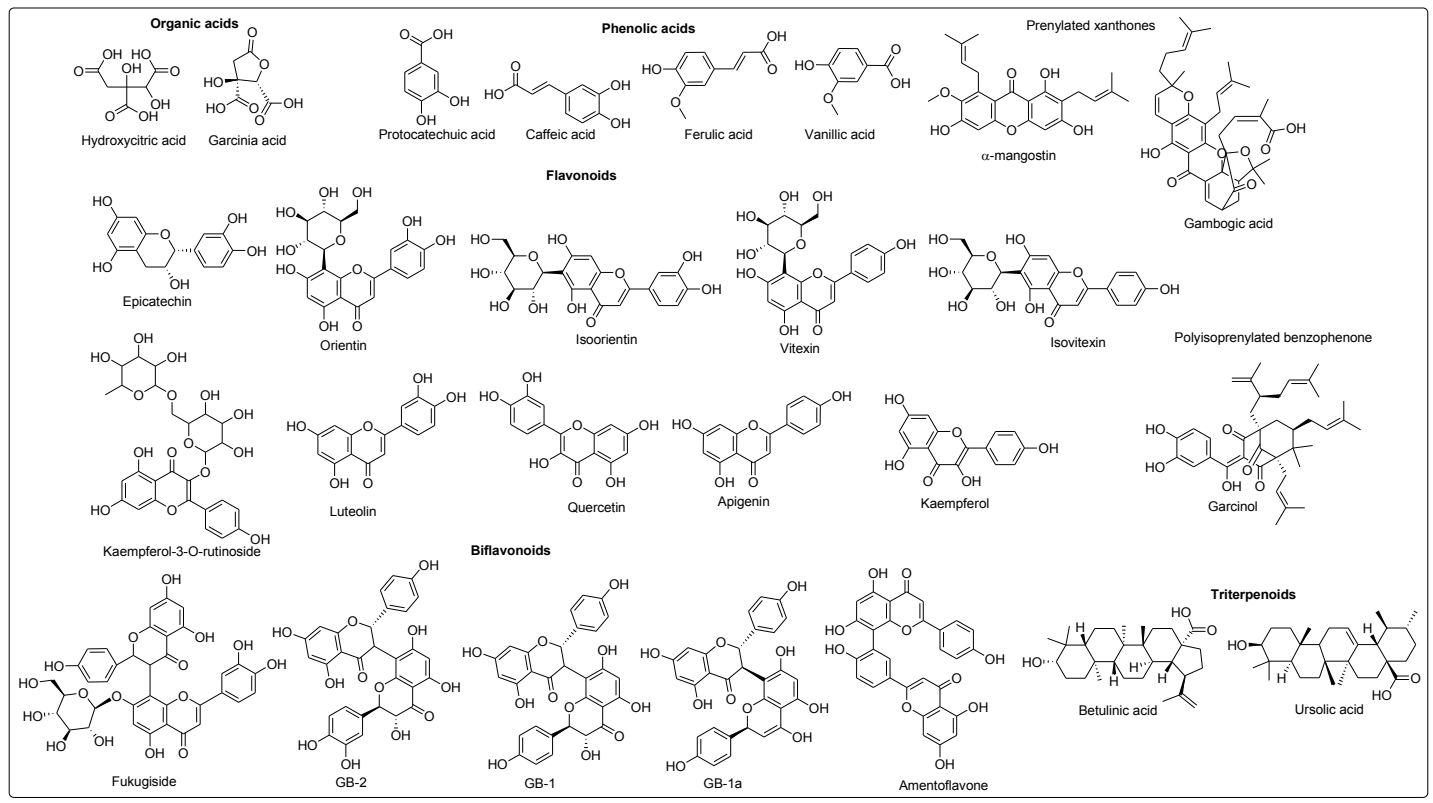

Figure 1. Structures of targeted analytes

Among the nine Garcinia species studied, G. rubro-echinata, G. gummi-gutta, and G. indica were distinct by high content of acids compared to other species. Among the 4 biflavonoids screened, only amentoflavone possess I(5')-II(8) biflavonoid linkage, whereas the other 3 biflavonoids were with I(3)-II(8) linkage, the most prevalent interflavonoid linkage reported in Garcinia biflavonoids. It is interesting to note that the three species G. rubro-echinata, $G$. gummi-gutta, and G. indica were also distinct with regard to the biflavonoid distribution, where amentoflavone was present in higher quantity in the three species compared to the common I(3)-II(8) biflavonoids.

\section{Conclusions}

The developments in the field of analytical technologies improved fingerprinting authentication and quantitative determination of medicinally active constituents from plants and their commercial products. The selectivity and specificity in phytochemical analysis have increased significantly through hyphenation of chromatographic separation and mass spectrometry detection as in the case of LC-MS. Twenty six multi-class bioactive constituents in the leaf extracts of nine Garcinia species of the Western Ghats were detected and estimated through the UHPLC-MS/MS analysis. The UHPLC system combined with mass spectrometry detection in MRM acquisition mode enables significant reductions in separation time, solvent consumption and ensures excellent selectivity and sensitivity for quantitative analyses in shorter duration. In G. rubro-echinata, G. gummi-gutta and G. indica, organic acids were present in higher level, while in other Garcinia species (G. morella, G. pushpangadaniana, G. talbotii and G. wightii, G. imberti and G. travancorica) biflavonoids were the major class of compounds. 


\section{References}

1. Acuna UM, Dastmalchi K, Basile MJ and Kennelly EJ. 2012. Quantitative high-performance liquid chromatography photo-diode array (HPLC-PDA) analysis of benzophenones and biflavonoids in eight Garcinia species. J. Food Compst. Anal., 25(2), 215-220.

2. Aisha A, Abu-Salah K, Siddiqui M, Ismail Z and Majid AA. 2012. Quantification of $\alpha$, $\beta$-and $\gamma$ mangostin in Garcinia mangostana fruit rind extracts by a reverse phase high performance liquid chromatography. J. Med. Plant Res., 6(29), 4526-4534.

3. Baggett S, Protiva P, Mazzola EP, Yang H, Ressler ET, Basile MJ, Weinstein IB and Kennelly EJ. 2005. Bioactive benzophenones from Garcinia xanthochymus Fruits. J. Nat. Prod., 68(3), 354-360.

4. Bharate JB, Vishwakarma RA, Bharate SB, Kushwaha M and Gupta AP. 2014. Quantification of the polyisoprenylated benzophenones garcinol and isogarcinol using multiple reaction monitoring LC/electrospray ionization-MS/MS analysis of ultrasoundassisted extracts of Garcinia indica fruits. J. AOAC Int., 97(5), 1317-1322.

5. Chattopadhyay SK and Kumar S. 2006. Identification and quantification of two biologically active polyisoprenylated benzophenones xanthochymol and isoxanthochymol in Garcinia species using liquid chromatography-tandem mass spectrometry. J. Chromatogr. B, 844(1), 67-83.

6. Chattopadhyay SK and Kumar S. 2007. A rapid liquid chromatography-tandem mass spectrometry method for quantification of a biologically active molecule camboginol in the extract of Garcinia cambogia. Biomed. Chromatogr., 21(1), 55-66.

7. Han QB, Yang L, Wang YL, Qiao CF, Song JZ, Sun HD and Xu HX. 2006. A pair of novel cytotoxic polyprenylated xanthone epimers from Gamboges. Chem. Biodivers., 39(1), 101105.

8. Hemshekhar MK, Sunitha M, Sebastin Santhosh S, Devaraja K, Kemparaju BS, Vishwanath SR, Niranjana and Girish KS. 2011. An overview on genus Garcinia: Phytochemical and therapeutical aspects. Phytochem. Rev., 10(3), 325-351.

9. Jayaprakasha GK and Sakariah KK. 2000. Determination of (-)-hydroxycitric acid in commercial samples of Garcinia cambogia extracts by liquid chromatography using ultraviolet detection. J. Liq. Chromatogr. Relat. Technol., 23, 915-923.

10. Jena BS, Jayaprakasha GK and Sakariah KK. 2002. Organic acids from leaves, fruits, and rinds of Garcinia cowa. J. Agric. Food Chem., 50(12), 3431-3434.

11. Ji X, Avula B and Khan IA. 2007. Quantitative and qualitative determination of six xanthones in Garcinia mangostana L. by LC-PDA and LC-ESI-MS. J. Pharm. Biomed. Anal., 43(4), 1270-1276.

12. Kumar S, Sharma S and Chattopadhyay SK. 2009. High-performance liquid chromatography and LC-ESI-MS method for identification and quantification of two isomeric polyisoprenylated benzophenones isoxanthochymol and camboginol in different extracts of Garcinia species. Biomed. Chromatogr., 23(8), 888-907.

13. Kumar S, Sharma S and Chattopadhyay SK. 2013. Rapid and sensitive HPLC-PDA method for simultaneous identification and quantification of dietary weight reducing compound hydroxy citric acid lactone and chemo preventive compounds isoxanthochymol and xanthochymol in Garcinia indica. Int. Food Res. J., 20(1), 397-402.

14. Li SL, Song JZ, Han QB, Qiao CF and Xu HX. 2008. Improved high-performance liquid chromatographic method for simultaneous determination of 12 cytotoxic caged xanthones in 
gamboges, a potential anticancer resin from Garcinia hanburyi. Biomed. Chromatogr., 22, 637-644.

15. Padhye S, Ahmad A, Oswal N and Sarkar FH. 2009. Emerging role of garcinol, the antioxidant chalcone from Garcinia indica Choisy and its synthetic analogs. J. Hematol. Oncol., 2(1), 1-13.

16. Pandey R, Chandra P, Kumar B, Srivastva M, Aravind AA, Shameer PS and Rameshkumar, KB. 2015. Simultaneous determination of multi-class bioactive constituents for quality assessment of Garcinia species using UHPLC-QqQuit-MS/MS. Ind. Crops Prod., 77, 861872.

17. Ritthiwigrom T, Laphookhieo S and Pyne SG. 2013. Chemical constituents and biological activities of Garcinia cowa Roxb. Maejo Int. J. Sci. Technol., 7, 212-231.

18. Sarma J, Shameer PS, Mohanan NN. 2016. A new species of Garcinia (Clusiaceae) from Assam, North East India. Phytotaxa, 252 (1), 73-76.

19. Stark TD, Losch S, Wakamatsu J, Balemba OB, Frank O and Hofmann T. 2015. UPLC-ESITOF MS-Based Metabolite profiling of the antioxidative food supplement Garcinia buchananii. J. Agric. Food Chem., 63, 7169-7179.

20. Wittenauer J, Falk S, Weisz US and Carle R. 2012. Characterisation and quantification of xanthones from the aril and pericarp of mangosteens (Garcinia mangostana L.) and a mangosteen containing functional beverage by HPLC-DAD-MS ${ }^{n}$. Food Chem., 134(1), 445452.

21. Xu G, Kan WLT, Zhou Y, Song JZ, Han QB, Qiao CF, Cho CH, Rudd JA, Lin G and Xu HX. 2010. Cytotoxic acylphloroglucinol derivatives from the twigs of Garcinia cowa. J. Nat. Prod., 73(2), 104-108.

22. Zadernowski R, Czaplicki S and Naczk M. 2009. Phenolic acid profiles of mangosteen fruits (Garcinia mangostana). Food Chem.,112(3), 685-689.

23. Zhou Y, Lee S, Choi FFK, Xu G, Liu X, Song JZ, Li SL, Qiao, CF and Xu HX. 2010. Qualitative and quantitative analysis of polycyclic polyprenylated acylphloroglucinols from Garcinia species using ultra performance liquid chromatography coupled with electrospray ionization quadrupole time-of-flight tandem mass spectrometry. Anal. Chim. Acta., 678(1), 96-107.

24. Zhou Y, Huang SX, Song JZ, Qiao CF, Li SL, Han QB and Xu HX. 2009. Screening of polycyclic polyprenylated acylphloroglucinols from Garcinia species using precursor ion discovery (PID) scan and ultra performance liquid chromatography electrospray ionization QTOF tandem mass spectrometry. J. Am. Soc. Mass. Spectrom., 20(10), 1846-1850.

25. Zhou Y, Liu X, Yang J, Han QB, Song JZ, Li L, Qiao CF, Ding LS and Xu HX. 2008a. Analysis of caged xanthones from the resin of Garcinia hanburyi using ultra-performance liquid chromatography/electrospray ionization quadrupole time-of-flight tandem mass spectrometry. Anal. Chim. Acta., 629(1), 104-118.

26. Zhou Y, Han QB, Song JZ, Qiao CF and Xu HX. 2008b. Characterization of polyprenylated xanthones in Garcinia xipshuanbannaensis using liquid chromatography coupled with electrospray ionization quadrupole time-of-flight tandem mass spectrometry. J. Chromatogr. A, 1206(2), 131-139. 


\title{
Chapter 7
}

\section{Morphological, chemical and molecular taxonomy of a new Garcinia species- Garcinia pushpangadaniana Sabu et al.}

\author{
P.S. Shameer ${ }^{1}$, K. B. Rameshkumar ${ }^{2}$, A. R. Sivu ${ }^{3}$, T. Sabu ${ }^{1}$, N. S. Pradeep ${ }^{4}$ and N. Mohanan ${ }^{1 *}$ \\ ${ }^{1}$ Garden Management, Education, Information and Training Division \\ ${ }^{2}$ Phytochemistry and Phytopharmacology Division \\ ${ }^{4}$ Microbiology Division \\ Jawaharlal Nehru Tropical Botanic Garden and Research Institute \\ Palode, Thiruvananthapuram-695562, Kerala, India \\ ${ }^{3}$ Department of Botany, NSS College Nilamel, Kollam- 691535, Kerala, India \\ ${ }^{*}$ Corresponding author
}

\begin{abstract}
The genus Garcinia is an important component of the forest flora of the Western Ghats, and the region hosts a wide diversity with several taxa, including ones yet to be described. The genus is considered as a taxonomically difficult one due to the complexity and diversity in floral characteristics. The present chapter describes the biosystematics of a new Garcinia species, G. pushpangadaniana, described from the Western Ghats, using chemosystematics and molecular systematics. The HPTLC profile and volatile chemical profiles of the leaves supported the species status and allied nature to G. xanthochymus and G. talbotii. Molecular taxonomy using the chloroplast coding region matK could demarcate the new taxon as a distinct species, closely allied to the species G. xanthochymus and G. talbotii.
\end{abstract}

Keywords: Garcinia pushpangadaniana, Garcinia xanthochymus, Garcinia talbotii, Chemotaxonomy, Molecular taxonomy

\section{Introduction}

The forests of the Western Ghats, with nearly 7500 flowering plants, is a rich repository of plant wealth with several new species having been discovered from the region (Nayar et al., 2014). The region hosts wild relatives of many important spice crops and food crops and also is the centre of origin and diversity of several such plant groups. The genus Garcinia is an economically important group of plants distributed in the tropical regions of the world. The Western Ghats is a centre of diversity of Garcinia species in India. Out of the 37 Garcinia species distributed in India, 7 are endemic to the Western Ghats.

The genus Garcinia is considered as a taxonomically difficult one due to the complexity and diversity in floral characteristics with many unresolved phylogenic issues surrounding the genus. Characteristic differences in the floral architecture were observed even among closely related taxa of Garcinia (Gustafsson et al., 2002, Sweeney, 2008). Morphological characters are known to be affected by developmental and environmental factors and in the case of Garcinia species, an unusual evolutionary plasticity has been generally observed and the classification of Garcinia species and its phylogeny solely depending on morphological characters proved to be more uncertain. The incorporation of biosystematics in such taxonomically difficult groups will allow classifications using new descriptors and methods that yield more robust inter relations. 
Biosystematics based on secondary metabolite profile has proven as an efficient supportive tool for plant systematics. The genus Garcinia is characterized by the presence of a large number of secondary metabolites such as xanthones, benzophenones and biflavonoids, in addition to volatile secondary metabolites (Hemsekhar et al., 2011). Several attempts have been made to evaluate the phylogeny among Clusiaceae members through secondary metabolite profiling (Waterman and Hussain, 1983). Among the secondary metabolites, volatile chemicals can efficiently be utilized for chemotaxonomic purposes (Labra et al., 2004). Though the volatile chemical profile reflects the evolutionary history, it is more indicative of the ecological conditions (Nogueira et al., 2001).

In the last decade, new valuable tools based on DNA analysis were made available for taxonomic studies (Winfield, 2003; Labra et al., 2004). The use of DNA genotyping has been instrumental in solving controversial taxon attributions by comparing genotypes independently from phenotypes. DNA genotyping offers the unique capacity to classify accessions regardless of environmental condition and plant growth stage.

A new taxon of the genus Garcinia has been collected from the forests of the Western Ghats. In the present chapter, the efficiency of chemotaxonomy and molecular taxonomy to support the species status of the new Garcinia taxon has been evaluated.

\section{Morphological studies}

The new taxon Garcinia pushpangadaniana T. Sabu, N. Mohanan, Krishnaraj, \& Shareef (Holotype TBGT 72601) was collected from Kadalar forests, Idukki district, Kerala (Figure 1). Detailed evaluation of the vegetative and reproductive morphological features revealed the new taxon has distant relation to $G$. xanthochymus and $G$. talbotii with pentamerous flowers and the absence of rudimentary pistils in male flowers (Table 1). G. xanthochymus Hook. f. ex T. Anderson is an indigenous tree in Indo-Malay region, and its distribution in India is extended to the evergreen to semi-evergreen forests (100-1000m) of North East India and Andaman Nicobar Islands. G. talbotii Raizada ex. Santapau is an endemic species to the evergreen to semi-evergreen forests $(100-350 \mathrm{~m})$ of the Western Ghats. However, the prominent morphological differences in shape of leaf, pedicel length of male and female flowers, nature of staminodes, number of stigma, ovary and seeds, features in fruits and seeds qualify the new taxa to be a distinct species. The demarcating feature of the new taxon is the large fruits that weigh upto $750 \mathrm{~g}$, with irregular ridges on the fruit surface.

Table 1. Characteristic morphological features of the new taxon in comparison with G. talbotii and $G$. xanthochymus

\begin{tabular}{|c|c|c|c|}
\hline Plant part & G. talbotii & G. xanthochymus & G. pushpangadaniana \\
\hline Leaf & $\begin{array}{l}\text { Ovate, elliptic-oblong or } \\
\text { lanceolate. } \\
\text { Emarginate or acute at apex } \\
9-22 \times 4-8 \mathrm{~cm} .\end{array}$ & $\begin{array}{l}\text { Linear- oblong or oblong- } \\
\text { lanceolate. } \\
\text { Acute or acuminate at apex } \\
12-35 \times 4-10 \mathrm{~cm} .\end{array}$ & $\begin{array}{l}\text { Elliptic- oblong. } \\
\text { Acute or obtuse at apex } \\
14-20 \times 6-8 \mathrm{~cm} .\end{array}$ \\
\hline Flower & $\begin{array}{l}\text { Fascicled or pseudo spikes } \\
\text { Stamens 8-10 in each of } 5 \text { long } \\
\text { clawed, spathulate bundles. } \\
\text { Stigma 3-4 lobed, peltate } \\
\text { Ovary 3-4 locular. }\end{array}$ & $\begin{array}{l}\text { Fascicled } \\
\text { Stamens } 15-20 \text { in } 5 \text { phalanges } \\
\text { bundles of } 3-5 \text { each. } \\
\text { Stigma } 5 \text { lobed, oblong } \\
\text { Ovary } 5 \text { locular }\end{array}$ & $\begin{array}{l}\text { Fascicled } \\
\text { Stamens } 12-15 \text { in } \\
\text { phalanges } \\
\text { Stigma 6-8 lobed, oblong } \\
\text { Ovary 6-8 locular. }\end{array}$ \\
\hline Fruit & $\begin{array}{l}\text { Broadly oblong, smooth } \\
\text { Up to } 4 \mathrm{~cm} \text { diam. } \\
\text { Weight: Upto } 45 \mathrm{~g}\end{array}$ & $\begin{array}{l}\text { Subglobose, smooth. } \\
\text { ca. } 6.5 \mathrm{~cm} \text { diam } \\
\text { Weight: Upto } 55 \mathrm{~g}\end{array}$ & $\begin{array}{l}\text { Irregular ridges on the } \\
\text { surface, } c a .12 \times 11 \mathrm{~cm} \\
\text { diam. Weight: Upto } 750 \mathrm{~g}\end{array}$ \\
\hline Seeds & $\begin{array}{l}\text { Oblong } \\
1-3 \text {, up to } 2.5 \mathrm{~cm}\end{array}$ & $\begin{array}{l}\text { Oblong } \\
1-4 \text {, up to } 3.5 \times 1.8 \mathrm{~cm}\end{array}$ & $\begin{array}{l}\text { Plano convex } \\
2-6, \text { ca. } 2 \times 1 \mathrm{~cm}\end{array}$ \\
\hline Latex & White or yellowish white & $\begin{array}{l}\text { Milky white or pale green turning } \\
\text { yellow }\end{array}$ & Milky white \\
\hline
\end{tabular}



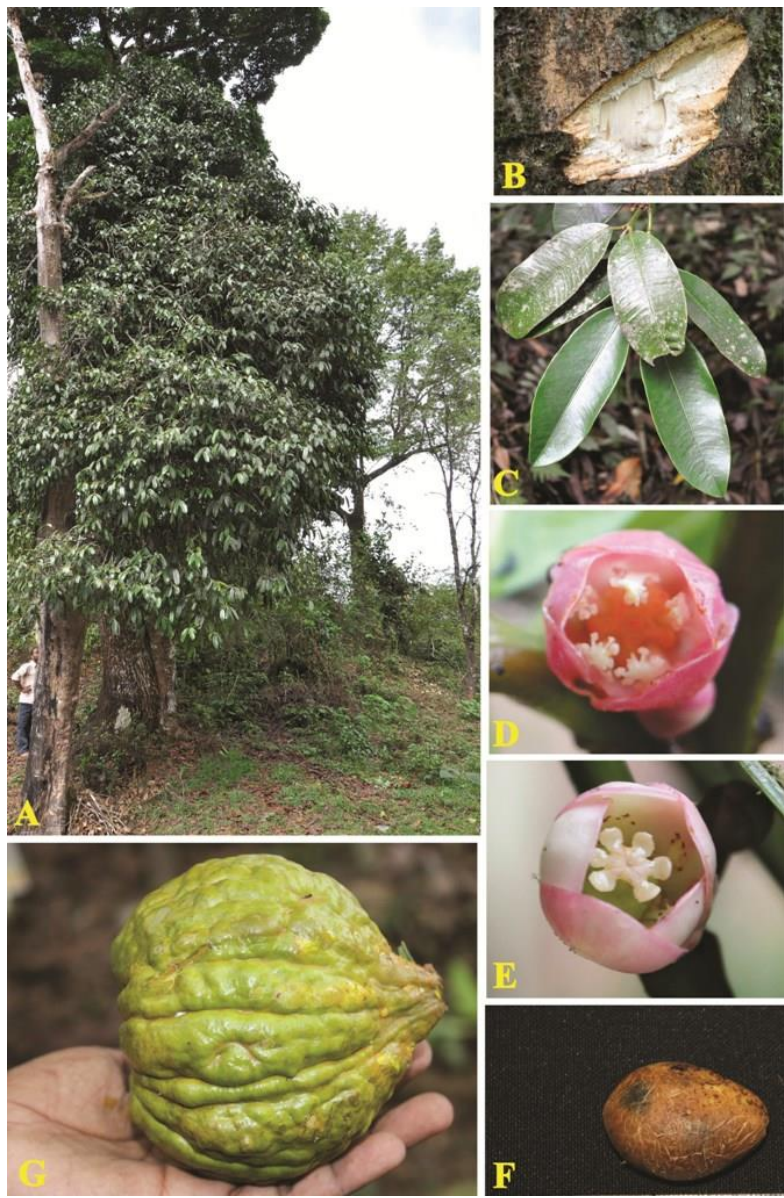

Figure 1. G. pushpangadaniana A. Habit, B. Stem bark, C. Leaf, D. Male flower, E. Female flower, F. Seed and G. Fruit

\section{Dichotomous key prepared for G. pushpangadaniana and related species}

Stamens in 5 phalanges; sepals and petals 5 rarely 4

Leaves more than thrice as long as abroad, over $30 \mathrm{~cm}$ long; berry with distinct mamilla or beak G. xanthochymus

Leaves less than twice as long as broad, less than $20 \mathrm{~cm}$ long; berry without distinct mamilla or beak Fruit large, without any pulp, irregularly ridged on the surface, seeds planoconvex G. pushpangadaniana

Male flowers fascicled or pseudo spikes stigmatic lobes 3- 4

G. talbotii

\section{Chemotaxonomy of the new species}

The use of distribution patterns of secondary metabolites is well established as a major tool for characterize, classify and describe taxa. The vast information of secondary metabolites can also be utilized for investigating population structures, species and phyletic relationships and evolutionary status. The genus Garcinia is characterized by the presence of a large number of secondary metabolites with diverse structural features such as xanthones, 
benzophenones, flavonoids, biflavonoids and terpenoids and the vast data on secondary metabolites has been utilised successfully to demarcate species (Waterman and Hussain, 1983).

\subsection{Chemotaxonomy based on HPTLC profiles}

The versatile and cost effective analytical tool HPTLC allows us to analyze up to 20 plants in a single analytical run and the phytochemical profile can yield valuable information on plant identity. The HPTLC profile can be utilized as very detailed differentiating fingerprints of different species, often closely related species that would otherwise be impossible to distinguish from each other physically (Reich and Schibli, 2007).

In the present study, the leaf methanol extracts were analysed using Camag HPTLC system, using silica gel HPTLC plates (Kieselgel $60 \mathrm{~F} 254,20 \mathrm{~cm} \times 20 \mathrm{~cm}, 0.2 \mathrm{~mm}$ thickness, Merck, Germany). The extracts were spotted by means of Camag Linomat V fitted with a Hamilton microlitre syringe. The plates were developed using chloroform: methanol (17:3) in the CAMAG twin-trough glass chamber, previously saturated with the solvent for 30 minutes. The mobile phase compositions were chosen after testing different solvent systems of varying polarity. The flavonoid profile was obtained on exposure of the plate to $\mathrm{NH}_{3}$ vapour.

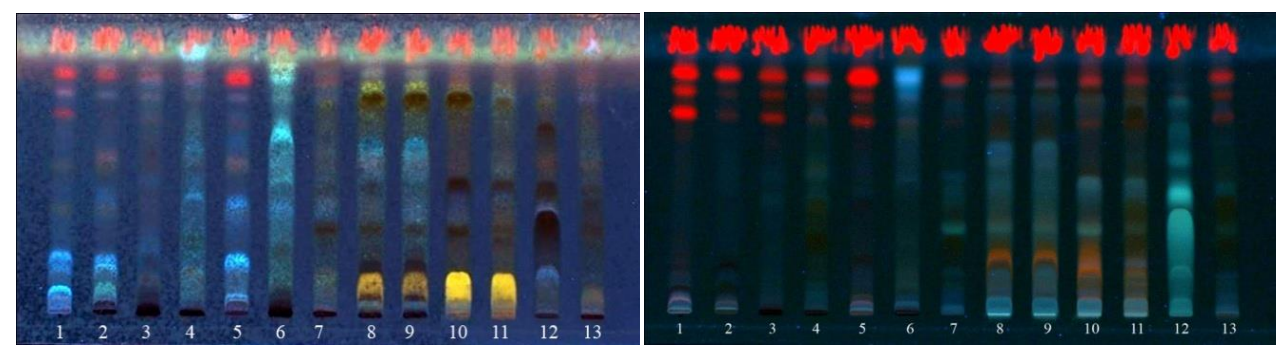

Figure 2. HPTLC profile of the leaf methanol extract along with 11 other Garcinia species A. $366 \mathrm{~nm}$ after exposure to $\mathrm{NH}_{3}$. B. $366 \mathrm{~nm}$ after derivatisation (1. G. gummi-gutta; 2. G. cowa, 3. G. rubroechinata, 4. G. imberti, 5. G. indica, 6. G. mangostana, 7. G. morella, 8. G. pushpangadaniana (I ${ }^{\text {st }}$ acc.), 9. G. pushpangadaniana ( $\mathrm{II}^{\mathrm{nd}}$ acc.), 10. G. talbotii, 11. G. xanthochymus, 12. G. travancrica, 13. G. wightii)

Biflavonoids, xanthones and benzophenones are the major phenolic compounds present in Garcinia species and the HPTLC of the methanol extracts represents the phenolic profile, especially the biflavonoids that shows intense fluorescence under exposure to $\mathrm{NH}_{3}$ vapour. The secondary metabolite profile revealed that G. xanthochymus, G. talbotii and the new taxon comes under the same group and the presence of characteristic spots to the new taxon supports its species status (Figure 2).

\subsection{Chemotaxonomy based on leaf volatile chemical profiles}

Standardized descriptors based on volatile oil constituents have been proposed as an efficient tool for differentiation of plants. However, the use of volatile oil constituents for species differentiation is limited by the fact that several environmental factors may influence the plant chemical composition (Labra et al., 2004 and Grayer et al., 1996). 
Volatile chemical profiles of the leaves were studied using GC-MS analysis of the essential oils. The essential oils were isolated from fresh leaves by hydrodistillation for $3 \mathrm{~h}$ using Clevenger type apparatus. The oils were analyzed by gas chromatography methods. The GC-FID analysis was carried out on a Varian CP-3800 gas chromatograph equipped with a flame ionization detector (FID) and a CP Sil 8CB fused silica capillary column $(30 \mathrm{~m} \times$ $0.32 \mathrm{~mm}$, film thickness- $0.25 \mu \mathrm{m}$ ). The GC/MS analysis was done on a Hewlett Packard 6890 gas chromatograph fitted with a cross-linked 5\% phenyl methyl siloxane HP-5 MS capillary column $(30 \mathrm{~m} \times 0.32 \mathrm{~mm}$, film thickness- $0.25 \mu \mathrm{m})$ coupled with a 5973 series selective mass detector. The constituents were identified by retention indices calculated using homologues of n-alkanes ( $\mathrm{C}_{8}-\mathrm{C}_{22}$ ) (Dool and Kratz 1963), comparing mass spectra with published data (Adams, 2007) and by mass spectra library search (Wiley 275 and NIST).

Gas chromatography- mass spectrometry (GC-MS) studies of the leaf essential oils resulted in the identification of 58 volatile compounds in all the three species (Table 2). The major volatile constituents of all the three species, the sesquiterpenoids, were derived from trans, trans farnesyl pyrophosphate (FPP), through mevalonic acid pathway, pointing to the allied nature of the species. However, in the new taxon compared to other species, monoterpenoids $(2.8 \%)$ biosynthesized through trans geranyl pyrophosphate (GPP) were also present, while in G. xanthochymus, diterpenoids (4.4\%) biosynthesized through trans geranyl geranyl pyrophosphate (GGPP) were exclusively present. The presence of monoterpenoids formed from a distinct biosynthetic pathway support the species status for the new taxon, as elucidated through morphological studies. The presence of more complicated diterpenoids $\left(\mathrm{C}_{20} \mathrm{H}_{32}\right)$ in $\mathrm{G}$. xanthochymus compared to the simple monoterpenoids $\left(\mathrm{C}_{10} \mathrm{H}_{16}\right)$ and sesquiterpenoids $\left(\mathrm{C}_{15} \mathrm{H}_{24}\right)$ suggests that $G$. xanthochymus is more evolved in the group.

Table 2. Essential oil composition of the leaves of Garcinia pushpangadaniana, Garcinia xanthochymus and Garcinia talbotii

\begin{tabular}{lllll}
\hline Compound & RRI & G. xan $(\%)$ & G. pus $(\%)$ & G. tal (\%) \\
\hline Z- $\beta$-Ocimene & 1032 & -- & 0.2 & -- \\
Linalool & 1095 & -- & 1.8 & -- \\
Terpineol & 1186 & -- & 0.4 & -- \\
Geraniol & 1249 & -- & 0.4 & -- \\
$\delta$-Elemene & 1338 & 0.3 & 0.3 & -- \\
$\alpha$-Cubebene & 1348 & 0.9 & 0.7 & 0.7 \\
Cyclosativene & 1371 & 0.4 & -- & -- \\
$\alpha$-Ylangene & 1373 & -- & 0.8 & - \\
$\alpha$-Copaene & 1376 & 13.0 & 3.1 & 27.0 \\
$\beta$-Bourbonene & 1387 & 3.2 & 6.8 & 0.1 \\
$\beta$-Cubebene & 1387 & -- & 0.4 & -- \\
$\beta$-Elemene & 1390 & 4.6 & -- & - \\
$\beta$-Caryophyllene & 1419 & 17.0 & 11.4 & 30.4 \\
$\beta$-Copaene & 1430 & 1.6 & -- & 0.1 \\
$\beta$-Gurjunene & 1433 & -- & -- & 2.2 \\
$\gamma$-Elemene & 1434 & 0.1 & 0.4 & - \\
Aromadendrene & 1439 & 0.3 & 1.1 & 1.6 \\
$\alpha$-Humulene & 1452 & 6.6 & 3.2 & 10.7 \\
cis-Cadina-1(6)-4-diene & 1461 & -- & 1.4 & 0.1 \\
$\alpha$-Acoradiene & 1464 & -- & -- & 0.1 \\
$\gamma$-Gurjunene & 1475 & 1.2 & -- & 3.1 \\
$\gamma$-Muurolene & 1478 & 12.5 & 11.7 & 3.8 \\
\hline & & & & \\
\hline
\end{tabular}




\begin{tabular}{|c|c|c|c|c|}
\hline Amorpha-4,7 (11)-diene & 1479 & 0.1 & -- & -- \\
\hline$\alpha$-Amorphene & 1483 & -- & -- & 1.3 \\
\hline$\beta$-Selinene & 1489 & 0.1 & 0.6 & -- \\
\hline$\delta$-Selinene & 1492 & 3.2 & 0.9 & -- \\
\hline trans-Muurola-4(14)-5-diene & 1493 & 9.0 & -- & -- \\
\hline$\gamma$-Amorphene & 1495 & -- & 2.6 & -- \\
\hline$\alpha$-Muurolene & 1500 & 1.2 & 3.7 & -- \\
\hline$\delta$-Amorphene & 1511 & -- & 1.2 & -- \\
\hline$\gamma$-Cadinene & 1513 & 2.7 & 12.4 & -- \\
\hline$\delta$-Cadinene & 1522 & 4.6 & 13.1 & -- \\
\hline trans Cadina 1,4-diene & 1533 & 0.1 & 1.0 & 0.1 \\
\hline Cadina-1(2),4-diene & 1535 & -- & -- & 0.9 \\
\hline$\alpha$-Cadinene & 1537 & 0.4 & 1.4 & 0.1 \\
\hline Cadala-1(10),3,8-triene & 1540 & -- & -- & 0.3 \\
\hline$\alpha$-Calacorene & 1544 & 0.3 & 1.2 & -- \\
\hline Germacrene B & 1559 & 0.5 & 0.4 & -- \\
\hline Nerolidol & 1561 & -- & 0.4 & -- \\
\hline Epiglobulol & 1576 & -- & -- & 0.2 \\
\hline Spathulenol & 1577 & 0.1 & -- & -- \\
\hline Caryophyllene oxide & 1582 & 2.3 & 0.8 & 2.6 \\
\hline Globulol & 1590 & -- & -- & 0.1 \\
\hline Cubeban-11-ol & 1595 & -- & -- & 0.1 \\
\hline Humulene epoxide II & 1608 & 0.4 & -- & 0.5 \\
\hline 1,10-di epi Cubenol & 1618 & -- & -- & 1.2 \\
\hline$\alpha$-Corocalane & 1622 & -- & 0.2 & -- \\
\hline 1-epi-Cubenol & 1627 & 0.1 & 1.5 & 0.1 \\
\hline cis-Cadina-4-en-7-ol & 1635 & & 0.9 & -- \\
\hline allo Aromadendrene epoxide & 1639 & 0.4 & -- & -- \\
\hline Caryophylla-4(12),8(13)-diene & 1639 & -- & -- & 0.1 \\
\hline$\alpha$-Muurolol & 1644 & -- & 0.5 & 0.2 \\
\hline Cubenol & 1645 & 0.1 & -- & 0.8 \\
\hline$\alpha$-Cadinol & 1652 & 0.5 & 0.9 & 0.1 \\
\hline Cis-calamenen-10-ol & 1660 & 0.1 & -- & -- \\
\hline $\begin{array}{l}\text { 14-Hydroxy 9-epi-Z- } \\
\text { caryophyllene }\end{array}$ & 1666 & -- & -- & 0.5 \\
\hline $\begin{array}{l}\text { 14-Hydroxy 9-epi-E- } \\
\text { caryophyllene }\end{array}$ & 1668 & -- & -- & 0.1 \\
\hline 3E-Cembrene A & 1947 & 4.4 & -- & -- \\
\hline Total (\%) & & 92.3 & 87.8 & 89.2 \\
\hline Monoterpenoids & & Nil & 2.8 & Nil \\
\hline Sesquiterpene- Hydrocarbons & & 83.9 & 79.8 & 82.6 \\
\hline Sesquiterpene-Oxygenated & & 4 & 5.2 & 6.6 \\
\hline Diterpenoids & & 4.4 & Nil & Nil \\
\hline
\end{tabular}

RRI: Relative retention index calculated on HP-5 column

Similarity and cladistic analyses performed statistically based on the distribution of 58 volatile chemicals using SPSS software (ver.16.0) showed G. pushpangadaniana distinct from other two species (Figure 3, Table 3). The species is more related to G. xanthochymus $62 \%$ ), compared to G. talbotii (39\%). 


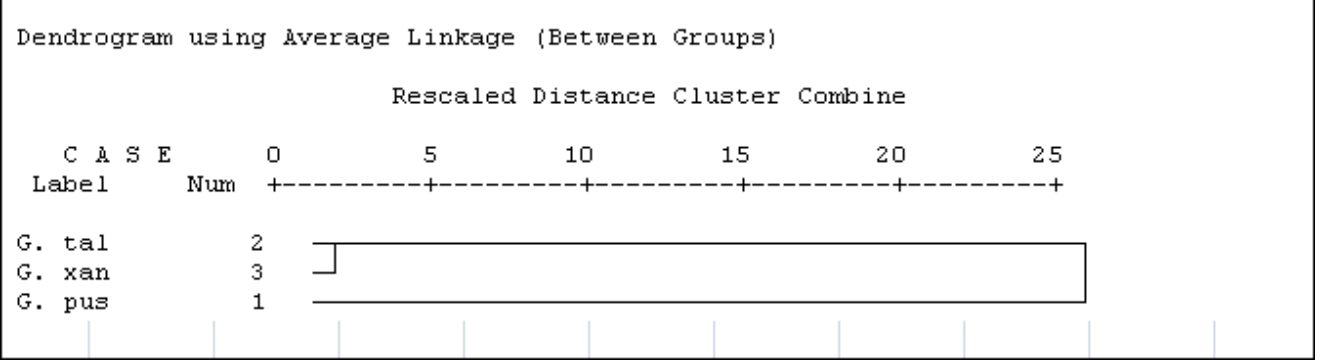

Figure 3. Dendrogram based on essential oil constituents of the leaves of Garcinia pushpangadaniana, Garcinia xanthochyma and Garcinia talbotii.

Table 3. Similarity matrix between three Garcinia species of the Western Ghats based on volatile chemical profile.

\begin{tabular}{|l|l|l|l|}
\hline Case & \multicolumn{3}{|l|}{ Correlation between vectors of values } \\
\hline & $1: 1$ & $2: 2$ & $3: 3$ \\
\hline $1: 1$ & 1.000 & .391 & .622 \\
\hline $2: 2$ & .391 & 1.000 & .794 \\
\hline $3: 3$ & .622 & .794 & 1.000 \\
\hline
\end{tabular}

\section{Molecular taxonomy}

Molecular taxonomic approaches may be defined as DNA based methods that permit an exact and rapid method of distinguishing specimens based on their variation in genetic composition. Molecular markers are a direct assay of hereditary material and unlike morphological markers, molecular markers are not prone to environmental influences and can complement data from descriptors such as morphological characters (Mba and Tohme, 2005). Molecular systematics has become a major tool used in conservation biology for describing biodiversity, discriminating among taxa and establishing likely paths of evolution through phylogenetic analysis (Avise, 1989; Soltis et al., 1999).

In the present study, Genomic DNA was isolated from young leaves using DNeasy plant DNA isolation kit (Qiagen). The PCR amplification was carried out in a PCR thermal cycler (GeneAmp PCR System 9700, Applied Biosystems). The sequence quality was checked using Sequence Scanner Software v1 (Applied Biosystems). Sequence alignment and required editing of the obtained sequences were carried out using Geneious Pro v 5.6. The phylogenetic analyses of 28 accessions of 10 Garcinia species were done using matK with Clusia criuva of Clusiaceae family as the out group member (ncbi-TNS:SK08071206). The analysis involved 28 nucleotide sequences. In the present study, G. pushpangadaniana, $G$. talbotii and $G$. xanthochymus comes under separate clad, in congruence with the morphological and chemical classifications. The dendrogram clearly delimits the species status of G. pushpangadaniana and is more allied to G. talbotii (Figure 3). 


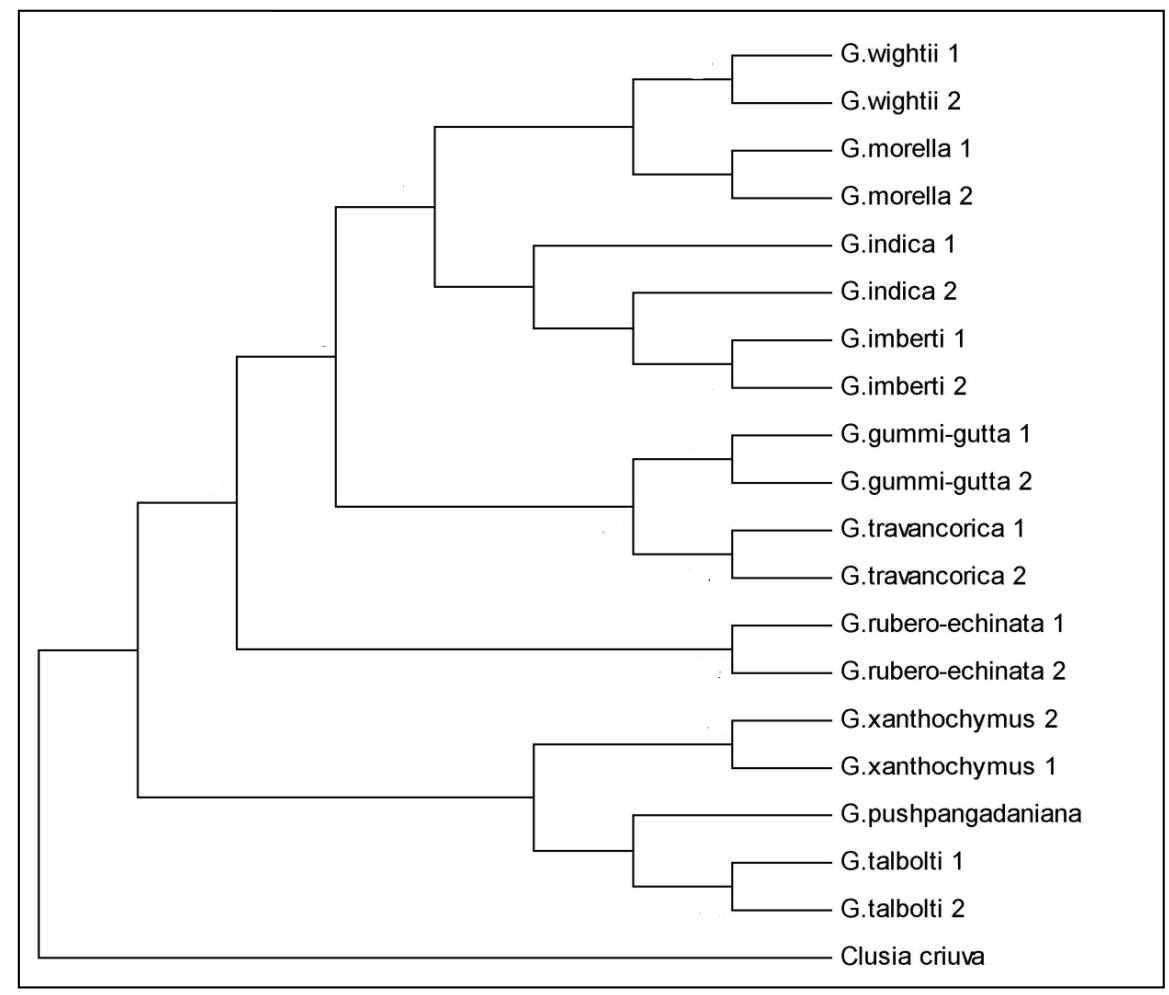

Figure 4. Phylogram based on matK loci of 28 accessions of 10 Garcinia species and the out group Clusia criuva

\section{Conclusions}

The HPTLC profile as well as the biosynthetic evaluation of the volatile terpenoids supported the species status for the new taxon. The molecular phylogeny also points to its proximity to G. talbotii and G. xanthochymus as elucidated through morphological evaluation. The present study highlights the importance of combined analysis of morphological traits, chemical profiles and genetic diversity that represents the optimal approach to assign species status to a new taxon.

\section{References}

1. Adams RP. 2007. Identification of Essential Oil Components by Gas Chromatography/Mass Spectrometry. Fourth edition. Allured Pub. Co., Carol Stream, IL.

2. Avise JC. 1989. A role for molecular genetics in the recognition and conservation of endangered species. Trends Ecol. Evol. 4, 279-281.

3. Dool VH and Kratz PD. 1963. A generalization of the retention index system including linear temperature programmed gas liquid partition chromatography. J. Chromatogr., 11, 463-471.

4. Grayer RJ, Kite GC, Goldstone FJ, Bryan SE, Paton A and Putievsky E. 1996. Infraspecific taxonomy and essential oil chemotype in sweet basil, Ocimum basilicum. Phytochemistry, 43, 1033-1039. 
5. Gustafsson MHG, Bittrich V and Stevens PF. 2002. Phylogeny of Clusiaceae based on rbcL sequences. Internat. J. Plant Sci. 163, 1045- 1054.

6. Hemshekhar M, Sunitha K, Santhosh MS, Devaraja S, Kemparaju K, Vishwanath BS and Girish KS. 2011. An overview on genus Garcinia: phytochemical and therapeutical aspects. Phytochem. Rev., 10(3), 325-351.

7. Labra M, Miele M, Ledda B, Grassi F and Mazzei M. 2004. Morphological characterization, essential oil composition and DNA genotyping of Ocimum basilicum L. cultivars. Plant Sci., 167, 725-731.

8. Mba C and Tohme J. 2005. Use of AFLP markers in surveys of plant diversity. Meth. Enzymol., 395, 177-201.

9. Nayar TS, Beegam AR and Sibi M. 2014. Flowering plants of the Western Ghats, India. JNTBGRI, Thiruvananthapuram.

10. Nogueira PC, Bittrich V, Shepherd GJ, Lopes AV and Marsaioli AJ. 2001. The ecological and taxonomic importance of flower volatiles of Clusia species (Guttiferae). Phytochemistry, 56(5), 443-452.

11. Reich E and Schibli A. 2007. High-Performance Thin-Layer Chromatography for the Analysis of Medicinal Plants. Thieme, New York.

12. Soltis PS, Soltis DE and Chase MW. 1999. Angiosperm phylogeny inferred from multiple genes as a tool for comparative biology. Nature, 402, 402-404.

13. Sweeney PW. 2008. Phylogeny and floral diversity in the genus Garcinia (Clusiaceae) and relatives. Int. J. Plant Sci., 169(9), 1288-1303.

14. Waterman PG and Hussain RA. 1983. Systematic significance of xanthones, benzophenones and biflavonoids in Garcinia. Biochem. Syst. Ecol., 11(1), 21-28.

15. Winfield MO, Wilson PJ, Labra M and Parker JS. 2003. A molecular analysis of Gentianella ssp. in Britain. Plant Syst. Evol., 267, 137-151. 


\title{
Chapter 8
}

\section{Diversity of Malabar Tamarind (Garcinia gummi-gutta (L.) N. Robson) in the Western Ghats- Morphological and phytochemical evaluation}

\author{
P. S. Shameer ${ }^{1}$, K. B. Rameshkumar ${ }^{2}$, T. Sabu ${ }^{1}$ and N. Mohanan ${ }^{1 *}$ \\ ${ }^{1}$ Garden Management, Education, Information and Training Division \\ ${ }^{2}$ Phytochemistry and Phytopharmacology Division \\ Jawaharlal Nehru Tropical Botanic Garden and Research Institute \\ Palode, Thiruvananthapuram- 695 562, Kerala, India \\ ${ }^{*}$ Corresponding author
}

\begin{abstract}
Garcinia gummi-gutta (L.) Robs. (Clusiaceae) is an economically important fruit crop and the most widely distributed species in the Western Ghats of Kerala. The diversity of G. gummigutta in terms of morphological and chemical characters is discussed in this chapter. Three varieties of the species viz; G. gummi-gutta (L.) Robs. var. gummi-gutta, G. gummi-gutta var. papilla (Wight) N. P. Sing., and G. gummi-gutta var. conicarpa (Wight) N. P. Sing., are reported in India. The variety conicarpa is morphologically distinct by the absence of leaf ligules and by the arrangement of stamens in a convex torus head, in addition to the conical nature of fruits. The difference in morphological variation has been manifested in chemical constitution as well. Dendrogram based on leaf volatile chemical distribution of the three varieties revealed nearly $75 \%$ correlation between var. gummi-gutta and var. papilla, while variety conicarpa showed less than $20 \%$ similarity with the other two varieties. HPTLC analysis also showed distinct chemical profile for the variety conicarpa. The morphological and chemical variation of G. gummigutta var. conicarpa suggests species status for the variety. The diversity among cultivated accessions of var. gummi-gutta is also discussed in detail.
\end{abstract}

Keywords: G. gummi-gutta var. gummi-gutta, G. gummi-gutta var. papilla, G. gummi-gutta var. conicarpa, Leaf essential oils

\section{Introduction}

Garcinia species are an important component of the forest flora of the Western Ghats, with 9 species and 2 varieties, of which 7 species and 2 varieties are endemic to the region. Garcinia gummi-gutta (L.) Robs. the most widely distributed species among these, is also an economically important fruit crop of Kerala. The fruits are popularly known as Malabar tamarind or Kudampuli whose dried pericarp is used as a condiment and is used as an alternative of tamarind to impart a special flavour and taste to curries in Kerala (Anonymous, 1950). Also the fruits are commercially important as a rich source of the much valued antiobesity phytochemical hydroxycitric acid and several industrial units are located in central Kerala for extracting the value added product from the fruits (Hemesekhar et al., 2011).

Though three varieties are reported, literature review and herbarium specimen analysis revealed ambiguity in proper demarcation of the varieties. In this background, male 
and female accessions of the varieties were collected from different parts of the Western Ghats and the present chapter elaborates the morphological features of the varieties along with comparison of chemical profile. Moreover, the diversity among the cultivated variety has also been evaluated critically.

\section{Taxonomical history of the Garcinia gummi-gutta}

Carl Linnaeus described the species Cambogia gummi-gutta L., in Gen. Pl., ed. 5: (1754) with a short description and Van Rheede referred the material as 'Coddam-pulli' in Hortus Malabaricus (Van Rheede, 1678). A combination nova was proposed for Cambogia gummigutta L. and G. cambogia (Gaertn.) Desr. (Desrous, 1792) by Robson as G. gummi-gutta (L.) N. Robson (Robson, 1968). Though Robert Wight proposed Garcinia conicarpa Wight [Wight, Icon. (Pl. Ind. Orient. t. 121. 1839 \& Ill. Ind. Bot. 1.126. 1840, TYPE: Madras, Shevagherry hills, 1836, ex. Herb, Wight 142 (CAL)], the taxon was further treated by T. Anderson as a variety of G. cambogia (Gaertn.) Desr. var. conicarpa (Wight) T. Anderson (1874). Wight also collected another specimen from the evergreen forests of the Western Ghats and described the variety papilla (Wight, 1840) under G. cambogia (Desrous, 1792). Later N. P. Singh (Singh, 1993) proposed combination nova for these varieties as G. gummigutta var. conicarpa (Wight) N.P. Singh, and G. gummi-gutta var. papilla (Wight) N. P. Singh respectively.

\section{Distribution and conservation status of the varieties of Garcinia gummi-gutta}

The variety gummi-gutta is distributed wildly in the evergreen forests of Western Ghats ranging, from $400 \mathrm{~m}$ to $900 \mathrm{~m}$. It is fairly common and abundant in the forests of western Sri Lanka from sea level to $600 \mathrm{~m}$ and in Malaysia also. In Kerala, it is very popular in the Central Travancore areas, where maximum diversity is seen. Field studies revealed that the var. gummi-gutta is cultivated all over the low lands and mid lands of Kerala ranging from sea shore to the high lands up to $600 \mathrm{~m}$. The other two varieties are restrictedly endemic to the Western Ghats. Variety conicarpa is a high altitude species $(1350-1950 \mathrm{~m})$ distributed rarely in evergreen forests of South Western Ghats (Table 1). var. papilla is also very rare in the evergreen forests of Southern Western Ghats and found in an altitude of 800-1850 m. Samples of G. gummi-gutta var. papilla were collected from Silent Valley, Palakkad district and G. gummi-gutta var. conicarpa were collected from from Kadalar, Rajamala, Kottamala forest regions of Idukki district and Vellarimala, Chembra hills of Wayanad district. Though varieties papilla and conicarpa were not included in IUCN categories, we suggest both to be included in 'endangered' category, based on their restricted distribution within small scattered populations.

\section{Morphological features of the varieties of Garcinia gummi-gutta}

Critical evaluation of morphological characters through detailed qualitative and quantitative characters of male and female accessions of the varieties were carried out (Table 1, Figure 1). The demarcating morphological features noted for the varieties are lamina shape, presence of leaf ligule, pedicel length, stamen arrangement, fruit shape and number of fruit grooves in fruits. Based on the distinguishing morphological features of var. conicarpa such as absence of leaf ligules, lamina shape, arrangement of stamens in convex torus head, pedicel length, conical nature of fruits and the fibrous nature of arils, the variety conicarpa need to be reinstated as species $G$. conicarpa, early proposed by Wight. 

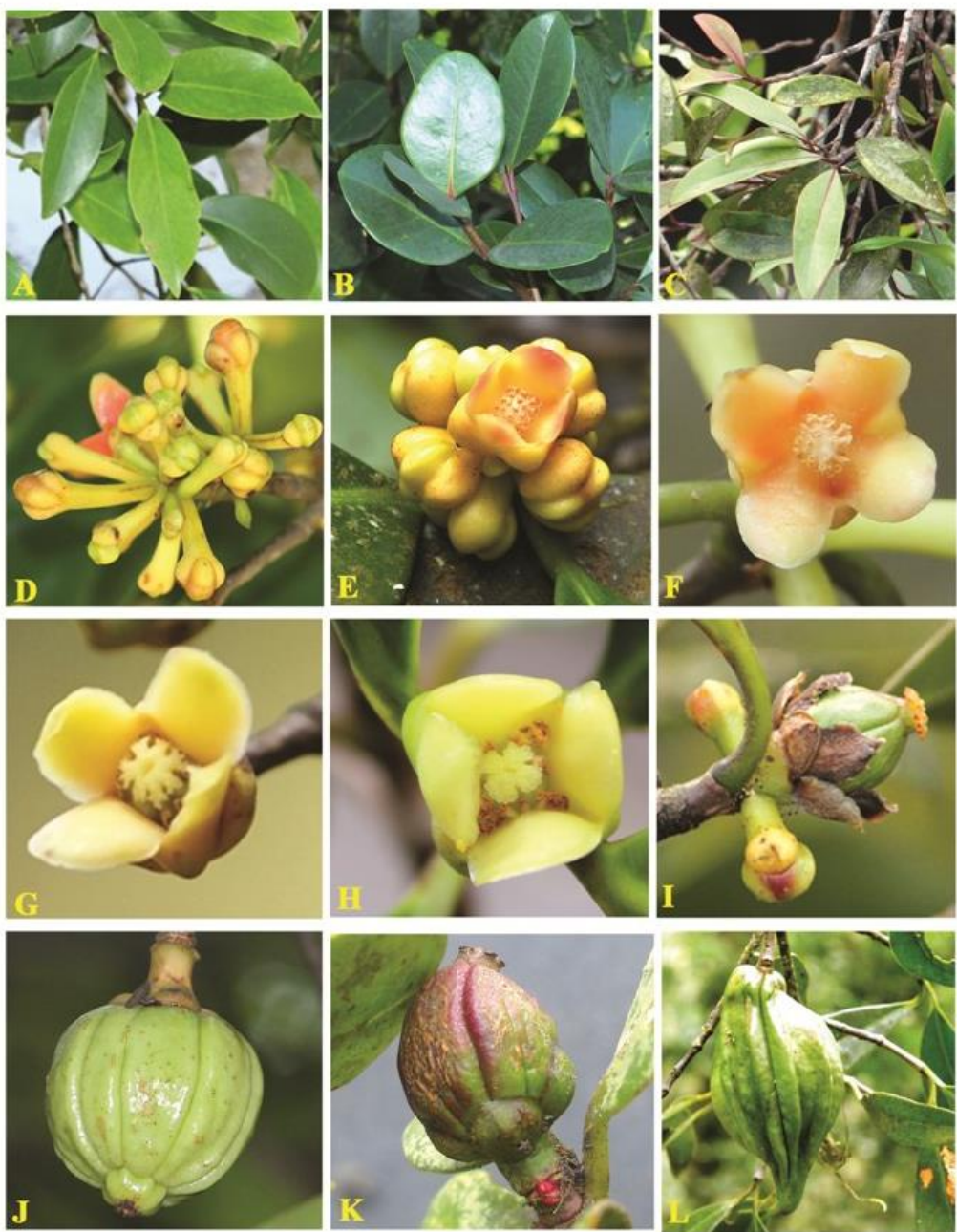

Figure 1. G. gummi-gutta varieties (A-C. Leaves, D-F. Male flowers, G-H. Female flowers, J-K. Fruits)

\subsection{Key to Garcinia gummi-gutta varieties}

1 Stamens 12-20, ovary 4-12 locular, stigmatic ray 6-10; berries 6-10 grooves.............................var. gummi-gutta

1 Stamens more than 20; ovary 3 - or 6- 8 locular, stigmatic rays 3 or 6-8; berries 3 or $6-8$ grooves....................................

2 2.a Leaf ligule present; ovary 6-8 locular; stigmatic rays 4-8; berries ovoid-oblong, 4-8 grooved, var. papilla

2.b Leaf ligule absent; ovary 3-5 locular; stigmatic rays 3-5; berries ovoid or conical, 3-5 grooved var. conicarpa 
Table 1. Distinguishing characters of Garcinia gummi-gutta varieties

\begin{tabular}{|c|c|c|c|c|}
\hline $\begin{array}{l}\text { Sl. } \\
\text { No. }\end{array}$ & Parameter & var. gummi-gutta & var. papilla & var. conicarpa \\
\hline 1 & Branches & $\begin{array}{l}\text { Parallel or pendulous } \\
\text { drooping }\end{array}$ & Parallel & Parallel \\
\hline 2 & Leaf shape & $\begin{array}{l}\text { Elliptical-oblong or } \\
\text { obovate }\end{array}$ & Elliptical & $\begin{array}{l}\text { Obovate-ovate rarely } \\
\text { oblong or broader } \\
\text { beyond the middle }\end{array}$ \\
\hline 3 & Length of petiole & $1.5-2 \mathrm{~cm}$ & $1.5 \mathrm{~cm}$ & $>1 \mathrm{~cm}$ \\
\hline 4 & Leaf ligule & Present & Present & Absent \\
\hline 5 & $\begin{array}{l}\text { Length of Male flower } \\
\text { pedicel }\end{array}$ & $1.5-1.7 \mathrm{~cm}$ & $0.7 \mathrm{~cm}$ & $>0.5 \mathrm{~cm}$ \\
\hline 6 & $\begin{array}{l}\text { Length of Female flower } \\
\text { pedicel }\end{array}$ & $4-6 \mathrm{~mm}$ & Ca. $5 \mathrm{~mm}$ & sessile \\
\hline 7 & Arrangement of Stamen & Globose head & $\begin{array}{l}\text { Globose and } \\
\text { androphore }\end{array}$ & Convex torus \\
\hline 8 & $\begin{array}{l}\text { Number of stamen / } \\
\text { flower }\end{array}$ & $12-20$ & 25 or more & Ca. 35 \\
\hline 9 & Rudimentary pistil & Present & Absent & Absent \\
\hline 10 & Ovary & 4-12 locular & 6-8 locular & 3-5 locular \\
\hline 11 & Female flower position & Terminal or axillary & Terminal or axillary & $\begin{array}{l}\text { Terminal or } \\
\text { subterminal }\end{array}$ \\
\hline 12 & No. of Stigmatic lobes & $6-10$ & 3- 8 & $3-5$ \\
\hline 13 & Staminodes & $10-20$ & $9-12$ & Ca. 20 \\
\hline 14 & Fruit shape & Globose & Sub globose & Ovoid- conical \\
\hline 15 & $\begin{array}{l}\text { Number of groove / } \\
\text { Berries }\end{array}$ & $6-10$ & $3-8$ & $4-5$ \\
\hline 16 & Nature of Seed & Covered with pulpy aril & $\begin{array}{l}\text { Covered with thick } \\
\text { mass of fibrous aril }\end{array}$ & $\begin{array}{l}\text { Covered with thin } \\
\text { fibrous aril }\end{array}$ \\
\hline 17 & Number of seeds & $4-8$ & $3-5$ & $2-4$ \\
\hline 18 & Seed shape & Ovoid & Sub triangular & Ovate- oblong \\
\hline 19 & Flowering & Jan-Mar & Jan-Mar & Apr-Jun \\
\hline 20 & Fruiting & Apr-Aug & Apr-Jul & Jul-Oct \\
\hline 21 & Habit & Large tree & Large tree & Large tree \\
\hline 22 & Habitat (wild) & $\begin{array}{l}\text { Semi-evergreen to } \\
\text { evergreen forests of } \\
\text { Western Ghats at }\end{array}$ & $\begin{array}{l}\text { Endemic to evergreen } \\
\text { forests of Western } \\
\text { Ghats in between }\end{array}$ & $\begin{array}{l}\text { Endemic to } \\
\text { Evergreen forests of } \\
\text { Western Ghats in } \\
\text { between }\end{array}$ \\
\hline 23 & Cultivation status & $\begin{array}{l}\text { Cultivated from sea } \\
\text { shore to mid land and } \\
\text { up to high land }\end{array}$ & Wild only & Wild only \\
\hline 24 & Altitude (m) & $50-900 \mathrm{~m}$ & $800-1850 \mathrm{~m}$ & $1350-1950 \mathrm{~m}$ \\
\hline 25 & Distribution status & Common & Rare & Rare \\
\hline
\end{tabular}

\subsection{Morphological diversity of Garcinia gummi-gutta var. gummi-gutta}

Kerala seems to be the centre of diversity of cambogia and wide variations in the morphological characters are observed in the leaves, flowers, fruits and seeds of Garcinia gummi-gutta (Tharachand et al., 2015, Abraham et al., 2006). The diversity of var. gummigutta is more manifested among the cultivars, compared to the wild accessions. 


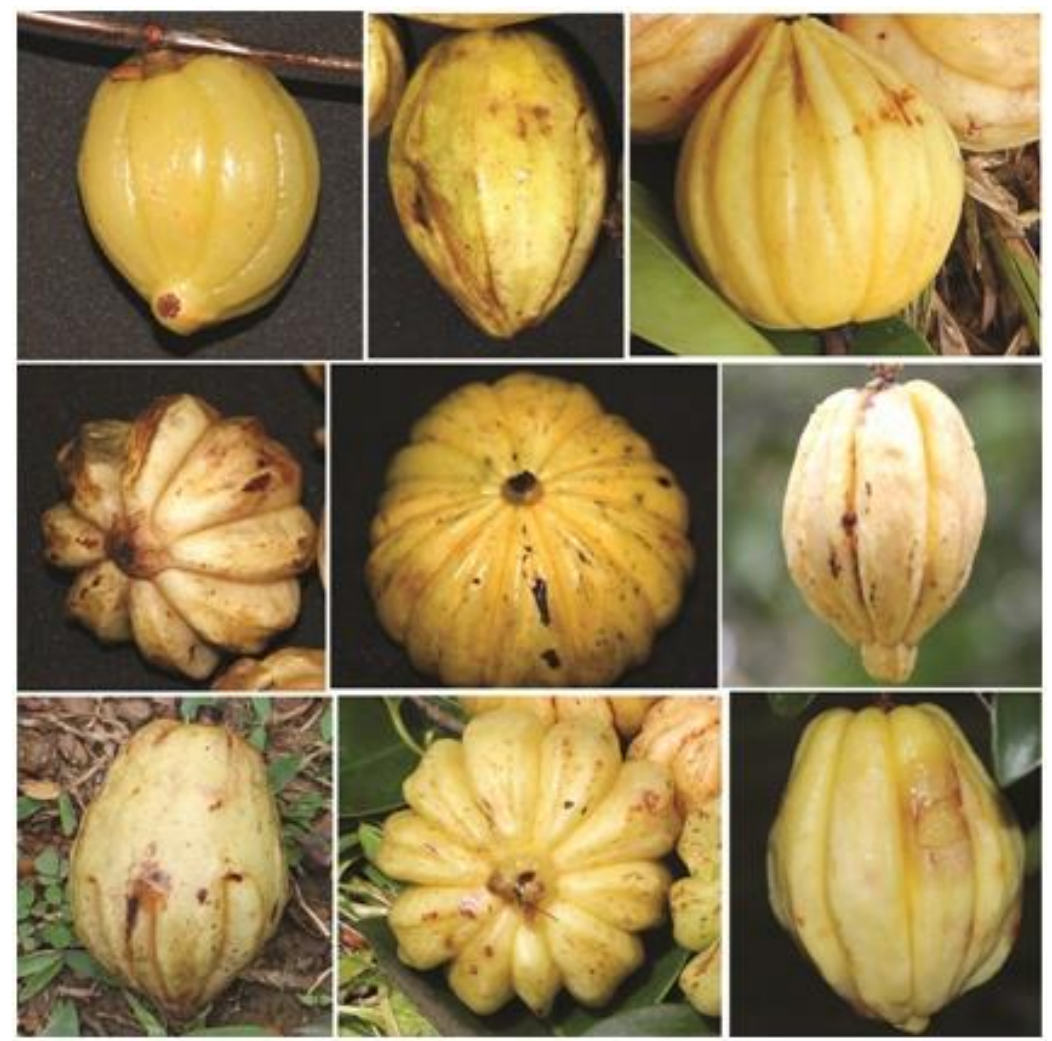

Figure 2. Diversity of Garcinia gummi-gutta var. gummi-gutta fruits

Fruits of 18 accessions of var. gummi-gutta, cultivated in different parts of Kerala extending from coastal region to middle land, were collected and studied for assessing the variability in size and shape (Table 2, Figure 2). The large fruit size, pulpy aril and more number of seeds (4-8) per fruit were the favorable features of var. gummi-gutta supporting its wide distribution and preference for cultivation over the other two varieties. The processed pericarp of var. gummi-gutta is of great value for its delicate taste and flavour and the accessions were evaluated in terms of fruits size, rind thickness, acidity and yield. The average weight of fruits was $173 \mathrm{~g}$. Previous studies on 13 fruit and five seed characters of 51 accessions of Malabar tamarind by Abraham et al., (2006) reported that the variability was found to be maximum for nipple length $(74.8 \%)$ and minimum for fruit girth $(12.8 \%)$ and the average fruit weight was $161 \mathrm{~g}$.

Usually the branching pattern was horizontal, while pendulous drooping pattern has also been observed rarely. The average size of leaves was 7-12 x 3.5-5 cm while the leaf shape varied considerably from the typical elliptic to broad shapes. The apex and base of leaves were acute and rarely obtuse. The variation was also exhibited in flowers, fruits and seeds morphology. The fruit shape varied from globose, oblong and rarely to discoid shape. The thickness of fruit rind is a detrimental factor in food sector and the thickness varies from $6.25 \mathrm{~mm}$ to $16.03 \mathrm{~mm}$ among the selected accessions. The fresh weight of fruit was in the range 45.7-173.3 g. The number of grooves over the fruit surface also varied significantly from 5 to 11 . 
Table 2. Morphological variation in Garcinia gummi-gutta var. gummi-gutta

\begin{tabular}{|c|c|c|c|c|c|c|c|c|c|c|c|}
\hline \multirow{2}{*}{$\begin{array}{l}\text { Sl. } \\
\text { No }\end{array}$} & \multirow[t]{2}{*}{ Accession } & \multirow{2}{*}{$\begin{array}{c}\text { Branching } \\
\text { pattern }\end{array}$} & \multicolumn{3}{|c|}{ Leaf shape } & \multirow{2}{*}{$\begin{array}{l}\text { Leaf } \\
\text { size } \\
(\mathrm{cm})\end{array}$} & \multirow{2}{*}{$\begin{array}{l}\text { Number } \\
\text { of fruit } \\
\text { grooves }\end{array}$} & \multirow{2}{*}{$\begin{array}{c}\text { Fruit } \\
\text { rind } \\
\text { thick } \\
\text { ness } \\
(\mathrm{mm})\end{array}$} & \multirow{2}{*}{$\begin{array}{l}\text { Fruit } \\
\text { shape }\end{array}$} & \multirow{2}{*}{$\begin{array}{c}\text { Fruit } \\
\text { wt. }\end{array}$} & \multirow{2}{*}{$\begin{array}{r}\text { No. } \\
\text { of } \\
\text { seed }\end{array}$} \\
\hline & & & Lamina & Apex & Base & & & & & & \\
\hline 1 & Kotta & $\begin{array}{l}\text { Horizontal } \\
\text { spreading }\end{array}$ & $\begin{array}{l}\text { Elliptic- } \\
\text { Ovate }\end{array}$ & Acute & Acute & $\begin{array}{l}6-10 x \\
4-6\end{array}$ & $6-9$ & 11.21 & $\begin{array}{l}\text { Globose, } \\
\text { grooves } \\
\text { splitted }\end{array}$ & 52.16 & $2-4$ \\
\hline 2 & Mezhuveli & $\begin{array}{l}\text { Horizontal } \\
\text { spreading }\end{array}$ & Elliptic & Acute & Acute & $\begin{array}{l}7-13 x \\
4-6\end{array}$ & $7-9$ & 10.31 & Oblong & 43.52 & $1-2$ \\
\hline 3 & $\begin{array}{l}\text { Karanikun } \\
\text { nu (i) }\end{array}$ & $\begin{array}{l}\text { Horizontal } \\
\text { spreading }\end{array}$ & $\begin{array}{l}\text { Elliptic- } \\
\text { oblance } \\
\text { olate }\end{array}$ & $\begin{array}{l}\text { Acute- } \\
\text { obtuse }\end{array}$ & Acute & $\begin{array}{l}6-10 x \\
3-4.5\end{array}$ & $7-8$ & 11.71 & $\begin{array}{l}\text { Oblong, } \\
\text { mamillae }\end{array}$ & 89 & $5-7$ \\
\hline 4 & $\begin{array}{l}\text { Karanikku } \\
\text { nu (ii) }\end{array}$ & $\begin{array}{l}\text { Horizontal } \\
\text { spreading }\end{array}$ & $\begin{array}{l}\text { Elliptic- } \\
\text { ovate }\end{array}$ & Acute & $\begin{array}{l}\text { Obtus } \\
\mathrm{e}\end{array}$ & $\begin{array}{l}5-9 x \\
3-4\end{array}$ & $7-10$ & 7.2 & Oblong & 45.68 & $2-4$ \\
\hline 5 & $\begin{array}{l}\text { Karanniku } \\
\text { nnu(iii) }\end{array}$ & $\begin{array}{l}\text { Horizontal } \\
\text { spreading }\end{array}$ & Elliptic & Acute & Acute & $\begin{array}{l}6-9 \mathrm{x} \\
3.5-5\end{array}$ & $7-10$ & 6.25 & $\begin{array}{l}\text { Globose- } \\
\text { oblong }\end{array}$ & 54.86 & $4-6$ \\
\hline 6 & Ullanoor & $\begin{array}{l}\text { Pyramidal } \\
\text { drooping }\end{array}$ & $\begin{array}{l}\text { Elliptic- } \\
\text { broad } \\
\text { elliptic }\end{array}$ & $\begin{array}{l}\text { Obtus } \\
\text { ely } \\
\text { acute }\end{array}$ & Acute & $\begin{array}{l}7-9 x \\
3-6\end{array}$ & 8 & 11.51 & $\begin{array}{l}\text { Globose, } \\
\text { mammilla } \\
\text { te }\end{array}$ & 85.28 & 7 \\
\hline 7 & $\begin{array}{l}\text { Arammull } \\
\text { a }\end{array}$ & $\begin{array}{l}\text { Pyramidal } \\
\text { drooping }\end{array}$ & Elliptic & Acute & Acute & $\begin{array}{l}6-10 x \\
3-4\end{array}$ & 8 & 13.8 & Discoid & 99.92 & 4 \\
\hline 8 & $\begin{array}{l}\text { Kurianipp } \\
\text { ally }\end{array}$ & $\begin{array}{l}\text { Horizontal } \\
\text { spreading }\end{array}$ & Elliptic & Acute & Acute & $\begin{array}{l}5-9 \mathrm{x} \\
3.5-4\end{array}$ & 8 & 9.2 & Oblong & 58.42 & 5 \\
\hline 9 & $\begin{array}{l}\text { Manipuzh } \\
\text { a }\end{array}$ & $\begin{array}{l}\text { Horizontal } \\
\text { spreading }\end{array}$ & Elliptic & Acute & Acute & $\begin{array}{l}6-10 x \\
3.5-5\end{array}$ & 8 & & $\begin{array}{l}\text { Globose, } \\
\text { grooves } \\
\text { splitted }\end{array}$ & $\begin{array}{l}124.8 \\
2\end{array}$ & 5 \\
\hline 10 & Pulikezh & $\begin{array}{l}\text { Horizontal } \\
\text { spreading }\end{array}$ & Elliptic & Acute & Acute & $\begin{array}{l}5.5-9 \\
\times 3.5- \\
4.5\end{array}$ & 9 & 13.41 & $\begin{array}{l}\text { Globose- } \\
\text { oblong } \\
\text { with } \\
\text { mamillae }\end{array}$ & 46.98 & 7 \\
\hline 11 & Podiyadi & $\begin{array}{l}\text { Horizontal } \\
\text { spreading }\end{array}$ & $\begin{array}{l}\text { Elliptic- } \\
\text { broad } \\
\text { elliptic }\end{array}$ & Acute & Acute & $\begin{array}{l}6-10 x \\
4-5\end{array}$ & 6 & & $\begin{array}{l}\text { Globose- } \\
\text { oblong } \\
\text { with } \\
\text { depressed }\end{array}$ & 85.48 & 3 \\
\hline 12 & $\begin{array}{l}\text { TBG. G.g } \\
-1\end{array}$ & $\begin{array}{l}\text { Pyramidal } \\
\text { drooping }\end{array}$ & & & & & $6-8$ & 16.03 & & 198.8 & $4-5$ \\
\hline 13 & $\begin{array}{l}\text { TBG. G.g } \\
-2\end{array}$ & $\begin{array}{l}\text { Horizontal } \\
\text { spreading }\end{array}$ & & & & & $6-9$ & & & $\begin{array}{l}148.9 \\
4\end{array}$ & $4-6$ \\
\hline 14 & Karimbam & $\begin{array}{l}\text { Horizontal } \\
\text { spreading }\end{array}$ & Elliptic & Acute & Acute & & $8-11$ & & Globose & 58.94 & $6-9$ \\
\hline 15 & Calicut & $\begin{array}{l}\text { Horizontal } \\
\text { spreading }\end{array}$ & & & & & $8-9$ & & $\begin{array}{l}\text { Globose,g } \\
\text { rooves } \\
\text { splitted }\end{array}$ & 66.24 & $7-8$ \\
\hline 16 & Vaikom 1 & $\begin{array}{l}\text { Horizontal } \\
\text { spreading }\end{array}$ & & & & & $6-7$ & & $\begin{array}{l}\text { Globose,g } \\
\text { rooves } \\
\text { splitted } \\
\text { with } \\
\text { mamillae }\end{array}$ & 95.53 & $5-6$ \\
\hline 17 & $\begin{array}{l}\text { Vaikom - } \\
2\end{array}$ & $\begin{array}{l}\text { Horizontal } \\
\text { spreading }\end{array}$ & & & & & $7-9$ & & $\begin{array}{l}\text { Globose,g } \\
\text { rooves } \\
\text { splitted } \\
\text { with } \\
\text { mamillae }\end{array}$ & & $6-8$ \\
\hline 18 & Wayanad & $\begin{array}{l}\text { Horizontal } \\
\text { spreading }\end{array}$ & $\begin{array}{l}\text { Ovate- } \\
\text { elliptic }\end{array}$ & Acute & Acute & $\begin{array}{l}6-9 x \\
3-5\end{array}$ & $5-6$ & 12.7 & Oblong & & $3-4$ \\
\hline
\end{tabular}




\section{Chemotaxonomical studies of the varieties of G. gummi-gutta}

The genus Garcinia is considered as a taxonomically difficult one due to the complexity and diversity in floral characteristics and differences in the floral architecture were observed even among closely related taxa of Garcinia (Sweeney, 2008, Nimanthika and Kaththriarachchi, 2010). Morphological characters are known to be affected by developmental and environmental factors and in the case of Garcinia species, an unusual evolutionary plasticity has been generally observed. Incorporation of biosystematics permits classifications using new descriptors and methods that yield more robust inter relations. Chemosystematic studies based on secondary metabolite profile has proven as an efficient supportive tool for plant systematics. The genus Garcinia is characterized by the presence of a large number of secondary metabolites such as xanthones, benzophenones and biflavonoids, in addition to volatile secondary metabolites (Hemshekhar et al., 2011). In the present study, volatile chemical profile as well as non volatile chemical profile was utilized for differentiating the three varieties.

\subsection{Volatile chemical analysis of the varieties of G. gummi-gutta}

Several attempts have been made to evaluate the phylogeny among Clusiaceae members through secondary metabolite profiling (Waterman and Hussain, 1983). Among the secondary metabolites, volatile chemicals can efficiently be utilized for chemotaxonomic purposes (Labra et al., 2004). Most of the Clusiaceae members are known for their oil glands and secretary canals and volatile chemical profiles of several Garcinia species have been reported (Rameshkumar et al., 2005, Martins et al., 2008).

In the present work, volatile chemical profiles of the leaves of the female accessions of the three varieties were studied using GC-MS analysis of the essential oils. The essential oils were isolated from fresh leaves by hydrodistillation for $3 \mathrm{~h}$ using Clevenger type apparatus. The oils were analyzed by gas chromatography methods. GC-FID analysis was carried out on a Varian CP-3800 gas chromatograph equipped with a flame ionization detector (FID) and a CP Sil 8CB fused silica capillary column $(30 \mathrm{~m} \times 0.32 \mathrm{~mm}$, film thickness- $0.25 \mu \mathrm{m})$. The GC-MS analysis was done on a Hewlett Packard 6890 gas chromatograph fitted with a cross-linked 5\% phenyl methyl siloxane HP-5 MS capillary column $(30 \mathrm{~m} \times 0.32 \mathrm{~mm}$, film thickness- $0.25 \mu \mathrm{m})$ coupled with a 5973 series selective mass detector. The constituents were identified by retention indices calculated using homologues of n-alkanes ( $\mathrm{C}_{8}-\mathrm{C}_{22}$ ) (Dool and Kratz 1963), comparing mass spectra with published data (Adams, 2007) and by mass spectra library search (Wiley 275 and NIST). Similarities among the varieties were studied by hierarchical clustering based on the volatile chemical distribution, using SPSS (ver.16.0).

Thirty eight compounds were identified in the leaf essential oils of 3 varieties and sesquiterpenoids were the predominant compounds (Table 3). Comparison of the volatile chemical profile revealed that the variety conicarpa possess distinct chemical profile. While $\alpha$-copaene was the major compound in varieties gummi-gutta (30.2) and papilla (24.3), var. conicarpa possess only $1.5 \% \alpha$-copaene. The content of $\beta$-caryophyllene was higher in var. conicarpa (18.1) compared to varieties gummi-gutta (5.7\%) and papilla (8.4). Major component of var. conicarpa was $\gamma$-cadinene $(46.2 \%)$, which is present in less quantity in varieties gummi-gutta (3.4\%) and papilla (3.4\%). 
Table 3. Distribution of leaf volatile chemicals in Garcinia gummi-gutta varieties

\begin{tabular}{|c|c|c|c|c|}
\hline Compound & RI & Gg.vg. F1 & Gg.vp. F1 & Gg.vc. F1 \\
\hline E- $\beta$-Ocimene & 1044 & 1.1 & - & - \\
\hline Terpinolene & 1086 & 0.2 & _ & _- \\
\hline$\alpha$-Cubebene & 1348 & 0.4 & 0.3 & - \\
\hline Cyclosativene & 1369 & 1.3 & 1.1 & 1.3 \\
\hline$\alpha$-Copaene & 1374 & 30.2 & 24.3 & 1.5 \\
\hline$\beta$-Panasinsene & 1382 & 1.3 & 0.6 & 0.1 \\
\hline$\alpha$-Gurjunene & 1409 & 0.3 & - & 0.1 \\
\hline$\beta$ - Caryophyllene & 1417 & 5.7 & 8.4 & 18.1 \\
\hline$\beta$-Copaene & 1430 & 1.3 & 1.1 & - \\
\hline$\gamma$-Elemene & 1434 & 2.1 & 1.3 & - \\
\hline$\alpha$-Guaiene & 1437 & 0.3 & _- & 2.3 \\
\hline cis- Muurola- 3,5- diene & 1448 & 0.8 & - & 0.1 \\
\hline Amorpha- 4,11 - diene & 1449 & 0.4 & _. & 7.1 \\
\hline$\alpha$-Humulene & 1452 & 1.8 & 0.9 & 3.7 \\
\hline cis- Cadina-1(6),4- diene & 1461 & 0.9 & _- & 0.7 \\
\hline trans- Cadina- 1(6),4 - diene & 1475 & 0.9 & - & - \\
\hline$\gamma$ - Muurolene & 1478 & 4.3 & $\overline{6} .3$ & - \\
\hline Amorpha- 4,7(11)-diene & 1480 & 0.5 & 0.1 & - \\
\hline$\beta$-Selinene & 1489 & 1.1 & 12.3 & _- \\
\hline$\delta$-Selinene & 1492 & _- & 1.5 & 0.7 \\
\hline trans- Muurola- 4,(14)5 - diene & 1493 & - & _- & 1.2 \\
\hline$\alpha$-Selinene & 1498 & 1.5 & 13.9 & _- \\
\hline$\alpha$ - Muurolene & 1500 & 1.5 & 2.5 & - \\
\hline Germarene A & 1509 & 0.6 & _ & - \\
\hline$\gamma$-Cadinene & 1513 & 3.4 & 3.4 & $\overline{4} 6.2$ \\
\hline 7- epi- $\alpha$-Selinene & 1520 & _- & _- & 1.9 \\
\hline$\delta$ - Cadinene & 1522 & 32.4 & 10.6 & 10.0 \\
\hline Zonarene & 1525 & _- & 0.8 & _- \\
\hline trans- Cadina 1,4 diene & 1533 & 0.7 & 0.5 & 0.1 \\
\hline$\alpha$ - Cadinene & 1537 & 0.5 & 0.6 & 0.5 \\
\hline$\alpha$-Calacorene & 1544 & 0.5 & 0.8 & 1.0 \\
\hline Germarene B & 1559 & 0.3 & _- & _- \\
\hline Caryophyllenyl alcohol & 1570 & - & - & $\overline{0} .9$ \\
\hline 1-epi-Cubenol & 1627 & -- & - & _- \\
\hline$\alpha$ - Muuralol & & 0.4 & 0.2 & - \\
\hline Cubenol & 1645 & 0.2 & _- & - \\
\hline n- Hexadecanol & 1874 & $\ldots$ & - & $\overline{0} .1$ \\
\hline n- Octadecanol & 2077 & - & - & 0.1 \\
\hline Total identified (\%) & & 96.9 & 91.5 & 97.7 \\
\hline Total identified (No.) & & 30 & 21 & 21 \\
\hline Monoterpenoids & & 1.3 & nil & nil \\
\hline Sesquiterpene- hydrocarbons & & 95.0 & 91.3 & 96.8 \\
\hline Sesquiterpene-oxygenated & & 0.6 & 0.2 & 0.9 \\
\hline Total sesquiterpenoids & & 95.6 & 91.5 & 97.7 \\
\hline
\end{tabular}

RRI: Relative retention index calculated on HP-5 column.

Dendrogram based on distribution of volatile compounds (SPSS) in the leaves of the varieties revealed $75 \%$ similarity between var. gummi-gutta and var. papilla, while var. conicarpa showed only $20 \%$ similarity with the other two varieties (Table 4, Figure 3). 


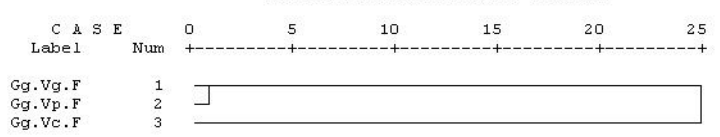

Figure 3. Dendrogram based on distribution of volatile compounds in the leaves of Garcinia gummigutta varieties

Table 4. Proximity matrix between varieties

\begin{tabular}{llll}
\hline Sample & Gg. vg & Gg. vp & Gg. vc \\
\hline Gg. vg & 1.000 & .750 & .209 \\
Gg. vp & .750 & 1.000 & .173 \\
Gg. vc & .209 & .173 & 1.000 \\
\hline
\end{tabular}

\subsection{HPTLC analysis of the varieties of G. gummi-gutta}

The non volatile chemical profiles of the varieties were studied through HPTLC method. $5 \mathrm{~g}$ each of the dried leaf powders were extracted with hexane, followed by methanol in a Soxhlet apparatus for $4 \mathrm{~h}$ each. The HPTLC profile of the hexane and methanol extracts were studied using CAMAG HPTLC using the solvent system hexane: ethyl acetate (7:3) for hexane extracts and ethyl acetate: methanol: water (10: 1.7: 1.3) for methanol extract. The developed plates were visualized under UV light, both in long and short wavelengths. The spray reagent used for hexane extract was anisaldehyde-sulphuric acid, while $10 \%$ ethanolic $\mathrm{KOH}$ and $10 \%$ ethanolic phosphomolybdic acid were used as spraying reagents for methanol extracts.

HPTLC profiles of both the hexane and methanol extracts revealed characteristic differences for var. conicarpa compared to var. gummi-gutta and var. papilla (Figure 4).
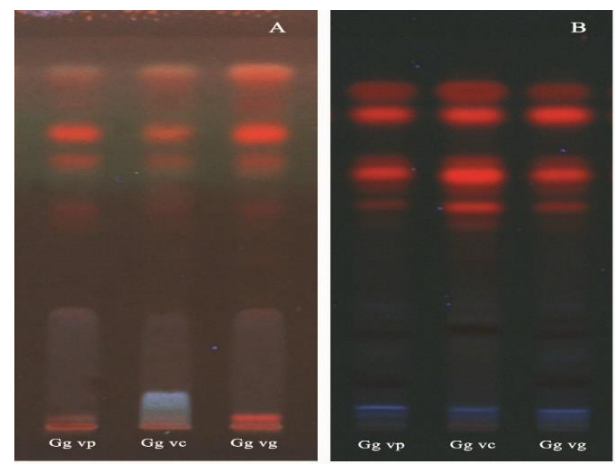

Figure 4. HPTLC profiles of Garcinia gummi-gutta varieties.

\section{Conclusions}

A. Leaf hexane extract; B. Leaf methanol extract

The chapter provides a comprehensive account on the distribution and diversity of G. gummigutta in the Western Ghats, combining morphological and phytochemical features. Among the three varieties, var. papilla, and var. conicarpa are rare and distributed only in the highlands of forests. The diversity of G. gummi-gutta var. gummi-gutta was more manifested among the cultivars. Evaluation of the morphological and chemical diversity of G. gummigutta varieties revealed distinct morphological and chemical characteristics for G. gummigutta var. conicarpa, which needs reinstating it as the distinct species, G. conicarpa done by Wight. The study supports the hypothesis that the southern Western Ghats is the centre of origin and diversity of Garcinia gummi-gutta. 


\section{References}

1. Abraham Z, Malik SK, Rao GE, S Narayanan L, Biju S. 2006. Collection and Characterization of Malabar Tamarind (Garcinia cambogia (Gaertn.) Desr.). Genet. Resour. Crop Ev., 53 (2), 401-406.

2. Adams RP. 2007. Identification of Essential Oil Components by Gas Chromatography / Mass Spectrometry. Fourth edition. Allured Pub. Co., Carol Stream, IL.

3. Anderson T. 1874. Guttiferae. In: Hooker JD. (ed.) Flora of British India. 1. L. Reeve \& Co., London. 259-278.

4. Anonymous. 1950. Wealth of India Raw Materials Vol. IV. CSIR, New Delhi, pp.99-108.

5. Desrousseaux LAJ. 1792. In:Lamarck Encyclopédie Méthodique, Botanique. Paris 3, 701.

6. Dool VH and Kratz PD. 1963. A generalization of the retention index system including linear temperature programmed gas liquid partition chromatography. J. Chromatogr., 11, 463-471.

7. Hemesekhar M, Sunitha K, Santhosh MS, Devaraja S, Kempararaju K, Viswanath B S, Niranjana SR and Girish KS. 2011. An overview of genus Garcinia: Phytochemical and therapeutical aspects. Phytochem. Rev., DOI 10.1007/s 11101-011-9207-3.

8. Labra M, Miele M, Ledda B, Grassi F and Mazzei M. 2004. Morphological characterization, essential oil composition and DNA genotyping of Ocimum basilicum L. cultivars. Plant Sci., 167, 725-731.

9. Linnaeus C. 1754. Cambogia. Genera Plantarum, 5, 225.

10. Martins FT, Doriguetto AC, de Souza TC, de Souza KR, dos Santos MH, Moreira ME and Barbosa LC. 2008. Composition and anti-inflammatory and antioxidant activities of the volatile oil from the fruit peel of G.brasiliensis. Chem. Biodivers., 5(2), 251-258.

11. Nimanthika WJ and Kaththriarachchi HS. 2010. Systematics of genus Garcinia L. (Clusiaceae) in Sri Lanka. New insights from vegetative morphology. Journal of National Science Foundation, 38, 29-44.

12. Rameshkumar KB, Shiburaj S and George V. 2005. J. Trop. Med. Plants, 6, 271-273.

13. Robson N. 1968. Garcinia gumm-gutta (L.) N. Robson, Comb. nov. In: Brittonia. The American Society of Plant Taxonomist, 20, 103.

14. Singh NP. 1993. Clusiaceae (Guttiferae nom. alt.) In: Flora of India Vol. 3. (Eds) Sharma BD and Balakrishnan NP Botanical Survey of India, Kolkatta, 109-111.

15. Sweeney PW. 2008. Phylogeny and floral diversity in the genus Garcinia (Clusiaceae) and relatives. Int. J. Plant Sci., 169(9), 1288-1303.

16. Tharachand C, Immanuel Selvaraj $C$ and Abraham Z. 2015. Molecular insights into the genetic diversity of Garcinia cambogia germplasm accessions. Braz. Arch. Biol. Technol, 58(5), 765-772.

17. Van Rheede HA. 1678. Codam-pulli. Horti Indici Malabarici. Amsterdam 1, 41-42, t. 24.

18. Waterman PG and Hussain RA. 1983. Systematic significance of xanthones, benzophenones and biflavonoids in Garcinia. Biochem. Syst. Ecol., 11(1), 21-28.

19. Wight R. 1839. Icones Plantarum Indiae Orientalis Part 1(6), Pharoah JB, Madras, tt. 101-121.

20. Wight R. 1840. Icones Plantarum Indiae Orientalis Part 2(1), Pharoah JB, Madras, tt. 319-416. 


\title{
Chapter 9
}

\section{Phytochemicals and bioactivities of Garcinia indica (Thouars) Choisy- A review}

\author{
R. Ananthakrishnan and K. B. Rameshkumar* \\ Phytochemistry and Phytopharmacology Division \\ Jawaharlal Nehru Tropical Botanic Garden and Research Institute \\ Palode, Thiruvananthapuram-695562, Kerala, India \\ *Corresponding author
}

\begin{abstract}
Garcinia indica is well known as a fruit tree of culinary, pharmaceutical, nutraceutical and industrial significance in south India, especially in the Konkan region. The fruit juice is much appreciated as a health drink while the dried fruit rind is used as a spice and condiment. The fat extracted from $G$. indica seeds is known as kokum butter and is used in foods, cosmetics and medicines. Stearic acid and oleic acid are the major fatty acids in kokum butter, while the fruit rind contains hydroxy citric acid, the much valued anti-obesity agent. The major class of secondary metabolites reported from different parts of the species are benzophenones, biflavonoids, xanthones and anthocyanin pigments. The fruit rind is a rich source of the benzophenone garcinol, attributed with potential bioactivities, especially antioxidant and cytotoxic. Cyanidin-3-glucoside and cyanidin-3-sambubioside were identified as the major red pigments in the fruit rind. The present review gives an overview of the phytochemical and pharmacological aspects of $G$. indica.
\end{abstract}

Keywords: Garcinia indica, Kokum, Anthocyanins, Garcinol, Isogarcinol

\section{Introduction}

Garcinia indica (Thouars) Choisy (Family: Clusiaceae) is one of the important indigenous Garcinia species grown in the Western Ghats of India. Garcinia indica (Kokum) is a slender, tropical evergreen tree that grows up to $15 \mathrm{~m}$ height. The branches are drooping, leaves ovate or oblong lanceolate, dark green above and pale beneath, stem bark thin lined, with pale yellow coloured exudates, and fruits globose or round, purple coloured when ripe, about $4 \mathrm{~cm}$ in diameter with 5-8 seeds. Flowering was observed during November-February and fruiting season was during April-June (Singh, 1993). G. indica is generally known as 'kokum tree', 'wild mangosteen' or 'goa butter tree' (Watt, 1890; Baliga et al., 2011).The species is well known for its food, medicinal and commercial values. The National Medicinal Plant Board (NMPB) has identified G. indica as an important plant for promotion and development. The present chapter gives a review on the distribution, traditional uses, pharmacological activities and phytochemical constituents of $G$. indica. 


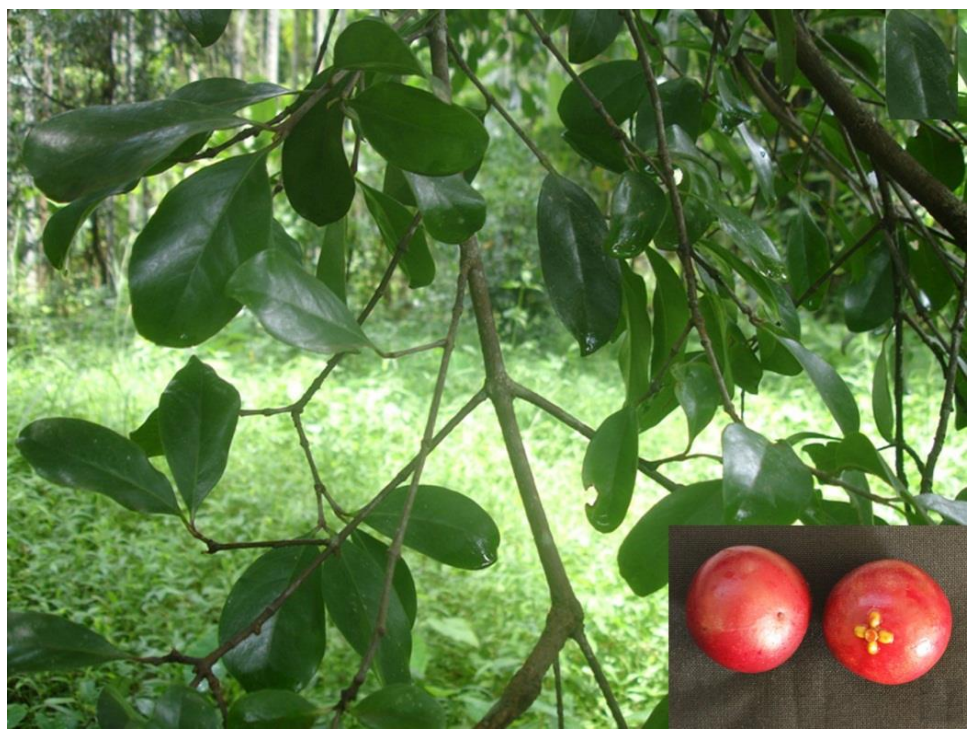

Figure 1.Garcinia indica twig and fruits

\section{Distribution and conservation status}

Garcinia indica is widely distributed along the Western Ghats of India and also found in the forests of Assam, Meghalaya and West Bengal. In the Western Ghats, the tree is mainly found along the costal belt of Konkan region of Ratnagiri district of Maharashtra, Goa, Uttara Kannada, Udupi and Dakshina Kannada Districts of Karnataka and Kasaragod area of Kerala. It thrives well below an altitude of $800 \mathrm{~m}$ and at coastal areas (Braganza et al., 2012; Nayak et al., 2010). A wide diversity has been observed for kokum trees in the Western Ghats due to the dioecious nature and cross pollination (Swami et al., 2014; Joseph and Murthy, 2015). The study conducted on 268 accessions of $G$. indica from different parts of the State of Goa, showed that the sugar level varied from 1.9 to $22.4^{\circ}$ Brix, while the total acid in fresh fruit rind was in the range 1.2 to $11.2 \%$ (Braganza et al., 2012). G. indica is under vulnerable status as categorised by IUCN. Western Ghats Kokum Foundation (WGKF) is an organisation which promotes cultivation and works on conservation of $G$. indica in India.

\section{Traditional uses of Garcinia indica}

$G$. indica has got multifarious uses and finds various applications among the local population. The dried fruit rind of $G$. indica impart a sweet-tangy taste to food and is widely used as flavouring agent in food preparations as substitute for tamarind (Anonymous. 1956; Jayaprakasha and Sakariah, 2002). The fruits are also used as a substitute for grapes in wine making (Baliga et al., 2011). The fruit rind has also been utilized as a pink and purple food colouring agent (Kaur et al., 2012). Kokum drinks, made from the fruits of G. indica, served as a welcome drink in Goa during summer seasons. Konkani people of Goa and Maharashtra make bhirindi saar, a soup using kokum juice and also kokum kadi by mixing kokum juice and coconut milk, both used as after-meal drink to relieve any gastric problems (Menezes, 2001). Dried fruit rinds and syrup can be found as reserve in every house hold of Konkan region. Kokum butter is another important product obtained from the seeds of G. indica, 
which is an important ingredient in cosmetic products like lip balms, lotions and soaps (Baliga et al., 2011).

Traditionally, kokum is used in herbal medicines to treat diarrhoea, inflammatory ailments, dermatitis, bowel problems, rheumatic pains and to prevent hyper perspiration. Fruits are used as antihelmintic and cardiotonic. Kokum juice from the rind is used against piles, colic problems, dysentery and diarrhoea (Baliga et al., 2011; Watt, 1890). Decoction of fruit rinds are traditionally used against diabetes. Kokum butter is used traditionally to heal wounds, fissures in hands and is supposed to restore elasticity of skin and used as a moisturiser (Jeyarani and Reddy, 1999; Padhye et al., 2009). Leaves of G. indica are used to treat skin ulcers, dyspepsia and hyperplasia.

\section{Value added products from Garcinia indica fruits}

With an estimated annual production of 10,200 tonnes of fruits (yield is $8.5 \mathrm{t} / \mathrm{ha}$ ), the species is important for several industrial sectors such as nutraceutical, food supplementary, beverage and cosmetics (Braganza et al., 2012; Swami et al., 2014).. Several consumer products such as Kokum syrup, Kokum Agal (Kokum juice concentrate), Kokum sarbat, Kokum solkdhi, Kokum amsul (dried salted rind), Kokum butter and Kokum beverages are available in the market based on kokum fruits, rinds and kokum fat. Rinds are dried and stored, which can be used to prepare reconstitutable drinks during off season (Baliga et al., 2011). It is also marketed as a spice in the local markets of Goa. Fresh rinds are added during wine making process, which gives the wine a pinkish appearance and a tingling taste. Kokum butter, because of its fatty acid content is used in soap and face creams (Padhye et al., 2009). Kokum butter can be used as an ingredient in chocolate and due to the relatively high melting point (mp. 39 to $43^{\circ} \mathrm{C}$ ), kokum butter prevents the chocolate from melting and can be used for preparing heat resistant chocolates (Maheshwari and Reddy, 2005; Jeyarani and Reddy, 1999). Kokum butter is sold as egg shaped lumps, used as edible fat and as a substitute of ghee in Goa.

\section{Phytochemistry of Garcinia indica}

The seed kernels of $G$. indica contains hard and brittle fat (mp. 39 to $43^{\circ} \mathrm{C}$ ) up to $45 \%$ yield, which is commercially known as 'kokum butter'. Kokum butter contains about $30 \%$ of fat content. Extensive studies have been carried out on the fatty acid composition of kokum butter and kokum fat was found to be rich in stearic acid $\left(\mathrm{C}_{17} \mathrm{H}_{35} \mathrm{COOH}\right)$ and oleic acid $\left(\mathrm{C}_{17} \mathrm{H}_{33} \mathrm{COOH}\right)$ (Krishnamurthy et al., 1982, Jeyarani and Reddy, 1999). Quantitative analysis of kokum butter revealed that in addition to fatty acids, it contains glycerides such as oleodistearin and stearodiolein (Lipp and Anklam, 1998). Seed oil is a source of palmitic acid, stearic acid, oleic acid and linoleic acid. Reports show that seed oil of G. indica, because of high content of fatty acid methyl esters, can be used as biofuel or can be mixed with other fuels to enhance its efficiency (Hosamani et al., 2009).

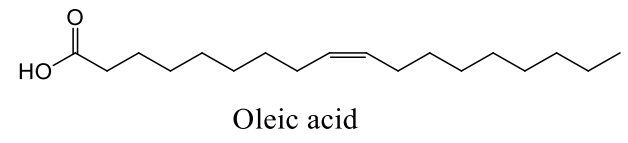

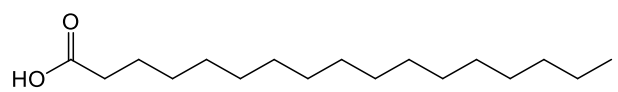

Stearic acid

Figure 2. Structures of stearic acid and oleic acid 
The fruit juice of $G$. indica is very acidic with a $\mathrm{pH} 1.5$ to 2.0 and contains large amounts of acids. Major portion of organic acids in kokum is hydroxycitric acid (HCA) (1, 2 dihydroxypropane-1, 2, 3-tricarboxylic acid). Rinds contain about 20-30\% of (-)-HCA on dry basis (Swami et al., 2014). HCA is an anti-obesity agent, attributed with reduced food intake, increased energy expenditure, suppression of fatty acid synthesis and an enhancement of glycogen synthesis in liver (Jena et al., 2002). Among the different Garcinia fruits, $G$. gummi-gutta possesses the highest HCA content, followed by G. indica. However, in a recent study, Pandey et al (2015) reported that among the 11 Garcinia species leaves analysed, HCA content was highest in $G$. indica leaves, $120 \mathrm{mg} / \mathrm{g}$ leaf methanol extract, while in $G$. gummi-gutta, the HCA content was $95 \mathrm{mg} / \mathrm{g}$. The total acid content (HCA and HCA lactone) was however higher in G. gummi-gutta leaves $(308 \mathrm{mg} / \mathrm{g}$ ), compared to G. indica leaves (276 $\mathrm{mg} / \mathrm{g}$ ). Besides HCA, kokum juice contains malic acid, citric acid and tartaric acid (Parthasarathy et al., 2012).<smiles>O=C(O)CC(O)(C(=O)O)C(O)C(=O)O</smiles>

Figure 3. Structure of hydroxycitric acid

Table 1. Phytochemicals reported from Garcinia indica

\begin{tabular}{|c|c|c|}
\hline Plant part & Compound & References \\
\hline \multirow[t]{4}{*}{ Leaves } & D- Leucine & Cotterill and Scheinmann1977 \\
\hline & isogarcinol, xanthochymol, isoxanthochymol, & $\begin{array}{l}\text { Chattopadhyay et al.,2006; Kumar et al., } \\
2013\end{array}$ \\
\hline & HCA and HCA lactone & Jayaprakasha and Sakariah2002 \\
\hline & $\begin{array}{l}\text { Cambogic acid, mangostin, garcinol, } \\
\text { fukugicide, GB-1, GB- } 2 \text { and amentoflavone }\end{array}$ & Pandey et al.,2015 \\
\hline \multirow[t]{4}{*}{$\begin{array}{l}\text { Fruits and fruit } \\
\text { rinds }\end{array}$} & (-) HCA, HCA lactone & $\begin{array}{l}\text { Cotterill and Scheinmann } 1977 \text {; } \\
\text { Jayaprakasha and Sakariah 2002; Padhye } \\
\text { et al., } 2009\end{array}$ \\
\hline & $\begin{array}{l}\text { Garcinol, isogarcinol, citric acid, oxalic acid, } \\
\text { xanthochymol, isoxanthochymol }\end{array}$ & $\begin{array}{l}\text { Yamaguchi et al., 2000; Chattopadhyay } \\
\text { et al.,2006; Padhye et al., 2009; Nayak et } \\
\text { al., 2010; Kaur et al., 2012; Kumar et al., } \\
\text { 2013; Bhagwat et al., 2014 }\end{array}$ \\
\hline & $\begin{array}{l}\text { Anthocyanin, glucose, xylose, cyanidin-3- } \\
\text { glucoside, cyanidin-3-sambubioside and } \\
\text { 14-deoxyisogarcinol. }\end{array}$ & Nayak et al., 2010 \\
\hline & Polyprenylated acylphloroglucinol derivative & Kaur et al., 2012 \\
\hline \multirow[t]{2}{*}{ Bark } & $\begin{array}{l}\text { Euxanthone (1,7-dihydroxy xanthone), } \\
\text { volkensiflavone and morelloflavone }\end{array}$ & Cotterill and Scheinmann1977 \\
\hline & $\begin{array}{l}\text { Xanthochymol, isoxanthochymol and } \\
\text { camboginol }\end{array}$ & $\begin{array}{l}\text { Chattopadhyay et al.,2006; Kumar et al., } \\
2009\end{array}$ \\
\hline $\begin{array}{l}\text { Seed pericarps } \\
\text { and Seed oil }\end{array}$ & $\begin{array}{l}\text { Isoxanthochymol, camboginol, palmitic acid, } \\
\text { stearic acid, oleic acid and linoleic acid }\end{array}$ & $\begin{array}{l}\text { Kumar et al., 2009; Hosamani et al., } \\
2009\end{array}$ \\
\hline
\end{tabular}

The major secondary metabolites reported from $G$. indica are polyisoprenylated benzophenones, xanthones and biflavonoids. Garcinol (camboginol), isogarcinol (xanthochymol) and isoxanthochymol are the major benzophenone derivatives isolated from G. indica fruits, dry rinds and leaves (Yamaguchi et al., 2000; Kumar et al, 2009; Kumar et al., 2013; Kaur et al., 2012, Chattopadhyay et al., 2006; Pandey et al.,2015). Garcinol is 
crystallized out as yellow needles (1.5\%) from the hexane extract of the fruit rind, while its isomeric form isogarcinol is colourless. A simple reverse-phase high-performance liquid chromatography-electrospray ionization mass spectrometric method (ESI-MS) for the identification and quantification of the two isomeric benzophenones, isoxanthochymol and camboginol in the extracts of the stem bark, seeds and seed pericarps of Garcinia indica have been reported by Kumar et al. (2009). Two new compounds, 14-deoxyisogarcinol and a polyprenylated acylphloroglucinol derivative were isolated from $G$. indica fruits by Kaur et al., (2012). Xanthones and biflavanoids were also detected from G. indica (Cotterill and Scheinmann, 1977). An extensive LC-MS study on methanol extracts of $G$. indica leaves led to the identification of multiclass bioactive constituents belonging to organic acids, phenolic acids, flavonoids, biflavonoids, xanthones, benzophenones and terpenoids (Pandey et al., 2015).

The fruit rind of G. indica has been utilized as a pink and purple food coloring agent and the rind contains 2 to $3 \%$ of water soluble red colour pigments. The major colouring compounds are the anthocyanin pigments cyanidin-3-glucoside and cyanidin-3-sambubioside which are usually present in the ratio of 4:1 (Nayak et al., 2010). The variation in colour shades of kokum fruits can be attributed to the variation in substitution of hydroxyl and methoxyl groups to the anthocyanin structural skeletons. Anthocyanins are the major antioxidant constituents in G. indica and the 3' and 4'-OH in B-ring determine radical scavenging capacity with a saturated 2, 3- double bond. Major phytochemicals isolated from G. indica and their structures are given in Table 1 and Figure 1.

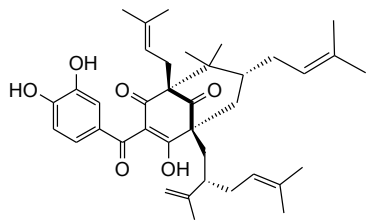

Garcinol

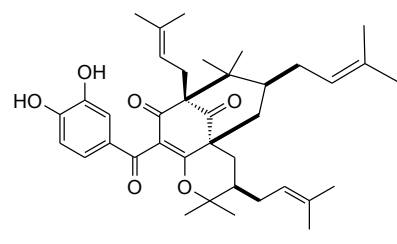

Isoxanthochymol

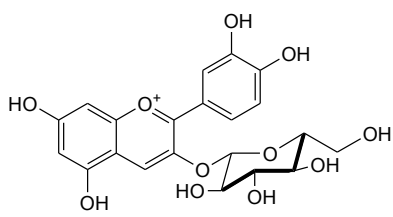

Cyanidin-3-glucoside

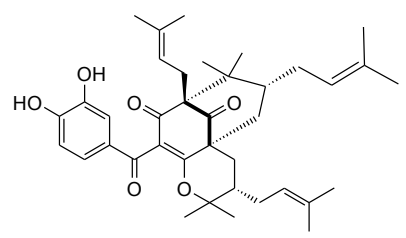

Isogarcinol

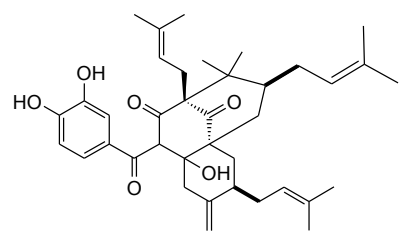

Polyprenylated acyl phloroglucinol

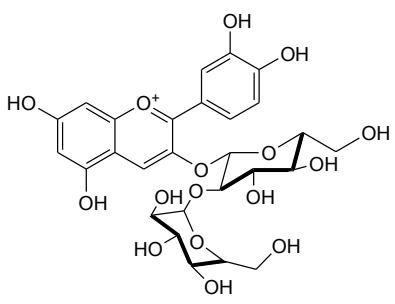

Cyanidin-3-sambubioside

Figure 1. Characteristic compounds reported from Garcinia indica 


\section{Bioactivites of Garcinia indica}

Extracts as well as compounds isolated from $G$. indica have been studied extensively for various bioactivities like antioxidant, antibacterial, antifungal, antiobesity, antidiabetic, gastroprotective and anticancer activities. The pharmacological studies validated the traditional uses of the plant in various ailments. Benzophenones, anthocyanins and organic acids are the major bioactive constituents reported in G. indica.

Among the different bioactivities reported, antioxidant properties are perhaps the most important activity for G. indica (Krishnamurthy and Sampathu 1988; Mishra et al., 2006). Choloroform extracts of $G$. indica fruit rinds exhibited excellent antioxidant activities in $\beta$-carotene-linoleate and DPPH assays (Tamilselvi et al., 2003). Aqueous extracts of $G$. indica fruits available in markets acts as very good antioxidants as evident from their DPPH and lipid peroxidation assays. Aqueous extracts of kokum inhibit ascorbate-Fe ${ }^{2+}$ induced lipid peroxidation in rat liver mitochondrial fractions (Mishra et al, 2006). Organic acids like citric acid and malic acid from G. indica also acts as good antioxidants (Swami et al, 2014). A recent study on $G$. indica bark exudates showed its total phenol and xanthone content as $53.43 \mathrm{~g} / 100 \mathrm{~g}$ and $32.42 \mathrm{~g} / 100 \mathrm{~g}$ respectively, revealing it as a potential source of antioxidants (Parthasarathy and Nandakishore, 2016).

Kokum rind extracts showed antifungal effects against Candida albicans, Penicillium sp. and Aspergillus flavus. Also the extract showed inhibitory activity against '3T3' mouse fibroblasts (Mishra et al, 2006; Varalakshmi et al., 2010; Tamilselvi et al., 2003). Aqueous and methanol extracts of $G$. indica leaves and fruit rinds showed antibacterial activity against Salmonella sp (Pasha et al., 2009). Methanol extracts of kokum fruits acted as an effective neuroprotective agent for striatal dopaminergic neurons in 6-OHDA lesioned rat model of Parkinsons disease (Antala et al., 2012). Aqueous fruit rind extract of the kokum exhibited antidiabetic activity in streptozotocin-induced hyperglycemic rats (Kirana and Srinivasan, 2010). However, lyophilized aqueous-methanol extracts in water of $G$. indica fruit rinds showed a dose dependant genotoxicity in mice (Das et al., 2016).

The major anthocyanin in $G$. indica fruits, cyanidin-3-glucoside decreased the number of non-malignant and malignant skin tumours in the two staged skin carcinogenesis and also caused a dose-dependent inhibitory effect on the migration and invasion of metastatic A549 human lung carcinoma cells (Ding et al., 2006, Chen et al., 2006). It was found effective in blocking accumulation of intracellular ROS and neurofilament protein expression and was effective against bipolar disorder by reducing ethanol-mediated activation of GSK3 $\beta$. (Chen et al., 2009). The biological activities of garcinol, the major polyisoprenylated benzophenone isolated from $G$. indica and (-) hydroxy citric acid, the major acid in G. indica fruits were dealt in detail in Chapter 10.

\section{Conclusions}

Recently, Garcinia species have received considerable attention worldwide from scientific as well as industrial sectors and several novel structures, bioactivities and potential utilities have been reported. In USA alone, mangosteen containing beverages had a turnover of more than $\$ 200$ million in 2008. Kokum can be considered as a functional food that provide in addition to nutritional components, other physiological benefits as well. The consumption of high value products of kokum have increased tremendously due to the awareness of the potential health benefits associated with the diverse bioactive constituents in the plant. The review also 
highlights the potential for developing $G$. indica as an economic crop to derive value added products with scientific validation.

\section{References}

1. Anonymous. 1956. The Wealth of India Raw Materials. Vol. IV, NISCAIR, India.

2. Antala BV, Patel MS, Bhuva SV, Gupta S, Rabadiya S, and Lahkar M. 2012. Protective effect of methanolic extract of Garcinia indica fruits in 6-OHDA rat model of Parkinson's disease. Indian J. Pharmacol., 6, 683-687.

3. Baliga MS, Bhat HP, Pai RJ, Boloor R and Princy LP. 2011. The chemistry and medicinal uses of the underutilized Indian fruit tree Garcinia indica Choisy (kokum): A review. Food Res. Int., 44, 1790-1799.

4. Bhagwat $M$ and Datar A. 2014. Isolation and identification of antibacterial compounds from the extracts of Garcinia indica and Curcuma aromatica, using bioautography and mass spectrometric techniques. J. Biol. Active Prod. Nat., 4, 295-302.

5. Braganza M, Shirodkar A, Bhat J D and Krishnan S, (Eds). 2012. Resource Book on Kokum, Western Ghats Kokum Foundation, Panaji, Goa. India.

6. Chattopadhyay SK and Kumar S. 2006. Identification and quantification of two biologically active polyisoprenylated benzophenones xanthochymol and isoxanthochymol in Garcinia species using liquid chromatography-tandem mass spectrometry. $J$. Chromatogr. B, 844(1), 67-83.

7. Chen G, Bower KA, Xu M, Ding M, Shi X and Ke ZJ. 2009. Cyanidin-3- glucoside reverses ethanol-induced inhibition of neurite outgrowth: Role of glycogen synthase kinase 3 Beta. Neurotox. Res., 15, 321-331.

8. Chen PN, Chu SC, Chiou HL, Kuo WH, Chiang CL and Hsieh YS. 2006. Mulberry anthocyanins, cyanidin 3-rutinoside and cyanidin 3-glucoside, exhibited an inhibitory effect on the migration and invasion of a human lung cancer cell line. Cancer Lett., 235, 248-259.

9. Cotterill P J and Scheinmann F. 1977. Phenolic Compounds from the Heartwood of Garcinia indica. Phytochemistry, 16, 148-149.

10. Das A, Ghosh I, Mukherjee A. 2016. Garcinia indica fruit extract induces genotoxicity in mice. The Nucleus, 59, 1-6.

11. Ding M, Feng R, Wang SY, Bowman L, Lu Y, Qian, Y, Castranova V, Jiang BH and Shi X. 2006. Cyanidin-3-glucoside, a natural product derived from blackberry, exhibits chemopreventive and chemotherapeutic activity. J. Biol. Chem, 281, 17359-17368.

12. Hosamani KM, Hiremath VB and Keri RS. 2009. Renewable energy sources from Michelia champaca and Garcinia indica seed oils: A rich source of oil. Biomass Bioenergy, 33, 267-270.

13. Jayaprakasha GK and Sakariah KK. 2002. Determination of organic acids in leaves and rinds of Garcinia indica (Desr.) by LC. J. Pharm. Biomed. Anal., 28, 379-384.

14. Jena BS, Jayaprakasha GK, Singh RP and Sakariah KK. 2002. Chemistry and biochemistry of (-)-hydroxycitric acid from Garcinia. J. Agric. Food Chem., 50, 10-22.

15. Jeyarani $\mathrm{T}$ and Yella Reddy, S 1999. Heat-resistant cocoa butter extenders from mahua (Madhuca latifolia) and kokum (Garcinia indica) fats. J. American Oil Chem. Soc., 76 (12), 1431-1436. 
16. Joseph KS and Murthy HN. 2015. Sexual system of Garcinia indica Choisy: geographic variation in trioecy and sexual dimorphism in floral traits. Plant Syst. Evol., 301, 10651071.

17. Kaur R, Chattopadhyay SK, Tandon S and Sharma S. 2012. Large scale extraction of the fruits of Garcinia indica for the isolation of new and known polyisoprenylated benzophenone derivatives. Ind. Crop. Prod., 37, 420-426.

18. Kirana H and Srinivasan B. 2010. Aqueous extract of Garcinia indica Choisy restores glutathione in type 2 diabetic rats. J. Young Pharm., 2, 265-268.

19. Krishnamurthy N and Sampathu SR. 1988. Antioxidant principles of kokum rind. J. Food Sci. Tech. 25(1), 44-45.

20. Krishnamurthy N, Lewis YS and Ravindranath B. 1982. Chemical constitution of Kokum fruit rind. J. Food Sci. Tech. 19, 97-100.

21. Kumar PSN, Gowda DGB, Mantelingu K and Rangappa KS. 2013. Development and validation of a reversed-phase HPLC method for the analysis of garcinol and isogarcinol in Garcinia indica. J Pharm Res, 7, 103-106.

22. Kumar S, Sharma S and Chattopadhyay SK. 2009.High-performance liquid chromatography and LC-ESI-MS method for identification and quantification of two isomeric polyisoprenylatedbenzophenonesisoxanthochymol and camboginol in different extracts of Garcinia species. Biomed. Chromatogr., 23, 888-907.

23. Lipp $M$ and Adam E. 1998. Review of cocoa butter and alternative fats for use in chocolate-Part A. Compositional data. Food Chem., 62 (1), 73-97.

24. Maheshwari B and Reddy S Y. 2005. Application of kokum (Garcinia indica) fat as cocoa butter improver in chocolate. J. Sci. Food Agric., 85, 135-140.

25. Menezes MT. 2001. The Essential Goa Cookbook, Penguin Books, India.

26. Mishra A, Bapat MM, Tilak JC and Devasagayam TPA. 2006. Antioxidant activity of Garcinia indica (kokum) and its syrup. Curr. Sci., 91, 90-93.

27. Nayak CA, Rastogi NK and Raghavarao KSMS. 2010. Bioactive constituents present in Garcinia indica Choisy and its potential food applications: A review. Int. J. Food Prop., 13, 441-453.

28. Nayak CA, Srinivas P and Rastogi NK. 2010. Characterisation of anthocyanins from Garcinia indica Choisy. Food Chem., 118, 719-724.

29. Padhye S, Ahmad A, Oswal N and Sarkar FH. 2009. Emerging role of garcinol, the antioxidant chalcone from Garcinia indica Choisy and its synthetic analogs. J. Hem. Onc., 2, 1-13.

30. Pandey R, Chandra C, Brijeshkumar, Srivastva M, AnuAravind AP, Shameer PS and Rameshkumar KB. 2015. Simultaneous determination of multi-class bioactive constituents for quality assessment of Garcinia species using UHPLC-QqQLIT-MS/MS. Ind. Crop. Prod., 77, 861-872.

31. Parthasarathy U and Nandakishore OP. 2016. Garcinia bark exudates- an important phytochemical source. Curr. Sci., 110, 1617-1619.

32. Parthasarathy U, Nandakishore OP, Kumar SR, Babu NK, Zachariah TJ and Parthasarathy VA. 2012. Chromatographic fingerprinting and estimation of organic acids in selected Garcinia species. Int. J. Innovative Horticulture., 1, 68-73.

33. Pasha C, Sayeed S, Ali MS and Khan MZ. 2009. Anti Salmonella activity of selected medicinal plants. Turkish J. Biol., 33, 59-64. 
34. Singh NP. 1993. Clusiaceae (Guttiferae nom. alt.) In: Sharma, BD and Balakrishnan NP (eds.), Flora of India Vol. 3. Botanical Survey of India, Kolkatta, pp.86-151.

35. Swami SB, Thakor NJ and Patil SC. 2014.Kokum (Garcinia indica) and its many functional components as related to the human health: A review. J. Food Res. Tech., 2, 130-142.

36. Tamilselvi A, Joseph GS and Jayaprakasha GK. 2003. Inhibition of growth and aflatoxin production in Aspergillus flavus by Garcinia indica extract and its antioxidant activity, Food Microbiol., 20, 455-460.

37. Varalakshmi KN, Sangeetha CG, Shabeena AN, Sunitha SR and Vapika J. 2010. Antimicrobial and cytotoxic effects of Garcinia indica fruit rind extract. Am. Euras. J. Agric. Environ. Sci., 7, 652-656.

38. Watt G. 1890. Dictionary of the Economic Products of India, Vol. II, (Second reprint 1972) Periodical Experts, Delhi.

39. Yamaguchi F, Saito M, Ariga T, YoshimuraY and Nakazawa H. 2000. Free radical scavenging activity and antiulcer Activity of garcinol from Garcinia indica fruit rind. $J$. Agric. Food Chem., 48, 2320-2325. 


\title{
Chapter 10
}

\section{Phytochemicals and bioactivities of Garcinia gummi- gutta (L.) N. Robson- A review}

\author{
V. Anju and K. B. Rameshkumar* \\ Phytochemistry and Phytopharmacology Division \\ Jawaharlal Nehru Tropical Botanic Garden and Research Institute \\ Palode, Thiruvananthapuram- 695562, Kerala, India \\ ${ }^{*}$ Corresponding author
}

\begin{abstract}
Among the different Garcinia species, G. gummi-gutta is the most widely distributed Garcinia species in Kerala, south India. The fruit is used as culinary spice, preservatives and also as a source of several nutraceutical products. The phytochemical analysis of G. gummigutta revealed the presence of several bioactive molecules such as xanthones, benzophenones and organic acids. The fruit contains $10 \%$ to $30 \%$ (-) hydroxycitric acid (HCA), a well known hypo-lipidemic agent and an important constituent of food supplement for weight management. The species is a rich source of the bioactive benzophenones camboginol (garcinol) and cambogin (isogarcinol). The present review summarises the traditional uses, phytochemicals and pharmacological activities of G. gummi-gutta.
\end{abstract}

Keywords: Garcinia gummi-gutta, Hydroxy citric acid, Benzophenones, Camboginol, Cambogin

\section{Introduction}

Garcinia is the largest genus of the Clusiaceae family comprising nearly 250 species. Garcinia gummi-gutta (L.) Roxb. (Syn.: Garcinia cambogia (Gaertn.) Desr; Common name: Malabar tamarind), is one of the most important members of the Clusiaceae family (Figure 1). It is a small or medium sized tree up to $12 \mathrm{~m}$ tall with dark green and shining leaves. The leaves are elliptic obovate, 2-5 inch long and 1-3 inch broad. Fruits are ovoid, 2 inches in diameter, yellow when ripe, with 6-8 grooves; seeds 6-8 surrounded by succulent aril (Singh, 1993). The aril and the fleshy covering encasing the seed is edible when ripe. The differentiation between male and female trees is known only at the flowering stage which takes approximately 7 to 9 years (Kalia et al., 2012). G. gummi-gutta is a common species found in the Western Ghats, from the Konkan southwards to Travancore eastwards. The species has now been introduced elsewhere in the subtropical region of Asia including China, Malaysia and the Philippines (Chuah et al., 2013). The present chapter reviews the traditional uses, pharmacological activities and phytochemicals of G. gummi-gutta. 


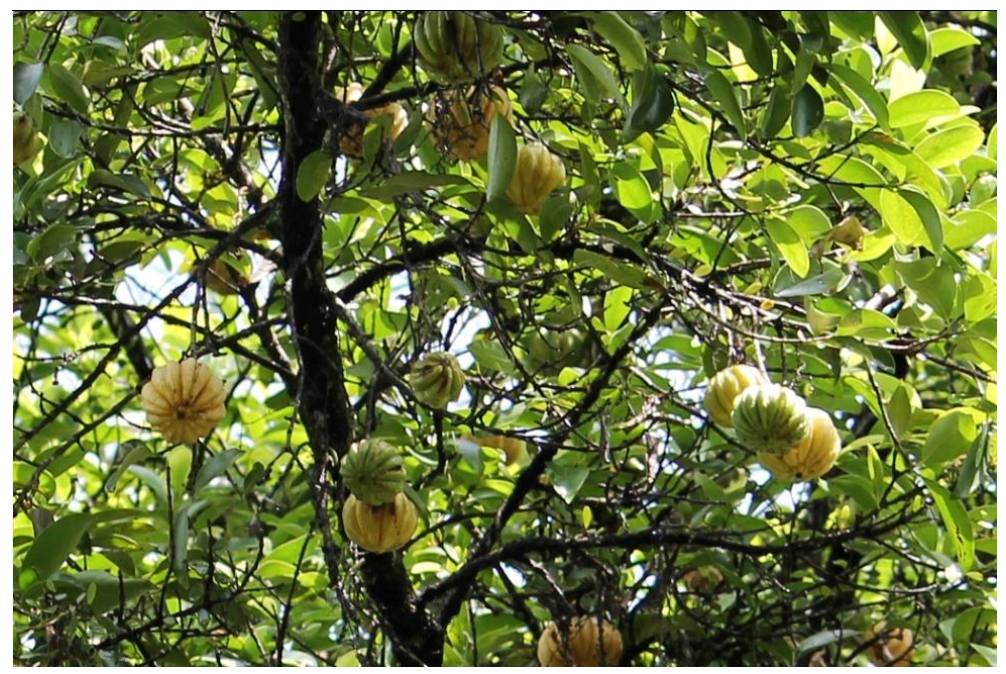

Figure 1.Garcinia gummi-gutta twig with fruits

\section{Traditional uses}

G. gummi-gutta is traditionally used as a condiment for flavouring curries and as a fish preservative. The traditionally smoke dried fruit rind of G. gummi-gutta, known as 'Malabar tamarind" was used for "Colombo curing" of fish, where the pickling was done in brine along with the smoke dried rinds of G. gummi-gutta (Sreenivasan and Venkataraman 1959; Lewis and Neelakantan, 1965). The species yield an yellow, adhesive gum resin similar to gamboge from G. morella, but of inferior quality and insoluble in water. The seeds yield an oil, which is used in medicine (Watt, 1890). The wood is grey, cross grained, shining, hard and can be used in furniture making (Watt, 1890). The dried rind was used for polishing gold and silver and also used as a substitute for acetic and formic acids in the coagulation of rubber latex (Anonymous, 1956).

Though the tree has been mentioned in the $17^{\text {th }}$ century treatise of medicinal plants, Hortus Malabaricus, the species is not part of the Ayurvedic medicine of ancient India (Manilal, 2003). However, it was widely reputed in the folk herbal healing practices and has been used traditionally for the treatment of edema, delayed menstruation, ulcers, open sores, hemorrhoids, fever, rheumatism, and also against intestinal parasites (Majeed et al., 1994, Semwal, et al., 2015). The astringent properties of the rind make it an indispensible ingredient in gargles for weak gums, bowel complaints, constipation, diarrhoea and dysentery. The plant is used in veterinary medicine, for mouth diseases in livestock.

\section{Phytochemicals reported from G. gummi-gutta}

Though G. gummi-gutta is an economically important species, widely cultivated in south India, only a few reports are available in literature on the phytochemistry of the plant (Table 1). The fruit is well known for the acidic nature and the chemistry and analytical techniques of hydroxycitric acid, the major organic acid in G. gummi-gutta, has been dealt with detail in literature (Jena et al., 2002). Benzophenones are the major secondary metabolites in $G$. gummi-gutta, followed by xanthones and biflavonoids. 


\subsection{Organic Acids}

Organic acids are of great significance in plants as intermediates in the metabolic processes and are directly involved in growth and maturation of fruits. The organic acids play a key role in fruit flavour and taste. Most of the Garcinia fruits are well known for their sour taste and high acidity, and of the different acids reported from Garcinia fruits, (-)-hydroxycitric acid (HCA) is the important one, being an anti-obesity agent and a chiral molecule of wide utility in chiral synthesis (Jena, et al., 2002). Malic acid, ascorbic acid, tartaric, oxalic acid and citric acids are also present to a lesser extent in Garcinia fruits.

Hydroxy citric acid: Hydroxycitric acid (HCA) is the major organic acid occurring in the fruits of G. gummi-gutta. The acid and its lactone were mistakenly identified as citric acid and tartaric acid, however, the acids failed to give positive result for pentabromacetone test for citric acid and cream of tartar test for tartaric acid (Sreenivasan and Venkataraman 1959, Lewis et al., 1964). HCA has been first reported from nature by Lewis and Neelakantan in 1965 from the fruit rinds of G. gummi-gutta (Lewis and Neelakantan, 1965). HCA (1,2 dihydroxypropane-1,2,3- tricarboxylic acid) has four isomeric forms, since it contains two asymmetric carbons: (-)-HCA, (+)-HCA, (+)-allo-HCA and (-)-allo-HCA (Figure 2). (2S, 3S) Hydroxycitric acid is the major acid from the fruit rinds of G. gummi-gutta. The fruit contains $10 \%$ to $30 \%$ (-)HCA which can be isolated in the free form, as a mineral salt or as a lactone. An HPLC analysis showed 4.1-4.6\% (-)-HCA in the leaves while $10.3-12.7 \%$ in the fruits of G. indica (Jayaprakasha and Sakariah, 2002).

The leaves also contain HCA and a recent LC-MS screening revealed that among 13 Garcinia species, G. gummi-gutta contains the highest quantity of acids $(308 \mathrm{mg} / \mathrm{g}$ leaf methanol extract) and the HCA content was $95 \mathrm{mg} / \mathrm{g}$ (Pandey et al., 2015). HCA is available in the market in the form of various salts such as calcium, magnesium and potassium as well as their mixtures (Yamada et al., 2007). Citrin is the trade name given to the calcium salt of hydroxy citric acid. HCA lactone or garcinia lactone was also reported from the fruit. Other organic acids such as tartaric acid, citric acid and malic acid also have been reported as minor constituents. It also contains $1.5 \%$ phosphoric acid as calcium triphosphate.<smiles>O=C(O)C(O)C(O)C(C(=O)O)C(=O)O</smiles>

(-) $\mathrm{HCA}$

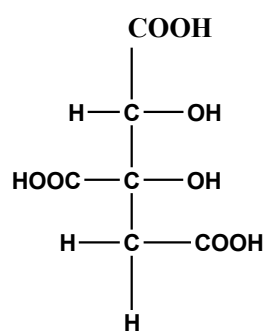

$(+) \mathrm{HCA}$

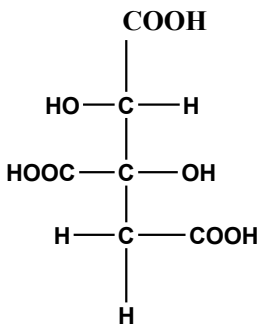

$(+)$ allo HCA

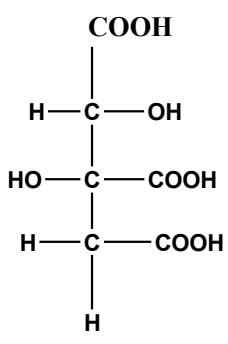

(-) allo HCA

Figure 2. Isomeric forms of hydroxycitric acid

Though citric acid is a common acid in plants, hydroxy citric acid is distributed in limited plant species such as the flowers of Hibiscus subdariffa and H. rosasinensis. However, the stereochemistry of HCA from Hibiscus species is $(+)$ allo form and is different from that of 
Garcinia (Lewis et al., 1964). Microbial strains such as Streptomyces sp. U121 and Bacillus megaterium G45C also produces HCA in trace amounts (Yamada et al., 2007). Hydroxycitric acid has also been synthesized from citric acid, through dehydration to form aconitic acid, which forms hydroxycitric acid via oxidation (Chen et al., 2001).

Paper chromatographic method (solvent system: n-butanol: acetic acid:water (BAW) in the ratio $(4: 1: 5)$ separates and detects hydroxy citric acid, along with its lactone, on Whatman No.1 paper using bromophenol blue as spray reagent. The acid content of the fruits can be estimated by titrating against $0.1 \mathrm{~N}$ sodium hydroxide using phenolphthalein as indicator. However, in this method the concentrations of (-)-HCA and lactone cannot be estimated separately (Jayaprakasha and Sakariah, 1998). HCA can be estimated spectrophotometrically by the formation of reddish orange color complex between HCA and sodium meta vanadate (Antony et al., 1999). Quantification of HCA was also possible through HPLC analysis of aqueous solution, where (-)-HCA and its lactone can be quantified separately (Majeed et al., 1994, Jayaprakasha and Sakariah, 1998, 2000, 2002). The acid can also be detected and estimated using gas chromatography of the trimethyl derivative (Lowenstein and Brunengraber, 1981). In a recent report, UHPLC-QqQLIT-MS/MS method has been applied for the validated estimation of HCA and lactone separately in leaf samples of different Garcinia species (Pandey et al., 2015).

The fatty acid content of G. gummi-gutta seeds were $46.5 \%$, and the major fatty acid was stearic acid (30.6\%), followed by oleic acid (26.2\%), linoleic acid (11.4\%), elaidic acid (9.5\%), palmitic acid (6.3\%) and arachidic acid (5.4\%) (See chapter 12 for further details).

The amino acid profile of G. gummi-gutta fruits was also reported. The amount of total free amino acids was determined to be less than $60 \mathrm{mg}$ in $100 \mathrm{~g}$ of G. gummi-gutta fruit. The amino acids such as arginine, asparagine, glutamine, threonine, glycine, proline, $\gamma$-amino butyric acid, leucine, isoleucine, ornithine and lysine were detected in the fruits (Carratu et al., 2008).

Volatile chemical profiling of the leaves of G. gummi-gutta revealed sesquiterpenoids as the major class of volatile compounds and $\alpha$-copaene has been reported as the major compound (30.2\%) (refer chapter 5 for details).

\subsection{Benzophenones}

Rama Rao et al. in the late 1970's, isolated the benzophenones camboginol (garcinol) and cambogin (isogarcinol; xanthochymol) from the latex of G. gummi-gutta in large quantities (37.0\% and 5.5\% respectively) (Rao et al., 1973). Camboginol (m.p. $132^{\circ} \mathrm{C}$ ) was obtained in $37 \%$ yield from the latex of G. gummi-gutta by a simple crystallisation from pet-ether. Silica gel column chromatography of the remaining residue using hexane as the eluting solvent gave cambogin (Rao et al., 1973). Cambogin has identical chemical and spectral properties as isoxanthochymol but having exactly opposite specific rotation, clearly indicating the compound as an enantiomer of isoxanthochymol. Later Iinuma, et al has also isolated garcinol and isogarcinol from the barks of G. gummi-gutta (Iinuma, et al., 1998). Phytochemical investigation of the fruits of G. gummi-gutta resulted in the isolation and characterisation of the benzophenones garcinol and guttiferones I, J, K, M, N (Masullo et al., 2008, 2010). In a recent report, the content of garcinol was highest in G. gummi-gutta $(0.593 \mathrm{mg} / \mathrm{g})$ leaf methanol extract among the 13 Garcinia species screened (Pandey et al., 2015). 


\subsection{Xanthones}

The xanthones garbogiol and rheediaxanthone A were isolated from the barks and roots of $G$. gummi-gutta (Iinuma, et al., 1998). Oxy-guttiferones M, K2, I and K were isolated from the fruits of G. gummi-gutta (Masullo et al., 2008, 2010). Oxy-guttiferones are tetracyclic xanthones derived from the oxidation of the corresponding polyisoprenylated benzophenones.

\subsection{Biflavonoids}

In a recent report, the biflavonoids fukugicide, GB-1 and amentoflavone were reported from G. gummi-gutta leaf extracts through a validated LC-MS analysis (Pandey et al., 2015). However, the biflavonoid content was lowest in G. gummi-gutta among all the screened Garcinia species. The phenolic acid and flavonoids were also lower compared to other Garcinia species (Pandey et al., 2015).

The major secondary metabolites benzophenones, xanthones and biflavonoids reported from the species are listed in Table 1.

Table 1. Phytochemicals reported from Garcinia gummi-gutta

\begin{tabular}{|c|c|c|}
\hline Plant Part & Compounds & References \\
\hline Leaf & $\begin{array}{l}\text { Cambogic acid, mangostin, garcinol, fukugicide, GB-1 } \\
\text { and amentoflavone }\end{array}$ & Pandey et al.,2015 \\
\hline Heart wood & $\begin{array}{l}\text { Morelloflavone, dihydromorelloflavone, isomorellic } \\
\text { acid }\end{array}$ & Venkataraman, 1973 \\
\hline Bark & Rheediaxanthone, guttiferone $\mathrm{E}$ and isogarcinol & Iinuma et al.,1998 \\
\hline Latex & Cambogin (isogarcinol) and camboginol (garcinol) & Rao et al., 1973 \\
\hline Root & Garbogiol & Iinuma et al.,1998 \\
\hline & $\begin{array}{l}\text { Morelloflavone, dihydromorelloflavone, isomorellic } \\
\text { acid }\end{array}$ & Venkataraman, 1973 \\
\hline Fruit & $\begin{array}{l}\text { Guttiferones - K, I, J, M and N; oxy-guttiferones M, K, } \\
\text { K2 and I }\end{array}$ & Masullo et al, 2008,2010 \\
\hline
\end{tabular}

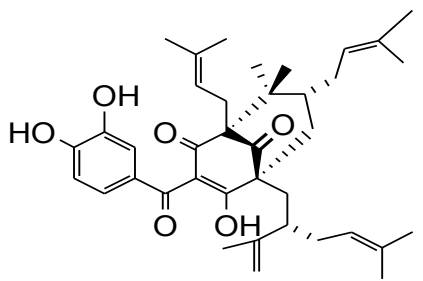

Garcinol

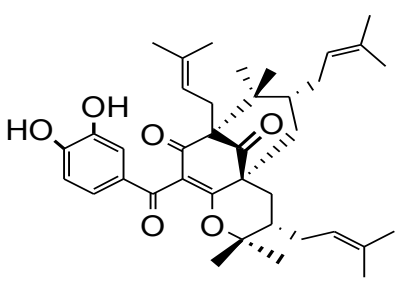

Isogarcinol

Oxy-guttiferone M

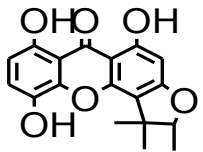

Garbogiol

Figure 3. Structures of some secondary metabolites isolated from G. gummi-gutta 


\section{Biological activities reported for Garcinia gummi-gutta}

3.1. Bioactivities of G. gummi-gutta crude extracts: The crude extract and isolated constituents from G. gummi-gutta exerted wide spectra of biological activities such as anthelmintic, anticholinesterase, diuretic, antifungal, gastroprotective and hepatoprotective activities in various in vitro and in vivo models (Semwal, et al., 2015). G. gummi-gutta also showed effect on reproductive system, lipid peroxidation, blood viscosity, haematology and plasma biochemistry (Semwal et al., 2015). G. gummi-gutta extract has shown significant antidiabetic property by efficiently improving glucose metabolism and displaying leptin like activity (Hayamizu et al., 2003). Remarkable antibacterial effect has been observed for various extracts of G. gummi-gutta (Jacob et al., 2015, Rani and Lawerence, 2015, Maridass et al., 2010). Different extracts of G. gummi-gutta fruits have shown good antioxidant property in various in vitro assays such as DPPH, hydroxyl radical, ferric reducing and lipid peroxidation (Jacob et al., 2015, Ranjani et al., 2014, Shivakumar et al., 2013, Subhashini et al., 2011). G. gummi-gutta extracts showed significant anti inflammatory activity in various experimental systems. In TNBS-induced colitis rats, the extract showed significant anti inflammatory activity and it could be related to a reduction in DNA damage in isolated colonocytes, observed with the comet assay. The extract also improved the macroscopic damage and caused substantial reductions in MPO activity, COX-2 and iNOS expression. It was also observed that treatment using Garcinia extract reduced PGE2 and IL$1 \beta$ colonic levels. The leaves of G. gummi-gutta showed significant anti-inflammatory activity, especially against carrageenan induced paw oedema in rats and also exhibited moderate in vitro anti-inflammatory action in hRBC membrane stabilization method (Prasanth et al., 2013). Several compounds such as garcinol, guttiferone K and guttiferone M isolated from G. gummi-gutta also posses anti-inflammatory activity (Semwal et al., 2015). G. gummi-gutta decreases the acidity and increase the mucosal defence in the gastric areas, thereby it can be used as an anti ulcerogenic agent (Mahendran et al., 2002). The oral administration of a fruit extract of G. gummi-gutta at doses of $1000 \mathrm{mg} / \mathrm{kg} \mathrm{BW} /$ day for 5,10 or 15 days exerted protective effects against indomethacin-induced damage of the gastric mucosa in rats. G. gummi-gutta fruit extract showed anti-tumour activity against the cell viability in the murine neuroblastoma cell line (Neuro-2A cells) (Mazzio and Soliman, 2009). Garcinol, the major secondary metabolite in G. gummi-gutta was effectively used against different cancer types such as breast cancer, Burkitt lymphoma, colon cancer, esophageal cancer, hepatocellular carcinoma, HeLa cells, kidney cancer, leukemia, lung cancer, medulloblastoma, multiple myeloma, pancreatic cancer, prostate cancer and tongue cancer (Saadat and Gupta, 2012).

3.2. Antiobesity property of hydroxyl citric acid (HCA): (-)-HCA is one of the important supplements for anti-obesity and weight management (Chuah et al., 2013). The inhibition of faty acid synthesis in vivo by HCA was first reported by Lowenstein et al., in 1971. (-)-HCA at 1 mmole per $\mathrm{kg}$ of body weight inhibited fatty acid synthesis by about $75 \%$ (Lowenstein et al., 1981). Sullivan et al., reoprted that fatty acid and cholesterol synthesis were blocked significantly by HCA and also that rats fed with HCA tended to eat less compared to the control animals (Sullivan et al., 1974). They have also reported that HCA lowered body fat levels with no loss of body protein in test animals (Sullivan et al., 1974). Followed by these 
observations, there has been a plethora of experiments on different models to test the anti obesity activity of HCA (Majeed et al., 1994).

HCA exhibited antiobesity activity by inhibiting the ATP-citrate lyase, a catalyst for the conversion process of citrate to acetyl-coenzyme A, the building block for fatty acid and cholesterol synthesis (Tharachand et al., 2013, Downs et al., 2005). In human trails HCA significantly improved blood lipid profiles by reducing total cholesterol, LDL and triglycerides levels significantly (Preuss et al., 2005). HCA promotes weight loss in humans without causing any stimulation in the central nervous system and produce only short term anorexia and does not carry the risk of being addictive (Majeed et al., 1994, Downs et al., 2005). HCA also regulated the serotonin levels related to satiety and decreased lipogenesis.

Garcinia extracts and HCA have widely been used for obesity and weight control treatments and the long term continuous consumption demands systematic toxicity evaluation and a number of reports about the toxicity of G. gummi-gutta fruits and supplements are available in literature (Majeed et al., 1994). However, the potential contributions of HCA as a weight loss agent in humans were controversial, especially regarding the long term benefits and when the randomized, placebo-controlled clinical trials were counted (Heymsfield et al., 1998; Marquez et al., 2012). Also, some clinical studies reported various toxic effects such as toxicity towards spermatogenesis and hepatotoxicity (Kim et al., 2013). However, scientific evidence based on structure, mechanism of action and long history of the use of Garcinia had shown 'no observed adverse effect level' (NOAEL) at levels up to $2800 \mathrm{mg} /$ day and suggests that HCA is safe for use (Chuah et al., 2012, 2013).

3.3: Biological activities of garcinol: Garcinol, the major polyisoprenylated benzophenone isolated from $G$. indica exhibits potential antioxidant activity by scavenging DPPH radicals, hydroxyl radicals, suppressing superoxide anion, effective against peroxynitrite-induced lipid peroxidation and inhibiting xanthine oxidase activity. The strong antioxidant activity of garcinol is attributed to the presence of both the phenolic hydroxy groups and $\beta$-diketone moiety that shows keto enol tautomerism as in the case of curcumin (Padhye et al., 2009). Garcinol plays an important role in the treatment of gastric ulcers caused by the hydroxyl radical or by a chronic infection with Helicobacter pylori as evident from its antiulcer activity in rats induced by indomethacin and acts as a good antioxidant when administered orally (Yamaguchi et al., 2000; Kolodziejczyk et al., 2009). It shows antibiotic activity against methicillin-resistant Staphylococcus aureus comparable to that of vancomycin and also proven to exhibit several anticancer activities. Garcinol is also able to suppress colonic aberrant crypt foci (ACF) formation in rats and inhibits topoisomerases I and II at concentrations comparable to that of etoposide. Garcinol decreases the cell viability, increases cell death and apoptosis in human leukemia HL-60 cells, HT-29 cells, HeLa cells and colon cancer cells (Pan et al., 2001; Balasubramanyam et al., 2004). 4-NQO induced oral carcinogenesis in rats and Nic-induced human breast cancer (MDA-MB-231) cell proliferation were suppressed by garcinol (Yoshida et al., 2005; Chen et al., 2011). Earlier studies showed that garcinol acts as a neuroprotective agent by inhibiting the expression of inducible nitric oxide synthase (iNOS) and cyclooxygenase-2 (COX-2) in lipopolysaccharide activated macrophages (LPS) and blocks activation of eukaryotic transcription factor NF- $\mathrm{BB}$ induced by LPS (Liao et al., 2004). It has been established that the phenolic hydroxyl groups as well as $\beta$-diketone moiety, that shows keto-enoltautomerism as in the case of curcumin, is 
important for the biological activities of garcinol. The isoprenyl chain consists of hydrophobic sites, is also important for binding to biological targets (Padhye et al., 2009).

In addition, other secondary metabolites isolated from G. gummi-gutta also showed various biological activities. Xanthones reported from G. gummi-gutta shows activities such as vasodilatory, antimalarial, antiviral activity, human leukemia, cytotoxic activity, $\alpha-$ glucosidase activity, CNS activity and platelet activating factor (PAF). Guttiferones and polyisoprenylated benzophenones reported from G. gummi-gutta have shown interesting biological properties such as leishmanicidal, anticancer, antifungal, antiproteolytic, cytotoxicity, apoptotic, cytoprotection against HIV-1 in vitro and inhibited the binding activity of a-liver X receptor (LXRa) but is less effective against b-receptor (LXRb).

\section{Conclusions}

G. gummi-gutta is a common fruit plant of the Western Ghats, attributed with a wide range of applications ranging from food, medicines and nutraceutics. The fruit rind of G. gummi-gutta is the major source of (-)-hydroxycitric acid (HCA). In addition, secondary metabolites such as xanthones, benzophenones, organic and amino acids were also reported from this plant. The potential beneficial effects include antioxidant, antihelmenthic, antidiabetic, antimicrobial, antiobesity and hyperlipidaemic properties. Reports on the toxicity and observations during clinical trials suggest that G. gummi-gutta is safe for human consumption.

\section{References}

1. Anonymous. 1956. The wealth of India: Raw materials, Vol: IV: F-G, NISCAIR, New Delhi.

2. Antony B, Varghese $\mathrm{W}$ and Elias M, 1999. Spectrophotometric determination of hydroxycitric acid. Indian J. Pharm. Sci., 316-317.

3. Balasubramanyam K, Altaf M, Varier RA, Swaminathan V, Ravindran A, Sadhale PP and Kundu TK. 2004. Polyisoprenylated benzophenone, garcinol, a natural histone acetyltransferase inhibitor, represses chromatin transcription and alters global gene expression. J. Biol. Chem., 279(32), 33716-3326.

4. Carratu B, Boniglia C, Giammarioli S, Mosca M and Sanzini E. 2008. Free amino acids in botanicals and botanical preparations. J. Food Sci., 73, C323-8.

5. Chen CS, Lee CH, Hsieh CD, Ho CT, Pan MH, Huang CS, Tu SH, Wang YJ, Chen LC, Chang YJ, Wei PL, Yang YY, Wu CH and Ho YS. 2011. Nicotine-induced human breast cancer cell proliferation attenuated by garcinol through down-regulation of the nicotinic receptor and cyclin D3 proteins. Breast Cancer Res Treat, 125(1), 73-87.

6. Chen L, Qing J and He S. 2001. Study on synthesis of hydroxycitric acid. J. Nanjing. Univ. Sci. Technol., 25, 282-285.

7. Chuah LO, Ho WY, Beh BK and Yeap SK. 2013. Updates on Antiobesity effect of Garcinia origin (-)-HCA. Evid. Based Complement. Alternat. Med., 2013.

8. Chuah LO, Yeap SK, Ho WY, Beh BK and Alitheen NB. 2012. In vitro and in vivo toxicity of garcinia or hydroxycitric acid: A review. Evid. Based Complement. Alternat. Med., 2012. 
9. Downs BW, Bagchi M, Subbaraju GV, Shara MA, Preuss HG and Bagchi D. 2005. Bioefficacy of a novel calcium-potassium salt of (-)-hydroxycitric acid. Mutat. Res., 579, 149-162.

10. Hayamizu K, Hirakawa H, Oikawa D, Nakanishi T, Takagi T, Tachibana T and Furuse M. 2003. Effect of Garcinia cambogia extract on serum leptin and insulin in mice. Fitoterapia, 74, 267-273.

11. Heymsfield SB, Allison DB, Vasselli JR, Pietrobelli A, Greenfield D and Nunez C. 1998. Garcinia cambogia (Hydroxycitric acid) as a potential antiobesity agent: a randomized controlled trial. J. Am. Med. Assoc., 280(18), 1596-1600.

12. Iinuma M, Ito T, Miyake R, Tosa H, Tanaka T and Chelladurai V. 1998. A xanthone from Garcinia cambogia. Phytochemistry, 47, 1169-1170.

13. Jacob KMP, Ali MA, Vishnu H, Shylaja G, Mythili S and Sathiavelu A. 2015. Evaluation of antibacterial and antioxidant activity of Garcinia gummigutta. Int. J. Drug Dev. Res., 7, 57-59.

14. Jayaprakasha GK and Sakariah K K. 2000. Determination of (-)-hydroxycitric acid in commercial samples of Garcinia cambogia extracts by liquid chromatography using ultraviolet detection. J. Liq. Chromatogr. Relat. Technol., 23, 915-923.

15. Jayaprakasha GK and Sakariah K K. 2002. Determination of organic acids in leaves and rinds of Garcinia indica (Desr.) by HPLC. J. Pharm. Biomed. Anal., 28(2), 379-384.

16. Jayaprakasha GK and Sakariah KK. 1998. Determination of organic acids in Garcinia cambogia (Desr.) by HPLC. J. Chromatogr. A., 806, 337-339.

17. Jena BS, Jayaprakasha GK, Singh RP and Sakariah KK. 2002. Chemistry and biochemistry of (-)-hydroxycitric acid from Garcinia. J. Agric. Food Chem., 50, 10-22.

18. Kalia RK, Malik SK and Chaudhury R. 2012. In vitro morphogenetic studies on three species of Garcinia. J. Plant Biochem. Biotechnol., 21, 279-85.

19. Kim YJ1, Choi MS, Park YB, Kim SR, Lee MK and Jung UJ. 2013. Garcinia Cambogia attenuates diet-induced adiposity but exacerbates hepatic collagen accumulation and inflammation. World J. Gastroenterol., 19 (29), 4689-701.

20. Kolodziejczyk J, Masullo M, Olas B, Piacente S and Wachowicz B. 2009. Effects of garcinol and guttiferone $\mathrm{K}$ isolated from Garcinia cambogia on oxidative/nitrative modifications in blood platelets and plasma. Platelets, 20(7), 487-492.

21. Lewis YS and Neelakantan S. 1965. (-)-Hydroxycitric acid-the principal acid in the fruits of Garcinia cambogia Desr. Phytochemistry, 4, 619-625.

22. Lewis YS, Neelakantan S and Anjanamurthy C. 1964. Acids in Garcinia cambogia. Current Sc., 33(3), 82-83.

23. Liao CH, Sang S, Liang YC, Ho CT and Lin JK. 2004. Suppression of inducible nitric oxide synthase and cyclooxygenase-2 in down regulating nuclear factor-kappa B pathway by garcinol. Mol. Carcinog., 4, 140-149.

24. Lowenstein JM and Bruneugraber H. 1981. Hydroxycitrate. In Methods in Enzymology; Lowenstein JM. Ed. Academic Press, New York, 72, pp 486-497.

25. Mahendran P, Vanisree AJ and Shyamala Devi CS. 2002. The antiulcer activity of Garcinia cambogia extract against indomethacin induced gastric ulcer in rats. Phytother. Res., 16, 80-83. 
26. Majeed M, Rosen R, McCarty M, Conte A, Patil D and Butrym E. 1994. Citrin; A revolutionary, herbal approach to weight management. New editions publishing. Burlingame, California.

27. Manilal KS. 2003. Van Rheede's Hortus Malabaricus, Vol. 1, English edition. University of Kerala, Thiruvananthapuram.

28. Maridass M, Ramesh U and Raju G. 2010. Evaluation of phytochemical, pharmacognostical and antibacterial activity of Garcinia Gummicutta Leaves. Pharmacologyonlin., 1, 832-837.

29. Marquez F, Babio N, Bullo M and Salas-Salvado J. 2012. Evaluation of the safety and efficacy of hydroxycitric acid or Garcinia cambogia extracts in humans. Crit. Rev. Food Sci. Nutr., 52, 585-594.

30. Masullo M, Bassarello C, Bifulco G and Piacente S. 2010. Polyisoprenylated benzophenone derivatives from the fruits of Garcinia cambogia and their absolute configuration by quantum chemical circular dichroism calculations. Tetrahedron., 66, 139-45.

31. Masullo M, Bassarello C, Suzuki H, Pizza C and Piacente S. 2008. Polyisoprenylated benzophenones and an unusual polyisoprenylated tetracyclic xanthone from the fruits of Garcinia cambogia. J. Agric. Food Chem., 56, 5205-5210.

32. Mazzio EA and Soliman KFA. 2009. In vitro screening for the tumoricidal properties of international medicinal herbs. Phytother., 23, 385-398.

33. Padhye S, Ahmad A, Oswal N and Sarkar FH. 2009. Emerging role of Garcinol, the antioxidant chalcone from Garcinia indica Choisy and its synthetic analogs. J. Hem. Onc., 2(38).

34. Pan MH, Chang WL, Lin-Shiau SY, Ho CT and Lin JK. 2001. Induction of apoptosis by garcinol and curcumin through cytochrome c release and activation of caspases in human leukemia HL-60 cells. J. Agric. Food Chem. 49(3), 1464-1474.

35. Pandey R, Chandra P, Kumar B, Srivastva M, Aravind AA, Shameer PS and Rameshkumar KB. 2015. Simultaneous determination of multi-class bioactive constituents for quality assessment of Garcinia species using UHPLC-QqQ LIT-MS/MS. Ind. Crops Prod., 77, 861-872.

36. Prasanth NV, Rasheed SP, Thomas T, Joseph S and Varghese CP. 2013. Evaluation of in vitro and in vivo anti- inflammatory activity of Garcinia combogia. IJPPS., 5, 263-264.

37. Preuss HG, Garis RI, Bramble JD, Bagchi D, Bagchi M, Rao CV and Satyanarayana S. 2005. Efficacy of a novel calcium/ potassium salt of (-)-hydroxycitric acid in weight control. Int. J. Clin. Pharmacol. Res., 25(3), 133-144.

38. Rani J and Lawerence B. 2015. Leaf extract of Garcinia gummi-gutta (L.) Robson against pathogenic microorganisms. Int. J. Pharmaceut. Sci. Health Care., 1, 20-29.

39. Ranjani R, Khadira S A, Priya N and Vijayalakshmi K. 2014. Antioxidant profile of the fruit rind of Garcinia cambogia and leaves of Bauhinia variegata an in vitro investigation. Int. J. Pharmaceut. Res. Bio Sci., 3, 528-538.

40. Rao AR, Venkataraman K and Yemul SS. 1973. The structure of bronianone. Tetrahedron Lett., 14(50), 4981-4982.

41. Saadat N and Gupta S V. 2012. Potential Role of Garcinol as an anticancer Agent. $J$. Oncology, 1-8. 
42. Semwal RB, Semwal D.K, Vermaak I and Viljoen A. 2015. A comprehensive scientific overview of Garcinia cambogia. Fitoterapia, 102, 134-148.

43. Shivakumar S, Sandhiya S, Subhasree N, Agrawal A and Dubey GP. 2013. In vitro assessment of antibacterial and antioxidant activities of fruit rind extracts of Garcinia cambogia. L. Int. J. Phar. Pharmaceut. Sci., 5, 254-257.

44. Singh NP. 1993. Clusiaceae (Guttiferae nom. alt.) In: Sharma, BD and Balakrishnan NP (eds.), Flora of India 3. Botanical Survey of India, Kolkatta, 86-151.

45. Sreenivasan A and Venkataraman R. 1959. Chromatographic detection of the organic constituents of Gorikapuli (Garcinia cambogia Desr.) used in pickling fish. Current Sc., $28(04), 51-52$.

46. Subhashini N, Nagarajan G and Kavimani S. 2011. In vitro antioxidant and anticholinesterase activities of G. combogia. Int. J. Phar. Pharmaceut. Sci., 3, 129-132.

47. Sullivan AC, Triscari J, Hamilton JG, Miller ON and Wheatley VR. 1974. Effect of (-) hydroxycitrate upon the accumulation of lipid in the rat: I. Lipogenesis. Lipids, 9, 121128.

48. Tharachand, Selvaraj I and Avadhani M. 2013. Medicinal properties of Malabar Tamarind, Garcinia Cambogia (Gaertn.) DESR. Int. J. Pharm. Sci. Rev. Res., 19, 101107.

49. Venkataraman K. 1973. Pigments of Garcinia species. Indian National Science Academy, New Delhi. 39(A) 6, 365-381.

50. Watt G. 1890. Dictionary of the Economic Products of India, Vol. II, (Second reprint 1972) Periodical Experts, Delhi.

51. Yamada T, Hida H and Yamada Y. 2007. Chemistry, physiological properties, and microbial production of hydroxycitric acid. Appl. Microbiol. Biotechnol., 75, 977-982.

52. Yamaguchi F, Saito M, Ariga T, Yoshimura Y and Nakazawa H. 2000. Free radical scavenging activity and antiulcer Activity of garcinol from Garcinia indica fruit rind. $J$. Agric. Food Chem., 48, 2320-2325.

53. Yoshida K, Tanaka T, Hirose Y, Yamaguchi F, Kohno H, Toida M, Hara A, Sugie S, Shibata $\mathrm{T}$ and Mori H. 2005. Dietary garcinol inhibits 4-nitroquinoline 1-oxide-induced tongue carcinogenesis in rats. Cancer Lett., 221, 29-39. 


\title{
Chapter 11
}

\section{Gamboge- The bark exudate from Garcinia species}

\author{
Siji Aral and K. B. Rameshkumar* \\ Phytochemistry and Phytopharmacology Division \\ Jawaharlal Nehru Tropical Botanic Garden and Research Institute \\ Palode, Thiruvananthapuram- 695562, Kerala, India \\ *Corresponding author
}

\begin{abstract}
Garcinia bark exudates, known as gamboges, has been used as a pigment in Indian murals and European water colour-paintings. It has also been used for dyeing clothes and for colouring wood, metal and leather. Gamboge has several uses in traditional medicinal systems, especially as a purgative and also externally used for treating infected wounds. The major sources of gamboges are Garcinia hanburyi and Garcinia morella. Gamboge contains $70 \%$ to $80 \%$ yellow resin and $15 \%$ to $25 \%$ water soluble gum and the remaining portion is composed of esters, hydrocarbons, wax and ash. The characteristic bioactive compounds in gamboges were identified as caged xanthones, such as gambogic acid and morellin, that possess potential anticancer properties. This chapter provides a detailed account on history, distribution, chemistry and uses of gamboge.
\end{abstract}

Keywords: Gamboge, Garcinia hanburyi, Garcinia morella, Caged xanthones, Gambogic acid, Morellin

\section{Introduction}

Recently there has been an increased demand for plant derived natural products, mainly due to the safety concerns of the synthetic pigments, colouring agents and other additives that are essential ingredients in several industrial sectors such as cloth dyeing, food and nutraceutical. Among the different plant products, exudates are in high demand now, due to the low toxicity, abundant availability, biocompatibility, biodegradability and inertness compared to synthetic alternatives.

Gamboge, also known as camboge, is the exudate from the bark of Garcinia species. Garcinia species are perhaps known all over the world in ancient times by this value added product. The dried exudates are used as a pigment in Indian murals and European waterpaintings and dyeing clothes and also for colouring wood, metal and leather. Though primarily gamboge was used as a colouring agent, several traditional medicinal uses were also attributed to the exudate. Recent phytochemical investigations showed the bark exudates as rich source of bioactive secondary metabolites such as caged xanthones. The present chapter summarises the history, traditional uses and phytochemistry of gamboge.

\section{History of gamboge as a natural colouring agent}

Plant exudates were used by ancient civilisations world over for various purposes and the usage can be traced back to about $3000 \mathrm{BC}$, where the Egyptian civilization used gum Arabica, the exudates from Acacia. The word gamboge comes from Gambogia, the Latin 
word for Cambodia. Gamboge was used from ancient times to dye the clothes and also to make a transparent yellow varnish for the coloring of wood, metals and leather. The pigment was made more usable by mixing with other yellow pigments such as lemon yellow or alumnia. The color of gamboge is a deep tone of saffron, and gamboge is recognised as a distinct colour (Maerz and Paul, 1930). When used as a water colour, it gives a bright transparent golden yellow colour and is not a true pigment. In ancient India, gamboge had an important place among artists, herbalists and spiritual communities. The earliest evidence of the use of gamboge comes from artefacts of eighth century from East Asia, where the yellow colour is presumed to be derived from gamboge. Garcinia exudates were used to dye the robes of Buddhist monks (Lewington et al., 1990). Gamboge was first brought to Europe, in 1603, by Admiral Van Neck, and used as a transparent oil color by Flemish painters (Chantarasriwong et al., 2010). John Smith in 'The Art of Painting in Oyl', published in 1701, describes a method for preparing the colour. The botanic artist William Hooker created the pigment 'Hooker's Green' that gives a special green to colouring leaves by mixing Green Malachite or Prussian blue and gamboge (Winter et al., 1997). One can assume that since the gamboge faded so rapidly relative to iron blue, trees in some old artworks have become blue. A tradition of mural paintings in Kerala, south India, following the sixteenth century techniques, uses the exudates of G. morella, locally known as Eravikkara in Malayalam in combination with the leaves of Indigofera tinctoria to get different shades of green (Nayar et al., 1999). Jean Baptiste Perrin in his work on Brownian movement used a colloidal suspension of gamboge particles to investigate the phenomenon and derive a value for the Avogadro number in 1926 (Chantarasriwong et al., 2010).

\section{Traditional medicinal uses of gamboge}

The exudates from different Garcinia species were used therapeutically in traditional medicine, especially as emetics and cathartics (Majeed et al., 1994). Gamboge obtained from Garcinia hanburyi is used externally for infected wound and for pain and oedema in traditional Thai medicine. It has cathartic activity and is used in veterinary medicine as a drastic purgative. Gamboge is a laxative in doses of 10-15 cgm., produces abundant evacuations with violent colicky pains in doses of 30-50 cgm. It can cause vomiting, nausea and griping in high doses. It is also used as a vermifuge. It is usually combined with other purgatives such as aloe or calomel, to strengthen their effect. It is used in traditional medicine for the treatment of ulcers, skin infection, appetite suppression and to lower blood pressure (Panda, 2005). The resin of G. morella has purgative action and was mainly applied for intestinal complaints. The cathartic property of the exudate was made use for expelling tapeworms from the intestine. However, large doses are toxic, leading to gastro enteritis.

\section{Extraction of gamboge}

Gamboge is generally extracted by tapping of Garcinia species. The plant tissues of the Clusiaceae members were characterized by the presence of latex channels and different shades of yellow were reported for the exudates from Garcinia species (Nogueira et al., 2001). Generally trees of ten years old are tapped by making spiral incisions in the bark and traditionally collected in bamboo containers. The hard and brittle lumps of the solidified raw gamboge are dark yellow in color, which when pulverized, turns into a bright yellow powder. This powder is mixed with a variety of binders to make paints and varnishes. 


\section{Major sources of gamboge}

The major sources of gamboge were G. hanburyi (Cambodia and Thailand), G. morella (India and Sri Lanka), and G. elliptica and G. heterandra (Myanmar). The chief trade supply was obtained from Siam in the form of cylindrical pieces or sticks and until recently, the gum resin of Siam was referred to Garcinia cochin-sinensis and that of Ceylon to Hebradendron cambogioides, while that of Southern India was supposed to be the produce of Garcinia pictorial (Watt,1890; Utpala and Nandakishore, 2016).

True gamboge of use in arts and medicine in India derives mainly from the gum resin of G. morella (Figure 1). The tree is distributed in Indo-Malay and Sri Lanka. All parts of the plant yield a thick yellow exudate.
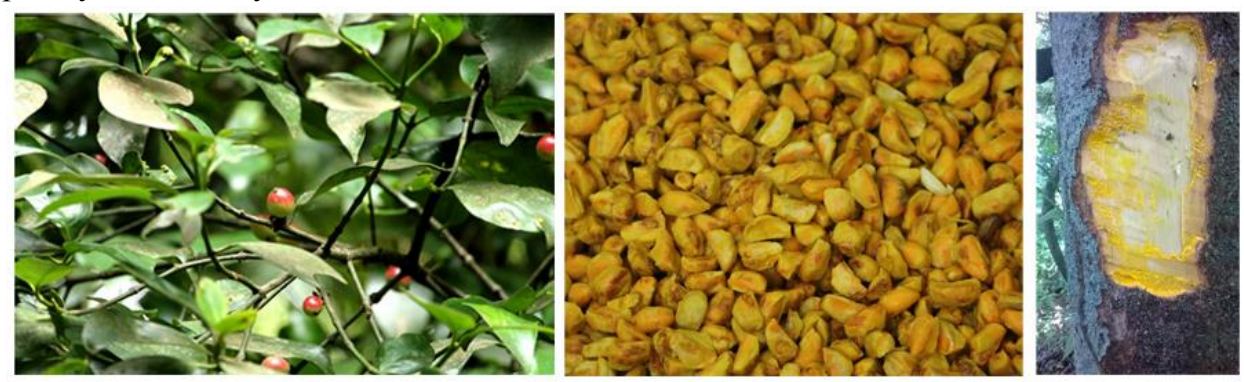

Figure 1. Garcinia morella twig, seeds and bark

Table 1. Distribution of gamboge in different Garcinia species

\begin{tabular}{|c|c|c|}
\hline \multirow{2}{*}{$\begin{array}{l}\text { Sl. } \\
\text { No. }\end{array}$} & Garcinia species & Remarks \\
\hline & G. anomala Planci. \& Trian. & Gamboge is inferior in quality. \\
\hline & G. cornea Linn. & Gamboge is inferior in quality. \\
\hline & G. cowa Roxb. & $\begin{array}{l}\text { Gamboges is inferior in quality, with paler colour than that of } G \text {. } \\
\text { morella and is insoluble in water. Bark is used to extract a light } \\
\text { yellow colour for colouring of the cloth for the garments of } \\
\text { Buddist monks. }\end{array}$ \\
\hline & G. eugeniaefolia Wall. & The exudate a green varnish \\
\hline & G. gummi-gutta (L.) N. Robson & $\begin{array}{l}\text { The tree yields a yellow, insoluble, very adhesive gum, which is } \\
\text { valueless as a pigment on account of its insolubility in water }\end{array}$ \\
\hline & G. hanburyi Hook. f. & $\begin{array}{l}\text { Exudates is known as Siam gamboge and is used as a purgative } \\
\text { and externally used for infected wounds in Thai traditional } \\
\text { medicine. }\end{array}$ \\
\hline & G. heterandra Wall. & $\begin{array}{l}\text { This tree yields a superior kind of gamboge, so similar to the } \\
\text { Gamboge of commerce. It readily forms an emulsion with water. } \\
\text { Burmese priests occasionally use this gamboges to dye their } \\
\text { robes and the Karens to dye their thread. The gum resin is } \\
\text { occasionally employed as a medicine by Burman native } \\
\text { practitioners. }\end{array}$ \\
\hline & G. indica & The exudate is sparingly soluble in water, but it became \\
\hline
\end{tabular}




\begin{tabular}{|c|c|}
\hline & insoluble when dried. \\
\hline G. mangostana Linn. & This species exudes gamboge of inferior quality \\
\hline G. morella Desrouss & $\begin{array}{l}\text { This species produces the true gamboge of medicine and of the } \\
\text { arts. }\end{array}$ \\
\hline G. speciosa Wall. & It yields an inferior gamboge. \\
\hline G. stipulata T. And. & The tree and fruit yield a yellow gum, but not used as gamboge. \\
\hline G. succifolia Kurz & The species yield inferior quality gamboge at very little yield. \\
\hline G. travancorica Beddome & $\begin{array}{l}\text { Every portion of the tree yields an abundance of bright yellow } \\
\text { gamboge. }\end{array}$ \\
\hline G. wightii T. Anderson & $\begin{array}{l}\text { The gamboge of this species is very soluble and yields a good } \\
\text { pigment. }\end{array}$ \\
\hline G. xanthochymus Hook. f. & $\begin{array}{l}\text { This species yields a large quantity of inferior gamboge both } \\
\text { from the stem and the fruit rind which is extensively used as a } \\
\text { cotton dye in Assam. The exudate contains a larger proportion of } \\
\text { gum than that derived from other species. The exudates are } \\
\text { sparingly soluble in water, but it became insoluble when dried. }\end{array}$ \\
\hline
\end{tabular}

Figure 2 shows the exudates from 25 Garcinia species distributed in India. The colour of the exudates varies from white to different shades of yellow.

\section{Chemistry of gamboge}

Gamboge, being a well known commercial commodity of historical importance, had been a subject of intensive analytical investigation (Chantarasriwong et al., 2010; Utpala and Nandakishore 2016). Venkataraman (1973) has reviewed the chemistry of pigments from Garcinia species.

Exudates are a complex mixture of organic compounds that ooze out of plants through pores, or wounds. Gamboge is odorless but slightly acidic (Nayar et al., 1999). Exudates consist largely of gum, resin or latex, depending on the tree species. The exudates from Garcinia species are generally yellow translucent and sometimes white to reddish, which get solidified when exposed to air.

The resin portion of the exudates was separated through partition with ethyl acetate. The remaining aqueous portion represents gum content of the exudate. Gamboge contains about $70 \%$ to $80 \%$ yellow resin, $15 \%$ to $25 \%$ water soluble gum, and the remaining portion is composed of esters, hydrocarbons, wax and ash. In a recent report, G. gummi-gutta exudates contains $68 \%$ resin, while $G$. indica contains $60 \%$ resin followed by G. xanthochyma $(40 \%)$ (Parthasarathy and Nandakishore, 2016). The brittle resin is deep orange colour in thin layers and when it is fine powdered, its colour is gamboge yellow. Gamboge resin is insoluble in water, but soluble in alcohol. It dissolves in a solution of caustic potash, forming a dark red liquid which gets precipitated by acids and lime water, and some metallic salts like lead, brown by protosulphate of iron and green by the nitrate of copper. The precipitates formed with the metallic salts are regarded as gambogiates of the respective metals, as they consist of the resin and the oxide of the metal. 

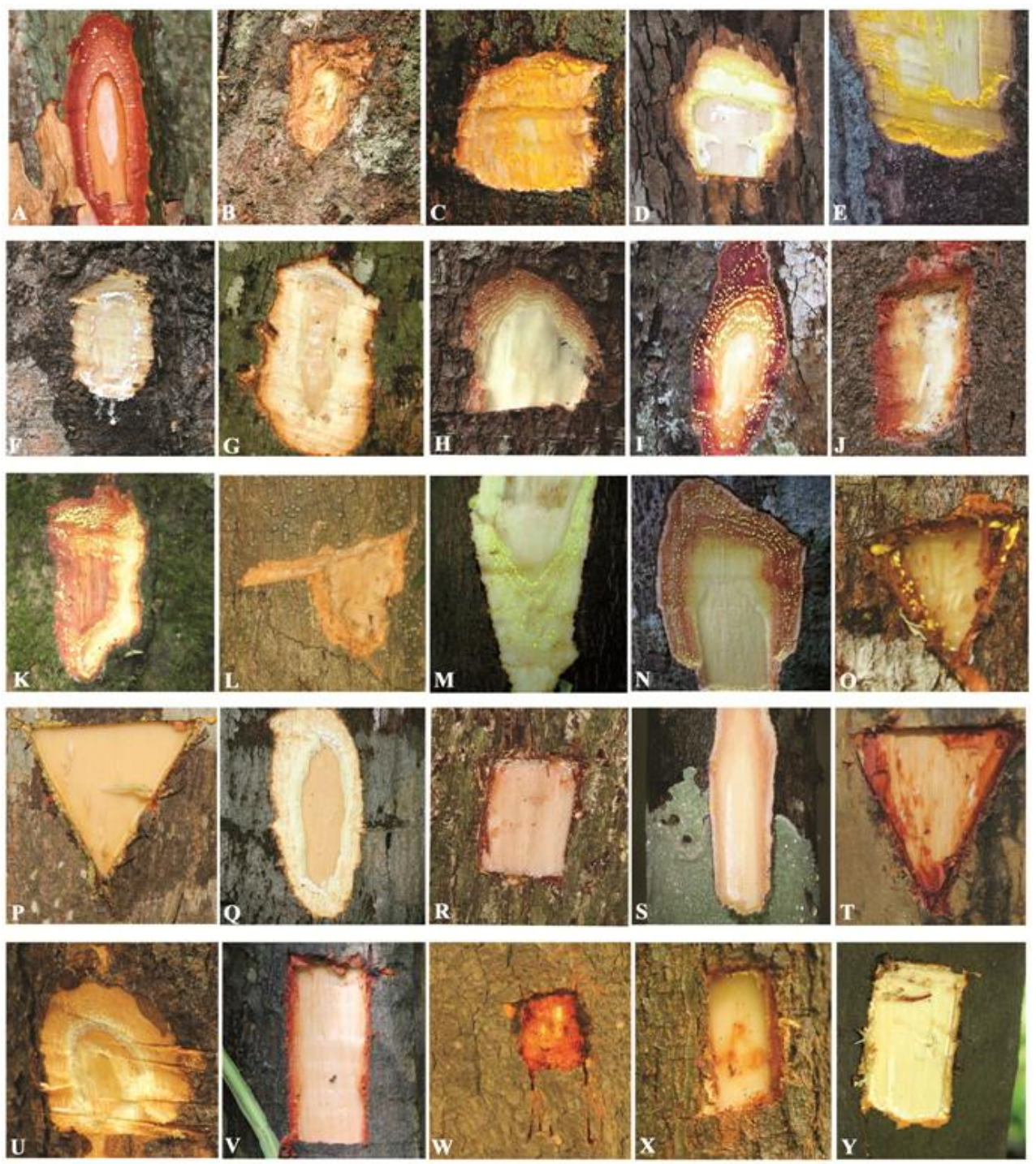

Figure 2. Garcinia bark exudates (A. G. rubro-echinata, B. G. imberti, C. G. wightii, D. G. travancorica, E. G. morella, F. G. talbotii, G. G. pushpangadaniana, H. G. indica, I. G. gummi-gutta var. gummi-gutta, J. G. gummi-gutta var. papilla, K. G. gummi-gutta var. conicarpa, L. G. andamanica, M. G. assamica, N. G. anomala, O. G. cowa, P. G. dhanikariensis, Q. G. dulcis, R. G. hombroniana, S. G. kydia, T. G. speciosa, U. G. xanthochymus, V. G. cornea, W. G. livingstonei, X. G. mangostana, Y. G. spicata)

(-) Gambogic acid has been identified as the principal pigment of gamboge derived from Garcinia hanburyi, while related investigations of the seeds and the resin of Garcinia morella led to the isolation of (-) morellin (Figure 3) (Rao, 1937; Lang and Katz, 1949; Yates et al., 1963). Both of the compounds belong to an interesting group of complex compounds known as caged xanthones, with unique 4-oxatricyclo [4.3.1.0] dec-2-one ring system. Gambogic acid occurs in nature as a mixture of epimers at the $\mathrm{C} 2$ center $(\mathrm{C} 2 \mathrm{R}$ and 
$\mathrm{C} 2 \mathrm{~S}$ ) that can be separated by modern chromatographic and analytical techniques (Han et al., 2006). C2S Gambogic acid is also known as epigambogiac acid. Garcinia hanburyi has been reported as a rich source of such cytotoxic caged xanthones (Reutrakul et al., 2007). Many of such caged xanthones have been shown to possess anticancer and antitumor properties.

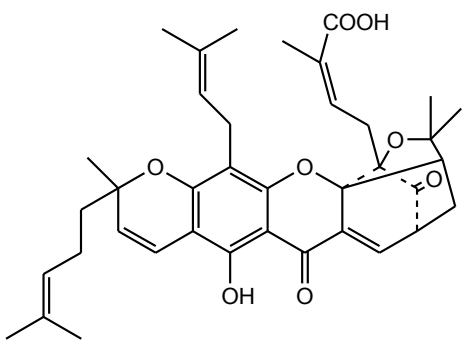

Gambogic acid

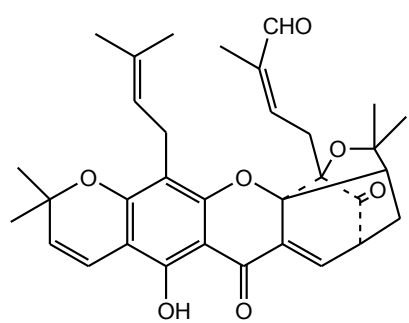

Morellin

Figure 3. Structure of gambogic acid and morellin

\section{Pharmacological activities of gamboge}

The caged xanthone gambogic acid has been a centre of attraction for the pharmacological researchers as evident from the ever increasing number of publications over the compound (Chantarasriwong et al., 2010). The toxicity of gamboge was also noted early onwards and several accounts warn against licking brushes containing gamboge. Gambogic acid has been identified as a potent anti-tumor agent that inhibited cancer cell growth in vitro and in vivo with minimal toxicity to normal cells, in its pre-clinical trials (Kasibhatla et al., 2005). The unique caged xanthone structure is the basis of gambogic acid induced anti-cancer effects. Gambogic acid induced apoptosis has been reported in many cancer cell types including leukemia, cervical cancer, cholangio carcinoma, hepatoma, breast cancer, gastric cancer, glioblastoma and osteosarcoma (Zhao et al., 2004; Yu et al., 2006; Yang et al., 2007; Wang and Chen, 2012). Gambogic acid inhibits cell proliferation in multidrug-resistant cancer cells. It has also prevented cancer metastasis and angiogenesis, and has finished phase II clinical trials in China (Wang et al., 2011). The potent anticancer activity of gambogic acid is mainly attributed to its activation of the impaired apoptotic pathways in cancerous cells via downregulation of telomerase (Guo et al., 2006). Morellin and gambogic acid have been reported as potential antibacterial compounds and exhibited high in vitro specific growth inhibitory effects on Gram-positive bacteria (Rao and Natarajan, 1950; Chantarasriwong et al., 2010).

\section{Conclusions}

Gamboge, the dried exudate from several Garcinia species, was used as a pigment in water paintings, dyeing cloths and also for coloring wood, metals and leather. Alternative products obtained from renewable sources, are getting prominence and the potential of gamboge as a natural substitute for colouring material is highly appreciated. Though historically known as source of coloring pigments, gamboge is now reputed as source of a new family of natural products, known as caged xanthones. The remarkable chemical structure, biosynthesis, biology and medicinal potential of the caged xanthones open up a new window to the potential utility of gamboge. 


\section{References}

1. Chantarasriwong O, Batova A, Chavasiri W and Theodorakis EA. 2010. Chemistry and biology of the caged Garcinia xanthones. Chem. Eur. J., 16(33), 9944-9962.

2. Guo QL, Lin SS, You QD, Gu HY, Yu J, Zhao L, Qi Q, Liang F, Tan Z and Wang X. 2006. Inhibition of human telomerase reverse transcriptase gene expression by gambogic acid in human hepatoma SMMC-7721 cells. Life Sci., 78(11), 1238-1245.

3. Han QB, Song JZ, Qiao CF, Wong L and Xu HX. 2006. Preparative separation of gambogic acid and its $\mathrm{C}-2$ epimer using recycling high-speed counter-current chromatography. J Chromatogr A, 1127:298-301.

4. Kasibhatla S, Jessen KA, Maliartchouk S, Wang JY, English NM, Drewe J, Qiu L, Archer SP, Ponce AE, Sirisoma N, Jiang S, Zhang HZ, Gehlsen KR, Cai SX, Green DR and Tseng B. 2005. A role for transferrin receptor in triggering apoptosis when targeted with gambogic acid. Proc. Natl. Acad. Sci. U.S.A., 102(34), 12095-12100.

5. Lang M and Katz A. 1949. Chemistry of gamboge. Pharm. Acta Helv., 24(11), 387-401.

6. Lewington A. 1990. Recreation- Plants that Entertain Us, Plants for people, Natural History Museum Publications, London.

7. Maerz A and Paul MR. 1930. A Dictionary of Color. McGraw-Hill, New York.

8. Majeed M, Rosen R, McCarty M, Conte A, Patil D and Butrym E. 1994. Citrin; A revolutionary, herbal approach to weight management. New Editions Publishing. California.

9. Nayar TS, Binu S and Pushpangadan P. 1999. Uses of plants and plant products in traditional Indian mural paintings. Econ. Bot., 53(1), 41-50.

10. Nogueira PC, Bittrich V, Shepherd GJ, Lopes AV and Marsaioli AJ. 2001. The ecological and taxonomic importance of flower volatiles of Clusia species (Guttiferae). Phytochemistry, 56(5), 443-452.

11. Panda H. 2005. Herbs Cultivation and Medicinal Uses. National Institute of Industrial Research, New Delhi.

12. Parthasarathy U and Nandakishore OP. 2016. Garcinia bark exudates- an important phytochemical source. Curr. Sci., 110, 1617-1619.

13. Rao BS. 1937. Morellin, a constituent of the seeds of Garcinia morella. J. Chem. Soc., 853-855.

14. Rao RR and Natarajan S. 1950. On morellin, the antibacterial principle of the seeds of Garcinia morella Desrous. Curr. Sci.19 (02) 59-60.

15. Reutrakul V, Anantachoke N, Pohmakotr M, Jaipetch T, Sophasan S, Yoosook C, Kasisit J, Napaswat C, Santisuk T and Tuchinda P. 2007. Cytotoxic and anti-HIV-1 caged xanthones from the resin and fruits of Garcinia hanburyi. Planta Med., 73(01), 33-40.

16. Utpala $P$ and Nandakishore OP 2016. Garcinia bark exudates- an important phytochemical source. Cur. Sc., 110 (9), 1617-1619.

17. Venkataraman K. 1973. Pigments of Garcinia species. Indian National Science Academy, New Delhi. 39(A)6, 365-381.

18. Wang $X$ and Chen W. 2012. Gambogic acid is a novel anti-cancer agent that inhibits cell proliferation, angiogenesis and metastasis. Anti-Cancer Agents Med.Chem., 12(8), 9941000 .

19. Wang X, Lu N, Yang Q, Gong D, Lin C, Zhang S, Xi M, Gao Y, Wei L, Guo Q and You Q. 2011. Studies on chemical modification and biology of a natural product, gambogic 
acid (III): determination of the essential pharmacophore for biological activity. Eur. $J$. Med. Chem., 46(4), 1280-1290.

20. Watt G. 1890. Dictionary of the Economic Products of India, Vol. II, (Second reprint 1972) Periodical Experts, Delhi.

21. Winter J. 1997. Gamboge In. Fitzhugh EW (Ed.) Artists pigments a handbook of their history and charecteristics. Vol. 3. Oxford University Press, Washington.

22. Yang Y, Yang L, You QD, Nie FF, Gu HY, Zhao L, Wang XT and Guo QL. 2007. Differential apoptotic induction of gambogic acid, a novel anticancer natural product, on hepatoma cells and normal hepatocytes. Cancer Lett., 256(2), 259-266.

23. Yates P, Karmarkar SS, Rosenthal D, Stout GH and Stout VF. 1963. Acetyl- $\alpha$-gambogic acid. Tetrahedron Lett., 4(24), 1623-1629.

24. Yu J, Guo QL, You QD, Zhao L, Gu HY, Yang Y, Zhang HW, Tan Z and Wang X. 2006. Gambogic acid-induced G2/M phase cell-cycle arrest via disturbing CDK7-mediated phosphorylation of $\mathrm{CDC} 2 / \mathrm{p} 34$ in human gastric carcinoma BGC-823 cells. Carcinogenesis, 28(3), 632-638.

25. Zhao L, Guo QL, You QD, Wu ZQ and Gu HY. 2004. Gambogic acid induces apoptosis and regulates expressions of Bax and Bcl-2 protein in human gastric carcinoma MGC-803 cells. Biol. Pharm. Bull., 27(7), 998-1003. 


\title{
Chapter 12
}

\section{Nutrient properties of important Garcinia fruits of India}

\author{
Utpala Parthasarathy ${ }^{*}$ and O. P. Nandakishore \\ ICAR-Indian Institute of Spices Research \\ Kozhikode- 673012, Kerala, India \\ ${ }^{*}$ Corresponding author
}

\begin{abstract}
The importance of natural products is increasing day by day as the safety of synthetic alternatives has generated lots of controversial questions. Garcinia species are an important group of plants, being used for different purposes, especially as fruit crops, source of edible oils and fats, and nutraceuticals in different parts of the world. The nutraceutical property of a fruit is determined by the metabolites like carbohydrates, proteins, vitamins and minerals and also the secondary metabolites such as phenols and flavonoids. The food and nutritive values of Garcinia species have attracted significant scientific attention and the present chapter is an attempt to review the nutrient properties of important Garcinia fruits in India.
\end{abstract}

Keywords: Garcinia fruits, Nutrient properties, Minerals, Vitamins, Phenolics

\section{Introduction}

Plants and fruits are nature's wonderful gift to mankind; indeed, the edible fruits are life enhancing medicines packed with vitamins, minerals, antioxidants and many phyto-nutrients. They are an absolute feast to our sight, not just because of their color and flavor but for their unique nutrition profile that help to keep human body healthy. There are plenty of underutilized fruit crops which possess immense nutraceutical value. The underutilized species are restricted to the geographical place of their availability but not explored properly for their constitution or utility (Gruere et al., 2006). Majority of them produce fruits which are rich sources of carbohydrates, proteins, fats, vitamins and minerals than the conventional fruits (Krishnamurthy and Sarala, 2011). Garcinia is one such underutilized group of fruit bearing plants.

Many species of Garcinia have fruits with edible arils and are eaten locally. Fresh and dry Garcinia fruit rinds (exocarp) are used as spice, condiment and garnish in several cuisines to impart an acidic flavour to the food and to enhance shelf life (Utpala et al., 2010). Garcinia species such as G. cowa, G. kydia, G. cowa, G. lanceaefolia, G. mangostana, G. atroviridis and $G$. prainiana were cultivated for their fruits world over. The best known species is the mangosteen (G. mangostana), also known as the 'queen of tropical fruits', which is now cultivated throughout Southeast Asia and other tropical countries. In Travancore, Malabar and Konkan region of south India, the fruits of G. cambogia and G. indica are used in garnishing curries and also as a substitute for tamarind. Fruit and syrup of $G$. indica is very popular in 'Konkan' region as a refreshing and rejuvenating drink. Garcinia pedunculata, G. kydia, G. cowa and G. lanceaefolia are the most important species in North Eastern parts of India, where the sundried slices of the fruits were used for culinary purposes and as folk medicine. 
The seeds of Garcinia species yield oil that can be used as edible oil as well as illuminating fuels. Garcinia butter is obtained from the seeds and used mainly as an edible fat. The seed of $G$. indica fruits yield valuable edible fat known as 'kokum butter' and is popular in south India. Refined and deodorized fat from Garcinia seeds are generally white or creamy in colour and compares favorably with high class hydrogenated fat. Garcinia fats are rich in stearic acid and are considered nutritive, demulcent, astringent and emollient. The use and preparation of Garcinia butter is still under exploited. Garcinia species have been considered recently to have ample medicinal importance as well (Korikanthimath and Desai, 2005; Utpala and Nandakishore, 2014).

Garcinia species are abundant in the Western Ghats and in the North Eastern Himalayas. G. indica and G. gummi-gutta are the most common fruit species of the Western Ghats while G. pedunculata, G. lanceaefolia and G. kydia are the common fruit species of North Eastern foot hills of Himalayas. G. xanthochymus and G. mangostana are available in both the ecosystems. The nutraceutical property of a fruit is determined by the metabolites like carbohydrates, proteins, vitamins and minerals present in it and their relative amount. The secondary metabolites such as phenols and flavonoids also contribute significantly to the medicinal utility. The present chapter elaborates the nutritional constituents of important Garcinia species in India.

\section{Primary metabolites of Garcinia fruits}

Primary metabolites are directly involved in the growth and development of the plant and also serve as source of energy. The concentration of primary metabolites such as sugars, proteins and crude fats of the Garcinia fruits are given in Table 1. Carbohydrates were the major metabolites present in Garcinia fruits followed by proteins. Carbohydrates are the major nutrients in fruits. They are the primary energy source of the cell and the simplest biomolecules that are synthesized naturally. Reducing sugars are the simplest carbohydrate molecules having free aldehyde or ketone group and can reduce metal ions to lower oxidation state. Reducing sugars like glucose and fructose are the sweetness principles of a fruit. Carbohydrate content showed a great variation among various Garcinia species; from $3.75 \%$ to $15.12 \%$. Total proteins ranged from $1.82 \%$ to $4.93 \%$. The percentage of reducing sugars is less in comparison to the other organic acids present. This may be the reason of very sour taste of the fruits even when they are ripened. The palatability of $G$. mongostana was due to the high content of reducing sugars $(1.28 \%)$. G. indica showed a higher amount of total proteins $(4.78 \%)$, while total carbohydrates and crude fats were higher in G. mangostana. This indicates that G. mangostana provides more calories than other Garcinia species. Crude fats were very nominal in all the Garcinia fruits, showing only very small variation among them.

\section{Mineral composition of Garcinia fruits}

Minerals do not provide energy, but play a major role in metabolism and functioning of cells and are required in small amounts for human health. The mineral composition of the fruit rinds of Garcinia species is given in Table 2. 
Table 1. Primary metabolite composition of Garcinia fruits (Utpala and Nandakishore, 2014)

\begin{tabular}{lllll}
\hline Garcinia species & $\begin{array}{l}\text { Total } \\
\text { carbohydrates } \\
(\mathrm{g} / 100 \mathrm{~g})\end{array}$ & $\begin{array}{l}\text { Reducing } \\
\text { sugars } \\
(\mathrm{g} / 100 \mathrm{~g})\end{array}$ & $\begin{array}{l}\text { Total } \\
\text { proteins } \\
(\mathrm{g} / 100 \mathrm{~g})\end{array}$ & $\begin{array}{l}\text { Crude fats } \\
(\mathrm{g} / 100 \mathrm{~g})\end{array}$ \\
\hline G. gummi-gutta & 7.11 & 0.51 & 3.25 & 0.34 \\
G. indica & 6.24 & 0.63 & 4.78 & 0.12 \\
G. mangostana & 15.72 & 1.28 & 1.82 & 0.49 \\
G. xanthochymus & 4.12 & 0.98 & 4.01 & 0.41 \\
G. subelliptica & 4.82 & 0.71 & 3.76 & 0.15 \\
G. kydia & 9.07 & 0.6 & 4.33 & 0.42 \\
G. lanceaefolia & 5.85 & 0.65 & 3.45 & 0.13 \\
G. pedunculata & 7.93 & 0.95 & 4.93 & 0.20 \\
\hline
\end{tabular}

G. mangostana $(163.6 \mathrm{mg} / 100 \mathrm{~g})$ was richer in total minerals followed by G. indica $(109.3$ $\mathrm{mg} / 100 \mathrm{~g}$ ). Potassium, calcium and magnesium showed a great variation (CV\% being 27.5, 40.6 and 20.87 respectively) among the species while amount of sodium, iron and phosphorus were almost similar.

Table 2. Mineral compositions of Garcinia fruits (Utpala and Nandakishore, 2014)

\begin{tabular}{lllllll}
\hline Garcinia species & $\begin{array}{l}\text { Sodium } \\
(\mathrm{mg} / 100 \mathrm{~g})\end{array}$ & $\begin{array}{l}\text { Potassium } \\
(\mathrm{mg} / 100 \mathrm{~g})\end{array}$ & $\begin{array}{l}\text { Calcium } \\
(\mathrm{mg} / 100 \mathrm{~g})\end{array}$ & $\begin{array}{l}\text { Magnesium } \\
(\mathrm{mg} / 100 \mathrm{~g})\end{array}$ & $\begin{array}{l}\text { Iron } \\
(\mathrm{mg} / 100 \mathrm{~g})\end{array}$ & $\begin{array}{l}\text { Phosphorus } \\
(\mathrm{mg} / \mathrm{kg})\end{array}$ \\
\hline G. gummi-gutta & 2.88 & 26.6 & 12.67 & 14.35 & 9.00 & 5.34 \\
G. indica & 1.55 & 44.5 & 13.21 & 33.45 & 12.06 & 4.51 \\
G. mangostana & 2.58 & 78.3 & 5.82 & 60.43 & 9.02 & 7.45 \\
G. xanthochymus & 2.06 & 28.4 & 13.07 & 30.62 & 10.82 & 3.48 \\
G. subelliptica & 1.52 & 43.3 & 12.33 & 34.45 & 9.00 & 5.43 \\
G. kydia & 2.54 & 38.7 & 12.54 & 25.25 & 10.00 & 4.32 \\
G. lanceaefolia & 1.35 & 52.3 & 12.54 & 30.23 & 9.00 & 3.64 \\
G. pedunculata & 2.48 & 27.3 & 13.21 & 35.43 & 10.12 & 4.32 \\
\hline
\end{tabular}

Magnesium and potassium were found to be the predominant minerals in Garcinia fruits. $G$. mangostana is richer in potassium $(78.3 \mathrm{mg})$, magnesium $(60.43 \mathrm{mg})$ and phosphorus $(7.45$ $\mathrm{mg} / \mathrm{kg}$ ) (Utpala and Nandakishore, 2014). Potassium, calcium and magnesium are present in good percentage in fruit rind tissues, and make Garcinia an important medicinal fruit. Calcium is the major component of bones and teeth and is essential for muscular function and blood clotting (Decupyre, 2014). Other than potassium, Garcinia has a mineral content similar to major fruits like apple, grapes, peaches or banana (Decupyre, 2014). Magnesium, phosphorus and iron contents were also higher in Garcinia than the commonly consumed fruits.

\section{Vitamin composition of Garcinia fruits}

Vitamins are organic compounds that play a major role in regulation of enzymes, cell signals and metabolic pathways. The vitamins present in the detectable range were vitamins B1, B2, B3, B12 and C. Vitamin A, E and D could not be detected in Garcinia fruit extracts. The composition of vitamins in the fruits of Garcinia species are given in Table 3. Ascorbic acid was found to be the major vitamin in Garcinia fruits. The total vitamin content was highest in 
G. mangostana $(61 \mathrm{mg} / 100 \mathrm{~g})$, followed by $G$. pedunculata $(36 \mathrm{mg} / 100 \mathrm{~g})$. Except ascorbic acid, other vitamins showed only small variation $(<10 \%)$ among the species studied. Ascorbic acid was in a range of $14.0 \%$ to $60.0 \%$. Ascorbic acid, known as vitamin C, is a water soluble vitamin, not synthesized in the body, but must get through foods or supplements. It is an important antioxidant and its deficiency causes delayed healing and scurvy. Ascorbic acid works as a preservative to prevent rancidity, acts as a dough conditioner in baking and prevents enzymatic browning. Riboflavin (vitamin B2) is another water soluble vitamin. As it is also not synthesized in the body or being stored, it is essential to eat foods rich in riboflavin every day. Riboflavin helps body cells use fat, protein and carbohydrates from foods to produce energy.

Table 3. Vitamin composition of Garcinia fruits (Utpala and Nandakishore, 2014)

\begin{tabular}{lllllll}
\hline Garcinia species & $\begin{array}{l}\text { Thiamine } \\
(\mathrm{B} 1) \\
(\mu \mathrm{g} / 100 \mathrm{~g})\end{array}$ & $\begin{array}{l}\text { Riboflavin } \\
(\mathrm{B} 2) \\
(\mu \mathrm{g} / 100 \mathrm{~g})\end{array}$ & $\begin{array}{l}\text { Niacin }(\mathrm{B} 3) \\
(\mu \mathrm{g} / 100 \mathrm{~g})\end{array}$ & $\begin{array}{l}\text { Ascorbic } \\
\text { acid }(\mathrm{C}) \\
(\mathrm{mg} / 100 \mathrm{~g})\end{array}$ & $\begin{array}{l}\text { Vitamin } \\
\mathrm{B} 12 \\
(\mu \mathrm{g} / 100 \mathrm{~g})\end{array}$ & $\begin{array}{l}\text { Total vitamin } \\
(\mathrm{mg} / 100 \mathrm{~g})\end{array}$ \\
\hline G. gummi-gutta & 48 & 275 & 45 & 14.35 & 8.75 & 14.75 \\
G. indica & 52 & 320 & 63 & 33.45 & 12.06 & 34.00 \\
G. mangostana & 50 & 300 & 60 & 60.43 & 9.52 & 61.05 \\
G. xanthochymus & 37 & 250 & 50 & 30.62 & 10.76 & 30.97 \\
G. subelliptica & 50 & 281 & 45 & 34.45 & 9.03 & 34.94 \\
G. kydia & 47 & 267 & 50 & 25.25 & 10.15 & 25.82 \\
G. lanceaefolia & 52 & 283 & 45 & 30.23 & 8.02 & 30.62 \\
G. pedunculata & 49 & 276 & 47 & 35.43 & 8.12 & 35.81 \\
\hline
\end{tabular}

\section{Organic acids composition of Garcinia fruits}

Organic acids are of great significance in plants. As intermediates in the metabolic processes of the fruit, acids are directly involved in growth and maturation. Fruit juices have a low $\mathrm{pH}$, because they contain high levels of organic acids (James, 1985, Jena et al., 2002). The organic acids detected in the Garcinia fruits studied were (-) hydroxycitric acid (HCA), malic acid, citric acid, tartaric acid and acetic acid. The retention factor $\left(\mathrm{R}_{\mathrm{f}}\right)$ values of standard acids were found to be oxalic acid (0.14), tartaric acid (0.21), malic acid (0.45), citric acid (0.38), hydroxycitric acid (0.24) and acetic acid (0.60) (Utpala and Nandakishore, 2014). The total acid content of Garcinia fruits and the percentage compositions of various organic acids present in the Garcinia acid extracts are given in Table 4. The total acidity of the fruits varied significantly from $4.39 \%$ (G. mangostana) to $27.3 \%$ (G. kydia). A very high variability in concentration was observed for HCA and malic acid.

G. kydia was the most acidic $(27.3 \%)$ followed by G. gummi-gutta $(23.81 \%)$. The anti-obesity compound HCA was highest in G. gummi-gutta (15.48\%), followed by G. kydia $(8.97 \%)$. Garcinia species and Hibiscus sabdariffa are the only abundant natural sources of HCA (Yamada et al., 2007). HCA was found to be the major organic acid in the Western Ghats species namely G. gummi-gutta and G. indica whereas in other species, malic acid was the predominant organic acid. During extensive animal studies, HCA has been proven to effectively curb appetite, suppress food intake, increase the rates of hepatic glycogen synthesis, reduce fatty acid synthesis and lipogenesis and decrease body-weight gain. Other organic acids were detected as minor compounds. G. xanthochymus had a total acid content 
of $10.95 \%$ of which citric acid was the major acid component $(8.0 \%)$. HCA was absent in $G$. xanthochymus. In case of G. mangostana, the percentages of organic acids were very low and HCA could not be detected.

Table 4. Total acidity and major organic acids present in Garcinia fruits (Utpala and Nandakishore, 2014)

\begin{tabular}{llllllll}
\hline Garcinia species & $\begin{array}{l}\text { Total acidity } \\
(\%)\end{array}$ & $\begin{array}{l}\text { HCA } \\
(\%)\end{array}$ & $\begin{array}{l}\text { Malic } \\
\text { acid }(\%)\end{array}$ & $\begin{array}{l}\text { Oxalic } \\
\text { acid (\%) }\end{array}$ & $\begin{array}{l}\text { Citric } \\
\text { acid (\%) }\end{array}$ & $\begin{array}{l}\text { Tartaric } \\
\text { acid (\%) }\end{array}$ & $\begin{array}{l}\text { Acetic } \\
\text { acid (\%) }\end{array}$ \\
\hline G. gummi-gutta & 23.81 & 15.48 & 4.62 & 0.18 & 0.62 & 0.11 & 0.07 \\
G. indica & 14.11 & 7.43 & 2.67 & 0.63 & 0.79 & 0.51 & 0.31 \\
G. mangostana & 4.39 & 0.26 & 0.54 & 0.73 & 1.42 & 1.66 & 0.26 \\
G. xanthochymus & 10.95 & 0.10 & 0.73 & 0.37 & 8.00 & 0.20 & 0.04 \\
G. subelliptica & 9.76 & 1.16 & 4.87 & 0.92 & 0.81 & 1.18 & 1.32 \\
G. kydia & 27.30 & 8.97 & 13.42 & 0.60 & 1.35 & 1.80 & 0.23 \\
G. lanceaefolia & 15.17 & 1.93 & 10.02 & 1.70 & 1.45 & 0.23 & 0.14 \\
G. pedunculata & 12.92 & 1.33 & 8.95 & 0.51 & 1.30 & 0.12 & trace \\
\hline
\end{tabular}

The organic acids play a key role in food products because of their influence on organoleptic properties. Besides, they also provide the sour flavour to the product and also act as antimicrobial agent for enhancing shelf life (Lillian et al., 2013). The total content of organic acids in a food affects the product's acidity, whereas the levels of a specific organic acid can directly influence the flavor and taste of the drink. Malic acid and citric acids are $\alpha$ hydroxy acids reported to have functions like enhancing salivation, gastric secretion and exfoliation and are therefore important constituents of food and cosmetic formulations (Fiume, 2001). Citric acid also acts as food preservative and acidifying agent. The higher carbohydrate content and low acid content explains the sweeter taste of G. mangostana compared to other Garcinia fruits.

\section{Phenolic compounds and antioxidant activities of Garcinia fruits}

Phenolic compounds are a class of secondary metabolites attributed with several bioactivities, especially antioxidant properties. Antioxidant activity of a substance is the ability of a molecule to eliminate or to neutralize a free radical. Several phytochemicals such as curcumin, tocopherol, catechin, xanthones and anthocyanins were attributed with antioxidant properties (Harborne, 2005). Phenolic compounds also facilitate pollination through colour and fragrance, defense against pathogens and prevent fruits consumed by herbivores (Harborne, 2005). In Garcinia, xanthones, biflavonoids and benzophenones were reported to be the major phenolic compounds (Aisha et al., 2012).

The total phenolic contents (Table 5) were recorded to be highest in G. indica (5.01\%), followed by G. xanthochymus $(4.43 \%)$ and G. kydia $(4.32 \%)$. The xanthone content was highest in G. xanthochymus $(2.66 \%)$ and was least in G. indica (0.9\%). The relative percentage of xanthones to the total phenolics was highest in G. gummi-gutta, $G$. xanthochymus and G. subelliptica (60.0\%) and lowest in G. indica $(20.0 \%)$. 
Table 5. Total phenol, xanthone content and antioxidant activity of Garcinia fruits (Utpala and Nandakishore, 2014)

\begin{tabular}{llll}
\hline Garcinia species & $\begin{array}{l}\text { Total phenolics } \\
(\mathrm{g} / 100 \mathrm{~g})\end{array}$ & $\begin{array}{l}\text { Total xanthones } \\
(\mathrm{g} / 100 \mathrm{~g})\end{array}$ & $\begin{array}{l}\mathrm{DPPH} \text { activity } \mathrm{IC}_{50} \\
(\mu \mathrm{g} / \mathrm{ml})\end{array}$ \\
\hline G. gummi-gutta & 3.26 & 1.96 & 38.39 \\
G. indica & 5.01 & 0.91 & 42.66 \\
G. mangostana & 2.33 & 1.30 & 39.42 \\
G. xanthochymus & 4.43 & 2.66 & 35.75 \\
G. subelliptica & 3.14 & 1.88 & 48.12 \\
G. kydia & 4.32 & 2.19 & 40.50 \\
G. lanceaefolia & 3.03 & 1.22 & 43.16 \\
G. pedunculata & 2.43 & 1.36 & 47.84 \\
Ascorbic acid & - & - & 10.25 \\
\hline
\end{tabular}

As most of the Garcinia fruits are sour, they are consumed only as processed food or through formulations. The most commonly used forms are syrups, juices and dried rinds boiled along with other food ingredients. Hence the antioxidant activity of aqueous extract of fruits were also determined (Table 5). Piyawan et al. (2005) reported that antioxidant activity of $G$. mangostana is of moderate, close to that of orange, grapes, and papaya, while other tropical fruits such as mango, litchi and guava have higher antioxidant activities ( $\mathrm{IC}_{50}$ ranging from 1.10 to 9.60 ), compared to Garcinia fruits.

\section{Biochemistry of Garcinia seed butter}

Lipids or fats are hydrocarbon molecules, but are hydrophobic. In plants, fats are the storage form of energy and found much abundant in seeds. Fats are the second largest energy source for living cells (Jain et al., 2005). Garcinia seed kernel contains (30-40\%) fixed oil, in comparison to other vegetable seed fats like castor seed $(50 \%)$, ground nut kernel $(42 \%)$, mustard (35\%), palm kernel (36\%), sunflower (32\%), sesame $(50 \%)$ and coconut $(60 \%)$. High yield of fixed oil indicates that Garcinia seeds can be utilized as a rich source of fatty acids. The physical properties of the seed fats of four Garcinia species showed that the yield of fatty oil is high in G. gummi-gutta (47\%) while in G. indica and in G. xanthochymus it was around $30 \%$ and in case of G. mangostana it was less, around 24\% (Table 6).

Table 6. Physical properties of Garcinia seed butter (Utpala and Nandakishore, 2014)

\begin{tabular}{lllll}
\hline Parameters & G. gummi-gutta & G. indica & G.xanthochymus & G. mangostana \\
\hline Total fat content (\%) & 46.54 & 29.33 & 25.71 & 24.20 \\
Colour of fat & Light brown & Pale white & Creamy-yellow & Creamy-yellow \\
State at room temperature & Solid & Solid & Solid & Solid \\
Melting point $\left({ }^{\circ} \mathrm{C}\right)$ & 39.4 & 40.3 & 38.2 & 37.9 \\
\hline
\end{tabular}

Garcinia butter is solid at room temperature and is quite hard, almost as hard as cocoa butter, and is a good substitute in the recipes for cocoa butter. The melting point of Garcinia seed butter is high (about $40^{\circ} \mathrm{C}$ ), hence it can be used along with cocoa butter to increase the heat resistance property and hardness of the chocolate. It is helpful in preventing heat induced softening and loss of consistency of chocolates, mainly in hot climatic regions (Utpala et al., 
2012). Acid value and percentage free fatty acids represent the freshness and storage quality of an oil or fat. It is the measure of susceptibility and the extent of decomposition. The acid value of the four species of Garcinia varies from 3.7 to 4.5; which shows the butter is good for the consumption. Free fatty acid content is commonly called the free acidity percent and lesser the free fatty acid content, better is the fat. Other than G. indica oil, all are having very low acid value (Table 7). Saponification number gives the information concerning the character of the fatty acid present in the fat. Fats with the high saponification number yield quite soluble soaps. The saponification value of olive oil is $187-196$, for sunflower oil, it is $188-194$, for ground nut it is $188-195$, for mustard oil it is $169-176$ and for sesame oil it is 188-195, while it is very high in coconut oil and ghee (251-263 and 220 respectively). For Garcinia fats, the value ranged from 140 to 200 . Iodine value is a measure of the unsaturated nature of the fat. The iodine value preferably should be 25-50. In different Garcinia seed butters, iodine value varies from 37-51(Table 7). Iodine value allows predicting the tendency of fat to become rancid. In coconut oil, the iodine value is very low (7.5-10.5) and hence shows a high tendency to get rancid easily.

Table 7. Chemical properties of Garcinia seed butter (Utpala and Nandakishore, 2014)

\begin{tabular}{lllll}
\hline Chemical properties & G. gummi-gutta & G. indica & G. xanthochymus & G. mangostana \\
\hline $\begin{array}{l}\text { Acid value } \\
\text { (mg NaOH/g of oil) }\end{array}$ & 3.7 & 4.9 & 4.8 & 4.5 \\
$\begin{array}{l}\text { Saponification number } \\
\text { (mg KOH/g of oil) }\end{array}$ & 187.9 & 200.2 & 190.3 & 140.5 \\
$\begin{array}{l}\text { Iodine value } \\
\text { Free acids (\%) }\end{array}$ & 50.2 & 39.4 & 37.4 & 51.8 \\
\hline
\end{tabular}

The fatty acid profile presented in the Table 8 shows that Garcinia butter has 7 important fatty acids with various percentages in different species. The major fatty acids present were palmitic acid, stearic acid, elaidic acid, oleic acid, linoleic acid, arachidic acid and eicosenoic acid. Palmitic acid is present in very high yield (47\%) in G. mangostana, while it is moderate in other species. Palmitic acid is an ionic surfactant, which has a pleasing sensation to the body. It is thus mainly used to produce soaps, cosmetics and releasing agents. Palmitic acid is the commonest saturated fatty acid in the plants and animal lipids. Kokum butter from $G$. indica is popular in skin care products because of its ability to soften skin and heal ulcerations and fissures of the lips, hands and soles of feet. Palmitic acid helps to control obesity and also helps to recover some reproductive abnormalities (Scott et al., 1988). It is reported that the diet enriched with palmitic acid is good for diabetes (Utpala et al., 2012). Stearic acid is present in very high concentration (30-40\%) in G. gummi-gutta, G. indica and G. xanthochymus; while its percentage is less in G. mangostana (2.3\%) Stearic acid is commonly used in the manufacture of soaps, detergents, shampoo, shaving creams and other cosmetic products. It is one of the most common saturated fatty acids found in the nature following palmitic acid (Utpala and Nandakishore, 2014). Butter rich in stearic acid is solid at room temperature. It is also used in many food products because it remains stable at high temperatures. It is commonly used in margarine and other spreads. Garcinia fats could be taken as good source of stearic acid as well. A few plants which have stearic acid more than $30 \%$ in its seed oil are Butyrospermum paradoxum (shea), Shorea robusta (sal) and Vateria 
indica (dhupa). It is reported that the total plasma cholesterol is decreased by an average of $14 \%$ during the consumption of high stearic acid diet (Andrea and Scott, 1988). Oleic acid also present in a good percentage in all the four species of Garcinia (26-35\%). High oleic acid makes the butter less susceptible to spoilage, so could be useful in food preservation. Oleic acid may hinder the progression of adrenoleuko dystrophy, a fatal disease that affects the brain and adrenal glands and also may be responsible for the hypotensive effects of olive oil (Teres et al., 2008). Linoleic acid is another important acid which is present in a moderate percentage (5-11\%) in different Garcinia species. The use may include, helping to lose body fat and possibly preventing colon or breast cancer (Nirvair et al., 2007). It is a strong antioxidant with benefits such as lowering high cholesterol and controlling weight. Arachidic acid (1-8\%) is a saturated fatty acid and a minor constituent of peanut oil (1.1-1.7\%) and corn oil $(3 \%)$. Arachidic acid is used for the production of detergents, photographic materials and lubricants. The food rich with arachidonic acid is attributed with anti-inflammatory properties (Adama et al., 2003).

Table 8. Fatty acid profile of Garcinia species (Utpala and Nandakishore, 2014)

\begin{tabular}{llllll}
\hline Fatty acid & $\begin{array}{l}\text { Saturated/ } \\
\text { unsaturated }\end{array}$ & $\begin{array}{l}\text { G. gummi-gutta } \\
(\%)\end{array}$ & $\begin{array}{l}\text { G. indica } \\
(\%)\end{array}$ & $\begin{array}{l}\text { G. xanthochymus } \\
(\%)\end{array}$ & $\begin{array}{l}\text { G. mangostana } \\
(\%)\end{array}$ \\
\hline Palmitic acid & saturated & 6.31 & 3.25 & 3.05 & 47.20 \\
Stearic acid & saturated & 30.61 & 45.33 & 44.53 & 2.31 \\
Elaidic acid & unsaturated & 9.54 & 3.00 & 1.51 & - \\
Oleic acid & unsaturated & 26.23 & 34.42 & 35.33 & 34.02 \\
Linoleic acid & unsaturated & 11.38 & 5.25 & 4.82 & 1.32 \\
Arachidic acid & saturated & 5.41 & 1.20 & 1.00 & 8.04 \\
Eicosenoic acid & unsaturated & -- & 2.25 & 1.01 & 0.51 \\
Other fatty acids & & 10.52 & 5.30 & 8.75 & 6.61 \\
\hline
\end{tabular}

\section{Conclusions}

The awareness towards natural options in every walk of life created a new thrust for the plant based products that involve food additives, nutracueticals, cosmetic ingredients and herbal medicines. Herbal Technology (HT) is emerging as a promising field of modern science for India. The rich floristic wealth of our region offers several underutilized plants that can be used as source of gum, resins, fats, oils, condiments and nutraceutics. Garcinia is one among such underutilized tropical forest tree that accounts to the economy of the ethnic community associated. Pharmacological works are in progress in different parts of the world to use the products from Garcinia fruits as anti obesity, anti cancer and to solve other digestive problems The vitamins, minerals, micro-nutrients, pigments and phenolic compounds of major Garcinia fruits in India were reviewed in the chapter and the fruits are having very high nutraceutical values.

\section{References}

1. Adama O, Wolframb $G$ and Zöllnerb N. 2003. Influence of dietary linoleic acid intake with different fat intakes on arachidonic acid concentrations in plasma and platelet lipids and eicosanoid biosynthesis in female volunteers. Ann. Nutr. Metab. 47, 31-36.

2. Aisha AFA, Abu-Salah MK, Ismail $Z$ and Amin MSAM. 2012. Determination of total xanthones in Garcinia mangostana fruit rind extracts by ultraviolet (UV) spectrophotometry. J. Med. Plants Res., 7(1), 29-35. 
3. Andrea B and Scott M. 1988. Effect of dietary stearic acid on plasma cholesterol and lipoprotein levels. New England J. Med., 318(19), 1244-1248.

4. Decupyre JD. Nutrient Charts- Fruit Chart, http://www.healthalternatives.com/fruitnutrition-chart.html (accessed on 11-4-2014).

5. Fiume Z. 2001. Final report on the safety assessment of malic acid and sodium malate. Int. J. Toxicol., 20 (1), 47-55.

6. Gruere GP, Giuliani A and Smale M. 2006. In: Marketing Underutilized Plant Species for the Benefit of the Poor: A Conceptual Framework; EPT Discussion Paper 154. International Food Policy Research Institute, Washington DC, pp.2-6.

7. Harborne JB. 2005. Phenolic Compounds. In: Phytochemical Methods: A Guide to Modern Techniques of Plant Analysis, Springer, Edn.3, pp.40-43.

8. Jain JL, Sunjay J and Nitin J. 2005. In: Fundamentals of Biochemistry. S Chand and Co. Ltd, New Delhi, Edn.1, pp.11-13.

9. James G. 1985. The Science Workbook: Student Research Projects in Food-AgricultureNatural Resources. College of Agriculture, Ohio State University.

10. Jena BS, Jayaprakasha GK, Singh RP and Sakariah KK. 2002. Chemistry and Biochemistry of (-)-Hydroxycitric Acid from Garcinia. J. Agri.Food Chem. 50, 10-22.

11. Krishnamurthy SR and Sarala P. 2011. Determination of nutritive value of Ziziphus rugosa Lamk.: A famine edible fruit and medicinal plant of Western Ghats. Ind. J. Nat. Prod. Resour., 3(1), 20-27.

12. Korikanthimath VS and Desai AR. 2005. Status of Kokum (Garcinia indica Choisy) in Goa. In: Proc. $2^{\text {nd }}$ National Seminar on Kokum (Garcinia indica Choisy). University of Goa, India, pp.75-78.

13. Lillian C, Brian De B and Jeffrey R. 2013. Determination of Organic Acids in Fruit Juices and Wines by High-Pressure IC. Application Note 1068, Thermo Fisher Scientific Inc.

14. Nirvair SK, Neil EH and Kent LE. 2007. Conjugated linoleic acid isomers and cancer. $J$. Nutri., 137(12), 2599-2607.

15. Piyawan S, Supannee K and Ranee S. 2005. Radical scavenging activity in fruit extracts. Acta Hort., 679, 201-203.

16. Scott G, Florentin L, Nix D and Whelan MF. 1988. Comparison of monounsaturated fatty acids and carbohydrates for reducing the raised levels of plasma cholesterol in man. Am. J. Clin. Nutr., 47, 965-969.

17. Teres S, Barcelo-Coblijn G, Benet M, Alvarez R, Bressani R, Halver JE and Escriba PV. 2008. Oleic acid content is responsible for the reduction in blood pressure induced by olive oil. Proc. National Acad. Sci., 105(37), 13811-13816.

18. Utpala P, Asish GR, Jayarajan K, Aravind R, Krishnamoorthy B and Mathew PA. 2010. Isozyme diversity of Garcinia gummigutta (L.) N. Robson in Western Ghats region, South India. J. Spices and Aromatic Crops, 19(1), 29-33.

19. Utpala P, Nandakishore OP, Senthil KR, Nirmal BK, Zachariah TJ and Parthasarathy VA. 2012. Chromatographic fingerprinting and estimation of organic acids in selected Garcinia species. Int. J. Innovative Hort., 1(1), 68-73.

20. Utpala $P$ and Nandakishore OP. 2014. A study on nutrient and medicinal compositions of selected Indian Garcinia species. Curr. Bioact. Compd., 10(1), 55-61.

21. Yamada T, Hida H and Yamada Y. 2007. Chemistry, physiological properties and microbial production of hydroxycitric acid. Appl. Microbiol. Biotechnol., 75(5), 977-982. 


\title{
Chapter 13
}

\section{Antioxidant and antibacterial activities of Garcinia species in the Western Ghats}

\author{
A. P. Anu Aravind ${ }^{1}$, T. G. Nandu ${ }^{2}$, S. Shiburaj ${ }^{2}$ and K. B. Rameshkumar ${ }^{1, *}$ \\ ${ }^{1}$ Phytochemistry and Phytopharmacology Division \\ ${ }^{2}$ Microbiology Division \\ Jawaharlal Nehru Tropical Botanic Garden and Research Institute \\ Palode, Thiruvananthapuram-695562, Kerala, India \\ ${ }^{*}$ Corresponding author
}

\begin{abstract}
Garcinia species are reputed for the diversity of phenolic compounds such as biflavonoids, xanthones and benzophenones that can act as antioxidants. In the present study, various in vitro methods were used to investigate the antioxidant properties of nine Garcinia species in the Western Ghats. DPPH radical scavenging activity of $G$. talbotii was higher (IC $50: 2.8 \pm 0.6$ $\mu \mathrm{g} / \mathrm{mL}$ ) compared to standard compound ascorbic acid (IC50: $3.2 \pm 0.5 \mu \mathrm{g} / \mathrm{mL}$ ), while $G$. pushpangadaniana showed the highest superoxide radical scavenging activity (IC50:16.75 $\pm 0.99 \mu \mathrm{g} / \mathrm{mL}$ ) and reducing activity. The potential antioxidant activities of the Garcinia species were in corroboration with the high phenolic and flavonoid contents present in these species. The antibacterial activities of the leaf methanol extracts were however negligible or nil, except against the Gram positive strain, Bacillus subtilis.
\end{abstract}

Keywords: Antioxidant, Antibacterial, Garcinia species, DPPH, Superoxide radical, Reducing power, Bacillus subtilis

\section{Introduction}

Oxygen is an indispensable element for life and is necessary for aerobic respiration in animals. However, reactive oxygen species (ROS) such as superoxide anion radicals $\left(\mathrm{O}_{2}^{-}\right)$, hydroxyl radicals $(\mathrm{OH})$ and non-free radical species such as hydrogen peroxide $\left(\mathrm{H}_{2} \mathrm{O}_{2}\right)$ and singlet oxygen, that are continuously produced during the normal metabolism of oxygen, are harmful to biological systems. Healthy humans can detoxify or eliminate these free radicals by enzymes such as superoxide dismutase, catalase, and peroxidase (Gulcin, 2006; Terashima et al., 2010). If the oxidative damage is beyond the capacity of the natural repair mechanisms of the cells, it may trigger several chronic diseases (Franco, 2008).

The consumption of diets which are rich in antioxidants can protect the human body from oxidative stress and associated diseases induced by endogenous and exogenous factors (Morganti, 2009). These health effects have been partially attributed to the presence of phenolic compounds in plants (Guo et al., 2011). Garcinia species are known to be rich in phenolic compounds such as flavonoids, phenolic acids, xanthones, biflavonoids and benzophenones. There are many compounds reported from the genus Garcinia with higher free radical scavenging activities compared to known standards. Griffipavixanthone, a prenylated xanthone isolated from Garcinia virgata was reported to possess promising antioxidant activity with lower $\mathrm{EC}_{50}$ value compared to the references $\mathrm{BHA}$ and $\alpha$-tocopherol 
(Merza et al., 2004). The phloroglucinol parvifoliol E from Garcinia parvifolia showed remarkable antioxidant acivity compared to standard BHT (Rukachaisirikul et al., 2006). 1,3,5,7-Tetrahydroxyxanthone exhibited strong antioxidant activity comparable to the reference molecule probucol (Jantan et al., 2012). $\alpha$-Mangostin is a common xanthone reported from different Garcinia species, that exhibited stronger antioxidant activity than $\alpha-$ tocopherol in ferric thiocyanate (FTC) assay (Taher et al., 2012). Biflavonoids are dimers of two flavonoids, limited in distribution to some genus. This interesting group of compounds was reported from different Garcinia species and many of them exhibited remarkable antioxidant activities. The flavanone-(3-8")-flavone biflavonoid morelloflavone displayed considerable antioxidant activity and was more potent than quercetin (Osorio et al., 2013). 1,3,6-trihydroxy-7-methoxy-2,8-(3-methyl-2-butenyl) xanthone isolated from Garcinia hombroniana exhibited stronger antioxidant activity than the standard compounds trolox, gallic acid and ascorbic acid (Jamila et al, 2014). Garcina species were reported to possess remarkable level of activities against different diseases and the antioxidant activities of phenolic compounds from the genus have a major role in the mechanism of bioactivities.

Recently, a wide range of plants have been screened for antimicrobial property, because of the increased microbial resistance and harmful side effects of existing antimicrobial agents (Djeussi et al., 2013). Garcinia species have also been a subject of antimicrobial screening and potential activities have been reported for extracts and isolated compounds from several Garcinia species (Negi et al., 2008; Policegoudra, 2012; Fouotsa et al., 2013; Semwal et al., 2015).

Although the Garcinia species are gaining much attention worldwide due to their potential bioactivities, the Garcinia species in the Western Ghats are least investigated for their bioactivities. The present chapter elaborates the antioxidant and antibacterial activities of the leaf methanol extracts of nine Garcinia species (G. gummi-gutta, G. imberti, G. indica, G. Morella, G. pushpangadaniana, G. rubro-echinata, G. talbotii, G. travancorica and G. wightii) from the Western Ghats.

\section{In vitro antioxidant activity of Garcinia species in the Western Ghats}

Antioxidants act by several mechanisms and it is difficult to predict the full spectrum of activity in a single assay. In the present study, in vitro methods such as DPPH scavenging assay, superoxide radical scavenging assay and reducing power assay were used to evaluate the antioxidant property of Garcinia leaf methanol extracts.

DPPH scavenging activity: Among free radical scavenging methods, DPPH method is more rapid, simple and inexpensive in comparison to other test models. DPPH (2, 2-diphenyl-1picrylhydrazyl ( $\alpha, \alpha$-diphenyl- $\beta$-picrylhydrazyl) is a stable free radical that has an absorbance maximum in the visible region $(517 \mathrm{~nm})$. On accepting hydrogen from a donor, DPPH solutions lose the characteristic deep purple colour (Villano et al., 2007). The free radical scavenging activities of tested compounds are expressed as $\mathrm{IC}_{50}$ value, the concentration of the compound required to decrease the absorbance of DPPH solution by $50 \%$.

Reducing power assay: In this method, antioxidant compound forms a coloured complex withpotassium ferricyanide, trichloro acetic acid and ferric chloride, which is measured at $700 \mathrm{~nm}$. Increase in absorbance ofthe reaction mixture indicates the reducing power of the samples (Jayaprakash et al., 2008). 
Superoxide radical scavenging assay: Superoxide anion radical is a weak oxidant that generates powerful and dangerous hydroxyl radicals as well as singlet oxygen, both of which contribute significantly to oxidative stress. In the PMS/NADH-NBT system, the superoxide anion derived from dissolved oxygen and PMS/NADH coupling reaction reduces NBT. The decrease of absorbance at $560 \mathrm{~nm}$ thus indicates the consumption of superoxide anion in the reaction mixture. The superoxide anion scavenging activity was measured as described by Robak and Gryglewski (1988).

Total phenolic and flavonoid contents: Phenolic compounds consist of diverse group of secondary metabolites such as flavonoids, anthocyanins, coumarins, xanthones, benzophenones and phenolic acids, and possess ideal structural features for free radical scavenging activity. Antioxidative properties of phenolic compounds are due to different mechanisms such as scavenging of free radicals, chelation of metal ions like iron and copper, and inhibition of enzymes responsible for free radical generation (Benavente-Garcia, 1997; Rice-Evans et al., 1997). The phenol content was determined by Folin-Ciocateu reagent method (McDonald et al., 2001). The content of flavonoids was determined by aluminum chloride colourimetric method (Chang et al., 2002).

Leaf methanolic extrcacts of9 Garcinia species from the Western Ghats (G. gummigutta, G. imberti, G. indica, G. morella, G. pushpangadaniana, G. rubro-echinata, G. talbotii, G. travancorica and $G$. wightii) were subjected to antioxidant evaluation using different in vitro methods. Most of the species showed remarkable levels of antioxidant activities using in vitro models like DPPH radical scavenging assay, reducing power assay and super oxide radical scavenging assay (Table 1). Among the species studied G. talbotii (IC502.8 $\pm 0.6 \mu \mathrm{g} / \mathrm{mL}$ ), G. rubro-echinata (IC $506.5 \pm 0.8 \mu \mathrm{g} / \mathrm{mL}$ ), G. imberti (IC509.0 \pm 1.2 $\mu \mathrm{g} / \mathrm{mL}$ ), and $G$. wighti ( $\mathrm{IC}_{50} 16.0 \pm 2.0 \mu \mathrm{g} / \mathrm{mL}$ ) showed a promising level of DPPH radical scavenging activity compared to standard ascorbic acid with $\mathrm{IC}_{50}$ value of $3.2 \pm 0.5 \mu \mathrm{g} / \mathrm{mL}$. $\mathrm{IC}_{50}$ of $G$. talbotii leaf methanol extract against DPPH radical was higher than that of standard ascorbic acid.

Superoxide radical scavenging activity revealed a moderate level of activity compared to the standard ascorbic acid (IC50 value of $5.8 \pm 0.25 \mu \mathrm{g} / \mathrm{mL}$ ). Among the species studied, $G$. pushpangadaniana showed highest activity with $\mathrm{IC}_{50}$ value of $16.75 \pm 0.99 \mu \mathrm{g} / \mathrm{mL}$ and $G$. indica showed the minimal level of activity with $\mathrm{IC}_{50}$ value of $196.96 \pm 14.16 \mu \mathrm{g} / \mathrm{mL}$. Superoxide radical scavenging activity of the extracts were not correlated to the phenolic or flavonoid contents.

Table 1. Phenolic and flavonoid contents and antioxidant activities of Garcinia leaf extracts

\begin{tabular}{llllll}
\hline $\begin{array}{l}\text { S1. } \\
\text { No. }\end{array}$ & Garcinia species & $\begin{array}{l}\text { Total phenolics } \\
(\mathrm{mg} / \mathrm{g})\end{array}$ & $\begin{array}{l}\text { Total flavonoids } \\
(\mathrm{mg} / \mathrm{g})\end{array}$ & $\begin{array}{l}\text { DPPH } \mathrm{IC}_{50} \\
(\mu \mathrm{g} / \mathrm{mL})\end{array}$ & $\begin{array}{l}\text { Superoxide } \mathrm{IC}_{50} \\
(\mu \mathrm{g} / \mathrm{mL})\end{array}$ \\
\hline 1 & G. gummi-gutta & $97.45 \pm 7.28$ & $17.2 \pm 2.83$ & $128 \pm 2$ & $86.2 \pm 2.62$ \\
2 & G. imberti & $273.6 \pm 9.6$ & $108 \pm 7.82$ & $9 \pm 1.2$ & $40.3 \pm 1.12$ \\
3 & G. indica & $46.67 \pm 15.08$ & $11.1 \pm 1.84$ & $558.3 \pm 18.65$ & $196.96 \pm 14.16$ \\
4 & G. morella & $177.57 \pm 18.86$ & $53.8 \pm 5.37$ & $104 \pm 3.35$ & $86.5 \pm 7.92$ \\
5 & G. pushpangadaniana & $884.6 \pm 83.51$ & $197.3 \pm 9.47$ & $9.04 \pm 0.83$ & $16.75 \pm 0.99$ \\
6 & G. rubro-echinata & $392.85 \pm 7.28$ & $48.05 \pm 2.19$ & $6.5 \pm 0.8$ & $27.2 \pm 0.42$ \\
7 & G. talbotii & $342.9 \pm 5.80$ & $55.56 \pm 2.31$ & $2.8 \pm 0.6$ & $30.4 \pm 1.13$ \\
8 & G. travancorica & $435.53 \pm 23.85$ & $143.4 \pm 11.60$ & $18.9 \pm 1.8$ & $53.2 \pm 3.09$ \\
9 & G. wightii & $239.3 \pm 24.18$ & $239.0 \pm 26.87$ & $16 \pm 2$ & $27.6 \pm 0.7$ \\
10 & Ascorbic acid & - & - & $3.2 \pm 0.5$ & $5.8 \pm 0.25$ \\
\hline
\end{tabular}


Leaf methanolic extracts of the Garcinia species studied showed varying levels of activity in reducing power assays (Table 2, Figure 1). The Garcinia species that contain higher amount of phenolics, especially G. pushpangadaniana, G. rubro-echinata and G. talbotii showed remarkable activity in reducing power assay, whereas $G$. gummi-gutta, G. indica and $G$. wightii showed only moderate levels of activities.

Table 2. Reducing power assayof Garcinia species leaf extracts at different concentrationsAbsorbance at $700 \mathrm{~nm}$

\begin{tabular}{llllll}
\hline Garcinia species & $20(\mu \mathrm{g} / \mathrm{mL})$ & $\begin{array}{l}40 \\
(\mu \mathrm{g} / \mathrm{mL})\end{array}$ & $\begin{array}{l}60 \\
(\mu \mathrm{g} / \mathrm{mL})\end{array}$ & $\begin{array}{l}80 \\
(\mu \mathrm{g} / \mathrm{mL})\end{array}$ & $\begin{array}{l}100 \\
(\mu \mathrm{g} / \mathrm{mL})\end{array}$ \\
\hline G. gummi-gutta & 0.026 & 0.045 & 0.082 & 0.103 & 0.122 \\
G. rubro-echinata & 0.026 & 0.308 & 0.503 & 0.669 & 0.858 \\
G. imberti & 0.011 & 0.172 & 0.39 & 0.55 & 0.678 \\
G. indica & 0.034 & 0.054 & 0.068 & 0.08 & 0.09 \\
G. morella & 0.051 & 0.133 & 0.196 & 0.255 & 0.295 \\
G. pushpangadani & 0.231 & 0.45 & 0.623 & 0.833 & 1.083 \\
G. talbotii & 0.185 & 0.347 & 0.5 & 0.681 & 0.721 \\
G. travancorica & 0.094 & 0.209 & 0.301 & 0.408 & 0.526 \\
G. wightii & 0.018 & 0.034 & 0.117 & 0.239 & 0.303 \\
\hline
\end{tabular}

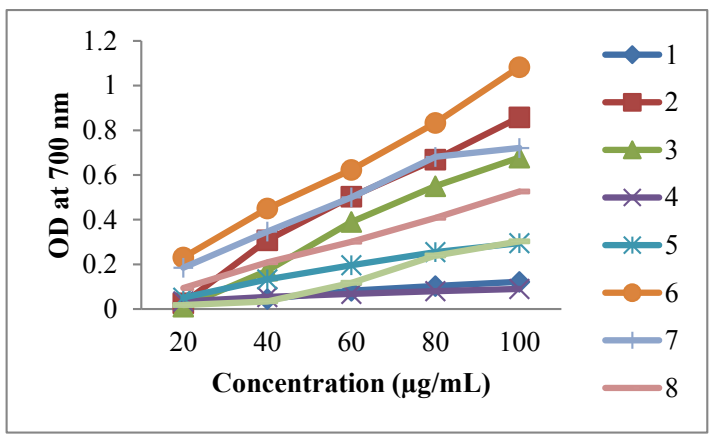

Figure 1. Reducing power assay of Garcinia leaf extracts (1- G. gummi-gutta, 2- G. rubro-echinata, 3- G. imberti, 4- G. indica, 5- G. morella, 6- G. pushpangadaniana, 7- G. talbotii, 8- G. travancorica, 9- G. wightii)

\section{Antibacterial activity of Garcinia leaf methanol extracts}

The plant extracts were dissolved in DMSO was used for the assay. The Kirby-Bauer method was used for antimicrobial susceptibility testing (Cappucino and Sherman1999). Briefly, the Mueller Hinton Broth (MHB) containing specific organisms were incubated at $37^{\circ} \mathrm{C}$ until it achieved the $0.5 \mathrm{McFarland}$ standards $\left(\sim 1.5 \times 10^{8} \mathrm{CFU} / \mathrm{ml}\right)$. The dried surface of the MuellerHinton agar plate is inoculated by streaking the swab over the entire sterile agar surface. The discs impregnated with the extracts were placed on Mueller Hinton agar and incubated at $37^{0}$ for 16-18 hours. After incubation, the diameters of the zones of complete inhibition were measured, including the diameter of the disc. 
Table 3. Antibacterial activity (zone of inhibition in $\mathrm{mm}$ ) of Garcinia leaf methanol extracts and standard kanamycin sulphate

\begin{tabular}{|c|c|c|c|c|c|c|c|c|}
\hline $\begin{array}{l}\text { Garcinia } \\
\text { species }\end{array}$ & $\begin{array}{l}\text { Conc. } \\
(\mu \mathrm{g} / \text { disc })\end{array}$ & $\begin{array}{l}P . \\
\text { vulgaris }\end{array}$ & $\begin{array}{l}\text { E. } \\
\text { faecalis }\end{array}$ & $\begin{array}{l}S . \\
\text { marscenes }\end{array}$ & $\begin{array}{l}P . \\
\text { aeruginosa }\end{array}$ & $\begin{array}{l}S . \\
\text { typhi }\end{array}$ & $\begin{array}{l}B . \\
\text { subtilis }\end{array}$ & $\begin{array}{l}S . \\
\text { mutants }\end{array}$ \\
\hline \multirow[t]{3}{*}{ G. cowa } & 100 & Nil & Nil & Nil & Nil & Nil & 9.0 & Nil \\
\hline & 500 & Nil & Nil & Nil & Nil & Nil & 9.5 & Nil \\
\hline & 1000 & Nil & Nil & Nil & Nil & Nil & 10 & Nil \\
\hline \multirow[t]{3}{*}{ G. rubro-echinata } & 100 & Nil & Nil & Nil & Nil & Nil & 6.5 & Nil \\
\hline & 500 & Nil & Nil & Nil & Nil & Nil & 7.5 & Nil \\
\hline & 1000 & Nil & Nil & 7.5 & Nil & Nil & 9.0 & 7.5 \\
\hline \multirow[t]{5}{*}{ G. gummi-gutta } & 100 & Nil & Nil & Nil & Nil & Nil & 7.5 & Nil \\
\hline & 500 & Nil & Nil & Nil & Nil & Nil & 8.0 & Nil \\
\hline & 1000 & Nil & Nil & Nil & Nil & Nil & 8.5 & Nil \\
\hline & 500 & Nil & Nil & Nil & Nil & Nil & 9.5 & 7.0 \\
\hline & 1000 & Nil & Nil & Nil & Nil & Nil & 10.5 & 8.0 \\
\hline \multirow[t]{3}{*}{ G. imberti } & 100 & Nil & Nil & Nil & Nil & Nil & 7.0 & Nil \\
\hline & 500 & Nil & Nil & Nil & Nil & Nil & 9.0 & Nil \\
\hline & 1000 & Nil & Nil & Nil & Nil & Nil & 10.5 & Nil \\
\hline \multirow[t]{5}{*}{ G. indica } & 100 & Nil & Nil & Nil & Nil & Nil & Nil & Nil \\
\hline & 500 & Nil & Nil & Nil & Nil & Nil & Nil & Nil \\
\hline & 1000 & Nil & Nil & Nil & Nil & Nil & Nil & Nil \\
\hline & 500 & Nil & Nil & Nil & Nil & Nil & Nil & Nil \\
\hline & 1000 & Nil & Nil & Nil & Nil & Nil & Nil & Nil \\
\hline \multirow[t]{3}{*}{ G. morella } & 100 & Nil & Nil & Nil & Nil & Nil & 6.5 & Nil \\
\hline & 500 & Nil & Nil & Nil & Nil & Nil & 8.0 & 7.0 \\
\hline & 1000 & Nil & Nil & Nil & Nil & Nil & 9.5 & 8.0 \\
\hline \multirow{3}{*}{$\begin{array}{l}\text { G. } \\
\text { pushpangadaniana }\end{array}$} & 100 & Nil & Nil & Nil & Nil & Nil & 7.0 & 6.5 \\
\hline & 500 & Nil & Nil & Nil & Nil & Nil & 9.5 & 7.5 \\
\hline & 1000 & Nil & Nil & Nil & Nil & Nil & 12.5 & 10.0 \\
\hline \multirow[t]{3}{*}{ G. talbotii } & 100 & Nil & Nil & Nil & Nil & Nil & 10 & 9.0 \\
\hline & 500 & Nil & Nil & Nil & Nil & Nil & 12 & 10.0 \\
\hline & 1000 & Nil & Nil & Nil & Nil & Nil & 13.5 & 13.0 \\
\hline \multirow[t]{3}{*}{ G. travancorica } & 100 & Nil & Nil & Nil & Nil & Nil & 8.0 & Nil \\
\hline & 500 & Nil & Nil & Nil & Nil & Nil & 10.0 & Nil \\
\hline & 1000 & Nil & Nil & Nil & Nil & Nil & 11.0 & Nil \\
\hline \multirow[t]{5}{*}{ G. wightii } & 100 & Nil & Nil & Nil & Nil & Nil & 9.0 & Nil \\
\hline & 500 & Nil & Nil & Nil & Nil & Nil & 11.0 & 6.5 \\
\hline & 1000 & Nil & Nil & Nil & Nil & Nil & 12.0 & 8.0 \\
\hline & 500 & Nil & Nil & Nil & Nil & Nil & 9.0 & Nil \\
\hline & 1000 & Nil & Nil & Nil & Nil & Nil & 10.0 & 9.0 \\
\hline $\begin{array}{l}\text { Kanamycin } \\
\text { sulphate }\end{array}$ & 30 & 20.0 & 22.0 & 25.0 & 20.0 & 27.0 & 28.0 & 25.0 \\
\hline
\end{tabular}


In most of the cases, the extracts were inactive against the tested strains of bacteria (Table 3). Remarkable observation was the moderate activity against the gram positive Bacillus subtilis for all the extracts except $G$. indica. It is interesting to note that previous reports also reveal the activity of Garcinia extracts and compounds against Gram positive strains, especially Bacillus subtilis (Rao and Natarajan, 1950, Negi et al., 2008; Semwal et al., 2015).

The antimicrobial activities of Garcinia leaf methanol extracts against food pathogens such as Escherichia coli, Bacillus cereus, Staphylococcus aureus, Salmonella enteric ser.typhi, and Vibrio cholera were also screened (Table 4). The MIC values were determined by modified broth microdilution method according to Clinical and Laboratory Standards Institute (CLSI) (2009). Briefly, 200 $\mu 1$ of Mueller Hinton Broth (MHB) was placed into each to wells of 96 well microplate. The plant extracts were dissolved in DMSO, and diluted to the required concentration. $1 \%$ of bacterial cell suspension was inoculated in MHB containing plant extracts and incubated at $37^{\circ} \mathrm{C}$ for 16 hours. Garcinia leaf methanol extracts were active against the Gram positive strains screened; Bacillus cereus and Staphylococcus aureus.

Table 4. Antibacterial activity (MIC in $\mu \mathrm{g} / \mathrm{ml}$ ) of Garcinia leaf methanol extracts against food pathogens

\begin{tabular}{llllll}
\hline Garcinia species & $\begin{array}{l}\text { Escherichia coli } \\
\text { MTCC 441 }\end{array}$ & $\begin{array}{l}\text { Bacillus } \\
\text { cereus } \\
\text { MTCC430 }\end{array}$ & $\begin{array}{l}\text { Staphylococcus } \\
\text { aureus } \\
\text { MTCC7443 }\end{array}$ & $\begin{array}{l}\text { Salmonella } \\
\text { enterica } \text { ser. } \\
\text { typhi } \\
\text { MTCC733 }\end{array}$ & $\begin{array}{l}\text { Vibrio cholera } \\
\text { MTCC 3906 }\end{array}$ \\
\hline G. pushpangadhania & Nil & $100 \mu \mathrm{g} / \mathrm{ml}$ & $\mathrm{Nil}$ & $\mathrm{Nil}$ & Nil \\
G. rubro-echinata & $\mathrm{Nil}$ & $100 \mu \mathrm{g} / \mathrm{ml}$ & $100 \mu \mathrm{g} / \mathrm{ml}$ & $\mathrm{Nil}$ & $\mathrm{Nil}$ \\
G. imberti & $\mathrm{Nil}$ & $\mathrm{Nil}$ & $\mathrm{Nil}$ & $\mathrm{Nil}$ & $\mathrm{Nil}$ \\
G. travancorica & $\mathrm{Nil}$ & $\mathrm{Nil}$ & $\mathrm{Nil}$ & $\mathrm{Nil}$ & $\mathrm{Nil}$ \\
G. talboti & $\mathrm{Nil}$ & $\mathrm{Nil}$ & $\mathrm{Nil}$ & $\mathrm{Nil}$ & $\mathrm{Nil}$ \\
G. morella & $\mathrm{Nil}$ & $200 \mu \mathrm{g} / \mathrm{ml}$ & $500 \mu \mathrm{g} / \mathrm{ml}$ & $\mathrm{Nil}$ & $\mathrm{Nil}$ \\
G. wightii & $\mathrm{Nil}$ & $100 \mu \mathrm{g} / \mathrm{ml}$ & $200 \mu \mathrm{g} / \mathrm{ml}$ & $\mathrm{Nil}$ & $\mathrm{Nil}$ \\
G. gummi-gutta & $\mathrm{Nil}$ & $\mathrm{Nil}$ & $\mathrm{Nil}$ & $\mathrm{Nil}$ & $\mathrm{Nil}$ \\
\hline
\end{tabular}

\section{Conclusions}

Leaf methanol extracts of nine Garcinia species from the Western Ghats exhibited remarkable in vitro antioxidant activity against various free radicals. The potential antioxidant activities were in corroboration with the high phenolic and flavonoid contents. Antioxidant activity is directly correlated to several curing mechanisms and the present study highlights the potential of Garcinia species as targets for future drug development. However, the antibacterial activities of the leaf methanol extracts were nil or negligible against the tested strains, except for Bacillus subtilis.

\section{References}

1. Benavente-Garcia O, Castillo J, Marin FR, Ortuño A and Del Río JA. 1997. Uses and properties of citrus flavonoids. J. Agric. Food Chem., 45(12), 4505-4515.

2. Cappucino JG and Sherman N. 1999. Microbiology: A Laboratory Manual, $5^{\text {th }}$ edition. p.254, Benjamin Cumming Science Publishing, California. 
3. Chang CC, Yang MH, Wen HM and Chern JC. 2002. Estimation of total flavonoid content in propolis by two complementary colorimetric methods. J. Food Drug Anal., 10(3). 178-182.

4. Clinical and Laboratory Standards Institute. Methods for Dilution Antimicrobial Susceptibility Tests for Bacteria That Grow Aerobically; Approved Standard-Ninth Edition. CLSI document M07-A9. 2009. Clinical and Laboratory Standards Institute, Pennsylvania USA.

5. Djeussi DE, Noumedem JAK, Seukep JA, Fankam AG, Voukeng IK, Tankeo SB, Nkuete AHL and Kuete V. 2013. Antibacterial activities of selected edible plants extracts against multidrugresistant gram-negative bacteria. BMC Compl. Alt. Med., 13, 164.

6. Fouotsa H, Mbaveng A T, Mbazoa C D , Nkengfack A E, Farzana S, Iqbal C M , Meyer JJM, Lall N and Kuete V. 2013. Antibacterial constituents of three Cameroonian medicinal plants: Garcinia nobilis, Oricia suaveolens and Balsamocitrus camerunensis. BMC Compl. Alt. Med., 13, 81.

7. Franco R, Schoneveld O, Georgakilas AG and Panayiotidis MI. 2008. Oxidative stress, DNA methylation and carcinogenesis. Cancer Lett., 266(1), 6-11.

8. Gulcin I. 2006. Antioxidant and antiradical activities of L-carnitine. Life Sci., 78(8), 803811.

9. Guo T, Wei L, Sun J, Hou CL and Fan L. 2011. Antioxidant activities of extract and fractions from Tuber indicum Cooke \& Massee. Food Chem., 127(4), 1634-1640.

10. Jamila N, Khairuddean M, Khan SN and Khan N. 2014. Complete NMR assignments of bioactive rotameric $(3 \rightarrow 8)$ biflavonoids from the bark of Garcinia hombroniana. Magnetic Res. Chem., 52(7), 345-352.

11. Jantan I and Saputri FC. 2012. Benzophenones and xanthones from Garcinia cantleyana var. cantleyana and their inhibitory activities on human low-density lipoprotein oxidation and platelet aggregation. Phytochemistry, 80, 58-63.

12. Jayaprakasha GK, Girennavar B and Patil BS. 2008. Radical scavenging activities of Rio Red grapefruits and Sour orange fruit extracts in different in vitro model systems. Bioresource Tech., 99(10), 4484-4494.

13. McDonald S, Prenzler PD, Antolovich M and Robards K. 2001. Phenolic content and antioxidant activity of olive extracts. Food Chem., 73(1), 73-84.

14. Merza J, Aumond MC, Rondeau D, Dumontet V, Le Ray AM, Séraphin D and Richomme P. 2004. Prenylated xanthones and tocotrienols from Garcinia virgata. Phytochemistry, 65(21), 2915-2920.

15. Morganti P. 2009. The photoprotective activity of nutraceuticals. Clin. Dermatol., 27(2), 166-174.

16. Negi PS, Jayaprakasha GK and Jena BS. 2008. Antibacterial activity of the extracts from the fruit rinds ofGarcinia cowa and Garcinia pedunculata against food borne pathogens and spoilage bacteria. Food Sc. Tech., 41, (10), 1857-1861.

17. Osorio E, Londono J and Bastida, J. 2013. Low-density lipoprotein (LDL)-antioxidant biflavonoids from Garcinia madruno. Molecules, 18(5), 6092-6100.

18. Policegoudra RS, Saikia S, Das J, Chattopadhyay P, Singh L and Veer V. 2012. Phenolic content, antioxidant activity, antibacterial activity and phytochemical composition of Garcinia lancifolia. Indian J. Pharm. Sci., 74(3), 268-271. 
19. Rao RR and Natarajan S. 1950. On morellin, the antibacterial principle of the seeds of Garcinia morella Desrous. Curr. Sci., 19 (02) 59-60.

20. Rice-Evans C, Miller N and Paganga G. 1997. Antioxidant properties of phenolic compounds. Trends Plant Sci., 2(4), 152-159.

21. Robak J and Gryglewski RJ. 1988. Flavonoids are scavengers of superoxide anions. Biochem. Pharmacol., 37, 837-841.

22. Rukachaisirikul V, Naklue W, Phongpaichit S, Towatana NH and Maneenoon K. 2006. Phloroglucinols, depsidones and xanthones from the twigs of Garcinia parvifolia. Tetrahedron, 62(36), 8578-8585.

23. Semwal RB, Semwal DK, Vermaak I and Viljoen A. 2015. A comprehensive scientific overview of Garcinia cambogia. Fitoterapia, 102, 134-148.

24. Taher M, Susanti D, Rezali MF, Zohri FSA, Ichwan SJA, Alkhamaiseh SI and Ahmad F. 2012. Apoptosis, antimicrobial and antioxidant activities of phytochemicals from Garcinia malaccensis Hk. f. Asian Pacific J. Trop. Med., 5(2), 136-141.

25. Terashima M, Watanabe R, Ueki M and Matsumura S. 2010. Comprehensive evaluation of antioxidant activity for various substances with 5-axe cobweb chart. Food Chem., 120(1), 150-155.

26. Villano D, Fernandez-Pachon MS, Moya ML, Troncoso AM and Garcia-Parrilla MC. 2007. Radical scavenging ability of polyphenolic compounds towards DPPH free radical. Talanta, 71(1), 230-235. 


\title{
Chapter 14
}

\section{Antioxidant and cytotoxic activities of Fukugiside- The major biflavonoid from Garcinia travancorica Bedd.}

\author{
A. P. Anu Aravind and K. B. Rameshkumar* \\ Phytochemistry and Phytopharmacology Division \\ Jawaharlal Nehru Tropical Botanic Garden and Research Institute \\ Palode, Thiruvananthapuram-695562, Kerala, India \\ * Corresponding author
}

\begin{abstract}
Garcinia species are well known as source of complex molecules with diverse biological activities, especially antioxidant and anticancer activities. The present chapter elaborates the in vitro antioxidant activity of Garcinia travancoria extract and isolated compounds. The biflavonoid fukugiside has been identified as the active compound with significant free radical scavenging activities in DPPH ( $\mathrm{IC}_{50}: 8.34 \mu \mathrm{g} / \mathrm{mL}$ ), superoxide( $\mathrm{IC}_{50}: 6.95 \mu \mathrm{g} / \mathrm{mL}$ ), and reducing power assays. Cytotoxicity studies of the biflavonoid fukugiside revealed a dose dependent cancer cell growth inhibition in A431 and HeLa cells. The antiproliferative effect appears to be due to the ability of fukugiside to induce S-phase arrest and apoptotic cell death. In HeLa cells, fukugiside reduced the expression of MAPKp38 by $26.1 \%$ compared to untreated control.
\end{abstract}

Keywords: Garcinia travancoria, Biflavonoid, Fukugiside, Antioxidant, Cytotoxicity

\section{Introduction}

Cancer, the uncontrolled division of abnormal cells in the body, still remains a threat to humankind. Surgery, chemotherapy, and radiation are the widely practised treatment methods to combat cancer (Tannock, 1998). Besides being expensive, most chemotherapeutic and radiation treatments suffer from adverse side effects. The situation warrants effective therapeutic approaches, and encourages researchers to depend more on medicinal plants that produce new and novel chemotherapeutics (Sheldon et al., 1997; Reed and Pellecchia, 2005). Over $60 \%$ of the clinically used anticancer drugs are of natural origin and most of them are derived from higher plants. Vinblastine, vincristine, etoposide, teniposide, taxol, taxotere, topotecan, and irinotecan are examples for plant derived chemotherapeutics approved for use in cancer therapy (Lee, 1999).

Oxidative stress is perhaps a major cause for several diseases including cancer, and the chemical components of medicinal plants possessing antioxidant properties can protect the human body from oxidative stress and associated diseases (Guo et al., 2011, Nema et al., 2013). Phenolic compounds belonging to xanthones, biflavonoids and phloroglucnols present in Garcinia species were reported as potential antioxidant compounds (Merza et al., 2004; Rukachaisirikul et al., 2006; Jantan et al., 2012; Taher et al., 2012; Osorio et al., 2013; Jamila et al, 2014).

A number of extracts and isolated compounds from Garcinia species were reported to exhibit remarkable cytotoxic activity against different cancer cell lines. Polyisoprenylated benzophenones are perhaps the most promising group of secondary 
metabolites in Garcinia species attributed with anticancer properties. The anticancer benzophenone garcinol induces apoptosis through the activation of caspases (Pan et al., 2001). Gambogic acid, the active component in gamboge, has potent cytotoxic activities against human hepatoma, gastric carcinoma, and lung cancer (Guo et al., 2004; Wang et al., 2008; Wu et al., 2004). Guttiferones, another group of polyisoprenylated benzophenones isolated from Garcinia species exhibited strong cytotoxic activity against different human cancer cell lines (Nguyen et al., 2011). Xanthones are another group of secondary metabolites from Garcinia species attributed with anticancer properties. Penangianaxanthone, cudratricusxanthone $\mathrm{H}$, macluraxanthone $\mathrm{C}$, and gerontoxanthone $\mathrm{C}$ from $G$. penangiana exhibited strong cytotoxic activity against three cell lines, MCF-7, NCI-H460) and DU-145 (Jabit et al., 2007). The xanthones bannaxanthone D, garcinone E and $\gamma$-mangostin inhibit cancer cell growth and promote cancer cell death in HeLa cells and the activity was more potent than clinically used anticancer drugs, camptothecin and etoposide (Han et al., 2008). Yahyaxanthone form G. rigida showed in vitro cytotoxic activity to L1210 murine leukemia cell lines (Elya et al., 2008). $\alpha$-Mangostin, $\gamma$ mangostin, and 8-deoxy gartanin exerted strong growth inhibition in human melanoma SK-MEL-28 cell line (Wang et al., 2011). Gaudichaudione $\mathrm{H}$, a xanthone from $G$. oligantha has potent apoptosis-inducing effect and cell growth inhibition effect on HeLaC3 cells (Gao et al., 2012). 1,4,5,6-Tetrahydroxy-7,8-di(3-methylbut-2-enyl)xanthone, globuxanthone and garciniaxanthone $\mathrm{E}$ exhibited moderate activities against human leukaemic HL-60 cell line in vitro (Niu et al., 2012). Cowanin and fuscaxanthone B from G. schomburgkiana exhibited remarkable cytotoxicity towards HeLa cells (Vo et al., 2012). Xanthones from G. cantleyana such as 7-hydroxyforbesione, cantleyanone B, cantleyanone $\mathrm{C}$, and deoxygaudichaudione A exhibited strong activity against the celllines, MDA-MB-231, MCF-7, CaOV-3, and HeLa cells (Shadid et al., 2007).

G. travancorica is a Western Ghats endemic tree species and the phytochemical studies of the plant showed the biflavonoid glycoside fukugiside as the major constituent (AnuAravind et al., 2016). The present chapter evaluates the antioxidant and cytotoxic activity of fukugiside isolated from $G$. travancorica.

\section{Antioxidant activities of $G$. travancorica leaf methanol extract and isolated compounds}

The isolated biflavonoids GB-1a, GB-1, GB-2 and morelloflavone-7'-O- $\beta$-D-glycoside (Figure 1), and leaf methanol extract (GTL) were studied for their antioxidant activities by various in vitro free radical scavenging assays. The activities were measured as percentage, calculated using the formula $\%$ scavenging $=\left[\left(\mathrm{A}_{\text {control}}-\mathrm{A}_{\text {sample }}\right) / \mathrm{A}_{\text {control }}\right] \times 100$ and reported as $\mathrm{IC}_{50}$ value; the concentration of sample required to scavenge $50 \%$ of radicals. Experiments were done in triplicate and the results were expressed as mean value with standard deviation.

The in vitro antioxidant activities of the extract and isolated biflavonoids against DPPH and superoxide radicals are shown in Table 1. High quantity of phenolics $(435.53 \pm 23.85 \mathrm{mg} / \mathrm{g}$ extract) and flavonoids $(143.4 \pm 11.60 \mathrm{mg} / \mathrm{g}$ of extract) present in the leaves showed a direct correlation with its antioxidant potential. The $\mathrm{IC}_{50}$ value of $\mathrm{DPPH}$ radical scavenging activity of morelloflavone-7' $-O-\beta$-D-glycoside was $8.34 \pm 2.12 \mu \mathrm{g} / \mathrm{ml}$, comparable to that of standard ascorbic acid $(3.2 \pm 0.50 \mu \mathrm{g} / \mathrm{ml})$. In superoxide radical scavenging assay also, the compound showed comparable activity (IC50 6.95 $\pm 1.33 \mu \mathrm{g} / \mathrm{ml}$ ), close to standard ascorbic acid ( $\mathrm{IC}_{50}$ value of $5.8 \pm 0.25 \mu \mathrm{g} / \mathrm{ml}$ ). In reducing power assay, the 
activity of the compound was very close to that of standard ascorbic acid (Figure 3). Though the antioxidant activity of glycosylated flavonoids is usually weaker than the corresponding aglycones, bioavailability is generally enhanced by the presence of glucose moiety (Ratty and Das 1988). The potential antioxidant activity of morelloflavone-7' -O- $\beta$-D-glycoside can be attributed to 3", 4"- dihydroxy unit present in the B ring. The B ring hydroxyl configuration is the most significant determinant of scavenging activity of flavonoids (Bors et al, 1990).
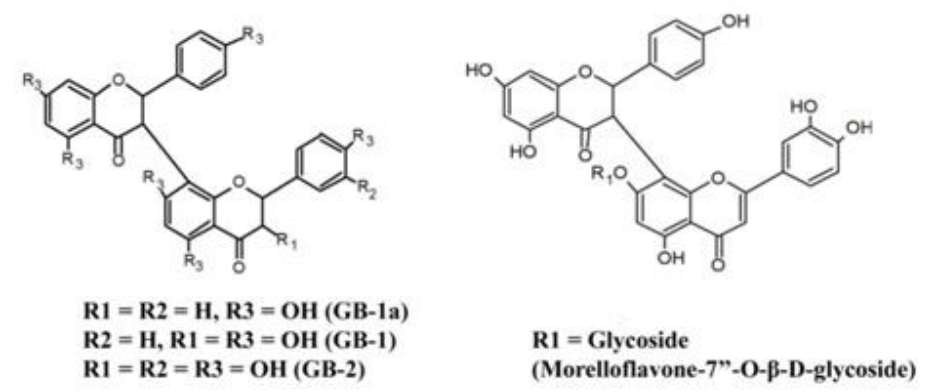

Figure 1. Structures of the biflavonoids GB-1a, GB-1, GB-2, and morelloflavone-7',-O- $\beta-\mathrm{D}-$ glycoside

Table 1. In vitro radical scavenging asays (DPPH and superoxide radical) of G. travancorica leaf methanol extract and isolated compounds

\begin{tabular}{lll}
\hline Extract/ compound & $\begin{array}{l}\text { DPPH IC } 50 \text { value } \\
(\mu \mathrm{g} / \mathrm{mL})\end{array}$ & $\begin{array}{l}\text { Superoxide } \mathrm{IC}_{50} \text { value } \\
(\mu \mathrm{g} / \mathrm{mL})\end{array}$ \\
\hline G. trav. Lf MeOH extract & $18.9 \pm 1.80$ & $53.2 \pm 3.09$ \\
GB-1a & $31.98 \pm 1.14$ & $42.13 \pm 0.51$ \\
GB-1 & $22.31 \pm 2.33$ & $37.52 \pm 2.10$ \\
GB-2 & $11.93 \pm 0.58$ & $23.31 \pm 1.60$ \\
Morelloflavone-7''-O- $\beta$-D-glycoside & $8.34 \pm 2.12$ & $6.95 \pm 1.33$ \\
Ascorbic acid & $3.2 \pm 0.50$ & $5.8 \pm 0.25$ \\
\hline
\end{tabular}

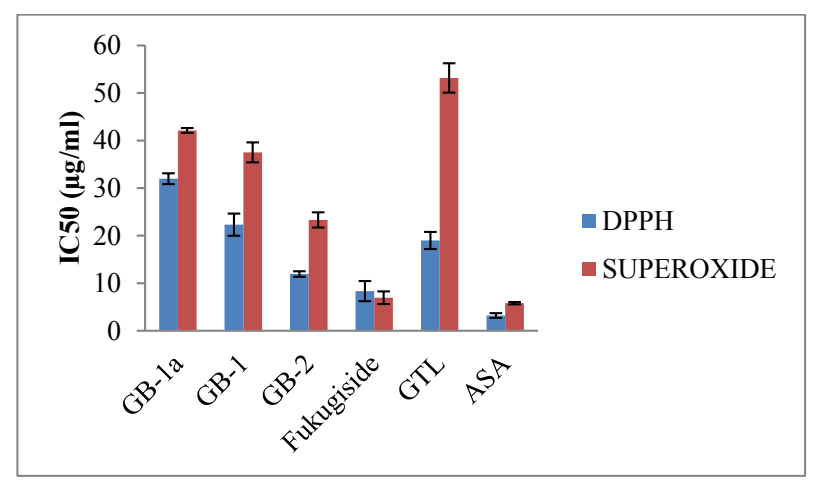

Figure 2. $\mathrm{IC}_{50}$ values of DPPH and superoxide radicals scavenging assay (GB-1a, GB-1, GB-2, Fukugiside, GTL- G. travancorica leaf methanol extract, ASA- standard ascorbic acid) 


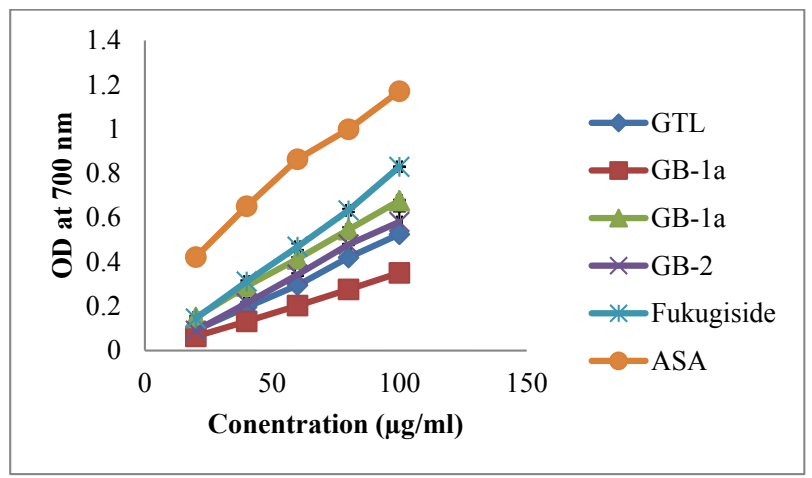

Figure 3. Reducing power assay (GB-1a, GB-1, GB-2, Fukugiside, GTL- G. travancorica leaf methanol extract, ASA- standard ascorbic acid)

\section{Growth inhibitory effect of Fukugiside on cancer cell lines A431, HeLa, HT29 and normal cell line WRL68 cells}

MTT assay was performed by seeding $\sim 5000$ cells per well in a 96 well plate and treating them under sub confluent conditions, with different concentrations of fukugiside such as 1 $\mu \mathrm{g} / \mathrm{mL}, 10 \mu \mathrm{g} / \mathrm{mL}, 25 \mu \mathrm{g} / \mathrm{mL}, 50 \mu \mathrm{g} / \mathrm{mL}, 100 \mu \mathrm{g} / \mathrm{mL}$ and $150 \mu \mathrm{g} / \mathrm{mL}$ respectively. The experiment was performed in batches with respect to the incubation time as $48 \mathrm{hrs}$. MTT assay is widely used in the in vitro evaluation of the biosafety of plant extracts and compounds. This colorimetric assay is based on the capacity of mitochondrial succinate dehydrogenase enzymes in living cells to reduce the yellow water soluble substrate 3-(4, 5dimethyl thiazol-2-yl)-2, 5-diphenyl tetrazolium bromide (MTT) into an insoluble, coloured formazan product which is measured spectrophotometrically at $570 \mathrm{~nm}$. Reduction of the dye MTT occurs only in metabolically active cells and the level of activity is a measure of the viability of the cells.

The study done on A431 and HeLa cells showed that fukugiside exhibited a concentration dependent cytotoxicity to both the cell lines. The cells were incubated with varying doses of fukugiside $(1 \mu \mathrm{g}, 10 \mu \mathrm{g}, 50 \mu \mathrm{g}$ and $100 \mu \mathrm{g}$ and $150 \mu \mathrm{g})$ and MTT assay was performed. Fukugiside inhibited the proliferation of human epidermal cancer cell line A431 and cervical cancer cell line HeLa in a dose dependent manner. Fukugiside exhibited significant cell death in A431 cell line with LD 50 value of $150 \mu \mathrm{g} / \mathrm{mL}$. Severe morphological changes were observed in HeLa cells treated with fukugiside under phase contrast microscope. Comparatively higher activity was exhibited by fukugiside against HeLa cells with $\mathrm{LD}_{50}$ value of $82.80 \mu \mathrm{g} / \mathrm{mL}$ compared with untreated control (Figure 4). The study done on normal liver cell line WRL68 and colorectal cancer cell line HT-29 cells treated with varying doses of fukugiside $(1 \mu \mathrm{g}, 10 \mu \mathrm{g}, 50 \mu \mathrm{g}$ and $100 \mu \mathrm{g}$ and $150 \mu \mathrm{g})$ did not exhibit any toxicity to the cells. From the results indicate that the compound exhibited toxicity to cancer cell lines A431 and HeLa in a dose dependent manner and no toxicity was observed against normal cell line WRL68.

Acridine orange/ethidium bromide (AO/EB) staining is used to visualize nuclear morphology and apoptotic body formation that are characteristic of apoptosis. Acridine orange is an important dye that will stain both live and dead cells, whereas ethidium bromide stain only those cells that have lost their membrane integrity (Jayadev et al., 2004). 
Table 2. Cell viability in Fukugiside treated A431 and HeLa cells by MTT assay

\begin{tabular}{lccc}
\hline Test material & \multicolumn{2}{c}{ \% Cell viability } \\
\cline { 2 - 4 } & & $\mathrm{A} 431$ & $\mathrm{HeLa}$ \\
\hline Control & 100 & 100 \\
$(0.01 \% \mathrm{DMSO})$ & & \\
Fukugiside & 1 & $110 \pm 3.6$ & $85.85 \pm 0.19$ \\
$(\mu \mathrm{g} / \mathrm{mL})$ & 10 & $125 \pm 4.3$ & $64.86 \pm 3.79$ \\
& 50 & $86 \pm 3.4$ & $56.50 \pm 2.46$ \\
& 100 & $64 \pm 3.6$ & $43.55 \pm 0.52$ \\
& 150 & $49 \pm 3.4$ & $39.88 \pm .67$
\end{tabular}

Values are mean $\pm \mathrm{SD}$ of three separate determinations. Cells were incubated at $37^{\circ} \mathrm{C}$ for $48 \mathrm{hrs}$ in DMEM media in $\mathrm{CO}_{2}$ incubator
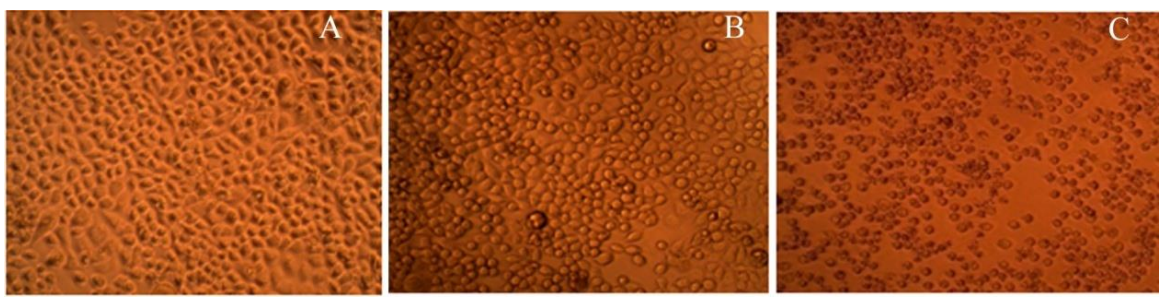

Figure 4. HeLa cells treated with fukugiside under phase contrast microscope: (A) HeLa cells treated with DMSO (0.01\%); (B) DLA cells treated with fukugiside $(50 \mu \mathrm{g} / \mathrm{mL})$; (C) HeLa cells treated with fukugiside $(150 \mu \mathrm{g} / \mathrm{mL})$

To corroborate that apoptosis has been induced by fukugiside, HeLa cells were analysed in the presence of acridine orange and ethidium bromide staining (AO/EB staining). Five concentrations of fukugiside used in MTT assay $(1 \mu \mathrm{g}, 10 \mu \mathrm{g}, 50 \mu \mathrm{g}$ and $100 \mu \mathrm{g}$ and 150 $\mu \mathrm{g})$ were chosen for this experiment. HeLa cells cultured in complete media and stained with $\mathrm{AO} / \mathrm{EB}$ (Figure 5) were used as control.
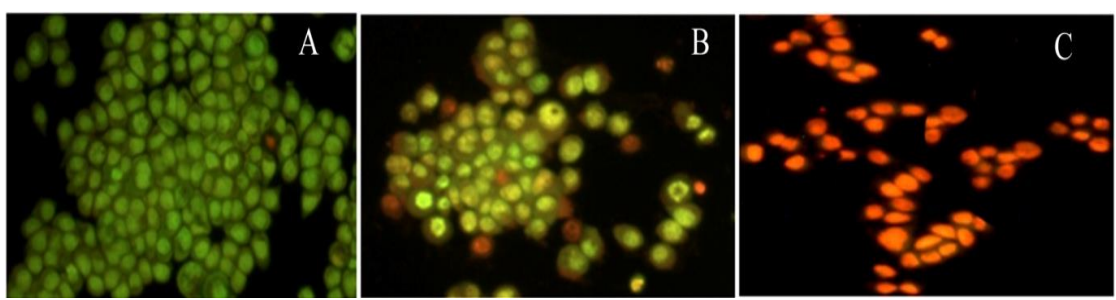

Figure 5. HeLa cells stained with acridine orange-ethidium bromide under fluorescent microscope: (A) HeLa cells treated with DMSO (0.01\%) appeared in green color (live), (B) DLA cells treated with fukugiside $(50 \mu \mathrm{g} / \mathrm{mL})$ appeared in slight yellowish (early apoptotic cells), (C) HeLa cells treated with fukugiside $(150 \mu \mathrm{g} / \mathrm{mL})$ appeared in yellowish red (dead cells)

Figure 5 shows that the fukugiside at tested doses induced apoptosis after 48 hours incubation. Cells stained green represent viable cells (Figure 5A), whereas yellow staining represented early apoptotic cells (Figure 5B) and yellow to reddish orange staining represents late apoptotic cells (Figure 5C). As shown in Figure 5, HeLa cells treated with $150 \mu \mathrm{g} / \mathrm{mL}$ of fukugiside showed changes in cellular morphology, including chromatin 
condensation and membrane blebbing. Stronger apoptosis signal was induced in HeLa cells with higher concentrations of fukugiside.

\section{Effect of fukugiside on cell cycle distribution by flow cytometry}

Considering that fukugiside decreased cell proliferation and induced cell death as evident from MTT assay and apoptotic induction by staining experiments, the effect of this molecule on cell cycle distribution was analysed by flow cytometry. Flow cytometric analysis was carried out on HeLa cells treated with $100 \mu \mathrm{g} / \mathrm{mL}$ of fukugiside for $48 \mathrm{hrs}$. In HeLa cells, 100 $\mu \mathrm{g} / \mathrm{mL}$ of fukugiside induced accumulation of cells in $\mathrm{S}$ phase concurrently to a significant decrease in G0/G1 cells (Figure 6).
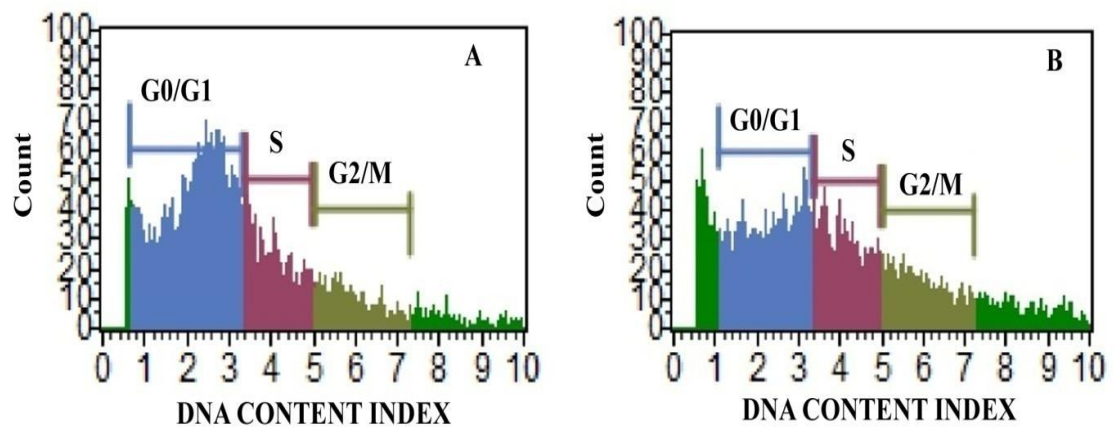

Figure 6. Comparison of DNA content in control $(0.01 \%$ DMSO) and fukugiside $(100 \mu \mathrm{g} / \mathrm{mL})$ treated HeLa cells by flow cytometry

Deregulation of cell cycle is one of the critical events that drive cancer cells into uncontrolled proliferation (Evan and Vousden, 2001). Molecular changes, including the over expression of cyclins and CDKs and the loss of CDK inhibitors and tumor suppressor proteins resulting from gene mutations or epigenetic inactivation, are frequently detected in tumor cells (Sherr, 1996; Malumbres and Barbacid, 2001). Because of the important roles of cell cycle deregulation in tumorigenesis and tumor progression, molecules involved in cell cycle regulation also serve as potential targets for therapeutic intervention in cancers. Modulation of $\mathrm{p} 21$, and MAPK/ERK pathway can have a potent role in inhibiting cells at $\mathrm{S}$ phase. In the present study, addition of the compound fukugiside induced significant change in cell proliferation and the cells were found to be arrested in S phase compared to untreated control. The results were comparable with previous reports regarding inhibtion of MCF 7 cells by resveratrol and other flavonoid compounds in S phase (Joe et al., 2002).

\section{Effect of fukugiside on the expression of MAPK p38 in HeLa cells}

In continuation with the studies on cell cycle deregulation seen in S phase by fukugiside, the effects of fukugiside on the level of MAPK p38 in HeLa cells were examined. A series of time course experiments were conducted to analyse the expression of Erk in HeLa cells treated with fukugiside, where DMSO served as control. Reverse transcription polymerase chain reaction (RT-PCR) followed by agarose gel electrophoresis demonstrated that the expression levels of MAPK was decreased after $48 \mathrm{hrs}$ of treatment with fukugiside. The intensity of the bands were analysed by Image J analyser and the results revealed that, 
treatment with fukugiside lead to inhibition of MAPK expression by $26.15 \%$ compared to untreated control (Figure 6).

(i)

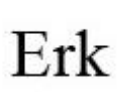

(ii)

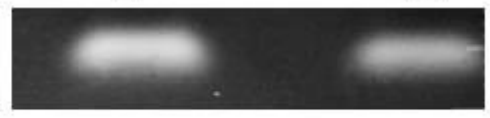

Figure 6. Intensity of MAPK p38 expression in agarose gel electrophoresis; (i) control, (ii) fukugiside

\section{Conclusions}

Garcinia species are well known for the diversity of secondary metabolites and potential bioactivities. The biflavonoid fukugiside has been identified as the major antioxidant component in G. travancorica through in vitro free radical scavenging assays and reducing power assay. Further, the antitumor properties of the molecule in different human cancer cell lines were also checked. Fukugiside caused a dose dependent cancer cell growth inhibition in A431 and HeLa cells, and the antiproliferative effect appears to be due to its ability to induce S-phase arrest and apoptotic cell death. In HeLa cells, fukugiside down regulated the MAPK p38 expression compared with untreated control. The study highlights fukugiside as a potential candidate for drug development.

\section{References}

1. Anu Aravind AP, Asha KRT and Rameshkumar KB. 2016. Phytochemical analysis and antioxidant potential of the leaves of Garcinia travancorica Bedd. Nat. Prod. Res. 30 (2), 232-236.

2. Bors W, Heller W, Michel C and Saran M. 1990. Flavonoids as antioxidants: determination of radical-scavenging efficiencies. Methods Enzymol. 186, 343-355.

3. Elya B, He HP, Kosela S, Hanafi M, Hao XJ. 2008. A new cytotoxic xanthone from Garcinia rigida. Fitoterapia. 79, 182-184.

4. Evan GI, Vousden KH. 2001. Proliferation, cell cycle and apoptosis in cancer. Nature. 17, 342-348.

5. Gao XM, Yu T, Cui M, Pu JX, Du X, Han Q, Hu Q, Liu TC, Luo KQ, Xu HX. 2012. Identification and evaluation of apoptotic compounds from Garcinia oligantha. Bioorg. Med. Chem. Lett. 22, 2350-2353.

6. Guo Q, You Q, Wu Z, Yuan S, Zhao L. 2004. General gambogic acids inhibited growth of human hepatoma SMMC-7721 cells in vitro and in nude mice. Acta Pharmacol. Sin. 25, 769-774.

7. Guo T, Wei L, Sun J, Hou C, Fan L. 2011. Antioxidant activities of extract and fractions from Tuber indicum Cooke \& Masse. Food Chem. 127, 1634-1640.

8. Han QB, Yang NY, Tian HL, Qiao CF, Song JZ, Chang DC, Chen SL, Luo KQ, Xu HX. 2008. Xanthones with growth inhibition against HeLa cells from Garcinia xipshuanbannaensis. Phytochemistry. 69, 2187-2192.

9. Jabit ML, Khalid R, Abas F, Shaari K, Hui LS, Stanslas J, Lajis NH. 2007. Cytotoxic Xanthones from Garcinia penangiana Pierre. Z Naturforsch C. 62, 786-792.

10. Jamila N, Khairuddean M, Khan SN, Khan N. 2014. Complete NMR assignments of bioactive rotameric $(3 \rightarrow 8)$ biflavonoids from the bark of Garcinia hombroniana. Mag. Reson. Chem. 52, 345-352. 
11. Jantan I, Saputri FC. 2012. Benzophenones and xanthones from Garcinia cantleyana var. cantleyana and their inhibitory activities on human low-density lipoprotein oxidation and platelet aggregation. Phytochemistry. 80, 58-63.

12. Jayadev R, Jagan MRP, Malisetty VS, Chinthapally VR. 2004. Diosgenin, a steroid saponin of Trigonella foenum graecum (Fenugreek), inhibits Azoxymethane-induced aberrant crypt foci formation in F344 rats and induces apoptosis in HT-29 human colon cancer cells. Cancer Epidemiol. Biomarkers Prev. 13, 1392-1398.

13. Joe AK, Liu H, Suzui M, Vural ME, Xiao D, Weinstein IB. 2002. Resveratrol induces growth inhibition, S-phase arrest, apoptosis, and changes in biomarker expression in several human cancer cell lines. Clin, Cancer Res. 8, 893-903.

14. Jones S. 1980. Morphology and major taxonomy of Garcinia (Guttiferae). Ph.D. dissertation. London, University of Leicester and British Museum, 474.

15. Lee K. 1999. Anticancer drug design based on plant-derived natural products. J. Biomed. Sci. 6, 236-350.

16. Malumbres M, Barbacid M. 2001. To cycle or not to cycle: a critical decision in cancer. Nat. Rev. Cancer. 1, 222-231.

17. Merza J, Aumond MC, Rondeau D, Dumontet V, Ray AML, Se'raphin D. 2004. Pascal Richomme Prenylated xanthones and tocotrienols from Garcinia virgata. Phytochemistry. 65, 2915-2920.

18. Nema R, Khare S, Jain P, Pradhan A, Gupta A, Singh D. 2013. Natural products potential and scope for modern cancer research. Am. J. Plant Sci. 4, 1270-1277.

19. Nguyen HD, Trinh BTD, Nguyen LHD. 2011. Guttiferones Q-S, cytotoxic polyisoprenylated benzophenones from the pericarp of Garcinia cochinchinensis. Phytochem. Lett. 4, 129-133.

20. Niu SL, Li ZL, Ji F, Liu GY, Zhao N, Liu XQ, Jing YK, Hua HM. 2012. Xanthones from the stem bark of Garcinia bracteata with growth inhibitory effects against HL-60 cells. Phytochemistry. 77, 280-286.

21. Osorio E, Londono J, Bastida J. 2013. Low-Density Lipoprotein (LDL)-Antioxidant Biflavonoids from Garcinia madruno. Molecules. 18, 6092-6100.

22. Pan MH, Chang WL, Lin-Shiau SY, Ho CT and Lin JK. 2001. Induction of apoptosis by garcinol and curcumin through cytochrome c release and activation of caspases in human leukemia HL- 60 cells. J. Agric. Food Chem. 49, 1464-1474.

23. Ratty AK and Das NP. 1988. Effects of flavonoids on non-enzymic lipid peroxidation: structure activity relationship. Biochem. Med. Metabol. Biol. 39, 69-79.

24. Reed J and Pellecchia M. 2005. Apoptosis-based therapies for hematologic malignancies. Blood. 106, 408-418.

25. Rukachaisirikul V, Naklue W, Phongpaichit S, Towatana NH, Maneenoon K. 2006. Phloroglucinols, depsidones and xanthones from the twigs of Garcinia parvifolia. Tetrahedron. 62, 8578-8585.

26. Shadid KA, Shaari K, Abas F, Israf DA, Hamzah AS, Syakroni N, Saha K, Lajis NH. 2007. Cytotoxic caged-polyprenylated xanthonoids and a xanthone from Garcinia cantleyana. Phytochemistry. 68, 2537-2544.

27. Sheldon JW, Balick M, Laird S. 1997. Medicinal Plants: Can Utilization and Conservation Coexist?. The New York Botanical Garden XII, USA.

28. Sherr CJ. 1996. Cancer Cell Cycles. Science. 274, 1672-1677. 
29. Taher M, Susanti D, Rezali MF, Zohri FSA, Ichwan SJA, Alkhamaiseh SI, Ahmad F. 2012. Apoptosis, antimicrobial and antioxidant activities of phytochemicals from Garcinia malaccensis Hk.f. Asian Pacific J. Tropical Med. 5, 136-141.

30. Tannock F. 1998. Conventional cancer therapy: promise broken or promise delayed? Lancet. 352, 9-16.

31. Vo HT, Nguyen NTT, Nguyen HT, Do KQ, Connolly JD, Maas G, Heilmann J, Werz UR, Pham HD, Nguyen LHD. 2012. Cytotoxic tetraoxygenated xanthones from the bark of Garcinia schomburgkiana. Phytochem. Lett. 5, 553-557.

32. Wang JJ, Sanderson BJS, Zhang W. 2011. Cytotoxic effect of xanthones from pericarp of the tropical fruit mangosteen (Garcinia mangostana Linn.) on human melanoma cells. Food Chem. Toxicol. 49, 2385-2391.

33. Wang T, Wei J, Qian X, Ding Y, Yu L, Liu B. 2008. Gambogic acid, a potent inhibitor of survivin, reverses docetaxel resistance in gastric cancer cells. Cancer Lett. 262, 214-222.

34. Wu ZQ, Guo QL, You QD, Zhao L, Gu HY. 2004. Gambogic acid inhibits proliferation of human lung carcinoma SPC-A1 cells in vivo and in vitro and represses telomerase activity and telomerase reverse transcriptase mRNA expression in the cells. Biol. Pharm. Bull. 27, 1769-1774. 


\title{
Chapter 15
}

\section{Molecular Characterization of Garcinia species in the Western Ghats}

\author{
A. R. Sivu ${ }^{1}$, N. S. Pradeep ${ }^{2, *}$ and K. B. Rameshkumar ${ }^{3}$ \\ ${ }^{1}$ Department of Botany, NSS College Nilamel, Kollam- 691535, Kerala, India \\ ${ }^{2}$ Microbiology Division \\ ${ }^{3}$ Phytochemistry and Phytopharmacology Division \\ Jawaharlal Nehru Tropical Botanic Garden and Research Institute \\ Thiruvananthapuram- 695 562, Kerala, India \\ * Corresponding author
}

\begin{abstract}
The genus Garcinia L. (Family: Clusiaceae) is an important component of the forest flora of the Western Ghats with 9 species, of which 7 are endemic to the region. Systematics of the genus Garcinia is primarily based on morphological data, especially reproductive morphology and the genus is considered as a taxonomically difficult one due to the complexity and diversity in floral characteristics. Molecular tools are getting more acceptances as a convenient tool in the phylogenic studies of such taxonomically difficult groups. Molecular markers are potential in portraying the genetic relationship between plant groups and DNA based molecular taxonomic approaches give an exact and rapid method of distinguishing specimens based on their interspecies variation. In the present study, the genetic profile of 9 Garcinia species, G. gummi-gutta, G. rubro-echinata, G. imberti, G. indica, G. morella, G. talbotii, G. pushpangadaniana, G. travancorica and G. wightii distributed naturally in the Western Ghats of south India, were analyzed for better understanding of interspecific genetic diversity. Molecular profiling using the chloroplast coding region matK could successfully demark different species of the genus Garcinia.
\end{abstract}

Keywords: Garcinia species, Western Ghats, Molecular taxonomy, matK

\section{Introduction}

Systematics of the genus Garcinia is primarily based on reproductive morphology. However, the field identification of Garcinias is challenging due to the presence of unisexual flowers and strict seasonality in flowering and fruiting. The morphological assessment and variability studies of Garcinia species demonstrated that the morphological variants are enormous within the species with characters always overlapped within and between populations and the genus is often treated as a taxonomically difficult group (Nimanthika and Kaththriarachchi, 2010). Combined approaches based on morphological, molecular and chemical analyses are getting more acceptances in the phylogenic studies of such taxonomically difficult groups (Labra et al., 2004). While classical phylogenetic approach relies on morphological characteristics of an organism, in molecular phylogeny, the relationships among organisms were studied by comparing nucleotide sequences of RNA and DNA and sequences of amino acids of a protein. Dissimilarities among the sequences indicate genetic divergence as a result of molecular evolution during the course of time. Molecular markers are a direct assay of hereditary material and unlike morphological markers, molecular markers are not prone to 
environmental influences and can complement data from descriptors such as morphological characters (Patwardhan, 2014; Mba and Tohme, 2005). Further, by comparing homologous molecules from different organisms it is possible to establish their degree of similarity, thereby establishing or revealing a hierarchy of relationship through a phylogenetic tree.

Many plant phylogenetic studies are based on chloroplast DNA (cpDNA). In plants, cpDNA is smallest as compared to mitochondria or nuclear genome. It is assumed to be conserved in its evolution in terms of nucleotide substitution with very little rearrangements which permits the molecule to be used in resolving phylogenetic relationships especially at deep levels of evolution. Selection of a gene of sufficient length and appropriate substitution rate is a crucial step and currently used cpDNA genes include rbcL, ndhF, rpl16, matK, atpB and many more.

In Garcinia, preliminary molecular phylogenetic work has been started by RismitaSari (2000) to test Jones (1980) classifications of Garcinia into 14 sections based mainly on male flower characters. Gustafsson et al. discussed the phylogenetic status of the Clusiaceae members in detail using chloroplast gene Rbcl and the study supported morphological based classifications (Gustafsson et al., 2002). The phylogenetic relationship among mangosteen and several wild relative species were analyzed by comparing sequences of the ITS region of nuclear ribosomal DNA. Both parsimonious and NJ analysis revealed that mangosteen is closely related to G. malaccensis (Chinawat and Subhadrabandu, 2004). Results from phylogenetic analyses utilizing chloroplast and nuclear DNA markers agree with morphology in support of the unification of all of Rheedia L. and part of Ochrocarpos Thouars with Garcinia (Sweeney, 2008). Genetic diversity based on morphological and Inter Simple Sequence Repeats (ISSR) of 19 accessions of mangosteen and their close relatives revealed that G. malaccensis and G. celebia were the ancestors for mangosteen (Sulassih et al. 2013).

Rao (2003) studied both intra and inter species relationship among six Garcinia species namely G. indica, G. cambogia (G. gummi-gutta), G. cowa, G. mangostana, G. xanthochymus and $G$. hombroniana, using RAPD polymorphism. RAPD markers could successfully distinguish different species of the genus Garcinia. The study indicated high molecular diversity within G. cambogia (Rao, 2003). Parthasarathy et al. studied RAPD polymorphism in 33 accessions of Garcinia species collected from different areas of Western Ghats (Parthasarathy et al., 2013). The dendrogram clearly separated the collections of the 3 main species studied, G. gummi-gutta, G. indica and G. xanthochymus, and suggested high amount of diversity within the collections of the same species. Similar study was also conducted on Garcinia collections from North East India using RAPD. High molecular diversity was observed with the heterogeneity index within species ranging from 0.81 to 0.82 in four species, namely G. gummi-gutta, G. indica, G. cowa and G. xanthochymus (Parthasarathy et al., 2013).

Though Western Ghats is a centre of diversity of Garcinia species, a comprehensive study on the molecular profiles of Garcinia species of the region including the rare and endemic species has rarely been attempted. Present chapter discusses the molecular characterization of Garcinia species naturally occurring in the Western Ghats region, using chloroplast coding region matK. 


\section{Genomic DNA isolation and sequencing}

Genomic DNA was isolated from young leaves using DNeasy plant DNA isolation kit (Qiagen). PCR amplification reactions were carried out in a $20 \mu 1$ reaction volume which contained 1X PCR buffer (150mM Tris $\mathrm{HCl}, \mathrm{pH}-8 ; 500 \mathrm{mM} \mathrm{KCl}), 0.2 \mathrm{mM}$ each dNTPs, $2.5 \mathrm{mM} \mathrm{MgCl}_{2}$, 20ng DNA, 1 unit of Ampli Taq Gold DNA polymerase enzyme, $0.1 \mathrm{mg} / \mathrm{ml}$ BSA and 4\% DMSO, 5pM of forward and reverse primers (Table:01). The PCR amplification was carried out in a PCR thermal cycler (GeneAmp PCR System 9700, Applied Biosystems) with an initial denaturation of $95^{\circ} \mathrm{C}$ for $5.00 \mathrm{~min}$. followed by 40 cycles of $48^{\circ} \mathrm{C}$ for $0.40 \mathrm{~min}, 72^{\circ} \mathrm{C}$ for $1.00 \mathrm{~min}$ and $72^{\circ} \mathrm{C}$ for $5.00 \mathrm{~min}$., followed by $4^{\circ} \mathrm{C}$. PCR amplification (Figure 1) was followed by sequencing using the BigDye Terminator v 3.1. The sequence quality was checked using Sequence Scanner Software v1 (Applied Biosystems). Sequence alignment and required editing of the obtained sequences were carried out using Geneious Pro v 5.6.

Table1. Primers used for the molecular study of Garcinia species

\begin{tabular}{lllll}
\hline Target & $\begin{array}{l}\text { Primer } \\
\text { Name }\end{array}$ & Direction & Sequence $\left(5^{\prime} \rightarrow 3^{\prime}\right)$ & Reference \\
\hline matK & $\begin{array}{l}\text { matK- } \\
390 \mathrm{~F}\end{array}$ & Forward & CGATCTATTCATTCAATATTTC & $\begin{array}{l}\text { CBOL Plant Working Group } \\
\text { (http://www.barcoding.si.edu }\end{array}$ \\
& & & /pdf/informationonbarcodeloci.pdf \\
& & & \\
\hline
\end{tabular}

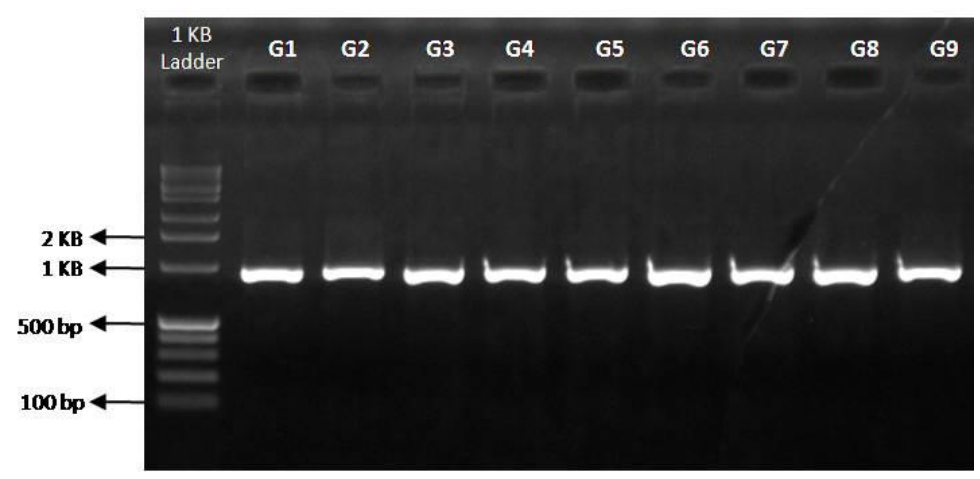

Figure 1. PCR products- matK region of nine Garcinia species

\section{Sequence analysis}

The phylogenetic analyses of 9 Garcinia species distributed naturally in the Western Ghats were done using MatK with Clusia criuva of Clusiaceae family as the out group member (ncbi-TNS:SK08071206). The evolutionary history was inferred using Neighbor-Joining method as elaborated by Saitou and Nei (1987). The optimal tree with the sum of branch length 0.093 is shown in Figure 2. The percentages of replicate trees in which the associated taxa clustered together in the bootstrap test (1000 replicates) are shown next to the branches (Felsenstein, 1985). The tree was drawn to scale, with branch lengths in the same units as those of the evolutionary distances used, to infer the phylogenetic tree. The evolutionary distances were computed using the Kimura 2-parameter method (Kimura, 1980) and are in the units of the number of base substitutions per site. All positions containing gaps and 
missing data were eliminated. There were a total of 802 positions in the final dataset. Evolutionary analyses were conducted in MEGA5 (Tamura et al., 2011).

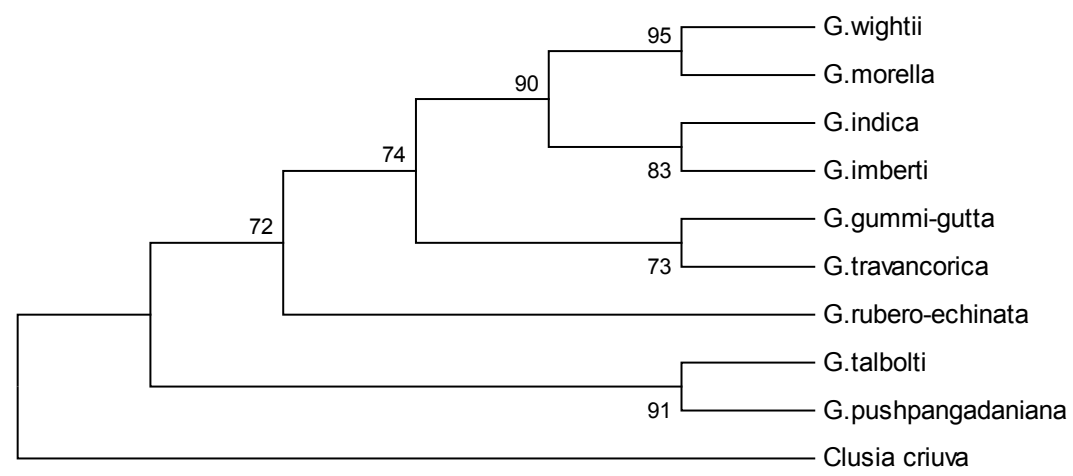

Figure 2. NJ- Phylogram based on matK loci of 9 species of Garcinia and the out group Clusia criuva.

All the accessions of the Garcinia species were clustered together in the NJ phylogram based on $m a t K$ loci and the phylogram distinctly delimit all the 9 species and were also clearly differentiated from the out group Clusia criuva. In the first clad the accessions of G. morella and $G$. wightii were clustered together with a bootstrap value of $95 \%$. The second clad includes $G$. indica and $G$. imberti and showed sister relationship with $83 \%$ bootstrap support. The third clad includes two sub clusters with G. travancorica in one cluster and G. gummigutta in the second cluster with bootstrap value of $73 \%$. The fourth cluster is purely monophyletic with G. rubro-echinata. The fifth cluster includes G. talbotii and a recently published species $G$. pushpangadaniana with bootstrap value of $91 \%$.

Generally, the classical morphology based classification and molecular analysis based classification complement each other since morphology of an organism is the manifestation of its genome, proteome and transcriptome profiles. The results of the current molecular study are in part congruent with the classification based on morphological features (Chapter 1). The species status of $G$. pushpangadaniana is confirmed and also its allied nature to $G$. talbotii (Sabu et al., 2013). G. pushpangadaniana and G. talbotii were morphologically distinct from other species by the characteristic features of stamens in 5 phalanges and 5 numbered sepals and petals. G. morella and G. wightii that showed as a separate clad in molecular phylogeny were allied and distinct from other species based on sessile fruits and 4 lobed stigma. G. rubro-echinata also stands distinct based on morphological features with echinate fruits and supports the monophyletic nature of G. rubro-echinata in the molecular phylogram. Combined multidisciplinary analysis of vegetative and reproductive morphology, along with molecular taxonomy yield more robust phylogeny which could be used for studies of phytogeography and evolutionary radiation of the Garcinia species.

\section{Conclusions}

The genus Garcinia is one of the taxa with poorly resolved phylogenetic relationships. Although widely practised even now, traditional morphology based systems of classification can have some limitations while systematics based on molecular markers can complement the traditional morphology based method for phylogenetic studies. Further, the genetic profile of 
the Garcinia species of the Western Ghats can be used to solve the taxonomic enigmas and for analyzing the phylogeny of the group. The present work shows that the Garcinia species can be distinctly identified by the phylogram based on matK loci of the Garcinia species and molecular profiling has been successfully used to resolve species circumscriptions and identification of Garcinia species in the Western Ghats.

\section{References}

1. CBOL Plant Working Group (http://www.barcoding.si.edu/plant_working_group.html). BigDye Terminator v3.1 Cycle sequencing Kit- User Manual, Applied Biosystems.

2. Chinawat $Y$ and Subhadrabhanu S. 2004. Phylogenetic relationship of Mangosteen and several wild relatives revealed by ITS Sequence data. J. Amer. Soc. Hort. Soc., 129 (3), 368-373.

3. Felsenstein J. 1985. Confidence limits on phylogenies: An approach using the bootstrap. Evolution, 39, 783-791.

4. Gustafsson MH, Bittrich V and Stevens PF. 2002. Phylogeny of Clusiaceae based on rbcL sequences. Int. J. Plant Sc., 163(6), 1045-1054.

5. Kimura M. 1980. A simple method for estimating evolutionary rate of base substitutions through comparative studies of nucleotide sequences. J. Mol. Evol., 16,111-120.

6. Labra M, Miele M, Ledda B, Grassi F and Mazzei M. 2004. Morphological characterization, essential oil composition and DNA genotyping of Ocimum basilicum L. cultivars. Plant Sci., 167, 725-731.

7. Mba C and Tohme J. 2005. Use of AFLP markers in surveys of plant diversity. Meth. Enzymol., 395, 177-201.

8. Nimanthika WJ, Kaththriarachchi HS. 2010. Systematics of genus Garcinia L. (Clusiaceae) in Sri Lanka. New insights from vegetative morphology. Journal of National Science Foundation, 38, 29-44.

9. Parthasarathy U, Nandakishore OP, Kumar S and Parthasarathy VA. 2013. Comparative effectiveness of inter-simple sequence repeat and randomly amplified polymorphic DNA markers to study genetic diversity of Indian Garcinia. Afr. J. Biotech., 12(46), 6443.

10. Patwardhan A, Ray S and Roy A. 2014. Molecular markers in phylogenetic studies- A Review. J. Phylogen. Evolution. Biol. 2, 131.

11. Rao PVV. 2003. Molecular characterization of Garcinia using RAPD polymorphism. M.Sc. Dissertation. Nagarjuna University, Andhra Pradesh, India.

12. Rismita-Sari. 2000. Review of Garcinia (Clusiaceae) Based on Molecular Systematics. In: A Phylogenetic study of molecular data of Garcinia spp. M. Sc. Thesis, Department of Tropical Plant Science, School of Tropical Biology, James Cook University.

13. Sabu T, Mohanan N, Krishnaraj MV, Shareef SM, Shameer PS and Roy PE 2013. Garcinia pushpangadaniana, (Clusiaceae) a new species from southern Western Ghats, India. Phytotaxa, 116 (2), 51-56.

14. Saitou N. and Nei M. 1987. The neighbor-joining method: A new method for reconstructing phylogenetic trees. Mol. Biol. Evol., 4, 06-25.

15. Sulassih, Sohr and Santosa E. 2013. Phylogenetic analysis of mangosteen and its relatives based on Morphological and ISSR markers. SABRAO J. Breeding Gen., 45 (30), 478-490.

16. Sweeney PW. 2008. Phylogeny and floral diversity in the genus Garcinia (Clusiaceae) and relatives. Int. J. Plant Sc., 169(9), 1288-1303. 
17. Tamura K., Peterson D., Peterson N., Stecher G., Nei M., and Kumar S. 2011. MEGA5: Molecular Evolutionary Genetics Analysis using Maximum Likelihood, Evolutionary Distance, and Maximum Parsimony Methods. Mol. Biol. Evol., 28(10), 2731-2739. 


\section{$\underline{\text { List of Authors }}$}

\section{Ananthakrishanan R.}

Phytochemistry and Phytopharmacology Division

Jawaharlal Nehru Tropical Botanic Garden and Research Institute

Palode, Thiruvananthapuram 695562, Kerala, India

E mail: ananthanr3@gmail.com

Mobile No.: 9495340654

\section{Anju V.}

Phytochemistry and Phytopharmacology Division

Jawaharlal Nehru Tropical Botanic Garden and Research Institute

Palode, Thiruvananthapuram 695562, Kerala, India

Email: av.anjuv@gmail.com

Mobile No.: 9526568757

\section{Anu Aravind A. P.}

Phytochemistry and Phytopharmacology Division

Jawaharlal Nehru Tropical Botanic Garden and Research Institute

Palode, Thiruvananthapuram 695562, Kerala, India

E mail: anumbc@gmail.com

Mobile No.: 9496324376
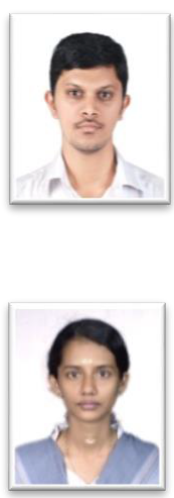

\section{Brijesh Kumar}

Sophisticated Analytical Instrument Facility

CSIR-Central Drug Research Institute, Lucknow-226031, Uttar Pradesh, India

E mail: gbrikum@yahoo.com

Mobile No.: 7800188889

\section{George V.}

Amity Institute of Phytochemistry and Phytomedicine

Peroorkada, Thiruvananthapuram 695 005, Kerala, India

E mail: georgedrv@yahoo.co.in

Mobile No.: 9447041156

\section{Lekshmi N. Menon}

Phytochemistry and Phytopharmacology Division

Jawaharlal Nehru Tropical Botanic Garden and Research Institute

Palode, Thiruvananthapuram 695562, Kerala, India

E mail: lekshminmenon@gmail.com

Mobile No.: 8590235085
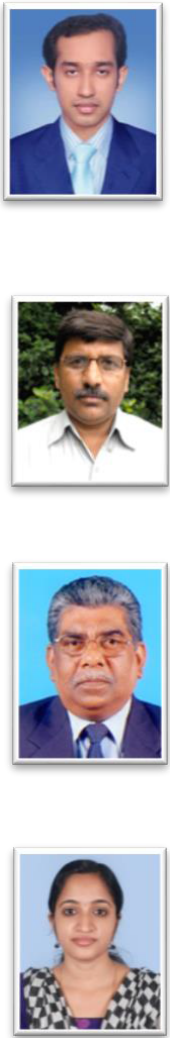

7. Mohanan N.

Garden Management, Education, Information and Training Division Jawaharlal Nehru Tropical Botanic Garden and Research Institute Palode, Thiruvananthapuram 695562, Kerala, India

E mail: nmohanan59@gmail.com

Mobile No.: 9496103427

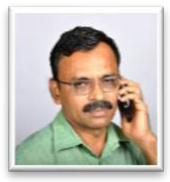


8. Nandakishore $\mathbf{O}$. $\mathbf{P}$.

ICAR- Indian Institute of Spices Research

Kozhikode- 673012, Kerala, India

E mail: opnandan@gmail.com

Mobile No.: 9446906839

9. Nandu T. G.

Microbiology Division

Jawaharlal Nehru Tropical Botanic Garden and Research Institute

Palode, Thiruvananthapuram 695562, Kerala, India

E mail: tg.nandu@gmail.com

Mobile No.: 9496354892

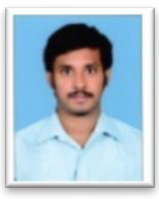

Pradeep N. S.

Microbiology Division

Jawaharlal Nehru Tropical Botanic Garden and Research Institute

Palode, Thiruvananthapuram 695562, Kerala, India

E mail: drnspradeep@gmail.com

Mobile No.: 9446093865

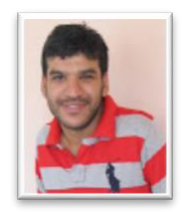

\section{Rameshkumar K. B.}

Phytochemistry and Phytopharmacology Division

Jawaharlal Nehru Tropical Botanic Garden and Research Institute

Palode, Thiruvananthapuram 695562, Kerala, India

E mail:kbrtbgri@gmail.com

Mobile No.: 9446376431

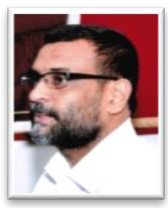

12. RenuPandey

Sophisticated Analytical Instrument Facility

CSIR-Central Drug Research Institute, Lucknow-226031, Uttar Pradesh, India

E mail: renupandeyji@gmail.com

Mobile No.: 09411516510

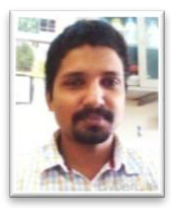

\section{Sabu T.}

Garden Management, Education, Information and Training Division

Jawaharlal Nehru Tropical Botanic Garden and Research Institute

Palode, Thiruvananthapuram 695562, Kerala, India

E mail: sabutbgri71@gmail.com

Mobile No.: 9447054118

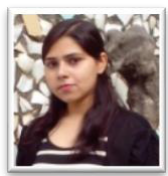

14. Shameer P. S.

Garden Management, Education, Information and Training Division

Jawaharlal Nehru Tropical Botanic Garden and Research Institute

Palode, Thiruvananthapuram 695562, Kerala, India

E mail: shameershameerps@gmail.com

Mobile No.: 9400796358
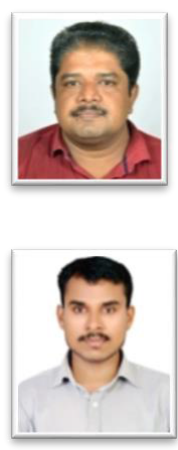

15. Shiburaj S.

Microbiology Division

Jawaharlal Nehru Tropical Botanic Garden and Research Institute

Palode, Thiruvananthapuram 695562, Kerala, India

E mail: drshiburaj@gmail.com

Mobile No.: 9495826669

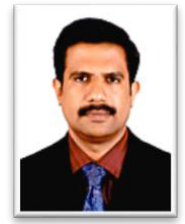




\section{Siji Aral}

Phytochemistry and Phytopharmacology Division

Jawaharlal Nehru Tropical Botanic Garden and Research Institute

Palode, Thiruvananthapuram 695562, Kerala, India

Email: sijiaraal@gmail.com

Mobile No.: 8547511746

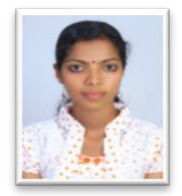

17. Sivu A. R.

Department of Botany

NSS College Nilamel, Kollam- 691535, Kerala, India

E mail: sivuar@gmail.com

Mobile No.: 9495592939

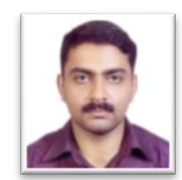

18. UtpalaParthasarathy

ICAR- Indian Institute of Spices Research

Kozhikode- 673012, Kerala, India

E mail: utpala@spices.res.in; utpalap@gmail.com

Mobile No.: 9446073162

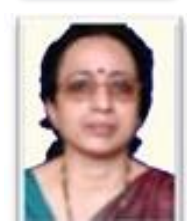





\title{
Diversity of Garcinia species in the Western Ghats: Phytochemical Perspective
}

\author{
K. B. Rameshkumar
}

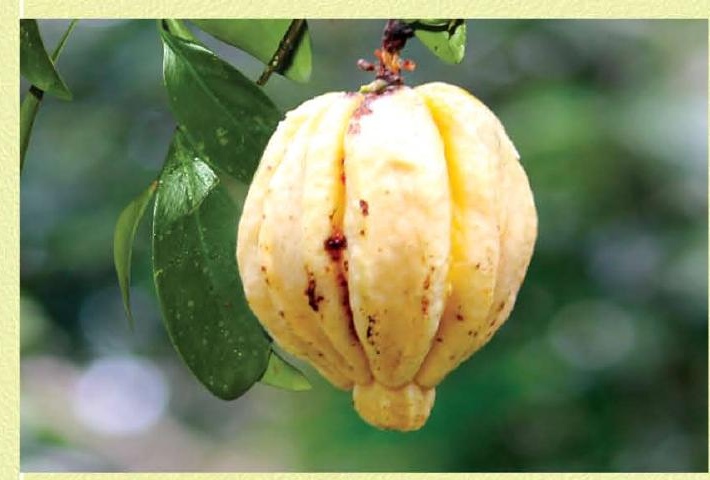

$R$ ecently, Garcinia species have received considerable attention worldwide from scientific as well as industrial sectors and several novel structures, bioactivities and potential utilities have been reported for Garcinia species. Though phytochemical investigation of Garcinia species is progressing in a fast pace worldover as indicated by ever increasing publications and patents around the genus, the phytochemistry of Garcinia species in India has least been explored. The book focuses on the phytochemical aspects of Garcinia species of the Western Ghats, and also elaborates the morphology, genetics, pharmacology and nutritional aspects as well. The wealth of information provided can be linked to boarder zones between chemistry and biology as in the case of chemical ecology, chemogenomics and phylogenic studies. The work also highlights the importance of the floristic wealth of the Western Ghats and the need to harvest the hidden treasure through wise selection and skillful application of different phytochemical methods.

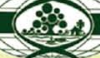

